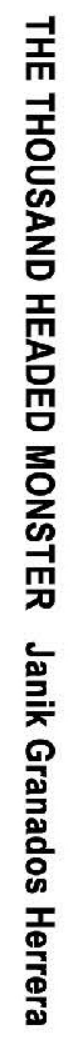

\title{
THE THOUSAND HEADED MONSTER: Interrogating the competing voices in México's PES Programme
}

\section{JANIK GRANADOS HERRERA}




\title{
THE THOUSAND HEADED MONSTER: INTERROGATING THE COMPETING VOICES IN MÉXICO'S PES PROGRAMME.
}

\author{
DISSERTATION
}

\begin{abstract}
to obtain
the degree of doctor at the University of Twente, on the authority of the rector magnificus, prof.dr.ir. A. Veldkamp, on account of the decision of the Doctorate Board, to be publicly defended on Thursday $6^{\text {th }}$ of May 2021 at 16:45 hours
\end{abstract}

by

\section{Janik Granados Herrera}

born on the $11^{\text {th }}$ of October 1974

in Distrito Federal, Mexico 
This dissertation has been approved by:

Supervisor(s): $\quad$ prof. dr. J.S. Clancy

prof. dr. M.K. McCall 


\section{Members of the Graduation Committee}

Chairman/secretary: prof. dr. T.A.J. Toonen University of Twente, BMS

Supervisor(s): $\quad$ prof.dr. J.S. Clancy Universiteit Twente, BMS-CSTM prof.dr. M. K. McCall Universidad Nacional Autónoma de México, Centro de Investigaciones en Geografía Ambiental.

Committee Members:

prof. dr. J.T.A. Bressers Universiteit Twente, BMS, Department of Governance and Technology for Sustainability

prof. dr. S. Kuhlmann Universiteit Twente, BMS, Science, Technology \& Policy Studies

prof. dr. E. Turnhout Wageningen University \& Research, WUR, Department of Forest and Nature Conservation Policy

prof. dr. A. Velázquez Universidad Nacional Autónoma de México, Centro de Investigaciones en Geografía Ambiental

The work described in this thesis was performed at the Section of Governance and Technology for Sustainability, Faculty of Behavioural, Management and Social sciences, University of Twente, P.O. Box 217, 7500 AE, Enschede, The Netherlands and The Centro de Investigaciones en Geografía Ambiental, Universidad Nacional Autónoma de México. Antigua Carretera a Pátzcuaro 8701, Col. Ex-Hacienda de San José de la Huerta. C.P. 58190. Morelia Michoacán, México.

This research project was funded by Netherlands Organisation for Scientific Research (NWO) under the program Science for Global Development through the project "Linking local action to international climate agreements in the tropical dry forests of Mexico" (Project number W01.65.331.00). 


\section{Colophon}

Cover image: "The thousand headed monster", digital illustration by Rolando Prado and Janik Granados.

Lay-out: $\quad$ Rolando Prado.

Printed by: Ipskamp Printing, Enschede, The Netherlands.

ISBN: 978-90-365-5166-3

DOI: $10.3990 / 1.9789036551663$

(c) 2021 Janik Granados Herrera, The Netherlands. All rights reserved. No parts of this thesis may be reproduced, stored in a retrieval system or transmitted in any form or by any means without permission of the author. Alle rechten voorbehouden. Niets uit deze uitgave mag worden vermenigvuldigd, in enige vorm of op enige wijze, zonder voorafgaande schriftelijke toestemming van de auteur.

UNIVERSITY OF TWENTE.

Faculty of Behavioural, Management and Social sciences (BMS)

Section of Governance and Technology for Sustainability (CSTM)

Enschede, The Netherlands.

UNIVERSIDAD NACIONAL AUTÓNOMA DE MÉXICO

Centro de Investigaciones en Geografía Ambiental

Morelia, Michoacán, Mexico

E-mail (for correspondence): janikgranados@gmail.com 


\section{Table of contents}

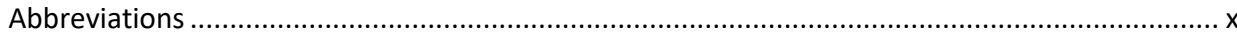

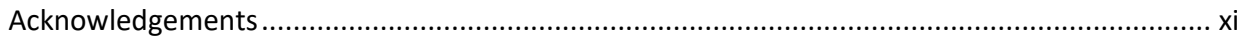

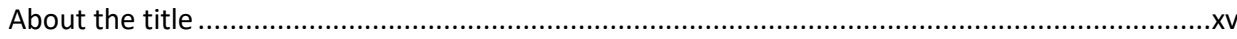

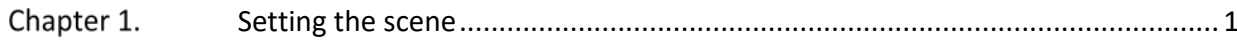

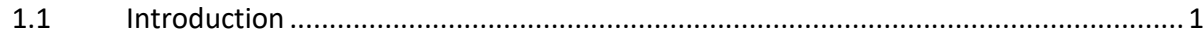

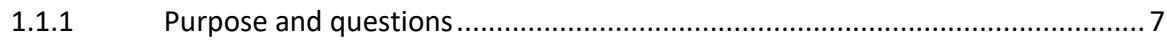

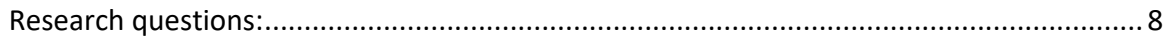

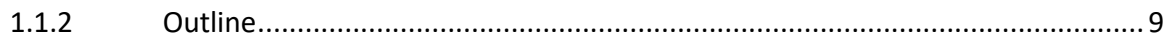

Chapter 2. Searching for appropriate concepts and theories on which to build .............. 11

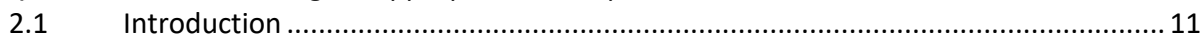

2.2 Research approaches in the analysis of policy .................................................... 12

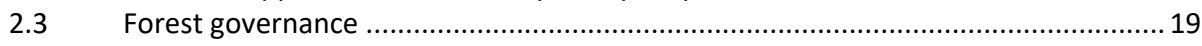

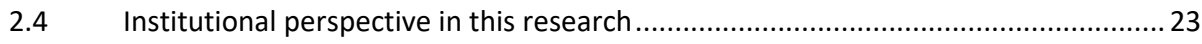

$2.5 \quad$ Intermediaries, their roles and disciplines in development programmes ...............27

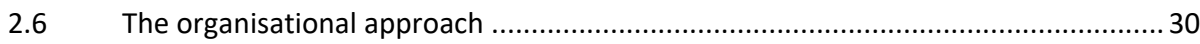

2.7 Conceptualising informality and its interaction with formality.............................32

Chapter 3. Selecting appropriate tools for capture the diversity of voices in PES ............ 41

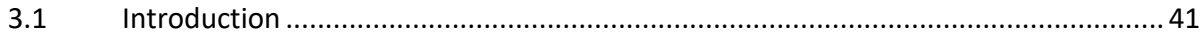

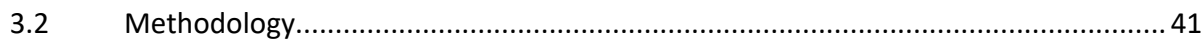

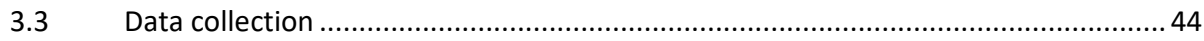

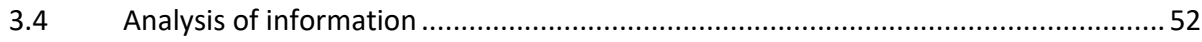

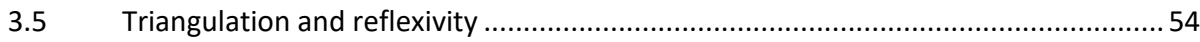

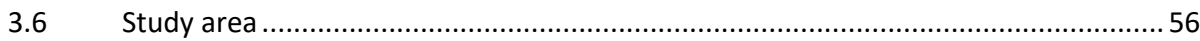

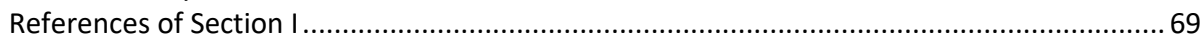

Chapter 4. The Mexican PES programme as context for the study............................... 81

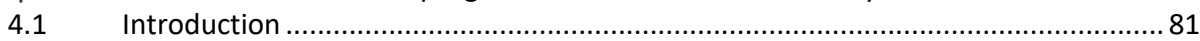

4.2 The Payment for Environmental Services (PES) programme ...............................81

4.3 General functioning of PES programme............................................................ 86

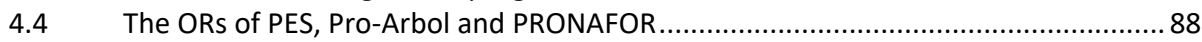

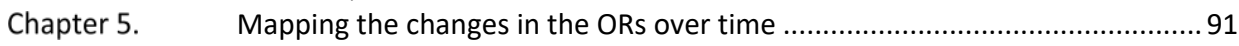

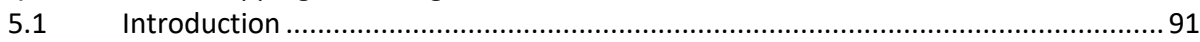

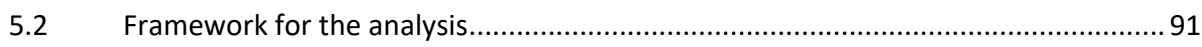

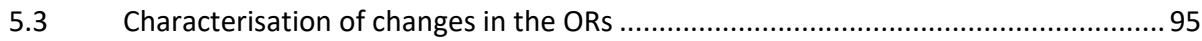

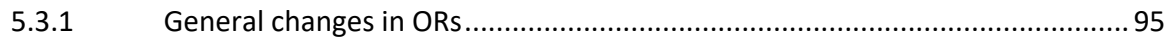

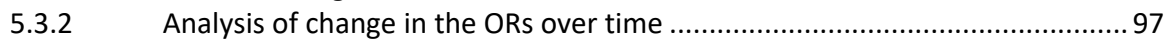

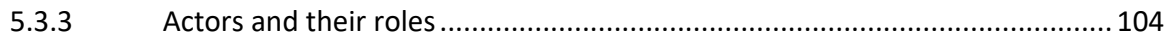

5.3.4 Procedures ..................................................................................... 116

5.3.5 Priority criteria for the selection of eligible communities and lands............. 118

5.4 Discussion and conclusions ....................................................................... 125

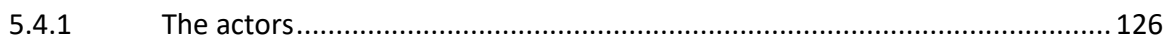

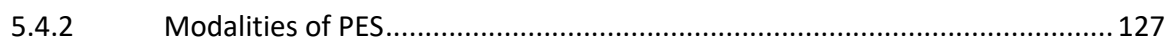

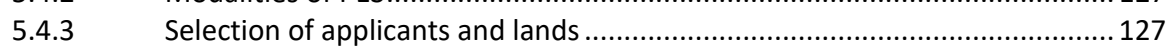

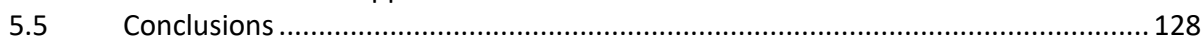

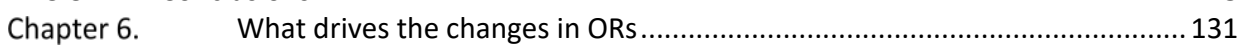

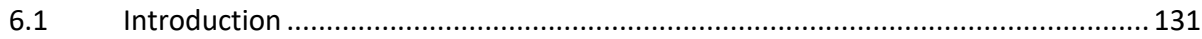

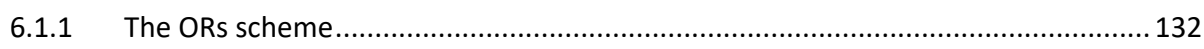

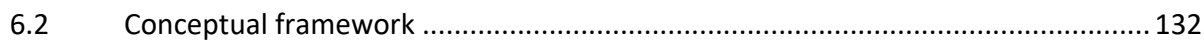

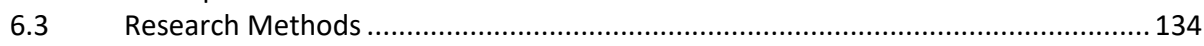

6.3.1 Sources for the data collection and analysis ............................................... 134 
$6.4 \quad$ Results

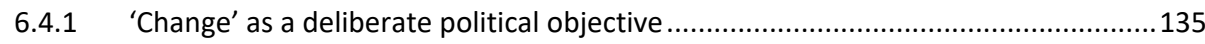

6.4.2 The definition, objectives and modalities of the programme ................................137

6.4.3 Priority criteria for selecting beneficiaries and lands for PES.................................... 140

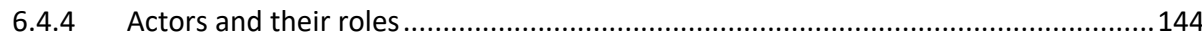

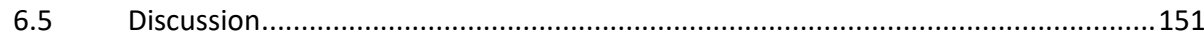

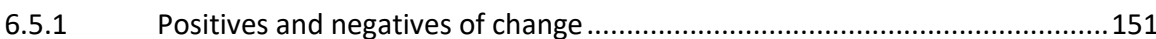

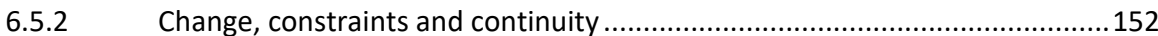

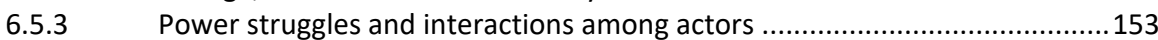

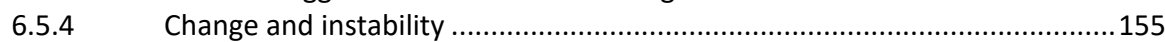

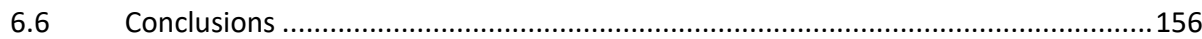

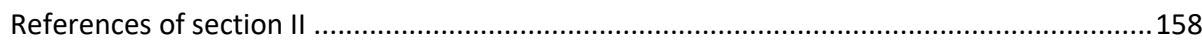

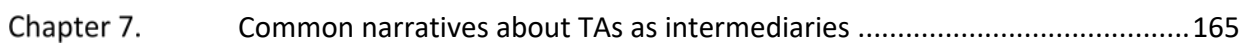

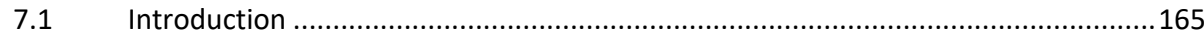

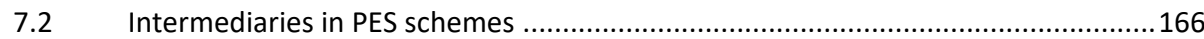

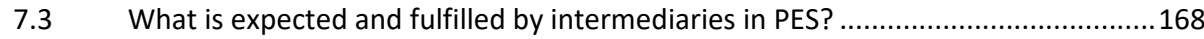

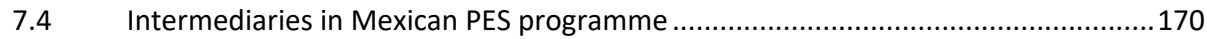

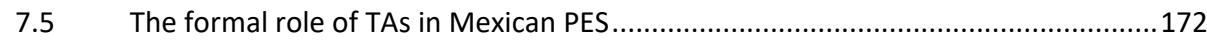

Chapter 8. Exploring the history of forest management in México .................................177

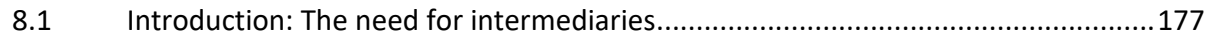

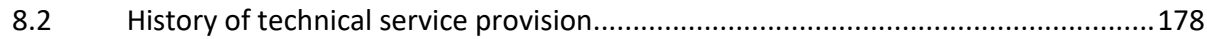

8.2.1 CONAFOR and the shift from technical forest service providers to TAs..........184

8.3 The TAs: professional profile, skills, and other characteristics.................................187

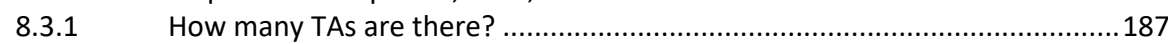

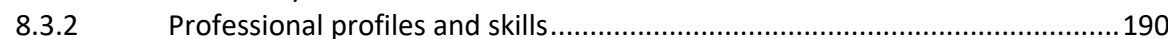

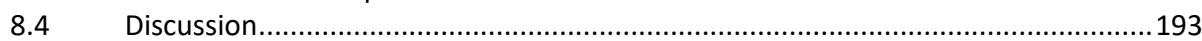

8.4.1 Why are technicians so important in Mexican PES? ........................................193

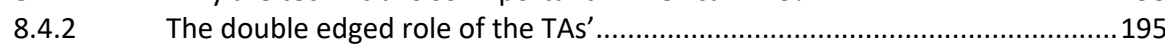

8.4.3 The Historical and current relations among actors ......................................195

8.4.4 How the TAs working situation affects their performance.............................197

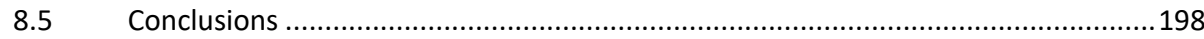

Chapter 9. Villains and scapegoats: analysing the narratives about the TAs .....................199

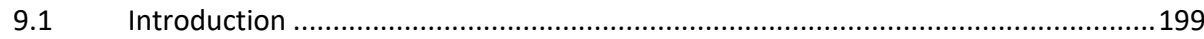

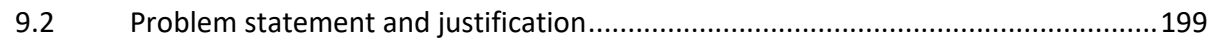

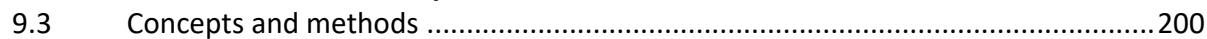

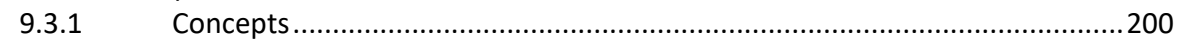

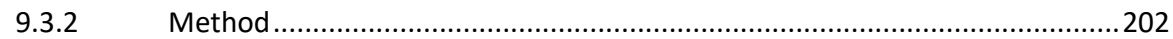

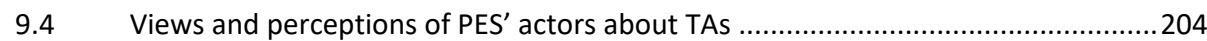

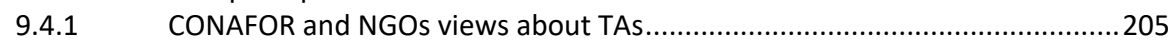

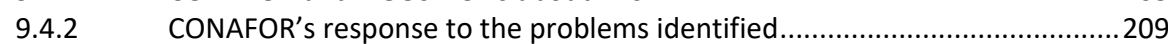

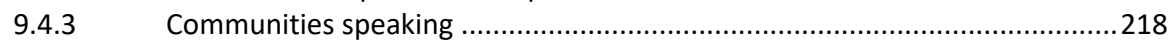

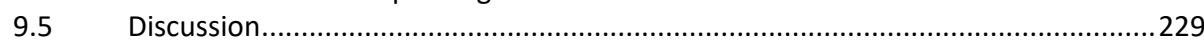

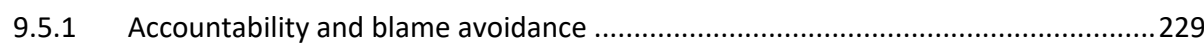

9.5.2 Communities learn how to balance the relations of power with their TAs..............232

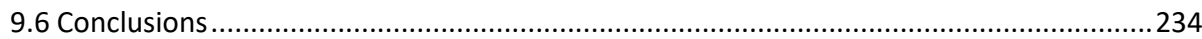

Chapter 10. Warhorses and bad apples: analysing the narratives of TAs ..........................237

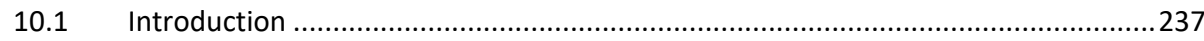

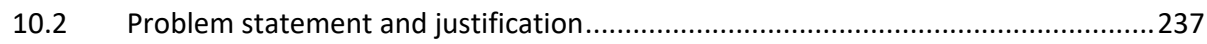

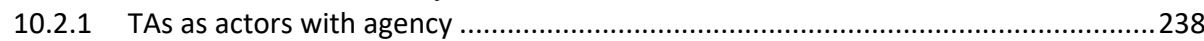

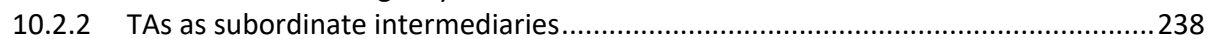




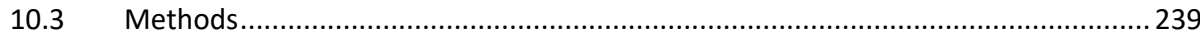

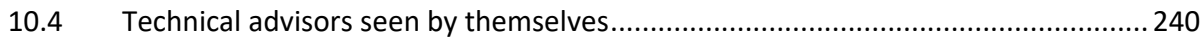

10.4.1 What TAs say about their roles, interests and motivations ...................................2. 240

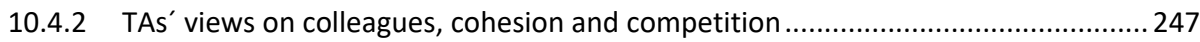

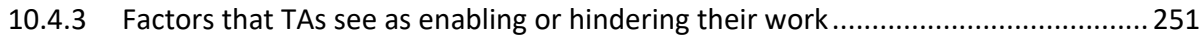

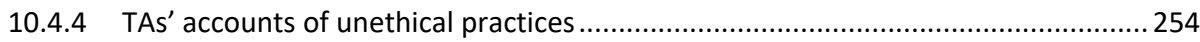

10.4.5 TAs views on certification as a mechanism of quality control ................................2.260

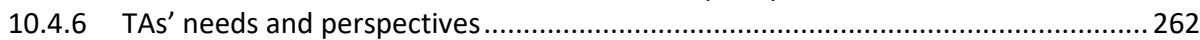

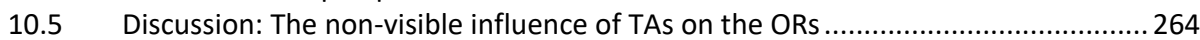

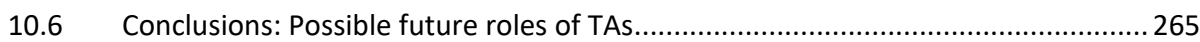

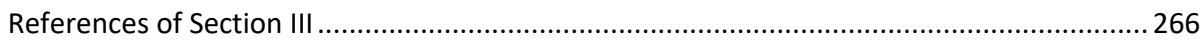

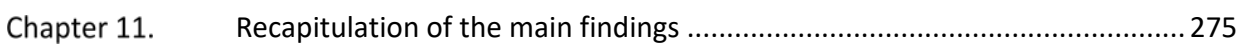

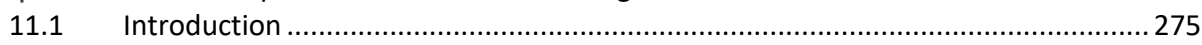

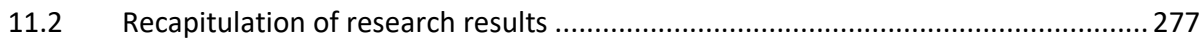

11.2.1 On the importance of ORs and TAs in the PES programme implementation............277

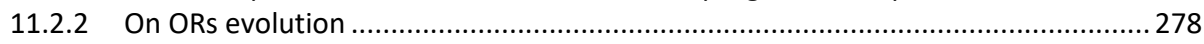

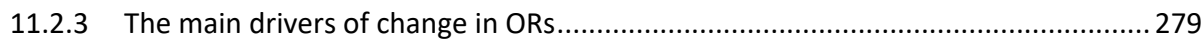

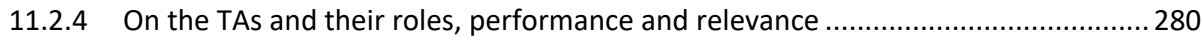

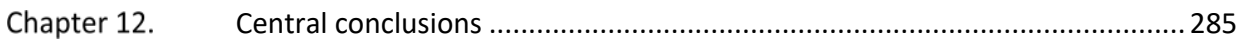

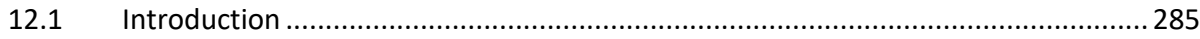

12.2 PES as a global model, with adaptation and co-construction at the local level .......286

12.3 CONAFOR's narratives about ORs and TAs in the construction of a façade..............288

12.4 The interplay between formality and informality in theory and in practice.............293

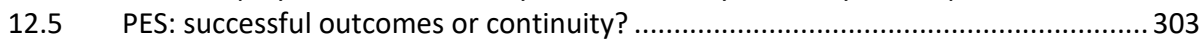

12.6 Local PES constructions beyond the official expectations of outcomes ................... 308

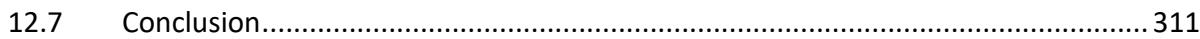

Chapter 13. Future research to further explore the monster, and reflections on policy... 315

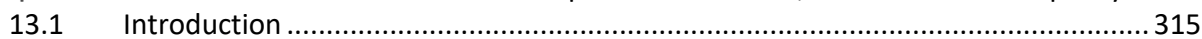

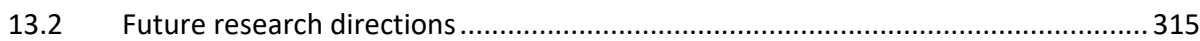

13.2.1 Gaps and limitations in the research which generate ideas for future research ..... 315

13.2.2 Questions for future research that came directly out of the findings ...................... 317

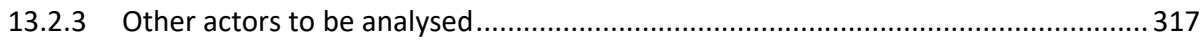

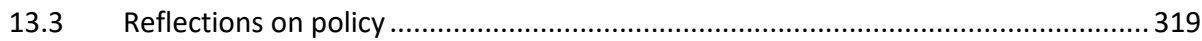

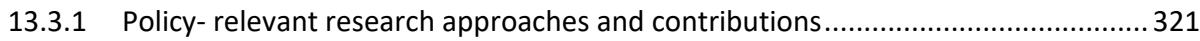

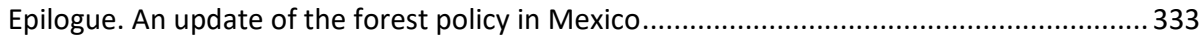

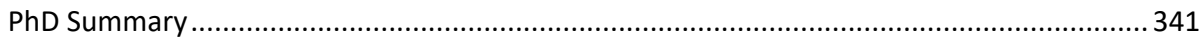

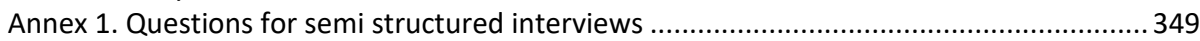

\section{List of Tables}

Table 2.1. Structures organisations

Table 2.2. Informal organisational structures in relation to formal structures38

Table 2.3. Forms of informality according to its relationship to the organisation's order ..............38

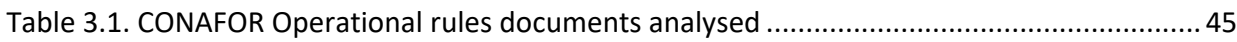

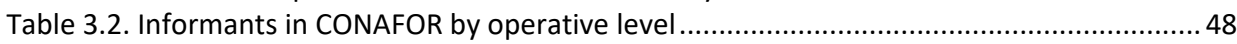

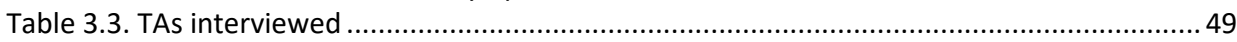

Table 3.4. Communities and informants by location and modality of PES ..................................50

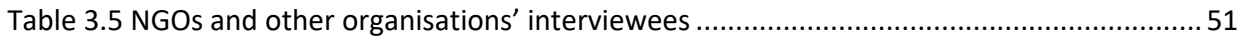

Table 3.6. PES contracts and modality of ejidos located in Ayuquila basin (Jalisco) ......................61

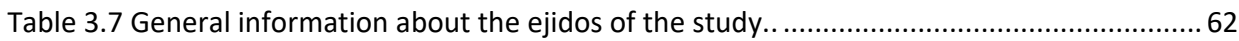

Table 3.8. General information about the ejidos of the study in Michoacán..................................68 
Table 4.1. Events and influences for the development of the progrPES programme...................82

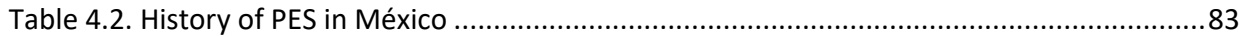

Table 4.3. Differentiated payments for the two modalities of PES and areas enrolled in $2012 \ldots . .88$

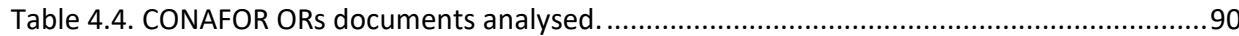

Table 5.1. Example of the graph to illustrate the change over time..............................................94

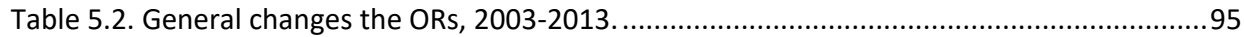

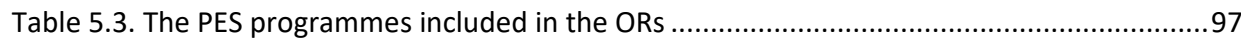

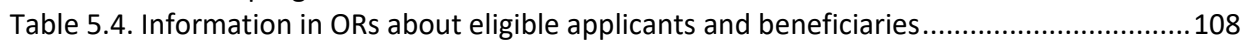

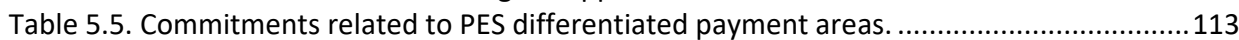

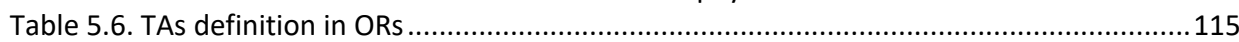

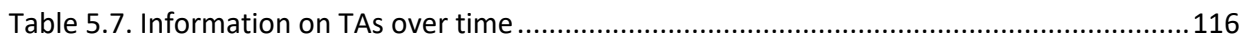

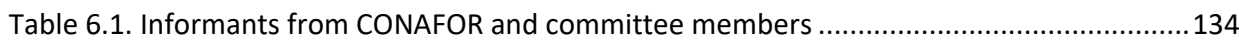

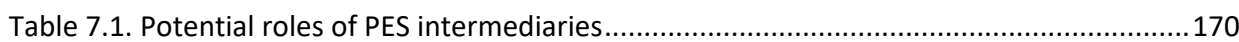

Table 7.2. List of activities to be fulfilled by TAs in the PES programme ..................................173

Table 7.3. Main roles of Mexican PES' TAs, according to Huber-Stearns et al. (2013).................175

Table 9.1. Organisational interviewees, who contributed information on TAs ............................202

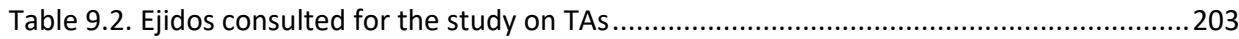

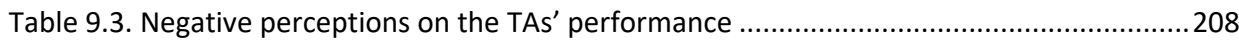

Table 9.4. Summary of measures taken by CONAFOR to improve TAs performance...................217

Table 9.5. Roles and bad practices carried out by TAs in 6 communities....................................228

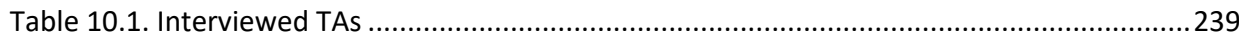

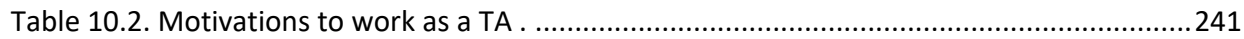

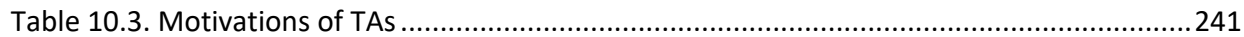

Table 10.4. CONAFORs dependency on $\mathrm{f}$ TAs, according to the TAs programme..........................242

Table 10.5. The roles of TAs in PES as perceived by themselves ..............................................245

Table 10.6. TAs views on lack of union and competition between colleagues............................250

Table 10.7. Unethical practices carried out by TAS as mentioned in their interviews. .................255

Table 10.8. Main criticisms of TAs about the certification process ...........................................261

Table 11.1. Recapitulation of the objectives and research questions of this thesis .....................276

Table 12.1. Three aspects of governance and actors in the PES programme..............................292

Table 12.2. Informal practices in PES programme, according to Luhmann ..................................296

Table 12.3. Interaction between formality and informality in PES programme...........................298

\section{List of Figures}

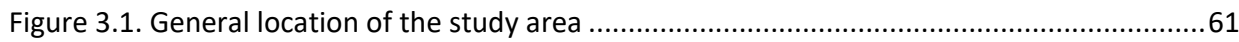

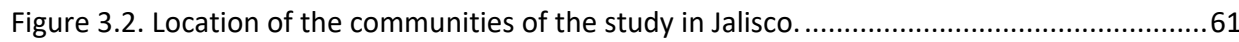

Figure 3.3 Location of the communities of study in Michoacán .................................................64

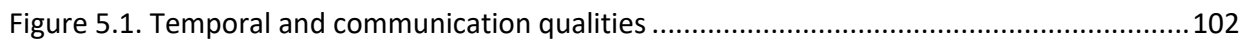

Figure 5.2. Temporal and communication qualities: Payment modalities ...................................104

Figure 5.3. Temporal and communication qualities: CONAFOR obligations.................................. 105

Figure 5.4. Temporal and communication qualities: CONAFOR competencies...........................107

Figure 5.5. Information about Technical Committees in ORs over time.......................................108

Figure 5.6. Temporal and communication qualities: Eligible applicants ...................................110

Figure 5.7. Temporal and communication qualities: Beneficiaries' rights.................................111

Figure 5.8. Temporal and communication qualities: Beneficiaries' obligations ...........................114

Figure 5.9. Temporal and communication qualities: PES Procedures over time .........................117

Figure 5.10. Number of PSAH priority criteria by category and year.......................................120 
Figure 5.11. Temporal and communication qualities: PSAH priority criteria ............................... 121

Figure 5.12. Number of priority criteria by category and year (Biodiversity) ............................. 123

Figure 5.13. Temporal and communication qualities: Biodiversity ......................................... 123

Figure 5.14. Number and types of sources of information of PSAH Priority criteria .................... 124

Figure 5.15. Number and types of sources of information of Biodiversity.................................. 124

Figure 8.1. Average number of PRONAFOR TAs per state in México. ........................................ 188

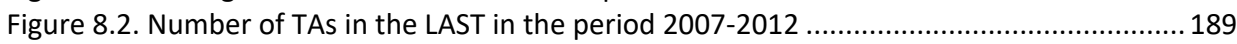

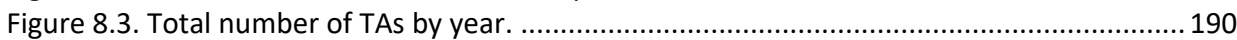

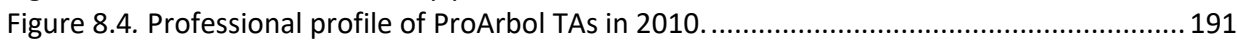

Figure 8.5. Relevance of TAs in connecting the main actors of PES programme ........................ 194

Figure 9.1. The actors involved in the study, and their position relative to the other actors ..... 204

Figure 9.2 Contextual factors of incidence of unethical practices of TAs ................................. 230

Figure 10.1. Perceptions of the role of TAs: contrasting the TAs view with that of CONAFOR ... 246

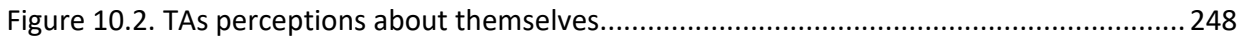

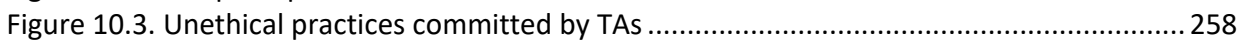

Figure 10.4. Expressions used by the TAs when referring to the certification. ............................ 261

\section{List of Timelines}

Timeline 5.1. Institutional goal, values expressed over time in the ORs ....................................98

Timeline 5.2. Justification/ Arguments used in the ORs to justify the CONAFOR programmes .... 99

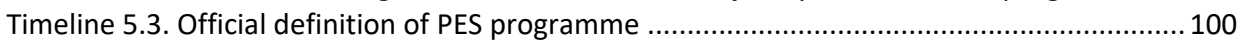

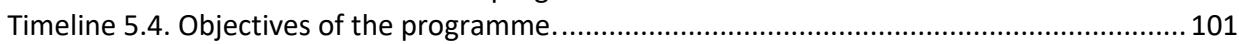

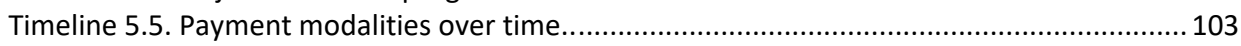

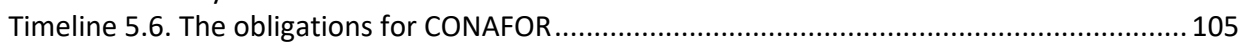

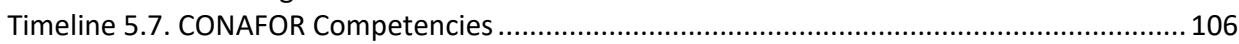

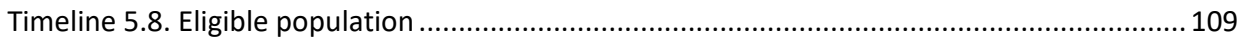

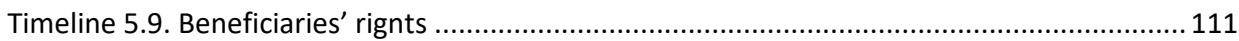

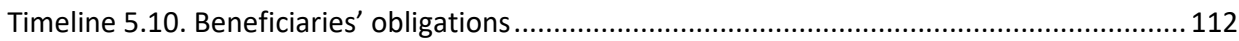

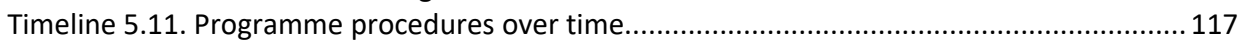

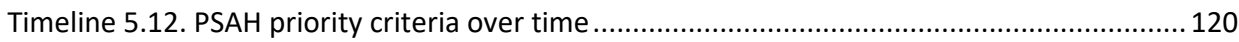

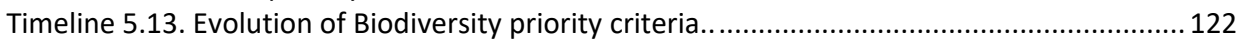

Timeline 8.1. The history of rural and forest provision of technical services in México................ 178

Timeline 8.2. Forest technical services over time... ................................................................. 181

Timeline 8.3. The evolution of forest technical assistance after the creation of CONAFOR ....... 185

\section{List of Boxes}

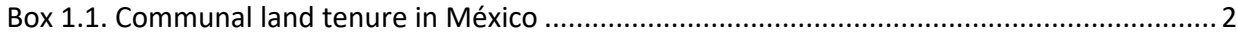

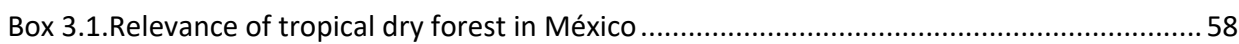




\section{Abbreviations}

CDI: Comisión Nacional para el Desarrollo de los Pueblos Indígenas / National Commission for the Development of Indigenous Peoples

CONAFOR: Comisión Nacional Forestal / National Commission for Forestry

DOF: México Federal Official Gazette (Diario official de la federación) contains up-to-date publications of laws and regulations at the national and state levels.

INE/INECC: Instituto Nacional de Ecología y Cambio Climático / National Institute for Ecology and Climate Change

INEGI: Instituto Nacional de Estadística, Geografia e Informática / National Institute of Geography, Statistics, and Information Systems

JIRA: Junta Intermunicipal del Río Ayuquila

NPA: Natural Protected Areas

ORs: Operational Rules (of the PES programmes of CONAFOR)

PRONAFOR: Programa Nacional Forestal / National Forest Programme

PSA-CABSA: Programa para Desarrollar el Mercado de Servicios Ambientales por Captura de Carbono y los Derivados de la Biodiversidad y para Fomentar el Establecimiento y Mejoramiento de Sistemas Agroforestales / Payments for Biodiversity, Carbon and Agroforestry Services

PSAH: Programa de Pago por Servicios Ambientales Hidrológicos/ Payments for Hydrological Environmental Services Programme

RAN: Registro Agrario Nacional / National Agrarian Register SEMARNAT Secretaría de Medio Ambiente y Recursos Naturales / (Federal) Secretariat for the Environment, Natural Resources

REDD+: Avoided deforestation and including reductions in forest degradation

SEMARNAP/SEMARNAT: Secretaría de Medio Ambiente y Recursos Naturales / (Federal) Secretariat for the Environment, Natural Resources

TAs: Technically trained personnel in forestry, agriculture, etc. May be members of the community, but usually are independent

TDF: Tropical dry forest 


\section{Acknowledgements}

This thesis is a representation of a stage in my life that has been one of great personal transformation. During this time, I have had wonderful moments, but also the hardest so far. The path that has brought me to this point has been full of learning, much of which is surely reflected in the thesis. I learned new ways of relating to people, to knowledge, to life; I discovered and cultivated new interests, and I broke preconceptions and personal paradigms. And although this was a long journey full of twists, forks, turns and interruptions, I am now certain that I am reaching the end at the right time. So, the first reason to be grateful is for all that has been travelled, (un)learned, questioned, visited, discovered, recognised, broken, built, and imagined because of this slow-cooked thesis. And although it may seem a solitary journey, this monster has in fact a thousand heads, represented by the people who accompanied me in different ways. This, then, is my account of them, which I hope will be as complete as possible.

\section{DANKE JE VEL! THANK YOU VERY MUCH! ¡MUCHAS GRACIAS!...}

\section{...for the supervision, guidance and revision}

Mike McCall, for having been with me before and throughout the whole PhD, but most especially for having fought for me, alongside me and even against me at times; for your effort to keep me going. For your inputs in making the arrangements that allowed me, finally, to defend the thesis. For your patience, your openness in listening to some of my crazy and stubborn ideas, your constructive feedback, your questioning and criticisms, the fieldwork experiences and the good times we have shared. And of course, for the great example of hospitality and generosity that you and Margaret have taught me in opening the doors of your house (the beautiful Basil's house) in Enschede, and in Morelia.

Joy Clancy, for your generous and enthusiastic participation that made it possible for this project to see the light of day, for the careful review of the thesis, for your effort and dedication in managing the last steps of the defence amidst this terrible pandemic, and for showing me your warmth even though we did not know each other in person. Margaret Skutsch, for being present for every part of this thesis, but especially for the thorough review of the draft. For your great support in the coordination of the WOTRO project, for your help at the beginning of the thesis, and of course for your many kindnesses, as well as your solidarity and accompaniment also in personal aspects.

Yola Georgiadou, for sharing your knowledge and critical insight during the time you were involved in the thesis, and for introducing me to authors and concepts that were instrumental in putting the pieces of the research together.

To the review committee, dr. T.A.J. Toonen, prof. dr. J.T.A. Bressers, prof. dr. S. Kuhlmann, prof. dr. E. Turnhout, and prof. dr. A. Velázquez.

To Dr. Gerardo Bocco and Dr. Alejandro Velázquez for their support throughout my career. 


\section{...for the financial, logistical and administrative support}

To the Netherlands Organisation for Scientific Research (NWO) under the programme Science for Global Development through the project "Linking local action to international climate agreements in the tropical dry forests of Mexico" (Project number W01.65.331.00), through which this research was financed.

To Dr. Paul van Dijk, director of the Twente Graduate School, for providing the conditions for the thesis defence.

To ITC, for giving me not only an academic education, but also the opportunity to work in an environment of great diversity of ideas and approaches to knowledge, and for providing me with all the facilities to carry out the research during my stays in Enschede. Special thanks to Loes Colenbrander and Petra Weber for their kind support.

To CSTM for hosting me and thus making the defence possible, thanks to the efforts of Dr Joy Clancy and Dr Michiel Heldeweg. To the CSTM staff, in particular Annemiek van Breugel, Ada Krooshoop and Barbera van Dalm-Grobben, who supported me in the first phase of this project and in managing the paperwork and travels. Barbera van DalmGrobben also for guiding me through the final part of the process.

To Astrid Scholtens-Hofenk and Mariska Buurman from the Support Office Doctorate Board, for their kind guidance.

To CIGA, UNAM for the opportunity to meet colleagues from diverse disciplines and make dear friends, for providing me with workspace. To Geraldy García, Nidia Romero, and José Luis for their administrative support during field trips, and Dr Luis Miguel Morales for the designation of a workspace. To Lupita Cázares and Dr Antonio Vieyra for faciliating a room for the defence.

To the National and State level (in Jalisco and Michoacán) offices of the Forest Environmental Services, as well as the office of Forest Education, Training and Culture of CONAFOR, for their willingness to allow me to attend meetings, workshops and field verification visits, and for the provision of key documents.

\section{...for the technical, field and desk support}

Miguel Salinas for all the shared experiences and your generous and constant help. Gabriela Cuevas, for your moral support and advice in the making of the map. Raquel González and Fabiola Velázquez for saving me more than once when my computer went crazy, and in other technological emergencies. Rolando Prado, for your support in the field trips, in the editing of figures and in the creation of the book cover. Beth Bee for being a great partner during your time in Morelia, for the field trips together, for nurturing this project with your knowledge, ideas, and connections, for the exchange of ideas and the many practical tips you gave me. Your contribution to this research is tangible and very valuable. To Tzitzi Delgado, for the shared field trips, among many other things. To Pavka Patiño and Israel Guadian for their help in the fieldwork; and Anahí Medrano and Obsidiana Granados for their help in transcribing interviews.

\section{... for the information that brought this research to life.}

I would like to express my emotional and profound gratitude to the people who generously shared time, knowledge, experiences, interests and opinions on different aspects of the PES programme. They are the main source of information and therefore 
the co-authors of this research: Al personal de la Gerencia de Servicios Ambientales del Bosque a nivel nacional y estatal (Jalisco y Michoacán) y a la Gerencia de Educación, Capacitación y Cultura Forestal, ambas de CONAFOR. Al personal de la Junta Intermunicipal de Río Ayuquila (JIRA), así como de las Reservas de la Biósfera de Manantlán, De Zicuirán-Infiernillo y de La Mariposa Monarca. Al personal del Consejo Civil Mexicano para la Silvicultura Sostenible (CCMSS), del grupo Interdisciplinario de Tecnología Rural Apropiada (GIRA), de Alternare, del Fondo Mexicano para la Conservación de la Naturaleza (FMCN), de Globe International. Mi agradecimiento especial a los comisiariados y ejidatarios de los seis ejidos en Ayuquila (Jalisco), y en Zitácuaro y La Huacana (Michoacán) que permitieron mi presencia en diversas actividades y estuvieron dispuestos a darme entrevistas, y a los asesores técnicos (los mencionadísimos TAs) que confiaron en mí, proporcionando gran cantidad de información valiosa y esclarecedora, algunos de los cuales incluso me invitaron a conocer sus áreas de trabajo.

\section{... for the mental and emotional support}

In addition to my friends and family, who have really contributed to my mental health during this time, I owe special recognition to Elsa Gutiérrez, ya que sin ti en verdad no hubiera sido capaz de llegar hasta aquí, eres una profesional impecable y una persona empática, cálida y entrañable. Singing has become a necessity that allows me to get in touch with myself, to channel stress, to express my emotions and to enjoy life more, but if this is also done in a choir, lovely bonds are formed and the beauty that comes from cooperation becomes evident, so I love you ENES choir. And may I mention my furry little friends, those who left and those who are still here, those indoors and outdoors: Mina, Lucho, Huma, Caba and Tana, my source of tenderness, joy and unconditional non-submissive love and a precious gift.

\section{...for the moral support, friendship, and love, in Mexico and the Netherlands}

To my friends and colleagues who shared with me many moments of entertainment, fun, despair, enthusiasm, frustration, and growth. Your presence, your willingness to listen and talk, your solidarity, your patience, your support and interest have done more for me than you can imagine: Tzitzi Delgado, Sandra Pola, Karine Lefevbre, Hugo de Vroom and Eunice Herrera, Berenice Solís (y también por acogerme en tu hermoso proyecto) and Gabo, Beth Bee, Gabi Cuevas, Gabi Guerrero, Elsa Morejón, Danays Castelo, Sergio Morales, Sandra Tovar, Armonía Borrego, Lucía Morales, Óscar Jurado, Miguel Salinas, Karla Oceguera, Paty Martínez, Alina Álvarez, Mabel Sánchez, Irene Pérez, Lulú González y Armando Navarrete, Lorena Poncela y Edmundo Ortuño, Raquel González, Dani López, Andrés Keiman. Ai miei cari amichi Brenda, Chely, Esme, Ireri y Mau, bon appetit!, no, no, Grazzie tante! To my comrades in a thousand battles who always have a space and a moment for me, even though years and kilometres separate us: Fernanda Marrans du Chanch, Toño Tapi-Yacson and Toko Chan, Vietminh Diezmilpas, Lore Morales, Mauro Currou Cervantes, Javier (Víctor) Ladrón de Guevara. To the wonderful people I met in Enschede, who made my stays friendly, welcoming, full of warmth, solidarity, and pleasant moments. I always have you in my memory and you are part of my life: Emile Dopheide and Caroline, Henk Kloosterman, Tina Tian, 
Divyani Kohli, Javier Martínez, Claudia Uberhuaga, Alicia Rodríguez, Esther Hondebrink, Daniela Flores-Magón and Óscar Henríquez, Alfredo Vázquez, Nick Hamm, Analía Guachalla, Laura García, Ana Maldonado, Andreea Nicolescu and many more.

\section{....and to the most important people in my life}

A mi hermosa familia, compuesta de personas amorosas, brillantes, luminosas, solidarias y generosas que siempre están conmigo, más aún en la distancia. Obsidiana, mamá, te dedico esta tesis con todo mi agradecimiento, admiración y amor, por enseñarme a luchar por lo que quiero, por tu alegría, tu inteligencia, tu increíble fortaleza, tu dulzura y la libertad en la que me formaste. Horacio, papi, todo lo que soy está iluminado por tu luz, tu amor y tus enseñanzas de vida, estás en mi corazón como una llama que me entibia el alma. Flor, hermana, aunque ya no estés físicamente, tu gran sabiduría se refleja en mi vida, te llevo conmigo siempre y a la vez te extraño con toda el alma. Abi, hermana, gracias por siempre estar presente, por escucharme, por nuestras maravillosas conversaciones, por las risas locas, por todo lo que hemos compartido en la vida, por las incontables formas en las que siento tu apoyo, por siempre infundirme confianza y seguridad, por tu ejemplo de trabajo y tu congruencia. Anahí, Zayani, Detzaní, sus palabras, sus abrazos, sus sonrisas, sus distintas formas de ser y abordar la vida, su compañía, sus logros, me hacen admirarlas cada día más, celebrar la vida, sentir que el mundo puede ser mejor si hay personas como ustedes, las amo mucho. Mariana (Pepa), te admiro por tu forma de luchar y entregarte a la vida, por las sabias palabras que se quedan en mi corazón, por tu cálido apoyo, por la manera en que transmites el amor a Chile y también a México. Lautaro y Olivier, por su eterna amabilidad y dulzura, por los hermosos detalles que siempre tienen conmigo, por su interés y atenciones, por su generosidad encantadora, Merci beaucoup! Rogelio, por siempre estar al pendiente de mí, por la música, películas y muchas otras cosas de Chile que me gustan gracias a ti. Rosalinda, Paulo y Pancho, porque con ustedes aprendí que la familia también se elige y puede crecer de formas inesperadas. Quiero quedarme siempre en sus vidas y que estén la mía, estoy muy orgullosa de verlos evolucionar. A Anita, mi adorada y preciosa tía, y a Ati y Vecha, que los tengo en mi corazón y en mis más hermosos recuerdos.

Rolo, mos, mi gran amor, mi casa, mi lugar feliz, mi mejor amigo, mi mayor cómplice, nuevamente estás presente apoyándome activamente y dándome fuerza, alegría, luz y color, tanto en lo cotidiano como en los peores y mejores momentos. He sentido tu apoyo en innumerables formas, tangibles e intangibles, como acompañarme al campo, ayudarme a materializar las ideas en imágenes, prepararme té y escuchar mi perorata sobre los capítulos, la teoría, mis dudas, mis enredos y mis iluminaciones. A través de tus ojos se disolvieron muchos miedos y pesares, tus palabras hicieron que la confianza regresara, tu amor y cuidados han sido curativos. Por supuesto que esta tesis es para ti, y el logro es compartido, como todo lo demás.

A legion of coincidences and encounters happened in this time and some names have faded in memory, but they are no less part of this journey. Thanks also to the possible readers of the thesis, I hope they will find in it some useful and interesting questions, answers, or approaches. And thanks to life for putting this great monster in my way. 


\section{About the title: The thousand-headed monster}

The thousand-head monster is a metaphor that has acquired many meanings in the making of this thesis. The term was born during the first interviews of my field work and it acquired more meanings as the research progressed. The metaphor was brought up by the head of the PES programme, who told me that sometimes the programme was like a thousand-headed monster, in order to explain the complexity of the PES concept and the difficulty of transmitting the message of the policy to forest owners, environmental services users and the general public. Many people couldn't understand what PES was, who paid and what was being paid for because of this complexity.

Some months later, in another interview with a technical advisor (TAs) who works for an NGO in Michoacán, another allusion to this monster arose, but this time, it referred to the performance of the programme's TAs, and how the government (CONAFOR) has contributed to the problem by giving these field agents indiscriminate power, ignoring their malpractices, meanwhile imposing control measures that give no results: "CONAFOR created this monster against whom it fights". This view relates to one expressed by another TA about TAs being the "villains of the movie".

As field work and data analysis progressed, this metaphor acquired greater meaning. Just like it did when I found that PES really does have a thousand heads in the implementation phase, because every year the Operational Rules (ORs) change, creating a situation in which PES cases sometimes cross over adjacent forest lands under a different types of rule, which directly impacts the work of TAs and state programme representatives. Moreover, it creates confusion among the communities enrolled in the programme, especially if there are beneficiaries in the adjacent lands, who start the programme in different years. I understood that the ORs are a shield behind which the monster hides.

I understood that one head (or many) is blind to the unethical practices existing in the programme, the closer it is to the beneficiaries and the further away it is from CONAFOR. To deal with this situation, CONAFOR blames external TAs, as the "villains" or the other "monsters". Malpractices within PES are something CONAFOR accepts, but for the beneficiaries it is a tangible and negative reality. And it is they who have to deal with it... and with the TAs.

Finally, the metaphor gained a personal meaning. My incursion to this study of the programme turned many times into a fascinating but also frightening monster. Like the Greek hydra, this monster's heads reproduced every time I tried to grasp the nature of one head. Suddenly there it was -the complexity of the programme in front of me-and I had not the necessary conceptual tools to deal with it. After many attempts to look at this monster from different points of view and different lenses, I started to discover the key problems and components that needed to be explored, I began to identify and understand its actors, to learn its language, to notice its multiple changes, its bureaucratic structure, and to understand the mechanisms that feed it so that it can survive and grow more heads. Lastly, the interaction with this monster became something very familiar, just as I myself went through great transformations. This thesis is an account of the encounter and of what resulted from my interaction with this thousand-headed monster. 


\section{Approaching the monster: Introduction, concepts and methods}

Chapter 1. Setting the scene

Chapter 2. Searching for appropriate concepts and theories on which to build

Chapter 3. Selecting appropriate tools for capture the diversity of voices in PES

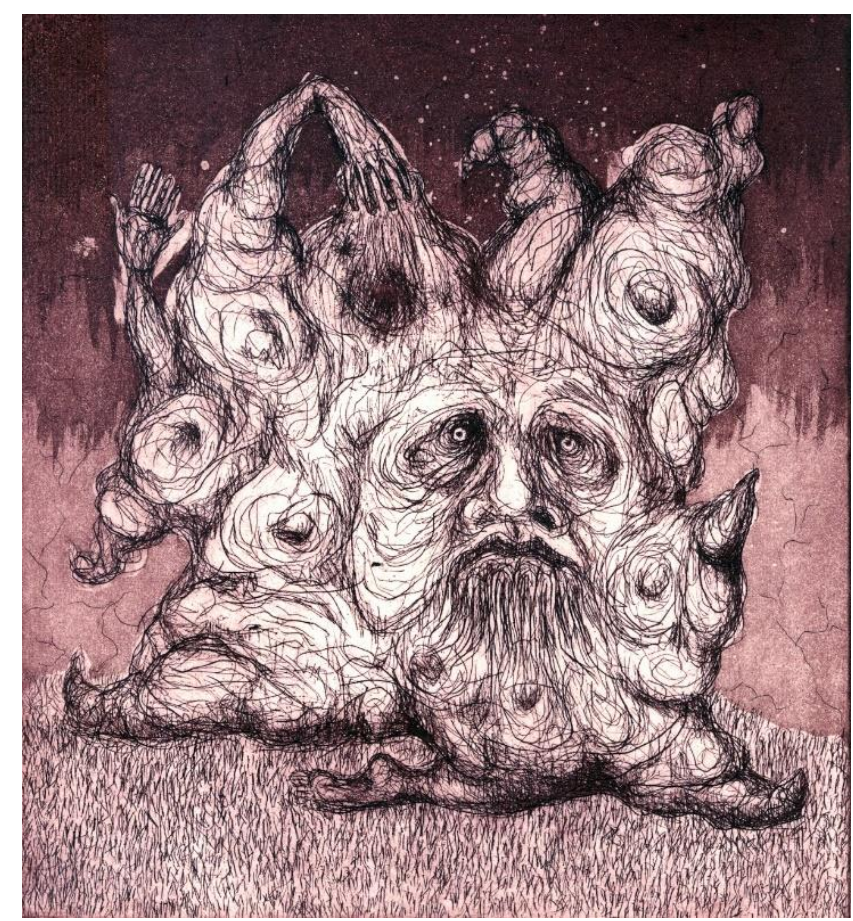

Dulce Ácido. 2015. Untitled [Engraving]. Michoacán, México. 


\section{Chapter 1. Setting the scene}

\subsection{Introduction}

In many Mexican thesis and articles about environmental matters, especially those dealing with conservation issues and natural resource management (including one of mine), México is presented as a megadiverse country: this includes its genetic, species and ecosystem diversities. It is also common to talk about cultural diversity in México and the direct relationship between the location of ethnic groups and biodiversity hot spots. Regarding forest management, a "known fact" is that 50 to $80 \%$ (the percentage varies depending on the author) of forest resources are managed collectively and belong to either ejidos or comunidades indígenas ${ }^{1}$, most of which high poverty and marginalisation ${ }^{2}$ indices. This recurring recognition made sense during my visits to the field, where human actions are manifested in the mosaic of natural and agricultural landscapes, which, when viewed in the light of the literature on forest policy and governance, began to shape my research questions. It was in this phase that the complexity expressed through diversity became tangible and clear; between what we recognise as social and natural there exist dynamic processes through which they shape each other. This has implications for the definition of strategies and policies for management, conservation and the improvement of socio-environmental conditions. Although it has been slowly changing, environmental policy in México is still vertical; it is still created by policy makers who work from their centralised offices. These policy makers find themselves surrounded by many dilemmas, starting with the conceptualisation of forests, what forest problems are, and the possible solutions to the problems that they themselves devise and those claimed by local people. In order to establish environmental policy strategies at the national level, a simplified conceptualisation of local-level socio-environmental richness, complexity and heterogeneity needs to be created.

Environmental policy in México has gone through transformations at different levels throughout its history. Relations with the local actors have ranged from the traditional top-down approaches to policies based on community management and organisation (Garcia-Berger, 2015). In parallel, there has been a conceptual/discursive transition

\footnotetext{
${ }^{1}$ Although these are legally and administratively different entities, community and ejido will be used as synonyms in this thesis. See Box 1.1

${ }^{2}$ The marginalisation index is a measure that categorises the degree of exclusion and socioeconomic deficiencies of the populations. The categories are: very low, low, medium, high and very high. The index was created by the National Population Council (CONAPO), is updated every 10 years and is presented at the state, municipal and local levels. It is measured through four dimensions: education, housing, population distribution and monetary income. These in turn are subdivided indicators (https://www.gob.mx/conapo).
} 
concerning the valuation of forests, which has moved from a predominantly productive vision (1940's-1980's decades), to a conservationist vision (1990's), and on to the recent adoption of a socio-environmental and market-based approaches ( $21^{\text {st }}$ century).

But new policy conceptions are constructed on the foundations of old laws, procedures and customs that co-exist with the new approaches. Institutional changes at the national level are not always perceived and acquired in the same way and at the same pace among the great diversity of local environments, which also have their own rules, practices and traditions (Koning, 2011). Generally, the creation of new policies and rules does not consider the necessary interaction between formal rules and local institutional dynamics (Long, 2001).

\section{Box 1.1. Communal land tenure in México}

Rural lands in México are mostly owned by ejidos and indigenous communities. These are the two legal categories of communal land tenure in the country, also named agrarian nuclei (núcleos agrarios).

In the glossary of legal-agrarian terms, ejido is "a rural agrarian population, formed by the set of lands, forests and waters of an endowment as well as the group of individuals entitled to agricultural rights" (https://www.gob.mx/pa; Alarcon, 2015). The ejido was institutionalised in the post-revolutionary period. This consists in granting land to a group or families of farmers for agriculture. Although between the period of 1917 and the 1970s the distribution of communal lands has been more intensive, the creation of new ejidos continues today (https://www.gob.mx/pa). The ejido land is formed by a parceled area for agriculture, a portion of land communally used (which are generally forests), and another to establish the settlement (legal estate). The members of the ejido are named ejidatarios

The indigenous community is the group of people who live in rural areas and share traditions, uses and customs. It is made up of all lands, forests, and waters (https://www.gob.mx/pa). It is also constitutionally recognised as legal entity and has special protection (Alarcon, 2015). The communal lands are inalienable, imprescriptible and unattachable (Alarcon, 2014). The members of the indigenous community are named comuneros.

It is estimated that about $70-80 \%$ of the forests in México are common property (Bray \& Merino, 2004; AlixGarcia et al., 2012), and that $86 \%$ of the national forests are in regions with high and very high social marginalisation (Alix-Garcia et al., 2012). Although the PES programme provides support to private land holders, it favours the participation of ejidos and communities.

Both, ejidos and indigenous communities are governed through a collective assembly, which determines the rules for the use and distribution of resources and lands, and who has access and can benefit from forest services. Therefore, property rights underlying ES stocks and flows are critical in the design of the PES programme in México, especially in terms of the distribution of ES benefits (Corbera et al., 2009). 
In México these transitions on policy-making coexist in the local forest lands, and they have left tracks; for example, the forest roads, the young forests in recovery and sawmills as evidence of the productive vision, or the 181 Natural Protected Areas $^{3}$ established from the conservationist vision. In local forests, it is even possible to read the exclusion of certain types of vegetation types that were not previously considered forests, such as tropical dry forests, which were declared useless lands and that could be cleared without permits, for agriculture.

The Payment for Environmental Services (PES) programme in México is a scheme that arose precisely from visualising socio-environmental problems from a market perspective, as a reflection of the paradigm shift occurring in the last two or three decades. The first PES programme in México, the Payment for Hydrological Environmental Services (PSAH), was established in 2003 to address deforestation in areas which where water supply potentials and where commercial forestry could not compete with land use change due to the agricultural activities (Muñoz-Piña- et al., 2008). The next year (2004), a second PES-based initiative was established, the Programme for the Development of Markets for the Ecosystem Services of Carbon Sequestration, the Derivatives of Biodiversity (CABSA) was launched, which included incentives to forest owners for biodiversity conservation through habitat restoration, the introduction of agroforestry systems and carbon sequestration (Shapiro-Garza, 2013). Carbon sequestration was later dropped, and currently, the programmes are merged in the National PES programme (which includes two modes of payment, hydrological environmental services and biodiversity) and is part of a set of programmes called PRONAFOR.

In her doctoral dissertation, Elizabeth Shapiro (2010) started showing the way in which a World Bank public servant, a Mexican president (during the 2006-2012

\footnotetext{
3 The NPAs (Natural protected areas) are one of the environmental policy instruments in México aimed to protecting biological diversity and maintaining the ecological integrity of ecosystems, which provide a wide range of environmental services, and livelihoods to local communities. México has 181 ANP: 45 Biosphere Reserves, 39 Areas of Protection of Flora and Fauna, 66 National Parks; eight Natural Resources Protection Areas, five Natural Monuments and 18 Sanctuaries. It covers an area of 90.6 million hectares, which covers $10.78 \%$ of the land area and $22.05 \%$ of the sea surface. In addition there are 377 areas voluntarily dedicated to conservation, with an area of 407 thousand 446 hectares. NPAs are under the administration of the National Commission of Natural Protected Areas (CONANP) (CONABIO http://www.conabio.gob.mx).
} 
administration) and a leader of a peasant movement frame the Mexican PES programme ${ }^{4}$ :

"Market-driven PES programmes are the most likely to be sustainable because they depend on the self-interest of the affected parties rather than taxes, tariffs, philanthropy, or the whims of donors. By providing payments on an ongoing basis, PES programmes avoid the pattern of short-term adoption followed by rapid abandonment that has characterised past approaches. They can also help reduce poverty because the areas that provide environmental services (and receive payments) correlate highly with areas of rural poverty."

(World Bank, Project Information Document, Report No.: 35419, 2006, p. 4).

"Our natural riches [...] should be the solution to resolve the problems of marginalisation and poverty in many rural and indigenous communities. For this reason we have launched programmes focused on PES, such as ProÁrbol, with which we can offer dignified sources of income for those who dedicate themselves to protect and restore our forests and woodlands, of which the indigenous people are the first owners."

Felipe Calderón Hinojosa, President of México (2006-2012), May 31, 2007, México City (Public speech for the presentation of ProArbol).

"[PES] is new type of relation within a country and between countries. It is not just about sales and monetary gains, it is new form of relationship: between the city and the countryside; industries and campesinos; developed countries and undeveloped countries; regions that are producers of waste and those that are producers of oxygen."

Miguel Tejero, leader in the movimiento iEl Campo no Aguanta Más! rural social movement, November 22, 2005 (when CABSA was launched).

In these examples Shapiro shows how, departing from a single policy, many meanings can be construed that reflect the context, values and objectives of the actors that subscribe to it, as well as the political stances of these actors. At the same time these quotes show that PES can be seen as a charismatic initiative, widely seen as an instrument reconciling the trade-offs between both development and conservation policies to promote sustainable management of natural resources and local development (Barrett et al., 2005; Engel et al., 2008; Muñoz-Piña et al., 2008; Wunder, 2005).

Apparently, the Mexican PES programme has been a meeting point, a boundary object (Star \& Greisemer, 1989), where a number of ideologies, knowledges, values, and understandings about the relations between forests and people converge and compete to gain more influence to transform, cancel or reinforce each other, resulting in a

\footnotetext{
${ }^{4}$ The quotes were taken from: Shapiro, N. E. (2010). To Revalue the Rural? Transformation of the Mexican Federal Payments for Ecosystem Services Programs from Neoliberal Notion to Development Dogma (Doctoral dissertation).
} 
"thousand-headed monster". The way in which PES has been appropriated and transformed by different actors has transcended the original rationale under which PES was created (Shapiro-Garza, 2013; Van Hecken et al., 2017). Studies on the Mexican PES programme such as those of Shapiro (2013) and Corbera et al. (2009) have shown that this encounter of competing visions has given rise to a multiplicity of results (Corbera et al., 2009; McAfee \& Shapiro, 2010; Shapiro-Garza, 2013; Van Hecken et al., 2017; Van Hecken et al., 2015).

This multiplicity of conceptualisations has materialised into a programme whose operation is built around the message to persuades forest owners to participate, as a necessary step to reach specific goals in their forest management practices (e.g. no forest land use change, prevent the presence of cattle in the plots, perform soil protection activities, among others). It is in this way that the concepts of markets, equity, sustainability, among others, can become reflected in the local forests, as well as power and identity relations among some or all of whom take part in this scheme. Forests then, as well as the territory, become an object for "symbolic operations and a screen on which social actors project their conceptions of the world" (Gimenez, 1999).

At this point I ask: through which processes do the concepts - idealised, generalised and simplified- of policies (Scott, 1998) begin to move through operative levels until they tangibly touch forests and local societies, in order to become practices embedded in heterogeneous local spaces? And it is here that we identify two spheres and two types of actors that seem far away from each other: the national level policymakers and the local forest owners, each group with their corresponding languages, rules and practices regarding forests. And what is in-between, and what is needed for the transition to happen? In the case where recipients of the PES message accept it and adhere to it, how are these new concepts interpreted so that they are adopted, and adhered-to, or end up replacing concepts that have been established at the local level (Koning \& Cleaver, 2012)? How do these new interpretations and the forms that policy acquires when it comes in contact with local territories influence and contribute to the evolution and continuity of (forest) policies?

Therefore, the first focus of this research the processes that occur at the interface between definition and practice of policy (implementation). In the implementation, the messages generated through policy pass through interpretation, negotiation, persuasion (Stone, 2002) and the exercise of discretion as they move through the different operational levels (Elmore, 1979; Hamann \& Lane, 2004). The implementation of policy is then a process of "co-construction where the values, knowledge and contexts of the actors involved influence the results" (Levin \& Datnow, 2012). 
In the case of PES in México, implementation follows a set of guidelines called the "Operational rules" (Reglas de Operación) (ORs), which establish the formal objectives, procedures, obligations, rights and restrictions of programme participants. ORs also define the main actors involved in the programme and the roles they fulfil in the programme. There are many actors involved in implementation, such as the governmental organisation in charge of the programme, CONAFOR (Comisión Nacional Forestal), and the forest owners, who are the potential beneficiaries of the programme. But a key set of intermediary actors in PES programme are external professional services providers (Asesores técnicos) (TAs), who are individuals or organisations in charge of a large part of implementation and have the closest contact with beneficiaries of the programme.

The PES is considered as emblematic, and one of the most successful programmes in the history of CONAFOR and Mexican forest policy in general, and it is also known as one of the most flexible (Alix-Garcia, 2014; Alix-Garcia et al., 2009; Sims et al, 2014). From 2003 to 2013 about 3.2 million hectares of forest have been enrolled, involving 6000 ejidos and other forest communities, while 600 million dollars have been assigned to it (GarciaBerger, 2015). The design and mode of operation of the programme has made it a potential model for the implementation of new forest management initiatives, such as REDD+. According to CONAFOR, the programme has evolved in eleven years in order to better suit national heterogeneous conditions. But, in which ways has this programme evolved? What are the main factors that fuel these changes? Do some visions have more influence than others in the evolution of the programme? How has the role of local actors and intermediaries been presented over time? What has been the role of the ORs in transmitting the message of the programme to those actors? and finally, in which ways have the messages of the programme been adapted to local conditions by intermediaries and local actors?

Some studies about the Mexican PES case have focused on its success in reaching environmental (reduction or prevention of deforestation) (Benneker \& McCall, 2008) and social (poverty reduction, and creation of ES markets) objectives. At the implementation level there has been a discussion and evaluation of different aspects of the programme, especially regarding the evolution of potential beneficiary selection and location criteria (targeting) in ORs (Alix-Garcia, 2014; Alix-Garcia et al., 2004; Sims et al., 2014; Garcia-Berger, 2015), which are thought to be crucial for the programme's success. However, in this research, ORs are seen as a multi-purpose/multifaceted device that not only indicates guidelines for the selection of participants and description of procedures. ORs are also mediating the interactions among actors and shaping both formal and informal practices in the universe of PES. And lastly, ORs are a formal representation of the PES message, the official voice, with a particular narrative, that 
can be transmitted from CONAFOR to the beneficiaries and to the public at large and analysed in those terms, since they contains the objectives, values, priorities and the role that local actors and intermediaries are expected to fulfil within the programme. In this analysis it is relevant not only to take into account what is explicitly included, but also what is implicit (e. g. the power asymmetries); and what is excluded, strategically manipulated, under-represented or less visible in ORs (Georgiadou \& Stoter, 2010; Stone, 2002).

Another critical point is the participation of the intermediaries, the TAs, in the implementation of the programme, for it is they who transfer the message of PES, enforce the ORs and maintain direct interaction with the beneficiaries of the programme. Even though the importance and performance of PES intermediaries has been recognised as highly relevant (Bosselmann \& Lund, 2013; Huber-Stearns et al., 2013; Kosoy et al., 2008; Schomers \& Matzdorf, 2013; Sternlieb et al., 2013; Vatn, 2010, among others), there are still few studies in México that focus deeply on this issue. The TAs are not mere messengers and mediators in the implementation, they are actors with agency, interests and values shaping their intervention in the programme, and their functions and influence go beyond its formal expectations. Because of that, their performance and relevance are controversial. The development of forestry policies in México has always been accompanied by intermediary figures, and currently it is not only PES that includes them in its design; they are part of most of the national programmes of forest and rural development in the country. This means that their roles have been delineated historically even before the existence of PES.

Thus, the present research is focused on the analysis of two boundary key components in the implementation of the National PES programme: 1 ) the evolution of the ORs and their drivers, as a representation of the PES message which also mediates the interaction of the actors involved in PES implementation, and 2) the interactions between actors and with the formal rules, emphasising the role and relevance of TAs as key messengers in the transmission of the ORs for the PES implementation at local level. Both ORs and TAs are shaping the perceptions of participants about the programme. ORs also represent the formality in PES, and TAs are agents that combine formality with informality in order to adjust the rules to the local contexts, also to obtain certain benefits.

\subsubsection{Purpose and questions}

The general objective is to investigate the main processes and the dynamics involved in the implementation of PES programme, identifying and analysing the role and relevance of key components and actors involved in the transference of the information. This includes considering the mediating interactions between the main actors, and the 
contributions of formal and informal practices in the continuing of the programme and their implications in the construction of local (appropriated, contextualised, adapted) PES.

The first objective of the research is to identify the key components involved in the transfer of the PES message for the implementation of the programme and the dynamics that occur in this process.

\section{Research questions:}

- Who are the main actors involved in different stages of implementation of PES programme? (Section I: chapters 1, 3).

- What are the key elements enabling the establishment of relationships between actors in PES implementation? (Section I, chapters 1 and 3; Section II, chapter 4; and Section III, chapter 7).

The second objective is to analyse the evolution of the PES programme through the examination of its Operational Rules (ORs), as the key device for implementation, and as a representation of the PES message, in terms of objectives, priorities, and the intended role of the actors involved, as well as the influence of actors and events in shaping this evolution (Section III, chapters 4, 5, and 6).

\section{Research questions:}

- How has the PES programme evolved? What changes have been most relevant? In what way are such changes represented over time? (Chapter 5)

- What are the main influences (actors and factors) shaping the evolution of the programme? (Chapter6)

The third objective is to analyse the significance of the establishment of the relationships between actors and rules in the PES programme, emphasising the role and relevance of technical experts, the PES' Technical Advisors (TAs) as messengers and mediators between local knowledge and official agencies (Section III, Chapters 7, 8,9 and 10).

\section{Research questions:}

- What are the main characteristics of CONAFOR's TAs and their expected roles in the programme? (Chapters 7 and 8)

- What are the perceptions of the main actors (CONAFOR staff and the local beneficiaries involved in the programme) about the role and performance of TAs, as well as their power and influence on the beneficiaries? (Chapter 9) 
- What are the actual roles, problems, needs and relevance of the TAs in the different processes involved in the implementation of PES? (Chapter 10)

And the fourth objective is to analyse how the dynamics occurring between formality and informality in the roles and representations of ORs and TAs have contributed to the persistence of the PES programme over time (Section IV, Chapter 12).

- How are ORs and TAs articulated through the interaction of formality and informality? (Chapter 12)

- What is the significance of the official representations of ORs and TAs in the continuity of the programme, and how do informal accounts contribute to it? (Chapter 12)

- What dynamics and alternative understandings, practices and benefits have contributed to the persistence of the Mexican PES over time? (Chapter 12).

\subsubsection{Outline}

The thesis is constructed in four distinct sections:

Section I. Approaching the monster: Introduction, concepts and methods, is composed of three chapters:

1. The introduction of the thesis, the objectives and research questions and the outline of the book. I explain briefly the origin of my questions for this research, the need for a deeper analysis on the processes and dynamics occurring at the interface between the conceptualisation and the operation of the PES programme, by the analysis of two key elements in its implementation and their role in forest governance.

2. The concepts and overall approach used to address the objectives and answer the research questions. In this chapter I explain the ways in which I use some concepts, especially relating to framing the research questions and the findings on the analysis of ORs and TAs.

3. The methodological approach, where I describe the methodology and techniques used for the data collection, the process of fieldwork and the analysis of the information, as well as a brief description of the actors and locations included in this research.

Section II. Placing the ORs under the microscope, is composed of the empirical results about the ORs, and includes three chapters:

4. An overview of what is the PES programme, its general functioning and the role of ORs in implementation. a

5. The analysis of the evolution of the PRONAFOR's ORs (which include the PES programme) over eleven years, emphasising the different types of changes that occurred. 
6. The analysis of the factors, events and dynamics between actors which influenced specific changes in selected aspects of the ORs, (the objectives, modalities and selection criteria of the programme), as well as the main actors considered and their roles in the universe of PES. The chapter also considers the omissions and under-representations of issues and actors.

Section III. TAs as the hinges in the implementation of PES, includes 4 empirical chapters about the TAs:

7. An overview of the expected role of intermediaries in the implementation of PES in several countries and especially in México.

8. The analysis of the PRONAFOR's Technical Advisors (TAs) who are engaged in PRONAFOR as controversial intermediary figures in the operation of CONAFOR programmes, by situating their historical and current working conditions, contexts, roles and relations with rural/environmental government organisations and beneficiaries of the programmes.

9. The perceptions of CONAFOR employees, relevant non- governmental actors, and PES programme beneficiaries about the importance of the role of TAs and the main problems regarding their performance. This includes the response of beneficiaries but especially of CONAFOR in dealing with the identified problems.

10. The perceptions of a number of TAs about their own role, relevance, performance, problems and needs in the development of their work. They also talk about some aspects of their relationship with the other actors involved and the perspectives of their jobs in the future.

Section IV. Dealing with the monster: Synthesis, includes three chapter about the integration of the outcomes, and the final considerations of the research:

11. Recapitulation of the research results

12. Integration of the research findings and the relation to findings of other scholars by discussing the interaction between formality and informality in the implementation of PES programme

13. Future research directions and policy recommendations.

Epilogue. A brief account of the main changes in forest policy with emphasis on the PES after the conclusion of the fieldwork for this research is provided.

References of the chapters are in the end of each section. 


\section{Chapter 2. Searching for appropriate concepts and theories on which to build}

\subsection{Introduction}

The main issues addressed in this research are:

1) the roles and evolution of two important components in PES programme implementation, that is, the Operational Rules (ORs) and the Technical Advisors (TAs);

2 ) the dynamics occurring between them: the ORs (as an instrument devoted to sending the message of the PES policy), and TAs (as the agents of the programme implementation at the local level), and in particular,

3 ) the dynamics and interactions between formal and informal rules and practices, mediated by ORs and TAs, that occur during the processes of implementation. The research also aims at making visible the 'side effects' around the official PES programme expectations, that is, the alternative constructions, relationships, meanings and practices, as well as the co-production and reproduction of informal ways that are used to fulfil the objectives of the programme. These 'side effects' are result of the interaction between the most relevant actors, and of the actors with the rules (ORs), which all contribute to the continuation of the programme over time, independently of its formally expected outcomes.

The main analysis is focused on a set of processes and interactions that occur primarily (but not exclusively) in the implementation of the PES programme. Implementation is a set of processes and interactions with fuzzy boundaries, which is intertwined and dependent on other processes in policy making. Although for the purposes of the analysis, implementation is delimited in an arbitrary way, and considering specific elements and key moments. Implementation itself is not the central object of analysis but forms the context within which the elements of the analysis, the ORs and TAs, work together.

In this process, the relevance of the 'strategies, arrangements, practices and informal means' that coexist with the formal structures of PES in three main aspects are intertwined in the implementation: the rules, the communication channels and the actors involved (Kühl, 2014), in this case, the actors are especially the TAs. Through the dynamics between actors and rules, and the parallel construction of informal structures, actors appropriate and recreate the programme by adding their own meanings to it, and by obtaining alternative and specific benefits, which may or may not coincide with the officially established goals. 
In the analysis, several concepts from a variety of different theoretical frameworks have been used. These are explained and justified in the following sections:

In Section 2.2 approaches to analysis are explored, focusing on definitions of the implementation process, the relevance it has, and the way this term is addressed and understood in this research.

Section 2.3 is focused on the analysis of the concept of governance and especially environmental/forest governance, in reference to how the PES programme has been addressed in México.

Section 2.4 is about the institutional change perspectives which inform this research.

Section 2.5 explores theory concerning the role of intermediaries.

Section 2.6 addresses the organisational approach, employed in this thesis, to the analysis of the findings as a whole.

Lastly, section 2.7 addresses the concepts and categorisation of the relationship between formality and informality, especially from the institutional and organisational perspectives.

\subsection{Research approaches in the analysis of policy}

Given that the present research is centred in the Mexican PES programme, which is carried out by a government agency focused on forest development and conservation (CONAFOR), it is necessary to situate this research in the broad framework of policy analysis, and describe briefly the specific approaches.

The dynamic processes occurring in the interaction between the social and natural systems produce complex realities. Policy makers must deal with that complexity in order to conceptualise, frame and define public problems and search for strategies. Policy makers often find dilemmas in the definition of goals, and the means and actions needed to meet those goals. In order to establish policies at the national level like PES, a simplified conceptualisation of local-level socio-environmental complexity and heterogeneity must be created by the policy makers.

It has always been a concern of the academic world to understand and improve government interventions that seek that address a given problem. The study of policies is a multidisciplinary field that encompasses a diversity of approaches, scales, methods and purposes. Although they are interconnected, public policy analysis is often divided into two strands: the study for policies and the study of policies. Analysis for policy is about observing and analysing public affairs from certain lenses in order to transform governmental actions, as well as devising mechanisms to attend to what are perceived as public problems. The analysis of policy, in contrast, has heuristic purposes and focuses 
on explaining what governments do to address public problems, that is, how and why decisions are made about the problems, the establishment of agendas, the means and procedures by which these policies are implemented, and the evaluation of the (intended or unintended) effects of such decisions (Aguilar, 1992; Dye, 1972; Howlett, 1991; Howlett \& Cashore, 2014; Parsons, 1995). This thesis follows the second of these two lines of study, the "of".

The analysis of policy as 'the study of their nature, causes and effects' (Nagel, 1990) or the study of "how, why and to what effect governments pursue particular courses of actions or inaction' (Heidemheimer et al., 1990, p.3), have been addressed from a multiplicity of approaches, and using tools from disciplines such as sociology, political science, economics, psychology, anthropology, management, among others. Depending on the nature of the goals and problem definition of the policy under study, the analysis can involve concepts and tools from different areas of knowledge, as long as they are problem focused. Regarding this multi/cross disciplinary feature of policy analysis, Majone \& Wildavsky define it as 'an applied sub-field whose content cannot be determined by disciplinary boundaries but by whatever appears appropriate to the circumstances of the time and the nature of the problem' (Majone \& Wildavsky, 1979, p. 15 in Parsons, 1995). Policy analysis involves examining how public issues are considered relevant, defined and framed, and the ways in which those issues are placed on the policy agendas, and the intended or unintended effects of these policies addressing the identified problems (Aguilar, 1992).

In this research, the dynamic of two specific components of the PES programme (ORs and TAs) are analysed in order to envision their role in addressing specific forest problems framed by policy makers (e.g. deforestation and poverty), and the way in which they shape evolution, and enable the continuity of the program over time.

\subsubsection{What is policy making?}

There is no single meaning of the term 'policy', because it depends on the different contexts and purposes in which it is developed, and its understanding has evolved over time. However, there are classic definitions of policy making, such as the one provided by Thomas Dye, as "anything a government chooses to do or not to do" (Dye, 1972). According to Howlett \& Cashore (2014), policymaking "involves both technical and political processes of articulating and matching actors' goals and means". Thus, we can say that policy is a sequence of decisions made by a government or an authority of a political system, which is always linked towards taking a specific course of action (or inaction), which produces effects on the social and political environment (Friedrich, 1963: 79, in Aguilar, 1992). More than a set of actions done once and for all, policymaking is a continuous process (Aguilar, 1992). It can take the form of formal 
structures (official, written laws, local orders, court judgments, executive orders, administrative decisions) but also of informal structures (such as unwritten agreements about what should be done) (Aguilar, 1992). Deborah Stone also provides a definition where public policy is "an attempt to achieve community goals" (Stone, 2002, p. 21). However, since everyone (as individuals or as small groups) has her/his own understanding of priorities, objectives or goals, the political community becomes a place of struggle (Stone, 2002). The policy-making process thus becomes a continuous interaction between conflict and cooperation, ideas and alliances (Stone, 2002, p. 34).

The study of what governments do, how, and why they do it, as well as the effects/impacts that these actions produce in meeting specific goals or in addressing an identified problem (Dye, 1976). In terms of these possible effects, Stone (2002) argues that ideas can define "who will be affected", and "how will they be affected" - "the ideas are the very stuff of politics"; and the authority to interpret ideas is a key factor in the policy-making process.

Although the main agent of the policy making is usually a government, the visions, values, interests, and activities of other non- government actors often influence, shape and condition the process of decision-making as well as the perception of the reality (Mendez \& Lendo, 2006). The influence and participation of non-government actors varies in different settings, contexts and political systems, but in in general, governments (try to) keep control over the moments and ways in which those other actors can be involved (Howlett \& Cashore, 2014). These interventions often shape and reshape the policies, with the possible consequence that their results do not resemble the original intentions and plans (Aguilar, 1992). This also implies that government actions and decisions very often involve unintended consequences.

Policymaking also has a discursive component, by employing narratives to explain and transmit a desired message to the public. For instance, Stone consider that policy actors create stories to tell the public, making a strategic use of arguments and metaphors in order to make their ideas persuasive. Stone examines the way in which political actors employ certain story lines and symbolic devices in order to control or manipulate the understandings about problems and their solutions, making it appear that the decisions are 'objectively' based on facts (Stone, 2002). Kühl also refers to the "exhibition aspect" of organisations, and the importance of the construction of a façade in its survival (Kühl, 2014). 


\subsubsection{Approaches to policy analysis and to implementation}

Policy analysis proceeds from a variety of disciplines and frameworks, and it seems unlikely that a single framework will be able to encompass its complexity. Approaches emphasises different aspects of public policy (Parsons, 1995). Aguilar (1992) observes two extreme stances in the analysis of policy: the rational or technical notion, and the transactional or political notion. Between them, however, there is a gradient of approaches. At one extreme the rational vision assumes maximum rationality in the formulation and decision of the policy. At the other extreme, there is a pragmatic vision which sees policy as the outcome of a negotiation between different competing interests and parties. This observation is in line with the conceptualisation made by Stone in the models she called 'market' and 'polis' (Stone, 2002).

The rational model has been criticised because it focuses on the goal-setting of the policy and the steps needed to accomplish them in a top-down manner, ignoring the actors involved who have capacities to transform those policies, and have their own interests, interpretations, feelings, and hopes. Under this conceptualisation, organisations should work as a machine, and the institutions as prescriptions to be followed, and there is no place to recognise uncertainty. Wyeland (2002) asserts that rational models give much more attention to the formal rules, leaving aside wellestablished informal rules and practices (Wyeland, 2002).

\subsubsection{Approach to implementation}

In analytical terms, there are different lines and scales of approach to the subject. The most common way to analyse policy is by dividing it into stages, the steps or processes through which a policy is developed and transformed from ideas into actions. Other visions are added from other disciplines, such as sociology and political sciences. Stone argues that in the rational model, decision-making is portrayed as going through logical/discrete steps, in order to follow the stages model of policy-making, that is, the identification of the goals to be met, determination of courses of action and possible consequences, the evaluation of those consequences, and the selection of the best alternatives. Even in this model, all decisions are ultimately serving political purposes, and the logical steps followed are mere rationalisations for such decisions (Stone, 2002, May and Jochim, 2013).

The stages model is a practical way to dissect policy in a way that facilitates the analysis of moments of the development of a policy. However, it does not necessarily imply that the stages are sequential, nor reflect the order in which these policies are developed in real settings. The stages may be intertwined or overlapping, and some may even be nonexistent. The stages model has been widely criticised for being linear, excessively 
simplistic (it does not recognise or take into account the multiplicity of internal and external factors and actors trying to influence the processes and the decisions of other actors, as well as the power games, which give it greater complexity), deterministic (it gives the impression of predicting the results if the stipulated steps are followed) and top down (decision-making process usually do not take into account the visions and influence of other actors) (Stone, 1989; Sabatier, 1999; Lindblom \& Woodhouse, 1993, among others).

However, the stages model is easy to comprehend - it allows for focusing on specific processes that occur in transitional times and spaces, where the ideas and concepts of the policy are transformed into practices, and the dynamics occurring between the actors are addressed. However, it is also pertinent to realise that stages are not discrete, but are part of a continuum, which involves multiple decision-making processes, interactions, interpretations and changes to the original decisions (Hill, 2003; May, 2013; Hupe \& Hill, 2016). Important Authors from different disciplines and approaches consider that the analysis of policy formulation separately from its implementation is artificial and ineffective (Sabatier, 1999). Lindblom \& Woodhouse (1993), for example, consider that the policymaking is incremental, such that decisions are made throughout the process and the agenda continuously modified.

At this point it is important to clarify that the concepts mentioned above are used as reference, but the analysis of findings has not followed a specific model. On the other hand, this research is not an analysis of the implementation of PES per se. And although they are important at other moments of the development of the programme, both the operational rules (ORs) and the technical advisors (TAs) play important and multiple roles in shaping what we could roughly identify as the implementation process of PES. The 'boundaries' of implementation of the PES programme have been determined empirically with the help of participants and official documents, and therefore they are arbitrary and fuzzy. This process includes the whole operationalisation of the programme, including the call for applicants, the submission of applications, the selection of beneficiaries, the development of activities required by the programme in the field, and the reporting and verification processes.

The research has been developed under the assumption (and subsequent observation) that the transition from ideas to objectives, which may or may not subsequently become specific practices, do not necessarily occur sequentially and separately. Neither ORs nor TAs are neutral entities that simply transfer the ideas and values unaltered from the higher levels of CONAFOR to the local actors or participate in the transformation of concepts into practices at the local level in an 'aseptic' way. The interaction of actors 
does not happen in a linear and pristine way. Agency of the key actors (such as the TAs) plays a fundamental role in shaping the policy and, as I will show, the ORs have "stickiness" and limits. The process contains plenty of ambiguity, ideological conflicts, power struggles, opportunistic alliances, and informal practices.

Ideas about implementation of policies are developed in the next section.

\subsubsection{Implementation and its relevance in this research}

Despite the debates between the relevance of describing the policymaking in stages or in cycles, the interaction between the ideas formulated and the courses of action is a critical process in the development of public policy. March et al. 2011 say about that: "you can design whatever you want; the problem starts when you stop designing and implementing. Please take care of the process, not of the design"(March, et al., 2011, p. 241).

According to Anderson (1975) and Van Meter \& Van Horn (1975) it used to be assumed that implementation was a set of mundane and tedious decisions and procedures unworthy of the attention of the researchers. However, those decisions occurring within implementation can have more relevance and deeper effects in policymaking (Van Meter \& Van Horn, 1975, p. 450; Anderson, 1975, p. 78-79, in Parsons, 1995). According to Parsons (1995), implementation is about "how change occurs, and possibly how it may be induced" in policies (Parsons, 1995, p. 461). The way in which the policy/ implementation relationship is perceived has consequences for the way empirical variation in policy objectives is explained. Following this idea of accomplishing a given task, Mazmanian and Sabatier (1983, p. 20-21) define implementation as the period in the policy process concerned with turning policy intentions into action.

The first understandings of implementation describe a rational and linear process that involves a sequence of steps that move from one point to another and assume that the actors simply meet the steps previously set during the formulation of policy. This is related to a top-down approach to the process, where the government defines and controls the goals, and the means to accomplish them, to the 'rational' model of policymaking or to the 'stages' model of policy analysis.

However, some scholars see those policy processes as non-linear and a-rational, using analyses to show that implementation is a complex, multidimensional, dynamic and interactive process. Some of these visions take an actor-centred approach, including various types of non-government actors interacting and playing roles at different levels of policy operation. In such a context, policy implementation involves bargaining and 
persuasion between actors with different values, interests and objectives, and whose outcomes are uncertain (Stone, 2002).

For instance, Palumbo and Calista (1990) provide a definition of implementation as a series of interactions and interpretations between the outputs of policy formation and the effects of organisational and inter-organisational impacts, between the latter and street-level bureaucratic behaviours, and between the latter and target group behaviours (Palumbo \& Calista, 1990), emphasising the role and dynamics occurring among actors in implementation, especially the local and low (street and field) level implementers and target groups, as well as the interaction of the governmental organisations with external conditions or environments.

In this context, DeLeon (1999), and DeLeon \& DeLeon (2002) and O'Toole (2000) introduce the notions of intentionality and non-linearity between 'inputs' and 'outputs'. Deleon refers to the process of implementation as the difference between what was expected and what was achieved (De Leon, 1999), and, O'Toole describes implementation as "what develops between the establishment of an apparent intention on the part of government to do something, or to stop doing something, and the ultimate impact in the world of action" (O'Toole, 2000, p.266). Both notions are relevant in this research since it considers the 'side effects' and alternative outcomes of implementation of the PES programme.

In line with the vision focused on the actors, some authors consider implementation not as an outcome, but as a multidimensional process, which involves 'emergent expressions of agency' with multiple interacting influences in dynamic contexts (May, 2015; Nilsen, 2015). This vision stresses the agency of implementers, especially the lowlevel public servants or the so-called street-level bureaucrats (and, in the case of PES, the state-level CONAFOR employees and the TAs) and their capabilities to interpret and use discretion in decision-making (Elmore, 1979; Hamman \& Lane, 2004; Lipsky, 2010). Thus, authors like Bressers (2007) focus on the actor's dynamics in the policy process to define it as participatory social interactions, where the results of the process depend on the involved actors' motivations, information availability, and relative power. This process may or may not lead to actual implementation (Bressers, 2007).

The implementation of policy is then a process of "co-construction where the values, knowledge and contexts of the actors involved influence the results" (Levin \& Datnow, 2012). Lipsky goes further by suggesting that the actions and decisions of the actors in the field become the policies they implement (Lipsky, 2010). 
It is recognised that implementation is also about decision-making in the political realm (Hupe \& Hill, 2016). May and Jochim (2013) stress the fundamental role of politics in shaping the evolution of policies, by enhancing their legitimacy, coherence, and durability (May \& Jochim, 2013).

Among the multiple conceptual lenses with which political processes are analysed, there is a growing interest in approaching policy implementation from an organisational perspective (Nilsen, 2015) to situate organisations as the main agents in the policy process (Conteh, 2011). A common interest in the organisational, governance and policy implementation perspective is to understand the ways in which government organisations interact with their external environment to carry out policies, and how this interaction affects the results of the policy (Conteh, 2011). Within the organisational perspective, concepts and theories envision different aspects of organisations, such as Institutional Theory (e. g. DiMaggio \& Powell, 1991), and the Theory of Diffusion (and change agents), which emphasises the relevance of intermediary actors for successful implementation (Rogers, 1995, in Nilsen, 2015). In this research, Luhmanns' approach to organisations is useful to visualise the development and interaction of formal and informal structures, in order not only to fulfil organisational goals, but also in order to adapt to changes and ensure continuity (Kühl, 2014). This concept is explained in detail in section 2.7 .

The study of implementation has led to the development of new models of governance --decentralisation, outsourcing of implementing agencies, multi-level and multiorganisational models, and cross-cutting policies-- (Conteh, 2011). As a result, implementation research is broadening its scope towards a multi-disciplinary, multilevel, and multi-focus perspective, recognising the multiplicity of settings, actors, loci and levels involved in new models of governance (Conteh, 2011; Lindquist, 2006), including the distribution of power in more horizontal and inter-organisational coordination. Finally, given that the role of the actors has also become more dynamic, it is crucial to understand the forms of interaction in which the messages of the policy are shared, negotiated, transmitted, assimilated, interpreted and transformed in the implementation process.

\subsection{Forest governance}

Changes in the understanding of the complexity of socio-environmental problems and the need to establish strategies to deal with them, as well as recognising the demands of local actors to play active roles in such strategies, have led to a shift in the ways to conceptualise and approach policy-making. 
In traditional models of government schemes, policy-making is carried out by the state under a command and control style, and administrative boundaries of decision-making authority are clearly defined (Sternlieb, et al., 2013). However, these state-driven environmental and development policy regimes have been evolving from top down, centralised and hierarchical schemes towards decentralised, more inclusive and cooperative models of governance (Hill, 2013), involving multi-actor, multi-level participation and multi-purpose management schemes (Lemos \& Agrawal, 2006; Arts and Buizer, 2009). Although the definition of the term is still contested, governance can be defined as "the formulation and execution of collective action at the local level. Thus, it encompasses the direct and indirect roles of formal institutions of local government and government hierarchies, as well as the roles of informal norms, networks, community organisations, and neighbourhood associations in pursuing collective action" (Bradway and Shah 2009, p. 242 in Wolman, et al., 2011). Thereby, in contrast to 'government' where non-state actors (such as communities, intermediaries, business and non-profit organisations, foundations, farmers and foresters groups, among others) are seen as passive subjects, in "governance" they are seen to take an active role in decision-making processes through participation in social networks and interactions (Hill, 2013).

According to Lemos \& Agrawal (2006), environmental governance is defined as a "set of regulatory processes, mechanisms and organisations through which political actors influence environmental actions and outcomes". Thus, environmental governance is concerned with "interventions aiming at changes in environmental-related incentives, knowledge, institutions, decision-making, and behaviours" (Lemos \& Agrawal, 2006, p. 298). In a 'governance' framing the state has less control over knowledge, and institutional resources (Natera-Peral, 2005). Given the diversity of actors and institutional arrangements involved, in environmental governance settings the authority and management are less formalised and more difficult to control, and the role of market actors are unclear (Lemos \& Agrawal, 2006; Sternlieb, et al., 2013).

Specifically regarding forests, policymakers, politicians, and scientists have explored standards of good practices, policy instruments and institutional arrangements in order to reduce and avoid forest degradation and deforestation and promote sustainable forest development. Forest governance is seen as the way in which public and private stakeholders and formal and informal institutions negotiate, produce and enforce decisions about the sustainable management of forest resources (FAO-ITTO, 2009). In this way, institutions acquire and exercise authority in the sustainable management of forest, addressing collective problems through the establishment of rules that determine forestry practices, and the roles of the actors and their interactions (Gueneau 
\& Tozzi, 2008; FAO-ITTO, 2009). Forest governance is influenced by international global declarations and treaties, but also by the market (including market -based policies such as Payment for Environmental Services (PES) and Reduction of Emissions for Deforestation and Degradation (REDD+)) (Agrawal, 2010).

In (forest) governance, there is a move towards decentralisation, which strengthens more the decision-making power of local communities, and the participation of nonstate actors (Lemos \& Agrawal, 2006). But often, the government organisations are still in control of the establishment of rules and sanctions as well as monitoring (Hill, 2013), and the definition of roles and authority of non-governmental actors remain fuzzy or unclear (Lemos \& Agrawal, 2006).

According to Hogenboom et al., (2015), in environmental governance, Latin America has been a locus of constant tensions between social movements, governments, business and NGOs, and their goals of social inclusion, ecosystem conservation and market development, in order to find inclusive ways to configure sustainable environmental and forest management. They also argue that there is a gap between the governmental discourses and production of knowledge, and between policy design/ regulation and implementation/monitoring. Thus, governments in Latin America refer to the Millennium Development Goals as a strategy to address socio-environmental problems (such as poverty, inequality, provision of environmental services, biodiversity, among others). But in practice, large-scale economic projects of mining and oil extraction are supported by many governments as a priority (Hogenboom, et al., 2015).

The establishment of neoliberal policies in Latin America since the mid-1980s promoted the privatisation of natural resources (lands, forests and water, fisheries), and produced critical socio-environmental impacts in the region (Hogenboom et al., 2015; Liverman \& Vilas, 2006). At the same time, alliances were established between civil society organisations, international NGOs and academic organisations, and, in the case of México, peasant associations (McAfee \& Shapiro, 2010), giving rise to alternative institutional perspectives of governance linked to local actors and their interests (Hogenboom et al., 2015). This facilitated 'glocalisation' processes that linked local and global actors to the management of natural resources. However, the prevalence of inequality, poverty, corruption and violence, as well as the limited institutional capacities and elite power hindered the implementation of initiatives based on those perspectives (Larson \& Ribot, 2009). According to Hogenboom et al., (2015) in the past decade more environmental/forest governance initiatives for the resolution of socioenvironmental problems from the local/civil to national level have emerged (bottom 
up), and others still come from international pressure to the governments (top-down), such as PES schemes.

\subsubsection{Critique on forest governance}

The perspectives on forest governance have implied a significant change in the way resources are administered and in the resolution of public problems. However, some authors have observed that these new schemes do not necessarily lead to better results in terms of promoting equity, balancing of powers among actors, or fairer strategies for the use of natural resources.

Forest governance tends to seek administrative decentralisation, the active participation of state and non-state stakeholders in a variety of potential arrangements, as well as a more balanced distribution of power. In practice, governance systems are a gradient of hybrid forms of governance, composed to a greater or lesser extent by elements of both traditional government and new governance arrangements beyond the state (Arts, 2014). In these arrangements, the role of the state can vary, since, according to Arts, "governance may at the same time refer to governing by, governing with and governing without the state". The role of relative power in the involvement of the state actors can also determine if governing occurs by "forcing others, persuading others or exchanging resources with others to let them do things in accordance with public policy objectives" (Arts, 2014, p.19).

There are criticisms about the scope of forest governance schemes and the way in which they are used to maintain the asymmetric power relations that characterise traditional government models. For instance, Hill argues that the role of the state in the establishment and application of legislation and regulation remains key in governance schemes and it can unilaterally change the "rules of the game" (Hill, 2013). According to Arts (2014), governmentality studies have provided alternative views about the ways in which the state adjusts its role and influence regarding non-state actors. Thus, although some philosophical and empirical aspects of the governmentality perspective can be incompatible with the governance approach, this perspective provides some arguments to analyse and understand the role of the state in new models of governance. The concept of governmentality was coined by Michel Foucault in 1978, defined in a broad sense as the "techniques and procedures for directing human behaviour" and "the reason of the state", in order to analyse political power (Rose, et al., 2006) and explain the transformation and functioning of the state (Arts, 2014). The advocates of this vision claim that, contrary to the expected reduction of government control and increasing local participation and decision-making, the state strategically uses governance ideas to keep central control and reaffirm power relations (Arts, 2014). 
Other criticisms of the concepts and idealisation of forest governance come from critical institutionalism (Cleaver \& de Koning, 2015; Koning \& Cleaver, 2012), especially from the institutional bricolage perspective, which is explored in more detail in section 2.5.2. They argue that the mainstream institutional approaches centred in institutional formalisation, do not consider the complexity of the different settings and levels of operation, and tend to be based on a rational conceptualisation. According to Koning and Cleaver (2012), forest governance is a very popular concept in policymaking, because, in the view of mainstream institutionalists, it promotes principles and guidelines for forest use, local development, and social justice. In this perspective, formal, well-designed institutions are key mechanisms for promoting "good governance" of forests at the local level. They recognise local knowledge and traditions of cooperation as useful for good natural resources management, but they must be integrated in formal and public institutional frameworks (Koning \& Cleaver, 2012). Thus, institutions provide "information and assurance about the behaviour of others, to offer incentives to behave in accordance with the collective good and to monitor opportunistic behaviour" (Koning \& Cleaver, 2012, p. 278). These ideas have influenced sustainable forest and natural resource management initiatives and regulations over time, such as community forest management, forest/timber certification mechanisms, and payment for environmental services schemes. However, the actual practices and outcomes produced in forest management from those interventions remain ambiguous (Koning \& Cleaver, 2012; Cleaver \& Koning, 2015).

In this research it is assumed that the actors in PES programme are entities with agency, who dynamically shape the rules, and produce (and reproduce) formal and informal arrangements that allow them to align, fulfil and transform the collective and individual objectives of the programme. These actors interact under power asymmetric conditions, so they sometimes compete to gain more influence in decision-making and challenge and resist the influence of the dominant actors, but they also carry out practices that facilitate cooperation. Different governance models may enable the construction of more horizontal relations but can also perpetuate the privilege of certain actors.

\subsection{Institutional perspective in this research}

Since governance involves the establishment of formal and informal institutions (seen as sets of rules, standards, and procedures) shaping the relationships between the actors to fulfil certain objectives, institutional approaches are also relevant in this research, especially those focused on the dynamics affecting institutional change and continuity. 


\subsubsection{What are institutions?}

Although some perspectives consider them synonymous, this research distinguishes between institutions and organisations. In simple terms, institutions are rules that structure social interaction by shaping and constraining the actor behaviours that structure social interaction (Helmke and Levitsky 2004; North 1990); the formal and informal constraints, that is, the rules, standards and procedures. Meanwhile organisations are the actors or "groups of individuals with some common purpose to achieve objectives", who create, enforce, fulfil and transform the institutions (North, 1990, p. 5; North, 1991).

Ostrom provides a wider definition of institutions as "the prescriptions that humans use to organise all forms of repetitive and structured interactions including those within families, neighbourhoods, markets, firms, sports leagues, churches, private associations, and governments at all scales"(Ostrom, 2005, p. 3).

Formal and informal institutions shape actors' behaviour within a policy (North, 1991; Ostrom, 2005). Vatn says about this relationship: "governance is about forming institutional structures. It concerns making social priorities, resolving conflicts and facilitating human coordination. It is hence about how we establish goals, how we define rules for reaching the defined goals, and finally how we control outcomes following from the use of these rules" (Vatn, 2010, p. 1246). It also has to do with the type of actors who can be involved, the ways in which they interact and the institutional arrangements that are put in place for management of resources or achieving certain goals. He proposes a broad definition of institutions as "solutions to collective choice problems" (Vatn, 2010).

Some authors have distinguished between formal and informal institutions that shape social interactions and are relevant in the natural resource management at the local level (Ostrom, 2005). For instance, according to Helmke and Levitsky (2004), formal institutions are officially accepted rules, generally enforced by a state actor. Meanwhile, informal institutions are socially shared behaviours and norms enforced outside official channels, (Helmke \& Levitsky, 2004).

State and non-state actors seek to influence the policy outcomes through formal and informal rules, and this configures a variety of modes of governance (Hill, 2013). For instance, Thompson (1991) has classified three modes of governance according to the influence of state and non-state actors: bureaucratic hierarchies, networks and markets. Hierarchical governance refers to top down command and control government (Hill, 2013). In networks, state and non-state actors are involved, where interactions are predominantly shaped by informal institutions. In market-based modes, the non-state 
actors become more relevant across formal and informal institutions. The Mexican PES programme is a combination of the market-based mode with the traditional centralised top-down mode.

The everyday interaction between actors involved in different modes of governance, their power struggles and alliances, and the flexibility of the roles they can perform under different schemes, contribute to shaping formal and informal institutions that guide behaviour over time.

\subsubsection{Institutional change}

Chapter 6 of this thesis addresses the evolution of the PES programme and one of the key elements guiding its implementation, the Operational Rules (ORs). For analytical purposes, ORs can be seen as micro-institutions, which determine the expected roles of actors involved in the programme, and the outcomes of interactions between them. To carry out this task, elements of institutional theory allow us to analyse ORs as institutions that govern the behaviour of the actors involved in PES. Using this approach, it is possible to describe and explain the influences, pressures, and tensions between actors, ideologies, interests, the search for legitimacy, and the preservation (in a dynamic, adaptive way) of the PES programme over time.

According to Campbell (2010), "institutional continuity and change are flip sides of the same coin, they are mutually constitutive, and many of the drivers that influence change, also stabilise them" (Campbell, 2010). There is the recognition of institutions as dynamic entities in continuous processes of reproduction and adaptation (Streeck \& Thelen, 2005), which is driven by actors with agency, different interests and capacities to interpret and enforce rules, and unbalanced power relations (North, 1990; Streeck \& Thelen, 2005). In these visions, institutions have been conceived not only as limits that restrict the decisions of the actors, but also as opportunities for actors to influence, transform and change the rules themselves (Campbell, 2010; Jackson, 2010).

\subsubsection{Theory of gradual institutional change}

Mahoney and Thelen's (2010) theory of gradual institutional change is centred on the endogenous process of change, driven by the actors involved in promoting subtle and continuous change over time. Mahoney and Thelen do not deny the exogenous drivers which can operate bigger transformations of the rules, but they pay more attention to how actors transform institutions through their everyday actions and interactions (Mahoney \& Thelen, 2010). According to this vision, agency, power (exogenous and endogenous), and ambiguity are significant elements to explain the gradual change 
(Mahoney \& Thelen, 2010). Thus, through continuous revision, interpretation and enforcement of the rules, actors can take advantage of the resources and ambiguities of the institution to finally shaping it.

Institutions can also be subject of different interpretations by the actors involved (Mahoney and Thelen 2010). There are 'gaps and soft spots' and actors are able to take advantage of them to manipulate the results and compete to gain influence (Mahoney and Thelen, 2010). This depends not only on agency (Mahoney and Thelen, 2010), but also on the ambiguity of the rules. Power is significant in the analysis, since it is assumed that there are asymmetrical power relations between actors, and through alliances, struggles and political arrangements, actors frequently try to obtain benefits within the institutions. Thus, power dynamics, agency (and creativity), and ambiguity produce a constant instability of the rules (Hall, 2010), which can permit to subtle or deep changes over time. Explaining change requires an understanding of the complexity of the interactions of actors and factors at different levels, both within and outside the rules themselves.

\subsubsection{Path Dependence and Bricolage}

In Chapter 6 of this thesis other concepts have been adopted: path dependence and institutional bricolage. Path dependence focuses on the forces driving reproduction or limited change (Pierson, 2000), although this approach has been criticised for being highly deterministic (Cleaver, 2001; Thelen, 1999). There is a constant play between institutional stability and change, which is determined by constraints in which the rules are introduced. Path dependence seeks to "analyse the drivers of continuity" (Thelen, 1999). Path dependence points out that decisions made in the past have (directly or indirectly, intended or unintended) consequences on present and future choices, and that the sequence in which these decisions are made does matter (David, 1985, 2007; Rixen and Viola, 2015). Continuity does not necessarily mean repetition of the same outcome over time. According to North (1991) path dependency can also be a process of limited change (North 19901). Institutions can also be subject to gradual changes, even if they are following a pathway, so that stability and change can occur simultaneously (Thelen, 1999; Rixen and Viola, 2015). Among the criticisms of the concepts of gradual institutional change and path dependence, is the assumption that actions of stakeholders are always rational. Instead, actors can make more idiosyncratic and opportunistic decisions, producing non-intended results within institutions (Peters, 2012).

Institutional bricolage, described by Cleaver, 2001 is "a process by which people consciously and unconsciously draw on existing social and cultural arrangements to 
shape institutions in response to changing situations". It helps to explain the role of creativity of actors in the development of institutions (Cleaver, 2001). It helps to make evident the ways in which actors use the resources they have at hand and make arrangements to transform or produce institutions (Douglas, 1986; Cleaver, 2001; Koning, 2012). Actors take advantage of their social, cultural background, social arrangements from other institutions, ideas and emotions, more than just using rational strategies (Koning, 2012). All the processes above can together contribute to explain in a better way the complexities and dynamics of institutions.

Ideas and concepts from Institutional approaches have informed three aspects of this research.

- $\quad$ First, they help to understand the interaction between actors, and between actors and rules in the implementation of the Mexican PES scheme, especially regarding the programme's intermediaries, the TAs (this is present throughout the whole thesis).

- Second, they are used in the analysing and explaining the causes of the evolution of the ORs over a period of 11 years, by employing ideas from theories such as path dependency and gradual institutional change (chapter 6).

- Third, they inform the relevance of the interaction between formal and informal rules, communication channels and actors, in the implementation and persistence of PES programme over time (addressed in section 2.7 of this chapter, and in chapter 12).

\subsection{Intermediaries, their roles and disciplines in development programmes}

Since TAs are the main intermediaries in the implementation of the Mexican PES programme, it is necessary to address definitions and theoretical approaches about their role. Chapters 7, 8, 9 and 10 of this book address the role and relevance of the TAs in PES programme, from different perspectives. This section (2.5) explores the understandings, expectations and relevance of these agents in implementation of policy, both in classic government systems and in more horizontal and multi-actor governance schemes. Implementers can be government officials (bureaucrats), or other agents who perform this work. There are PES schemes in which the government hires third parties to carry out the implementation. These agents acquire different names and responsibilities, and in the literature, they appear as intermediaries, although also as development agents, implementers, among others. 


\subsubsection{What are intermediaries?}

The need for theoretical and empirical research on intermediaries has been recognised by different authors: (Meulen et al., 2005; Bracer et al., 2007; Medd and Marvin, 2007; Moss et al., 2009; Moss, 2009; Muradian et al., 2013; Pham et al., 2013; among others). However, there is a scarcity of empirical literature about the actual roles of intermediaries (Meulen et al. 2005).

Intermediaries are entities that can be defined by their "in- between-ness" (Moss, 2009; Moss, Medd, Guy, \& Marvin, 2009), that is, the position or occurrence between two persons or things (Mike \& Simon, 2008). They are recognised by their capacity for cutting across and connecting entities, which can be seen as a transboundary function (Moss et al., 2009; Sternlieb et al., 2013), agents mediating interactions (Mike \& Simon, 2008). Intermediaries can play different roles depending of the contexts, sometimes fulfilling an intermediary function by chance, and sometimes, situating their work "deliberately 'in between', bringing together and mediating between different interests" (Meulen, et al., 2005). Intermediaries are fundamental to the mediation in the interaction of groups moved by different interests, speaking different languages (Olivier de Sardan, 2005) or having different knowledges (Meulen et al., 2005; Sternlieb et al., 2013). In natural resources management, they fulfil a multiplicity of roles (Medd \& Marvin, 2007). They are key actors in the implementation of policy strategies into local practices (Hamann \& Lane, 2004; Medd \& Marvin, 2007).

According to Khurana (2002), the actors to be connected "often are aware of each other's existence, but their relationships are initiated and developed largely through an intermediary". In situations where they cannot, or choose not to, interact directly, a third party fills the gap between them (Khurana, 2002).

The nature and characteristics of intermediaries vary considerably (Medd \& Marvin, 2007; Meulen et al., 2005; Moss, 2009; Moss et al., 2009; Schomers, et al., 2015). They can be individuals or organisations stemming from different sectors, such as government, academic, civil society organisations, and private companies, operating between other entities, institutions, scales, etc. (Moss, 2009; Schomers et al., 2015; Sternlieb et al., 2013). The common characteristic of intermediaries is not in the type of organisation they come from, but in the type of work they perform (Moss et al., 2009). They can act within bilateral relationships, traditional government and multi-actor governance schemes, social networks and in information flows among actors (Meulen et al., 2005; Van Lente, et al., 2003).

The role and relevance of intermediaries have demonstrated in innovation systems (Boon, et al., 2011; Howells, 2006; van Lente et al., 2003); brokerage in markets 
(Khurana, 2002; Medd \& Marvin, 2007; Moss, 2009; Moss et al., 2009), agro-food marketing (Keys, 2005) education (Hamann \& Lane, 2004), development projects (Olivier de Sardan, 2005), market-based forest management strategies (Coggan et al., 2013; Huber-Stearns et al., 2013; Pham et al., 2013; Davis et al., 2015; Schomers et al., 2015; Bosselmann \& Lund, 2013; Ezzine-De-Blas, et al., 2016; Huang \& Upadhyaya, 2007; Swallow, et al., 2007; Vatn, 2010), and boundary organisations connecting science and policy (Guston, 2001; Klerkx \& Leeuwis, 2008). Intermediaries can emerge and adjust to new institutional arrangements, in contexts of changing models of governance (Sternlieb et al., 2013). They are agents of social learning (Sternlieb et al, 2013) and institutional change.

\subsubsection{Ambivalent effects of the work of intermediaries}

The work of intermediaries is not neutral (Mike \& Simon, 2008; Olivier de Sardan, 2005); their own interests, values and goals are also a determinant factor in the types of relationships in which they intervene (Bosselmann \& Lund, 2013; Mike \& Simon, 2008; Moss, 2009). The results of such intermediation can help to reduce conflicts and divisions, but can also produce or maintain divisions between groups, for example to keep influence and legitimacy over some interactions (Moss et al., 2009, Bosselman and Lund, 2013). Hamman and Lane (2004) assert that the formation and implementation of policies imply interpretation and negotiation, sense-making, ambiguity management and the exercise of discretion, emphasising the key role of actors working in the interstices of those processes (Hamann \& Lane, 2004).

Although the positive effects of the involvement of intermediaries have been recognised in PES, there are also examples negative or unintended consequences of their interventions (Pham, et al., 2010). For example, they can positively or negatively influence the transaction costs to carbon offset buyers and sellers (Coggan, et al., 2013). As information providers, intermediaries can take advantage of isolated, dependent or less powerful stakeholders, exerting excessive influence and control over processes (Huber-Stearns, et al., 2013; Pham et al., 2010) and decision-making. They can contribute to the loss of aspects of the local culture (Pham et al., 2010), by imposing or inhibiting certain practices and knowledge, and produce or reinforce inequalities in access to resources (Bosselmann \& Lund, 2013; Huber-Stearns et al., 2013). Intermediaries can transfer information among stakeholders, but they can also hide it or distribute it discretionally (Bosselman and Lund, 2013), deliberately favouring or negatively affecting actors.

Olivier de Sardan (2005) suggests that "the intermediaries comprise the primary vectors of the moral economy of corruption [...] by virtue of their functions, which are centred 
around mediation"(Olivier de Sardan, 2005, p. 168). Specifically on PES, Vatn and Angelsen (2009) warn about the potential unethical practices in schemes like PES and REDD+, when intermediaries with influence hoard resources for other purposes or actors (Vatn \& Angelsen, 2009). There are also claims that PES intermediaries consume most of the payments in transaction costs (Wunder, et al., 2008). Intermediaries can involve in careless and poor practices, such as carrying out participatory work only to meet predetermined goals, rather than to capture local needs and capabilities (Pham et al., 2010).

\subsection{The organisational approach}

This research focuses on the processes and interactions in the implementation of the PES programme, paying special attention to the multiple roles of the key boundary components (TAs and ORs) in this phase. As is evident in the empirical chapters of this thesis, specific concepts provide theoretical support to findings in different areas of the research (chapters 4, 5 and 6 about ORs, and chapters 6, 7, 8 and 9 about TAs). In order to visualise the findings as a whole, it is considered that organisational theory, especially which was developed within the systems approach (e.g. Luhmann, in Kühl, 2014), provides concepts that enable the analysis of such components in action.

A variety of ways to conceptualise organisations with different approaches (rational, institutionalisms, systemic, among others), and from a variety of academic disciplines (such as economics, psychology, anthropology, sociology, labour and administrative sciences) have developed. Aldrich and Ruef's definition of organisations in centred on the social processes involved in their creation and persistence as "goal- directed, boundary-maintaining, and socially constructed systems of human activity" (Aldrich \& Ruef, 2006). In systems theory, organisation is defined as "a form of social system which can be differentiated from other social systems like families, groups, networks, protest movements, and nation-states" (Kühl, 2014, p. 6), which "has the ability to hold their ground in a world of at first unlimited complexity".

Scholars have identified certain characteristics that contribute to defining organisations. For example, in the first place, they are expected to pursue common objectives, some of which are generalisable and others specific to each organisation. Within the generalisable objectives are the search for survival (perpetuation), and therefore continuity, legitimacy, coherence, delimitation of boundaries, and conditions of membership (Pfeffer, 1997). Luhmann, in Kühl's account, focuses on the basic features of organisations in modern society, namely, membership, goals, and hierarchies (Kühl, 2014). 
In functional terms, scholars have employed metaphors that illustrate the various ways in which the functioning of organisations is represented, emphasising or blurring out certain features of them. Kühl elaborates on three of these metaphors of organisations: machines, games and façades. In this research I use the concept of the function of façade, described as the 'visible side' or 'polished image' of organisations, "to make as favourable an impression as possible on the outside world" in order to gain legitimation (Kühl, 2014, p. 89). The façade is dynamic and flexible, because it responds to the needs of the organisation to demands from public. In the PES programme, it will be seen the ways in which both, the ORs (as institutional guidelines for the implementation of the programme), and the TAs (and the ways in which their performance is portrayed) have Led specific roles in the building of CONAFOR's façade.

Kühl (2014) also stresses that informality is an integral component of organisations, since their functioning depends on the continuous interaction between formal and informal structures, decisions, premises or preconditions that exert a formative influence on future decisions (Kühl, p. 95). To understand the interaction and mutual shaping of formality and informality in organisations, three distinctive structures have been examined by Kühl, namely: programmes, communication channels and personnel (Kühl, 2014).

- Programmes determine which actions in the organisation are permitted (rewarded) and which are not (sanctioned).

- Communication channels define the way information can and must be communicated within the organisation and the pathways it must follow.

- Personnel determine the type of individual who is placed in a given position and will make decisions.

Table 2.1. Structures organisations described by Kühl (2014)

\begin{tabular}{|l|l|l|}
\hline \multicolumn{1}{|c|}{ Formal structure } & \multicolumn{1}{|c|}{ Examples } & \multicolumn{1}{c|}{ Purpose } \\
\hline Programmes & $\begin{array}{l}\text { Management planning programs, } \\
\text { directives, computer software, } \\
\text { and business policies fall into this } \\
\text { category. }\end{array}$ & $\begin{array}{l}\text { To determine which actions in the } \\
\text { organisation are to be viewed as } \\
\text { right and which as wrong. }\end{array}$ \\
\hline $\begin{array}{l}\text { Communication } \\
\text { channels. }\end{array}$ & $\begin{array}{l}\text { Rules and procedures, the } \\
\text { division of labour, the flow of } \\
\text { information, co-signing authority, } \\
\text { the hierarchical structure, or } \\
\text { rules concerning signatures. }\end{array}$ & $\begin{array}{l}\text { To define the way information } \\
\text { can and must be communicated } \\
\text { within the organisation and the } \\
\text { pathways it must follow. }\end{array}$ \\
\hline $\begin{array}{l}\text { Personnel or } \\
\text { members }\end{array}$ & $\begin{array}{l}\text { Work positions and hierarchies } \\
\text { Make a difference for future } \\
\text { decisions }\end{array}$ \\
\hline
\end{tabular}


In this research, the ORs are one of the many formal expressions of the organisation, which represent the Kühl's 'programmes'. They contain the goals, as well as the specific conditions of membership and hierarchical functioning of the Mexican PES scheme. The interactions occurring between actors in the PES programme correspond to Kühl's 'communication channels'. Personnel includes the main actors involved in the programme, namely, CONAFOR's central and state level staff, the local beneficiaries, and especially for this research, the technical advisors (TAs). The TAs are actors who play a challenging role in terms of membership in PES, and in some cases in the hierarchical arrangement of the programme. Their main task is ensuring that the PES' ORs are known and fulfilled by the beneficiaries at the local level, far from the view and monitoring of the CONAFOR headquarters. In doing so, they interact with multiple actors, with whom they develop a set of formal and informal arrangements and practices that impact the implementation of the programme.

\subsection{Conceptualising informality and its interaction with formality through organisational and institutional perspectives}

Traditional perspectives around the analysis of public policy conceive implementation as a more or less linear progression of formally pre-established processes and interactions to achieve the expected outcomes. However, as seen in section 2.2.4, policy implementation is a complex and multi-dimensional process, it involves a set of interactions and interpretations (Palumbo \& Calista, 1990), where the final outcomes are co-produced by the actors involved (Levin \& Datnow, 2012). Organisations indeed establish a set of 'decision premises'" or formal structures for implementing frameworks to meet their goals, but this can fail if the members adhere exclusively to formal commands (Kühl, 2014). Following this logic, Helmke and Levitsky say: "when institutions function effectively, we often assume that the formal rules are driving actors' behaviour. Yet in some cases, underlying informal norms do much of the enabling and constraining that we attribute to the formal rules" (Helmke \& Levitsky, 2004).

We see the importance of recognising the interaction processes of formal and informal structures (which are equivalent to the formal and informal institutions described by Helmke and Levitsky) in the implementation of instruments such as the PES programme. Such analysis allows us to understand the ways and strategies through which the actors interact and try to gain influence in the implementation (and its outcomes). In this thesis, informality and its interaction with formal institutions and structures is included to explore the dynamics underlying the adaptation of the PES programme message and precepts, as well as the persistence of the PES programme over time. 
One of the difficulties of studying informality is precisely its non-visibility, since it is (re)produced in 'grey zones' with 'blurred boundaries' (Ledeneva, 2018). Additionally, the diversity of informal expressions is context- bound, complex and ambivalent (Ledeneva, 2018). Informality is created, communicated and enforced by non-official, outside of public official channels (Helmke \& Levitsky, 2004). It used to be neglected in official discourses and policy analysis too. However, according to Ledeneva, informality is associated with our capacity for "doublethink, double standard, double deed and double incentive" (Ledeneva, 2018, p. 4).

While informality has been increasingly recognised as a significant aspect of the human action, it is not easy to define it in theoretical terms. Guha-Khasnobis et al., suggest that it is easier to think of formality and informality as metaphors (Guha-Khasnobis, et al., 2006).The term includes a wide range of definitions, since it has been addressed from a variety of purposes, disciplines and perspectives. Ahlers et al., suggest that through informality we understand more about the authority to legitimate certain practices we do than about the condition of the particular practices (Ahlers, 2014).

\subsubsection{So, what is informality?}

In the first page of her Global Encyclopaedia of informality (2018) Ledeneva refers to it as the "world's open secrets, unwritten rules and hidden practices" or the "ways to getting things done" (Ledeneva, 2018, p. 1). Generally, informal practices are marginal, since they "emerge unofficially or underground" and "coexist but also penetrate, divert and exploit formal institutions" (Ledeneva, 2018, p. 1-2).

Different approaches and aspects of informality have been addressed by a variety of authors (Hart, 1973; Bromley, 1978; Lipton, 1984; Ostrom 1990; Olivier de Sardan, 2005; North, 2008, among many others). This section is focused especially on Helmke and Levitsky's institutional perspective (2004), and the organisational perspective provided by Kühl (2014).

Depending on the modes of governance of the settings, informality can emerge from a vertical "top-down", or from bottom-up decentralised processes with multiple actors, or even as an unintended structure as a result of particular conflicts and compromises (Helmke \& Levitsky, 2004).

For Helmke and Levitsky (2004), informal institutions are-"socially shared rules usually unwritten that are created, communicated and enforced outside officially sanctioned channels".-And, formal institutions are "rules and procedures that are created, communicated, and enforced through channels widely accepted as official" (p. 727). This 
is compatible with the way in which Kühl describes informality in organisations as "the expectations [...] that are not formulated with reference to the terms of membership". According to him, informality can also be the "underlife and culture of an organisation", which represents "undecided decision premises" (Kühl, 2014, p. 114, 117).

Both Külh and Helmke \& Levitsky argue that a simple, localised, brief deviation in the course of formal daily practices cannot be considered as 'informality'; the informal practices must be reproduced routinely, as preconditions for the decision making processes: "We speak [of informality] only when we recognise that the deviation occurs with certain regularity, one might say, when it has a structural quality; [...] ] network of reliable organisational pathways that are travelled time and time again" (Kühl, 2014, p. 115).

Another characteristic recognised by both Kühl and Helmke and Levitsky is that informal rules and expectations have their own mechanisms of enforcement or imposition, through positive and negative sanctions. According to Helmke and Levitsky, the informal sanctions are often "subtle, hidden and even illegal" (Helmke and Levitsky, 2004, p. 733). But, according to Kühl, sometimes the imposition of informal expectations can be also linked to formal structures: "when imposing informal expectations, we must not overlook that it is also possible to draw on the resources available through an organisation's formal structure" (Kühl, 2014, p. 128).

Kühl mentions that, according to Luhmann (1968, 2002, in Kühl, 2014) trust is an important component of informality, since informality is developed and enforced through the exchange of favours and concessions, which are generally based on the assumption that they will be paid back in the future.

\subsubsection{The relation between formality and informality}

Many studies have categorised the relationship between formality and informality as a dichotomy, but this is widely debated (Guha-Khasnobis, et al., 2006). For instance, some authors have suggested that, since the division between formality and informality is not clear, in practice they are not split in discrete terms, but there is a fluid connection between them as a continuum (Lipton, 1984, in Guha-Khasnobis, et al., 2006). But there are also different interpretations of the divide between formality and informality. For instance, rather than visualise the duality as "either-or", to describe the formality and informality deemed as mutually exclusive, authors have centred on the "both-and", where the formality and informality are considered as mutually constituted (Helmke \& Levitsky, 2004; Kühl, 2014, Ledeneva, 2018; Katomero \& Georgiadou, 2018). 
Following the perspective of 'both-and', through the interaction between formality and informality new practices and meanings are co-produced and reproduced. This also implies that the relation between formality and informality is dynamic, in continuous redefinition and negotiation (Ahlers, et al., 2014). Ahlers et al., refer to this as 'coproduction', and not only as the results of cooperation between state and non-state actors. For them, these interactions occur with manifest tensions and political and power asymmetries, producing or perpetuating distributive inequalities (in services, resources, etc.) among the actors involved (Ahlers, et al., 2014).

In institutional terms, formality and informality can seem contested or opposite, but they are interconnected and shape each other (Ledeneva, 2018). Informal rules are fundamental to explaining institutional outcomes, since they support or hinder the trust and effectiveness of governance schemes (Hill, 2013). They can also incentivise the compliance of formal institutions and resolve tensions between what it is permitted and what it is not (Helmke \& Levitsky, 2004; Ledeneva, 2018). For instance informality can shape the outcomes of rules without directly disobeying them, thus reconciling actors' interests with existing formal institutions (Helmke \& Levitsky, 2004; Hill, 2013). In the same ways, formality enables or hinders the options and forms of informality (Ledeneva, 2018). In organisational terms, according to Luhmann, organisations often "tolerate and even promote illegality" to balance the rigidity of rules, thus facilitating the response and adaptation in face of external changes (Luhmann, 1964, in Kühl, 2014).

\subsubsection{How does informality emerge and persist?}

There are several drivers and contexts under which informality emerges to play a role, for instance providing fluidity and resistance to formal expectations (Ledeneva, 2018). Kühl mentions that it is impossible to formalise every expectation of an organisation, and that it is not even necessary (Ahlers, et al. 2014). Organisations are "pervaded by shortcuts, tricks, and back channels which in theory could be translated into routines that are officially endorsed" (Kühl, 2014, p. 120), but, consciously or not, their formalisation is restrained, or simply there is no decision reached about some expectations. But, generally, informality can arise and persist in the following cases:

- When rules are rigid, and actors seek ways to make them more flexible (Kühl, 2014; Ledeneva, 2018)

- Given that formal expectations /rules/ procedures are general parameters of behaviour, actors have to create guidelines in specific contexts and unforeseen situations (Helmke \& Levitsky, 2004).

- When organisations have multiple and contradictory goals, which cannot be resolved through formal structures (Kühl, 2014). 
- When formal expectations/rules/procedures are incomplete, since they provide general parameters of behaviour, and actors have to establish guidelines in specific contexts and unforeseen situations (Helmke \& Levitsky, 2004).

- When actors do not have the power to change the formal rules.

- When the solution offered by the formal means is not satisfactory for these actors.

- When formal rules are ineffective in practice.

- When actors have alternative but non-acceptable goals, which can range from non-popular to illegal.

\subsubsection{Visions of informality and its relationship with formality}

Informality is subject to readings and connotations, often contested. Ahlers et al., distinguish two main approaches in the literature about informality. According to them, the policy-oriented literature tends to define informality with respect to the regulatory influence of the state, and it also maintains a more traditional dichotomy ("either-or") between formal and informal. This vision of the formal is linked with 'positive' values, such as modern, efficient and necessary, which have been often attributed to developed countries (Katomero \& Georgiadou, 2018). In opposition, the informal is often viewed with disdain for being backwards, inefficient, undesirable, chaotic, and in need of being formalised (Ahlers, et al., 2014). It is often related with developing countries (Katomero \& Georgiadou, in 2018).

On the other hand, in opposition to the binary notion of (in)formality, the critical literature is centred on the recognition that informality is a fundamental part of formal systems, and that there exists an intimate and interdependent relationship. They have explored the ways in which the binary categorisation (formal versus informal) has contributed to "consolidate power and privilege, to legitimate some practices at the expense of others, and to perpetuate inequalities" (Katomero \& Georgiadou, 2018, pp.2). According to this vision, the state's formal governance structures play an active role in producing informality, through the selective and temporary legitimation and formalisation of informal practices (Ahlers, et al., 2014). However, the state is not the only actor producing or setting the conditions to informality; there are also non-state actors and processes involved in its co-production (Ahlers, et al., 2014). In this perspective, the relationship between formality and informality is not discrete, but continuous. Both occur at the same time and in the same space and are mutually shaped.

For his part, Kühl questions those interpretations that confer a positive moral connotation to informality by associating it with human benevolence, which casts 
informality as "emotional, playful interactions to develop between people, whereas they are otherwise required to function like gears in a machine"(Kühl, 2014, p. 115). However, interpretations like Luhmann's show that informality can be well structured, established in pathways and networks that are employed repeatedly by members of organisations (Kühl, 2014).

Ledeneva alludes to the ambivalent quality of informality, that is, its connotation and meaning depends on the position of who describes it: "informal practices are one thing for participants and another for observers" (Ledeneva, 2018, p.7). Therefore, she claims that the traditional mutually exclusive dichotomy of (in)formal practices is reductionist (Ledeneva, 2018).

In this research (in)formality is conceptualised as "both-and", since it captures the mutual constitution of formal and informal structures. To understand the role of (in)formality in the implementation of the PES programme and its persistence over time, it is considered that:

- Informality is a polysemic concept, which encompasses a set of rules (institutions), practices, and organisational structures co-produced, reproduced and transformed by state and non-state actors, who employ their agency to make decisions about the ways in which the PES programme is implemented.

- Informality is ambivalent, the ways in which its role in PES programme can be framed depends on the position of the observer. The effects of informality in the programme may be positive and negative at the same time for different actors.

- Formality and informality develop in a variety of settings, and establish complex and fluid relationships, which are not free of conflicts and power struggles.

- The state tries to keep the control over the institutional frameworks and discourses under which implementation is carried out. It sets the conditions to enable informality, and selectively formalises, legitimises or normalises certain informal practices occurring at the local levels.

- Non-state stakeholders mobilise their agency and establish informal practices (that can become structures) to align a diversity of interests and resist the state's formal control.

- Formal and informal institutions/structures are not separated in practice, they can work together in a variety of ways that contribute to the functioning of the programme.

- Informality contributes to institutional change/evolution in PES, and in the permanence of the PES programme over time. 


\subsubsection{Categories of informality}

In this research the organisational perspective is used, in which informality is categorised in structural terms, that is, as complementing the organisational formal structures, namely programmes, channels and personnel. Table 2.2 shows the informal organisational structures related to their formal counterparts.

Table 2.2. Informal organisational structures in relation to formal structures (Source: Kühl, 2014)

\begin{tabular}{|l|l|l|}
\hline \multicolumn{1}{|c|}{\begin{tabular}{c}
\multicolumn{1}{|c|}{ Organisational } \\
structures
\end{tabular}} & \multicolumn{1}{c|}{ Formal } & \multicolumn{1}{c|}{ Informal } \\
\hline Programmes & $\begin{array}{l}\text { To determine which actions in the } \\
\text { organisation are permitted } \\
\text { (rewarded) and which are not } \\
\text { (sanctioned). }\end{array}$ & $\begin{array}{l}\text { Well-established, customary routines or } \\
\text { objectives that are not openly } \\
\text { articulated. }\end{array}$ \\
\hline $\begin{array}{l}\text { Communication } \\
\text { channels }\end{array}$ & $\begin{array}{l}\text { To define the way information can } \\
\text { and must be communicated within } \\
\text { the organisation and the pathways it } \\
\text { must follow. }\end{array}$ & $\begin{array}{l}\text { When employees communicate with } \\
\text { one another without interposing their } \\
\text { respective superiors, or when an } \\
\text { unofficial hierarchy evolves among } \\
\text { employees who are equals in the formal } \\
\text { sense. }\end{array}$ \\
\hline Personnel (Members) & $\begin{array}{l}\text { To determine who will make } \\
\text { decisions in any given position. }\end{array}$ & $\begin{array}{l}\text { Expectations that cannot be officially } \\
\text { sanctioned, for example, when } \\
\text { employees are known to employ their } \\
\text { personal contacts. }\end{array}$ \\
\hline
\end{tabular}

Informality is also differentiated according to its relationship with the organisation's formal order (Table 2.3). That is, whether the informality is compatible with the formal rules and standards, whether it breaks the formal expectations or rules, and whether it might even break laws that are beyond the organisation's reach (Kühl, 2014).

Table 2.3. Forms of informality according to its relationship to the organisation's formal order. (Source: from Kühl, 2014, pp. 121-123).

\begin{tabular}{|l|l|l|}
\hline \multicolumn{1}{|c|}{ Form of informality } & \multicolumn{1}{|c|}{ Description } & \multicolumn{1}{c|}{ Function } \\
\hline $\begin{array}{l}\text { Informality that is } \\
\text { compatible with formality }\end{array}$ & $\begin{array}{l}\text { Informal expectations that cannot be } \\
\text { enforced by citing the terms of } \\
\text { membership, although they also do not } \\
\text { break any of an organisation's official } \\
\text { rules. }\end{array}$ & $\begin{array}{l}\text { It fills regulatory gaps, but often it } \\
\text { also provides an additional } \\
\text { safeguard for formal expectations. }\end{array}$ \\
\hline $\begin{array}{l}\text { Informality that breaks the } \\
\text { rules }\end{array}$ & $\begin{array}{l}\text { It has to do with minor or major } \\
\text { deviations from the organisation's } \\
\text { official objectives, a disregard of } \\
\text { prescribed if-then programs, or } \\
\text { bypassing a superior to move } \\
\text { something ahead quickly. It can be only } \\
\text { fulfilled by violating formal regulations. }\end{array}$ & $\begin{array}{l}\text { Luhmann's "useful illegality" } \\
\text { It allows avoiding time-consuming } \\
\text { procedures. }\end{array}$ \\
\hline $\begin{array}{l}\text { Informality that breaks the } \\
\text { law }\end{array}$ & $\begin{array}{l}\text { Informal expectations go as far as also } \\
\text { breaking laws that are beyond the } \\
\text { organisation's reach. }\end{array}$ & $\begin{array}{l}\text { Obtaining individual and } \\
\text { organisational benefits. }\end{array}$ \\
\hline
\end{tabular}


From the above it can be seen that organisational and institutional perspectives have at least three points in common. In the first place, both are compatible with the "both and" view of the relationship between formality and informality. Second, they consider the importance of enforcement mechanisms of informality through sanctions and rewards. Third, they determine certain informal structures or practices, for example Kühl's programmes can be associated with Helmke and Levitsky's rules. However, Kühl is more explicit about the communication channels and personnel as fundamental structures of organisations (Katomero \& Georgiadou, 2018). Likewise, they differ, but are complementary, in the ways in which they categorise informality: Helmke and Levitsky in a functional way according to the outcomes and the efficiency of institutions, and Kühl in a structural way, and with respect to the social order of the organisation. According to Ledeneva, "informality is grounded in the human ability to justify subverting constraints. Such subversion, however, may also support those constraints, just as an exception supports the rule" (Ledeneva, 2018, p. 7). The typologies of informality suggested by Helmke and Levitsky and Kühl express the extent to which the informality subverts or supports the constraints established by formality. Chapter 12 of this thesis includes an integrative analysis and discussion of the results of this research in the light of these theoretical insights about (in)formality. 


\section{Chapter 3. Selecting appropriate tools for capture the diversity of voices in PES}

\subsection{Introduction}

The present chapter is dedicated to the description and the rationale of the methodological approach of this research. The choice of the methods and procedures reflects the ways in which researchers see the nature of reality (ontology), the type of relationship between the researcher and the knowable (epistemology), and the procedures to study them (methodology) (Guba, 1990). To accomplish the objectives, I carried out research with stakeholders involved at different levels of operation/implementation of the Mexican PES programme from March 2012 to August 2014. The methods (tools, techniques and processes) I used combined semi-structured interviews, simple and participant observation and participatory activities in some cases. The principle guiding the methods is qualitative research.

This chapter includes a description of the methodology and the epistemological approach informing this research (3.2), the data collection (3.3) and analysis (3.4), some considerations about triangulation and flexibility (3.5) and a description of the study area (3.6).

This thesis is part of a larger research project entitled "Linking local action to international climate agreements in the seasonally dry tropical forests of México", carried out with the support of the Netherlands Organisation for Scientific Research programme 'Science for Global Development (WOTRO)'. The project aimed to increase understanding how design and implementation of international market-based policies of ecosystem services could promote equitable participation, by forest owners and agricultural communities engaged in different forms of community forest management in the dry tropical forests of México. This research takes the example of PES programme in México, to analyse the information flows and the role of intermediary actors in its implementation, paying especial attention to two key implementation components the ORs, and the roles and relevance of local intermediaries, the TAs.

\subsection{Methodology}

The present work is guided by constructivism, which assumes a multiplicity of social realities in which knowledge is socially constructed, and its production depends on the subjective perceptions of individuals (Mansvelt \& Berg, 2005). It also recognises that knowledge is a co-production of the viewer and the viewed (Charmaz \& Smith, 2003). 
My approach starts from the premise of reality or realities as a multitude of constructions, which are based on experience and coexistence of individuals, based on experiences, interactions, contexts and situations. My position regarding reality is neither external to this reality nor objective; my learning process has been affected by my own experiences and assumptions in life. Thus, I used my knowledge (obtained before and during the development of this research) and my preferences (Denzin \& Lincoln, 2000; Mason, 2002) to choose an approach that allowed me to capture the vision of different actors in order to build an informed version of what the evolution of the programme represents for them, and the performance of the intermediaries in the programme. Qualitative research is an interpretive practice whereby "the researcher builds a complex holistic picture, analyses words, reports detailed views of informants, and conducts the study in a natural setting", focusing on the "meaning of participants" (Creswell, 1998), in order to obtain in-depth information on the phenomenon studied 'from the interior' (Flick, 2009; Salkind, 2002). Qualitative research is highly relevant to recognising the human experience, visualising socially constructed phenomena, and the researcher is an active part of this (Mansvelt \& Berg, 2005; Delyser, 2010). It also contributes to explain how social institutions influence human relations and behaviours, and the processes that construct, sustain, legitimate and resist them (Hay, 2005). Qualitative methods allowed me to explore in depth the perceptions of stakeholders (Ritchie \& Lewis, 2003) about key issues in the implementation of the PES programme. The findings of this research are the result of a process of interaction between the interviewees and me, and of my process of interpretation, analysis, and contrasting of different visions in order to create a relatively integrated account.

In the process of qualitative research the researcher must start recognising her/himself as a multicultural subject (Denzin and Lincoln, 2000), and then selecting the theoretical paradigm, the research strategy, and the methods and tools for data collection, analysis, interpretation and presentation (Denzin and Lincoln, 2000). The world under study is, then, represented by the field notes, interviews, photographs, and other records (Denzin \& Lincoln, 2000).

I needed to identify the actors, their relations and problems, and the procedures that allow the transformation of generalised government messages towards specific practices in the forests in the context of the PES programme. I used flexible or mixed methods of data collection to allow me to reflect on the factors impacting on the processes, using document reviews and analysis, participant observation and interviews as the main methods of data collection.

For indeed, this research did not start with fixed objectives and questions. Instead, it included a process of coming and going, of confusion, learning and surprises. The 
investigation was built over time and through stumbles and illuminations, some of them catalysed by my advisors, readings, field observations, informal conversations and interviews. The questions and objectives solidified only after much of the fieldwork and some analytical work was accomplished.

Within qualitative research there is a range of designs and research methods that approach the phenomena or realities of study. Although the borders of these approaches are diffuse and juxtaposed in certain aspects, my initial approach could resemble grounded theory, in the sense that the strategy and research questions began to be really structured after my incursions in the field.

Silverman values the construction of the social world through sequential interaction, by using naturally occurring data to locate the interaction sequences (the how), in which the meanings of the participants are developed (the what). Once the problem or phenomenon is characterised, it is possible to answer the "why" questions (Silverman, 2005). These first 'pilot' visits allowed me to make modifications and adaptations to the research design as I formed my own assumptions. Immersion in the research context was highly relevant to my process, and spending time observing, introducing myself, having informal conversations and interviews with CONAFOR personnel, attending workshops and meetings of the programme operators, technicians and beneficiaries, and visiting the communities were all part of this.

In these incursions some of my initial questions gained more meaning, others lost it and so some objectives and questions were transformed. It was during this process, that two elements came to stand out as especially significant in the implementation of the PES programme, 1) the operational rules (ORs) of the programme, and 2) the role of the most significant of the intermediaries, the technical advisors (TAs). Once I began to delve into the analysis of these elements, I began to use elements of institutional change theory, focusing on the interaction and transformative influence between the rules and practices of the actors in the programme. Both are situated at interfaces, representing the transition from concepts proposed at the national level to practices carried out at the local level.

So, this research is situated in the processes occurring at interfaces of the programme: between concepts and practices; and between the national and the local levels. Interfaces are important 'spaces' where different types of institutions 'meet', resulting in a change or discontinuity (Long, 1992).

I consider that my way of immersing myself in the investigation allowed the joining of pieces and building a puzzle with the actors interviewed. I discovered the relevant actors one by one, and I built an image of them based on what they told me about themselves 
and others. Key pieces of information such as activities, concepts, metaphors and documents began to emerge, as well as key moments of convergence and interaction between actors. I started locating the events, factors and actors that had differential influence on the transformation of the programme. I focused on those that helped me better understand how the universe of the programme worked. My questions were refined once I understood that the ORs fulfilled many functions, since they are devices made to communicate and reflect the messages of PES (e.g. ideals. objectives, procedures and roles of the actors involved).

On the selection of participants, I was initially focused on working at three levels of operation of the programme. But when conducting the first interviews, the complexity and problems around CONAFOR's TAs were clear. For this reason, my intervention with the communities who are beneficiaries of PES programme, which initially would have been deeper, was adapted to semi-structured interviews with current and former local authorities, as well as participant observation of interactions between TAs and beneficiaries, and TAs-beneficiaries-CONAFOR staff. I analysed and interpreted the information collected from all the interviewed actors using content and discourse analysis and sustained this using a systematic coding process.

\subsection{Data collection}

The primary sources of information and the techniques used to obtain data were document review, participant observation, and semi-structured interviews. Simple observations and informal interviews and conversations allowed complementing the data and resolving specific doubts. Although these activities were not taken into account directly in the results, they were valuable in building relationships, refining questions and validating information obtained by other methods.

\subsubsection{Document review (ORs)}

Although frequently information from documents is considered secondary, qualitative research admits them as a source of primary information, especially if they represent the source of antecedents, definitions, goals, proposals, results and evaluations of programmes and public policies (Carton, 2012; Patton, 2002). The main documents used in the review carried out for this work are the ORs of the set of programmes previously called ProArbol and now PRONAFOR, with emphasis on the PES programme. The ORs are a rich information source, containing the general vision of CONAFOR on the forests, the objectives of the programmes, and the modalities for each of them, the relevant actors and their roles, and the general procedures.

The ORs were mentioned in many interviewees with CONAFOR staff and TAs as key information for implementing the programme. In the initial review of the ORs, they were 
considered strategic in this study, as they are published annually, and contain the main elements that define the PES programme, and they also reflect the changes in its implementation. By assuming that the ORs represent to a large extent the programme itself, the review of the changes over time in the ORs documents would reflect the evolution of the programme. Thus, I conducted a review of the published ORs over 11 years from 2003, the first year of existence of the PES programme, to 2013 (Table 3.1). Other documents and interviews were also analysed in a complementary manner to corroborate and enrich the chronology. The additional documents analysed were regulatory documents, such as laws and decrees, as well as CONAFOR's internal documents, such as evaluations and reports. All the interviews used in this analysis were of CONAFOR central office staff. The details of the categories and sections analysed, as well as the general procedures used, are detailed in chapter 5.

\section{Table 3.1. CONAFOR Operational rules documents analysed}

\begin{tabular}{|c|c|c|}
\hline Date & Title of the document & Programmes included \\
\hline 2003 & $\begin{array}{l}\text { Acuerdo que establece las Reglas de Operación para el } \\
\text { otorgamiento de pagos del Programa de Servicios Ambientales } \\
\text { Hidrológicos. }\end{array}$ & $\begin{array}{l}\text { Payments for Hydrological Environmental } \\
\text { Services }\end{array}$ \\
\hline 2004 & $\begin{array}{l}\text { Acuerdo que establece las Reglas de Operación para el } \\
\text { otorgamiento de pagos del Programa de Servicios Ambientales } \\
\text { Hidrológicos. } \\
\text { Acuerdo que establece las Reglas de Operación para el } \\
\text { otorgamiento de pagos del Programa para desarrollar el mercado } \\
\text { de servicios ambientales por captura de carbono y los derivados } \\
\text { de la biodiversidad y para fomentar el establecimiento y } \\
\text { mejoramiento de sistemas agroforestales (PSA-CABSA). }\end{array}$ & $\begin{array}{l}\text { Separate ORs for } \\
\text { - Payment for Hydrological Environmental } \\
\text { Services (PSAH). } \\
\text { - Payment for the development of } \\
\text { environmental services markets (Carbon, } \\
\text { Biodiversity protection and establishment } \\
\text { and improvement of agro-forestry } \\
\text { systems, CABSA). }\end{array}$ \\
\hline 2005 & $\begin{array}{l}\text { Acuerdo que establece las Reglas de Operación para el } \\
\text { otorgamiento de pagos del Programa de Servicios Ambientales } \\
\text { Hidrológicos. }\end{array}$ & $\begin{array}{l}\text { - Payment for Hydrological Environmental } \\
\text { Services (PSAH). }\end{array}$ \\
\hline & $\begin{array}{l}\text { Acuerdo que establece las Reglas de Operación para el } \\
\text { otorgamiento de pagos del Programa para desarrollar el mercado } \\
\text { de servicios ambientales por captura de carbono y los derivados } \\
\text { de la biodiversidad y para fomentar el establecimiento y } \\
\text { mejoramiento de sistemas agroforestales (PSA-CABSA). }\end{array}$ & $\begin{array}{l}\text { - Payment for the development of } \\
\text { environmental services markets (Carbon, } \\
\text { Biodiversity protection and establishment } \\
\text { and improvement of agro-forestry } \\
\text { systems, CABSA). }\end{array}$ \\
\hline 2006 & $\begin{array}{l}\text { Acuerdo por el que se expiden las Reglas de Operación de los } \\
\text { Programas de Desarrollo Forestal de la Comisión Nacional } \\
\text { Forestal. }\end{array}$ & $\begin{array}{l}\text { Integrated CONAFOR programmes, } \\
\text { including PSAH and CABSA }\end{array}$ \\
\hline 2007 & $\begin{array}{l}\text { Acuerdo por el que se expiden las Reglas de Operación del } \\
\text { Programa Pro-Árbol de la Comisión Nacional Forestal. }\end{array}$ & $\begin{array}{l}\text { Integrated CONAFOR programmes, } \\
\text { including PES in ProÁrbol. }\end{array}$ \\
\hline 2008 & $\begin{array}{l}\text { Acuerdo por el que se expiden las Reglas de Operación del } \\
\text { Programa Pro-Árbol de la Comisión Nacional Forestal. }\end{array}$ & $\begin{array}{l}\text { Integrated CONAFOR programmes, } \\
\text { including PES in ProÁrbol. }\end{array}$ \\
\hline 2009 & $\begin{array}{l}\text { Acuerdo por el que se establecen las Reglas de Operación del } \\
\text { Programa Pro-Árbol } 2009 .\end{array}$ & $\begin{array}{l}\text { Integrated CONAFOR programmes, } \\
\text { including PES in ProÁrbol. }\end{array}$ \\
\hline 2010 & Reglas de Operación del Programa ProÁrbol 2010. & $\begin{array}{l}\text { Integrated CONAFOR programmes, } \\
\text { including PES in ProÁrbol. }\end{array}$ \\
\hline 2011 & REGLAS de Operación del Programa ProÁrbol 2011. & $\begin{array}{l}\text { Integrated CONAFOR programmes, } \\
\text { including PES in ProÁrbol. }\end{array}$ \\
\hline 2012 & REGLAS de Operación del Programa ProArbol 2012. & $\begin{array}{l}\text { Integrated CONAFOR programmes, } \\
\text { including PES in ProÁrbol. }\end{array}$ \\
\hline 2013 & REGLAS de Operación del Programa Nacional Forestal 2013. & $\begin{array}{l}\text { Integrated CONAFOR programmes, } \\
\text { including PES in PRONAFOR. }\end{array}$ \\
\hline
\end{tabular}




\subsubsection{Identification/selection of relevant actors and in-depth semi-structured interviews}

The research was directed at the following categories of actors in the PES universe:

- Officials and employees of CONAFOR central and state level offices (in the states of Jalisco and Michoacán)

- Representatives of national and local NGOs, members of the PES National Advisory Committee

- The key intermediaries in implementation of the PES programme, that is, the TAs

- The beneficiaries of the PES programme, that is, rural communities with forest lands (3 in Jalisco and 3 in Michoacán).

Being an investigation that required the participation and consent of the informants, it required time and effort in making the contacts, personally knowing the possible informants, explaining many times my intentions, and gaining a certain level of trust to speak openly about many topics.

I carried out the fieldwork between March 2012 and August 2014, using a mix of purposeful design strategy and snowball sampling for the selection of informants. Annex 1 shows the general guides of the semi-structured interviews.

Semi-structured interviews allow obtaining systematic but flexible information about issues relevant to the researcher (Fontana \& Frey, 2005), such as explaining the reasons underlying a practice, problem or phenomena. The interview is a dynamic process whereby both the interviewer and the interviewee co-produce knowledge and meanings, which are in turn influenced by their background (Kvale, 1996; Legard et al., 2003). In this research the interviews were used to collect detailed data about the action of each of the interviewees within the PES programme (procedures, obligations, or changes in the programme and its causes, for example) and also perceptions, particular interests, ways of framing the problems, and identifying the forms of interaction with the rules and with other actors. They also served to triangulate information obtained through documentary sources or by observations.

To protect the privacy of informants and for security reasons, both the names of the people interviewed, and the communities have been replaced by numbers.

\section{CONAFOR national level}

CONAFOR (National Commission of Forestry) is the government organisation directly in charge not only of PES programmes, but of all forest policy in México, including wood and non-timber forest production, reforestation, forest plantations, soil restoration and 
conservation, fire control, and education and training about forests. Various programmes are formally integrated in PRONAFOR (National Forest Programme, previously called ProArbol), including the PES scheme, but are managed separately. Within CONAFOR, the Forest Environmental Services Office (Gerencia de Servicios Ambientales del Bosque or GSAB) oversees the PES programmes. I searched the CONAFOR website for the organisational chart and directory, to identify the names and positions of the officials who had a direct relationship with the operation of the programme and with TAs' affairs, and also other officials who could provide important information related to the research. I defined an initial list of possible informants whom I contacted by e-mail or phone to request interviews. After the initial interviews, the respondents suggested other former and current officials with functions related to the programme that could be relevant. Not all the officials agreed to be interviewed, some for lack of time or interest, and because the fieldwork began at election time, so public information and transparency about social programmes was restricted. In total, I carried out 6 visits of 4-5 days to the CONAFOR central office in the city of Guadalajara to conduct the interviews, and 3 extra visits to make official requests for information. I also attended a couple of meetings in México City to which I was invited as an observer. Interviews with central office staff included specific questions about their daily tasks and aspects of the programme related to their area of knowledge (for example, programme history, eligibility criteria, implementation of the programme procedures), and general questions such as their perceptions about other actors, especially the TAs.

\section{CONAFOR state levels}

The second step was the selection of state-level CONAFOR employees. I focused on CONAFOR offices and contacted the officials in charge of PES in Jalisco y Michoacán. I also conducted interviews with three officers in charge of the PES programme in Michoacán and with two in Jalisco (Table 3.2). The interviews lasted between one and two hours, and I conducted a second interview with two of them. Because we were in the same city, I had more interaction with the employees of CONAFOR in Michoacán. With them, I attended 5 workshops for beneficiaries on rights and obligations, PES concepts and the 'Guide to Best Forestry Practices'. In addition, I accompanied them to their visits to ejidos, in order to observe the verification process in the field. On these journeys I had informal conversations with them, which gave me a greater knowledge of the processes, and the common issues related to their work, as well as their impressions of the communities and the performance of the TAs. The main questions to the state-level employees were about the implementation of the programme, the relevance of the ORs and the coordination and interaction with other actors of the programme, with an emphasis on TAs. They also helped me to find other relevant actors and were active in contacting the TAs. 
Table 3.2. Informants in CONAFOR by operative level

\begin{tabular}{|l|r|}
\hline \multicolumn{1}{|c|}{ Operative level } & Informant \\
\hline National level Director & 1 \\
& 2 \\
\hline National level Coordinator & 3 \\
\hline National level Manager & 4 \\
& 5 \\
\hline National level Sub-Manager & 6 \\
\hline National level Department chief & 7 \\
& 8 \\
\hline State level manager and employees & 9 \\
(technicians) & 10 \\
Jalisco and Michoacán & 11 \\
& 12 \\
& 13 \\
& 14 \\
& 15 \\
& 16 \\
\hline
\end{tabular}

\section{PRONAFOR's Technical advisors}

For the recruitment of TAs, it took me longer than expected to get interviews for several reasons. In first place, they are not concentrated in a single place, so it was necessary to get their contact information from CONAFOR and request the interviews by e-mail and phone. With this strategy I only received two answers. Additionally, many TAs were reluctant to participate in the research because they looked at me with suspicion. Then, I asked the CONAFOR state level employees if I could attend the beneficiary workshops, which TAs use to attend. In those workshops I personally met and talked briefly with TAs with current contracts with PES beneficiaries in Michoacán and Jalisco and we arranged first appointments, although not all materialised in interviews. TAs that agreed to be interviewed subsequently recommended or put me in contact with other TAs. The interviews were developed in several scenarios. In most cases I travelled to their places of residence in Michoacán and Jalisco (Uruapan, Zitácuaro, Hidalgo, Morelia, La Huacana, in Michoacán and Guadalajara, El Grullo and Autlán in Jalisco). I carried out 15 interviews including 18 informants (since two of these interviews included more than one person, that is, one with 3 and the other with 2 informants) (Table 3.3). Three TAs invited me to accompany them to the communities they work with, and there I could observe assemblies and informal verifications of activities. The questions I asked the TAs included information about their professional profile, interests, work areas, and the main aspects that hinder or facilitate their work, their relationship with the other actors, and their vision about their own role in the CONAFOR programmes. The interviews lasted between one and two hours. I also had informal conversations with several TAs, 
in the workshops for beneficiaries and in the visits to communities in the PES scheme, which allowed me to complete and corroborate data obtained in the interviews.

\section{Table 3.3. TAs interviewed}

\begin{tabular}{|c|c|c|c|}
\hline State & $\begin{array}{l}\text { Informant } \\
\text { number }\end{array}$ & Professional profile & Organisation \\
\hline \multirow[t]{9}{*}{ Michoacán } & $\begin{array}{l}17 \\
+2 \text { employees }\end{array}$ & $\begin{array}{l}\text { Forest engineer } \\
\text { Wood technology engineer } \\
\text { Forest engineer }\end{array}$ & Consulting firm \\
\hline & 18 + employee & Forest engineers & Civil society \\
\hline & 19 & Forest engineer & Civil society \\
\hline & 20 & Biologist/MSc Natural resources & Consulting firm \\
\hline & 21 & Biologist & Individual \\
\hline & 22 & Agroforest engineer & Individual \\
\hline & 23 & Geographer & Consulting firm \\
\hline & 24 & $\begin{array}{l}\text { Physicist/ Specialist in } \\
\text { Conservation, Restoration and Uses } \\
\text { of Forest Resources }\end{array}$ & NGO \\
\hline & 25 & Agricultural Engineer & Consulting firm \\
\hline \multirow[t]{6}{*}{ Jalisco } & 26 & $\begin{array}{l}\text { Agricultural engineer/specialist in } \\
\text { forests }\end{array}$ & Consulting firm \\
\hline & 27 & $\begin{array}{l}\text { Agricultural engineer/specialist in } \\
\text { rural development }\end{array}$ & Consulting firm \\
\hline & 28 & $\begin{array}{l}\text { Natural resources and agricultural } \\
\text { engineer/PhD Student }\end{array}$ & Individual \\
\hline & 29 & Middle education & Individual/promotor \\
\hline & 30 & Forest engineer & Consulting firm \\
\hline & 31 & Forest engineer & Individual \\
\hline
\end{tabular}

\section{PES programme beneficiaries}

Six communities were selected, three in Michoacán and three in Jalisco. The initial selection of sites was based on two main criteria. The first was communities that had been involved in the PES programme during the last years or at the time of the fieldwork. This considerably restricted the possible areas in both Michoacán and Jalisco. Secondly, the WOTRO project under which this research was carried out was proposed in areas with tropical dry forest (TDF). PES programme beneficiaries in these ecosystems generally participate in the biodiversity PES modality. I also considered it important to document experiences of programme beneficiaries with Payments for Hydrological Environmental Services (PSAH), so I chose at least one community with this modality in each state. In the Ayuquila basin (Jalisco) both modalities are present, but not in La Huacana (Michoacán), which has mostly biodiversity PES. This, coupled with an increase in violence in La Huacana and a lack of sufficient security for me, but also because my intervention in the area could represent a risk for the informants), I decided to take a community located in the East of Michoacán, which has PSAH. All the communities considered are within the influence area of Natural Protected Areas (NPAs), and some 
of them are within the core and buffer zones of NPAs, which apparently gave greater relevance to their participation in PES. The communities located in the Ayuquila watershed area were already part of the WOTRO project, and therefore my entrance to the communities was mediated by project colleagues. Additionally, I had previously collaborated with them in participatory mapping sessions about forests in Ton and Ahu. In Ich and Cir people already knew me very well because I had worked with them in previous projects (MSc thesis, COINBIO and UNAM projects). I carried out 'pilot' interviews in some communities in order to test the structure and contents and learn more about the local context. My entry to Zen and Cresm were mediated by TAs and other colleagues. I carried out between two and three visits in each community and spent time not on the interviews, but also talking informally with people and answering the doubts they had about my presence in the ejido. I did 14 interviews with an average duration of 60-90 minutes (Table 3.4). In Cir, Zen and Cresm I observed interactions between TAs and employees of CONAFOR. I was also able to talk informally with some authorities of the ejidos in the workshops organised by CONAFOR. I conducted interviews with authorities or ex-authorities of the ejidos involved in the PES scheme. The interviews at the local level were made to the PES programme beneficiaries' experiences of the implementation mediated by the TAs, their influence in the decision making, and the forms of interaction with them. Before conducting the interviews, I had made visits or phone calls to request their permission to participate in the investigation.

Table 3.4. Communities and informants by location and modality of PES

\begin{tabular}{|c|c|c|c|c|}
\hline State & Region & Ejido & $\begin{array}{l}\text { Informant } \\
\text { number }\end{array}$ & Type of PES/status \\
\hline \multirow[t]{3}{*}{ Michoacán } & $\begin{array}{l}\text { Monarch } \\
\text { butterfly }\end{array}$ & Cresm & $\begin{array}{l}32 \\
33\end{array}$ & $\begin{array}{l}\text { Hydrological PES } \\
\begin{array}{l}\text { Starting } \\
\text { contract }\end{array}\end{array}$ \\
\hline & La Huacana & Ich & $\begin{array}{l}31 \\
35 \\
36\end{array}$ & $\begin{array}{l}\text { Biodiversity } P E S \\
5 / 5 \text { years contract }\end{array}$ \\
\hline & La Huacana & Cir & $\begin{array}{l}37 \\
38\end{array}$ & $\begin{array}{l}\text { Biodiversity PES } \\
6 / 5 \text { years contract } \\
\text { (1 year delayed) }\end{array}$ \\
\hline \multirow[t]{3}{*}{ Jalisco } & Ayuquila & Ahu & $\begin{array}{l}39 \\
40 \\
41\end{array}$ & $\begin{array}{l}\text { Hydrological PES } \\
2 / 5 \text { years contract }\end{array}$ \\
\hline & Ayuquila & Ton & $\begin{array}{l}42 \\
43\end{array}$ & $\begin{array}{l}\text { Biodiversity } \mathrm{PES} \\
5 / 5 \text { years contract }\end{array}$ \\
\hline & Ayuquila & Zen & $\begin{array}{l}44 \\
45\end{array}$ & $\begin{array}{l}\text { Biodiversity PES } \\
2^{\text {nd }} \text { period, } 3 / 5 \text { years } \\
\text { contract }\end{array}$ \\
\hline
\end{tabular}




\section{Other actors}

I interviewed other actors involved in certain aspect of the PES programme and/ or working with the communities of the study. Among these are national organisations and International level NGOs staff $(46,48,52,53)$, local Protected Areas staff $(47,48)$, the former head of an inter-municipal organisation (JIRA) in Ayuquila Basin (54), members of the REDD and PES National Advisory Committees $(50,51,52)$, local NGOs $(49,56,57)$, and a community level technician (29) (Table 3.5). These interviews were carried out in order to enrich the data and to have more resources to corroborate information obtained from the main actors of the PES programme. Some of the interviews were carried concurrently with interviews with other actors; others required specific appointments. In the case of local NGOs, JIRA and the protected areas officials, I arranged the appointments in the days of fieldwork in communities or with TAs. NGOs and organisations were contacted in meetings of the PES and REDD+ National Advisory Committees.

Table 3.5 NGOs and other organisations' interviewees

\begin{tabular}{|l|r|}
\hline \multicolumn{1}{|c|}{ Organisation/ level } & $\begin{array}{c}\text { Informant } \\
\text { number }\end{array}$ \\
\hline International NGO & 46 \\
\hline Protected Natural Area & 47 \\
& 48 \\
\hline NGO International & 49 \\
\hline NGOs (National) & 50 \\
\cline { 2 - 2 } & 51 \\
\cline { 2 - 2 } & 52 \\
& 53 \\
\hline Inter-municipal Organism & 54 \\
\hline Local NGO & 55 \\
\cline { 2 - 2 } & 56 \\
\cline { 2 - 2 } & 57 \\
\cline { 2 - 2 }
\end{tabular}

I prepared in advance guides that contained the main topics to be discussed depending on the type of informant (Annex 1). These scripts were only used to guide the discussion in the interviews, which I tried to make flow as freely and spontaneously as possible. Thus, some topics not related to the research could be interspersed which threw up (sometimes valuable information), and then I tried to gently pick up the thread of the conversation. Not all the themes of the guides were addressed in all interviews or to the same depth. Nor did I follow an established order in the conversation. The dynamics of the interviews were different; it was necessary to adapt to the different forms of communication, to the use of colloquial/ technical words, and according to the disposition of each interviewee, as well as to their time availability. 
All interviews were conducted under the prior and informed consent of the participants. I gave all the participants a short summary of my research and answered the questions they had about me and my project. I also let everyone know that the data provided by them would be used for academic purposes and that their real names would not be revealed. I requested the permission of all participants to record the interviews. I also clarified that they could ask me to stop the recording if they wanted to say something offline. All except one informant agreed to be recorded, and two employees of CONAFOR, four TAs and two ejido authorities asked me to erase certain passages of the interview or pause the recording at times.

\subsubsection{Simple and participant observation}

I used different observation techniques. During the different stages of fieldwork, I carried out participant observation. This method allows obtaining detailed information about the lives of people or the phenomena under study (Jackson 1983). Observation depends on the context as well as the social and geographical position of the observer (Denzin 1998). I spent many hours of observation in different settings, situations and processes during the whole fieldwork. My role in these processes depended on the restrictions or autonomy that those being observed gave me. In some cases, my presence in meetings was conditioned not to intervene any way, for example when I was invited to attend internal meetings in CONAFOR or sessions of the PES advisory Councils. In those cases, I just sat behind the rest of the participants, and took notes. In others I was free to participate in the activities observed, and in other cases, such as when accompanying state-level CONAFOR officials or technical advisors (TAs) in the communities where they worked, they even assigned me specific tasks to perform. My activities included for example walking for hours in the hills with them, in order to observe the verification of PES activities, or taking part (as a facilitator or as a participant) in workshops for programme beneficiaries. I was also present at the meals that people of the communities use to prepare when the employees of CONAFOR make the visits. Other observations were made casually, for example during the time spent (that could be hours) in waiting for some elusive official of CONAFOR whom I was trying to interview. I took notes in a fieldwork diary, generally at the end of the day.

\subsection{Analysis of information}

According to Spencer (et al., 2003), data analysis is a "challenging and exciting stage of the qualitative research process. It requires a mix of creativity and systematic searching, a blend of inspiration and diligent detection" (Spencer et al., 2003).

In this research, transcription and analysis of the data collected took a long time, especially because the information gathered through qualitative methods tends to be abundant, rich, messy and complex (Miles, 1979, in Ritchie \& Lewis, 2003), but also due 
to my lack of experience at doing that sort of analysis, and in the use of the software. The analysis of qualitative data allows looking for explanations of phenomena and meanings associated with the information collected, through a process of ordering and searching for data relationships (Ritchie \& Lewis, 2003).

The analysis of qualitative information involves three approaches: the literal analysis, the interpretative analysis, and the reflexive (in which the researcher considers his/her own position/role in the research) (Mason, 2002). In my case the three combined during the process.

All the audio-recorded data from interviews and field notes were transcribed verbatim (in Spanish) into a text document in Word and also in NCH Express Scribe Free, which is "professional audio player software designed to help transcribe audio recordings" (http://www.nch.com.au/scribe/index.html) by me and two assistants. I read and checked the transcriptions made by the assistants in order to explain points of confusion and to ensure quality of the transcriptions. I selected and edited some textual quotes from the interviews and translated them into English.

I conducted an analysis of the narratives captured in spoken words, texts and actions, in order to understand how the informants involved in PES construct meaning through their stories and experiences, representing their perceptions, values, interests and ways of framing diverse aspects of its implementation (Czarniawska, 2004).

There are different types of software that help handle the large amounts of data produced, known as Computer-Assisted Qualitative Data Analysis Software (CAQDAS). CAQDAS does not replace the analytical and synthesis abilities of the researcher, but it facilitates organising information (Spencer et al., 2003), defining categories, classifying the texts, and organising them according to their relationship with other codes, and also writing memos, making queries, and visualising data trends. I used the software basically to integrate all the information in a single space and have it organised by codes and categories. In this research I used the software QSR NVivo 10, which is one of several tools designed to help in organisation, analysis and finding insights in qualitative data (https://www.qsrinternational.com/nvivo/home).

To analyse and interpret the data obtained, I carried out data coding. Coding is an analytical process in which the textual data are classified into groups that share characteristics, such as key themes, concepts or categories (Spencer, et al., 2003), which involves reading in detail the data, assigning codes and categories, reviewing the coding system in an iterative process of reviewing the data and verifying the coding system (Patton, 2002). This implies a complex process of learning from the 'interaction' and 
'dialogue' with the data. In that process, the data confirmed or rejected some of my assumptions, but they also opened the way to new questions.

I used a combination of inductive and deductive techniques. First, I made a reading of the transcripts keeping in mind the basic questions and the objectives of the research, and some issues that seemed relevant to me or were repeated consistently throughout the interviews in the field. During the coding process I also found new relevant themes, words or recurring expressions that I had not considered prior to the analysis (Mason, 2002). I made a list or guide of the possible codes (called nodes in NVivo), and based on it I began to categorise the transcripts in the software: Then I repeated the process in order to refine the coding and regroup the codes into categories.

I also made a comparative analysis of the ORs to identify changes through the 11 years of operation of the programme in order to understand how CONAFOR's conceptions about the interaction between forests and people have been framed, represented, made legible (Scott, 1998), and communicated to the public. It is also a way to identify the main shifts in this vision about forest and people and the drivers behind those shifts, as a representation of the programme itself. This "history of narratives" helps us to "understand a society or some part of a society by discovering its repertoire of legitimate stories and find out how it evolved" (Czarniawska, 2004). To do this, I identified the elements of the first ORs (2003) and checked that these elements were present in the documents of the following years. Those sections of the document were used as coding categories, so I sorted them by section and by year in an Excel sheet. From there, I extracted the central information of each category and year to make the comparison (the results of this analysis are explained in detail in Chapter 5).

\subsection{Triangulation and reflexivity}

Triangulation is a strategy used in qualitative research to identify, explore and understand the different dimensions of the phenomenon studied, in order to strengthen the researcher's position about the observed phenomena. It is also be used to verify the consistency of the findings by using several collection methods, and from different sources (Patton, 2002). In this work I used both types of triangulation. In the case of the documental analysis of ORs, I consulted alternative sources, as well as other information from CONAFOR staff. In the case of interviews, I interviewed a variety of actors directly and indirectly involved in PES, ranging from directors, operators at different levels, TAs and community authorities, as well as national and local governmental and nongovernmental organisations, in order to have represent key actors in the universe of PES. I used the information obtained through participant observation collected in a 
variety of settings and participated in workshops and sought to corroborate some data in official documents, evaluations and existing literature. I also discussed the findings widely with colleagues working in the same areas of study, to share impressions, and reconstruct, corroborate, nourish and reflect on my findings during the data collection and analysis.

Qualitative research is an approach that enables finding explanations to phenomena, exhibiting a diversity of experiences, visions and outcomes, and underlying reasons and influences (Miles \& Huberman, 1994). This research aims to exhibit the different influences driving the evolution of a forest policy, and the different ways in which the actors' visions compete in the PES arena. The study also shows that the implementation of PES is an interface or intermediary space where complex process and dynamics between actors occur; producing transformative effects on the ORs before they become practices, and then can lead to a variety of outcomes at the local level.

On the other hand, under the constructivist paradigm it is assumed that the researcher is not separated from the research and therefore this results depend on her/his skills and experience in the use of methods, and also her/his values, beliefs, pre-conceptions, personal history, and professional background. Consequently, it is necessary that the researcher carries out a continuous exercise of reflection or reflexivity, that is, a critical introspection, a conscious scrutiny of her/himself as a researcher (Rose, 2007), in order to recognise her/his personal bias or conceptual baggage (Kirby \& McKenna, 1989). In this process, the researcher should make public those aspects (Mansvelt \& Berg, 2005), as well as the way in which s/he has prepared to carry out her/his research, and the strategies used to balance her/his personal biases (Patton, 2002). I have tried to account for this and provide information on it in a reflexivity exercise, presented in the following subsection.

\subsubsection{The researcher's Positionality}

I am woman, mestizo with the characteristics of an "average" Mexican. I grew up in México City in a middle-class family and lived there until I was 23 years old. All my education has been in public schools, and much of my career has been carried out in public organisations as well. My parents were militants of leftist movements, so my first notions about government programmes may be determined by this ideology. I am a biologist, trained in the positivist tradition, where the researcher is represented as an external, neutral agent who observes and analyses reality 'objectively'. From that perspective I have gradually transformed into someone who tries to assume her subjectivity and personal biases, which define how to build her own knowledge. I have 
unfinished studies in drama, and this defined my need to see the multiplicity of characters and roles that each person performs in different situations and moments of life.

In my first job outside the academy, I was a kind of TA for the implementation of biodiversity conservation projects in rural communities of Michoacán. In this position I was able to know from the inside the implications of being an external intermediary who transmits and exchanges languages and knowledge and creates bridges between very different realities. The time I lived in rural communities moved my interests towards the social sciences.

I have worked for non-governmental, governmental and academic organisations. These experiences have been very useful to approach and empathise with the different informants of this research. However, I have also absorbed the prejudices regarding 'others', in relation with the role I am playing at that time (in this case, a PhD student). I have tried to identify these prejudices and suspicions when conducting interviews, especially with government employees, TAs and NGOs. Although I have devoted years on working with rural communities, I must recognise that I am unaware of many aspects of rural everyday life, and I often try too hard to take care of my expressions, attitudes, and language. I am aware that my ways of interpreting what I see, and of approaching people are still very urban, so I constantly try not to look so "chilanga" (Mexican derogatory slang for people born or living in México City) and condescending, which is surely perceived by people.

In the case of this research, my deepest immersion into social issues meant feeling a permanent neophyte, with multiple doubts about my procedures in the field and in the analysis of information. And although it has been a gradual process during my career, the PhD has mobilised major changes in my ideology. It has been very difficult to learn to be aware of the position from which I conduct this research and understand my own subjectivity as a source of understanding of others. I know that my appearance, position as a student, my way of expressing myself influences my performance and interaction with people. I have been through a crisis of responsibility to understand that the people interviewed use their time to talk to me, and that I must use carefully of the information they have shared with me. Finally, I have made an effort to understand how far I would be willing to answer the questions I have asked in the fieldwork.

\subsection{Study area}

For this study, actors were included at three levels of the programme. The national level was mainly CONAFOR, a decentralised public organisation whose central office is located in Guadalajara, in the state of Jalisco. At the subnational or state level, I focused on the 
states of Jalisco and Michoacán, since the WOTRO research focus on these states with a strong forest management tradition, a considerable amount of TDF in the PES programme. The programme does not include municipal representation, so the next level of operation was the locality, represented by six ejidos, three from Jalisco and three from Michoacán states, specifically in Ayuquila Basin in the case of Jalisco, and La Huacana and Zitácuaro municipalities in Michoacán.

\subsubsection{State of Jalisco}

Jalisco is in Western México, it covers $4 \%$ of the national territory and its capital is Guadalajara, the second largest city of México. It lies in the transition area between the temperate north and tropical south, and at the northern edge of the Sierra Madre del Sur, on the Trans-Mexican Volcanic Belt. $68 \%$ of its territory is sub-humid warm climate in the coastal and central zone; $18 \%$ in the sub-humid higher zone of the mountains; $14 \%$ is dry and semi-dry, in the north and northeast of the state. The average annual temperature is $20.5^{\circ} \mathrm{C}$, with $850 \mathrm{~mm}$ annual average precipitation and $1000 \mathrm{~mm}$ in the coastal areas. $26 \%$ of the surface of Jalisco is covered by natural vegetation and $74 \%$ corresponds to land for agriculture, pastureland, urban areas, areas without apparent vegetation, bodies of water, and secondary vegetation. Jalisco has a population of 7 , 844,839 inhabitants (2015) in 125 municipalities. One out of every 100 habitants is an indigenous language speaker. The most common indigenous languages are Huichol (35.8\%), and Nahuatl (25.3\%). $11.1 \%$ of the population is considered indigenous and 0.8 of afro-descent.

The GDP of Jalisco in 2014 represented 6.3\% of the total national. Of every 100 pesos contributed to the economy, 64 correspond to commercial and service activities; 31 to industrial activities and 5 to agriculture, livestock, forestry, hunting and fishing. 5,222. 54 hectares were dedicated to forestry in $2014,80 \%$ of which covered in conifers or broad-leafed trees. Jalisco is a major producer of poultry, beef and pork, as well as sugarcane and maize. Among the state's varied industries are textile mills, computer product manufacturers, and cement and electric-power plants. 
Tropical dry forest (TDF) is widely distributed in México (Miranda \& Hernández-Xolocotzi, 1963; Rzedowski, 2006) along the Pacific Ocean coast, and also in the Gulf of México and certain parts of the east coast. In México it represents about $60 \%$ of the total plant communities (Rzedowski, 2006; Trejo, 1996), harbouring a rich biodiversity including $37 \%$ of the flora and $34 \%$ of the vertebrates species in México (Trejo, 1998), and having the highest indexes of endemism in the country (Ceballos \& Miranda, 2000). Evidence of human occupation in tropical dry forest ecosystems dates back thousands of years. Important crops such as maize, beans and squashes were domesticated from the wild (Maass et al., 2005). Tropical dry forest is among the most threatened ecosystems in México, estimated to be degraded and converted at rates of three times higher than in temperate forests (Bray et al., 2008). Government agricultural policies have been the main drivers of its transformation for more than four decades. These transformations have occurred by promotion of these areas as suitable for livestock, and by considering them "waste lands" (Maass et al., 2005). In the past, financial and technical support was given to ejidatarios for clearing land and for subsequent establishment of agriculture or pasture (Maass et al., 2005). On the other hand, there is recent evidence that some tropical areas deforested in the past, are now recovering due to agricultural abandonment (Bray et al., 2008). The biodiversity modality of PES programme is generally focused on TDF.

\section{Main uses of tropical dry forest}

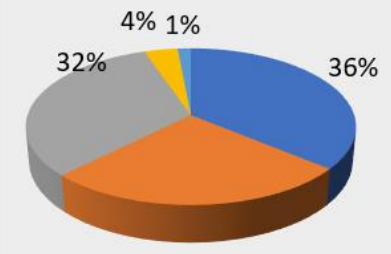

$27 \%$
Incorporated extension

PES- biodiversity 2007-2009

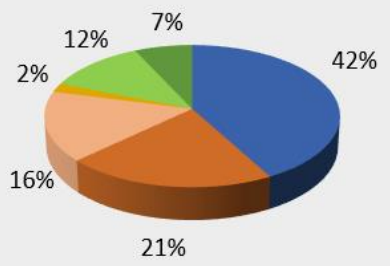

- Tropical forests

- Temperate

forests

Arid and semiarid vegetation

- Pasture land

Wetlands

Other types

\subsubsection{Ayuquila basin, Jalisco}

Three ejidos located in the Ayuquila Watershed, $\left(19^{\circ} 42^{\prime} \mathrm{N}, 103^{\circ} 54^{\prime} \mathrm{W}\right)$, in the Western of México were chosen for this research. The Ayuquila watershed has an area of about $4,000 \mathrm{~km}^{2}$, distributed over 10 municipalities. The area hosts high biodiversity, water and other ecosystem services. Municipalities included in the watershed have been organised and they are working together on productive and environmental projects, plans and programmes, with the support and technical assistance of by the Junta Intermunicipal del Rio Ayuquila (JIRA). This initiative was created in 2007 in order to "achieve the integral management of the territory providing technical support to the Municipalities for the preparation, management and implementation of projects and programmes related to the environment and management of natural resources" (JIRA, 2010). In 2011 the area was selected to take part in a pilot programme on REDD+ Early Actions (Skutsch, et al., 2015; Morales-Barquero, 2015; Morales-Barquero et al., 2014).

Two of the three ejidos, Ahu and Zen, are within the boundaries of the Sierra de Manantlan Biological Reserve $\left(103^{\circ} 45^{\prime}-104^{\circ} 30^{\prime} \mathrm{W}, 19^{\circ} 25^{\prime}-19^{\circ} 45^{\prime} \mathrm{N}\right)$, which hosts a high 
biodiversity and a water catchment providing water for more than 400,000 people (Cuevas et al., 1998). Figure 3.1 and 3.2 show the location of these communities.

\subsection{The ejidos}

Ahu has an area of 4,641 hectares, of which 762 ha are TDF, and 2,012 ha are temperate forest including pine, oak, oak-pine and mesophilic forest. Around 200 ha are within the core area of the Sierra de Manantlan Biosphere Reserve. The village population is 985 is divided into 270 families (Table 3.9). In 2002, the PROCEDE ${ }^{5}$ programme divided 822 ha into plots, leaving 3,741 ha for common use. The Ahu ejido is divided into three sections, corresponding to the land granted to ejidatarios at three different times. The extraction of timber is currently an important source of income in the first and second sections. The third section is the most recent (1985) and is located in the highest and best conserved areas of the ejido, so that almost all of its area is included in the core and buffer zones of the reserve, which prohibits management of any type, and only allows programmes such as PES, reforestation, soil conservation and fire prevention. The TDF located in the lower areas is used for cattle and is highly degraded, although cattle activity is said to be in decline. The inhabitants of the settlement use resources like firewood and wood for posts exclusively for domestic use. 50 years ago, the ejido practiced intensive extraction of pine wood and had a sawmill. The logging ceased during the 1990s, which allowed the process of regeneration of the forest. However, the forests are very affected by fires. The ejido began with forest surveillance in the 1970s, but the frequency of fires started to drop only in 2002 when the ejido began to organise fire brigades financed by CONANP. In Ahu milpa has been reduced considerably to produce much more profitable crops, such as agave and sugarcane (Mwampamba et al. 2015).

Ton is an ejido located in the centre of the watershed of the River Ayuquila, within the peri-urban area of the city of Ton; the ejido has a population of 3,497 in 955 households; 288 persons are active ejido members (ejidatarios) (Table 3.9). Through the PROCEDE programme the ejido, which has an area of 7,050 ha, was divided into plots for ejido households in 2001. 5,112 hectares were allocated to individual ejido members for agriculture, and 1,908 hectares for common use, although in practice a large part of this common land has informally been divided in private plots too. Due to the boom in the production and commercialisation of distilled agave beverages, such as mezcal and

\footnotetext{
${ }^{5}$ Programa de Certificación de Derechos Ejidales y Titulación de Solares/ Programme for the Certification of Ejidal Rights and Titling of Rural Gardens. It is an inter-institutional programme in which the Procuraduría agraria, the National Agrarian Registry (RAN) participate, as well as the National Institute of Statistics, Geography and Informatics (INEGI). The programme aims to regularise social land tenure, that is, land which is owned by ejidos and communities. It has been active since 1992 (RAN 2003).
} 
tequila, many ejidatarios rent their plots to companies that grow agave. Some people continue to carry out agriculture in the steep slopes, and there is much transformation from areas of tropical dry forest to pasture paddocks that are rented for livestock, which has led to the increase of areas with pasture replacing native forests. There are 390 hectares of pine-oak forest that are part of the PES programme in the ejido, which also includes areas of reforestation, forest recovery and soil conservation (Mwampamba et al. 2015).

Zen has an area of 4,027 hectares. The dominant vegetation type in the ejido is tropical dry forest, with some forests of oak and pine at higher elevations, which are within the Manantlan Reserve. Zen has 584 inhabitants and 125 households (Table 3.9). The lands of Zen are not parcelled under PROCEDE, and officially it conserves $100 \%$ of its area in common use, but in practice there are informal agreements on division of plots, while certain portions of the land remain in common use. Formerly, the lands belonged to a hacienda dedicated to raising livestock, but since the creation of the ejido they have significantly recovered their natural cover. The lower slopes of the ejido are used for agriculture (milpa) and livestock (pastures) in the dry season. The uppermost slopes are covered with pastures that are rented for keeping livestock and for pasture harvest as fodder. Sometimes these upper slopes are used for extensive cattle ranching, so they show a high degradation. Ejido people make use of various resources of the TDF, such as firewood and poles for domestic use, in addition to hunting and collecting non-timber products for subsistence. The PROCAMPO programme arrived in 1995 and continues to operate in the area and has granted the 64 ejidatarios economic support for agricultural production, including pastures on 250 hectares. Between 2000 and 2005 the most important programmes were PRODERS and PET, which supported plantations in agrosilvo-pastoral systems and grazing land management, soil conservation in private lands, and community projects for soil conservation and restoration. Zen has enrolled approximately 2000 ha in the PES twice, the first period from 2007 to 2011, mostly the ejido areas that are within the reserve, and the second time as part of the coastal basins PES programme which started in 2011 and ended in 2015. The analysis of change of cover indicates a

transition of TDF towards grassland and shrub land between 1995 and 2010. Also, the area

dedicated to milpa (coamil/temporal agriculture) was reduced (Mwampamba et al. 2015). 
Table 3.6. PES contracts and modality of ejidos located in Ayuquila basin (Jalisco)

\begin{tabular}{|l|l|l|l|l|}
\hline \multicolumn{1}{|c|}{ Ejido } & \multicolumn{1}{|c|}{$\begin{array}{c}\text { Natural } \\
\text { Protected Area }\end{array}$} & $\begin{array}{c}\text { PES area } \\
\text { Vegetation type }\end{array}$ & PES modality & PES contracts \\
\hline $\begin{array}{l}\text { Ahu, 3rd } \\
\text { allocation }\end{array}$ & $\begin{array}{l}\text { Manantlán } \\
\text { Biosphere Reserve } \\
\text { (core area) }\end{array}$ & $\begin{array}{l}\text { Coniferous } \\
\text { forest }\end{array}$ & $\begin{array}{l}\text { PSAH } \\
\text { (Hydrological) }\end{array}$ & 2011-2016 \\
\hline Zen & $\begin{array}{l}\text { Manantlán } \\
\text { Biosphere Reserve } \\
\text { (buffer area) }\end{array}$ & $\begin{array}{l}\text { Tropical dry } \\
\text { forest/oak } \\
\text { forest }\end{array}$ & Biodiversity & $\begin{array}{l}1^{\text {st: }} \text { 2007-2011 } \\
2^{\text {ndd }}: 2011-2016\end{array}$ \\
\hline Ton & $\begin{array}{l}\text { Manantlán } \\
\text { Biosphere Reserve } \\
\text { (influence area) }\end{array}$ & $\begin{array}{l}\text { Tropical dry } \\
\text { forest } \\
\text { Coniferous/Oak } \\
\text { forest }\end{array}$ & Biodiversity & 2011-2016 \\
\hline
\end{tabular}

Figure 3.1. General location of the study area
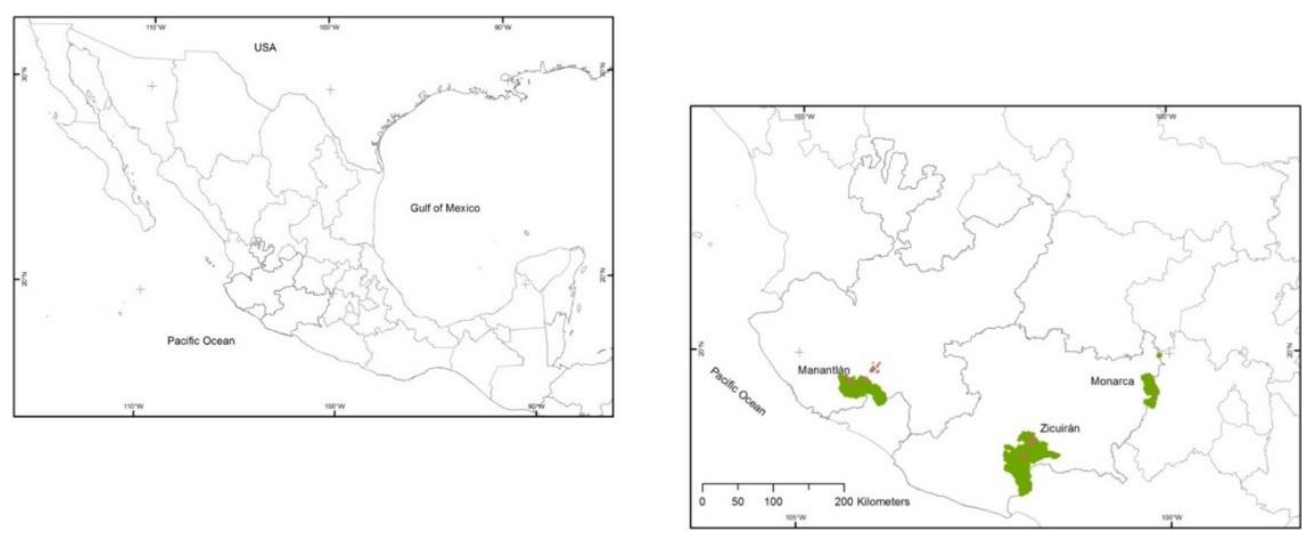

Figure 3.2. Location of the communities of the study in Ayuquila basin, Jalisco. 

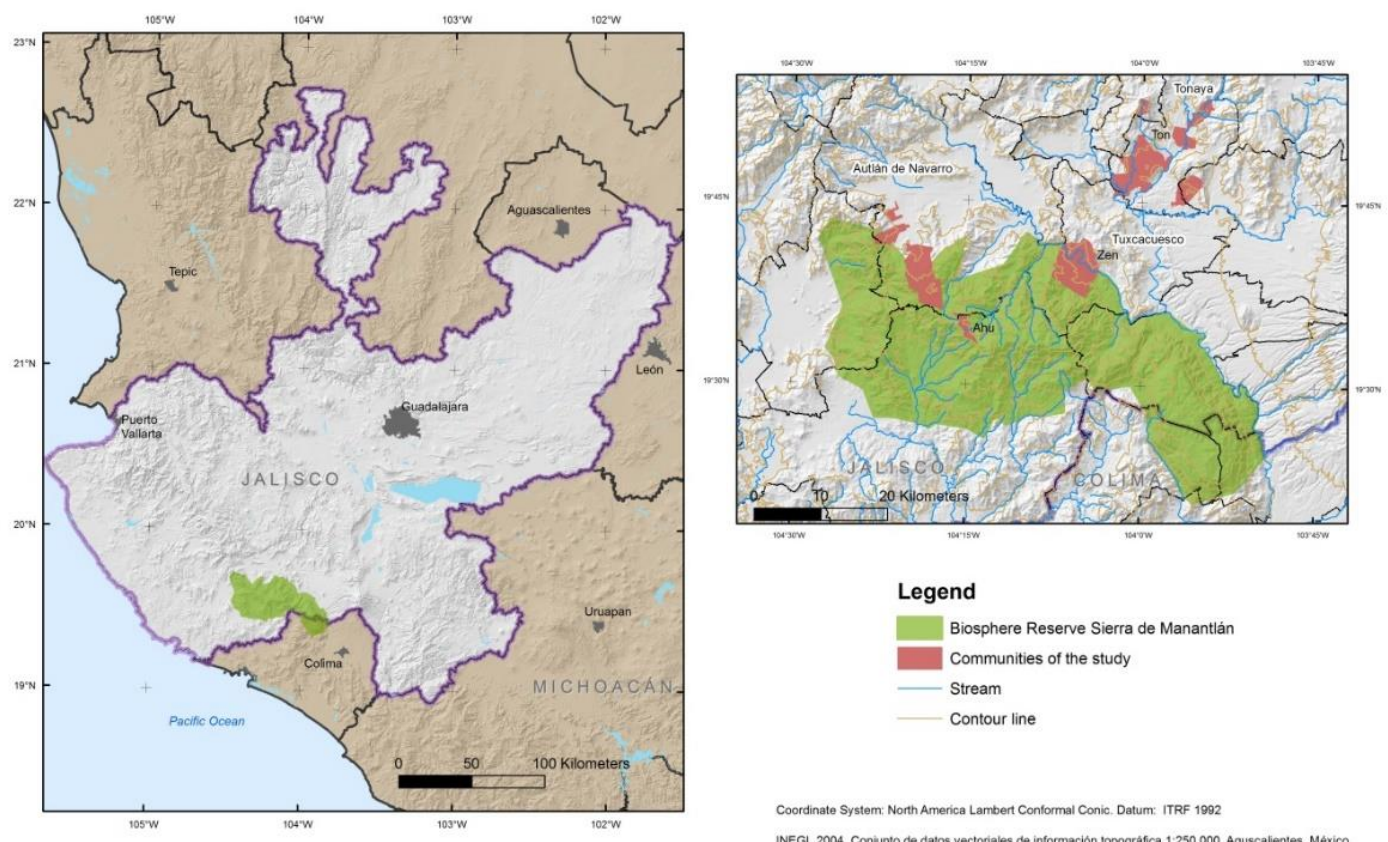

Coordinate System: North America Lambert Conformal Conic. Datum: ITRF 1992

Table 3.7 General information about the ejidos of the study. The number of ejido members in Ahu is divided because although they officially belong to the same ejido, in practice they work as separate ejidos.

\begin{tabular}{|l|l|r|r|r|r|c|}
\hline \multicolumn{1}{|c|}{ State } & Ejido & $\begin{array}{c}\text { Total } \\
\text { Area } \\
(\text { Ha) }\end{array}$ & $\begin{array}{c}\text { Settlement } \\
\text { (Ha) }\end{array}$ & $\begin{array}{c}\text { Total } \\
\text { population }\end{array}$ & $\begin{array}{c}\text { Ejido } \\
\text { members }\end{array}$ & $\begin{array}{c}\text { Marginalisation } \\
\text { degree }\end{array}$ \\
\hline \multirow{3}{*}{ Jalisco } & Ahu & $4,564.37$ & 77.44 & 985 & 141 & Low \\
& & & & 62 & \\
& & & & & 82 & \\
\cline { 2 - 7 } & Ton & $7,019.68$ & 33.53 & 3,497 & 306 & Low \\
\cline { 2 - 7 } & Zen & $3,991.20$ & 36.08 & 584 & 118 & High \\
\hline Michoacán & Ich & $5,283.29$ & 16.36 & 663 & 103 & High \\
\cline { 2 - 7 } & Cir & $3,510.31$ & 35.62 & 676 & 64 & High \\
\cline { 2 - 7 } & Cresm & $1,705.03$ & 14.071 & 1,686 & 27 & High \\
\hline
\end{tabular}

\subsubsection{State of Michoacán}

Michoacán is in Western México to the south and east of Jalisco. Michoacán occupies $3 \%$ of the national territory. It is divided into 113 municipalities and the capital city is Morelia. 54.5\% of its territory is warm sub-humid in the coastal plain of the Pacific and the Sierra Madre del Sur; $29 \%$ is temperate sub-humid in the neo-volcanic axis. $15 \%$ is dry and semi-dry in the lower and middle parts of the Balsas river depression and 
Tepalcatepec; $1 \%$ is humid temperate and $0.5 \%$ is humid warm in the highest regions of the neo-volcanic axis.

$23.41 \%$ of the area of Michoacán conserves its natural vegetation, and $46.59 \%$ is land for agriculture, grasslands, urban areas, areas without apparent vegetation, water bodies and secondary vegetation.

Michoacán has a population of 458, 471 (2015). 4 out of every 100 indigenous language speakers in México live in Michoacán (2015). The most common indigenous languages are Purepecha (81.91) and Nahuatl (8.19\%). $27.7 \%$ of the population is considered indigenous and 0.8 of afro-descent.

Its economy is based on agriculture, livestock, forest products, fishing and crafts. Regarding forestry, the production of timber generally comes from the temperate forests (pine, pine-oak) and in addition timber, pine resin is produced.

Michoacán's GDP represents $2.4 \%$ of the national total. Of every 100 pesos contributed to the economy, 65 correspond to commercial activities and services; 24 to industrial activities, and 11 to agriculture, livestock, forestry and hunting. Michoacán takes $1^{\text {st }}$ place in the country in guava, avocado and strawberry production; $2^{\text {nd }}$ place in lemon and mango production; $4^{\text {th }}$ in maize production and $5^{\text {th }}$ in pig production.

Three ejidos were included in the research, two located in La Huacana, in the Lower Balsas River watershed, and one in the San Juan Zitácuaro watershed, in the Monarch Butterfly Biosphere Reserve. (Figure 3.3) 

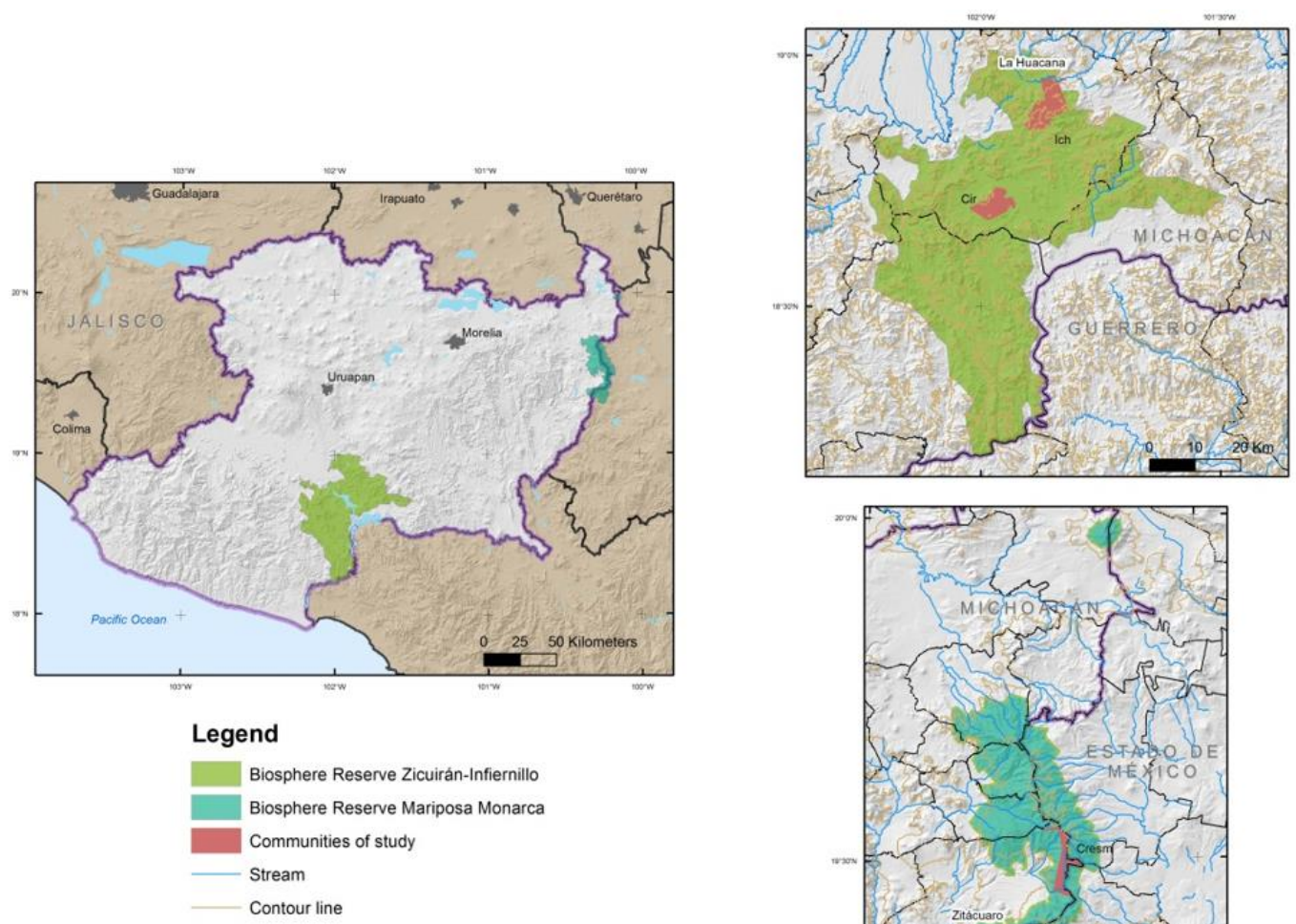

Coordinate Systemc North America Lambert Conformal Conic. Datum. ITRF 1992

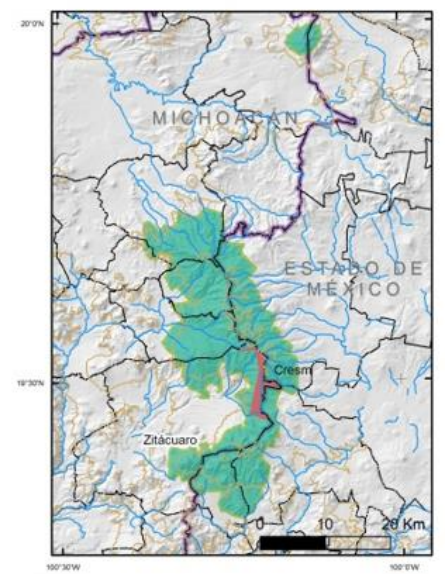

\subsubsection{La Huacana municipality}

La Huacana lays in the Lower Balsas River watershed, located in the south of the state of Michoacán. The municipality is composed of 118 settlements and 63 ejidos (INEGI 2010), and its capital is La Huacana. The municipality has average altitude of $480 \mathrm{~m}$ above the sea level, and an area of $1952.60 \mathrm{~km}^{2}$. It has an average annual rainfall of 800 $\mathrm{mm}$, and the temperature ranges from 10 to $54^{\circ} \mathrm{C}$. In 2005 , La Huacana had 32, 757 inhabitants. Recently the population in the area has been decreasing, probably because of the high rate of migration to USA and other Mexican states. The area has a high diversity in terms of its vegetation. In the higher mountains there are temperate forests and TDF. In the canyons there is tropical sub-deciduous forest, and in the driest lower plateau zone there are large patches of columnar cacti, especially pitire (Stenocereus quevedonis) (Camou et al., 2013). 


\section{The ejidos}

The ejido of Ich $\left(18^{\circ} 57^{\prime} 07^{\prime \prime} \mathrm{N}, 101^{\circ} 49^{\prime} 25^{\prime \prime} \mathrm{W}\right)$ was constituted in 1938. Nowadays the ejido has 681 inhabitants and 98 ejidatarios of whom 86 are active. The main activities are rainfed agriculture (sorghum, maize, peanut, jamaica (Hibiscus) and sesame) and livestock. Of the whole ejido, 580 ha are used in agriculture. In the past two decades this activity was very profitable. At the end of the 1970s, the production of sesame and peanut stopped, because of changes in market demand. Maize and sorghum production has also decreased, but they are still cultivated for domestic use and for livestock feed. Water is a significant factor limiting the productivity of the crops, and there is not an irrigation system. It is been estimated there are about 100 head of cattle in the ejido. This activity is not profitable due the high costs of livestock keeping in these areas, but the state and local governments provide subventions to ejido members in order to continue this activity. In the rainy season the cattle are left free to graze in the forests of the ejido, which has caused degradation, especially in the slopes and lower parts of the mountains. Ich's people use resources from their forests, generally for subsistence, and in some cases for trade, such as firewood and construction poles, medicinal plants, and wild animals. Given the economic difficulties in the zone, new productive options have been adopted, such as the provision of commerce, as well as the production of illegal crops. In 2003, COINBIO introduced a technicians' programme for biodiversity conservation to the ejido and carried out inventories of flora and fauna with the participation of the ejidatarios, as well as diagnoses of the condition of the local forests, and planning productive activities related to conservation. From this project, a community-based voluntary conservation area was established within the ejido, and a reproduction unit of white-tailed deer for game, and the sale of meat. In 2007, the Zicuirán-Infiernillo biosphere reserve was established, which included the local conservation area of Ich. The ejido has been enrolled in the PES programme for 20082013, and in the period of 2010-2015 another small area was included.

Cir is in the driest zone of La Huacana. The ejido was created in 1973 and was formed by workers at a farm on the banks of the Balsas River. They were displaced after the construction of the Infiernillo Hydroelectric dam in 1960 (Camou et al., 2013). During this time, agriculture and livestock production increased in the area causing deforestation. The main activity in the area currently is small-scale fishing in the reservoir with introduced silver biddies, locally called "chopas" or "mojarras", which began in 1975. The construction of dams and the introduction of fish was a common policy in México, aimed to increase productive activities in poor regions. In 1978 the "fileteras" began to work, a cottage industry established on the banks of the reservoir dedicated to preparing fish fillets (Camou et al., 2013). In 1985, the fish production started dwindling, as an effect of the drought produced by rainfall shortages. Maize, 
sorghum and sesame crops were also affected by this and replaced by plantations of columnar cactus pitire, raised for its edible fruits (Camou et al., 2013). The COINBIO project began in the ejido in 2003 with an inventory of flora and fauna. Like other ejidos in La Huacana, the arrival of COINBIO was an important factor in the life of Cir's people, and their vision about the forests. The established a local protected area in 2005 . The establishment of the Zicuirán-Infiernillo Biosphere Reserve in 2007 includes part of the ejido. This fact has further limited the productive options of the ejido, but at the same time it has facilitated obtaining financial support for the conservation of its natural resources. For example, they were developing a nursery of local species of cacti for commercialisation, but that was forbidden because of the presence of the protected area. The ejido has been enrolled in Biodiversity PES programme since 2008.

\subsubsection{San Juan Zitácuaro watershed}

The San Juan Zitácuaro watershed $\left(19^{\circ} 26^{\prime} \mathrm{N} 100^{\circ} 22^{\prime} \mathrm{W}\right)$ lies at the extreme eastern side of Michoacán at the border of state of México, at an elevation of 1,942 masl. In 2010 the municipality had 155,534 inhabitants, accounting for $3.6 \%$ of the state population. Of these, some 3,740 people spoke an indigenous language (primarily Otomi, Mazahua, and Nahuatl). It has an area of $498 \mathrm{~km}^{2}$. Its municipal capital is the city of Zitácuaro. The surrounding terrain is mostly the pine-covered mountains of the Sierra Madre Occidental; to the north of Zitácuaro are the famed Mexican wintering grounds of the Monarch butterfly.

The economy of Zitácuaro is based mainly on agriculture, commerce and industry, especially chemical products, fertilizers, cement and bricks.

The predominant climate is temperate sub humid with rain in summer, average annual temperatures of $8^{\circ}$ to $22^{\circ} \mathrm{C}$, average annual rainfall from $700 \mathrm{~mm}$ to $1250 \mathrm{~mm}$ and minimum temperatures between $-3^{\circ}$ and $18^{\circ} \mathrm{C}$. The relief produces important microclimatic variations that result from the combination of three thermal zones: semitemperate, temperate and four moisture levels, three sub-humid and one humid (CONANP, 2001). The type of vegetation includes fir forest, pine-oak forest, cedar forest, shrub vegetation, subtropical scrub and pasture (Ramirez, et al., 2005, Ramirez \& Zubieta, 2005); Due to its location within the Transversal Volcanic System it has a great diversity of wildlife species (CONANP, 2001). Five major social problems have been identified: the marginality and poverty of the rural population; the strong pressure on natural resources related to the above and the high density of population; the stagnation of the regional economy, the scarce inter-institutional coordination, and the lack of participation of the local population in decision-making (CONANP, 2001). 


\subsubsection{The ejido}

Cresm is one of eight indigenous ejidos in the municipality of Zitácuaro. It is one of the largest in the municipality with 8,000 hectares of forests, which was obtained during the colonial period. In the village of Cresm there is both an indigenous community and an ejido, and there are also private landowners. Cresm 2,310 inhabitants, in two subdivisions: San Mateo and Macho de Agua. The main activity is subsistence agriculture that includes the cultivation of maize but also wheat, barley, and to a lesser extent oats, beans, potatoes and garlic. Only a small portion of the community members have irrigated plots, and the rest practice rainfed agriculture. Livestock, especially sheep, is a complementary activity, from which people obtain wool for textiles as well as meat. Forestry activities are important in the community, especially for families that lack irrigation plots. Part of the ejido is within the buffer zone of the Monarch butterfly Biosphere Reserve, the most prominent best financed protected area in México.

Logging has been practiced since colonial times. The extraction of wood intensified towards the end of the nineteenth century with the construction of railroad lines and roads. In this period were sawmills that provided railroad ties and timber to the cities of Zitácuaro, Toluca and México. In the 1930s the inhabitants of San Mateo had strong conflicts with landowners in the neighbouring State of México. By 1934 the owners of the haciendas invaded the communal lands; they disputed the possession of the forest by the indigenous communities. With the agrarian re-distribution, the forest lands were restored to the indigenous people, who also received ejidal lands. By then, important forested areas had already been dismantled for agriculture. Logging has led to corruption and has accentuated internal conflicts and facilitated the individual appropriation of collective resources. In 1986 the Monarch Butterfly Biosphere Reserve was established by the national government. Before the establishment of the Reserve, part of the community land was devoted to forest use (timber and non-timber production). People saw the Reserve as an imposition, and resisted it by clearing and burning the forests, since the prohibition of using the forest dramatically affected the subsistence of many families. Currently, the extraction of wood is restricted by Reserve regulations to domestic use, such as firewood and poles for houses, as well as the extraction of non-timber products for self-consumption. Despite the restrictions, clandestine logging has remained. Cresm has been enrolled in the PES programme in two periods, 2008-2013, and 2013- 2018. The participation of the ejido in the programme has been problematic due to the corruption of the ejido authorities (for more detailed information see chapter 9) and the internal division between the members of the community. PES programme is only one of several programmes operating in the area. There are PES and restoration programmes especially designed for this region, which are spatially overlapping. 
Table 3.8. General information about the ejidos of the study in Michoacán.

\begin{tabular}{|c|c|c|c|c|}
\hline Ejido & Protected area & $\begin{array}{c}\text { PES Vegetation } \\
\text { type }\end{array}$ & PES type & PES contracts \\
\hline Ich & $\begin{array}{l}\text { Zicuirán-Infiernillo } \\
\text { Biosphere Reserve } \\
\text { (core and buffer } \\
\text { area) }\end{array}$ & Tropical dry forest & Biodiversity & $\begin{array}{l}1^{\text {st }}: 2008-2013 \\
2^{\text {nd }}: 2010-2015\end{array}$ \\
\hline Cir & $\begin{array}{l}\text { Zicuirán-Infiernillo } \\
\text { Biosphere Reserve } \\
\text { (buffer area) }\end{array}$ & Tropical dry forest & Biodiversity & $\begin{array}{l}2008-2015 \\
\text { (delayed for two } \\
\text { years) }\end{array}$ \\
\hline Cresm & $\begin{array}{l}\text { Monarch Butterfly } \\
\text { Biosphere Reserve } \\
\text { (Core and buffer } \\
\text { area) }\end{array}$ & Coniferous forest & $\begin{array}{l}\text { PSAH } \\
\text { (Hydrological) }\end{array}$ & $\begin{array}{l}1^{\text {st: }} 2008-2013 \\
\text { (Contract hidden to } \\
\text { the ejido). } \\
2^{\text {nd }: ~} 2014 \text { (contract } \\
\text { with } \\
\text { acknowledgement of } \\
\text { the ejido). }\end{array}$ \\
\hline
\end{tabular}




\section{References of Section I}

Agrawal, A. (2010). Local institutions and adaptation to climate change. In R. Mearns, \& A. Norton (Eds.), Social dimensions of climate change: Equity and vulnerability in the warming world (pp. 173-198). Washington, DC: The World Bank.

Aguilar, L. F. (1992). Estudio introductorio. In: La hechura de las politicas. México: Porrua.

Ahlers, R., Cleaver, F., Rusca, M., \& Schwartz, K. (2014). Informal space in the urban waterscape: Disaggregation and co-production of water services. Water Alternatives, 7(1), 1-14.

Alarcon, A.R. (2015). La organizacion ejidal en el desarrollo rural de México. Estudios Agrarios. 59, 181-204

Aldrich, H. E., \& Ruef, M. (2006). Organization Evolving. Sage Publications. http://doi.org/10.1073/pnas.0703993104

Alix-Garcia, J. (2014). Environmental and Socioeconomic Impacts of México's Payments for Ecosystem Services Program. Grantee Final Report, (March) 1-100.

Alix-Garcia, J., Janvry, A. De, Sadoulet, E., \& Torres, J. M. (2009). 10 Lessons Learned from México's Payment for Environmental Services Program. In Payment for Environmental Services in Agricultural Landscapes, Vol. 1951, pp. 1-27. http://doi.org/10.1007/978-0-387-72971-8

Alix-Garcia, J. de Janvry, A., Sadoulet, E., Torres, J. M., Braña, J., \& Zorrilla, R. M. (2005). An Assessment of México's Payment for Environmental Services Program. Report for FAO.

Arts, B. (2014). Assessing forest governance from a "Triple G" perspective: Government, governance, governmentality. Forest Policy and Economics, 49, 17-22. https://doi.org/10.1016/j.forpol.2014.05.008

Arts, B., \& Buizer, M. (2009). Forests, discourses, institutions. A discursive-institutional analysis of global forest governance. Forest Policy and Economics, 11(5-6), 340-347. https://doi.org/10.1016/j.forpol.2008.10.004

Barrett, C. B., Lee, D. R., \& McPeak, J. G. (2005). Institutional Arrangements for Rural Poverty Reduction and Resource Conservation. World Development, 33(2), 193-197. http://doi.org/10.1016/j.worlddev.2004.07.008

Benneker, C., \& McCall, M. (2008). Are existing programs for community based forest management and conservation suitable REDD strategies? A case study from México., EFTRN News, 50, pp. 1-8.

Boon, W. P. C., Moors, E. H. M., Kuhlmann, S., \& Smits, R. E. H. M. (2011). Demand articulation in emerging technologies: Intermediary user organisations as co-producers? Research Policy, 40(2), 242-252. https://doi.org/10.1016/j.respol.2010.09.006

Bosselmann, A. S., \& Lund, J. F. (2013). Do intermediary institutions promote inclusiveness in PES programs? The case of Costa Rica. Geoforum, 49, 50-60. https://doi.org/10.1016/j.geoforum.2013.05.009

Bracer, C., Scherr, S., Molnar, A., Sekher, M., Ochieng, B. O., \& Sriskanthan, G. (2007). Organisation and governance for fostering pro-poor compensation for environmental services. CES Scoping Study Issue Paper No. 4. ICRAF Working Paper No. 39. Nairobi, Kenya: World Agroforestry Centre.

Bray, D. B., Merino, L; (2005). La experiencia de las comunidades forestales en México. Veinticinco años de silvicultura y construccion de empresas forestales comunitarias. México: INE \& CCMSS.

Bray, D. B., Duran, E., Ramos, V. H., Mas, J. F., Velazquez, A., Barry, D., Radachowsky, J. (2008). Tropical deforestation, community forests and protected areas in the Maya forest. Ecology and Society 13(2):56

Bressers, H. (2007). Contextual Interaction Theory and the issue of boundary definition: Governance and the motivation, cognitions and resources of actors. International Journal of Policy And Administration, (January), 1-31. 
Bromley, R. (1978). Introduction: The Urban Informal Sector: Why is it Worth Discussing? World Development, 6(9/10): 1034-1035.

Camou-Guerrero, A., Ortiz-Avila, T., Ortiz-Avila, D., \& Odenthal, J. (2013). Community conservation experiences in three Ejidos of the lower Balsas river basin, Michoacán. In L. Porter-Bolland, I. Ruiz-Mallen, C. Camacho-Benavides, \& S.McCandless, Community action for conservation (pp.47-61). New York: Springer.

Campbell, J. L. (2010). Institutional reproduction and change. In Morgan, G., Campbell, J.L., Crouch, C., Pedersen, O.K., \& Whitly, R. (Eds.). Oxford Handbook of Comparative Institutional Analysis (pp.87-115), New York: Oxford University Press.

Carton-Grammont, P. (2012). Dimension geografica de las politicas publicas ambientales para la conservacion de la biodiversidad en México. PhD thesis. México: UNAM.

Ceballos, G., \& Miranda, A. (2000). A field guide to the mammals of the Jalisco coast. México: Fundación Ecologica de Cuixmala A. C.

Charmaz, K., \& Smith, J. A. (2003). Grounded theory. Objectivist and Constructivist Methods. Strategies for Qualitative Inquiry. In Denzin, N. \& Lincon, Y. Handbook of qualitative research (pp. 249-291). Thousand Oaks, U.S.A, London: Sage Publications.

Chisholm, D. (1989). Coordination Without Hierarchy: Informal Structures in Multiorganizational Systems. Berkeley: University of California Press.

Cleaver, F., \& de Koning, J. (2015). Furthering critical institutionalism. International Journal of the Commons, 9, 1-18.

Coggan, A., Buitelaar, E., Whitten, S. M., \& Bennett, J. (2013). Intermediaries in environmental offset markets: Actions and incentives. Land Use Policy, 32, 145-154. https://doi.org/10.1016/j.landusepol.2012.10.002

CONANP. (2001). Programa de Manejo Reserva de la Biosfera Mariposa Monarca, México.

CONANP \& SEMARNAT. (2007). Programa Nacional de Areas Naturales Protegidas 2007- 2012. México.

Conteh, C. (2011). Policy implementation in multilevel environments: Economic development in Northern Ontario. Canadian Public Administration (Vol. 54). http://doi.org/10.1111/j.17547121.2011.00163.x

Corbera, E., Soberanis, C., \& Brown, K. (2009). Institutional dimensions of Payments for Ecosystem Services: An analysis of México's carbon forestry programme. Ecological Economics, 68(3), 743-761. http://doi.org/10.1016/j.ecolecon.2008.06.008

Corbera, E., \& Schroeder, H. (2010). Governing and implementing REDD+. Environmental Science \& Policy, 14(2), 89-99. https://doi.org/10.1016/j.envsci.2010.11.002

Creswell, J.W. (1998). Qualitative inquiry and research design: Choosing among the five traditions. Thousand Oaks: Sage.

Cuevas, G. R., Nuñez, L. N., Guzman, H. L. \& Santana M. F. (1998). El bosque tropical caducifolio en la Reserva de la Biosfera Sierra de Manantlan, Jalisco-Colima, México. Boletin del Instituto de Botanica de la Universidad de Guadalajara, 5: 445-491.

Czarniawska, B. (2004). Narratives in Social Science Research. Knowledge Creation Diffusion Utilization, 2, 157. http://doi.org/10.4135/9781849209502

David, P. A. (1985). Clio and the Economics of QWERTY. American Economic Review, 75(2): 332 337.

David, P. A. (2007). Path Dependence: A Foundational Concept for Historical Social Science. Cliometrica 1(2): 91-114.

Davis, E. J., Gwin, L., Moseley, C., Gosnell, H., \& Burright, H. (2015). Beer, beef, and boards: the role of intermediaries in payment for ecosystem services arrangements in north western Montana. Journal of Environmental Planning and Management, 58(9), 1562-1576. https://doi.org/10.1080/09640568.2014.938803 
De Koning, J. (2011). Reshaping institutions: bricolage processes in smallholder forestry in the Amazon. PhD thesis, Wageningen, the Netherlands: Wageningen University.

De Koning J., Cleaver F. (2012). Institutional bricolage in community forestry: an agenda for future research. In Arts B., Van Bommel S., Ros-Tonen M., Verschoor G. (Eds). Forest-people interfaces. Wageningen: Wageningen Academic Publishers.

DeLeon, P. (1999). The missing link revisited: Contemporary implementation research, Policy Studies Review, 16 (3/4): 311-38.

DeLeon, P., \& DeLeon, L. (2002). What Ever Happened to Policy Implementation? An Alternative Approach. Journal of Public Administration Research and Theory, 12(4), 467-492. https://doi.org/10.1093/oxfordjournals.jpart.a003544

DeLyser, D. (2010). Introduction. In: DeLyser, D., Herbert, S., Aitken, S. Crang, M. \& L. McDowel (Eds.) The sage handbook of qualitative Geography (pp. 21-24). Thousand Oaks, U.S.A: Sage Publications.

Denzin, N. K., \& Lincoln, Y. S. (2000). Introduction: entering the field of qualitative research. In Denzin, N. K \& Lincoln, Y. S. (Eds.) Handbook of qualitative research (pp. 1-28). Thousand Oaks, U.S.A: Sage Publications.

DiMaggio, P. J. and Powell, W.W. (1983). The iron cage revisited: Institutional isomorphism and collective rationality in organizational fields. American Sociological Review, 48 (1): 147-60.

Douglas, M. (1986). How Institutions Think, Syracuse: Syracuse University Press.

Dye, T. R. (1972). Understanding public policy. Englewood Cliffs, N. J: Prentice-Hall.

Elmore, R. F. (1979). Mapping Backward and Implementation Policy Decisions. Political Science Quarterly, 94(4), 601-616. http://doi.org/10.2307/2149628

Engel, S., Pagiola, S., \& Wunder, S. (2008). Designing payments for environmental services in theory and practice: An overview of the issues. Ecological Economics, 65(4), 663-674. http://doi.org/10.1016/j.ecolecon.2008.03.011

Ezzine-De-Blas, D., Dutilly, C., Lara-Pulido, J. A., Le Velly, G., \& Guevara-Sangines, A. (2016). Payments for environmental Services in a policy mix: Spatial and temporal articulation in México. PLOS ONE, 11(4), 1-15. https://doi.org/10.1371/journal.pone.0152514

FAO \& ITTO. (2009). Forest governance and climate-change mitigation.

Flores, M. (2004). Implicaciones de los Paradigmas de Investigacion en la Practica Educativa. Revista Digital Universitaria, 5(1). http://www.revista.unam.mx/vol.5/num1/art1/ene_art1.pdf

Flick, U. (2009). An Introduction to Qualitative Research. London: Sage Publications.

Fontana, A., \& Frey, J. H. (2005). The Interview: From Neutral Stance to Political Involvement. In Denzin, N. K., \& Lincoln, Y. S. (Eds.) The Sage handbook of qualitative research (pp. 695727). Thousand Oaks, U.S.A: Sage Publications.

Garcia-Berger, A. M. (2015). Payment for Environmental Service Programs in Latin America as an Innovative Environmental Policy Instrument. Journal of Public Governance and Policy: Latin American Review, 1(1), 23- 41.

Georgiadou, Y., \& Stoter, J. (2010). Studying the use of geo-information in government - A conceptual framework. Computers, Environment and Urban Systems, 34(1), 70-78. http://doi.org/10.1016/j.compenvurbsys.2009.04.002

Gimenez, G. (1999). Territorio, Cultura e Identidades. La region socio-cultural. Estudios sobre las Culturas Contemporaneas V(9): 25-57.

Grol R, Wensing M. (2004). What drives change?. Barriers to and incentives for achieving evidence-based practice. Medical Journal of Australia, 180: 57-60.

Groth, L. (2012). Approaches to Organization Theory. Uio. No, 54-55.

Guba E. G. (1990). The alternative paradigm dialog. In Guba, E.G. (Ed.) The paradigm dialog. Newbury Park: Sage. 
Gueneau, S., \& Tozzi, P. (2008). Towards the privatization of global governance? The International Forestry Review, 10(3), 550-562. https://doi.org/10.1057/s41301-017-0077-x

Guha-Khasnobis, B., Kanbur, R., \& Ostrom, E. (2006). Beyond formality and informality. In GuhaKhasnobis, B., Kanbur, R., \& Ostrom, E. (Eds.) Linking the Formal and Informal Economy: Concepts and Policies (pp. 1-20). New York: Oxford University Press.

Guston, D. H. (2001). Boundary Organizations in Environmental Policy and Science: An Introduction. Science, Technology, \& Human Values, 26(4), 399-408. https://doi.org/10.1177/016224390102600401

Hall, P. A., \& Taylor, R. C. R. (1996). Political Science and the Three New Institutionalisms. MaxPlanck-Institut für Gesellschaftsforschung. Discussion Paper.

Hamann, E. T., \& Lane, B. (2004). The roles of state departments of education as policy intermediaries: Two cases. Educational Policy, 18(3), 426-455. https://doi.org/10.1177/0895904804265021

Hart, K. (1973). Informal Income Opportunities and Urban Employment in Ghana. Journal of Modern African Studies, 11(1): 61-89.

Hay, I. (2005). Qualitative research methods in human geography. New York: Oxford University Press.

Helmke, G., \& Levitsky, S. (2004). Informal Institutions and Comparative Politics: A Research Agenda. Perspectives on Politics, 2(4), 725-740.

Hill, H. C. (2003). Understanding Implementation: Street-Level Bureaucrats' Resources for Reform. Journal of Public Administration Research and Theory, 13(3), 265-282. https://doi.org/10.1093/jopart/mug024

Hill, M. J., \& Hupe, P. L. (2002). Implementing public policy: governance in theory and practice. London: Sage Publications.

Hill, M. (2013). A Starting Point: Understanding Governance. Good Governance and Water Governance, in: Climate Change and Water Governance: Adaptive Capacity in Chile and Switzerland (pp. 17-28). Springer Netherlands. https://doi.org/10.1007/978-94-007-57967

Hogenboom, B., Baud, M., Castro, F. de, \& Walter, M. (2015). La gobernanza ambiental en America latina. Mapeando miradas, dinamicas y experiencias. Voces En El Fénix, 43(6), 38-45. https://doi.org/10.1136/hrt.2008.151936

Howells, J. (2006). Intermediation and the role of intermediaries in innovation. Research Policy, 35(5), 715-728. https://doi.org/10.1016/j.respol.2006.03.005

Howlett, M. (1991). Policy instruments, policy styles, and policy implementation. Policy Studies Journal, 19(2), 1-21. https://doi.org/10.1111/j.1541-0072.1991.tb01878.x

Howlett, M., \& Cashore, B. (2014). Conceptualizing Public Policy. In Engeli, I.\& Allison, C. R. (Eds.) Comparative Policy Studies: Conceptual and Methodological Challenges (pp. 17-33). London: Palgrave Macmillan UK. https://doi.org/10.1057/9781137314154_2

Huang, M., \& Upadhyaya, S. K. (2007). Watershed-based payment for environmental services in Asia. SAMREM/OIRED Working Paper, (06)06-07.

Huber-Stearns, H. R., Goldstein, J. H., \& Duke, E. A. (2013). Intermediary roles and payments for ecosystem services: A typology and program feasibility application in Panama. Ecosystem Services, 6, 104-116. http://doi.org/10.1016/j.ecoser.2013.09.006

Hupe, P. L., \& Hill, M. J. (2016). And the rest is implementation. Comparing approaches to what happens in policy processes beyond Great Expectations. Public Policy and Administration, 31(2), 103-121. https://doi.org/10.1177/0952076715598828

Jackson, G. (2010). Actors and Institutions. In Morgan, G., Campbell, J., Crouch, C., Pedersen, O., Christensen, P. H. \& Whitley, R. (Eds.). Oxford Handbook of Comparative Institutional Analysis. Oxford University Press. 
Jackson, P. (1983). Principles and Problems of Participant Observation. Geografiska Annaler. Series B, Human Geography, 65(1), 39-46. doi:10.2307/490843

Jaramillo, V., García-Oliva, F. \& Martínez-Yrízar, A. (2010). La selva seca y las perturbaciones antropicas en un contexto funcional. In: Ceballos, G., Martínez, L., García, A., Espinoza, E., Bezaury, J. And Dirzo, R. (Eds). Diversidad, amenazas y areas prioritarias para la conservacion de las Selvas Secas del Pacifico de México (pp. 235-250). México City: FCECONABIO-TELMEX-CONANP-WWF.

JIRA. (2015). Programa de inversion para los municipios que integran la junta intermunicipal de medio ambiente para la gestion integral de la cuenca baja del Rio Ayuquila, Iniciativa de Reduccion de Emisiones de México (IRE). Estrategia Nacional REDD+.

Katomero, J. G., \& Georgiadou, P. Y. (2018). The Elephant in the Room: Informality in Tanzania's Rural Waterscape. ISPRS international journal of geo-information, 7(11), 1-21. [437]. https://doi.org/10.3390/ijgi711043713.

Keys, E. (2005). Exploring market-based development: Market intermediaries and farmers in Calakmul, México. The Geographical Review, 95(1), 24-46. https://doi.org/10.1017/СВ09781107415324.004

Khurana, R. (2002). Market triads: A theoretical and empirical analysis of market intermediation. Journal for the Theory of Social Behaviour, 32(2), 239-262+iii. https://doi.org/10.1111/1468-5914.00185

Kirby, S. \& McKenna, K. (1989). Methods from the Margins: Experience, Research, Social Change. Toronto, ON: Garamond Press.

Klerkx, L., \& Leeuwis, C. (2008). Delegation of authority in research funding to networks: experiences with a multiple goal boundary organization. Science and Public Policy, 35(3), 183-196. https://doi.org/10.3152/030234208X299053

Koning, J. De, \& Cleaver, F. (2012). Institutional bricolage in community forestry: an agenda for future research (pp. 277-290). https://doi.org/10.3920/978-90-8686-749-3

Kosoy, N., Corbera, E., \& Brown, K. (2008). Participation in payments for ecosystem services: Case studies from the Lacandon rainforest, México. Geoforum, 39(6), 2073-2083. http://doi.org/10.1016/j.geoforum.2008.08.007

Kühl, S. (2014). Organizations. A system approach. New York: Routledge.

Kvale, S. (1996). Interview Views: An Introduction to Qualitative Research Interviewing. Thousand Oaks, CA: Sage Publications.

Larson, A. M. \& Ribot, J. C. (2009). Lessons from forestry decentralisation. In: Angelsen, A. (Ed.) Realising REDD+: National Strategy and Policy Options (pp 175-190). CIFOR, Bogor.

Ledeneva, A. (2018). The Global Encyclopaedia of Informality vol. 1 \& 2. https://doi.org/https://doi.org/10.14324/111.9781787351899

Legard, R., Keegan, J. and Ward, K. (2003) In-depth Interviews. In: Richie, J. and Lewis, J., Eds., Qualitative Research Practice (pp. 139-168). London: Sage Publications.

Lemos, M. C., \& Agrawal, A. (2006). Environmental Governance. Annual Review of Environment and Resources, 31(1), 297-325. https://doi.org/10.1146/annurev.energy.31.042605.135621

Levin, J. A., \& Datnow, A. (2012). The principal role in DDDM. School Effectiveness and School Improvement, 23(2), 179-201. https://doi.org/10.1080/09243453.2011.599394

Lindblom, C. E. \& Woodhouse, E. (1993). The Policy Making Process. Englewood Cliffs: Prentice Hall.

Lindquist, E. (2006). Organizing for policy implementation: The emergence and role of implementation units in policy design and oversight. Journal of Comparative Policy Analysis: Research and Practice, 8(4), 311-324. https://doi.org/10.1080/13876980600970864

Lipsky, M. (2010). Street Level Bureaucracy: Dilemmas of the Individual in Public Services. The Russel Sage Foundation, 1-11. https://doi.org/10.1073/pnas.0703993104 
Lipton, M. (1984). Family, Fungibility and Formality: Rural Advantages of Informal Non-Farm Enterprise versus the Urban-Formal State. In Amin, S. (Ed.). Human Resources and Economic Development, Vol. 5: Developing Countries. London: MacMillan.

Liverman, D. M., \& Vilas, S. (2006). Neoliberalism and the Environment in Latin America. Annual Review of Environment and Resources, 31(1), 327-363. https://doi.org/10.1146/annurev.energy.29.102403.140729

Long, N. (1992). From paradigm lost to paradigm regained. In: Long, N. and Long, A. (Eds.). Battlefields of Knowledge: The Interlocking of Theory and Practice in Social Research and Development. London: Routledge.

Long, N. (2001). Development Sociology: Actor Perspectives. London and New York: Routledge.

Lowndes, V. (2002). Institutionalism. In: Marsh, D. and Stoker, G. (2002). Theory and Methods in Political Science. London: Palgrave.

Maass, J. M., Balvanera, P., Castillo, A., Daily, G. C., Mooney, H. A., Ehrlich, P., Quesada, M., Miranda, A., Jaramillo, V. J., et al. (2005). Ecosystem services of tropical dry forests: insights from long-term ecological and social research on the Pacific Coast of México. Ecology and Society 10 (1):17 http://www.ecologyandsociety.org/vol10/iss1/art17/

Mahoney, J., \& Thelen, K. (2010). Explaining Institutional Change: Ambiguity, Agency, and Power. Cambridge: Cambridge University Press.

Mansvelt, J. \& Berg. L. D. (2005). Writing qualitative geographies, constructing geographical knowledge. In: Hay, I. (Ed.) Qualitative Research Methods in Human Geography. Victoria, Australia: Oxford University Press.

March, J., Friedberg, E., \& Arellano, D. (2011). Institutions and organizations: Differences and linkages from organization theory. Gestion y Politica Publica, 20(2), 235-246.

Mazmanian, D. \& Sabatier, P. (1983). Implementation and Public Policy. Chicago: Scott Foresman.

May, C. (2013). Towards a general theory of implementation. Implementation Science, 8(1), 1. https://doi.org/10.1186/1748-5908-8-18

May, P. J. (2015). Implementation failures revisited: Policy regime perspectives. Public Policy and Administration, 30(3-4), 277-299. https://doi.org/10.1177/0952076714561505

May, P. J., \& Jochim, A. E. (2013). Policy regime perspectives: Policies, politics, and governing. Policy Studies Journal, 41(3), 426-452. https://doi.org/10.1111/psj.12024

Mason, J. (2002). Qualitative Researching. London and Thousand Oaks: Sage Publications

McAfee, K., \& Shapiro, E. N. (2010). Payments for Ecosystem Services in México: Nature, Neoliberalism, Social Movements, and the State. Annals of the Association of American Geographers, 100(3), 579-599. https://doi.org/10.1080/00045601003794833

Medd, W., \& Marvin, S. (2007). Strategic intermediation: Between regional strategy and local practice. Sustainable Development, 15(5), 318-327. https://doi.org/10.1002/sd.345

Mendez, I., \& Lendo, T. (2006). Review of the book Public Policy: An Introduction to the Theory and Practice of Policy Analysis by Parsons, W. Perfiles Latinoamericanos, 247-251.

Mike, H. \& Simon, M. (2008). Glossary of Intermediaries. Research Note 1. University of Salford, SURF Centre, UK.

Miles, M. \& Huberman, A. M. (1994). Data management and analysis methods. In Denzin, N. K. \& Lincoln, Y. S. (Eds.). Handbook of qualitative research. Sage Publications. Thousand Oaks, U.S.A

Miranda, F. \& Hernandez-Xolocotzi, E. (1963). Los tipos de vegetacion de México y su clasificacion. Boletin de la Sociedad Botanica de México. 28: 29-179.

Morales-Barquero, L., Skutsch, M., Jardel-Pelaez, E., Ghilardi, A., Kleinn, C., \& Healey, J. (2014). Operationalizing the Definition of Forest Degradation for REDD+, with Application to México. Forests, 5(7), 1653-1681. doi:10.3390/f5071653

Moss, T. (2009). Intermediaries and the governance of sociotechnical networks in transition. Environment and Planning A, 41(6), 1480-1495. https://doi.org/10.1068/a4116 
Moss, T., Medd, W., Guy, S., \& Marvin, S. (2009). Organising water: The hidden role of intermediary work. Water Alternatives, 2(1), 16-33.

Muñoz-Piña, C., Guevara, a, Torres, J., \& Brana, J. (2008). Paying for the hydrological services of México's forests: Analysis, Negotiations and Results. Ecological Economics, 65(4), 725-736. http://doi.org/10.1016/j.ecolecon.2007.07.031

Muradian, R., Arsel, M., Pellegrini, L., Adaman, F., Aguilar, B., Agarwal, B., Corbera, E., Ezzine de Blas, D., Farley, J., Froger, G., Garcia-Frapolli, E., Gomez-Baggethun, E., Gowdy, J., Kosoy, N., Le Coq, J.F., Leroy, P., May, P., Meral, P., Mibielli, P., Norgaard, R., Ozkaynak, B., Pascual, U., Pengue, W., Perez, M., Pesche, D., Pirard, R., Ramos-Martin, J., Rival, L., Saenz, Van Hecken, G., Vatn, A., Vira, B., \& Urama, K. (2013). Payments for ecosystem services and the fatal attraction of win-win solutions. Conservation Letters, 6(4), 274-279.

Mwampamba, T., Salinas-Melgoza, M.A., Larrazabal, A., Skutsch, M. (2015). Opciones en REDD+ para ejidos en la cuenca de Ayuquila, Jalisco Informe de actividades y resultados claves de los estudios de investigación hechos en los ejidos de Zenzontla, Ahuacapán, Tonaya, Temazcal y El Jazmín. Reporte técnico. México: CIGA-UNAM.

Nagel, S. S (1990). Bridging theory and practice in policy/program evaluation. Evaluation and Program Planning, 13(3), 275-283. https://doi.org/10.1016/0149-7189(90)90058-5

Nagel, S. S. ( 2002). Handbook of Public Policy Evaluation. Thousand Oaks, CA: SAGE publications.

Natera-Peral, A. (2005). Nuevas estructuras y redes de gobernanza. Revista Mexicana de Sociologia, 4, 755-791.

Nilsen, P. (2015). Making sense of implementation theories, models and frameworks. Implementation Science, 10(1), 1-13. https://doi.org/10.1186/s13012-015-0242-0

North, D. C. (1990). Institutions, Institutional Change, and Economic Performance. New York: Cambridge University Press.

North, D. C. (1991). Institutions. Journal of Economic Perspectives, 5(1), 97-112.

Olivier de Sardan, J. P. (2005). Anthropology and Development: Understanding Contemporary Social Change. London: Zed Books.

Ostrom, E. (1990). Governing the Commons. New York: Cambridge University Press.

Ostrom, E. (2005). Understanding Institutional Diversity. New Jersey: Princeton University Press.

O'Toole, L. J. (2000). Research on policy implementation: Assessment and prospects. Journal of Public Administration Research and Theory, 10 (2), 263- 288.

Palumbo, D. J. \& Calista, D. J. (1990). Opening up the black box: Implementation and the policy process. New York: Greenwood Press.

Parsons, W. (1995). Public Policy: An Introduction to the Theory and Practice of Policy Analysis, UK: Edgard Elgar, 247-251.

Patton, M. M. Q. (2002). Qualitative research and evaluation methods. Newbury Park, U.S.A.: Sage publications

Pfeffer, J. (1997). New directions for Organization Theory- Problems and Prospects. Oxford University Press.

Pham, T. T., Campbell, B. M., Garnett, S., Aslin, H., \& Hoang, M. H. (2010). Importance and impacts of intermediary boundary organizations in facilitating payment for environmental services in Vietnam. Environmental Conservation, 37(01), 64-72. https://doi.org/10.1017/S037689291000024X

Pierson P. (2000). Increasing returns, path dependence, and the study of politics. American Political Science Review. 94: 251-68.

Pierson, P. (2004). Politics in Time. History, Institutions, and Social Analysis. Princeton: Princeton University Press.

Procuraduría Agraria.( 2009). Glosario de términos jurídico-agrarios. México.

Ramirez, I. \& Zubieta, R. (2005). Análisis regional y comparación metodologica del cambio en la cubierta forestal en la Region Mariposa Monarca. México: WWF. 
Ramirez, I., Jimenez, C. M., \& Martinez, P. A. (2005). Estructura y densidad de la red de caminos en la Reserva de la Biosfera Mariposa Monarca. Investigaciones Geograficas, (57), 68-80. https://www.redalyc.org/articulo.oa?id=569/56905706

Richards, E. (1991). The Forest Ejidos of South-East México: a Case Study of Community Based Sustained Yield Management. The Commonwealth Forestry Review, 70(4 (224)), 290-311.

Ritchie, J. \& J. Lewis (2003). Qualitative Research Practice: A Guide for Social Science Students and Researchers. London and Thousand Oaks: Sage Publications.

Rixen, T., \& Viola, L. A. (2015). Putting Path Dependence in its Place: Towards a Taxonomy of Institutional Change. Journal of Theoretical Politics, 27(2), 301-323

Rose, G. (2007). Visual methodologies: An introduction to the interpretation of visual methodologies. London: Sage.

Rose, N., O'Malley, P., \& Valverde, M. (2006). Governmentality. Annual Review of Law and Social Science, 2(1), 83-104. https://doi.org/10.1146/annurev.lawsocsci.2.081805.105900

Rzedowski, J., (2006). Vegetacion de México. $1^{\text {st }}$ digital edition. México: Comision Nacional para el Conocimiento y Uso de la Biodiversidad.

Sabatier, P. (1999). The need for better theories. In Sabatier, P.A. (Ed.) Theories of the Policy Process (pp. 3-17). Boulder, Colorado: Westview Press.

Salkind, N. L. (2002). Introductory comments. In Miller, D. C. and Salkind, N. L (Eds.) Handbook of research design and social measurement (pp. 143). Thousand Oaks. U.S.A.: Sage Publications.

Schomers, S., \& Matzdorf, B. (2013). Payments for ecosystem services : lessons from around the world. Science for Environment Policy, May (327), 1. http://doi.org/10.1016/j.ecoser.2013.01

Schomers, S., Matzdorf, B., Meyer, C., \& Sattler, C. (2015). How Local Intermediaries Improve the Effectiveness of Public Payment for Ecosystem Services Programs: The Role of Networks and Agri-Environmental Assistance. https://doi.org/10.3390/su71013856

Scott, J. C. (1998). Seeing Like a State. Yale University Press (1st ed.). New Haven: Yale University Press. http://doi.org/10.1353/jsh.2000.0050

Scott, W. R. (1995). Institutions and organizations. Thousand Oaks, CA: Sage Publications.

Shapiro, N. E. (2010). To Revalue the Rural? Transformation of the Mexican Federal Payments for Ecosystem Services Programs from Neoliberal Notion to Development Dogma. PhD dissertation. UC Berkeley.

Shapiro-Garza, E. (2013). Contesting market-based conservation: payments for ecosystem services as a surface of engagement for rural social movements in México. Human Geography, 6, 134-150.

Silverman, D. (2005). Doing Qualitative Research. Los Angeles, London, New Delhi, Singapore: Sage Publications.

Sims, K. R. E., Alix-Garcia, J. M., Shapiro-Garza, E., Fine, L. R., Radeloff, V. C., Aronson, G., ... YañezPagans, P. (2014). Improving Environmental and Social Targeting through Adaptive Management in México's Payments for Hydrological Services Program. Conservation Biology, 28(5), 1151-1159. http://doi.org/10.1111/cobi.12318

Skutsch, M., Borrego, A., Morales-Barquero, L., Paneque-Gálvez, J., Salinas Melgoza, M., Ramirez, M. I., ... Gao, Y. (2015). Opportunities, Constraints and Perceptions of Rural Communities Regarding Their Potential to Contribute to Forest Landscape Transitions Under REDD+: Case Studies from México. International forestry review, 17(S1), 65-84. https://doi.org/10.1505/146554815814669025

Spencer, L., Ritchie, J., \& O'Connor, W. 2003. Analysis: Practices, Principles and Processes. In: Ritchie, J. \& Lewis, J. (Eds.). Qualitative Research Practice: A Guide for Social Science Students and Researchers. London and Thousand Oaks: Sage Publications. 
Star, S. L., \& Greisemer, J. (1989). Institutional Ecology, "Translations" and Boundary Objects: Amateurs and Professionals in Berkeley's Museum of Vertebrate Zoology. Social Studies of Science. http://doi.org/10.4135/9781412975704.n19

Sternlieb, F., Bixler, R. P., Huber-Stearns, H., \& Huayhuaca, C. (2013). A question of fit: Reflections on boundaries, organizations and social-ecological systems. Journal of Environmental Management, 130, 117-125. http://doi.org/10.1016/j.jenvman.2013.08.053

Stone, D. A. (2002). Policy paradox: The art of political decision making. New York: Norton.

Strauss, A. \& J. Corbin. (1994). Grounded theory methodology. An overview. In: Denzin, N. K. and Lincoln, Y. S. (Eds.). Handbook of qualitative research. Thousand Oaks, U.S.A.: Sage publications.

Streeck, W. \& Thelen, K. 2005. Beyond Continuity: Institutional Change in Advanced Political Economics. Oxford: Oxford University Press.

Swallow, B., Kallesoe, M., Iftikhar, U., Van Noordwijk, M., Bracer, C., Scherr, S., Raju, K.V., Poats, S., Duraiappah, A., Ochieng, B., \& Mallee, H. R. R. (2007). Compensation and Rewards for Environmental Services in the Developing World. Ecology \& Society, 14: 26.

Thompson, G., Frances, J., Levacic, R., \& Mitchel, J. (1991). Markets, hierarchies and networks: the co- ordination of social life. London: Sage publications.

Treib, O., Bähr, H., \& Falkner, G. (2007). Modes of Governance: A Note Towards Conceptual Clarification. European Governance Papers (EUROGOV), 14. https://doi.org/10.1080/135017606061071406

Trejo, I. (1996). Caracteristicas del medio físico de la selva baja caducifolia en México. Investigaciones Geográficas, Boletin, instituto de Geografia. 4: 95-110.

Trejo, I. (1998). Distribución y Diversidad de Selvas Bajas de México: Relaciones con el Clima y el Suelo. PhD thesis.

México: UNAM.

Van der Meulen, B., Nedeva, M., \& Braun, D. (2005). Intermediaries Organisation and Processes: theory and research issues. PRIME Workshop.

Van Hecken, G., Bastiaensen, J., \& Windey, C. (2015). The frontiers of the debate on Payments for Ecosystem Services A proposal for innovative future research. Institute of Development Policy and Management, University of Antwerp, Discussion Paper 2015.05, (August 2015).

Van Hecken, G., Kolinjivadi, V., Windey, C., McElwee, P., Shapiro-Garza, E., Huybrechs, F., \& Bastiaensen, J. (2017). Silencing Agency in Payments for Ecosystem Services (PES) by Essentializing a Neoliberal "Monster" Into Being: A Response to Fletcher \& Buscher's "PES Conceit." Ecological Economics, 0-1. http://doi.org/10.1016/j.ecolecon.2017.10.023

Van Lente, H., Hekkert, M., Smits, R., \& van Waveren, B. (2003). Roles of Systemic Intermediaries in Transition Processes. International Journal of Innovation Management, 07(03), 247-279. https://doi.org/10.1142/S1363919603000817

Van Meter, D. S. \& Van Horn, C. E. (1975). The policy implementation process: a conceptual framework. Administration and Society 6 (4), 445-487.

Vatn, A. (2010). An institutional analysis of payments for environmental services. Ecological Economics, 69(6), 1245-1252. http://doi.org/10.1016/j.ecolecon.2009.11.018

Vatn, A., \& Angelsen, A. (2009). Options for a national REDD+ architecture. Realising REDD+: National Strategy and Policy Options, 57-74.

Wolman, H., Levy, A., \& Hincapie, D. (2011). Government, Governance, and Regional Economic growth. Working paper 044. Washington, DC: George Washington Institute of Public Policy.

Wunder, S. (2005). Payments for environmental services: some nuts and bolts. Bogor: CIFOR. 
Wunder, S., Engel, S., \& Pagiola, S. (2008). Taking stock: A comparative analysis of payments for environmental services programs in developed and developing countries. Ecological Economics, 65(4), 834-852. https://doi.org/10.1016/j.ecolecon.2008.03.010

Weyland, K. (2002). Limitations of rational-choice institutionalism for the study of Latin American politics. Studies in Comparative International Development 37 (1): 57-85. 


\section{Placing the ORs under the microscope}

Chapter 4. The Mexican PES programme as context for the study

Chapter 5. Mapping the changes in the ORs over time

Chapter 6. What drives the changes in ORs: the interplay of institutional inertia and the pressure to accommodate the perspectives of different actors

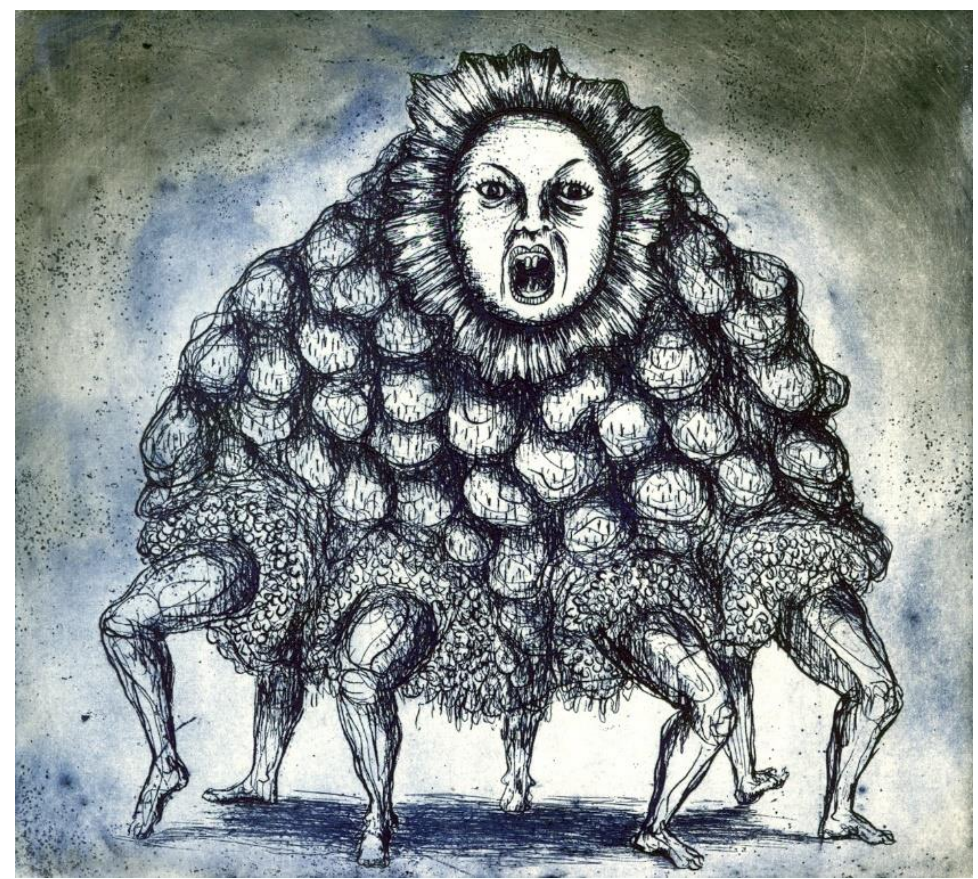

Dulce Ácido. 2015. Untitled [Engraving]. Michoacán, México. 


\section{Chapter 4. The Mexican PES programme as context for the study}

\subsection{Introduction}

The National Forest Commission (CONAFOR) is a decentralised governmental organism established in 2001. It is responsible for ensuring the implementation of a sustainable forest development policy, by promoting activities of forest conservation, restoration and sustainable activities in forests, arid and semi-arid lands. In 2006, some of the programmes in charge of CONAFOR were integrated into a scheme then called ProArbol (now PRONAFOR). The main tasks of CONAFOR are the development and maintenance of:

- The sustainable forest development planning,

- The national forest Information System,

- The national forest and soil inventory,

- Forest zoning,

- The national forestry registry,

- Mexican official norms in forestry,

- The national forest management system,

- Remote sensing studies about forest cover rate, on an annual basis.

\subsection{The Payment for Environmental Services (PES) programme}

The PES programme itself was started in 2003, and it was initially focused on hydrological environmental services (PSAH), in order to conserve both tropical and temperate forests associated with water supply. PSAH was designed by both CONAFOR and the National Institute of Ecology (INE) (Muñoz-Piña et al., 2008, Corbera et al., 2009). The programme objectives were to protect the capacity of watershed services through payment to beneficiaries ${ }^{6}$ for the services provided by their conserved forests. In this part of the process and in subsequent stages, specialists of the INE and the World Bank (WB) provided technical and academic advice for the programme (GonzalezVicente, 2012).

Later, in 2004, a group of social organisations in the forest sector lobbied in the Mexican Congress for the launching of a new programme: 'Programme for the development of markets for carbon capture, for biodiversity services, and for the promotion of the

\footnotetext{
${ }^{6}$ It refers to the actors officially recognised by CONAFOR as people who should benefit from PES programme, that is, the owners or legitimate holders of land with forest resources.
} 
establishment and improvement of agroforestry (CABSA)'. The objectives of this programme were to promote access to national and international markets for environmental services related to carbon sequestration and biodiversity of forest ecosystems, to promote the establishment of agroforestry ecosystems through uses that integrate agricultural and forestry elements, and to strengthen existing agroforestry (Gonzalez-Vicente, 2012).

In 2006, PSAH and CABSA were merged into a single scheme known as 'Programme of Payments for Forest Environmental Services'. Since 2006, the PES programme receives technical and financial assistance of the WB and the GEF "to increase efficiency in the implementation of [what was then called] Project forest environmental services (PSAB)" (CONAFOR, 2012).

According to CONAFOR the objective of this programme is to improve the provision of national environmental services through the strengthening of programmes being implemented by CONAFOR and supporting the establishment of local mechanisms of payment for environmental services.

Nowadays, the PES (PSA, in Spanish) programme and its two main components (Hydrological and Biodiversity) are included as sub/categories of PRONAFOR.

An overview prior of events and the influence they had on the development of PES in México is given in table 4.1, while table 4.2 addresses the main stages which PES went through from 2001 to 2013.

Table 4.1. Events and influences for the development of the programme of CONAFOR's Payments for Environmental Services in México (Source: CONAFOR, 2012; Del Angel-Mobarak et al., 2012; 1, pers. Comm. 2012)

\begin{tabular}{|l|l|l|}
\hline Year & \multicolumn{1}{|c|}{ Events } & \multicolumn{1}{c|}{ Influence } \\
\hline 1992 & $\begin{array}{l}\text { Rio de Janeiro Earth Summit } \\
\text { (International) }\end{array}$ & $\begin{array}{l}\text { Discussions about concerns such as the population } \\
\text { increase and rates of loss of forest cover, as well as the } \\
\text { continuous degradation of the forests led to increasingly } \\
\text { awareness of the importance of environmental services. }\end{array}$ \\
\hline 1993 & $\begin{array}{l}\text { Review of forestry and } \\
\text { conservation in México by the } \\
\text { Centre for Social and } \\
\text { Economic Research on the } \\
\text { Global Environment (CSERGE) }\end{array}$ & $\begin{array}{l}\text { A Chapter about Economic Valuation of forests reviewed } \\
\text { forestry and conservation in México, explored the state of } \\
\text { environmental values, such as ecotourism, carbon } \\
\text { sequestration, watershed protection, genetic stocks, } \\
\text { biodiversity and aesthetics. }\end{array}$ \\
\hline 1995 & $\begin{array}{l}\text { Review study of forestry and } \\
\text { conservation of natural } \\
\text { resources by the World Bank. } \\
\text { (México) }\end{array}$ & $\begin{array}{l}\text { Stressed the need to define environmental values of } \\
\text { forests for carbon sequestration, water regime regulation, } \\
\text { control of erosion, scenic beauty for tourism and } \\
\text { recreation, and biodiversity. Recommended mechanisms } \\
\text { such as franchise agreements and swaps of debt for } \\
\text { nature conservation projects, highlighting the experiences } \\
\text { of the latter in México. }\end{array}$ \\
\hline $1995-$ & $\begin{array}{l}\text { Costa Rica experience: } \\
\text { Certificates of forest } \\
\text { protection and establishment }\end{array}$ & $\begin{array}{l}\text { Changes in legal, forestry and fiscal framework to reduce } \\
\text { deforestation through incentives for reforestation and } \\
\text { conservation. Certificates recognising the environmental }\end{array}$ \\
\hline
\end{tabular}




\begin{tabular}{|c|c|c|}
\hline Year & Events & Influence \\
\hline & $\begin{array}{l}\text { of FONAFIFO (National Fund } \\
\text { for Forest Financing) }\end{array}$ & $\begin{array}{l}\text { services of forests; forest owners were paid for their } \\
\text { supply. }\end{array}$ \\
\hline 2001 & $\begin{array}{l}\text { Strategic Forestry Program } \\
2025 \\
\text { (México) }\end{array}$ & $\begin{array}{l}\text { Instrument of planning to develop the market, promote } \\
\text { the valuation, and define property rights of forest ESs. }\end{array}$ \\
\hline 2001 & $\begin{array}{l}\text { National forest land and soil } \\
\text { programme 2001-2006 } \\
\text { (México) }\end{array}$ & $\begin{array}{l}\text { Analysis of ESs, and visualisation of objectives and actions } \\
\text { for the development of these services. }\end{array}$ \\
\hline 2002 & $\begin{array}{l}\text { Public trust fund for the } \\
\text { promotion, preservation and } \\
\text { payment for forest } \\
\text { environmental services in the } \\
\text { mountainous region of } \\
\text { Coatepec (Fidecoagua) }\end{array}$ & $\begin{array}{l}\text { The first hydrological PES scheme in México (Cofre de } \\
\text { Perote, Veracruz). Financial instrument to manage the } \\
\text { economic resources to pay for watershed services, which } \\
\text { included voluntary contributions from local users } \\
\text { (Fuentes-Pantgay 2004). }\end{array}$ \\
\hline $\begin{array}{l}2001- \\
2002\end{array}$ & $\begin{array}{l}\text { México city's "Peso por árbol" } \\
\text { programme }\end{array}$ & $\begin{array}{l}\text { Payment for maintenance of environmental services in } \\
\text { reforested areas with native species in the South of } \\
\text { México City. With resources drawn from a share of } 2 \\
\text { cents per litre of gasoline sold in the metropolitan area of } \\
\text { México City, government paid one dollar per surviving } \\
\text { tree per year for the } 5 \text { years following the reforestation. }\end{array}$ \\
\hline 2002 & $\begin{array}{l}\text { Proposal for sustainable } \\
\text { development of forests } \\
\text { (México) }\end{array}$ & $\begin{array}{l}\text { Included the definition of ES and granted powers to } \\
\text { CONAFOR for charging and payment for ES, as well as the } \\
\text { modification of Section } 223 \text { A of the Federal Rights Law. }\end{array}$ \\
\hline
\end{tabular}

Table 4.2. History of PES in México (Source: Del Angel-Mobarak et al., 2012; and CONAFOR, 2012)

\begin{tabular}{|c|c|c|c|}
\hline Year & Event & Purpose & Context information \\
\hline \multirow[t]{2}{*}{2001} & $\begin{array}{l}\text { CONAFOR is } \\
\text { established }\end{array}$ & $\begin{array}{l}\text { To stimulate the development of forest } \\
\text { production, conservation and } \\
\text { restoration activities. }\end{array}$ & $\begin{array}{l}\text { Vicente Fox presidential } \\
\text { period. } \\
\text { First president from the } \\
\text { National Action Party } \\
\text { (PAN): } \\
\text { "In my administration, } \\
\text { water and forests are } \\
\text { considered matters of } \\
\text { national security" (Vicente } \\
\text { Fox, 2001) }\end{array}$ \\
\hline & $\begin{array}{l}\text { Pro-Arbol } \\
\text { programme is } \\
\text { created }\end{array}$ & $\begin{array}{l}\text { Initially supporting reforestation } \\
\text { activities }\end{array}$ & \\
\hline \multirow[t]{2}{*}{2003} & $\begin{array}{l}\text { General Law of } \\
\text { Forest Development }\end{array}$ & $\begin{array}{l}\text { A product of the evolution of the } \\
\text { previous forest laws. } \\
\text { Establishment of CONAFOR (replacing } \\
\text { the Ministry of Ecology and SEDUE), and } \\
\text { the National System of Forest } \\
\text { Information. } \\
\text { Gives more definition and operability to } \\
\text { sustainable forest management. }\end{array}$ & $\begin{array}{l}\text { Sustainability started to be } \\
\text { included in the Mexican } \\
\text { environmental discourse, } \\
\text { influenced by the Rio de } \\
\text { Janeiro's Earth Summit, } \\
1992 \text {. }\end{array}$ \\
\hline & $\begin{array}{l}\text { Mexican Forest } \\
\text { Fund (FFM) is } \\
\text { established }\end{array}$ & $\begin{array}{l}\text { "Instrument to promote conservation, } \\
\text { restoration and sustainable use of } \\
\text { forest resources, facilitating access to }\end{array}$ & \\
\hline
\end{tabular}




\begin{tabular}{|c|c|c|c|}
\hline Year & Event & $\begin{array}{l}\text { Purpose } \\
\end{array}$ & Context information \\
\hline & & $\begin{array}{l}\text { financial services, promoting projects } \\
\text { that contribute to the integration, } \\
\text { competitiveness and development of } \\
\text { mechanisms of payment for } \\
\text { environmental services". }\end{array}$ & \\
\hline & $\begin{array}{l}\text { Amendment of the } \\
\text { Federal Rights Law }\end{array}$ & $\begin{array}{l}\text { Article 223: "Of the revenue earned by } \\
\text { the collection of the rights for the } \\
\text { national water exploitation and use by } \\
\text { other users than municipalities and } \\
\text { water operator agencies. The money } \\
\text { was targeted to the Mexican Forest } \\
\text { Fund (FFM) for the development and } \\
\text { operation of the Payment for } \\
\text { Environmental Services programme" } \\
\text { (Federal Forest Law). }\end{array}$ & \\
\hline & $\begin{array}{l}\text { Payment for } \\
\text { hydrological } \\
\text { environmental } \\
\text { services (PSAH) } \\
\text { programme is } \\
\text { established }\end{array}$ & $\begin{array}{l}\text { "Designed to provide economic } \\
\text { incentives to owners of forests, for } \\
\text { conservation and avoidance of land use } \\
\text { change, in recognition of the } \\
\text { environmental services provided by } \\
\text { them. Intended as compensation to } \\
\text { forest owners prioritising cloud } \\
\text { mountain forests. }\end{array}$ & \\
\hline 2004 & $\begin{array}{l}\text { PSA-CABSA } \\
\text { programme created }\end{array}$ & $\begin{array}{l}\text { Parallel programme to PSAH, created } \\
\text { "to develop the environmental services } \\
\text { market for carbon capture and } \\
\text { biodiversity and promoting the } \\
\text { establishment and improvement of } \\
\text { agroforestry systems". To "improve the } \\
\text { capacity building of ES providers in } \\
\text { order to link them to markets". }\end{array}$ & \\
\hline 2005 & $\begin{array}{l}\text { Forest } \\
\text { environmental } \\
\text { services (7375-ME) } \\
\text { project, PSAH and } \\
\text { CABSA were merged }\end{array}$ & $\begin{array}{l}\text { This project started with the support } \\
\text { from World Bank (USD\$ } 81 \text { millions) and } \\
\text { GEF (USD\$15 millions), to "foster the } \\
\text { development of mechanisms of PES and } \\
\text { support to ES providers" }\end{array}$ & \\
\hline 2005 & $\begin{array}{l}\text { Integration of the } \\
\text { ORs of different } \\
\text { programmes of } \\
\text { CONAFOR: } \\
\text { "Operational rules } \\
\text { for forest } \\
\text { development" }\end{array}$ & $\begin{array}{l}\text { Started with the participation of the WB } \\
\text { and GEF (Global Environmental Facility) } \\
\text { in a Project called Forest environmental } \\
\text { services. }\end{array}$ & \\
\hline 2006 & $\begin{array}{l}\text { Endowment fund } \\
\text { for biodiversity } \\
\text { conservation }\end{array}$ & $\begin{array}{l}\text { WB and GEF funded together with } \\
\text { federal resources to support PES } \\
\text { projects related to biodiversity. }\end{array}$ & \\
\hline 2007 & $\begin{array}{l}\text { All CONAFOR } \\
\text { programmes } \\
\text { concentrated in Pro- } \\
\text { Arbol }\end{array}$ & $\begin{array}{l}\text { "Main federal programme to support } \\
\text { the forestry sector in one scheme, } \\
\text { granting incentives to landowners to } \\
\text { take actions to protect, conserve, } \\
\text { restore and sustainably exploit the } \\
\text { resources in forests, and dry lands in } \\
\text { México" }\end{array}$ & $\begin{array}{l}\text { Felipe Calderón Period } \\
\text { (from National Action } \\
\text { Party): } \\
\text { "That must be Pro-Arbol, a } \\
\text { large umbrella that covers } \\
\text { various aspects of } \\
\text { payment for } \\
\text { environmental services. } \\
\text { l.e.: I, Mexican society, will }\end{array}$ \\
\hline
\end{tabular}




\begin{tabular}{|c|c|c|c|}
\hline Year & Event & Purpose & Context information \\
\hline & & & $\begin{array}{l}\text { pay you for the oxygen and } \\
\text { water and climate balance } \\
\text { that can give me the trees } \\
\text { that are in your land; and } \\
\text { if you do conservation } \\
\text { actions, or if you make a } \\
\text { sustainable use of the } \\
\text { forests, or if you manage } \\
\text { to replant what has been } \\
\text { lost". (Felipe Calderon, } \\
\text { 2009). }\end{array}$ \\
\hline 2008 & $\begin{array}{l}\text { Local Mechanisms } \\
\text { of PES by } \\
\text { Concurrent Funds } \\
\text { programme }\end{array}$ & $\begin{array}{l}\text { "This scheme seeks to pool resources } \\
\text { between CONAFOR and users of } \\
\text { environmental services to provide a } \\
\text { payment or compensation to owners of } \\
\text { forest lands who engage in sustainable } \\
\text { management, which help to maintain } \\
\text { and improve the provision of } \\
\text { environmental services". }\end{array}$ & $\begin{array}{l}\text { Financial crisis, } \\
\text { Mexican GNP contracted } \\
6.1 \% \text { in } 2009\end{array}$ \\
\hline 2009 & $\begin{array}{l}\text { Unification of PSAH } \\
\text { and CABSA in PES } \\
\text { programme, with } \\
\text { payment areas (A1- } \\
\text { A6) }\end{array}$ & $\begin{array}{l}\text { Disappearance of the Carbon modality } \\
\text { of PES }\end{array}$ & \\
\hline 2012 & Forests and CC & $\begin{array}{l}\text { Integration of different programmes } \\
\text { related to CC, new guidelines, and } \\
\text { enforcement of the development } \\
\text { national REDD+ strategy }\end{array}$ & $\begin{array}{l}\text { It finishes the first phase } \\
\text { of the project with WB } \\
\text { New WB loan, and new } \\
\text { project. }\end{array}$ \\
\hline 2013 & $\begin{array}{l}\text { Change of } \\
\text { administration in } \\
\text { Federal government }\end{array}$ & $\begin{array}{l}\text { New head of CONAFOR } \\
\text { ProArbol becomes PRONAFOR }\end{array}$ & $\begin{array}{l}\text { New president and staff. } \\
\text { PRI comes back }\end{array}$ \\
\hline
\end{tabular}




\subsection{General functioning of PES programme}

The PES (PSA in Spanish) programme was designed to provide economic incentives to forest landowners to support conservation practices, avoid deforestation, and build capacities for developing ES markets in México (CONAFOR, 2011). The PES programme was to give economic incentives to the owners and holders of forest lands (ejidos, communities and smallholders) to support conservation practices, and help prevent land use changes in areas of importance for the provision of ES. The initial ideas were to compensate the forest owners for the costs of performing conservation practices. The owners and holders of forests are invited to be beneficiaries of the programme and obtain funding to carry out good forest management practices. Beneficiaries receive additional funding to pay for technical assistance. Table 4.3 shows the area of forest lands incorporated in the different modalities of PES since 2007.

PES was implemented under the concept of the ProArbol (re-named PRONAFOR in 2012) programme, through the so-called Operational Rules, which put together all the types of support offered by CONAFOR under one management document. A call annually is issued under which stakeholders are invited to participate. Resources are allocated by the National Technical Committee based on the feasibility of the requests received.

PES provides support in two modalities: Hydrological Environmental Services and Biodiversity Conservation. The Hydrological Environmental Services modality (PSAH in Spanish) is granted to conserve forest cover, with the purposes of favouring the recharge of aquifers and springs and preventing soil erosion. The objective of the Biodiversity Conservation modality is to promote the conservation of wildlife in forest ecosystems and agroforestry crops under shade, especially coffee (CONAFOR, 2012).

The incentives are granted only on lands that are located in areas of eligibility, which are determined by criteria relating to the environmental service in question. The scheme includes differentiated payments, depending on the location of the area proposed, and considering the importance of the ecosystem for the provision of ES, and considering the degree of threat or risk of those areas (Table 4.3).

Conservation commitments are established through a five-year agreement (contract) between the beneficiaries and CONAFOR. One of the main obligations for beneficiaries is to ensure the permanence of the original forest cover or land use. This is verified annually by CONAFOR, through monitoring with satellite images and/or field visits. Fulfilling commitments guarantees annual payments to beneficiaries for a period of 5 years. If loss of forest or change in the committed land use is detected the payment is cancelled or reduced proportional to the area lost (CONAFOR, 2011, 2012).

In addition to the PES payment area, CONAFOR provides each beneficiary financial support for the payment of technical assistance (TA). This is needed for the development 
and implementation of a "Programme/Guide for Best Forest Management Practices", which are used for planning the activities to be carried out on lands under PES during the term of the contract.

\subsubsection{The nature of payments}

At the beginning of the programme (2003) the amount of support was based on the estimated opportunity cost of growing maize in the area selected. Since 2004, the PES programme has established specific procedures for the determination of eligible areas, taking into account physical, environmental and social variables. This relies on digital thematic maps, generated by governmental, non-governmental and academic organisations, and other sources (CONAFOR, 2012). Increases in the payments rates over the programme history were determined based on inflation and the budget available for the operation of the programme each year.

Since 2010 the programme has established areas of differentiated payment per hectare, according to the type of ecosystem and the risk of being deforested, according to the land use and vegetation map (produced by INEGI) and the Risk of Deforestation Index (now known as the Index of Economic Pressure) developed by INE (re-named INECC in 2012). The amount of payment per hectare has been set higher for lands associated with cloud forest compared to other forest types, because this ecosystem is considered the most vulnerable (CONAFOR, 2012). The areas of eligibility are divided into 6 zones of differentiated payment corresponding to the two modalities of support. In 2012, the eligible area for watershed services was 19.8 million hectares, and for biodiversity conservation it was 28.82 million hectares (CONAFOR, 2012), see Table 4.3. 
Table 4.3. Differentiated payments for the two modalities of PES and areas enrolled in 2012 (Source: CONAFOR, 2012).

\begin{tabular}{|c|c|c|c|c|c|}
\hline Modality & $\begin{array}{l}\text { Payment } \\
\text { zone }\end{array}$ & $\begin{array}{l}\text { Ecosystem type } \\
\text { (INEGI) }\end{array}$ & $\begin{array}{l}\text { Deforestation risk } \\
\text { (INECC) }\end{array}$ & $\begin{array}{c}\text { Amount } \\
\text { Mxn } \$ / \mathrm{Ha} \\
(2012)\end{array}$ & $\begin{array}{c}\text { Area (Ha) } \\
\text { (2012) }\end{array}$ \\
\hline \multirow[t]{3}{*}{ Hydrological } & 1 & Cloud forest & Very high & 1,100 & 47,778 \\
\hline & 2 & Cloud forest & High, Medium, Low & 700 & $1,145,984$ \\
\hline & 3 & $\begin{array}{l}\text { Coniferous forest } \\
\text { Tropical sub- } \\
\text { deciduous forest } \\
\text { Oak forest (oak- } \\
\text { pine; pine-oak } \\
\text { forest) }\end{array}$ & $\begin{array}{l}\text { Very high, high, } \\
\text { medium, low, very } \\
\text { low }\end{array}$ & 382 & $18,643,529$ \\
\hline \multirow[t]{3}{*}{ Biodiversity } & 4 & Tropical rainforest & $\begin{array}{l}\text { Very high, high, } \\
\text { medium, low, very } \\
\text { low }\end{array}$ & 550 & $5,539,898$ \\
\hline & 5 & $\begin{array}{l}\text { Deciduous tropical } \\
\text { dry forest and } \\
\text { thorn scrub forest } \\
\text { Mangroves }\end{array}$ & $\begin{array}{l}\text { Very high, High } \\
\text { Very high, high, } \\
\text { medium, low, very } \\
\text { low }\end{array}$ & 382 & $3,374,877$ \\
\hline & 6 & $\begin{array}{l}\text { Tropical dry forest } \\
\text { and thorn scrub } \\
\text { forest } \\
\text { Arid and semi-arid } \\
\text { zones } \\
\text { Natural grasslands }\end{array}$ & $\begin{array}{l}\text { Medium, low, very } \\
\text { low } \\
\text { Very high, high, } \\
\text { medium, low, very } \\
\text { low }\end{array}$ & 280 & $19,911,939$ \\
\hline \multicolumn{4}{|l|}{ Total } & eligible area & $48,664,003$ \\
\hline
\end{tabular}

\subsection{The ORs of PES, Pro-Arbol and PRONAFOR}

In general terms, Operational Rules are the legal instruments for the implementation of a programme. They are composed of a set of provisions specifying the functioning of a programme aimed to achieve expected results. They are also instruments to protect vulnerable groups, as well as to provide support and incentives for productive sectors or activities (Fuentes, 2009). According to the Ministry of Public Administration (http://www.funcionpublica.gob.mx.htm), the operational rules are useful to inform the public about:

- $\quad$ the specific benefits that programmes are offering,

- the requirements for participation in the programmes, and the target population to receive programme support,

- $\quad$ the ways in which the programmes can contribute to social and personal welfare,

- $\quad$ the ways in which the programme monitors whenever public resources are being applied as scheduled. 
ORs are the legal instrument specifying guidelines under which programmes are implemented, but they are also one of the most important official means of communication with stakeholders.

The ORs are addressed to the general public, but in a practical way they provide guidelines about the expected roles of the applicants, beneficiaries, and CONAFOR operators.

The PES ORs are published annually, and contain the main objectives, components, procedures and guidance for potential beneficiaries. They are published on the CONAFOR website, and are available in central, regional and state level government offices.

PES for hydrological environmental services (PSAH) started in 2003, and its ORs remained unchanged until 2005. In 2004 the called CABSA programme was launched. Before 2006 each programme had its own ORs and the programmes worked in parallel. In 2006, the ORs of all CONAFOR's programmes were integrated in one document, and in the process PSAH and CABSA were merged into one programme called Forests Environmental Services. In 2007, the single set of programmes was called Pro-Arbol, although the programmes, categories, and modalities for payment have changed almost every year. In 2013 Pro-Arbol was re-named PRONAFOR (National Forest Programme). The ORs that were analysed in this research are shown in table 4.4.

The present section is composed by two chapters:

- Chapter 5 is a detailed analysis of the evolution of the official PES programme's ORs over a period of 11 years (2003-2013). The analysis includes analysis according to Temporal and communication qualities of the changes over time.

- Chapter 6 takes the most relevant areas of change in ORs identified in chapter 5 to explain the causes of those changes, identifying the actors involved in the process. 
Table 4.4. CONAFOR ORs documents analysed.

\begin{tabular}{|c|c|c|}
\hline Date & Title of the document & Programmes included \\
\hline 2003 & $\begin{array}{l}\text { Acuerdo que establece las Reglas de Operación para el } \\
\text { otorgamiento de pagos del Programa de Servicios Ambientales } \\
\text { Hidrológicos. }\end{array}$ & $\begin{array}{l}\text { Payments for Hydrological } \\
\text { Environmental Services }\end{array}$ \\
\hline 2004 & $\begin{array}{l}\text { Acuerdo que establece las Reglas de Operación para el } \\
\text { otorgamiento de pagos del Programa de Servicios Ambientales } \\
\text { Hidrológicos. } \\
\text { Acuerdo que establece las Reglas de Operación para el } \\
\text { otorgamiento de pagos del Programa para desarrollar el mercado } \\
\text { de servicios ambientales por captura de carbono y los derivados } \\
\text { de la biodiversidad y para fomentar el establecimiento y } \\
\text { mejoramiento de sistemas agroforestales (PSA-CABSA). }\end{array}$ & $\begin{array}{l}\text { Separate ORs for } \\
\text { - Payment for Hydrological } \\
\text { Environmental Services (PSAH); } \\
\text { - Payment for the development of } \\
\text { environmental services markets } \\
\text { (Carbon, Biodiversity protection } \\
\text { and establishment and } \\
\text { improvement of agro-forestry } \\
\text { systems, CABSA). }\end{array}$ \\
\hline 2005 & $\begin{array}{l}\text { Acuerdo que establece las Reglas de Operación para el } \\
\text { otorgamiento de pagos del Programa de Servicios Ambientales } \\
\text { Hidrológicos. } \\
\text { Acuerdo que establece las Reglas de Operación para el } \\
\text { otorgamiento de pagos del Programa para desarrollar el mercado } \\
\text { de servicios ambientales por captura de carbono y los derivados } \\
\text { de la biodiversidad y para fomentar el establecimiento y } \\
\text { mejoramiento de sistemas agroforestales (PSA-CABSA). }\end{array}$ & $\begin{array}{l}\text { - Payment for Hydrological } \\
\text { Environmental Services (PSAH); } \\
\text { - Payment for the development of } \\
\text { environmental services markets } \\
\text { (Carbon, Biodiversity protection } \\
\text { and establishment and } \\
\text { improvement of agro-forestry } \\
\text { systems, CABSA). }\end{array}$ \\
\hline 2006 & $\begin{array}{l}\text { Acuerdo por el que se expiden las Reglas de Operación de los } \\
\text { Programas de Desarrollo Forestal de la Comisión Nacional } \\
\text { Forestal. }\end{array}$ & $\begin{array}{l}\text { Integrated CONAFOR programmes, } \\
\text { including PSAH and CABSA }\end{array}$ \\
\hline 2007 & $\begin{array}{l}\text { Acuerdo por el que se expiden las Reglas de Operación del } \\
\text { Programa Pro-Árbol de la Comisión Nacional Forestal. }\end{array}$ & $\begin{array}{l}\text { Integrated CONAFOR programmes, } \\
\text { including PES in ProÁrbol. }\end{array}$ \\
\hline 2008 & $\begin{array}{l}\text { Acuerdo por el que se expiden las Reglas de Operación del } \\
\text { Programa Pro-Árbol de la Comisión Nacional Forestal. }\end{array}$ & $\begin{array}{l}\text { Integrated CONAFOR programmes, } \\
\text { including PES in ProÁrbol. }\end{array}$ \\
\hline 2009 & $\begin{array}{l}\text { Acuerdo por el que se establecen las Reglas de Operación del } \\
\text { Programa Pro-Árbol } 2009 .\end{array}$ & $\begin{array}{l}\text { Integrated CONAFOR programmes, } \\
\text { including PES in ProÁrbol. }\end{array}$ \\
\hline 2010 & Reglas de Operación del Programa ProÁrbol 2010. & $\begin{array}{l}\text { Integrated CONAFOR programmes, } \\
\text { including PES in ProÁrbol. }\end{array}$ \\
\hline 2011 & REGLAS de Operación del Programa ProÁrbol 2011. & $\begin{array}{l}\text { Integrated CONAFOR programmes, } \\
\text { including PES in ProÁrbol. }\end{array}$ \\
\hline 2012 & REGLAS de Operación del Programa ProArbol 2012. & $\begin{array}{l}\text { Integrated CONAFOR programmes, } \\
\text { including PES in ProÁrbol. }\end{array}$ \\
\hline 2013 & REGLAS de Operación del Programa Nacional Forestal 2013. & $\begin{array}{l}\text { Integrated CONAFOR programmes, } \\
\text { including PES in PRONAFOR. }\end{array}$ \\
\hline
\end{tabular}




\section{Chapter 5. Mapping the changes in the ORs over time}

\subsection{Introduction}

This chapter presents an empirical analysis of the PES ORs of PRONAFOR/ ProArbol, from 2003 to 2013 . The analysis of the ORs documents contributes to understand the patterns or trends that have given shape to this forest policy over time.

This analysis can also throw light on the institutional values or standards, on which the evolution of the programme is based, help to understand not only the direction that the programme is taking, but also the arguments under which this programme is justified (Hood \& Jackson, 1991). The ORs analysed as an instrument of communication with the public and potential users.

The chapter is structured in the following sections:

- Section 5.2 explains the elements, criteria and methods, and the framework for the analysis of the ORs.

- In section 5.3, the results of the analysis of OR evolution by category, period, and Temporal and communication qualities of change are presented, as well as the analysis of the ORs in general terms.

- Section 5.4 contains observations, comments, reflections and points of discussion about the evolution trends of ORs and their contribution to forest policy in México.

- Finally, section 5.5 presents general conclusions of the analysis, and links this chapter with the topics in the following chapter (the possible causes and influences of changes in the programme direction).

\subsection{Framework for the analysis}

The first step was to determine what aspects of the ORs to include and to explain why these are relevant for the analysis. The following questions framed the analysis of the ORs:

- What is the PES programme about? What is the apparent problem to solve? And why is PES seen as the solution?

- What kind of information is explained in detail? 
- Which actors are involved or mentioned in the documents? Which (expected) stakeholders are mentioned/not mentioned? What are the roles determined by CONAFOR about those stakeholders?

- How does the programme function? What are the key steps and procedures?

- What aspects of the ORs in general and of the PES programme have changed more frequently and more dramatically over time?

For analytical purposes, ORs can be seen as micro-institutions (see chapter 6), which determine the expected roles of actors involved in the PES programme, and the outcomes of interactions between them. To carry out this task, elements of institutional theory are used. With this approach, it is possible to describe and explain the influences, pressures, and tensions between actors, ideologies, interests, the search for legitimacy, and the preservation (in a dynamic, adaptive way) of the PES programme over time (Chapter 6).

In order to organise the information for the analysis, I assessed 12 categories of content in the ORs, organised in five groups as follows:

1. CONAFOR's institutional goals of the ProArbol/PRONAFOR programmes, and

Justification of ProArbol/ PRONAFOR programmes

2. What is the PES programme? including:

○ Definition of the programme

- Specific objectives

- Payment modalities

3. Actors and their roles, including:

- CONAFOR (National and state)

- Committees (National and state)

- Applicants/beneficiaries

- Technical advisors (TAs)

4. Procedures

5. Priority criteria for the selection of communities, including two modalities of PES:

- Hydrological

○ Biodiversity

The changes identified in the 12 categories contained in the ORs from 2003 to 2013 were analysed, both in terms of the intensity and frequency, and as a communicative device. 
In total I defined 6 descriptive criteria for analysis, which I called "temporal and communication qualities".

There are two qualities that can be seen as temporal criteria: the quality called 'dramatic-subtle' which refers to the intensity of the changes occurring from one year to the next in the categories of ORs analysed. And the quality, 'frequent-sporadic' is measuring the change in itself and concerns the periodicity of changes in the ORs over the whole 11 years.

The communication qualities are 4: 'complex-simple', 'rigid-flexible', 'specific-general' and 'technical-non technical language' which refer to how information is presented in ORs year by year, since this information is oriented to the main actors of the programme (CONAFOR staff, TAs, applicants and beneficiaries) and the public. It is important to make clear that there are no positive or negative connotations to the criteria; it is only a frame to describe the components of the ORs to be analysed.

All these criteria are arbitrary, the methodological purpose of developing them is to understand more and to analyse deeper the purposes and the scope of the ORs, because they are the primary means of communication between the principal PES policy designers and all the actors who have to implement the policy.

Although the qualities are qualitative criteria for the description of change, each one was considered on a six-point scale from 0-5 (which are subjective measures), which represents the intensity of each criterion in the ORs messaging of that year. For example, in the quality called 'technical-non-technical language', a value of 0 implies "the language used is non-technical", a value of 1 implies "the language is slightly technical", and so on until an assigned value of 5 implies "the language is very technical". With this information it was possible to construct illustrative graphs, where a colour was assigned to each quality to better identify them. The scale $0-5$ is marked on the y-axis of the graphs, and the $\mathrm{x}$-axis is the years 2003-2013 of publication of the ORs analysed (Table 5.1). 
Table 5.1. Example of the graph built to illustrate the change according to the qualities of the ORs over time.

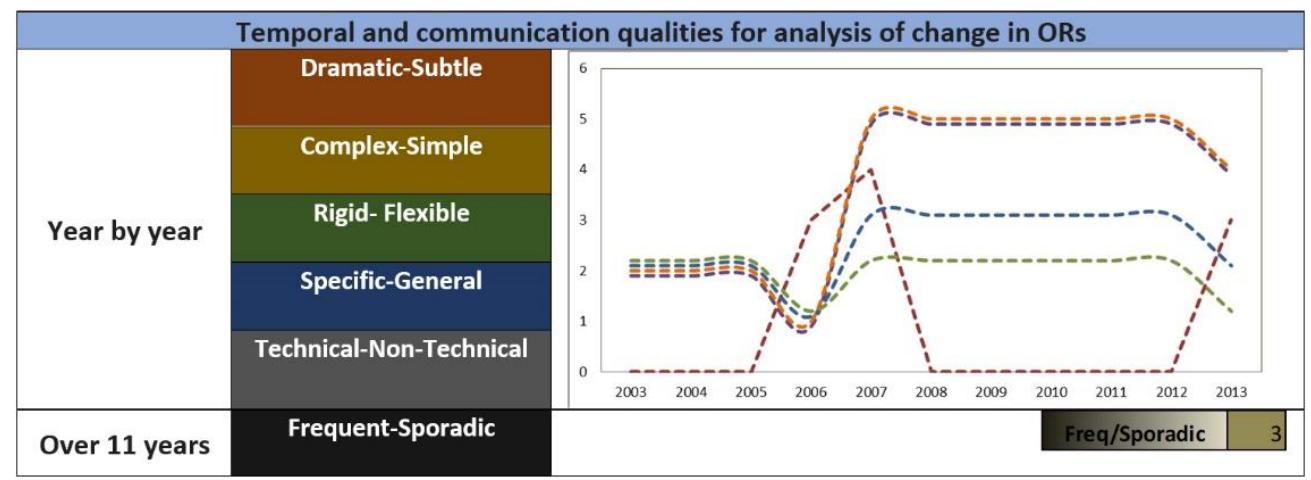

\subsubsection{Steps followed}

- All the 11 years of documents (2003-2013) were reviewed to find generalisations and the evident differences among them.

- Extract of information about the relevant topics directly from the ORs.

- Building of a 'basic information table, by transferring these extracts by topic to an Excel sheet, where the columns are the aspects to be analysed, and the rows correspond to the years, 2003-2013.

- Summarising the information obtained from each column, in order to visualise and identify patterns and the periods with more changes.

- Selecting the information to be analysed in ORs, and categorising it by topics (Goals and justification, definition of the programme, actors and their roles, procedures and priority criteria for selection of beneficiaries). After the integration CONAFOR programmes and their ORs in 2006, I took information of three main sections in the documents:

- General information for Pro-Arbol/PRONAFOR,

- Information concerning PES programme,

- Specific information for PES modalities (PSAH and Biodiversity), such as the selection criteria

- The changes were categorised according to the temporal and communication qualities described above in Table 5.1. Considering the numbers assigned in each quality graphs were constructed, in order to provide a notion of the type and intensity of the changes that occurred in the ORs, as can be seen in the figures 5.1-5.9, 5.11 and 5.13. 


\subsection{Characterisation of changes in the ORs}

\subsubsection{General changes in ORs}

In reviews of the ORs, I first took note of the most obvious differences in the ORs year by year. Table 5.2 shows the general changes in these with respect to the PES programme. After the integration of PES into Pro-Arbol ORs (2007-2010) many changes occurred, especially the targeting of beneficiaries and eligible areas for PES, and the definition of the roles of the stakeholders. 2010 was significant because after that the PES programme was simplified and reduced. As shown in chapter 4 , the modality of PES payments for carbon sequestration disappeared, and there remained only two modalities: Hydrological and Biodiversity PES which were divided into 6 differentiated payment areas. This scheme has remained in 2013. Also, in 2010 new "commitments" or obligations relating to the differentiated payment areas were made explicit, and CONAFOR determined the modalities of PES that applicants can access. In 2013, although there was a new name for the programme (PRONAFOR), and a change of administration of the national government, most of the changes were minor. These general changes are shown in Table 5.2

It can be concluded that the programme was experimental and adaptive, especially during the first years, with the creation of different modalities of PES, the integration of CONAFOR programmes in 2006, and the later incorporation into Pro-Arbol in 2007. The general structure of the ORs began to be standardised during those years, but many smaller changes were made thereafter. Particularly in 2008, 2010 and 2013 many small modifications appeared in the rules.

Table 5.2. General changes the ORs, 2003-2013.

2003

2004

2005

2006

- Creation of hydrological PES (PSAH) programme

- Eligible areas listed in an annex of the document

- Creation of the PES CABSA programme (Carbon sequestration, ES derived from

biodiversity in forests, and from the establishment and improvement of agroforestry)

- Based on projects to be developed by the applicants

- Indicators and procedures for the evaluation of results of the programme (the first and only time it is developed).

- Priority criteria increased.

- The eligible areas are not included in the document.

- Hydrological PES continued operating in parallel, with its own OR and no changes.

No changes in PSAH and CABSA

- Categorisation and integration of different programmes in a unified document:

"Operational rules for forest development".

- Beneficiaries' rights and obligations workshops are included.

- Best practices programme is included.

- Special priority criteria for each PES modality.

- Programmes or payment categories: 4 categories and 14 subcategories.

- Modality-specific performance, resolution and priority criteria are included.

- List of technical advisors (LAST). 


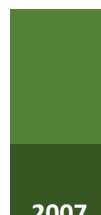

2008

- Technical committees: Including information about their structure, sessions, functioning and faculties as a mechanism for allocation of resources.

- New sections about: Decentralisation, internal audit, supervision, control, and monitoring of the programme.

- Several programmes of CONAFOR are incorporated into Pro-Arbol.

- Institutional goal emphasising socio-economic values and fighting poverty.

- Institutional coordination is added to the decentralisation section.

- Evaluation of the programme is reduced (regarding the 2004's OR) and does not include indicators.

- Rise of the endowment of biodiversity conservation, included as a PES modality

- Priority criteria: Social priority criteria become general for all the Pro-Arbol programmes.

- Technical advisors: The term Technical Advisor is introduced (before they were called just

'técnicos').

- Beneficiaries' obligations added: Hiring a technical consultant (by the beneficiaries) and the terms of the contract.

- Modalities of PES: The 'carbon capture' modality becomes 'development of an idea of carbon

capture project'.

- Promotion of natural regeneration in forests affected by weather events is added.

- Specific support for TA is included in the payment, based on type of programme and area.

- Application: The applicants decide the mode of PES to apply for.

- CONAFOR oversees geo-referencing the polygon in the proposals for PES.

- Objectives: Only the general objectives of Pro-Arbol are shown, but not objectives for each

programme.

- Objectives of each PES and other programmes' modalities reappear.

- General criteria for the implementation of PES are mentioned, specific to each modality, as well as performance, resolution criteria and priority criteria.

- Priority criteria: Refinement of some priority criteria, including studies with NGOs and universities.

- Institutional goal: The objectives related to poverty reduction are moved to second place.

- Eligibility: A typology of forest producers (not applicable to PES programmes) is included.

- The PES Modalities of payment change: Two modalities broken down into differentiated payment areas: Hydrological (1, 2, 3, 4 payment areas) and biodiversity (5 and 6 payment areas); Agroforestry systems are integrated to Biodiversity in the payment area 5 ; Carbon sequestration is removed.

- More detailed and organised information is included about the activities and requirements for new beneficiaries.

- Commitments for beneficiaries of PES: Specific obligations according to the payment areas.

- Beneficiaries' obligations added: the submission of a list of indirect beneficiaries.

- The obligations and competencies of state level and other offices are extended.

- Selection: CONAFOR determines the modality of PES and the hectares to be supported, instead of the applicants doing so.

- Good management certified cutting areas are permitted.

2011 - Procedures: Long section explaining the reasons and procedures for cancellation of supports is added, in legal language.

- More detailed information about the verification visits

- Pro-Arbol is renamed PRONAFOR

- General structure: Components and modalities modified.

- The ordering of the section's changes.

2013

- Technical advisors: the certification norm for TAs is added.

- Procedures: Reduction of the explanations on verification, as well as on the causes for cancellation of benefits.

- Priority criteria: The forest cover considers regionalisation: North-Centre ( $\geq 50 \%)$, and the Centre-

South (90\%).

- 'Best forest management practices' workshops for beneficiaries are established. 


\subsubsection{Analysis of change in the ORs over time}

\subsubsection{The programmes included in ORs}

After the integration of the CONAFOR programmes in 2006, and the establishment of ProArbol in 2007, the scheme of ORs has remained. However, but the number of programmes included, as well as the modalities for payment, as expressed in the ORs, has changed almost every year, as can be seen Table 5.3.

Table 5.3. The PES programmes included in the ORs: PSAH (2003-2005), CABSA (2004-2005), ProArbol (2006-2012) and PRONAFOR (2013)

\begin{tabular}{|l|l|}
\hline \multicolumn{1}{|c|}{ Date } & \multicolumn{1}{c|}{ Title of the document } \\
\hline $2003-2005$ & Payment for hydrological services (PSAH). \\
\hline $2004-2005$ & $\begin{array}{l}\text { Payments for the development of carbon sequestration, biodiversity, and } \\
\text { promote the establishment and improvement of agroforestry systems (PSA- } \\
\text { CABSA). }\end{array}$ \\
\hline 2006 & Integrated rules (4 payment categories/14 subcategories) \\
\hline 2007 & Pro-Árbol (4 categories, 16 subcategories) \\
\hline 2008 & Pro-Árbol (4 categories, 15 subcategories) \\
\hline 2009 & Pro-Árbol (4 categories, 15 subcategories) \\
\hline 2010 & Pro-Árbol (3 categories, 8 subcategories, 27 modalities) \\
\hline 2011 & Pro-Árbol (2 categories, 6 subcategories, 20 modalities) \\
\hline 2012 & Pro-Árbol (2 categories, 6 subcategories, 18 modalities) \\
\hline 2013 & PRONAFOR (4 categories, 6 subcategories, 18 modalities) \\
\hline
\end{tabular}

\subsubsection{CONAFOR's institutional goals and justification for the PRONAFOR programmes}

\section{a) Institutional goals}

The vision of CONAFOR as the organisation in charge of forest policy and its programmes is presented in the ORs. The most significant changes on this topic are the transition from purely environmental values, to environmental and socio-economic values. The idea of forest production and productivity is also evident. Competitiveness and economic expansion, which were early goals, were tempered in 2013 by the use of terms "sustainability" and "improvement of quality of life" (Timeline 5.1). 
Timeline 5.1. Institutional goal, values expressed over time in the ORs

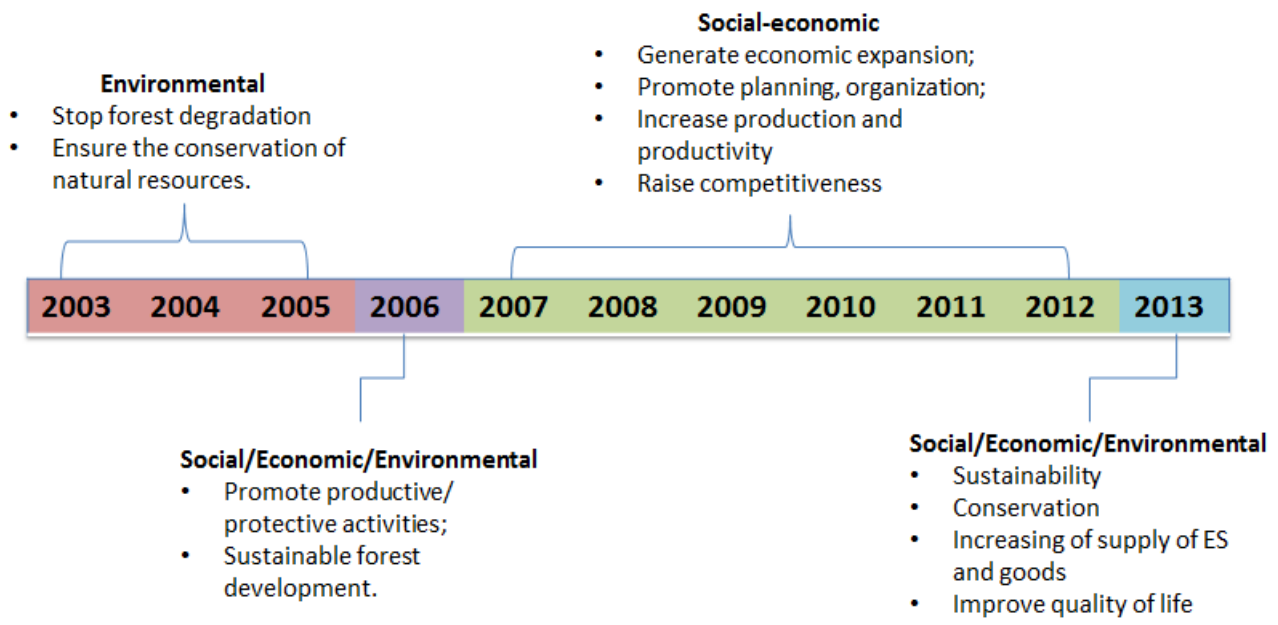

\section{b) Institutional justification of the programmes}

Although there is no section into the ORs specifically devoted to justification, the first pages each present several problems, needs and arguments for CONAFOR's programmes. These arguments were more specific for PES programmes in 2003, 2004 and 2005, with, for example, the emphasis on the lack of environmental services markets, and the potential of developing them in México. The recognition of ES in different ecosystems and in productive systems has been present since 2004 . It is noticeable that (at least in the official discourse) the positive role of local communities in the conservation of forest has been recognised from the beginning, as well as the need to incentivise good management practices. After the integration of the ORs, the arguments became more general, emphasising the need to promote production and productivity, sustainability, and competitiveness, and pay attention to the needs and priorities of forest owners. In 2013, arguments for the recognition of the importance of ES in forests and sustainable productive systems came back. Timeline 5.2 shows the evolution of the justifications in different periods. 
Timeline 5.2. Justification/ Arguments used in the ORs to justify the CONAFOR programmes (PSAH, CABSA, Pro-Arbol, PRONAFOR)

PSAH/CABSA

Pro-Arbol

PRONAFOR

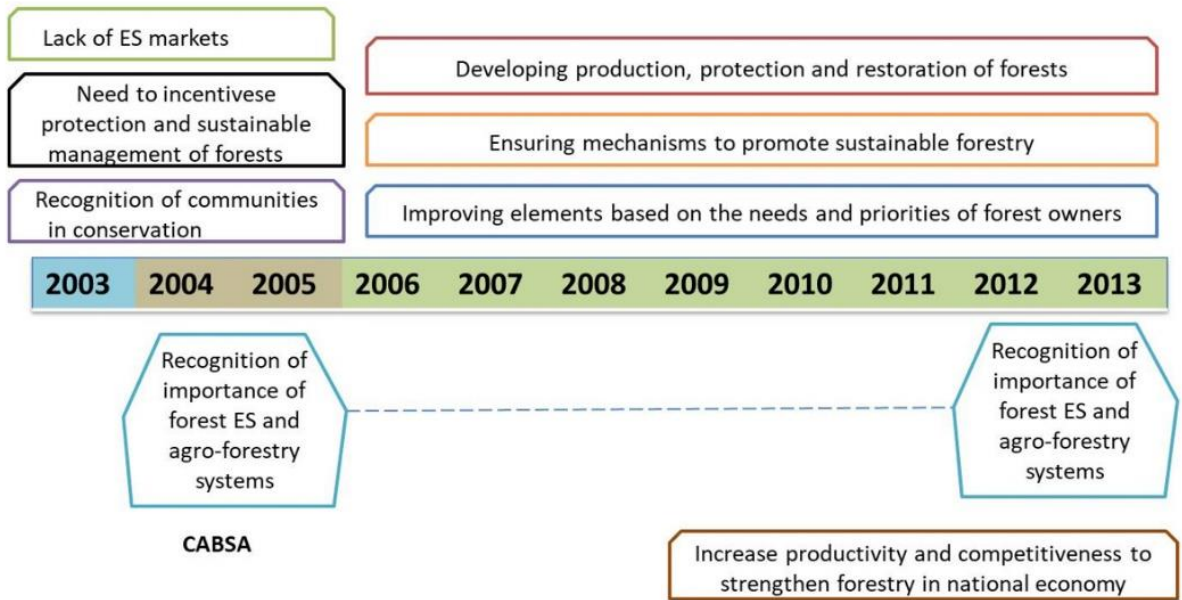

\subsubsection{What is the PES programme?}

\section{a) Definition of the PES programme}

The descriptions of PES in the specific ORs (PSAH and CABSA) of the first 3 years varied considerably from the descriptions presented after 2006. Only the 2004 ORs included the concept of capacity-building in the development of PES projects. The integration of programmes after 2006 caused reductions in the description of all the programmes, including PES. Between 2006 and 2008, an attempt was made to create a definition to include the PES programmes that had hitherto operated separately. From 2009 to 2013, the definition has remained brief and general, only including examples of environmental services provided by the forest, rather than providing a description of the programme itself (Timeline 5.3). 


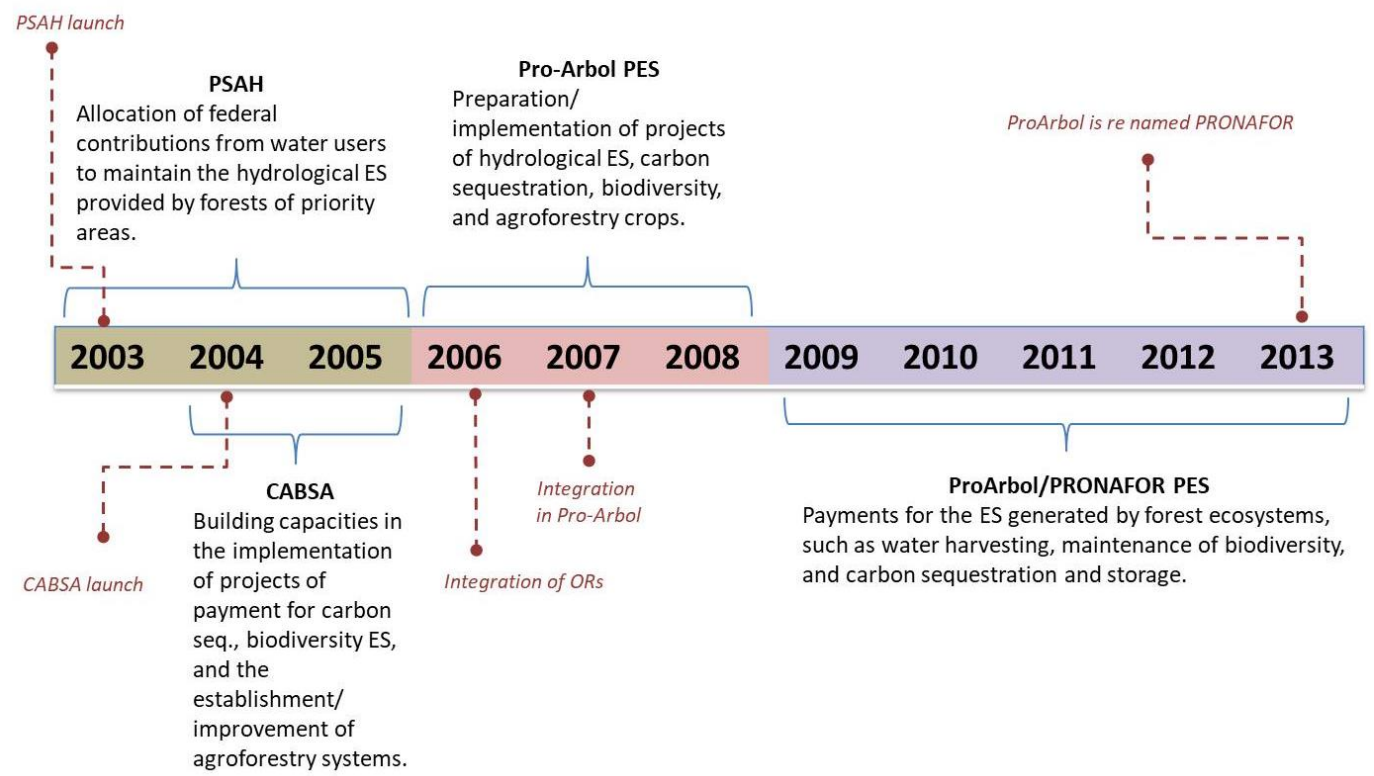

\section{b) Specific objectives of the PES programme}

The objectives of the programme in the ORs for PSAH in 2003-2005, are focused on environmental aspects, emphasising the protection of forest ecosystems. When the CABSA programme was launched, the approach became more social-economic and more inclusive than the traditional PSAH, by mentioning concepts like capacity-building, strengthening of institutional structures and participation in markets, with environmental topics in second place. Once the integration of PES programmes occurred in 2006 - 2007, the main idea was developing environmental services markets. But the institutional goals of the general ORs placed the idea of poverty reduction above that of forest ecosystem protection. The idea of developing carbon markets was introduced in 2008. From 2009 to 2012, although the modalities have changed over time, individual objectives for each modality were included, and the emphasis on the environmental approach came back. In 2013, the objectives included the improvement of forest management practices for the conservation of forest ecosystems (Timeline 5.4). 
Timeline 5.4. Objectives of the programme.

\begin{tabular}{|c|c|c|c|c|c|c|c|c|c|c|c|c|}
\hline \multicolumn{2}{|c|}{ Emphasis on } & 2003 & 2004 & 2005 & 2006 & 2007 & 2008 & 2009 & 2010 & 2011 & 2012 & 2013 \\
\hline Protecting & $\begin{array}{l}\text { Forest } \\
\text { resources }\end{array}$ & & & & & & & & & & & \\
\hline \multirow[t]{3}{*}{ Conserving } & Forests & & & & & & & & & & & \\
\hline & Aquifers & & & & & & & & & & & \\
\hline & Biodiversity & & & & & & & & & & & \\
\hline Building & Capacities & & & & & & & & & & & \\
\hline Strengthening & $\begin{array}{l}\text { Institutional } \\
\text { structures }\end{array}$ & & & & & & & & & & & \\
\hline Participating & ES markets & & & & & & & & & & & \\
\hline Establishing & $\begin{array}{l}\text { Agroforestry } \\
\text { systems }\end{array}$ & & & & & & & & & & & \\
\hline \multirow[t]{2}{*}{ Developing } & ES markets & & & & & & & & & & & \\
\hline & $\begin{array}{l}\text { Carbon } \\
\text { markets }\end{array}$ & & & & & & & & & & & \\
\hline Improving & $\begin{array}{l}\text { Provision of } \\
\text { ES }\end{array}$ & & & & & & & & & & & \\
\hline Avoiding & Soil erosion & & & & & & & & & & & \\
\hline Incorporating & $\begin{array}{l}\text { Good } \\
\text { management } \\
\text { practices }\end{array}$ & & & & & & & & & & & \\
\hline
\end{tabular}

Four dramatic changes have occurred in the PES objectives. The most important, in 2004, related to the establishment of CABSA. The others are related to the changes in conceptualisation of PES programme itself and the payment modalities. In CABSA, the objectives were complex, specific and rigid. Between 2006 and 2008 the objectives became simpler, referring to the development of ES markets. In 2009, when the Hydrological PES and CABSA were integrated in a single PES programme with different payment modalities, the objectives changed again, becoming more specific, and complex. Finally, in 2013, PES objectives again became even simpler and general, as shown in figure 5.1 . 
Figure 5.1. Temporal and communication qualities for analysis of change of PES objectives. The lines show the trajectory of each quality. For instance, Frequent and dramatic changes occurred in the definition of the PES objectives over time. The main changes occurred between 2003 and 2005. PES Objectives have become simpler, more general and more flexible. The frequent-sporadic criterion indicates the degree of change over the $\mathbf{1 1}$ years in a scale of 0-5. In this case the changes occurred frequently.

\section{Temporal and communication qualities for analysis of change} PES objectives

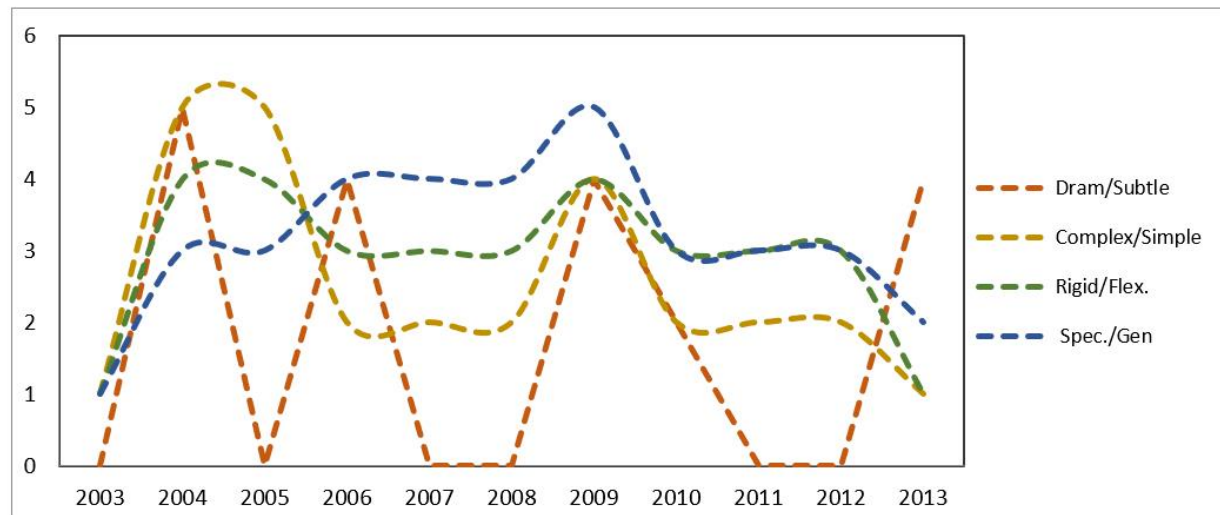

\section{c) Payment modalities}

The most important change in the programme has been the types and number of modalities of PES. The most stable modality has been the payments for hydrological services, followed by biodiversity payments. Agroforestry has been integrated into biodiversity. After trying different approaches, carbon sequestration was stopped in 2007, and then replaced in 2008-2009 by 'development of an idea of carbon sequestration', which was later dropped (from 2010). From 2010 until 2013 (the end of this analysis), there was only two modalities divided into 6 payment areas: 3 for hydrological and 3 for biodiversity, (one of the corresponding to the environmental services of agroforestry lands). 
Timeline 5.5. Payment modalities over time. In 2013, 2 modalities of PES divided into 6 types of payment, one of which corresponds to agro-forestry systems.

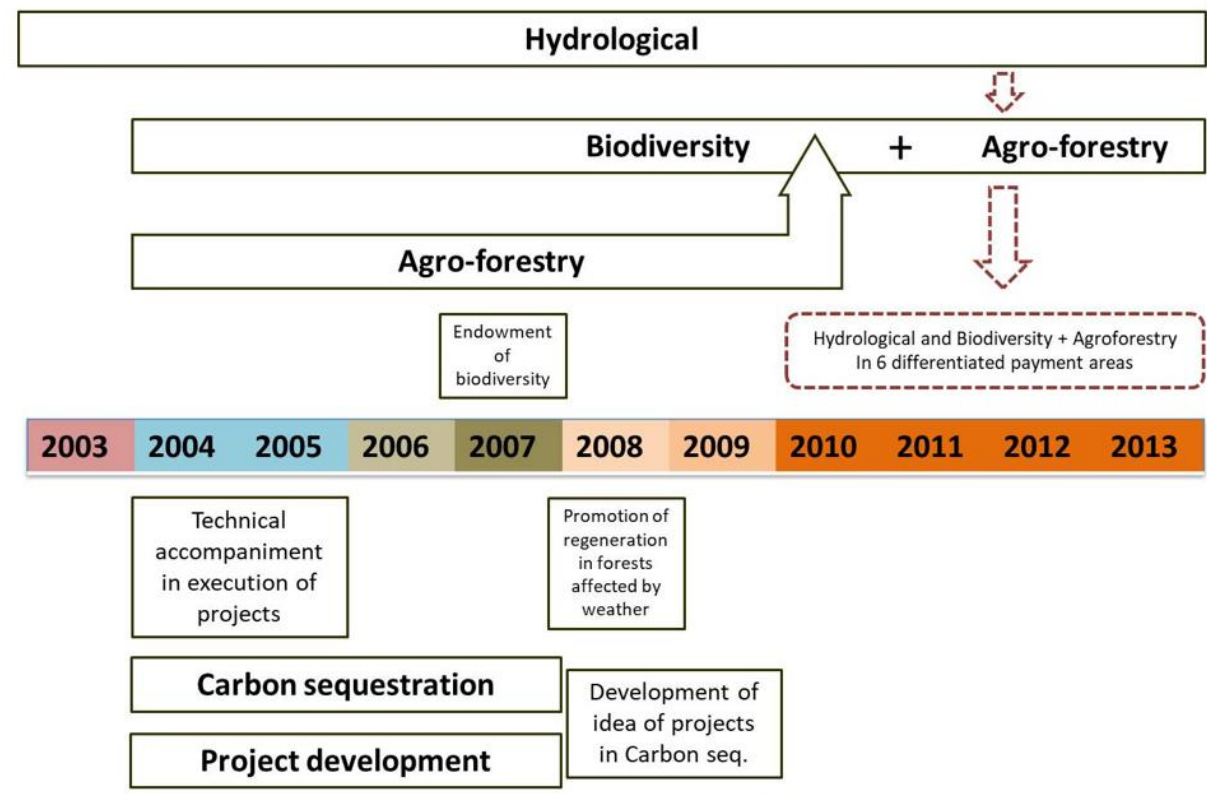

The modalities of payment in PES experienced many changes from 2004 to 2010, when finally they became stable. The arrangement in 2013 was much simpler, specific and rigid: spatial features of lands and the type of management define the payment area to be included in applications. The ambiguous options of 'development of projects and ideas for sequestration of carbon', and 'accompaniment in the execution of the programmes' constrained the possibilities for applicants to propose activities, but made it easier to apply the programme because there were fixed budgets and activities (Fig. 5.2). 
Figure 5.2. Temporal and communication qualities for analysis: Payment modalities

Temporal and communication qualities for analysis of change

Payment Modalities

Freq/Sporadic 5

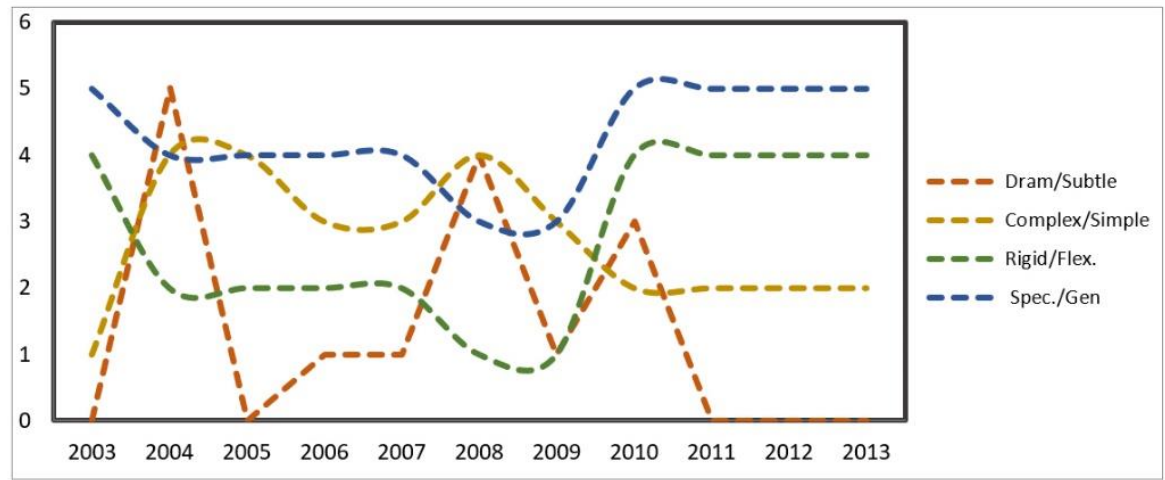

\subsubsection{Actors and their roles}

The main actors mentioned in the ORs and information about their roles, obligations, rights, competencies are the following:

- $\quad$ CONAFOR (National and state)

○ Competencies

- Obligations (national and state)

- Committees (National and state)

○ Membership eligibility (2004-2007)

○ General operation (2004-2007)

- Competencies

- Applicants/beneficiaries

- Eligible applicants and requirements

- Requirements for new beneficiaries

$\circ \quad$ Rights and obligations of beneficiaries

- $\quad$ Technical advisors (TAs)

○ Obligations and requirements

There was never any specific section regarding the role of TAs in the programme, although their tasks are briefly mentioned in the documents.

\section{a) CONAFOR (National and State level)}

CONAFOR includes both the National and the State Offices (Timeline 5.6). Although at both levels there is a department completely devoted to PES programmes, information 
about their competencies and obligations was ambiguous at the beginning. The information about obligations changed dramatically in 2006, and later they became more explicit, more specific, complex and rigid (Figure 5.3).

Timeline 5.6. The obligations for CONAFOR

PSAH

CABSA

Pro-Arbol

PRONAFOR

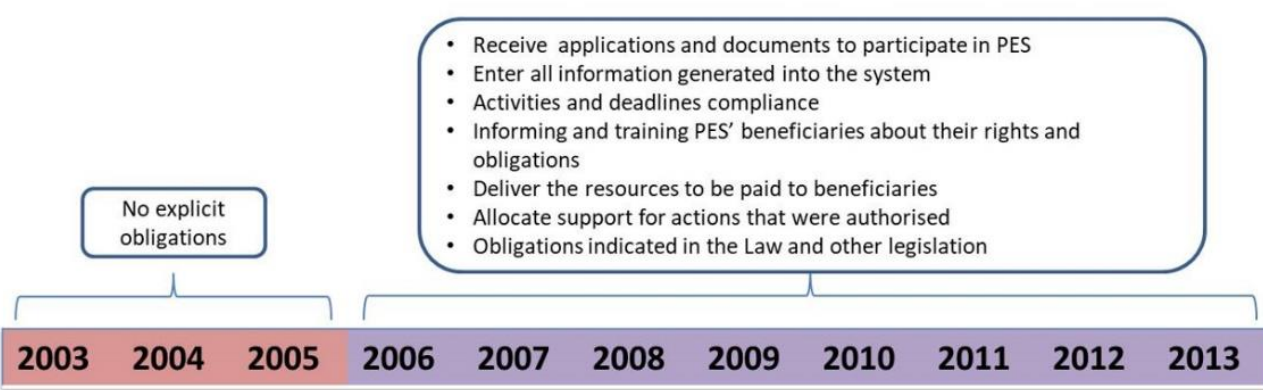

Figure 5.3. Temporal and communication qualities for analysis: CONAFOR obligations.

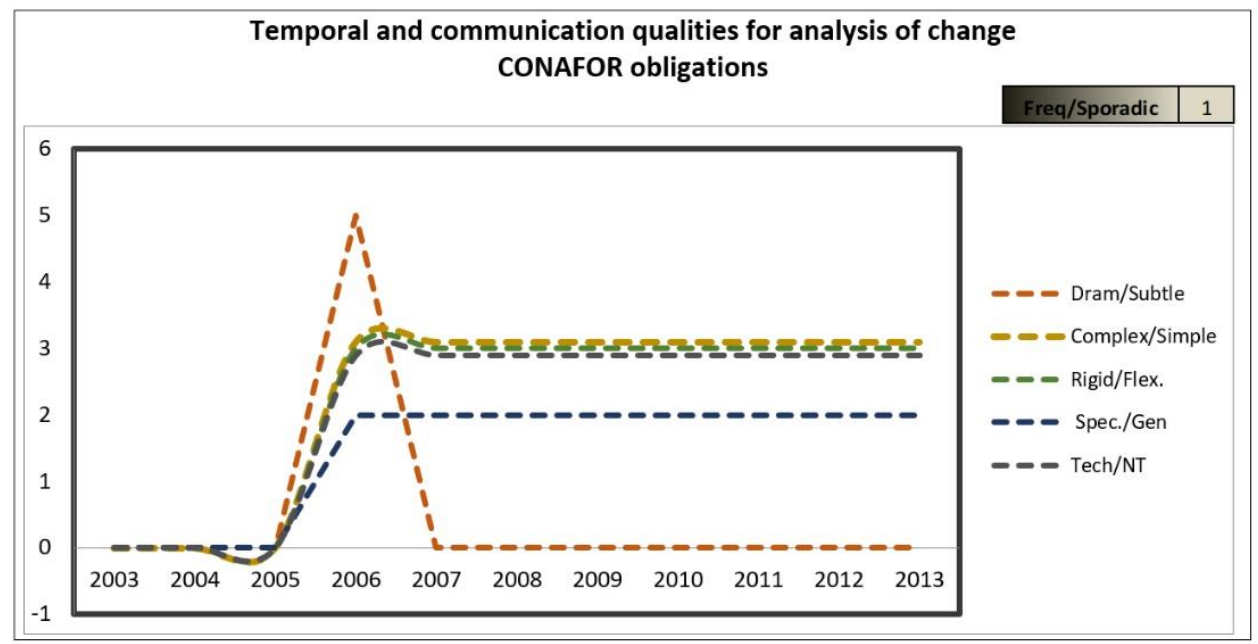

Before 2006 the competencies were more specific and shorter. They included tasks like the identification of eligible zones and marking out the zones or polygons of the applicants within them, because the applicants did not have the tools, assistance to do it themselves. In 2006 some of the competencies were considered to be obligations. In general, after 2006 modifications in this section were more subtle, many came to be 
more general (or ambiguous), or the language used became vaguer. The only competency present throughout the history of the PES programmes is that related to the determination of eligibility zones, but the geo-referencing of polygons was not present anymore in 2013. In 2008 the responsibilities of state level employees became more explicit. Responsibilities relating to the verification process disappeared in 2006 and reappeared in 2010 (Timeline 5.7; Figure, 5.4).

\section{Timeline 5.7. CONAFOR Competencies}

PSAH CABSA

Pro-Arbol

PRONAFOR

\section{$\begin{array}{lllllllllll}2003 & 2004 & 2005 & 2006 & 2007 & 2008 & 2009 & 2010 & 2011 & 2012 & 2013\end{array}$}

- Identifying eligibility zones

Geo-reference the polygons

- Promote the programme

- Register the applications

- Assess and select applications

- Integrate the beneficiaries file

- Allocate the payments

- Extend contracts annually (5 years)

- Cancel the contract in case of breach

- Evaluate the programme
- Establish criteria for the support priorities, amounts, reports

- Explicit state level responsibilities are included

- Determine the distribution and reallocation of support

- Perform the resolution of matters not contemplated

- Integrate into the system, and provide records, monitoring and reporting of supports

- Develop feasibility reports of each application and submit to the Committee

- Perform technical, operational and administrative activities, and implement the resolutions of the technical committee

- Issue the financial resources to the proper implementation of the ORs

- Random monitoring

- Verification process 
Figure 5.4. Temporal and communication qualities for analysis of change: CONAFOR competencies

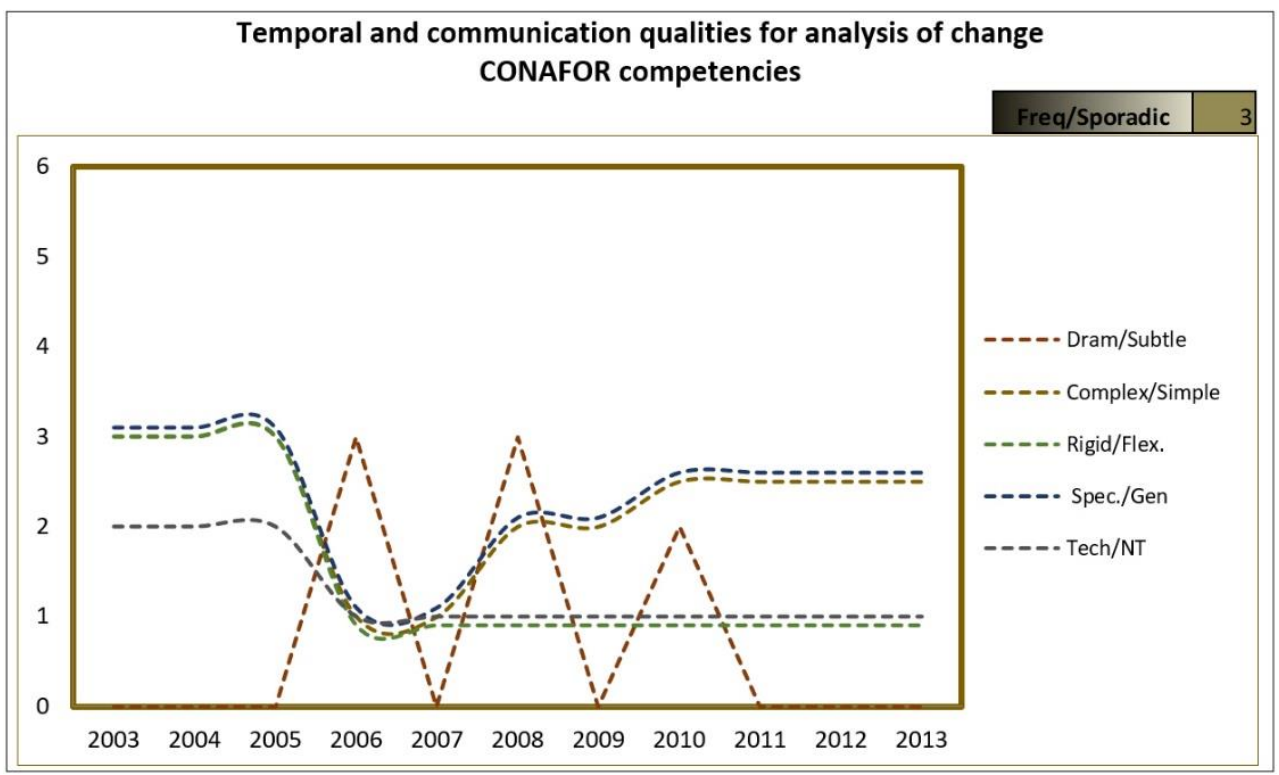

b) Technical Committees

The technical committees (at national and state level) are mentioned and established as decision-making entities in 2003. In that year, only the main competencies of the committees were described. For 2004 and 2005, the ORs included also detailed information about how to staff them. Information about the operation of the committees was added in 2006: the number of sessions and activities related to the allocation of payments over time. The rules became more specific concerning the activities and competencies of national and state level committees. The competencies changed in 2007, especially those related to the monitoring of the performance of CONAFOR. The competencies related to making decisions for reallocating funds was changed by suggesting that CONAFOR carry out any allocation.

In 2008 information about how to determine committee membership disappeared. Also, their competencies were reduced as regards the allocation of payments, and interventions in case of non-compliance of beneficiaries. After that year the information remained stable, with only the addition in 2013 of a new competency related to the capability to revoke the benefits and demand reimbursement from beneficiaries in cases of disputed lands (Figure 5.5). 


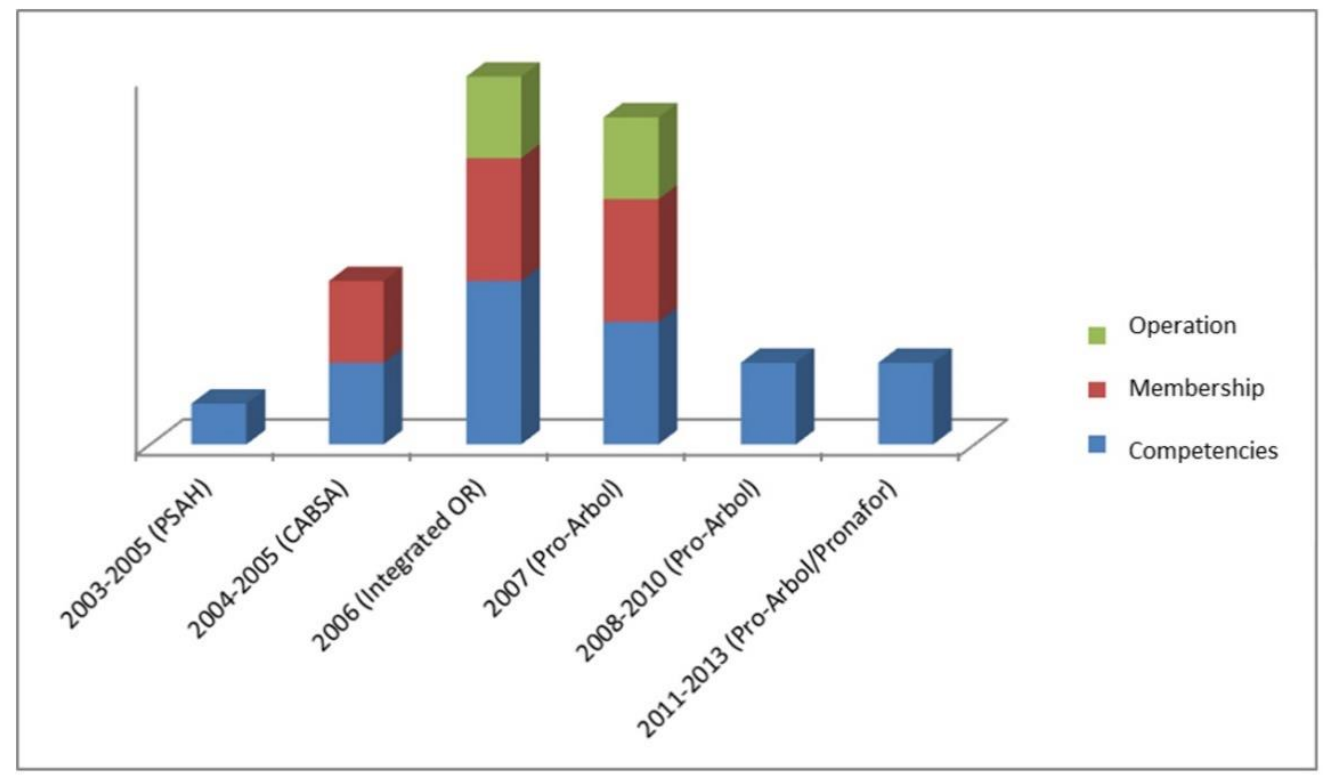

Information about the technical committees over time has varied. In 2006-2007 detailed and specific descriptions appeared in the ORs, but after that, the trend seems to be the reduction and simplification, and only the most general areas remained.

\section{c) Eligible Applicants and Beneficiaries}

Since the ORs are tools for disseminating information about CONAFOR programmes to potential users, is not surprising that most of the information about actors has to do with the (potential) beneficiaries. The rules provide a range of information, including the characteristics of the target population who can access the support, the requirements to be met, the documents to present with the application, and the rights, commitments and obligations acquired by the applicants once they have been accepted into the programme (McCall et al., 2017) (Table 5.4). In this section I will focus on the eligibility of applicants, and the rights and obligations of the new beneficiaries.

Table 5.4. Information in ORs about eligible applicants and beneficiaries 


\begin{tabular}{|l|l|}
\hline \multicolumn{1}{|c|}{ Actor } & \multicolumn{1}{c|}{ Information in the ORs } \\
\hline Target population & Description of eligible applicants. \\
\hline Eligible applicants & $\begin{array}{l}\text { Description of requirements and documents to be } \\
\text { delivered with the application. }\end{array}$ \\
\hline Beneficiaries & Requirements for new beneficiaries \\
& Rights \\
& Obligations \\
& Commitments \\
\hline
\end{tabular}

\section{- Eligible applicants}

The rules of allowable applicants or target population have experienced subtle changes over time. The main change has been 1) the intent to include associations like schools, government institutions, and private commercial companies willing to protect forest areas. But this idea was discarded in the 2008 rules. In 2009 there was an attempt to be more flexible and inclusive in areas under extraction but outside timber-cutting areas. $A$ typology of forest owners was included in 2010, in order to classify them according to the different programmes to request (such as the forest management, and timber extraction), but this was not applicable to PES (Timeline 5.8).

\section{Timeline 5.8. Eligible population}

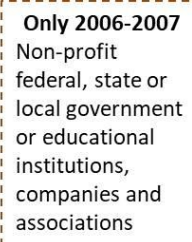

\begin{tabular}{l}
\multicolumn{2}{c|}{2009} \\
Timber forest \\
management \\
programme, \\
outside of \\
tree cutting \\
area
\end{tabular}

2010-2013

Typology of forest producers:

I. Potential

II. Selling standing timber

III. Forest raw materials

IV. Processing and marketing products

\section{$+\quad+\quad+$}

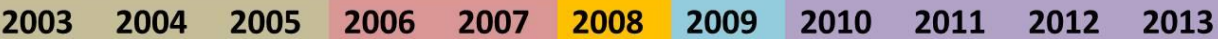

PSAH/CABSA

Ejidos, communities, smallholders, legitimate holders of forest resources and partnerships that are within eligible areas

\section{Pro-Arbol/Pronafor}

Individuals, and legal entities who are owners/ holders of forest lands, and non- owners who prove their eligibility. (Only Mexican nationals)

Therefore, after 2006-2007, rules about eligibility tended to be more general, but at the same time more restrictive, and in 2010 the complexity increased with the inclusion of the typology of forest producers according to their forest production activities (Figure 5.6). 
Figure 5.6. Temporal and communication qualities for analysis of change: Eligible applicants

Temporal and communication qualities for analysis of change

Eligible applicants

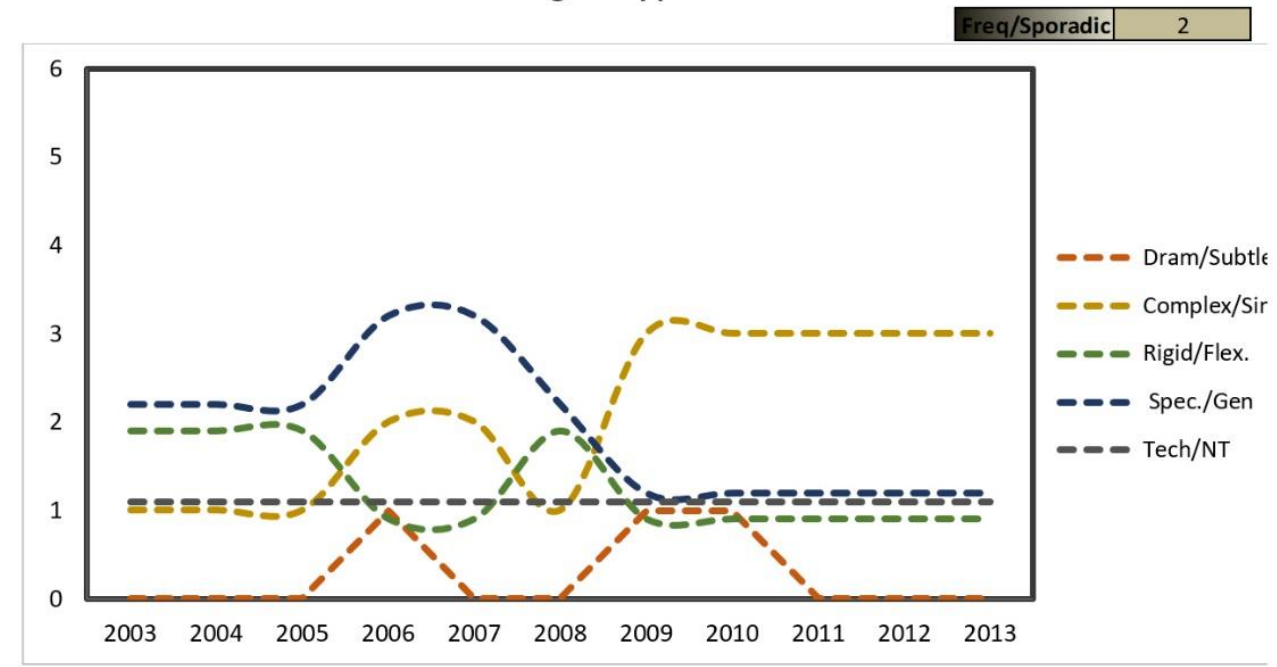

- Beneficiaries

\section{Rights, obligations and specific commitments of beneficiaries}

The rights and obligations of new beneficiaries have been present in the ORs since the origin of the programme. Rights and obligations were mixed in the ORs of 2003-2005 (PSAH) and 2004-2005 (CABSA), and after 2006 they were separated. Workshops to instruct new beneficiaries on their rights and obligations acquired were held after 2006.

\section{Beneficiaries' rights}

The rights of beneficiaries have not changed dramatically since the beginning. In comparison with the obligations, rights are few, vague, and repetitive; and they have not increased much over time. Since 2006 they remained relatively constant. The right of appeal for review in cases of administrative sanctions disappeared in 2013. In the same year the obligation to train beneficiaries on their rights and obligations became a requirement (Timeline 5.9). 
Timeline 5.9. Beneficiaries' rights

PSAH

CABSA

Pro-Arbo

PRONAFOR

Request to CONAFOR for support to carry out the forest management plan

Express written complaints and disagreements

\section{$\begin{array}{lllllllllll}2003 & 2004 & 2005 & 2006 & 2007 & 2008 & 2009 & 2010 & 2011 & 2012 & 2013\end{array}$}

Present the appeal of review before CONAFOR in case of administrative sanctions

Receive the assistance and information needed

Receive the payments in a timely manner

The rights tended to remain simple, general and even ambiguous. The transformation of an obligation into a right is probably an attempt to balance the difference between them (Figure 5.7).

Figure 5.7. Temporal and communication qualities for analysis of change: Beneficiaries' rights

Temporal and communication qualities for analysis of change Beneficiaries' Rights

Freq/Sporadic 13

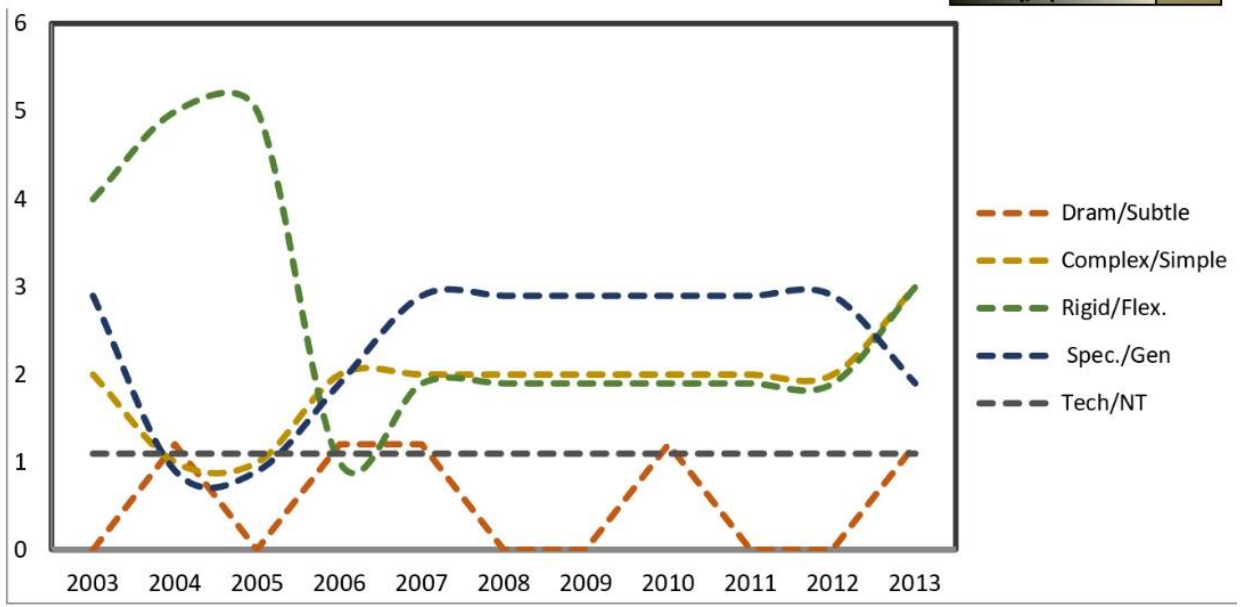




\section{Beneficiaries' obligations}

The obligations of beneficiaries increased considerably over time, but the most conspicuous change occurred in 2006. Before this year, obligations were related to the conservation of the natural condition of the forest lands, avoidance of deterioration, and self-monitoring by beneficiaries; and after 2006 to activities more related to accepting training programmes and CONAFOR verification visits, and the correct (predefined by CONAFOR) use of the funds provided, among others. Many of the obligations can be considered more passive. The 2003-2005 obligations were included later (2010) as "beneficiaries' commitments" specifically for PES beneficiaries. In general, the obligations established in 2006 continued, with enduring additions as in 2008 about hiring technical assistance, and, in 2011, the fulfilment of requirements for receiving the final payment after the 5 years of the contract. Thus, had been already present in past years but not as an obligation.

Timeline 5.10. Beneficiaries' obligations

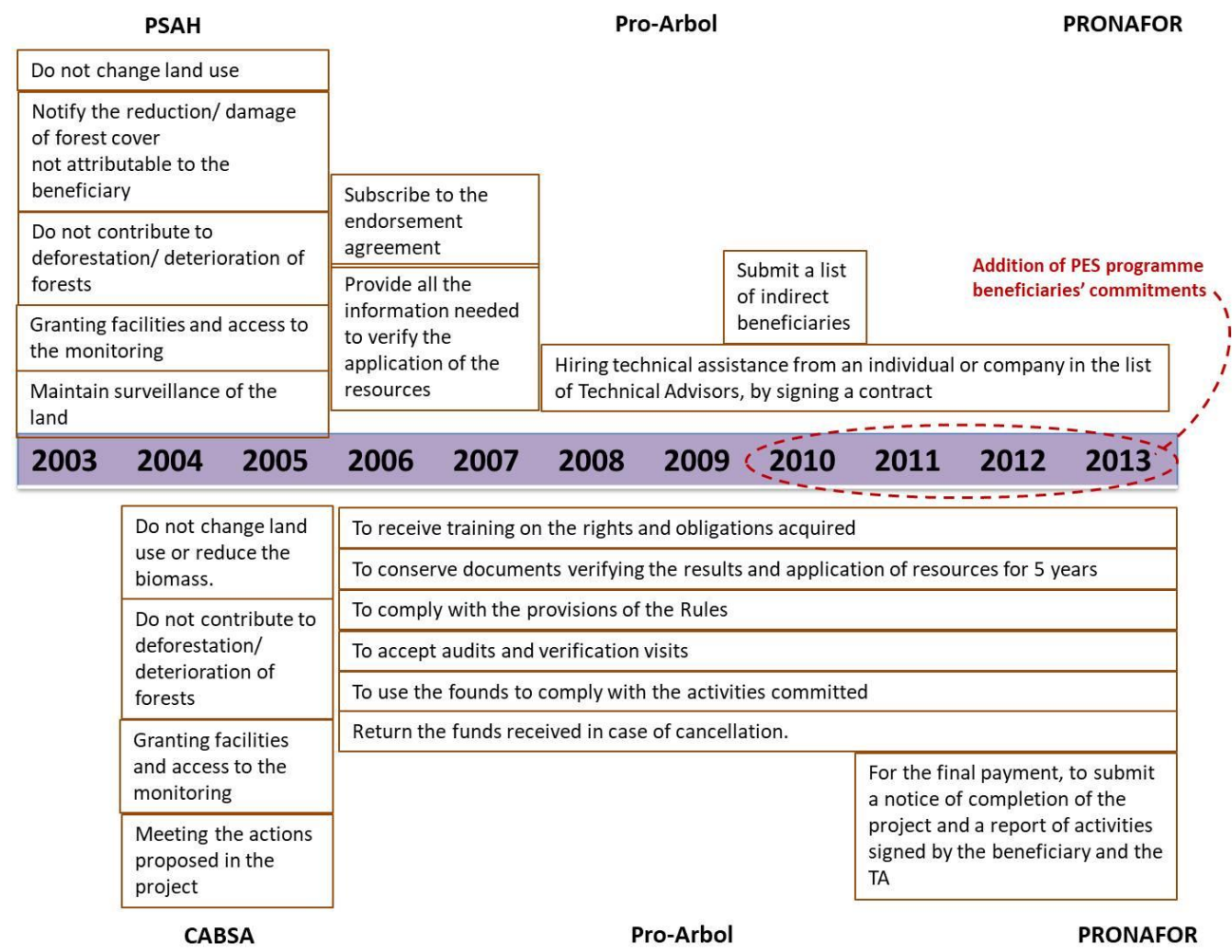


As mentioned before, the obligations are general for the beneficiaries of all the programmes included in Pro-Arbol/PRONAFOR. On the other hand, the commitments are specific obligations to be fulfilled by the PES programme beneficiaries (Table 5.5). They were added in the 2010 ORs and concern the conservation of the lands under the programme and the mandatory activities related to that. They vary according to the differentiated payment areas of PES. The commitments did not change since they were established in the ORs, but they were called "obligations" in 2013.

Table 5.5. Commitments related to PES differentiated payment areas. The payment areas are determined by the ecological features and ecosystem values of vegetation types and the risk of deforestation, with the amounts payable for each. The areas 1 to 2 or 3 correspond to hydrological environmental services which receive the highest payments per hectare, while the Areas 4-6 correspond to biodiversity and agroforestry PES, which have the lowest rates. The degree of responsibilities reflected in the commitments also increase or decrease depending on the corresponding payment area (e.g. modality 1-A3 have more commitments than 4-6). The stars indicate the mandatory activities, and numbers indicate the number of workshops, reports or activities to be done in relation the payment area of PES.

\begin{tabular}{|c|c|c|c|c|c|c|}
\hline \multirow[t]{2}{*}{ Commitments } & \multicolumn{6}{|c|}{ Payment area } \\
\hline & 1 & 2 & 3 & 4 & 5 & 6 \\
\hline Avoiding land use change & $*$ & $*$ & * & * & $*$ & * \\
\hline Conserving the forest cover & * & * & * & * & * & * \\
\hline Avoiding overgrazing & * & * & * & * & * & * \\
\hline Organising a brigade for prevention and firefighting and surveillance & * & * & * & * & * & * \\
\hline Placing signs or placards indicating the area of PES during the five years & 2 & 2 & 2 & 2 & 2 & 1 \\
\hline Organising workshops in capacity-building & 2 & 2 & & 1 & 1 & \\
\hline $\begin{array}{l}\text { Delivering a Program of best management practices** and starting implementation } \\
\text { from the second year of PES }(\mathrm{A} 1, \mathrm{~A} 2)\end{array}$ & * & * & & & & \\
\hline $\begin{array}{l}\text { Selecting activities each year from the list of Guide of Best Management Practices**, } \\
\text { from the second year. }\end{array}$ & & & 3 & 4 & 2 & 1 \\
\hline \multicolumn{7}{|c|}{$\begin{array}{l}\text { **The Programme and Guide of Best Management Practices are self-planning documents to be prepared by beneficiaries. The } \\
\text { Programme is a more complex document, written by the beneficiaries with the support of the Technical Advisors. The Guide is } \\
\text { simpler; it is a sort of format designed by CONAFOR from which the beneficiaries select from a list of pre-determined activities } \\
\text { to carry out on the lands. The selection of activities must also be supported by the TAs. }\end{array}$} \\
\hline
\end{tabular}

Unlike rights, the obligations of beneficiaries changed more frequently, and became more rigid, specific and technical over time. They also increased in number and in complexity. The obligations, and especially the commitments, are measured by CONAFOR in the verification process (Figure 5.8). 
Figure 5.8. Temporal and communication qualities for analysis of change: Beneficiaries' obligations over time, including the PES commitments

\section{Temporal and communication qualities for analysis of change} Beneficiaries' obligations

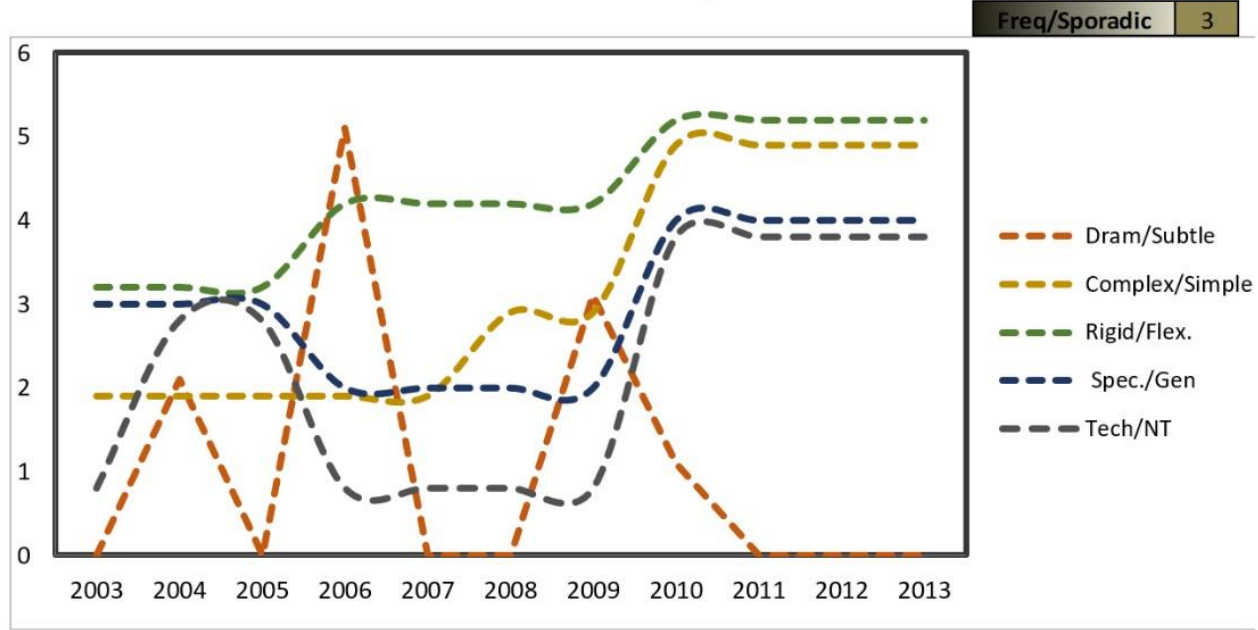

\section{d) Technical advisors}

Although Technical Assistance has been one of the most important components of the implementation of the PES programmes since the beginning, information about TAs in the ORs has been always scanty, variable and vague. There is no specific section in the ORs about the TAs, thus the relevant information is scattered amongst the documents. In 2004 they were mentioned for the first time, when CABSA had a modality focused on the support for training community level TAs. This modality ended in 2006, but in the same year a list of registered TAs to be hired by beneficiaries to carry out some activities, was included for the first time. The hiring of TAs started being considered as a requirement for beneficiaries. After 2008, hiring TAs became an obligation on the beneficiaries. Little, but more specific information was presented however about their tasks in the development of the programme. Terms related to Technical Assistance appeared in the Glossary in 2008, and the definition changed in 2011, with a subtle modification in 2013 (Figure 5.6): 
Table 5.6. TAs definition in ORs

\begin{tabular}{|c|c|c|}
\hline Period & Term & Definition \\
\hline 2003-2007 & No terms provided & \\
\hline 2008-2009 & Technical assistance & $\begin{array}{l}\text { "Activities to help foresters with the compliance of aspects of } \\
\text { the programme, such as use, conservation, restoration, } \\
\text { protection and transformation of forest resources" }\end{array}$ \\
\hline 2010 & $\begin{array}{l}\text { List of Technical Advisors } \\
\text { (LAST) }\end{array}$ & $\begin{array}{l}\text { "The names of individuals and organisations that meet the } \\
\text { requirements of the call issued by CONAFOR, to provide } \\
\text { technical assistance to beneficiaries under these Operational } \\
\text { Rules. [The list] is published in the Official Gazette of the } \\
\text { Federation, CONAFOR's website, and in the regional and state } \\
\text { offices" }\end{array}$ \\
\hline \multirow[t]{2}{*}{ 2011-2012 } & Technical advisors (TAs) & $\begin{array}{l}\text { "Individuals and organisations who voluntarily meet the } \\
\text { procedures and requirements to obtain accreditation to } \\
\text { provide technical assistance to beneficiaries of CONAFOR". }\end{array}$ \\
\hline & $\begin{array}{l}\text { Technical assistance to } \\
\text { beneficiaries }\end{array}$ & $\begin{array}{l}\text { "Technical support for beneficiaries to comply in activities } \\
\text { derived from these rules" }\end{array}$ \\
\hline 2013 & Technical advisors & $\begin{array}{l}\text { "Individuals and organisations that met the procedures and } \\
\text { requirements for certification that allows them to provide } \\
\text { technical assistance to the beneficiaries of CONAFOR; and } \\
\text { persons authorised to provide technical assistance that are } \\
\text { registered in the List of Technical Advisors published on } \\
\text { CONAFOR's website". }\end{array}$ \\
\hline
\end{tabular}

More details about the tasks and obligations of TAs, and restrictions on them have been added over time. The TA certification is mentioned for the first time in 2013, but no information is provided about the process (Table 5.7). 
Table 5.7. Information on TAs over time

\begin{tabular}{|l|l|}
\hline \multicolumn{1}{|c|}{ Period } & \multicolumn{1}{c|}{ Information on TAs in ORs } \\
\hline $\begin{array}{l}\text { 2003-2005 } \\
\text { (PSAH) }\end{array}$ & TA not mentioned \\
\hline $\begin{array}{l}2004-2005 \\
\text { (CABSA) }\end{array}$ & $\begin{array}{l}\text { Technical support is included in two ways in PSA-CABSA, providing payments for: } \\
\text { 1) Training of community technicians, and } \\
\text { 2) Technical support (external forest professionals hired by the beneficiaries). }\end{array}$ \\
\hline $\begin{array}{l}2006-2007 \\
\text { (Pro-Arbol) }\end{array}$ & $\begin{array}{l}\text { The } 2004 \text { modalities of training of community technicians, and technical accompaniment to } \\
\text { beneficiaries disappear. } \\
\text { For beneficiaries to receive the final payment, the signature of the TAs is required. } \\
\text { CONAFOR's registered technicians list (LAST) is mentioned for the first time. }\end{array}$ \\
\hline $\begin{array}{l}2008 \text { (Pro- } \\
\text { Arbol) }\end{array}$ & $\begin{array}{l}\text { The same as 2007 plus: } \\
\text { In performance criteria, it provides more information about the specific tasks of technical } \\
\text { advisors: Development of a programme of best forest management practices in the first year, } \\
\text { support in the implementation of activities in the next four years, and delivery of the annual } \\
\text { activity reports. } \\
\text { The section of obligations of beneficiaries includes the formal hiring of a person registered in the } \\
\text { CONAFOR's LAST. } \\
\text { It also includes the amounts payable to technical advisors. }\end{array}$ \\
\hline $\begin{array}{l}\text { 2009 (Pro- } \\
\text { Arbol) }\end{array}$ & $\begin{array}{l}\text { The same as 2008 plus: } \\
\text { The PES performance criteria include a restriction of the number of beneficiaries a TA can assist. }\end{array}$ \\
\hline $\begin{array}{l}2010 \text { (Pro- } \\
\text { Arbol) }\end{array}$ & $\begin{array}{l}\text { Subtle changes: } \\
\text { Performance criteria: The number of beneficiaries a TA may support is increased. } \\
\text { More detailed information about the TA's tasks and obligations: the need for the Manual of Best } \\
\text { Practices to be conducted in a participatory manner is emphasised. }\end{array}$ \\
\hline $\begin{array}{l}\text { 2011-2012 } \\
\text { (Pro-Arbol) }\end{array}$ & $\begin{array}{l}\text { More detailed information about the TA's tasks and obligations: } \\
\text { The need to maintain or improve the condition and functions of the ecosystems is emphasised. }\end{array}$ \\
\hline $\begin{array}{l}2013 \\
\text { (PRONAFOR) }\end{array}$ & $\begin{array}{l}\text { Emphasis in the need for TAs certification: if they are not certified, they cannot be hired to } \\
\text { provide services. }\end{array}$ \\
\hline
\end{tabular}

It can be said that rules about TAs have changed frequently and they have gradually increased over time, becoming slightly more complex. It is more rigid and specific, at least in terms of the tasks and restrictions on their performance. However, it is not consistent, and it is still vague.

\subsubsection{Procedures}

During the years corresponding with the independent ORs for PSAH and CABSA, information about the procedures was brief, and the contents were different from these or the following years (Timeline 5.11). With the integration of programmes (after 2006) the procedures appeared more detailed and standardised, and after that, the changes have been subtle. They gradually became more complex too, first in terms of the requirements that new beneficiaries would have to meet (2010), and in 2011 and 2012, regarding the explanation of the field verification process, which became exhaustive, with the increased use of technical language. In 2013 this information was simplified again, but still following the standard of 2010 (Figure 5.9). 
Timeline 5.11. Programme procedures over time. SNIF refers to the National System of Forest Information

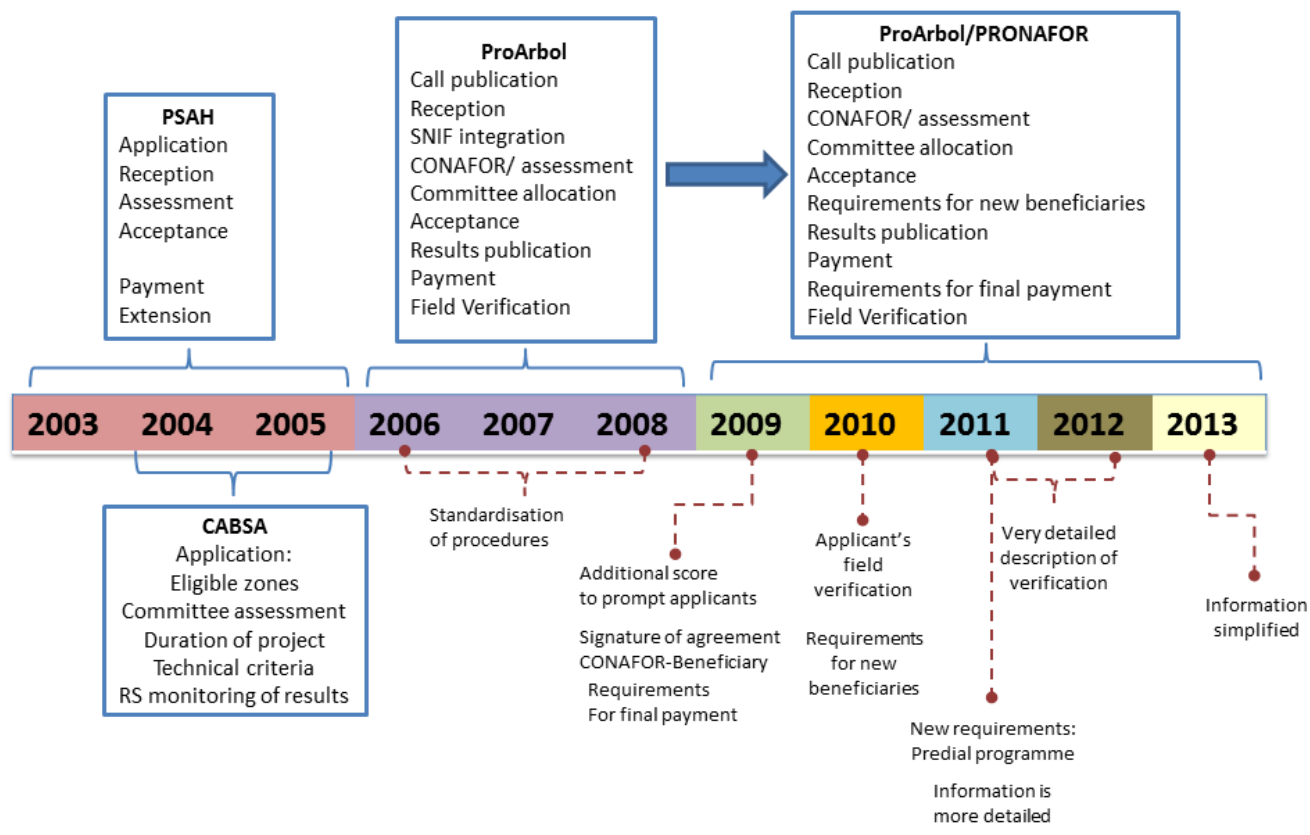

Figure 5.9. Temporal and communication qualities for analysis of change: PES Procedures over time

\section{Temporal and communication qualities for analysis of change PES' procedures}

\section{Freq/Sporadic $\quad 5$}

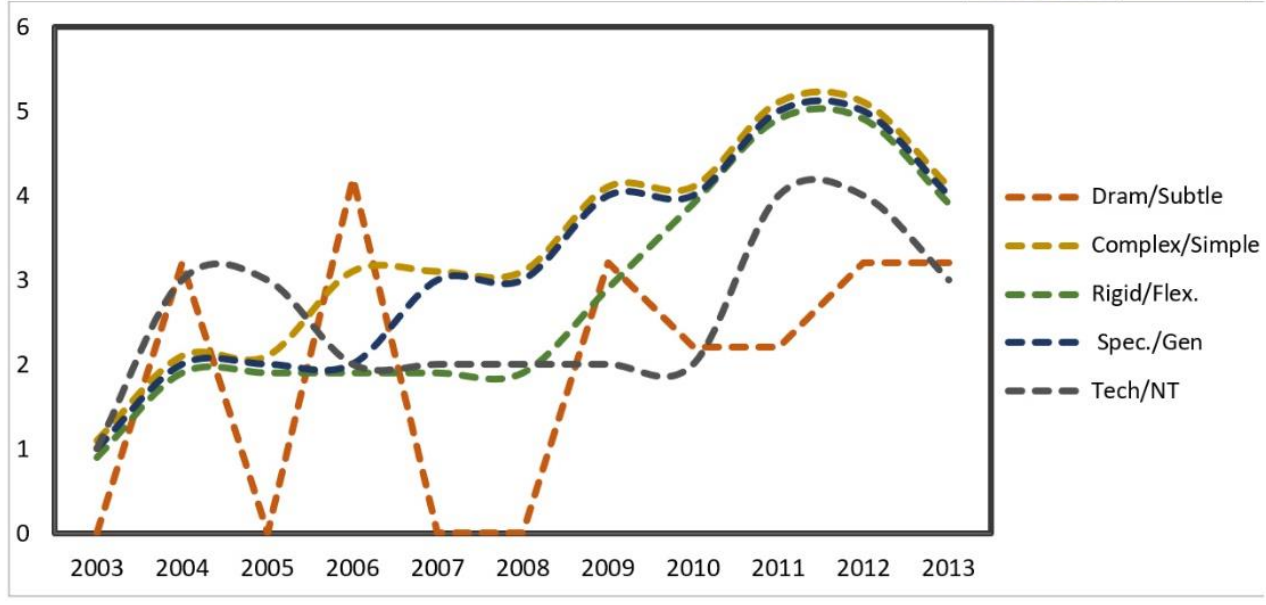




\subsubsection{Priority criteria for the selection of eligible communities and lands}

Priority criteria are one of the most debated and changing components of the programme. The criteria have increased in number, sources of information, complexity, specificity, and are progressively more technical. The institutional vision of CONAFOR (at least with respect to PES programmes) over time is also reflected in the types of criteria used to select the best possible beneficiaries. This is due to external pressure to improve the targeting of the programme, and because of the high demand of applicants and the relatively low budget available. For this analysis only the two most enduring modalities were considered: Hydrological PES, and Biodiversity PES.

CONAFOR established types of priority criteria:

- Social criteria

- Good forest management

- Encouragement of good forest management

- Encouragement to prompt responses of applicants

- General criteria for all the programmes

- Specific criteria of each modality of PES

For the analysis, the selection criteria were grouped as follows:

- Aquifers and water conservation (in the case of Hydrological PES)

- Environmental: Protection, conservation and other environmental measurements

- Criteria related to other PES initiatives/ modalities

- Social inclusion

- Internal organisation of applicants

- Good forest and agro-forest management (specially for Biodiversity PES)

The evolution of the two PES modalities is similar. In 2006, new types of selection criteria were included, within which there was a considerable increase in environmental criteria. This growth peaked between 2009 and 2010.

In 2008 the criteria of social type and good forest management became general for all the programmes included in Pro-Arbol, but maintaining some specific criteria for each modality, especially those of environmental and of internal organisation types.

The environmental criteria related to conservation areas were dominant in both modalities of PES, and the number of criteria continuously increased. Social criteria have always taken second place, but the number varied over time, and in the later years 
gained importance. The criteria related to good forest management, the spatial integration of other PES initiatives, and internal organisation, appeared between 2006 and 2007 and changed slightly. The interest in involving other factors that can contribute to the conservation of ES in forest and agro-forest systems also increased, especially for the PES of biodiversity.

\subsubsection{Hydrological PES priority criteria}

The timeline 5.12 shows the evolution of priority criteria for Hydrological PES (PSAH). In this case the categories of priority criteria are:

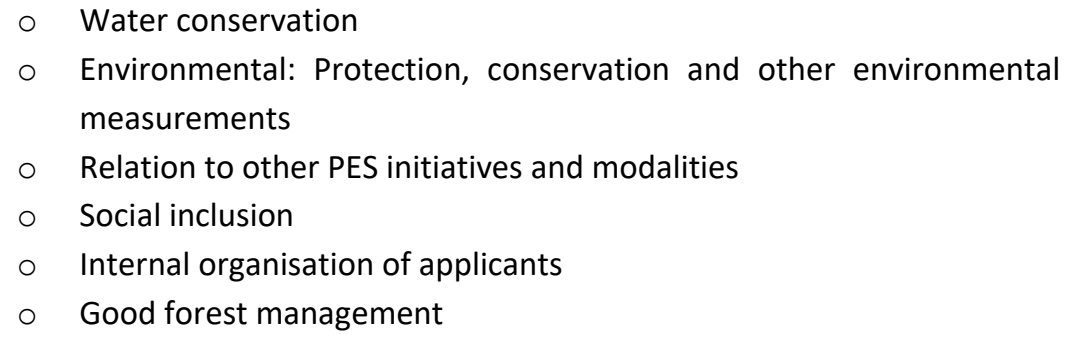
measurements

- Relation to other PES initiatives and modalities

- Social inclusion

- Internal organisation of applicants

- Good forest management

The basic hydrological criteria have not changed since the beginning of the programme (2003). They were, along with the forest cover, the only criteria used to select suitable areas to incorporate in PSAH. This modality of PES programme had a purely environmental objective: the protection of forests. New criteria were included in 2006, related to the integration of CONAFOR programmes, and the shift to socialenvironmental objectives. Environmental, other PES schemes and social inclusion criteria were also added then (Fig. 5.10). The first two have been the most changeable over time. In 2007 internal organisation criteria were incorporated, and in 2008 good forest management was added. Between 2009 and 2010 the number of criteria increased considerably, and they continued changing until 2013 (Timeline 5.12). 


\section{Timeline 5.12. PSAH priority criteria over time}

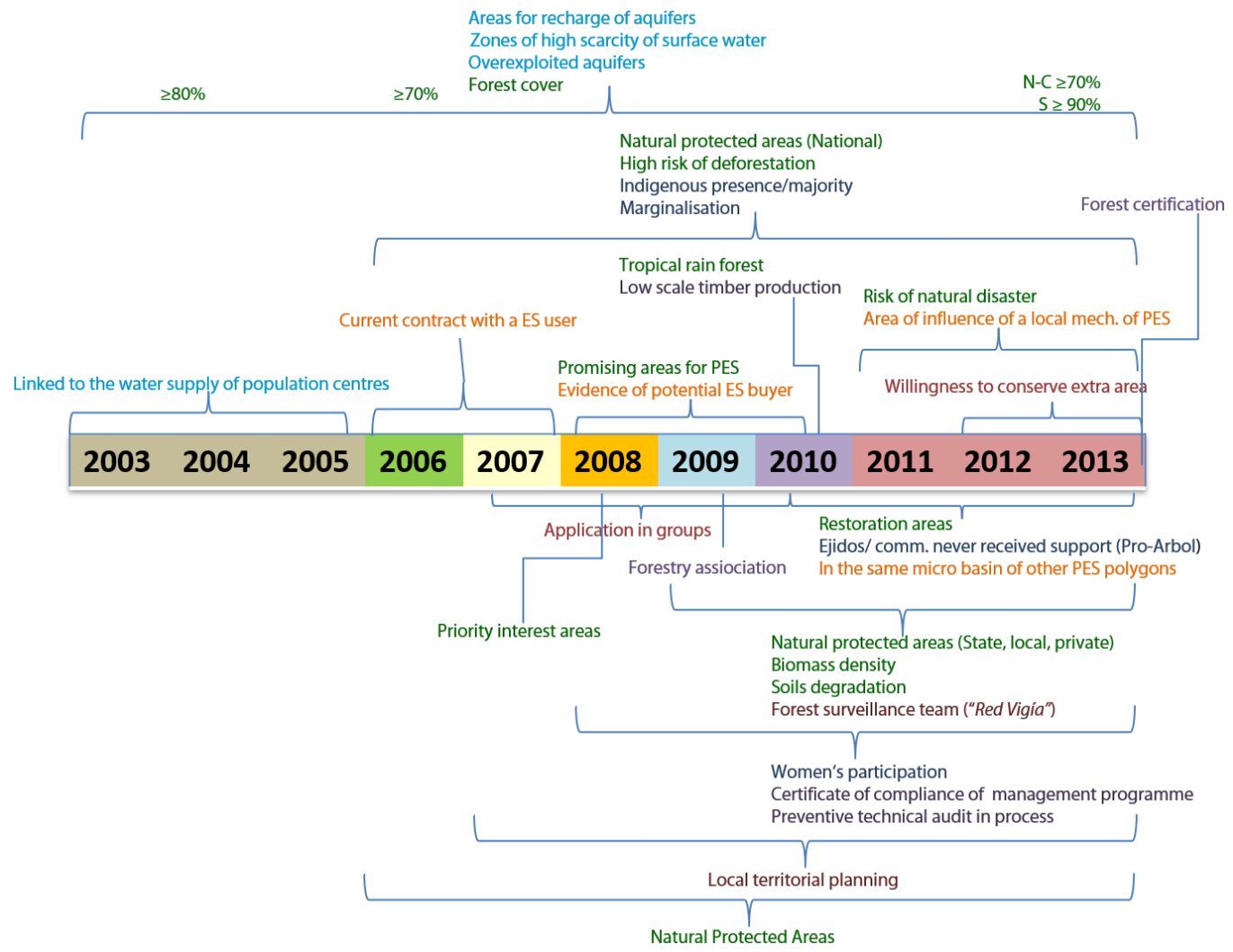

Figure 5.10. Number of PSAH priority criteria by category and year

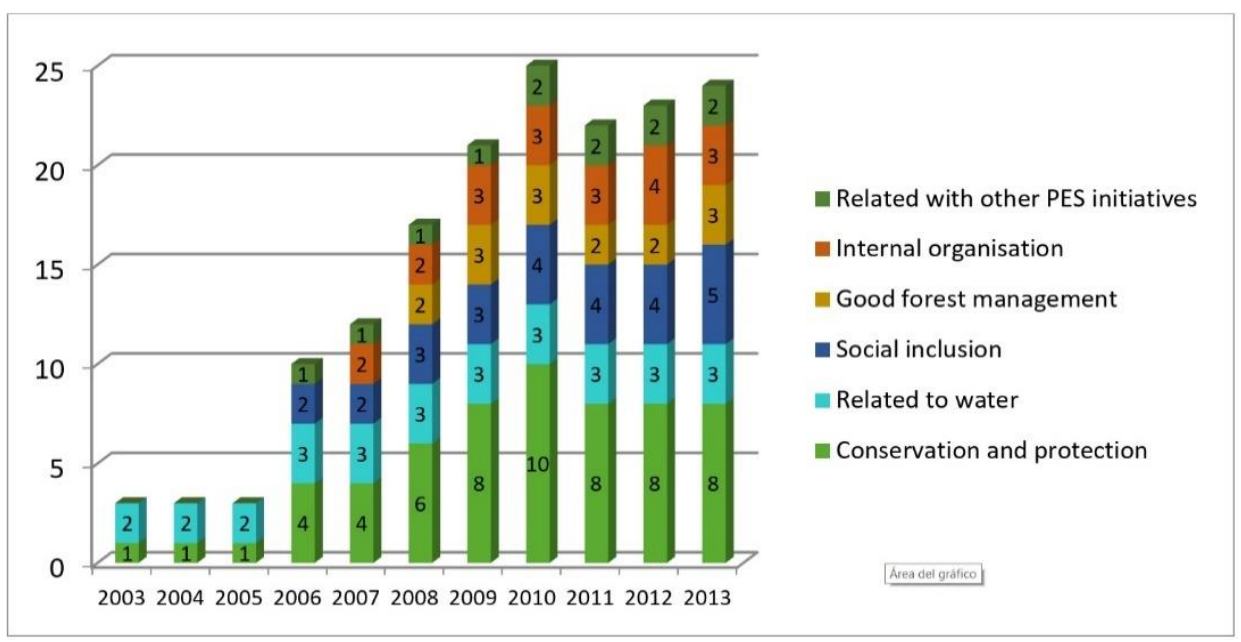


The priority criteria for hydrological PES continuously increased in complexity, and in specificity, and in the use of technical and scientific sources of information. The changes occurred frequently, and they dramatically affected the programme. (Figure 5.11) The rigidity of the selection measurements also grew. The oscillations in the years since 2010 responded to the periodic evaluation of the programme, and to the ample feedback received from scholars and NGOs (see chapter 6).

Figure 5.11. Temporal and communication qualities for analysis of change: PSAH priority criteria

Temporal and communication qualities for analysis of change

Priority criteria for Hydrological PES

\begin{tabular}{|l|l|}
\hline Freq/Sporadic & 4 \\
\hline
\end{tabular}

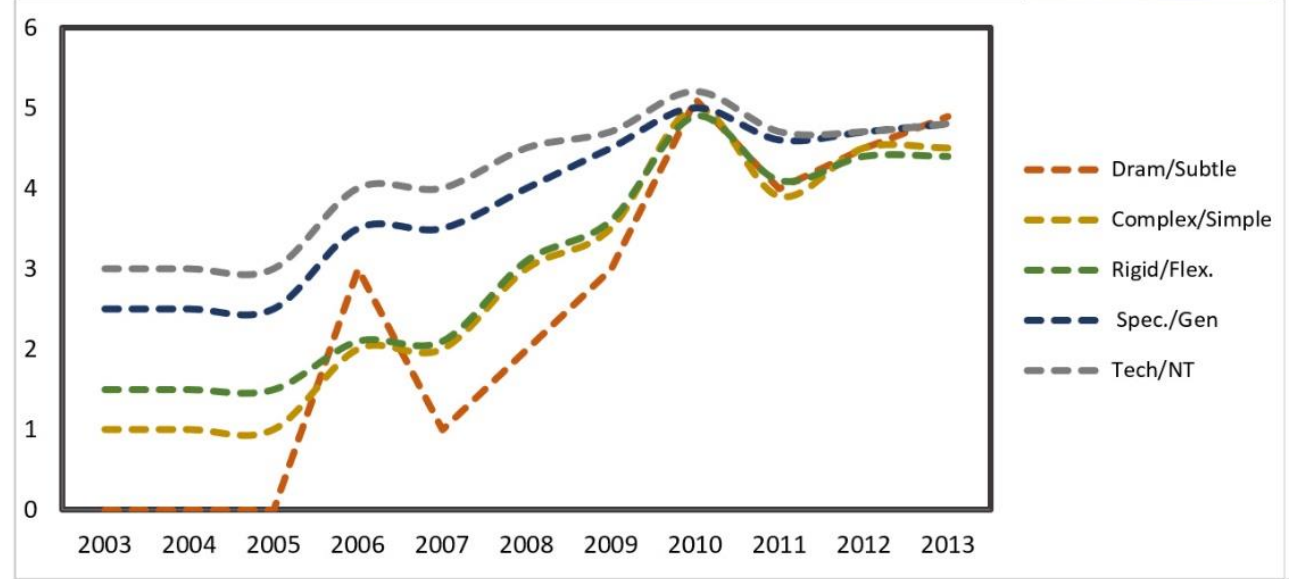

\subsubsection{Biodiversity PES priority criteria}

The timeline in Figure 5.13 shows the general evolution of the priority criteria for biodiversity PES. The categories of criteria present in this modality are:

- Environmental: Biodiversity conservation and protection

- Related to other PES initiatives and modalities

- Social inclusion

- Internal organisation of applicants

- Good forest and agro-forestry management

This modality considered social criteria since the beginning in 2003 , because it was conceived as a social-environmental programme. However, the environmental criteria are dominant. These are especially focused in the geographical location of the applicants in relation to traditional protected areas and ecosystem conservation areas 
(e. g. IBAs, RAMSAR sites ${ }^{7}$.), and the presence of endangered wildlife species. The social criteria are related to conventional measurements, such as marginalisation, presence, of indigenous people, and women and youth participation. New criteria were added every year, including participation in other PES schemes, and internal organisation criteria. In 2010 an important change occurred: the previously independent modality of Agroforestry systems PES was integrated as a payment area in Biodiversity PES. This added new types of criteria related to good agroforestry management practices. Also, new sources of environmental information were incorporated, so that the number of criteria jumped from 19 to 24 . After 2011, the number of criteria was reduced to 20 and this remained almost unchanged until 2013 (Timeline 5.13; Figure 5.12).

Timeline 5.13. Evolution of Biodiversity priority criteria. Colours indicate the categories of criteria: green: biodiversity conservation; blue: social inclusion; orange: related to other PES schemes; magenta: internal organisation; purple: good (agro-forestry) management practices.

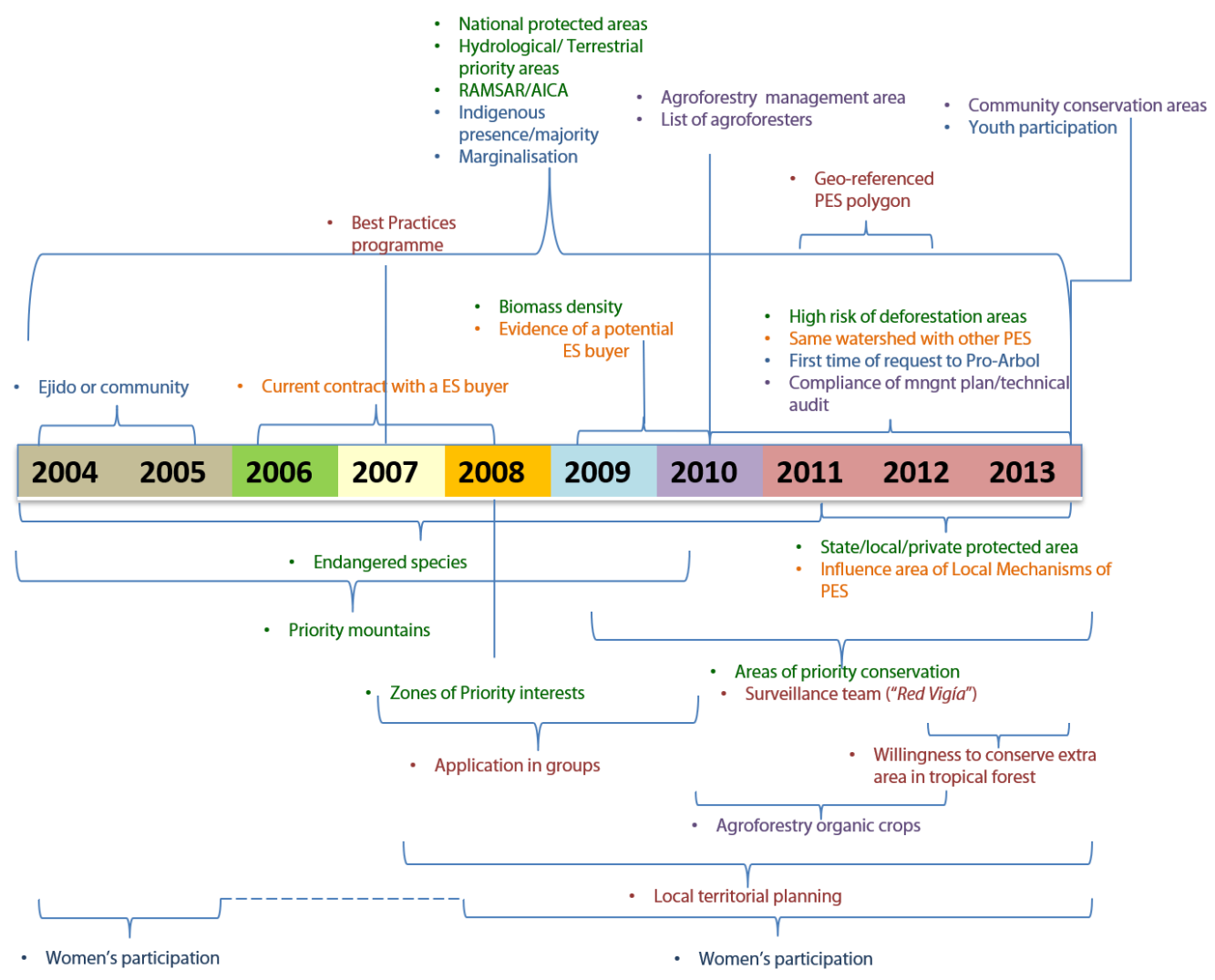

${ }^{7}$ IBA, Important Bird Area; Ramsar site, Wetlands of international importance 
Figure 5.12. Number of priority criteria by category and year (Biodiversity)

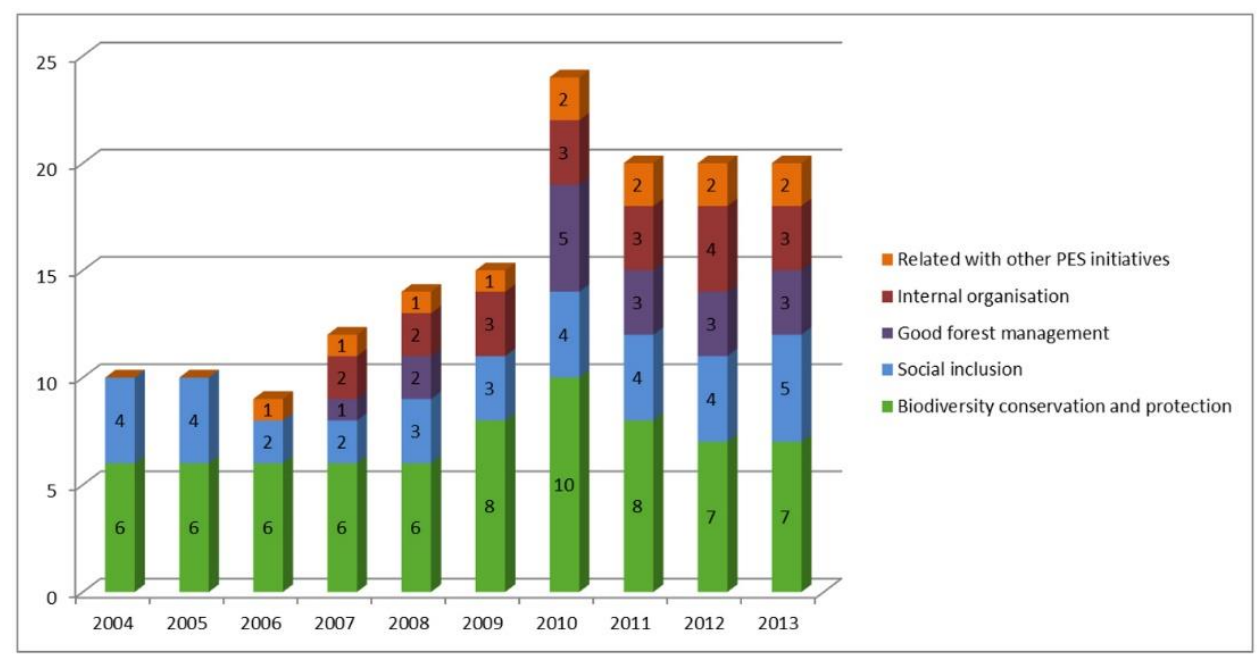

The Biodiversity priority criteria have been modified frequently, but in 2006 and especially in 2010 the most conspicuous changes happened. The criteria became more complex, because of the increment in the number and types of criteria. They also came to be more specific and rigid, and more specialised in the use of data and measurements to evaluate potential beneficiaries, which tended to be more "technical" and "scientific". From 2011-2013 there was a slight reduction of criteria (Figure 5.13).

Figure 5.13. Temporal and communication qualities for analysis of change: Biodiversity priority criteria

Temporal and communication qualities for analysis of change

Priority criteria for Biodiversity PES

\begin{tabular}{|l|l|}
\hline Freq/Sporadic & 4 \\
\hline
\end{tabular}

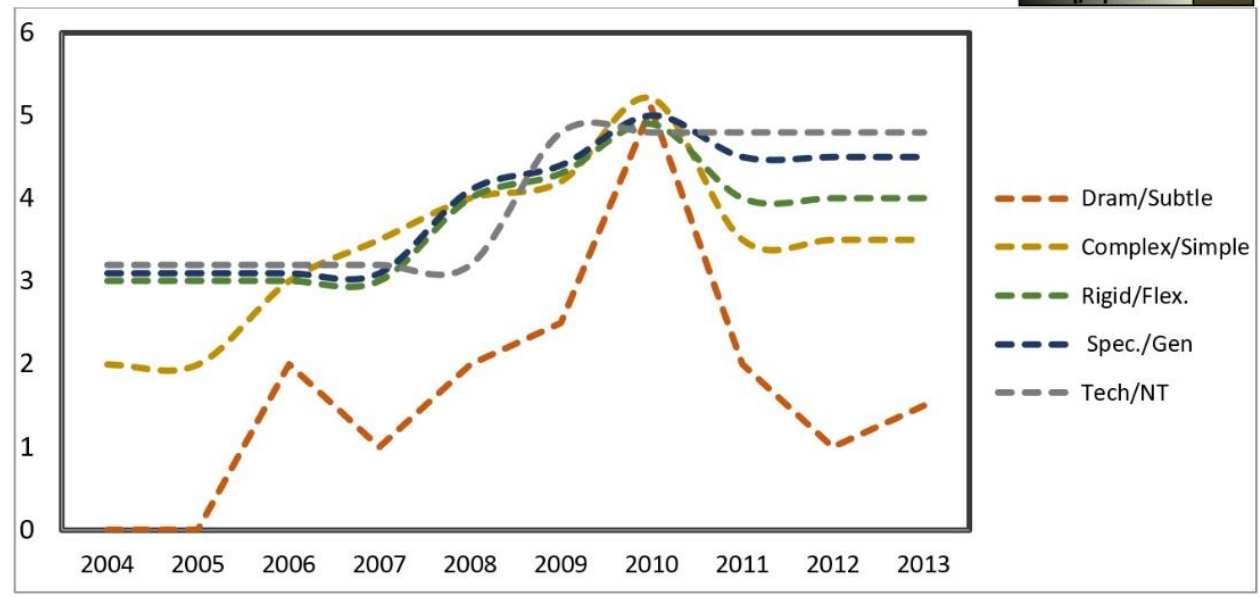


Not only the number and type of priority criteria changed over time; also, the sources of geo-information, measurements and parameters expanded to be provided not only by official agencies but also by powerful national NGOs and academic institutions. However, there were evident efforts to include these new sources of information, the use of official (government) measurements still dominated. The participation of NGOs and universities in the creation of standards and parameters was constrained by the need to collaborate with specific government institutions. Technical and scientific inputs grew, because they represented a way to make the public feel that the selection process and targeting of the PES programme were based on objective, valid, and credible data. The sources of information can be seen in Figure 5.14 for PSAH, and Figure 5.16 for Biodiversity PES.

Figure 5.14. Number and types of sources of information of PSAH Priority criteria over time

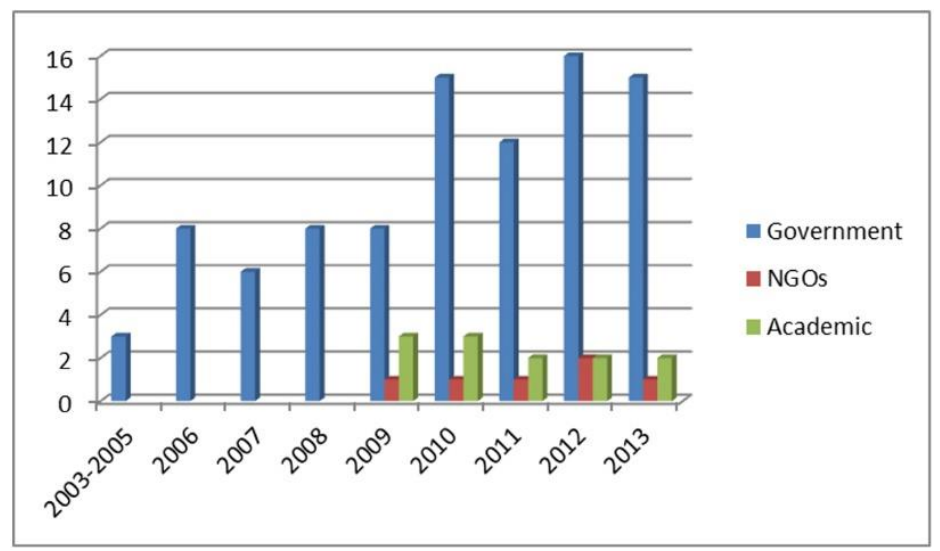

Figure 5.15. Number and types of sources of information of Biodiversity Priority criteria over time

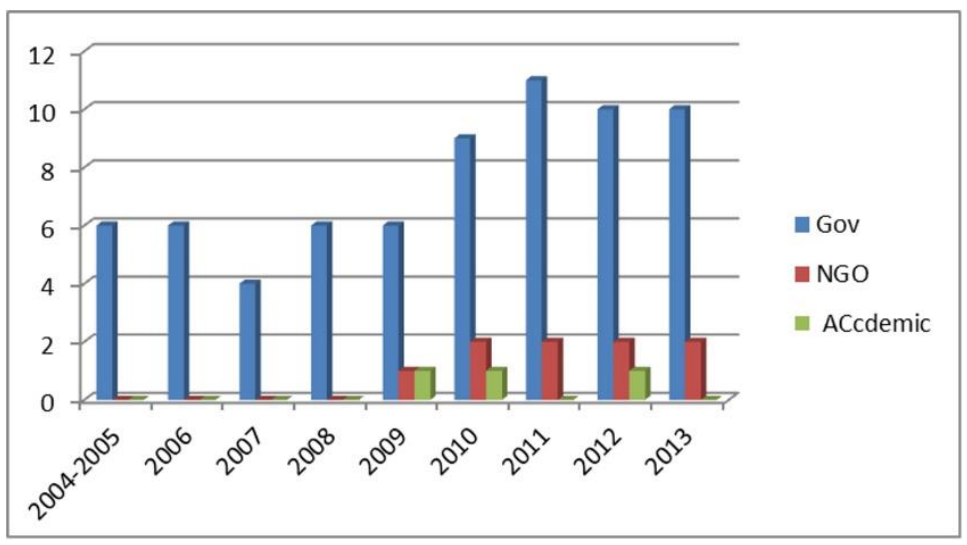




\subsection{Discussion and conclusions}

The PES programme is considered one of the most successful programmes in the history of CONAFOR, and it is also one of the most frequently analysed (some examples are AlixGarcia 2005, 2012, 2013; Corbera, et al., 2009; Costedoat, et al., 2015; Ezzine de Blas, et al., 2016; Kosoy, et al., 2008; McCall, et al., 2017; Shapiro, 2010, 2013; Perevochtchikova, 2013; Rivero-Cob, 2012; Sims, et al., 2014, among others). The first 11 years of its operation have been fundamental for its consolidation but also as a referent of other forest policies.

The evolution of PES is closely linked to the evolution of CONAFOR as an organisation, as it was one of its first programmes, and it contributed to the overall move towards unified ORs. The development of PES has significantly influenced the conceptualisation of other programmes: "On the design, [...] the PES scheme makes a difference because it becomes a results-based programme [...], in the past the custom was: "give me money and if reforested or lost I do not care". [...] [But now] you are paid for forest conservation and if you succeed, you get the right to receive payment [...]. [...] That has become a landmark [...]. [...] The PES programme caused the change in the CONAFOR's operating rules: before that nobody had eligible areas and priority criteria. [...] It was the first one to establish [...] an annual monitoring scheme for a period of five years. [...] PES marked CONAFOR, no other programme did multiyear projects, allowing you to start verification [...]. It becomes more rigorous. PES [...] institutionally contributed to the growth of CONAFOR in that sense: operational rules, critical areas, priority criteria in allocation, verification and multi-annuity" $(1,2012)$.

One key moment in the evolution of the PES programme and CONAFOR occurred in 2006, when many elements of the initial PES' ORs were adopted and the programmes merged. This integration brought, in turn, many modifications in the articulation of the rules, and in the conceptualisation of the programmes. The integration was an attempt to simplify procedures, avoid duplications (Mobarak \& Negrete, 2012), and align programmes - at least administratively - and communicate more effectively with potential users of the programme.

With the establishment of Pro-Arbol in 2007, the integration of programmes had repercussions for their operation. According to Mobarak and Negrete (2012) Pro-Arbol was not simply a change of name of existing programmes with minimal modifications, but it involved quantitative (in the budget), and qualitative (in operation) transformations to strengthen the forestry sector, tackling problems with cross-cutting strategies. The conceptualisation of the programmes changed from predominantly environmental to socio-environmental (pro-poor). But this had consequences for the quality and quantity of information in the ORs for each of the programmes included.

Some changes occurred in the way the programme was conceptualised, as it became necessary for CONAFOR to incorporate the objectives of individual programmes into 
one, and more generalised concepts - sustainability, efficiency, productivity promotion and protection of forests - were used to support this. Over time the goal of the development of markets was tempered (or replaced) by sustainability, and the promotion of good forest management practices, by the consideration of forest owners' needs, and the reintroduction of environmental premises. The definition of programmes, including PES, tended to be generalised, but the eligibility rules and criteria of PSAH and CABSA did not change much during their first years of operation until 2009, when they continued functioning as single programmes.

\subsubsection{The actors}

Despite being known as a flexible programme, there were areas that tended to be more rigid, especially the targeting and selection of beneficiaries, and the establishment of the responsibilities for beneficiaries of the programme. The monitoring measures also became more rigid, for example, a more detailed explanation of the verification process, and the clause to require participants to return payments in case of non-compliance with obligations. These formed an intimidating means to convince beneficiaries to comply with the requirements of the programme. These areas were changing continuously, oscillating between strictness and flexibility year by year. This could be a response to different (internal and external) political and social pressures on the programme, but they also make evident the limitations of CONAFOR in effectively applying those actions.

Corbera et al., (2009) argue that PES payments are not conditional on results, and they recall Wunder et al. (2008) who suggest that this lack of conditionality is common in government-led programmes. This implicitly acknowledges the political difficulties involved in prosecuting poor landowners for non-compliance (Corbera et al., 2009). On the other hand, in the definition of the roles of actors, it is notable that the beneficiaries' responsibilities increased over time. CONAFOR obligations tended to be rather general and even ambiguous. Thus, providing ways for CONAFOR to reduce its responsibilities, and at the same time keep or increase control over the actors having less power.

In the case of the technical committees (who are important in the selection of beneficiaries and allocation of resources) the information in the ORs minimal and very general, as if it is not relevant to the users of ORs.

Technical Advisors are not clearly defined as actors in PES programme. Unlike the other main actors, they do not have a separate section in ORs. They are mentioned throughout the $O R$ documents acting as independent entities. Although the beneficiaries are responsible for hiring TAs, at the same time CONAFOR makes explicit restrictions and obligations relating to the TAs. 


\subsubsection{Modalities of PES}

The PSAH and CABSA were established through different processes, but both are a result of international influences, and negotiations among scholars and social organisations to include these programmes in the Mexican forest agenda. In the first years of the different PES programmes, each one had very specific objectives, operational modes, and modalities of payment. PSAH (designed by CONAFOR and the National Institute of Ecology (INE)) was completely devoted to hydrological environmental services. Whereas the CABSA PES programme emerged from the need to include other environmental services, as a result of lobbying by peasant and forest-based organisations for the implementation of PES for carbon fixation, for rural communities to support biodiversity conservation, and, for the development of agroforestry systems (McAfee \& Shapiro, 2010; Shapiro, 2013). The CABSA modality of PES programme was initially difficult to implement, especially the carbon component, which needed a baseline to measure the subsequent results. Finally, the carbon component disappeared in 2009, after many adjustments and modifications. According to Corbera et al., (2009), the changes in this modality were due to an original misunderstanding of how carbon projects should be designed, implemented, and carbon traded in actual markets.

After many attempts to include and exclude modalities of PES programme, the most important simplification in the scheme occurred in 2010: the merging of PSAH with the most successful components of CABSA (Biodiversity, and a reduced and subordinated version of Agroforestry systems) into the PES Programme, with six areas of differentiated payment. This however restricted the options to participate in the programme (because it became more rigid) and excluded possibilities for the development of ideas and projects by the potential beneficiaries.

This simplification also affected the original objectives of both programmes and removed some of the social concerns that had been expressed in the negotiations for the implementation of CABSA.

\subsubsection{Selection of applicants and lands}

The priority criteria are the features of the ORs that are most analysed and discussed, especially with the PES' National Advisory Committee set up by CONAFOR, made up of intermediaries, academic institutions, civil organisations and government ministries and departments. This council gives advice to CONAFOR about topics such as the improvement of PES rules and the criteria for PES eligibility (Corbera et al., 2009).

The growing number of criteria for the selection of lands and applicants in PES programme was significant: in PSAH for example there were 10 criteria in 2006 and 25 in 2010. In 2010 there was an important review of the eligibility criteria and zones (4, 
personal communication, 2013), which reflected the change in the types and number of criteria in this year.

Priority criteria became more rigid and specialised. Measurements and geo-information available to make decisions became increasingly sophisticated and based on scientific data, especially for the environmental criteria. Attempts to include other sources of information, especially from powerful NGOs and research institutes are evident, but always in collaboration with official organisations. At the same time, social issues remained fuzzy and there was even opposition to such specialised technical measurements - for instance, NGOs asserted that it was possible to be selected even when the proposed lands are outside the eligible zones. But CONAFOR also made use of more "valid" or "official" sources of information. Moreover, only one or two priority criteria were calculated directly by CONAFOR. This may have partly in order to present a message of transparency, fairness and objectivity in the use of public resources.

\subsection{Conclusions}

ORs are the formal representation of the PES programme and a communicative tool transmitting the "PES message" to the public. ORs are not only a compendium of the actions, targets, and criteria for selection. The whole vision of CONAFOR as the organisation in charge of forest policy and its programmes is present in the ORs. They are also the implicit expression of the values, goals, and expected roles of the actors, and implicit ethical guidelines to achieve the goals.

The PES programme has been experimental, and first 11 years (analysed here) have been fundamental for its consolidation. After many adjustments, such as the creation of different modalities of PES, the integration of CONAFOR programmes in unique ORs in 2006, and the later incorporation into Pro-Arbol in 2007, the ORs began to be standardised and more stable. Changes continued, however, until 2013.

It is difficult to say if there were general patterns in the way the ORs evolved, because they changed unequally and under different pressures. During the period under analysis there was a constant interplay between the openness of certain features of the programme and the narrowness of others. The PES programme has simplified, but not only with the integration of the initial two PES programmes into one. The initial goal of establishing ES markets has been nuanced, and the priority objectives have shifted from purely environmental (avoiding deforestation, hydrological conservation), to socialeconomic-environmental (including alleviating poverty, and sustainable forest management).

Some areas of the ORs evolved in a very straightforward way, for example those relating to the procedures and the priority criteria. These were under constant review by 
different influential actors and under the scrutiny of official evaluators, such as the National Commission of Evaluation (CONEVAL), who periodically compared the results of the programme with the objectives, looking for mismatches. But other components show less clear patterns and even chaotic changes.

However, while the role of CONAFOR has become increasingly underspecified, the obligations and responsibilities of the beneficiaries have increased. The role of the TAs is poorly represented in ORs, only showing specific obligations and increasing restrictions for their work.

The fact that this programme was not afraid to change can be seen as adaptability. As Mathews (2011) says: "policies are apt to be more successful if they can be reversed once they start to go awry, and so good planners ensure reversibility. Officials should assume that there will be surprises. [...] Scott's well adapted institutions (metis-friendly) to the inevitability of spontaneity and informal innovations" (Mathews, 2011). And this reminds me of the Jassanoff's "technologies of humility, as institutionalised habits of thought, that try to come to grips with the ragged fringes of human understanding - the unknown, the uncertain, the ambiguous, and the uncontrollable" (2003).

The capacity of change can be seen as the result of institutional inertias. Some authors have observed historical problem of uncertainty and lack of coherency in Mexican forest policies and institutions (Mathews, 2011; Merino-Perez, 2004; Segura-Warnholtz, 2014). Are there limits to the flexibility in the implementation of programmes? Contextual information on the changes in ORs can help to understand better this ambiguity and answer this question (See chapter 6).

The analysis of the ORs through snapshots of key moments reflects the history of the programme itself, as well as the complexities and the definition of the roles of other actors involved. And this also contributes to providing a better understanding of the government conceptualisation of realities about forests. ORs are also a key expression of the official voice of CONAFOR, and the messages this organisation is transmitting to stakeholders and the public over time.

One of the major questions emerging from this analysis is: What and who is determining the changes of direction in the PES programme? There are many sources and influences for the changes in the programme: external influences from international organisations, other governmental organisms or the feedback from results in the field. The drivers of change of the relevant categories of the ORs, and the implementation of the programme itself, are topics to be analysed in Chapter 6 . 


\section{Chapter 6. What drives the changes in ORs: the interplay of institutional inertia and the pressure to accommodate the perspectives of different actors}

\subsection{Introduction}

This chapter focuses on the results obtained in chapter 5: the empirical analysis of the ORs of the PES programme over a period of 11 years (2003-2013). Three main areas are addressed in the analysis of causes of change in ORs: a) the definition, objectives and modalities of the programme; b) the priority criteria for selection of beneficiaries of the programme (i. e. the providers of the forest ES, who are incentivised by CONAFOR), and c) the roles of main actors involved. The chapter explores drivers of change, that is, the events and internal and external influential actors trying to lead the PES programme along specific paths. The shifts in the evolution of the national PES as reflected in ORs have consequences for the operation and results of the programme, and for the behaviour and response of actors involved, their interactions and the power balance among them. These impacts can be especially relevant in throwing light on the beneficiaries of the programme and their relation with government; as well as how PES affected the beneficiaries' relations with their own forests. The specific results of the analysis can also provide elements for the better understanding of the general processes mediating change and stability of policies and programmes, and how the actors influence decision making.

The present chapter is structured as follows:

- 6.2 contains the conceptual framework that inform this analysis

- 6.3 reports on the empirical sources and methods to obtain the information for the analysis.

- In 6.4 is a recapitulation of the most relevant areas of change identified in chapter 5 , incorporating the explanations of the processes and actors involved to produce specific changes.

- In 6.5 the results of the analysis are discussed in relation to the conceptual framework and the implications of the dynamics, struggles and influences pushing the ORs to change.

- 6.6 gives the conclusions of the analysis. 


\subsubsection{The ORs scheme}

\subsubsection{ORs as the representation of PES programme, ORs as institutions}

As it was explained in Chapter 4, ORs are legal instruments for the implementation of a governmental programme. They specify expected results, providing information about the benefits offered to the possible users, the target populations and requirements needed to apply, the contribution of the programme to social welfare, and the justification of appropriate use of public resources (http://www.funcionpublica.gob.mx.htm).

ORs are also the official means of communication with stakeholders. They mediate behaviour and interactions of stakeholders in the use of certain resources, as well as guidelines for the use and preservation of these resources over time (Thomson \& Schoonmaker, 1997). But behaviours, interests, and circumstances of actors tend to change over time (Thomson \& Schoonmaker 1997). These changes also influence and shape the rules, affecting the balance of power and the direction of the programme. However, actors move (push) the rules towards the areas of their own interest. The dynamics taking place between the actors will be reflected in the results, and stakeholders act and react on each other's ideas and interests.

\subsection{Conceptual framework}

Institutions are widely recognised as dynamic entities in continuous processes of reproduction and adaptation (Streeck and Thelen, 2005), driven by actors with agency, different interests and capacities to interpret and enforce rules, and unbalanced power relations (North, 1990; Streeck and Thelen, 2005). Moreover, in these visions, institutions have been conceived not only as limits that restrict the decisions of the actors, but also as opportunities for actors to influence and transform the rules themselves (Campbell, 2010; Jackson, 2010). Institutions provide elements to actors for the definition of their identities and interests (Jackson, 2010), which can also change over time.

This study has drawn mainly on elements of the Mahoney and Thelen's Theory of gradual institutional change (Mahoney \& Thelen, 2010), because is centred on the endogenous process of change, driven by the actors involved in promoting subtle and continuous change over time. Mahoney and Thelen do not deny that the exogenous drivers can operate bigger transformations of the rules, but they pay more attention to how actors transform institutions through their everyday actions and interactions (Mahoney \& Thelen, 2010). According to this vision, agency, power and ambiguity are significant elements to explain the gradual change (Mahoney \& Thelen, 2010). Thus, 
through the continuous revision, interpretation and enforcement of the rules, actors take advantage of the resources and ambiguities of the institution to re-shape it. Concerning agency, compliance with the rules does not always occur. Institutions can also be subject to different interpretations by the actors involved, as well in their ways of compliance (Mahoney and Thelen, 2010). There are "gaps and soft spots" (Mahoney \& Thelen, 2010), and actors are able to take advantage of them to manipulate the results and compete to gain influence (Mahoney \& Thelen, 2010).This depends not only on the agency (Mahoney and Thelen, 2010), but also on the ambiguity of the rules. Power is also significant in the analysis, since it is assumed that there are asymmetrical power relations between actors, who through alliances, struggles and political arrangements frequently try to obtain additional benefits (Gomez, 2010). Thus, power dynamics, agency (and creativity), and ambiguity produce a constant instability of rules (Hall, 2010), which can lead to subtle or deep changes over time.

Explaining change requires an understanding of the complexity of the interactions of actors and factors at different levels, both within and outside the rules themselves. The evolution of the rules is not isolated from external entities and factors that may affect them direct or indirectly. Institutions are multidimensional and interconnected with other institutions at many levels (Campbell, 2010), e. g. International, subnational, local, as well as formal and informal institutions.

The analysis of drivers in the evolution of ORs also has taken ideas from the concept of path dependence, since it is focused on the forces driving reproduction or limited change (Pierson, 2000), although this approach has been criticised for being highly deterministic (Cleaver, 2001; Thelen, 1999).

There is also a constant play between permanence and change, which is partly determined also by constraints in which the rules are inserted. Analysis of path dependence requires "analysing the drivers of continuity" (Thelen, 1999). Path dependence points out decisions made in the past that have (direct or indirect, intended or unintended) consequences on present and future choices. It recognises the sequence in which these decisions are made (Rixen \& Viola, 2015). Continuity does not necessarily mean repetition of the same outcome over time. According to North (1991) path dependency can also be a process of limited change (North, 1991). Institutions can also be subject to gradual changes, even though they are following a pathway, so that stability and change can occur simultaneously (Thelen, 1999; Rixen \& Viola, 2015).

Finally, the present analysis is informed by the concept of Institutional bricolage, described by Cleaver, 2001 as "a process by which people consciously and unconsciously draw on existing social and cultural arrangements to shape institutions in response to changing situations", since it helps to explain the role of creativity of actors in the 
development of institutions (Cleaver, 2001). It also contributes to making evident the ways in which actors use the resources that they have at hand and making different types of arrangements to transform or produce institutions (Douglas, 1986; Cleaver, 2001; Koning, 2012). Actors take advantage of their social, cultural background, social arrangements from other institutions, ideas and emotions, above and beyond rational strategies (Koning, 2012). This will be more evident in the chapter of section III which deals with the role and influence of TAs in PES (Chapter 10).

Theories of gradual institutional change and path dependence are often criticised for assuming that actions of stakeholders are always rational. In our analysis we recognise that actors can make more organic and opportunistic decisions, producing non-intended results within institutions. We start from the position that all the processes can be described from different points of view, which together can contribute to explain the complexities and dynamics of institutions in a better way.

\subsection{Research Methods}

\subsubsection{Sources for the data collection and analysis}

This analysis is based on the results of Chapter 5: the identification of changes in ORs. Three main areas of change in ORs were selected to conduct this analysis: a) the definition, objectives and modalities of the programme; b) the priority criteria for selection of beneficiaries of the programme, and c) the roles of main actors involved.

The narrative of causes of changes in ORs was built with the use of information obtained from semi-structured interviews to CONAFOR's central and state offices staff, as well as interviews with other actors, such as members of the PES' National Advisory Committee, especially influential NGOs. The interviews were carried out between July 2012 and November 2014. In order to identify them, the initials of the informants are shown, and the full names have been removed. Other references to official documents, papers and evaluations have been also used to complement and provide support to the findings.

Table 6.1. Informants from CONAFOR and committee members

\begin{tabular}{|l|l|l|}
\hline CONAFOR central offices & CONAFOR state level offices & $\begin{array}{l}\text { Committee members, local } \\
\text { NGOs, and other organisms }\end{array}$ \\
\hline $1,4,7,8,9,10$ & $12,13,14,15,16$ & $50,51,52,56$ \\
\hline
\end{tabular}




\subsection{Results}

\subsection{1 'Change' as a deliberate political objective}

Constant change is a recognisable characteristic of the PES programme. The evolution of the programme is seen by informants, especially programme heads and office and field operators as an intentional and positive process, showing the ability of the team to learn from experience and to hear and take into account the feedback coming both from employees and external actors $(9,1,4,7,8,2012 ; 10,2013)$. The informants have justified the plasticity of the overall programme by stating their willingness to constantly improve the implementation, through application of acquired wisdom, use of creativity to solve problems at both national and state level, deep reflection and discussions of the team. In interviews, they emphasised that decisions made in the programme were not the result of simple short-run decisions or rapid reactions $(9,2012)$. They highlighted the contribution of PES programme operators in the field (state level), who provide information and suggestions for changes in ORs every year $(8,2012)$.

In the same way the decisions are supported and guided by feedback from influential actors, such as universities or prestigious civil organisations, and evaluations, which reflect results observed in the field. As informant 4 said: "We have advice and comments from the many civil society organisations who have been working with us. My boss, who knows the programme since its inception, [...] has always been trying to perfect it. [...] We have many assessments. PES is the most evaluated CONAFOR programme. [These comments] coincide [...] with what our promoters see in the field. [...] I ask a lot of feedback from people who are in the field to see where we are going or how we can refine the ORs. Actually, this is an exercise involving many people" (4, 2013).

Also, the ORs are discussed by different actors in open fora and in the special advisory committees in the states, where they can express their opinion. There is also the possibility to send in suggestions for amendments in ORs. The PES programme team is open to receive feedback: "ORs are subjected to discussion fora each year in the forest Advisory Committees. It is not always we who can identify areas of change; sometimes these are seen by other groups such as NGOs, universities, etc. We are always open to such reviews, and the proof is that the ORs have been changing." $(7,2012)$

On the other hand, the evolution of the programme is restricted by institutional (CONAFOR's laws and rules), financial, informational (availability of reliable information at the national level) and organisational (the lack of employees or specific profiles) factors. These factors make it difficult to introduce specific changes in the programme and ORs. "It is not as simple as I say [...]. Changing the programme does not depend 
entirely on us [i.e. the programme team], but on the organisation, which would have to make deeper structural or operational modifications to make possible particular changes in the programme" $(9,2012)$. Thus, external criticisms of decisions made by the programme team sometimes do not consider the conditions under which PES staff work, and therefore the constraints they have in making changes. "My colleagues really have a lot of political will and creativity [...]. Given the operational situation they have been clever, because they have found the way to continue making the programme work $(9$, 2012).

The informants agreed that the most influential actors in this process of ORs change are in the first place the designers, heads and operators (national and state level) of the programme, and in the second place evaluators of the programme (which may be universities, and governmental and non-governmental organisations), civil organisations, universities, national and state advisory committees. Beneficiaries and technical advisors were not specifically mentioned in this overall process of change. The influence of international organisations such as the World Bank was continually mentioned in interviews, but it was not recognised specifically as an agent of change, in these interviews. But its influence is strong, especially since 2006, as it has provided conditional financial support. One such condition was the implementation of social safeguard policies (CONAFOR, 2012). In interviews, TAs reported that although CONAFOR actually asks their opinion on the ORs, their suggestions are rarely considered. In some cases, their opinion is requested very close to the deadline for receipt of suggestions, reducing its chance that it is incorporated in the new ORs $(22,2014$; JH, 2014).

According to the stories of the informants at this general level, ORs have gradually evolved in small events, such as forums, meetings and direct suggestions and ordinary sessions in the case of the technical and advisory committees. And, the evaluations play an important role in the process.

Even though the informants refer to incremental changes in the ORs as the result of internal processes of reflection, and the continuous exchange with external organisations, when they talked about specific changes in ORs they mentioned some abrupt or dramatic events that produced adjustments and also changes in the direction of the PES programme. According to Del Angel-Mobarak (2012), the fact that CONAFOR become the operator of ProArbol programme represents the most important change for CONAFOR since its creation, giving unprecedented availability of resources to the forestry development, and involving a process of transformation in the whole institution. 


\subsubsection{The definition, objectives and modalities of the programme}

\subsubsection{Description of the programme}

Originally (in 2003) PES programme was conceptualised as a project aimed at solving the problem of deforestation, through the establishment of economic incentives to encourage owners to conserve their forest land use in areas with high risk of deforestation $(1,2012)$. Two researchers in economics were instrumental in the theoretical design of the programme: Carlos Muñoz-Piña, from the National Institute of Ecology (INE), a governmental research centre, and Juan Manuel Torres Rojo from the Centre for Research and Teaching in Economics (CIDE), one of the most important think tanks in México. The latter was head of CONAFOR from 2009 to 2012 (1, 2012). The initiative was inspired by experiences in PES as developed in Costa Rica $(1,2012)$, in New York, and in an incipient attempt in México City (Del Angel-Mobarak et al., 2012). This all involved paying individual forest owners the opportunity cost and funding this through financial contributions from the downstream beneficiaries of the ESs, in a market-based approach.

But, under the Mexican administrative framework of public policy, this idea was not feasible. The market -based approach did not fit with CONAFOR's accustomed procedures, which had always involved subsidies from the public purse (Alix-Garcia, 2009). The idea of promoting local markets of ES is still alive in the CONAFOR's discourse, but in reality, the national PES scheme has never really developed these markets. However, in 2008 a new PES modality was established: the PES programme of localmechanisms through concurrent-funds, which took up the original idea of creation and developing of ES markets. Under this scheme CONAFOR did provide incentives to promote links between users and providers of hydrological services, through institutional arrangements. Half of the money invested came from the users of the ES and the other half came from CONAFOR (CONAFOR, 2012). This programme operates in parallel with the national PES programme, but it has its own guidelines and is not included in the ORs, which are analysed in this research.

According to informant 4, between 2010 and 2015, the designers did not want the programme labelled as a subsidy, because that undermined the philosophical essence of the initiative $(4,2013)$. A constraint here was the lack of social notion of scarcity of ES, and of a demand of the services by users $(4,2013)$. This restricted the establishment of a market and forced government to play the role of the sole buyer of the ES. Thereby, in words of McAfee and Shapiro, the national PES scheme has been a hybrid of market mechanisms, state regulations, and subsidies (McAfee \& Shapiro, 2010). 
The initial PES (PSAH) had a strong environmental approach, but including an economic component to promote ES markets in México. At that time, the original criteria for recruitment of lands into the scheme were vegetation types, such as temperate forests, rain forests and mesophilic forests, which are those traditionally and unquestionably considered as "forests", also in relation to the provision of water resources. These criteria also fitted with the CONAFOR's specific competencies $(9,2012)$. Dry tropical forests or vegetation of arid areas were not initially included. This conception was based on the notion that forest was a water factory, without strong evidence $(1,2012)$. This set up and the initial strong built-in ontological conceptual bias, in turn limited the scope of change that could come from accumulated experience, programme evaluations.

\subsubsection{Specific objectives of PES programme}

In 2006, CONAFOR started formal collaboration with the World Bank (WB), which provided funding and technical advice, and promoted several changes in the vision and implementation of the programme $(4,2013)$. With the contribution from the WB, the initial amount of MXN\$200 million for PES programme was increased by a factor of five. The WB not only provided financial support, but also involved international experts who evaluated the programme, and provided specialised advice in different areas of operation $(4,2013)$.

In 2007, the country's new presidency brought changes to CONAFOR's programmes. By presidential decree the scope of Pro-Arbol, as a set of programmes with unified ORs, was redefined as an antipoverty scheme (7, 2012; Del Angel-Mobarak et al., 2012; AlixGarcia, 2013; McAfee \& Shapiro, 2010). This shift caused in turn multiple changes in the original objectives of PES and the other Pro-Arbol programmes, as well as the selection criteria, and in the operation of the programme. The new scope was resisted by CONAFOR staff, mostly conformed by professionals in environmental and technical issues. Conflicts arose especially in the procedures and criteria for selection of beneficiaries, as 7 said:

"We have tried to put a greater weight on environmental issues, but "where a captain rules, a sailor has no say. And since 2007, the new administration has come with the idea of supporting the poor. Marginalised areas became priority, and it was determined that subsidy programmes must be open for their participation. Many of these marginalised municipalities were outside of PES eligible areas, but then we had to include them. They started upside down, first deciding who can access the programme, and then seeing how many requirements they actually meet. We are part of this government and of those decisions, but the design of public policy is sometimes left in the hands of those who are more political than technical" $(7,2012)$.

The influence of World Bank in the transformation of the purely environmental vision to a more social one is recognised, as well as its instrumental role in raising awareness about the need to include social safeguards, the promotion of participation, the training 
of employees and beneficiaries about different aspects of the programme, and the workshops carried out with the beneficiaries $(9,10,2012)$.

The inclusion of social criteria in the programme also brought changes in the organisational arrangement of PES programme area within CONAFOR. When the funding from World Bank started, it got influence in the decision making. One of the conditions of this funding was hiring professionals with a social profile, in order to improve communication with the beneficiaries, and meet WB social safeguards norms. Thus, in 2008 the first anthropologist was hired $(10,2012)$. The insertion of new professional profiles into CONAFOR has also influenced the performance and capacities of staff, from the head of the programme to the state level officials. Since it was not an internal decision, it was difficult to incorporate the new ideas. However, this has been gradually accepted by the team in the light of the outcomes obtained $(9,10,2012)$.

\subsubsection{Payment modalities of the programme}

In ORs the most important factor of change has been the types and number of modalities to pay for ES. That is, the type of ES included in the programme. The most stable modalities have been the hydrological, followed by the biodiversity payments, which are still operating. Agroforestry has been integrated into biodiversity. For the case of Carbon sequestration, it has been documented that practical and technical evidence made it difficult to continue with this modality. In first place, because the Carbon modality required a baseline in order to measure subsequent results. And, according to Corbera et al. (2009) there was a set of misunderstandings concerning the design, implementation and establishment of markets which brought problems in the operation of the scheme (Corbera et al., 2009). Additionally, lack of technical capacities within the communities and among the TAs in the development of the projects (FAO, 2013), produced poor participation (very few communities applied for this modality). The conventional idea of payment for Carbon sequestration stopped in 2007 and was replaced in 2008-2009 by the concept called 'Development of a Carbon sequestration plan', consisting of the presentation of a plan to be implemented in the future. However, this was also was also excluded from ORs in 2010 also because of the low number of applications. Since 2010 until the end of the analysis (2013), there are only two modalities divided in 6 payment areas: 3 areas for hydrological and 3 for biodiversity, one of them was for agroforestry lands).

Regarding the drivers for these changes in PES modalities, there have been on one side practical drivers and on other side pressures or criticisms from different actors. Between 2003 and 2004 social and farmers organisations started a movement, claiming before the Mexican Congress (both the Chamber of Deputies, and the Senate of the Republic) the need to recognise and include the environmental services provided by agroforestry 
systems (Corbera et al. 2009; McAfee \& Shapiro 2010). Also, scientific information about the multiple uses of forests, reflected and discussed internally by the team, as well as the pressure from NGOs supporting the inclusion of more environmental services and vegetation types in the scheme, led to the establishment of CABSA in 2004, the PES programme (7, 2013; Del Angel-Mobarak et al., 2012). CABSA included the development of carbon markets, the conservation of ES provided by the biodiversity, and the promotion of ES generated in agroforestry systems (CONAFOR, 2012), all of which were now possible due the availability of financial resources. In 2004 and 2005, the PSAH and CABSA operated independently. This separation was due not only to the different scopes of programmes, but also for budgetary reasons, since they were supported by different sources $(9,2012)$. The vegetation types included in PSAH remained the same. In contrast, CABSA included for the first-time other vegetation types, such as tropical dry forest, and deserts scrubs. The addition of these vegetation types in CABSA came from both inside and outside CONAFOR. Internally, the work team was reflecting and discussing concepts such as multiple provision of ES by forests $(9,2012)$. At the same time actors outside CONAFOR, such as universities, NGOs and social organisations criticised the lack of evidence for prioritising certain types of vegetation in the PES scheme over others. The change was possible because of a 'convenient' interpretation of the Mexican forest law, which was not specific about the types of vegetation that are officially considered as forests $(9,2012)$. As a result, PSAH and CABSA's ORs were merged in the scheme ProArbol in 2007. The CABSA scheme disappeared in 2009, but the biodiversity modality remained until 2013 (and agroforestry within biodiversity), in order to preserve the support to those ecosystems (See Timeline 5.5, in chapter 5).

\subsubsection{Priority criteria for selecting beneficiaries and lands for PES}

The selection process for enrolment in CONAFOR programmes goes through different stages. First, the applicants' lands must be located in eligible zones predefined annually by CONAFOR. Second, the applicants must meet several requirements, such as showing the legal ownership of lands, among others. Based on this, feasible requests are subject to a selection system that gives scores to applications that meet environmental and socioeconomic criteria, otherwise known as 'priority criteria'. According to Alix-Garcia et al., (2013) the eligible zones expanded between 2004 and 2009, but were downsized (Alix-Garcia et al., 2013), that is, the amount of land that could be brought under the programme in each zone was reduced.

Priority criteria are one of the most debated and assessed components of the programme. The criteria have increased in number, sources of information, complexity, specificity and have been progressively more technical. More sources of geographic 
information and inputs to be used, and more organisations have joined in providing opinions and proposing new criteria on appropriate ways of targeting. The changing organisational vision of CONAFOR over time is reflected in the types of criteria used to select the best possible beneficiaries.

Two important things have made the priority criteria one of the most changeable areas of PES. One is related to financial issues, due the increasing number of applicants, in relation to the budget available for the programme $(4,2013)$. The other is the involvement of external actors, from the PES' National Advisory Committee ${ }^{8}$, external evaluations, and the WB $(4,2013)$.

Thus, multiple actors and forces have been involved in the definition, addition and refining of priority criteria. WB plays a fundamental role, as well as the original designers and operators of the programme, and governmental organisations such as INECC (National Institute of Ecology and Climate Change). In this arena, the national advisory committee has also played a relevant role. There have been struggles in the selection of priority criteria on one side the people who conceptualised the programme, and the original staff, have tried to keep the environmental weight of the programme. A member of the committee talks about the different visions within the committee, and the power struggles between social and environmental advocates:

"The committee has been a platform of tension and negotiation between powerful actors from the government and the civil society. There were priority criteria to score the applications for the PES programme. We (the NGOs) managed to introduce a set of criteria related to internal organisation and territorial commitment of communities, e.g. communities with community land use planning could get 5 extra points in their applications. We also proposed to include "best forest management practices" in order to promote active participation of communities. But the head of the programme thought differently. He said: "beneficiaries must just leave the forest alone, they just need to stick to our plan year after year, and we monitor them using satellite imagery". He did not agree either with the inclusion of the Best forest management practices guide. That was a huge struggle. It was an achievement to include those criteria. Of course, there were other forces

\footnotetext{
8 The PES' National Advisory Committee is an independent group composed of members from different segments such asthe private sector, universities, international, national and local NGOs, peasant and forester organisations, rural development and environmental government agencies. They meet at least once a year to review and analyse the results of the last ORs and propose better ways of targeting and operationalising of the programme (JM, personal communication, 2013). Targeting of beneficiaries and lands is a key area of the committee's work. Therefore, both the eligible zones and the priority criteria are continuously discussed. PES' National advisory committee has had a relevant role in the annual review of ORs, with emphasis in the priority criteria.
} 
fighting there, and therefore the priority criteria considerably increased, making that the relative weight of the criteria we included reduced" $(50,2013)$.

The evolution of the two PES modalities is similar. New criteria related to the integration of CONAFOR programmes were included in 2006, and the shift to social-environmental objectives. The peak of this growth came between 2009 and 2010. In 2008 the social and good forest management criteria become general for all the Pro-Arbol programmes but keeping specific criteria for each payment concept. Criteria concerning internal organisation, but particularly the environmental criteria are more specific and differ more.

The environmental criteria related to conservation areas have been dominant in both modalities of PES, and the number is continuously increasing. Social criteria are in second place, but the number has varied more over time, and in the last years has gained importance. The criteria related to good forest management, the spatial integration of other PES initiatives, and internal organisation, appeared between 2006 and 2007 and have changed slightly at least until 2013. Interest in other factors that contribute to the conservation of ES in forest and agro-forest systems has also increased, especially in the Biodiversity PES (Timelines 5.12 and 5.13, in chapter 5).

Regarding the drivers of change, the initial PES programme, which was focused in Hydrological ES, used two types of selection criteria of applicants, one related to forest cover (forest cover $\geq 70 \%$ total land area), and three related to water protection, namely, areas for recharge of aquifers, zones of high scarcity of surface water, and overexploited aquifers. According to 1 (who was involved in the first years of implementation), when the programme started these rules were unclear. It was a universal scheme, without priority areas. Any area at risk of deforestation could be enrolled. At that time, the programme designers were working on an index of deforestation risk, but there was no a map of this available for the whole country. At stage, the only established commitment for beneficiaries was leaving their forest land conserved for a period of 5 years. Any forest owner who was willing to accept that condition could access the programme. The selection was carried out using satellite images analysis of the all proposed polygons that had forest cover of more than $80 \%$ (1, 2012).

In 2006 new criteria were added, and the idea of eligible areas was formalised. At that time one of the most important criteria for the eligible areas was the index of economic pressure for deforestation (IRDef), which is still used to "identify the sites with the greatest economic risk of being deforested, in order to target resources and support programmes in the areas of greatest need of intervention relative to cost, and obtain more conservation and sustainable use for the invested money (INECC website)". The 
addition of this criterion has been controversial and criticised by some NGOs for the use of geographical information as the only valid source, ignoring gaps on key social aspects $(52,2013)$. They have questioned the assumptions of a powerful individual actor connected with the development of the index:

"[The initiator of the PES programme] created the high deforestation risk index, which is not based on facts, but on assumptions imagined by him. [...] He related deforestation risk with marginalised areas, assuming that poor people destroy forests $(50,2013)$. [...] The committee in cases like this has been a platform of tension and negotiation between powerful actors from the government and the civil society" $(50,2013)$.

In social terms, due to social pressures from NGOs and farmer associations, the programme has gradually given priority to collective owners of lands $(52,2013)$, also granting extra points to applications from indigenous people in 2004 , women (as well as the involvement of women in the community board) in 2007, and young people in 2013 $(1,2012)$. Also as a result of submission from various groups from the claims of social groups, good forest management practices in communities was recognised as ac criterion: in 2010 internationally or nationally certified forest management producers can access to the PES programme, and get extra points in their applications $(12,2014)$.

Tensions and negotiations also exist between the governmental actors directly or indirectly linked to the programme. There are different interests defending the inclusion of certain criteria, and CONAFOR is constantly trying to balance all these interests in the targeting of beneficiaries (7, 2012). For instance, National Commission of Natural Protected Areas (CONANP) pushes to make protected areas determinant factors in the selection; National Water Commission (CONAGUA) tries to increase priority to overexploited aquifers, and the organisations working on social issues want to favour those communities which already do territorial ecological planning $(7,2012)$.

Other criteria have been modified for practical reason, such as the technical quality of the applicants' proposals $(7,2012)$. "There was a criterion to give extra points if the proposed two areas proposed are adjacent each other. We received polygons joined by a very thin line to fulfil that requirement (laughs), in a very forced way. In practice it is very difficult to operate these cases, so we removed the criterion of adjacency" (11, 2012).

A criterion that has been constantly debated, especially by applicants, is forest cover. Although it has not changed over time as qualifying criterion, the indicators to measure it have changed, and CONAFOR's definition of the concept has become more specific. This is a result of the multiplicity of conceptualisations of forest and forest cover, (e. g. 
Chazdon et al. 2016,) which give room to misunderstandings among actors, especially applicants (7, 2012; 1, 2012; 56, 2013).

"We try not to get to constantly discuss the issue because although a very specialised and large group could establish a forest definition, there would always be someone who would not agree" (7, 2012).

\subsubsection{Actors and their roles}

The main actors mentioned in the ORs are CONAFOR (especially) its central and state level offices, applicants and beneficiaries of the programme, and national and state level committees. As already shown in chapter 5 , there is no specific section regarding the TAs role, but they are regularly mentioned in the whole documents. Aspects such as obligations, competencies, tasks and rights are included in the documents. In this chapter we focus on CONAFOR, beneficiaries and TAs.

\subsubsection{CONAFOR's competencies and obligations (national and state levels)}

The ORs give information about competencies and obligations for national and state level together. Before 2006 the obligations of CONAFOR were not clearly specified in ORs. Since 2006 the obligations are explicit and have changed much (Timeline 5.6, in Chapter 5).

Before 2006 the competencies required of CONAFOR operators of the programmes included tasks like the identification of eligible zones, and surveying the eligible plots of applicants within them, because the applicants did not have the tools and capacities to do it. Since 2006 CONAFOR competencies have become more ambiguous. The only competency present in all the history of PES programme is related to determination of eligibility zones. In 2008 the responsibilities of state level CONAFOR offices became more explicit in this regard. Responsibilities about the verification process disappeared in 2006 and reappeared in 2010 (Timeline 5.7, in Chapter 5).

In operation, however, the definition of roles is clear, and centralised. Centralisation is part of the original design of the programme, and according to some informants the technical capacities and the equipment needed to make decisions are not available in the state level offices. This fact has always drawn criticisms from voices who claim that the operation and results of the programme would improve if state level offices have more decision-making power, as they have a better understanding of the local conditions for implementation. One response to those criticisms, informant 7 emphasised that the responsibilities of state level offices have gradually increased: 


\begin{abstract}
"We have been gradually transferring responsibilities to state level employees. At first, they only served to receive the requests and documents from applicants and send them to headquarters. Now they carry out $70 \%$ of the operating process. But they are not able to select the beneficiaries, because they do not have the technical skills and tools to do so, and because it would be inefficient. In central offices we have 4 workstations with capacity to process satellite images that are used intensively; state level managers would need having a workstation for only 15 days of use a year $(7,2014)^{\prime \prime}$.
\end{abstract}

But there are other reasons why the selection of beneficiaries is still controlled by central offices. One is about reliability and homogeneity in classifying satellite images, which can be controlled more easily if this is done by a small team $(7,2012)$. Another compelling reason to keep the control of decision making in central offices is the avoidance of corruption; as there is by distrust about the way state employees may make decisions. According to the informant, state level employees are usually under great pressures from possible recipients of the programme and other actors; they can be more vulnerable to subjectivity, corruption, favouritism. So, they may be guided by their personal preferences to favour their friends in the allocation of payments, and make subjective decisions because of their knowledge of the local people $(7,2014)$. In central offices the selection of beneficiaries is "blind", an automated process by number of applicant, allowing the decision to be more objective $(7,2014)$. It is assumed that decisions will be more objective if they are made by the national level operators. However, given the pressures to balance the decision- making power, CONAFOR has been exploring the possibility of allowing state level authorities to process the local level criteria for the selection of preferential applicants at the state level, but still leaving the final decisions to the central office.

\title{
6.4.4.2 Role of beneficiaries (obligations, commitments and rights)
}

\subsection{Beneficiaries' obligations and commitments}

Obligations have increased considerably over time, but the most conspicuous change occurred in 2006. Before this year, obligations were related to the conservation of the natural condition of the forest lands, avoidance of deterioration, and monitoring by the beneficiaries themselves, as well as accepting training and CONAFOR verification visits, the correct use of the money provided, etc. Many of these can be considered 'passive'. The 2003-2005 obligations were re-incorporated in 2010 as 'beneficiaries' commitments' specifically for PES beneficiaries. In general, the obligations established in 2006 continued, with enduring additions such as the one about hiring technical assistance in 2008, and the requirements for receiving the final payment (in 2011), which was already present in earlier years but not as part of the obligations. 
As mentioned before, the obligations are general for the beneficiaries of all the programmes included in Pro-Arbol/PRONAFOR. In the other hand, the commitments are specific obligations to be fulfilled by the PES programme beneficiaries. They were added in the 2010 ORs and concern the conservation of the lands under the programme, and mandatory activities related to it. They vary according to the differentiated payment areas or PES. The commitments have not changed since they were established in the ORs, but they were called "obligations" in 2013 (Table 5.5 in Chapter 5).

\subsection{Relevant changes in relation to the role of beneficiaries}

The changes in ORs occurred in relation with beneficiaries can be categorised in two main areas:

a) Interaction between CONAFOR and beneficiaries, encompassing events such as the verification of PES activities, and the workshops for beneficiaries, namely, (i) the one about rights and obligations (2008), (ii) the one about environmental services and strengthening of beneficiaries (2010), and (iii) for the carrying out of the guide and manual of best practices (2012). (CONAFOR's OR's 2003-2012); and

b) Beneficiaries' obligations, PES commitments and rights, the use of the payments, as well as the Guide (for PSAH) and the Manual (for Biodiversity) of best practices as planning documents to be completed for the beneficiaries with the help of technical advisors (2008). These points are elaborated bellow.

\section{A) Interaction CONAFOR- beneficiaries}

After 2007, when the substantial modification of the programme occurred, social inclusion criteria and new types of evaluations were involved. As part of the new approach, it became necessary to assess the degree of acceptance and understanding of the PES objectives among the beneficiaries. Evaluations focused not only in environmental indicators, such as the deforestation avoidance, but also involving the response of beneficiaries to the programme have increased gradually over time. In 2009 an analysis of gaps in the attention to indigenous communities was conducted, in order to improve the accessibility of ORs to those groups. Once again, the WB was an influential actor in this process $(9,2012 ; 10,2012)$.

Difficulties in the interaction between CONAFOR and beneficiaries became manifest. CONAFOR and evaluators realised that the beneficiaries agreed to participate in the programme, even without a clear understanding of its goals and activities. Two facts seriously affected the transfer of information from CONAFOR to applicants and beneficiaries were also recognised: the confusion especially in state level staff about the PES scheme, and the lack of skills in communication with stakeholders. For this reason, 
training to the CONAFOR staff in aspects of the programme such as forest ES provision, and participatory techniques, was carried out $(9,2012 ; 10,2012)$. CONAFOR also identified gaps in the spreading of information, which was addressed by increasing the call for applicants in different indigenous languages $(10,2012)$, and by the development of workshops for new beneficiaries.

\section{- Workshops:}

Workshops are key moments of interplay between CONAFOR, beneficiaries and technical advisors. Until 2013, CONAFOR organised three types of workshops: "strengthening for beneficiaries", "rights and obligations", and "best practices guide/manual". The workshops have become an important tool of communication of CONAFOR with ejidos and landholders $(10,2012)$. In the workshops, CONAFOR staff provides information and instruction to new beneficiaries about different aspects of the programme, and also receive feedback from beneficiaries and TAs. The first workshop developed was on rights and obligations (2009), and the last, about the guide of best practices, in 2013. Three influences are interesting about the evolution of these workshops: the WB social safeguard policies, the advice of new social staff in CONAFOR, and the practical experience of programme implementers.

The so called 'strengthening of beneficiaries' workshop (SBW), carried out since 2009, is the only one which was not official in 2014 (10, 2012). However, in words of informants, they used to organise them because "these workshops have been successful, because they allow information to flow more effectively among participants" $(10,2012 ; 13,15$, 2013; 12, 2014). In 2012, 62 SBW were carried out at the national level $(10,2012)$. Relevant topics addressed during the workshops are the definition of forest ES, the role of forest owners in the conservation of the forests, the operation of the programme during the five years contract, and the role of TAs. According to staff at state level, the response to these workshops has been positive, encouraging participation, and increased awareness about ES among beneficiaries $(13,15,2013 ; 12,2014)$.

The workshops have been also useful in defining of the roles of actors. Given the problems in the interaction between beneficiaries and TAs, the workshops have been one of the ways CONAFOR makes explicit the conditions under which this interaction must happen $(13,2013)$.

\section{- Verification:}

Since initially (conceptually at least) the payment was for the opportunity cost, i. e. the profit that would have been obtained by not conserving the forest, beneficiaries did not have to invest it in prescribed activities, such as construction of fences or integration of fire brigades $(1,2012)$. The original idea was that communities could see the money 
earned as an incentive for the work of keeping the forest cover $(1,2012)$. But this vision has changed over time, especially in the way communities get involved in the programme, and their interaction with CONAFOR. Control measures to verify activities carried out by beneficiaries have increased, and the methods and procedures to do it have changed considerably. In the first years (2003-2005), CONAFOR carried out verification every three years, using remote sensing (CONAFOR, 2003-2005). This process has gradually become more rigorous, especially since 2011 , since when activities in PES polygons must be verified in the field every year, with the active participation of the beneficiaries and TAs during the visits of CONAFOR staff. The procedures regarding verification are also described more specifically in the ORs (Timeline 5.11, in Chapter 5). These changes have happened for practical reasons; and because of the increasing of the obligations and activities required of beneficiaries in order to receive the payments $(12,2014)$.

\section{B) Beneficiaries' obligations, commitments and rights}

According to 1 , since its inception, PES scheme has been successful because it was a result-based programme. In the past it was customary that the government simply give money without demanding anything in return. In PES case, the payment is given on the condition that the forest remains conserved. This was a milestone, because this programme brought about a change in CONAFOR' thinking. Before this, programmes lacked criteria for eligible areas and priority criteria for targeting $(1,2012)$.

Since the conceptualisation of the programme, the only obligation for beneficiaries was to keep the forest cover for five years. Remote sensing annual monitoring of forest cover in the PES areas was carried out, and no specific activities for conservation of forests were requested to beneficiaries $(1,2012)$. This generated criticism from external groups, especially through the national advisory committee, because the scheme was not encouraging any active participation by communities, reinforcing the idea that the programme gave payments for 'doing nothing' $(1,2012 ; 4,2013)$. In response, CONAFOR established explicit activities and tasks to be fulfilled by beneficiaries to improve the quality of forests, and reduce the degradation given by cattle and legal or illegal use, as well as the fire risk, and the constant monitoring of the lands, which it called "commitments". Also, they determined rights and obligations of beneficiaries $(1,2012)$.

\section{- Use of payments}

Another change concerned the use of the payments. The initial idea considered payment as an economic return for the ESs provided. The idea was that beneficiaries could freely use this money, without having to invest in forest-related activities, or reporting to CONAFOR the use of the money $(1,2012)$. But in 2012 a clause appeared in ORs requesting beneficiaries -specifically communities and ejidos- to present an Assembly 
act proving the agreement of the whole community about the use of the money received $(12,2014)$. According to the head of the programme at 2012, PES operators made this decision because of the frequent cases of corruption that occurred within communities, where the community authorities administered the money in a discretionary way, or just kept it, never informing the rest of the people about their enrolment in PES. It was state level officials who raised this with Central Offices $(4,2012 ; 12,2014)$. CONAFOR is also exerting pressure on beneficiaries on how to spend the money. In 2014 it was necessary to use part of pay for activities in the field, and CONAFOR suggested "appropriate" (for collective benefit) uses of the remaining money $(12,2014)$.

\section{- Manual and Guide for Best Forest Management Practices:}

The manual and guide for best practices (GBFMP and MBFMP) "allow planning and management of the polygons under PES [...] and establish the minimum necessary actions to maintain or improve the provision of ES" (CONAFOR, 2012). The manual and guide helps the PES beneficiaries to make decisions about the most suitable activities to carry out in the context of the PES programme, such as fire protection, water catchment and filtration, soil conservation and management, road maintenance, erosion protection, monitoring of the forests, among others (CONAFOR, 2012). The modality of PES (or payment area) determines the type of document the forest owners should develop: the manual is a complex diagnostic and planning document for the areas within PSAH; while the guide is just a menu with predefined activities to be chosen by the beneficiaries in the PES Biodiversity areas. The beneficiaries, with the support of their TA must submit an annual report of activities carried out in the polygon within PES, compared to the activities previously defined in the manual or guide, which will be verified by CONAFOR every year. The activities must be determined by the community in a participatory way, with the assistance of the TA. The use of the manual and guide became mandatory in 2006. The idea of a manual and guide came from NGOs, who were trying to include criteria which would allow communities already carrying out conservation activities in their territory, giving them the opportunity to be directly involved in the decision making of the most suitable activities to conserve their forests. The idea was to recognise communities with an active profile, as well as participatory schemes, since NGOs and other groups were dissatisfied with the passive role expected of communities in the programme $(50,2013)$.

\subsubsection{TAs}

Although external technical assistance for beneficiaries has been one of the most important components in the implementation of the PES programmes, information about them in ORs is scanty and vague. There is no specific section in the ORs about them; the relevant information is scattered along the documents. In 2006 the list of registered TAs (named LAST) was mentioned for the first time, when hiring of TAs 
started being considered as requirement to be fulfilled by beneficiaries. In 2008 hiring of TAs became an obligation of beneficiaries, although more specific information about their tasks was presented. Since then, information about TAs has not changed dramatically: more details about their tasks and obligations have been added, and restrictions are given on the number of contracts they can hold. In 2013 the TAs' certification is mentioned for the first time, but no information is provided about that process (Table 5.7, in chapter 5).

In practice, the role of TAs has constantly changed over time, but these changes are not clearly defined in the ORs. It should be pointed out that there are other specific documents focused on TAs, which provide more detailed information about their work, and the requirements for taking part in CONAFOR programmes. Given their significant role in the implementation of such programmes, it is intriguing that, over 11 years, their rights and obligations have not been clearly defined in ORs.

Most of the changes related to TAs are, in fact, result of the observation in the field by CONAFOR staff, complaints from beneficiaries, and pressure from TA.

- Interaction with communities mediated by a contract. Since 2010 it has been established that relation between TAs and beneficiaries is mediated by a contract $(12,2014,14,2013)$. The contract must contain the amount of payment, as well as the responsibilities of TA. It also encompasses a clause of rescission of contract, implying that beneficiaries can dissolve the contract in case of breach of duties by the TAs $(12,2014)$.

- Direct payment allocation for their services. Before 2012 CONAFOR deposited the money for TA to the beneficiaries, and then the beneficiaries had to pay TAs. That brought many conflicts, either because beneficiaries did not pay always or paid less to TAs. More frequently, TAs took advantage of beneficiaries by overcharging $(4,2013 ; 12,2014) .17$, a technical advisor, mentioned that in this case, the TAs joined forces to lobby CONAFOR to change the mechanism of payment $(17,2013)$. Since 2012 CONAFOR has been paying directly to TA.

- Limited number of beneficiaries. A common problem was that some TAs had more beneficiaries than they could really assist. To avoid that, in 2012 CONAFOR determined a maximum number of beneficiaries to be helped by each TA $(12,2014 ; 15,2013)$.

- Joint responsibility clause. Given that beneficiaries were sometimes abandoned by the TAs, and to ensure that the programme worked better, in 2012 a joint responsibility clause was introduced, that obliges both beneficiaries and the TAs to fulfil their tasks $(4,2013)$. 
- Certification process. This is a formal measure established by CONAFOR to ensure the quality of the services provided by the TAs. More detailed information about this process is given in chapter 7 and 8 .

\subsection{Discussion}

Change has been a characteristic of the ORs since the creation of the programme. But it is necessary to point out that CONAFOR and the policies it developed are relatively new. The period in this study covers a time of major adjustments of the programmes.

"Since 2010, the PES programme has been steady, the learning curve has been passed, many of the deficiencies identified earlier have been overcome, and we are in a favourable moment in many ways [...]. This (2013) is an important moment when we can evaluate everything we have learned and then make a real evaluation of the programme itself, to see if it is meeting the objectives for which it was actually designed" $(4,2013)$.

But even if a point of greater balance is reached in the programme, actors will continue seeking new equilibria over time, for which a more far-reaching study would be pertinent to evaluate changes and their possible patterns.

But it is also necessary to remember that even in the most innovative programmes like PES, elements of previous forest policy schemes have been taken up.

\subsubsection{Positives and negatives of change}

As Mathews (2011) says: "policies are apt to be more successful if they can be reversed once they start to go awry, and so good planners ensure reversibility. Officials should assume that there will be surprises" (Mathews, 2011).

The change in the ORs, as well as in PES in general is usually seen as a positive feature. According to the informants, the evolution of PES has been product of a learning process of the operators of the programme, including the ability to take into account the visions of other actors. Although there are positive opinions about the continuous change, it is also clear that these have brought unintended effects. One of them is the loss of important original objectives.

PES programmes in México are the product of international influence, discussions among scholars and social organisations, and negotiations to include the scheme in the national forest agenda. As was mentioned in previous sections, PSAH and CABSA had different origins, objectives, operational modes, and modalities of payment until 2010, when the scheme was simplified by merging PSAH with some components of CABSA. This new simplified scheme limited the options for participants to present their own initiatives in the frame of ES. Since then, beneficiaries are expected simply to comply with the activities indicated in the rules. The simplification also affected the original 
objectives of both programmes and removed some of the social concerns that were expressed and negotiated for in the implementation of CABSA. This also brought new imbalances of power, pushing out the interests of groups that already had a weak participation in the programme.

In the same way, the continuous influence of certain actors pushing for change in the rules has made the programme a mix of many different visions, with conflicting results, and with actors assigned contradictory roles and expectations. For instance, the attempt at promoting more participation from beneficiaries collides with the increase of control in the activities to be done by them, because their capacity to make decisions about their lands is limited.

Additionally, the role of programme implementers has become blurred over time, including TAs, who play an important intermediary role between CONAFOR and beneficiaries. Their role is vaguely represented in the ORs, and the results expected from them are ambiguous. TAs have taken advantage of this vagueness and ambiguity in ORs, which has resulted in conflicts (which will be addressed in detail in chapters of section III: 8, 9 and 10).

Despite being known as a flexible programme, there are areas that have tended to be more rigid, especially as regards of targeting of beneficiaries, the establishment of responsibilities for beneficiaries of the programme, and control measures like the verification process. These areas have been changing continuously, oscillating between strictness and flexibility year by year. This could be a response to different political and social pressures in the programme but could also point to limitations of CONAFOR. Corbera, et al. (2009) mention that PES payments are not really conditional on results, and recall Wunder, et al. (2008), who suggest that this lack of conditionality is common in government-led programmes, implicitly acknowledging the political difficulties involved in prosecuting poor landowners for non-compliance (Corbera, et al 2009).

\subsubsection{Change, constraints and continuity}

Limits to the plasticity in the implementation of programmes have been evident too. For example, inertia from older schemes of Mexican public policy have restricted the development of the programme. All programmes and their rules in México are subject to the constraints of rigid bureaucratic and legal structures.

The evolution of ORs has been restricted by institutional (CONAFOR's laws and rules), financial, informational (availability of reliable information at the national level) and organisational (the lack of employees or specific profiles) factors. These factors make it difficult to introduce specific changes in the programme and ORs. Merino and Segura point out that limiting factors of institutional change inherited from past policies include 
restricted funding of environmental policies, lack of sufficient staff, and the centralisation of policy decisions (Merino \& Segura, 2007).

However, as we could see in the previous section, there have been key moments when staff of the PES programme tried to shape the rules despite the rigid structures (i.e. the definition of the types of forests as included in the PES programme), and also how internal and external actors, by re-interpreting the rules, and searching for what Mahoney \& Thelen (2010) called "gaps and soft spots" in these structures, have moved within the bureaucratic schemes to find ways of adjusting the programme and its rules according to their interests. Thus, is possible to see that, even though institutions limit the options available to actors, they do not completely determine their actions (Campbell, 2010).

\subsubsection{Power struggles and interactions among actors}

\subsubsection{Centralisation, devolution and trust}

Focusing on the interaction of the different actors and the definition of their roles, some issues come to light in the analysis, including centralisation, trust, responsibility and definition of social contract. On centralisation, there are negotiations and conflicts of power inside CONAFOR, in this case between the central with the state offices. Centralisation is part of the original design of the programme, and resistance from operators of the central offices to give more power to the state level operators in key aspects like the definition of eligible zones, priority criteria, and the selection of beneficiaries is evident. Change on these themes has been especially slow and subtle. To justify centralised decision-making, CONAFOR has argued administrative and financial constraints, pragmatism, avoidance of subjectivity and control of corruption.

In terms of the relations and the role of the actors outside CONAFOR, we can see that the conditions under which interactions with applicants and beneficiaries, as well as with technical advisors, have been determined almost unilaterally by CONAFOR.

\subsubsection{Changes in the 'social contract between the governing and governed}

Meanwhile the beneficiaries' responsibilities in ORs increased over time, CONAFOR obligations tended to be general and ambiguous. In terms of 'social contract', this can suggest that CONAFOR is shaping the ORs to reduce its own responsibilities, but the same time keeping or increasing the control measures over the less powerful actors. Furthermore, CONAFOR is not only increasing the burden of responsibility of the beneficiaries, but also increasing the criteria for prioritising and selecting both lands and beneficiaries. 
Interaction has also been limited to providing information to beneficiaries and increasing monitoring of compliance, through the establishment of clearer obligations and commitments, and also through verification. In response to criticisms from different organisations, CONAFOR made the control measures more rigorous, but it did not increase the participation opportunities of the beneficiaries.

In the case of TAs, they are not clearly defined as actors in the PES programme, and therefore they are not well represented in the ORs. Although ORs have gradually specified several restrictions and obligations of TA, the final responsibility for the behaviour and compliance of TAs lies with the beneficiaries.

CONAFOR is also indirectly arbitrating relations between TAs and beneficiaries, through establishing contracts between them and including clauses of co-responsibility but avoiding the monitoring of those interactions or the possible mediation in case of conflicts.

\subsubsection{About power relations}

Mahoney and Thelen point out that "institutions are full of tensions because they involve resources and have unequal distributional consequences for different actors" (Mahoney y Thelen, 2010). ORs of the PES programme have been developed in a contested way. Many different actors have been involved in the design and implementation of the programme, but all the interactions have been intervened by CONAFOR, and the position of these actors have been unequal.

Furthermore, the involvement of the actors is limited by CONAFOR to specific areas and moments of the programme development. In addition, the opinion of certain actors, such as international organisations, civil organisations and universities, has been favoured, leaving aside voices that have been lobbying for changes that come from more disadvantageous positions. This does not mean that there is no feedback from nonprivileged actors, but it is done through informal means, is not as visible as feedback from committees and evaluations and is almost always mediated by state and regional employees of CONAFOR.

The unbalanced power relations are especially evident with respect to beneficiaries of the programme. Their participation is limited to the simple compliance of the rules. Other forms of participation are not restricted, but there are no special mechanisms to get feedback from them. All the attempts of CONAFOR to improve the communication strategies with beneficiaries have come from external and influential organisations, such as the WB, which has provided financial, technical and analytical support to CONAFOR in many programmes. 
Power struggles have been more evident in the spaces especially designed by CONAFOR to enable participation. The advisory committees are the main entities devoted to discussion and advice about different areas of the ORs, and about the implementation of the programme. Power struggles among different groups trying to be influential in the programme are evident especially the definition of the priority criteria for targeting beneficiaries and lands, which are two of the main topics discussed in this committee. Given the nature of participants, the discussions tend to be technical. In that arena, there are continuously disputed themes, such as the environmental vs social, and local knowledge vs scientific knowledge, etc., which contribute to the asymmetries in power, and in turn to institutional changes over time.

The growing number of criteria for selection of lands and applicants in PES programme is significant: in PSAH there were 10 in 2006 and 25 in 2010. In 2010 there was an important review of the eligibility criteria and zones $(4,2012)$, which consider the change in the types and number of criteria in that year. Priority criteria have become more specific. Measurements and geo-information to make decisions have become increasingly more "sophisticated" and "scientific", especially in terms of the environmental criteria. The attempt to include other sources of information, especially from powerful NGOs and research institutes is evident though, always in collaboration with official organisations. At the same time, social issues remain lax and may even be contrary to such specialised technical measurements (e.g. the possibility of selection even though the proposed lands are outside the eligible zones has been made explicit), but they also make use of more "valid" or "official" sources of information. The other aspect to note about the sources of information is that only one or two priority criteria are calculated directly by CONAFOR, which may partly an attempt to demonstrate transparency, fairness and objectivity in the use of public resources.

\subsubsection{Change and instability}

The constant changes in the PES programme a role an important role in the public façade of CONAFOR. Change portrayed as adaptability, helps to create an image of CONAFOR as an organisation able to learn from its results, hearing opinions and evaluations, and making use of the evidence to improve the relationships with stakeholders and the impacts of the programme. But the continuous change in PES can also be seen as a product of the institutional inertias in which the programme is immersed. In this sense, the notion of path dependency becomes relevant (Cambpell, 2007). There are some works that make clear a historical problem of uncertainty and lack of coherency in Mexican forest institutions. Mathews (2011) mentions that temporality of official knowledge is an important aspect to be considered in understanding the authority promoted by the Mexican forest ministries: "Since the 1930's, official declarations, management plans, and forms tried to perform the forest service as a solid and stable 
institution that was the source of order and knowledge. [...] But in fact, the forest service has been unstable, with frequent reorganisations and new forest laws. The state's control over forests was tenuous and unstable". On this point, Zorrilla (2005) also refers to the paradox of forestry policy in México, because between 1986 and 2005 four different forest laws (1986, 1992, 1997 and 2003) were approved, but the average life of a forestry law has been 5 years in the last 20 years while the average growth of commercial tree species is $10-15$ years (Zorrilla, 2005). Thus, it is possible that the 'adaptability' of the PES programme is a continuation of this inertia. On this, Levitsky and Murillo state that institutional weakness is a recurring feature in developing nations and may be due to the replication of institutional models unsuited to the local realities, and the poor scope of the State, among other things (Levitsky \& Murillo, 2013). In these contexts, institutional change use can be sudden, repeated and abrupt (Levitsky \& Murillo, 2013). In this case we have been able to observe different mechanisms and processes involved in the process of institutional change.

\subsection{Conclusions}

The analysis of causes of change in ORs of PES contributes to a better understanding of factors and actors influencing the evolution of the programme. Although a variety of actors participated in different stages of the implementation of PES, they were not equally influential. The most influential actors were those at the highest levels of national policymaking (the government in power), and forest policy-setters, funding agencies (especially the World Bank), and officials from other national level government ministries. Additionally, other external actors provide advice, feedback, assessment and validation, for example recognised NGOs and universities, through their participation the PES advisory committees or in evaluations. The influence of other actors in ORs decreases as we approach the local levels. CONAFOR's state-level operators provide feedback from their observations in the field, and they are also the main spokespersons for beneficiaries and TAs claims and suggestions, whose direct influence in ORs is very limited.

The continuous influence of certain actors pushing for change in the rules has made the programme a mix of many different visions, and conflicting results, with actors playing contradictory roles.

Changes in ORs reflect power struggles, negotiations and tensions between the highlevel actors for the prevalence of their own interests, values and approaches. The main tensions/struggles taking place in the programme are between 1) environmental vs social criteria, 2) technical/scientific vs political basis for choices, 3) centralised vs decentralised decision making, 4) older vs innovative approaches (e.g. subsidy vs incentive), and 5) older vs innovative administrative procedures. 
We have seen that the ORs shape the behaviour of the actors within PES, but the actors also shape the ORs. In this analysis, external factors that produce changes in the ORs have been identified, but we have focused on the influence of different actors within the PES scheme. As the Theory of gradual institutional change indicates, the actors carry out rational strategies to move the rules closer to their interests. Examples of this are the demands made by farmers, academics or NGOs, to establish new PES modalities. In the same way, we have seen the constant re-arrangements of power of the actors to define priority criteria for targeting, which has made the ORs a mosaic of interests. CONAFOR employees exercise their agency, and take advantage of the ambiguities, "gaps and soft spots" of the ORs and the Law to be able to make desired changes despite the administrative inertia and institutional rigidity (path dependence). But the actors do not always push the rules in a rational way, which is more evident in implementation, when the ORs become concrete activities in forests. Although in this chapter is not so explicit, in later chapters it will be seen that the actors, especially the beneficiaries and the TAs (and even the state employees of CONAFOR) directly and indirectly influence the programme more than they appear to. This happens when formal institutions, such as ORs, converge with local institutions. Local actors (or actors with influence at the local level) use their own tools to accommodate, combine, or replace local rules with ORs, building their own PES (Cleaver, 2001; Koning, 2012), as a clear example of institutional bricolage.

The official nature of the ORs, their processes of change, and the influence of powerful and recognised actors have led to the intention of inscribing into the ORs of a set of values that include flexibility, transparency, efficiency, objectivity, public interest, and credibility. Those values have been taken advantage of by CONAFOR to build a narrative about ORs which is aimed at making them appear legitimate and even unquestionable. Thus, CONAFOR has been able to create and control the story about the programme. The response of actors, particularly the TAs to an institutional environment primarily produced by CONAFOR, will be addressed in the chapters of section III of this thesis. 


\section{References of section II}

Alix-Garcia, J. M., de Janvry, A., Sadoulet, E., \& Torres, J. M. (2005). An Assessment of México's Payment for Environmental Services Program. Berkeley: University of California.

Alix-Garcia, J.M., Sims, K.R., Yañez-Pagans, P., Radeloff, V.C., \& Shapiro, E.N. (2012). Twodimensional evaluation:

the environmental and socioeconomic impacts of México's Payment for Hydrological Services program. April.

Alix-Garcia, J. M., Shapiro, E. N., \& Sims, K. R. (2012). Forest Conservation and Slippage: Evidence from México's National Payments for Ecosystem Services Program. Land Economics, 88 (4), 613-638.

Alix-Garcia, J, Aronson, G, Radeloff, V, Ramirez-Reyes, C, Shapiro, E, Sims, K, Yañez-Pagans, P. (2014). Environmental and socioeconomic impacts of México's payments for ecosystem services program, 3ie Impact Evaluation Report 20. New Delhi: International Initiative for Impact Evaluation (3ie).

Alix-Garcia, J. M., K. R. E. Sims, \& P. Yañez-Pagans. (2015). "Only One Tree from Each Seed? Environmental Effectiveness and Poverty Alleviation in México's Payments for Ecosystem Services Program." American Economic Journal: Economic Policy, 7 (4): 1-40. http.doi.org.10.1257/pol.20130139

Campbell, J. L. (2004). Institutional Change and Globalization, Princeton: Princeton University Press.

Campbell, J. L. (2010). Institutional reproduction and change. In Morgan, G., Campbell, J.L., Crouch, C., Pedersen, O.K., \& Whitley, R. (Eds.). Oxford Handbook of Comparative Institutional Analysis (pp.87-115), New York: Oxford University Press.

CBD. (2010). List of Parties. Retrieved from http://www.cbd.int/information/parties.shtml

Chazdon, R. L., Brancalion, P. H. S., Laestadius, L., Bennett-Curry, A., Buckingham, K., Kumar, C., ... Wilson, S. J. (2016). When is a forest a forest? Forest concepts and definitions in the era of forest and landscape restoration. Ambio, 45(5), 538-550. https://doi.org/10.1007/s13280016-0772-y

Cleaver, F., \& de Koning, J. (2015). Furthering critical institutionalism. International Journal of the

Commons, 9, 1-18. https://doi.org/10.1126/scitranslmed.aar4439

CONAFOR. (2006). Pago de servicios ambientales hidrologicos. México City: Comision Nacional Forestal.

CONAFOR. (2006). Proyecto de Servicios Ambientales del Bosque. Prestamo del Banco Mundial para el Gobierno de México. México City: Comision Nacional Forestal.

CONAFOR. (2011). El pago por servicios ambientales como instrumento de conservacion. Los pagos por servicios ambientales. Mecanismos para gobernanza de los recursos naturales. México City: Comision Nacional Forestal.

CONAFOR. (2012). El pago por servicios ambientales como instrumento de conservación. Los pagos por servicios ambientales. Mecanismos para gobernanza de los recursos naturales. México City: Comision Nacional Forestal.

CONAFOR. (2013). Propuesta de actualizacion: programa estrategico forestal para México 2025. Comision Nacional Forestal. México City: Comision Nacional Forestal.

CONAFOR. (2014). Programa Anual de Trabajo. Gerencia de Servicios Ambientales del Bosque. México City: Comision Nacional Forestal.

Corbera, E., Gonzalez Soberanis, C., \& Brown, K. (2009). Institutional dimensions of Payment for Ecosystem services: An analysis of México's carbon forestry programme. Ecological Economics (68), 743-761.

Costedoat, S., Corbera, E., Ezzine-de-Blas, D., Honey-Rosés, J., Baylis, K., \& Castillo-Santiago, M. A. (2015). How Effective Are Biodiversity Conservation Payments in México? Plos One, 10(3), e0119881. https://doi.org/10.1371/journal.pone.0119881 
David, P. A. (1985). "Clio and the Economics of QWERTY." American Economic Review 75(2): 332337.

David, P. A. (2007). Path Dependence: A Foundational Concept for Historical Social Science. Cliometrica 1(2): 91-114.

Del Angel-Mobarak, G. A. \& Negrete C. S. (2012). Fortalecimiento y Retos con ProArbol. In Del Angel- Mobarak, G. A. (Coord.). La Comision Nacional Forestal en la historia y el futuro de la politica forestal de México (pp. 169-244). Coleccion Coyuntura y Ensayo. México City: CIDE-CONAFOR.

DOF. (2003). Secretaria de Medio Ambiente y Recursos Naturales. Acuerdo que establece las reglas de operacion para el otorgamiento de Pagos del Programa de Servicios Ambientales Hidrologicos. Diario Oficial de la Federacion, October $3^{\text {th }}$, pp 6-23.

DOF. (2004). Secretaria de Medio Ambiente y Recursos Naturales. ACUERDO que establece las Reglas de operacion para el otorgamiento de pagos del Programa para Desarrollar el Mercado de Servicios Ambientales por Captura de Carbono y los Derivados de la Biodiversidad y para Fomentar el Establecimiento y Mejoramiento de Sistemas Agroforestales (PSA-CABSA). Diario Oficial de la Federacion. Segunda Seccion, 24 November, pp 1-22.

DOF. (2006). Secretaria de Medio Ambiente y Recursos Naturales. ACUERDO por el que se expiden las Reglas de Operacion de los Programas de Desarrollo Forestal de la Comision Nacional Forestal. Diario Oficial de la Federación. Tercera Sección, 16 February, pp 1-130.

DOF. (2007). Secretaria de Medio Ambiente y Recursos Naturales. ACUERDO por el que se expiden las Reglas de Operacion del Programas Pro-Arbol de la Comision Nacional Forestal. Diario Oficial de la Federacion. Segunda Seccion, 20 February, pp 1-44.

DOF. (2007). Secretaria de Medio Ambiente y Recursos Naturales. ACUERDO por el que se expiden las Reglas de Operacion del Programa Pro-Arbol de la Comision Nacional Forestal (2008). Diario Oficial de la Federación. Cuarta Seccion, 28 December, pp 1-129.

DOF. (2008). Secretaria de Medio Ambiente y Recursos Naturales, ACUERDO por el que se establecen las Reglas de Operacion del Programa ProArbol 2009. Diario Oficial de la Federacion. Cuarta Seccion, 31 December, pp 1-112.

DOF. (2009). Secretaria de Medio Ambiente y Recursos Naturales. REGLAS de Operacion del Programa ProArbol 2010. Diario Oficial de la Federacion. Sexta Sección, 31 December, pp 1-80.

DOF. (2010). Secretaria de Medio Ambiente y Recursos Naturales. REGLAS de Operacion del Programa ProArbol 2011. Diario Oficial de la Federacion. Cuarta Sección. 29 December, pp 1-91.

DOF. (2011). Secretaria de Medio Ambiente y Recursos Naturales. REGLAS de Operacion del Programa ProArbol 2012. Diario Oficial de la Federacion. Segunda Seccion, 21 December, pp 1-89.

DOF. 2013. Secretaria de Medio Ambiente y Recursos Naturales. REGLAS de Operacion del Programa Nacional Forestal. Diario Oficial de la Federacion. Tercera Seccion, 8 March, pp $1-111$.

Douglas, M. (1986). How Institutions Think. Syracuse: Syracuse University Press.

Ezzine-De-Blas, D., Dutilly, C., Lara-Pulido, J. A., Le Velly, G., \& Guevara-Sangines, A. (2016). Payments for environmental Services in a policy mix: Spatial and temporal articulation in México. PLOS ONE, 11(4), 1-15. https://doi.org/10.1371/journal.pone.0152514

FAO. (2013). Forest Conservation in México. Ten years of Payments for Ecosystem Services. Case studies on Remuneration of Positive Externalities in PES. Rome: FAO.

Fuentes, D. G. (2009). Reglas de operacion de los programas del Gobierno Federal: Una revision de su justificacion y su diseño. CESOP, Working paper 71. 
Gomez-Guerrero, A. (2006). Evaluacion del Programa de Pago por Servicios Ambientales por Captura de Carbono, y los derivados de la Biodiversidad y para Fomentar el Establecimiento y Mejoramiento de Sistemas Agroforestales (PSA-CABSA). México City: CONAFOR.

Gonzalez-Vicente, C. E. (2012). La creacion de la Comision Nacional Forestal. In Del Angel-Mobarak (Coord.). La Comision Nacional Forestal en la historia y el futuro de la politica forestal de México (pp. 117-168). Coleccion Coyuntura y Ensayo. México City: CIDE-CONAFOR.

Hall, P. A. \& Taylor, R. C. R. (1996). Political Science and the Three New Institutionalisms. Discussion Paper. Max-Planck-Institut für Gesellschaftsforschung.

Hernandez, J. I. (2006). Evaluacion del Programa de Pago por Servicios Ambientales por Captura de Carbono, y los derivados de la Biodiversidad y para Fomentar el Establecimiento y Mejoramiento de Sistemas Agroforestales (PSA-CABSA). México City: CONAFOR.

Hood, C. C., \& Jackson, M. (1991). Administrative argument. London: Gower

INEGI. (2013). The Millennium Development Goals in México: Progress Report 2013. México: Presidencia de la Republica.

Jackson, G. (2010). Actors and Institutions. In Morgan, G., Campbell, J., Crouch, C., Pedersen, O., Christensen, P. H., \& Whitley, R. (Eds.), Oxford Handbook of Comparative Institutional Analysis. Oxford: Oxford University Press.

Koning, J., \& Cleaver, F. (2012). Institutional bricolage in community forestry: an agenda for future research. In: Arts B., van Bommel S., Ros-Tonen M., Verschoor G. (Eds.). Forest-people interfaces. Wageningen, N.L.: Wageningen Academic Publishers.

Kosoy, N., Corbera, E., \& Brown, K. (2008). Participation in payments for ecosystem services: Case studies from the Lacandon rainforest, México. Geoforum, 39(6), 2073-2083. https://doi.org/10.1016/j.geoforum.2008.08.007

Levitsky, S., \& Murillo, M. V. (2013). Lessons from Latin America: Building Institutions on Weak Foundations. Journal of Democracy 24(2), 93-107. doi:10.1353/jod.2013.0031

Mahoney, J. (2000). Path Dependence in Historical Sociology. Theory and Society 29: 507-48.

Mahoney, J., \& Thelen, K. (2010). Explaining Institutional Change: Ambiguity, Agency, and Power. Cambridge: Cambridge University Press.

Mathews, A. S. (2011). Instituting Nature. Authority, Expertise, and Power in Mexican Forests. The MIT Press.

McAfee, K., \& Shapiro, E. N. (2010). Payments for Ecosystem Services in México: Nature, Neoliberalism, Social Movements, and the State. Annals of the Association of American Geographers, 100(3), 579-599. https://doi.org/10.1080/00045601003794833

McCall M. K., Bermudez, R., Granados-Herrera, J. (2017). 'Signing up to PES' - Why communities participate in PES programmes in México. In Namirembe, S., Leimona, B., Van Noordwijk, M., Minang, P. (Eds.). Co-investment in ecosystem services: global lessons from payment and incentive schemes. Nairobi: World Agroforestry Centre (ICRAF).

Merino-Perez, L. (2004). Conservación o deterioro. El impacto de las politicas publicas en las instituciones comunitarias y en los usos de los bosques en México. México: SEMARNAT, INE \& CCMSS.

Muñoz-Piña, C., Guevara, A., Torres, J. M., \& Braña, J. (2008). Paying for the hydrological services of México's forests: Analysis, negotiations and results. Ecological Economics, 65 (4), 725 736.

North, D. C. (1990). Institutions, Institutional Change, and Economic Performance. New York: Cambridge University Press.

Pattanayak, S. K., Wunder, S., \& Ferraro, P. J. 2010. Show me the money: Do payments supply environmental services in developing countries? Review of Environmental Economics and Policy, 4 (2), 254-274.

North, D. C. (1991). Institutions. Journal of Economic Perspectives, American Economic Association, 5(1), 97-112, Winter. 
Perevochtchikova, M., \& Ochoa, A. M. (2012). Avances y Limitantes Del Programa De Pago Por Servicios Ambientales Hidrologicos en México, 2003 - 2009. Revista Mexicana de Ciencias Forestales, 3(10), 89-112. https://doi.org/10.29298/rmcf.v3i10.522

Pierson P. (2000). Increasing returns, path dependence, and the study of politics. American Political Science Review. 94: 251-68

Rivero-Cob, E. (2012). Problemas de Agencia y Busqueda de Rentas en el Programa de Pago por Servicios Ambientales Hidrologicos de México. Revista de Economia, XXIX (79), 33-70.

Rixen, T., \& Viola, L. A. (2015). Putting Path Dependence in its Place: Towards Taxonomy of Institutional Change. Journal of Theoretical Politics, 27(2), 301-323.

Segura-Warnholtz, G. (2014). Quince años de politicas publicas para la accion colectiva en comunidades forestales. Revista Mexicana de Sociologia, 76, 105-135

Shapiro, E. N. (2010). Political Economy and Community-Level Impacts of the Mexican Federal Payment for Ecosystem Services Programs. University of California, Environmental Science, Policy \& Management. Berkeley: University of California.

Shapiro-Garza, E. (2013). Contesting the market-based nature of México's national payments for ecosystem services program: Four sites of articulation and hybridisation. Geoforum, 46, 515

Streeck, W. \& Thelen, K. (2005). Beyond Continuity: Institutional Change in Advanced Political Economies, Oxford: Oxford University Press.

Thelen, K. (1999). Historical Institutionalism in Comparative Politics. Annual Review of Political Science 2: 369-404.

Wunder, S, Engel, S., \& Pagiola, S. (2008). Taking stock: A comparative analysis of payments for environmental services programs in developed and developing countries. Ecological Economics, 65(4), 834-852. https://doi.org/10.1016/j.ecolecon.2008.03.010

Zorrilla, R. M. (2005). Servicios Ambientales Forestales y Accion Colectiva. El Caso de la Cuenca del Rio Copalita, Oaxaca. MSc Thesis. México: Instituto de Investigaciones Dr. Jose Maria Luis Mora. 


\section{TAs as the hinges in the implementation of PES}

Chapter 7. Common narratives about TAs as intermediaries

Chapter 8. The specific role of TAs in the Mexican PES programme

Chapter 9. Villains and scapegoats: analysing the narratives of CONAFOR and other actors about the TAs

Chapter 10. Warhorses and bad apples: analysing the narratives of TAs about themselves

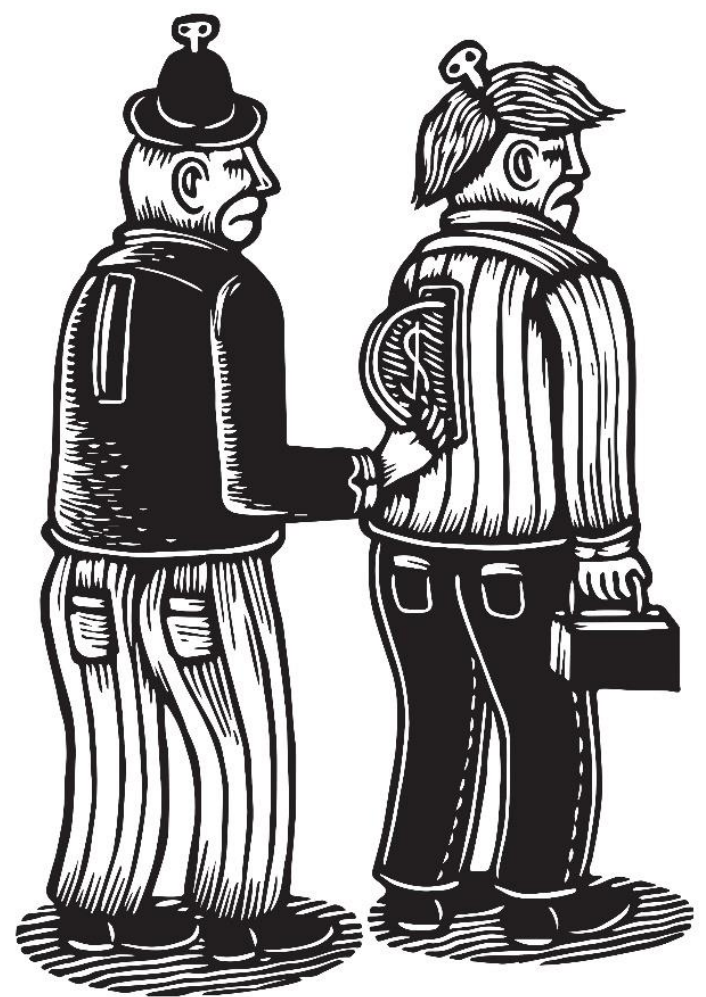

Iván Montero-Longoria. 2016. Generational slave [Engraving]. Michoacán, México. 


\section{Chapter 7. Common narratives about TAs as intermediaries}

\subsection{Introduction}

TAs are fundamental intermediary figures in the operation of almost all CONAFOR programmes. TAs are independent professionals and may be NGOs, small enterprises or individuals, who are generally specialised in forestry. They provide support and guidance to beneficiaries of CONAFOR's programmes in a changing institutional context. Although they are external services providers, they do not act in an isolated way, nor define their own roles by themselves. They are dependent on a particular policy framework, and act according to specific contexts and conditions, and to CONAFOR's expectations about technical advisory in its programmes.

The role of TAs in CONAFOR has been widely questioned because of the complexity of the relationships they establish as well as the informal practices that they co- and reproduce at the local level. Awareness of problems in performance these intermediaries is not new. In addition to positive effects some negative consequences of their participation in PES schemes have been documented. Their action and performance in the PES programme is controversial and a matter of discussion both by the policy makers, and by the programme analysts and scholars. This chapter deals with different aspects of the work of TAs, in order to make visible the problems, conditions, consequences and perspectives relating to their participation in the PES programme.

In many countries, the assistance provided by intermediaries is integral to the design of PES strategies. Both theoretical and empirical analysis of the functioning of intermediaries are significant in understanding and evaluating the design of PES strategies.

It is necessary to understand TAs are relational actors, so their role needs to be analysed in the contexts of these relations. Consequently, in order to obtain insights into actual relevance and performance, it is important to (a) situate them in a historical and current context of forest policy, and b) consider their position in relation to CONAFOR and beneficiaries of the PES programme, and (c) identify the kind of actors that are performing this job and the nature of their working conditions.

This chapter reviews the identity, role and relevance of intermediaries in PES schemes around the world and in México. A general description of technical and professional forest services providers, who are currently called Technical Advisors (TAs) in CONAFOR 
programmes, who are the most significant intermediaries in the development of forest policies in México, is given.

Section III includes four chapters, two based on documentary analysis and two based on empirical information gathered for this thesis. Chapter 8 addresses the historical relationship between forest policy schemes, intermediaries and communities in México, exploring the features and inertias around TAs performance, as well as the influence historically acquired and held by them over time. Chapter 8 also describes CONAFOR'S expectations about the role of TAs, and their present professional profiles, and working conditions.

Chapter 9 addresses the perceptions of different stakeholders on the role of TAs in the implementation of PES in México, especially the responses of CONAFOR to TAs performance. On the other hand, the chapter includes a brief description of the relationship of TAs and communities in 6 communities at different stages of the PES programme. This approach allows visualisation of dynamics, problems and needs as they occur in practice, at the local level.

And finally, chapter 10 addresses the perceptions of the TAs themselves, based on their own experiences and perspectives in the implementation of PES in México including: a) their motivation and interest in participating in PES and other CONAFOR programmes, b) their perceptions about the roles they play in PES programme and their relevance for the implementation of the programme, c) the dynamics in the interrelationship with their colleagues d) the enabling and hindering factors in the conduct of their work, e) their views on unethical practices and the certification process, and f) their main needs and perspectives regarding the fulfilment of their tasks in PES.

\subsection{Intermediaries in PES schemes}

To better understand the relevance of intermediaries in PES schemes in developing countries it is necessary to consider the following factors:

- In general, PES schemes are developed in contexts with uncertainty and deficiencies in information flows (Coggan et al., 2013; Davis et al., 2015). In many countries there is poor understanding of concepts and procedures of PES schemes among the actors involved (Pham et al., 2010). Intermediaries provide information and assistance to landowners and other actors in order to promote participation in PES (Schomers et al., 2015). 
- There is a need for facilitation of interaction between PES stakeholders with very different backgrounds, and sometimes conflicting interests (HuberStearns et al., 2013; Schomers et al., 2015). Frequently, the actors involved do not interact outside of the PES scheme (Pham, 2011), and therefore, the presence of intermediaries in establishing and maintaining social relations and networks is highly relevant (Schomers et al., 2015). They also contribute to creating social capital through the strengthening of interactions among actors (Schomers et al., 2015).

- Frequently, the land owners enrolled in PES are poor and do not have the economic and technical capacities needed to handle the activities required by the scheme (Locatelli et al., 2008). Intermediaries can reduce transaction costs (Vatn \& Angelsen, 2009; Bosselmann \& Lund, 2013; Coggan et al., 2013), and can enable fulfilment of both the environmental and the social objectives of PES (Bosselmann \& Lund, 2013). They can also help marginalised and isolated communities to access resources, and connect to people with power and influence (Kritsanaphan \& Sajor, 2011; Sternlieb et al., 2013). One of the intermediaries' tasks in cases of asymmetrical distribution of information, power and resources, is to ensure the access to benefits for the most marginalised actors (Pham et al., 2010).

Intermediaries may be integral actors of governmental PES policies, or in a PES with the market design, or they can be independent entities arising according to specific needs (Coggan et al., 2013). Intermediaries may be individuals, organisations or collaborative groups (Huber-Stearns et al., 2013), stemming from non-profit organisations, government agencies, consultant agencies, businesses, farmer organisations, individual forestry professionals, research organisations, philanthropists, among others (Daniels et al., 2010; Davis et al., 2015; Pham et al., 2010; Swallow et al., 2007), who coordinate with the PES stakeholders (Huber-Stearns et al., 2013; Swallow et al., 2007). When the intermediaries are present by design in the policy or market scheme, they operate for a fee (Coggan et al., 2013), in some cases paid by the ES buyers and sellers, in other cases by the government.

The potential relevance of intermediaries in PES is affected by several factors, such as their own interests in participating and connecting stakeholders, their technical capacities and social skills (Schomers et al., 2015), and their constraints (Huber-Stearns et al., 2013). The connecting role of intermediaries may be especially significant in settings with limited government presence, in isolated communities, and where there are changing rules (Sternlieb et al., 2013). 
Intermediaries may be influential in the institutional dynamics of PES, by directly or indirectly shaping the interactions between actors (Swallow et al., 2009), as well as the rules to be applied (Sternlieb et al., 2013). They are not only constantly harmonising diverse interests, but keeping trust among stakeholders, and enabling co-construction of knowledge (Boon, et al., 2011; Sternlieb et al., 2013). In some cases, intermediaries may be important in the development of new policies, by bringing new ideas upwards (Jindal \& Kerr, 2007).

\subsection{What is expected and fulfilled by intermediaries in PES? Potential and actual roles}

Moss (2009), and Moss et al. (2009), list a set of potential tasks of intermediaries in the establishment of relations between the providers and users of water and sanitation services (Moss, 2009; Moss et al., 2009). In their account, intermediaries play a role in "translating information (policy to practice), facilitating dialogue, providing guidance, bridging gaps, advocating changes, establishing new forms of interaction, and reconfiguring relationships" (Moss, 2009; Moss et al., 2009).

For Sternlieb et al. (2013), the main tasks of intermediaries in socio-ecological systems are translation, communication and representation (Sternlieb et al., 2013). They also state that intermediary organisations must have special capacity to learn, and to mediate conflict (Sternlieb et al., 2013). Finally, they list characteristics emerged from the literature about what they call transboundary organisations including: legitimacy, saliency, urgency, and credibility (Sternlieb et al., 2013).

In general, PES intermediaries are expected to fulfil tasks in:

a) Promoting and preparing stakeholders to be involved in the scheme, which includes targeting and feasibility assessments;

b) Accompanying, negotiating and facilitating contractual and paperwork processes; and,

c) Implementing, monitoring and reporting activities carried out in the ground (Swallow et al., 2009).

The influence of intermediaries in shaping and implementing a PES scheme in a specific setting are crucial for PES results (Swallow et al., 2009; Berhoffer et al., 2011). Depending on their position in the PES scenario, they also can exert political influence (Khurana, 2002). Intermediaries also act as representatives of ecosystem stewards, ES beneficiaries or landowners; and as a source of authority to the enforcement of rules, and control over resources (Swallow et al., 2007). 
Depending on the particular PES schemes adopted in different countries, intermediaries can help to connect PES buyers and sellers (Coggan et al., 2013; Huber-Stearns et al., 2013; Jindal \& Kerr, 2007), targeting suitable areas and providers of ES (Schomers et al., 2015). They interpret, translate, and reinforce rules, provide strategic information and assistance to stakeholders, accompany and legitimate processes of decision making, represent actors, and participate in the verification and monitoring of activities.

Some authors have proposed typologies of the potential roles of intermediaries in general (such as Van Lente, 2003), and according to their roles in specific fields. In agricultural and environmental programmes and schemes there have been few attempts to characterise and conceptualise the role of intermediaries. Although Coggan et al. (2013), in their transaction-cost analysis of the role of intermediaries in environmental offset markets, identified six types of intermediaries, namely:

(1) information/knowledge providers;

(2) brokers;

(3) offset aggregators;

(4) banks;

(5) in-lieu- fee intermediaries; and

(6) clearing houses.

In terms of the impacts and relevance of intermediaries in PES, Pham et al. (2010) found that PES intermediaries in Vietnam operated as "bridge builders, mediators, arbitrators, equalisers, developers of standards, representatives, and watch-dogs" (Pham et al., 2010). Intermediaries bridged actors with different goals, knowledges and languages, such as policy makers, local organisations and scientists. They also mediated in cases of conflicts amongst stakeholders (Pham et al., 2010).

In Costa Rica, Bosselman and Lund (2013) found several types of intermediaries facilitating PES contracts with landowners. A variety of intermediaries, from local forest engineers (both independent as well as members of organisations) to NGOs and local governmental organisations facilitated the contractual arrangements for PES. They acted in different ways to reduce the programme costs and promote inclusiveness of poor landowners in PES. The types and characteristics of intermediaries are significant, as well as the framing of their role in PES policy frameworks or from the ES buyers (Bosselmann \& Lund, 2013). 
Specifically, for the case of PES, Huber-Stearns et al. (2013), suggested a typology of potential roles of intermediaries built from literature review, which framed their findings in Panama (Table 7.1):

Table 7.1. Potential roles of PES intermediaries (Source: from Huber-Stearns et al., 2013)

\begin{tabular}{|l|l|}
\hline Information exchange & $\begin{array}{l}\text { Providing accessible information about the concept of PES to stakeholders and the } \\
\text { public. Providing information to potential participants about how the programme } \\
\text { works. Assisting with information sharing between buyers, sellers, and other groups } \\
\text { involved in the PES programme }\end{array}$ \\
\hline Programme design & $\begin{array}{l}\text { Convening stakeholders to obtain input into programme design (e.g., target } \\
\text { ecosystem services, landowner eligibility, payment structure, geographic } \\
\text { boundaries). Ensuring that region-specific and stakeholder- specific concerns are } \\
\text { incorporated into programme design considerations. Developing programme } \\
\text { standards and guidelines, including a protocol for programme monitoring and } \\
\text { evaluation. }\end{array}$ \\
\hline $\begin{array}{l}\text { Networking, } \\
\text { representation and } \\
\text { mediation }\end{array}$ & $\begin{array}{l}\text { Representing interests and concerns related to buyers, sellers, and other } \\
\text { programme participants. Where appropriate, acting as a neutral third party. } \\
\text { Representing buyers and/or sellers in the contract negotiation process. Serving as } \\
\text { honest brokers of information and resources across programme participants. } \\
\text { Helping to establish trust between programme participants. Facilitating connections } \\
\text { among organisations. } \\
\text { Administration }\end{array}$ \\
\hline $\begin{array}{l}\text { Administration } \\
\text { project coordination }\end{array}$ & $\begin{array}{l}\text { Promoting and publicising information about the PES programme. Project } \\
\text { administration, such as managing contracts, and administering programme funds. } \\
\text { Monitoring and evaluation. Helping and supporting with paperworkand programme } \\
\text { eligibility requirements. }\end{array}$ \\
\hline
\end{tabular}

\subsection{Intermediaries in Mexican PES programme}

As this literature shows, the concept of intermediary in PES and other fields includes a variety of schemes of work and of types of organisations. Many types and forms of intermediation can occur at different stages in the development of policies and market schemes (Mike \& Simon, 2008; Moss, 2009; Schomers et al., 2015).

In Mexican political strategies on natural resources management, and more specifically on forest management, different figures are recognised as intermediaries, fulfilling a variety of roles at different stages of policies and programmes. In the Mexican PES, there is a diversity of figures that, partially or fully, carry out intermediary roles, intervening in aspects ranging from the design of the programme to its implementation, and evaluation of its environmental and social outcomes. In more recent schemes like the funds for the development of local mechanisms of PES, new types of intermediary figures have been emerging and consolidating in new settings and markets (PB, pers. comm., 2012). 
However, the most prominent intermediaries in PES are the forest technical and professional services providers, and this analysis is focused on the currently called CONAFOR's Technical Advisors (TAs). TAs have participated in PRONAFOR programmes since the beginning of the PES programme (2003), in order to improve the targeting and of enrolment of applicants $(1,2012)$, and assist beneficiaries in the implementation. As we will see in chapter 8 , the roles they fulfil go beyond what is stipulated and expected by CONAFOR.

The role and relevance of TAs in México have not been deeply studied. The need of technical services providers is not only found in the forest policy implementation; technical assistance has long established in rural development policies, especially in the agricultural sector. For this reason, most of the studies about technical assistance in México are focused on agricultural and rural extension (e. g. Aguilar et al., 2010; Aguirre, 2012; Cuevas et al., 2012, among others). Although the role of forestry technical advisory is less documented, studies about forest governance, community- based forest sustainable management (Merino-Perez \& Segura-Warnholtz, 2002; Merino-Perez, 2004; Merino-Perez \& Hernandez-Apolinar, 2004; Segura-Warnholtz, 2014), and on different aspects of the PES programme (Alix-Garcia et al., 2009; Corbera et al., 2009; Costedoat et al., 2016; Costedoat et al., 2015; Kosoy et al., 2008; McAfee \& Shapiro, 2010; Shapiro-Garza, 2013; Sims et al., 2014), have indirectly considered the evolution, development and function of forest technical services. Weaver (2000), and Chapela (2000) have described and provided information about the operation and evolution of technical forest assistance throughout the history of forest management in México, and described some aspects of their tasks, power and the positive and negative effects they have had on forest management. The documentation and analysis of the historical role of TAs is relevant to understand the evolution of Mexican forest policy, as well as the modes of intervention from the government organisations in the forest sector, including the roles played by different actors (Chapela, 2000).

In the history of Mexican forest development, technical assistance has taken different forms, in parallel to what was happening in agricultural and rural policies. These services have different names and configurations in terms of their relationship with government organisations, and with forest landowners and other actors. The types of organisations and roles of technical services providers have been adapted to the conditions and requirements of the policies in turn (Chapela, 2000; Merino-Perez, 2004). But they have been always an important component of the forest policy (Chapela, 2000). 


\subsection{The formal role of TAs in Mexican PES}

Many PES programmes/schemes are market-based approaches, where transactions occur between users of ES who pay forest owners/ managers for the continued provision those services (Leimona and Lee, 2008). In those cases, the transactions are mediated in different ways by intermediaries (Huber-Stearns et al., 2013; Jindal \& Kerr, 2007; Swallow et al., 2007). CONAFOR National PES programme is a simplified version of those approaches, given that the government, represented by CONAFOR, is the only ES "buyer" (Alix-Garcia et al., 2009; McAfee and Shapiro, 2010; Rivero-Cob, 2012). This fact has constrained possibilities of the programme, because CONAFOR is the single actor able to determine the conditions, amounts to be paid, and the most suitable areas for PES (Muñoz-Piña, 2011). In the same way, CONAFOR determines the roles of the actors involved, including the TAs. Thus, the general tasks of TAs are fixed by the requirements of the programme. According to Chapela (2000), technical forest services can be understood as the assistance needed for the suitable management of forests. This last is related to the productive-extractive activities, which by law must be supervised by services of approved technicians qualified for it by the Mexican government (SeguraWarnholtz, 2014). In the Mexican Law of Sustainable Forestry Development (in force since 2003), the concept is defined as: "technical assistance is for activities related to the planning and implementation of forestry, forest management, counselling, and training to the forest owners. Providers of these services [...] can be individuals and legal entities [...] who prove competence and quality [...] to offer forestry services upon registration. [...] They may be contracted freely" (DOF, 2012). In general, CONAFOR's PES TAs are expected to fulfil tasks in:

- Preparing applicants to be involved in the scheme, including feasibility surveys in the field, and delineating the proposed polygon for the application,

- Accompanying, negotiating and facilitating contractual and paperwork processes, and

- Implementing, monitoring and reporting activities carried out in the ground.

For more detail, see Table 7. 2 
Table 7.2. List of activities to be fulfilled by TAs in the PES programme (Source: CONAFOR, 2012; Corbera et al., 2009; Kosoy et al., 2008)

\begin{tabular}{|c|c|c|}
\hline Preparation & $\begin{array}{c}\text { Accompaniment, negotiation } \\
\text { and facilitation }\end{array}$ & Implementing, monitoring and reporting \\
\hline $\begin{array}{l}\text { - Preliminary visits to the } \\
\text { landowners, for promotion of the } \\
\text { programme. } \\
\text { - Meetings to seek the approval of } \\
\text { owners or community members to } \\
\text { get involved in the programme. } \\
\text { - Meetings with the authorities } \\
\text { and assembly to organise the } \\
\text { application. } \\
\text { - Field technical survey for the } \\
\text { definition of the polygon to be } \\
\text { enrolled. } \\
\text { - Document review. } \\
\text { - Filling the application forms. } \\
\text { - Present the application. }\end{array}$ & $\begin{array}{l}\text { - Accompaniment new } \\
\text { beneficiaries to sign the } \\
\text { agreement with CONAFOR } \\
\text { - Formalisation the service } \\
\text { provision of TAs with } \\
\text { beneficiaries through a contract. } \\
\text { - Facilitating communication and } \\
\text { payments with CONAFOR } \\
\text { - Attending notifications from } \\
\text { CONAFOR } \\
\text { - Facilitate knowledge transfer } \\
\text { - Help to build local capacities }\end{array}$ & $\begin{array}{l}\text { - Implementation of the project, for a period of } \\
5 \text { years } \\
\text { - At least } 3 \text { visits to the area per year. } \\
\text { - Conducting of a participatory planning of } \\
\text { activities, called Guide or plan of best practices. } \\
\text { - Writing and delivering project progress reports } \\
\text { to CONAFOR, in an annual basis, with and geo- } \\
\text { referenced evidence of the fulfilment of } \\
\text { activities. } \\
\text { - Training about main concepts of PES } \\
\text { - Specific visits for review and monitoring of } \\
\text { activities in the polygon a period of } 5 \text { years. }\end{array}$ \\
\hline
\end{tabular}

Using the typology proposed by Huber-Stearns et al. (2013) (See Table 7.1), it is possible to determine the position of the PES TAs in terms of their functions (Table 7.3). By comparison, we can see that roles of TAs in the Mexican PES programme are more focused in transferring information to applicants and beneficiaries of the programme, as well as providing support in the implementation, verification, reporting and monitoring of activities carried out in the field for the beneficiaries, representing them in the first instance before CONAFOR. At the same time, they represent the interests of CONAFOR by helping beneficiaries to carry out the activities expected by CONAFOR. They also play a role in handling paperwork, which, according to Locatelli et al. (2008), reduces the transaction costs of the programme. On the other hand, TAs do not intervene directly in the design of different aspects of the programme, even though they can have an indirect influence on that. Although the activities of TAs in PES programme are pre-determined by CONAFOR, there are informal roles they fulfil, because they are actors constantly moving between structure and agency (Keys, 2005), developing connections, and relationships through which they can modify and amplify their roles. Furthermore, TAs work far away from the eyes of CONAFOR, given the lack of administrative mechanisms and of operational capacities of CONAFOR, and therefore, there is room for active agency. Their roles in connecting, interpreting, translating, mediating and bringing the ORs to potential or actual beneficiaries of the programme, make them institutional bricoleurs (Cleaver, 2001) and agents of institutional change. At least in official terms, Mexican PES TAs do not administer resources, but, as we will see in the next chapter, they can influence decision making about their use, or even, take 
control of them. They are mediating between knowledges, cultures, contexts, interests, values and institutions.

Lastly, in this typology there are roles that not all necessarily TAs fulfil, depending on the circumstances or characteristics of the individuals or organisations, such as building trust among stakeholders, acting as neutral third parties, and facilitating connections and sharing of knowledge. Many of the roles identified by the Huber-Stearns, may, in the Mexican case, be taken by other types of intermediaries, such as the PES National Advisory Committee, whose work is focused on the annual review of ORs and aspects of the design of the programme. Thus, the parallel work of a diversity of other intermediaries could be an interesting topic to be studied in the future. All these issues about the performance of TAs will be discussed in light of the empirical information in chapters 8,9 and 10. 
Table 7.3. Main roles of Mexican PES' TAs, according to the typology proposed by HuberStearns et al. (2013). Asterisks represent roles that are partially fulfilled or activities that are not generalisable.

\begin{tabular}{|c|c|c|c|}
\hline Information exchange & Programme design & $\begin{array}{l}\text { Networking, } \\
\text { representation } \\
\text { and mediation }\end{array}$ & $\begin{array}{l}\text { Administration and } \\
\text { project coordination/ } \\
\text { Promoting }\end{array}$ \\
\hline $\begin{array}{l}\text { Providing } \\
\text { accessible } \\
\text { information about } \\
\text { the concept of } \\
\text { PES (to forest } \\
\text { landowners) }\end{array}$ & $\begin{array}{l}\text { Convening } \\
\text { stakeholders to } \\
\text { obtain input into } \\
\text { programme design }\end{array}$ & $\begin{array}{l}\text { Representing } \\
\text { interests and } \\
\text { concerns related to } \\
\text { participants }\end{array}$ & $\begin{array}{l}\text { Monitoring and } \\
\text { verification }\end{array}$ \\
\hline $\begin{array}{l}\text { Providing } \\
\text { information to } \\
\text { potential } \\
\text { participants about } \\
\text { how the } \\
\text { programme works }\end{array}$ & $\begin{array}{l}\text { Ensuring that } \\
\text { region-specific and } \\
\text { stakeholder-specific } \\
\text { concerns are } \\
\text { incorporated into } \\
\text { programme design. }\end{array}$ & $\begin{array}{l}\text { Serving as honest } \\
\text { brokers of } \\
\text { information and } \\
\text { resources across } \\
\text { programme } \\
\text { participants }\end{array}$ & $\begin{array}{l}\text { Helping and support } \\
\text { with paperwork and } \\
\text { programme } \\
\text { eligibility } \\
\text { requirements }\end{array}$ \\
\hline $\begin{array}{l}\text { Assisting with } \\
\text { * information } \\
\text { sharing between } \\
\text { stakeholders } \\
\text { involved in the } \\
\text { PES programme }\end{array}$ & $\begin{array}{l}\text { Developing } \\
\text { programme } \\
\text { standards and } \\
\text { guidelines for } \\
\text { programme } \\
\text { monitoring and } \\
\text { evaluation. }\end{array}$ & $\begin{array}{l}\text { Acting as a neutral } \\
\text { third party }\end{array}$ & $\begin{array}{l}\text { Promoting and } \\
\text { publicising } \\
\text { information about } \\
\text { the PES programme }\end{array}$ \\
\hline & & $\begin{array}{l}\text { Helping to establish } \\
\text { trust between } \\
\text { programme } \\
\text { participants }\end{array}$ & $\begin{array}{l}\text { Managing contracts, } \\
\text { and administering } \\
\text { programme funds }\end{array}$ \\
\hline & & $\begin{array}{l}\text { Facilitating } \\
\text { connections among } \\
\text { organisations }\end{array}$ & \\
\hline
\end{tabular}

Beyond the practical roles of TAs in PES programme, Mexican TAs are complex (trans) boundary actors. They are not only connections between stakeholders, shaping the interactions between them, but also between theory (rules) and practice (implementation) (Hamann \& Lane, 2004). Even more, they can contribute to shape the relation between people and environment, influencing land use choices (Keys, 2005), by conveying and persuading potential PES programme beneficiaries to be enrolled in the PES programme (Keys, 2005), also looking for their own benefit. They are a key actor who put the rules on the ground, through the enforcement of the formal rules and the co/reproduction of informal practices. 


\section{Chapter 8. Exploring the history of forest management in México to understand the identity and role of TAs in PES}

\subsection{Introduction: The need for intermediaries}

Many studies of PES around the world, especially in marginalised areas, confirm the need for intermediaries to develop inclusive, efficient and sustainable PES schemes (Angelsen, 2009; Bosselman \& Lund, 2013; Corbera \& Brown, 2008; Corbera et al., 2009; Daniels et al., 2010; Mike \& Simon, 2008; Huber-Stearns et al., 2013; Jindal \& Kerr, 2007; Kosoy et al., 2008; Leimona \& Lee., 2008; Locatelli et al., 2008; Noordwijk et al., 2007; Pagiola, 2008; Pham et al., 2010; Sternlieb et al., 2013; Swallow et al., 2007). Intermediaries are boundary actors, fundamental to mediate the interaction of groups motivated by different interests, speaking different languages and having different knowledges. They have been widely recognised as agents of social learning and institutional change.

In some countries, the assistance provided by intermediaries is an integral part of the design of PES strategies. The theoretical and especially the empirical analysis of these schemes and of the different types of intermediaries and their functions can be significant for understanding and evaluating the relevance and needs of improvement for the design of suitable strategies of PES schemes.

TAs are fundamental intermediary entities in the operation of the CONAFOR programmes. Their participation has been envisaged since the beginning as an essential component in implementation. Although they are external services providers, they do not act in an isolated way, nor define their own roles. They act according to specific contexts and CONAFOR expectations about them in the programmes.

This chapter explores the history of the forest intermediaries in order to understand the ways in which they have evolved in parallel with forest policies in México. This exploration helps to visualise the positive and negative features of the current PES TAs, their relations with the government, with forest communities and with other stakeholders, the inertia around their performance, and the influence they have historically acquired and which holds over time. This chapter also describes CONAFOR'S expectations about the role of TAs, and information about their professional profiles and working conditions. 


\subsection{History of technical service provision}

As noted above, agriculture and forest technical services have evolved in parallel. Agricultural extension since its origin around 1950, has had shifting relevance, reaching a peak of development in the 1970s, with the green revolution and the need for implementation of new technologies (CONAFOR, 2012; Cuevas et al. 2012). In the 1980s the provision of these services declined considerably, because of the national financial crisis (Muñoz \& Santoyo, 2010; CONAFOR, 2012). In the 1990s a re-conceptualisation of the scheme (Cuevas et al., 2012), introduced the idea of external professional services providers (Muñoz \& Santoyo, 2010; Cuevas et al., 2012) (Timeline 8.1).

Timeline 8.1. The intertwined history of rural and forest provision of technical services in México. (Sources: Based on information from Merino \& Segura (2004); Muñoz \& Santoyo 2010; Cuevas et al. 2012, and CONAFOR, 2012).

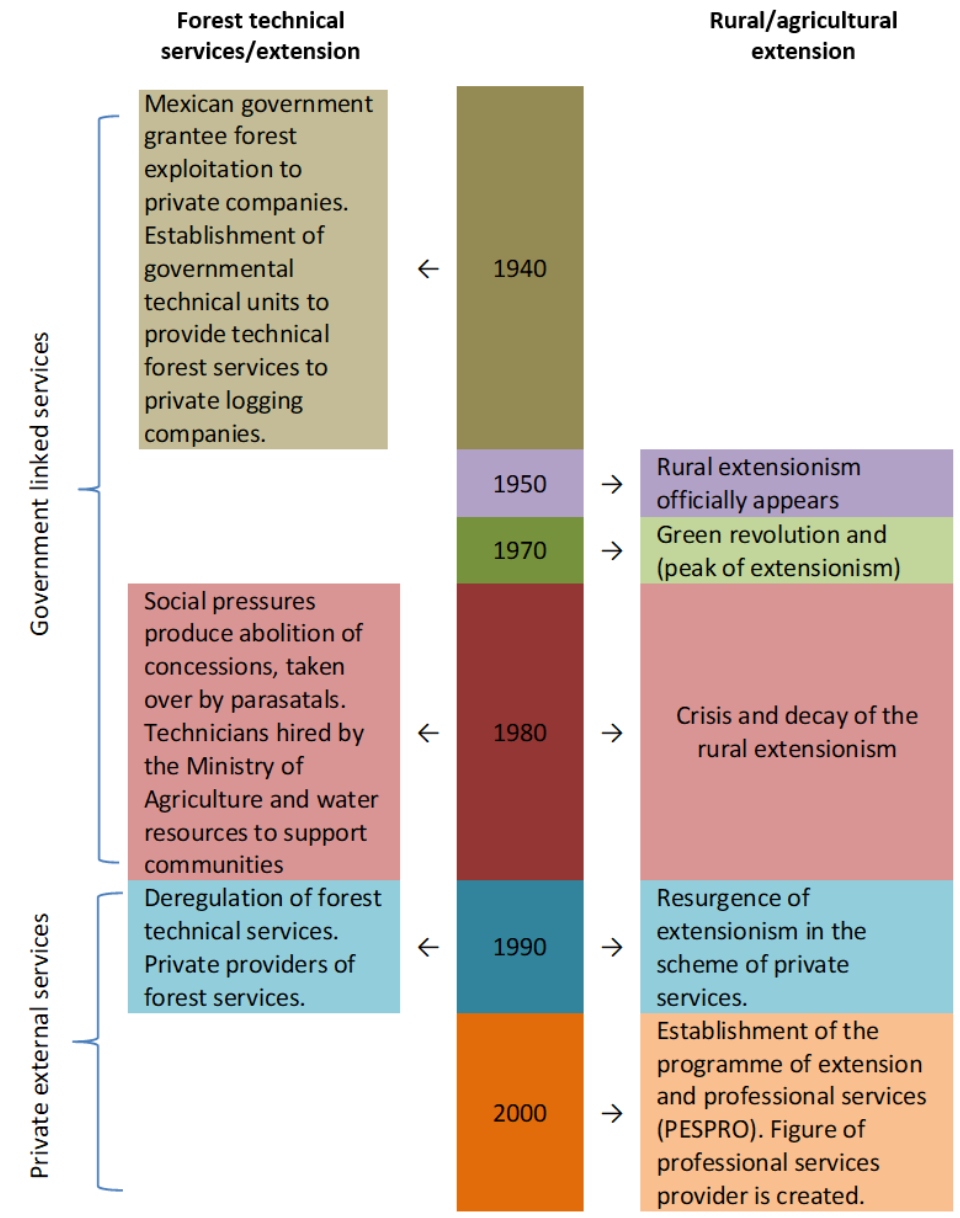


In México, policies in general, tend to be restructured with each new presidential administration (Weaver, 2000). In the same way, the conceptualisation of the forest technical provision has changed continually over time (Timeline 8.2).

According to Chapela (2000), the first technical services occurred in the postindependence period around 1859-1860, to promote exploitation. Large extensions of forest lands were expropriated by the church, and peasant communities (Chapela, 2000). Government forestry services were subsequently established, which continued extractive activities for various decades (Chapela, 2000; Weaver, 2000). The first large logging companies were established, and government technicians worked for them (Chapela, 2000).

In Merino and Segura's (2007) analysis of the history of forest management in the second half of the 20th century, five fundamental periods are identified, which are directly linked to the participation of forest technicians. In the 1940s decade, the national government leased out lands to private companies for logging (Merino \& Segura, 2007; CONAFOR, 2012). Forest communities were excluded from the use of their own forests. Thus, the development of forest technical assistance services is linked to productive and extractive forest management (Chapela, 2000) carried out by these logging concessions, which trained and hired technicians (Chapela, 2000; Merino \& Segura, 2007). Also, in the 1940s, regional forest service units were established.

In the 1960s, the bases for decentralisation and regionalisation of forest technical services occurred, promoting the first standards for forest management. Different types of units were created in order to improve services provision (Weaver, 2000). The units ranged from government-sponsored organisations to private schemes (Weaver 2000).

In the decades of 1970s and 1980s, communities affected by private and parastatals logging enterprises took strong social stand, which caused state intervention to abolish the concessions. The state took control of the private companies, and technicians were hired by the Directorate General for Forestry Development of the Ministry of Agriculture and Water Resources (SARH) to support communities and ejidos (Merino \& Segura, 2007; Merino, 2004; CONAFOR, 2013). Forest owners regained control over their forest lands. The General Directorate of Forestry Development provided owners with technical assistance and training. Only a few communities and organisations were able to get control over forest technical services. Most communities faced legal restrictions and resistance from the foresters, despite the law that stated that forest technical services could be exercised by those who demonstrated ability to perform them (Merino \& Segura, 2007; Chapela, 2000; Weaver, 2000). 
Since the 1990s the units of forest services were reorganised, along with a shift in vision about forests from a merely extractive position to a conservationist one (e. g. UCODEFO) (Weaver, 2000). Their management went to regional forestry organisations, regional associations of forest community producers (Weaver, 2000, Merino \& Segura, 2007; CONAFOR, 2012). These units were used by the government to continue to control the activities of the community forests. The units were in charge of operating the forest management plans (Segura-Warnholtz, 2014).

In the 1990s, reductions in public expenditure brought about the suspension of government technical assistance and training programmes for communities and ejidos (Merino and Segura, 2007). In 1992, in the middle of an economic crisis, the provision of forest technical services was de-regulated, allowing its privatisation, driven by the assumption that farmers could afford at least partially to pay the costs of private services. In the beginning, the creation of a free market of private technical services produced strong competition between providers, who reduced their quality to offer lower prices (Chapela, 2000). This liberalisation partially opened the possibility for communities to choose their own forestry technicians. But even in this scheme the state continued exercising control over community forestry through the technicians, because they were (and still are) required to prepare forest management plans (SeguraWarnholtz, 2014).

In 1997 an amendment to Mexican forest law established three new programmes, which included their own technical assistance component: the Development of Commercial Forest Plantations Programme (PRODEPLAN); the Conservation and Sustainable Management of Forest Resources Project (PROCYMAF), and the Forestry Development Programme (PRODEFOR) (CONAFOR, 2013; Merino \& Segura, 2007).

According to Segura-Warnholtz (2014), PROCYMAF brought important changes in the relations between forest communities and technical advisors. It was the first programme to create a list of forest service providers with entry and permanence rules, opening the possibility of entry not only to forest engineers but to other professionals providing a variety of services. It stimulated close interaction between communities and technicians, as well as community-based evaluation of the TA's performance before they receive payment. It also became possible to cancel the contractual relations between them in case of non-compliance. All these changes contributed to reduce the power and information asymmetries between communities and TAs, modifying the traditional hierarchical relationships, which was due to socio-economic and educational differences (Segura-Warnholtz, 2014). 
Since 2000, new approaches, institutions and actors have been responsible for implementing Mexican forest policy. The conservationist line has remained, but production has suffered significant reductions, and new market-based approaches, like PES, have emerged. PRODEPLAN, PRODEFOR and PROCYMAF and their models of technical advice were adopted in the new organisations, such as SEMARNAP (Secretariat of Environment, Natural resources and Fisheries, 1994-2000) and CONAFOR.

Timeline 8.2. Forest technical services over time. (Sources: Chapela, 2000; Weaver, 2000; Merino, 2004; Merino \& Segura, 2007; Lopez-Arzola, 2007; Gonzalez, 2012; CONAFOR, 2012; CONAFOR, 2013; Del Angel-Mobarak, 2012).

\begin{tabular}{|c|c|c|}
\hline Period & $\begin{array}{c}\text { Year/ } \\
\text { President }\end{array}$ & Forest technical services \\
\hline $\begin{array}{l}\text { Colonial period } \\
\text { before Mexican } \\
\text { independence } \\
(1810)\end{array}$ & $\begin{array}{l}\text { Development of } \\
\text { colonial cities and } \\
\text { mines }\end{array}$ & $\begin{array}{l}\text { Exploitation of high volumes of forests for the } \\
\text { development of cities and mines. } \\
\text { No records of technical forest services }\end{array}$ \\
\hline \multirow[t]{2}{*}{$\begin{array}{l}\text { Post-Independence } \\
\text { period }\end{array}$} & $\begin{array}{l}\text { Reform Laws } \\
\text { 1859-1860 } \\
\text { Benito Juarez }\end{array}$ & $\begin{array}{l}\text { Confiscation of "useless" lands. } \\
\text { Expropriation of lands to large estates by the } \\
\text { church, and by peasant communities. } \\
\text { Survey companies carried out the demarcation of } \\
\text { lands and selection of the best tree specimens for } \\
\text { sale. The companies received one-third of the land } \\
\text { as payment for their services. } \\
\text { These large private properties later became forest } \\
\text { companies. }\end{array}$ \\
\hline & $\begin{array}{l}\text { Forest service } \\
1895 \\
\text { Porfirio Diaz }\end{array}$ & $\begin{array}{l}\text { Forest service establishment, formed by } \\
\text { government wastelands agents, forest inspectors } \\
\text { and forest guards, who demarcated exploitation } \\
\text { areas and trees. }\end{array}$ \\
\hline $\begin{array}{l}\text { Post-Revolutionary } \\
\text { Period }\end{array}$ & $\begin{array}{l}\text { First forest law, } \\
\text { attributed to } \\
\text { Miguel Angel de } \\
\text { Quevedo } \\
1926 \\
\begin{array}{l}\text { Plutarco Elias } \\
\text { Calles }\end{array}\end{array}$ & $\begin{array}{l}\text { Technicians working for large private companies. } \\
\text { The contracts were not under any regulation, } \\
\text { payments were low, and service providers } \\
\text { acquired the responsibility of distant lands, leaving } \\
\text { the visits and fieldwork in the hands of assistants. }\end{array}$ \\
\hline $\begin{array}{l}1940-1972 \\
\begin{array}{l}\text { Concessions } \\
\text { private to } \\
\text { companies }\end{array}\end{array}$ & $\begin{array}{l}\text { Forest Law } \\
1943 \\
\text { Manuel Ávila } \\
\text { Camacho }\end{array}$ & $\begin{array}{l}\text { Private logging companies. } \\
\text { Establishment of government forest service } \\
\text { technical units (Industrial logging units, UIEF) to } \\
\text { provide technical services to private companies. } \\
\text { Forestry technicians trained and registered with } \\
\text { the Agriculture Ministry in charge of regulations, }\end{array}$ \\
\hline
\end{tabular}




\begin{tabular}{|c|c|c|}
\hline Period & $\begin{array}{c}\text { Year/ } \\
\text { President }\end{array}$ & Forest technical services \\
\hline & & $\begin{array}{l}\text { plans and projects for the preservation and } \\
\text { exploitation of forests. }\end{array}$ \\
\hline & $\begin{array}{l}\text { Forest law } \\
\text { Federal forest } \\
\text { service (SFF) } \\
1948 \\
\text { Miguel Aleman } \\
\text { Valdez }\end{array}$ & $\begin{array}{l}\text { The } 1948 \text { law maintains the guidelines regarding } \\
\text { the provision of technical forest services and } \\
\text { technical units. } \\
\text { Establishment of the Forest Service for lands } \\
\text { created out of the Industrial logging units. First } \\
\text { attempts at regionalisation of forestry services. }\end{array}$ \\
\hline & $\begin{array}{l}\text { Forest law } \\
1960 \\
\text { Adolfo Lopez } \\
\text { Mateos }\end{array}$ & $\begin{array}{l}\text { Emphasis on the decentralisation of forestry } \\
\text { services and agencies by placing them at the local } \\
\text { level and assuring the presence of better-trained } \\
\text { foresters in the field. } \\
\text { The Secretariat of Agriculture and Hydraulic } \\
\text { Resources (SARH) takes the responsibility of the } \\
\text { provision of forest technical services. }\end{array}$ \\
\hline & $\begin{array}{l}\text { Units of forest } \\
\text { planning (UOEF) } \\
1960-1986\end{array}$ & $\begin{array}{l}\text { Forest planning units (UOEF), established in areas } \\
\text { where large industrial logging units were not } \\
\text { established. } \\
\text { The } 1960 \text { law establishes the bases for } \\
\text { decentralisation and regionalisation of forest } \\
\text { technical services and agencies. The need to } \\
\text { establish standards for forest management is } \\
\text { emphasised. Units remained until } 1986\end{array}$ \\
\hline \multirow[t]{3}{*}{$\begin{array}{l}1942-1972 \\
\text { Private concessions } \\
\text { became State- } \\
\text { owned enterprises }\end{array}$} & $\begin{array}{l}\text { Coordination of } \\
\text { technical forest } \\
\text { services } \\
1977 \\
\text { Jose Lopez Portillo }\end{array}$ & $\begin{array}{l}\text { Coordination of the technical forest services is } \\
\text { established. The units of forest administration are } \\
\text { re-organised. And instructions for the } \\
\text { development of management plans and provision } \\
\text { of forest technical services. The programme- } \\
\text { budget is a document that technicians must } \\
\text { present to their customers and communities, with } \\
\text { approval of the authority, in order to establish the } \\
\text { provision of their services. }\end{array}$ \\
\hline & $\begin{array}{l}\text { Units of forest } \\
\text { management } \\
\text { (UAF) } \\
1979 \\
\text { Jose Lopez Portillo }\end{array}$ & $\begin{array}{l}\text { Within the regionalisation scheme, the forest } \\
\text { administration units had the purpose of } \\
\text { integrating supply basins. The establishment of } \\
\text { contiguous forest units led to a planning regional } \\
\text { strategy. }\end{array}$ \\
\hline & $\begin{array}{l}\text { Disbandment of } \\
\text { parastatal forestry } \\
\text { companies }\end{array}$ & $\begin{array}{l}\text { Communities affected by logging private and } \\
\text { parastatal enterprises began to regain control over } \\
\text { their forest lands. The General Direction of } \\
\text { Forestry Development provided technical }\end{array}$ \\
\hline
\end{tabular}




\begin{tabular}{|c|c|c|}
\hline Period & $\begin{array}{c}\text { Year/ } \\
\text { President }\end{array}$ & Forest technical services \\
\hline & $\begin{array}{l}\text { Establishment of } \\
\text { some community } \\
\text { based technical } \\
\text { forest services } \\
\text { 1980-1990 }\end{array}$ & $\begin{array}{l}\text { assistance and training. Only a few of the } \\
\text { communities and organisations get control of the } \\
\text { forest technical services. The rest of the } \\
\text { communities faced legal restrictions and } \\
\text { resistance from the foresters. }\end{array}$ \\
\hline \multirow[t]{2}{*}{$\begin{array}{l}1982-1992 \\
\text { Emergence of the } \\
\text { first community- } \\
\text { based forest } \\
\text { enterprises (CBFE) }\end{array}$} & $\begin{array}{l}\text { Forest Law } \\
1986 \\
\text { Miguel de la } \\
\text { Madrid Hurtado }\end{array}$ & $\begin{array}{l}\text { The law establishes the requirement to develop a } \\
\text { comprehensive forest management plan and } \\
\text { offers communities the chance to have their own } \\
\text { forest technical service providers. }\end{array}$ \\
\hline & $\begin{array}{l}\text { Units of } \\
\text { conservation and } \\
\text { forest } \\
\text { development } \\
\text { (Ucodefo) } \\
\text { 1986-1991 }\end{array}$ & $\begin{array}{l}\text { Reorganisation of forest service units. } \\
\text { The law incorporates the concept of conservation } \\
\text { and establishes the technical forest services in } \\
\text { Conservation and forest development units } \\
\text { (Ucodefos), to be under the control of regional } \\
\text { associations of forest producers (communities and } \\
\text { associations). }\end{array}$ \\
\hline \multirow[t]{3}{*}{$\begin{array}{l}\text { 1992-2002 } \\
\text { Economic } \\
\text { globalisation } \\
\text { uncertain } \\
\text { policies }\end{array}$} & $\begin{array}{l}\text { Deregulation of } \\
\text { technical forest } \\
\text { services. } \\
1992 \\
\text { Carlos Salinas de } \\
\text { Gortari }\end{array}$ & $\begin{array}{l}\text { The } 1992 \text { law deregulates the provision of } \\
\text { technical forest services, opening a free market of } \\
\text { private service providers (STPLC). The return to the } \\
\text { open market produces a decline in the quality of } \\
\text { services, because the providers in competition } \\
\text { lower their costs by reducing services. } \\
\text { Dismantling and re-organisation of Ucodefo as } \\
\text { government agents, being replaced by the service } \\
\text { providers. }\end{array}$ \\
\hline & $\begin{array}{l}\text { Forest Law } \\
1997 \\
\text { Ernesto Zedillo } \\
\text { Ponce de Léon }\end{array}$ & $\begin{array}{l}\text { The Secretariat of Environment, Natural resources } \\
\text { and Fishing (SEMARNAP) is created, the first purely } \\
\text { environmental ministry in México, taking over the } \\
\text { forest sector issues. } \\
\text { Forest law stablishes three new programmes, } \\
\text { which include a technical assistance component: } \\
\text { (PRODEPLAN); (PROCYMAF), and (PRODEFOR). } \\
\text { National forest registry is created }\end{array}$ \\
\hline & $\begin{array}{l}\text { National Forestry } \\
\text { Plan } \\
2000 \\
\text { Vicente } \quad \text { Fox } \\
\text { Quezada }\end{array}$ & $\begin{array}{l}\text { National forestry plan (NFP) represents a big } \\
\text { change in the scope and structure of Mexican } \\
\text { forest policy. NFP recognises the importance of } \\
\text { Mexican forests, as well as the community-based } \\
\text { forest management experience. "Water and } \\
\text { forests are considered matters of national }\end{array}$ \\
\hline
\end{tabular}




\begin{tabular}{|c|c|c|}
\hline Period & $\begin{array}{c}\text { Year/ } \\
\text { President }\end{array}$ & Forest technical services \\
\hline & & $\begin{array}{l}\text { security". The promotion and development of ES } \\
\text { markets are proposed. } \\
\text { The application of measures to improve the quality } \\
\text { of forest technical services is considered, enabling } \\
\text { interdisciplinary cooperation. }\end{array}$ \\
\hline \multirow[t]{3}{*}{ 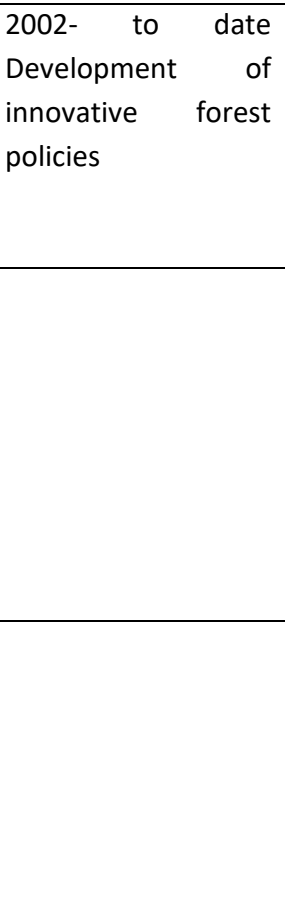 } & $\begin{array}{l}\text { Sustainable forest } \\
\text { development law, } \\
\text { CONAFOR } \\
2003 \\
\text { Vicente } \quad \text { Fox } \\
\text { Quezada }\end{array}$ & $\begin{array}{l}\text { National Forestry Commission (CONAFOR) and the } \\
\text { National system of forest Information are created. } \\
\text { All CONAFOR programmes include technical } \\
\text { assistance components, keeping free market } \\
\text { private forest services providers. }\end{array}$ \\
\hline & 2007 & $\begin{array}{l}\text { After the integration of ORs in ProArbol, the basis } \\
\text { for the integration of an evaluation system of } \\
\text { forest technical providers (PSTF) is established. } \\
\text { This allows the integration of a unified registry of } \\
\text { professional and technical forest service providers } \\
\text { (PSTyP). } \\
\text { Forest technical service providers officially } \\
\text { become Technical Advisors (TAs). }\end{array}$ \\
\hline & 2011 & $\begin{array}{l}\text { The procedure to join the list of TAs operates } \\
\text { through third parties ( } 12 \text { universities and institutes } \\
\text { of education and research related to forestry and } \\
\text { a Certifying Council). } \\
\text { Norm for the certification of technical advisors } \\
\text { appears. Certification consists of several tests for } \\
\text { TA applicants. }\end{array}$ \\
\hline
\end{tabular}

\subsubsection{CONAFOR and the shift from technical forest service providers to TAs}

\subsubsection{The 'LAST'}

The Mechanism for entry into the TA list (LAST, in Spanish) was an attempt to improve the access and evaluate the capabilities of the professionals to provide services in the CONAFOR programmes. Before that, SEMARNAT (Secretariat of Environment and Natural Resources, 2000-present) established the National Forest Registry (RFN) between 1988 and 1992 (Del Angel-Mobarak, 2012), which continues up to today to improve the evaluation of TAs. This is a special registry, which qualifies technicians for the elaboration of management plans of timber production and forest plantations. Most of the members of the RFN are forestry engineers. Some CONAFOR programmes require 
the TAs are also enrolled in RFN, but not all them. For example, the activities to be carried out in PES programmes only require TAs to be enrolled in CONAFOR's LAST.

After it was created in 2003, CONAFOR was in charge of forest issues, including the three programmes running at that time: PRODEFOR, PRODEPLAN and PROCYMAF. As mentioned, CONAFOR adopted aspects of the provision of technical service systems from those programmes. Since 2004, CONAFOR has sought to structure a system for evaluating performance of the TAs. But it was not until 2006, that CONAFOR established guidelines to integrate a system of evaluation and monitoring. In order to create a single register of TAs, CONAFOR's LAST was first published in 2008 (Timeline 8.3). In the ORs of that year it was stated that the recruitment of TA should be done based on professionals enrolled in the LAST (CONAFOR, 2013).

The regulations for entry to LAST describe their main objective, define the nature of TAs and the professional requirements for enrolment, their rights and obligations, the conditions of evaluation, and the possible sanctions to be applied in case of noncompliance (CONAFOR, 2008, 2009, 2010).

In 2007, the position of TA was established officially (earlier they were called Services Providers). The norm for TAs certification (CONAFOR, 2011) defines them as "individuals and legal entities with capabilities to provide technical counselling to the [CONAFOR] programme beneficiaries". In the LAST, technicians and professionals from a variety of disciplines, approaches and visions about forests and forest communities converge. A typology of TAs based on the profiles of PRONAFOR programmes (which include PES) is in the next section of this chapter.

Timeline 8.3. The evolution of forest technical assistance after the creation of CONAFOR (Source: CONAFOR, 2013)

\begin{tabular}{|l|l|}
\hline $2003-2005$ & $\begin{array}{l}\text { Definition of the external technical services and definition of the process of } \\
\text { enrolment. } \\
\text { Creation of a National Forest Record (RFN, in Spanish) }\end{array}$ \\
\hline 2004 & $\begin{array}{l}\text { By mandate of the governing board. } \\
\text { First attempt to structure an evaluation system of the performance of TA. }\end{array}$ \\
\hline 2006 & $\begin{array}{l}\text { Establishment of a list of external technicians for PROCYMAF, PRODEFOR, and } \\
\text { PRODEPLAN }\end{array}$ \\
\hline 2007 & $\begin{array}{l}\text { Establishment of "Technical Advisor" (TA) appears in ProArbol ORs. } \\
\text { mandatory for all the programmes included in ProArbol, and explaining a } \\
\text { mechanism to enrol in the list. }\end{array}$ \\
\hline 2011 & $\begin{array}{l}\text { Establishment of a process of certification and a norm (standard) regulating } \\
\text { the mechanism of certification. The norm is considered a transition phase, } \\
\text { during which the TAs could continue operating as they begin certification. }\end{array}$ \\
\hline
\end{tabular}


In general, the TAs look for potential beneficiaries of the programmes by visiting communities and smallholders. But sometimes, applicants or new beneficiaries do not have a fixed TA or want to replace him/her. In that case, CONAFOR employees have the obligation to show the LAST to them. Applicants/Beneficiaries can choose the most convenient TA freely, but CONAFOR employees are not allowed to provide extrainformation, recommendations or warnings about the performance of the chosen TA.

Currently, CONAFOR has an office in charge of administering all information regarding the LAST, but that is the only link between CONAFOR and TAs. This office also defines the main roles of TAs. The offices in charge of each programme under PRONAFOR have their own guidelines for the activities. However, there is no liability or obligation between CONAFOR and TAs. In fact, the service provision contract is made only between beneficiaries and TAs, and CONAFOR stipulates and sometimes mediates the contract signature.

Regarding the costs to the community of the technical service provision, in the case of PES the amounts of the payments is also determined by CONAFOR. The TAs receives a payment proportional to $17-20 \%$ of the size of the polygon under PES. The TAs' payments are covered by CONAFOR. In the beginning of the programme, the technical services were included in the payment received by programme beneficiaries, who then should pay the TAs. But this resulted in many problems and complaints from TAs, who often received less or no money. After 2012, CONAFOR started paying them directly.

The regulations controlling enrolment in the LAST simply included the provision of documents showing professional skills of TA applicants (CONAFOR, 2008-2010). The number of professionals enrolled in the LAST increased considerably year by year. The lack of a system for evaluating both skills and performance of TAs in the field resulted in criticisms of the LAST in external evaluations and internally in CONAFOR.

\subsubsection{Certification process}

The evaluation of the quality of the technical services provided by TAs has been identified as one of the major weaknesses of the mechanism of entry to the LAST, as well as the monitoring of performance in the field. There is also no formal mechanism to address the complaints and conflicts between TAs and beneficiaries. This situation has been pointed out in multiple platforms by different actors.

Among the problems identified in evaluations of TAs performance were (CONAFOR, 2013):

- Incomplete or non-existent evaluations of TA performance 
- Lack of a legally adequate process to establish and apply penalties for noncompliance

- Only the beneficiaries bear the responsibility for non-compliance in the programmes; the level of responsibility of TAs in such cases is not considered.

- The administrative units operating the ORs do not establish obligations or terms of reference that allow the evaluation of the TA performance.

- Lack of operational capacity to verify $100 \%$ of the enrolled areas in the field, and the impossibility of conducting visits before and after the execution of the programmes to verify changes made in the landscape.

In order to address all those criticisms, in 2011 CONAFOR started a process of what they called Certification of TAs, which consists of an evaluation of capacities and skills through a third-party evaluator (Del Angel-Mobarak, 2012), the certifier organisations such as research and educational on forestry organisations; and a certifier council (DOF, 2011), which make the final decisions. Aspiring TAs go through a set of written and oral exams. Once the applicants pass the tests, they can enter the LAST. Certification is divided into 9 technical capabilities, each one with specific tests. In 2011 those capabilities were: forest studies, forestry, reforestation and soils, environmental services, forest sanitation, strengthening of social capital, strengthening of human capital, diversification and conservation, and development of forest production chain (DOF, 2011). Applicants must pay a fee of MXN\$6,000 ( $\approx € 287.50$ ) for the evaluation of each of the capacities, and certification must be renewed every two years (DOF, 2011).

This strategy has been very controversial, and heavily criticised by different actors, especially because it only regulates entrance to the LAST, not the performance of the TAs in the field, and does not consider the opinion of the beneficiaries. TAs have especially complained about the process (the perceptions of TAs and other actors about certification will be addressed in chapters 9 and 10).

\subsection{The TAs: professional profile, skills, and other characteristics}

The present section is based on material from CONAFOR's internal data, external evaluations and CONAFOR staff interviews, providing information about the average profiles, types, skills and economic and labour features of the current TAs.

\subsubsection{How many TAs are there?}


Between 2009 and 2010, there was an average of 98.15 TAs per state, where Jalisco occupied the $4^{\text {th }}$ and Michoacán the $5^{\text {th }}$ place, with 151 and 146 TAs, respectively (CONAFOR, 2011) (Figure 8.1).

In 2010, the LAST included 3,143 TAs, 2,540 of whom were individual and 549 (17. 5\%) were legal entities (e. g. civil associations, enterprises). Individuals and legal entities registered an average of 3 and 7 employees respectively, which means that around 11,400 people provided forest technical services (CONAFOR, 2012).

In 2013, 2,828 TAs were in the LAST, of whom around 1,400 were active $(5,2013)$. At the National level, most of the TAs were enrolled in reforestation and soils, and about 200 were in PES $(5,2013)$.

Figure 8.1. Average number of PRONAFOR TAs per state in México, between 2009 and 2010 (Source: CONAFOR 2012; Rodriguez et al., 2012).

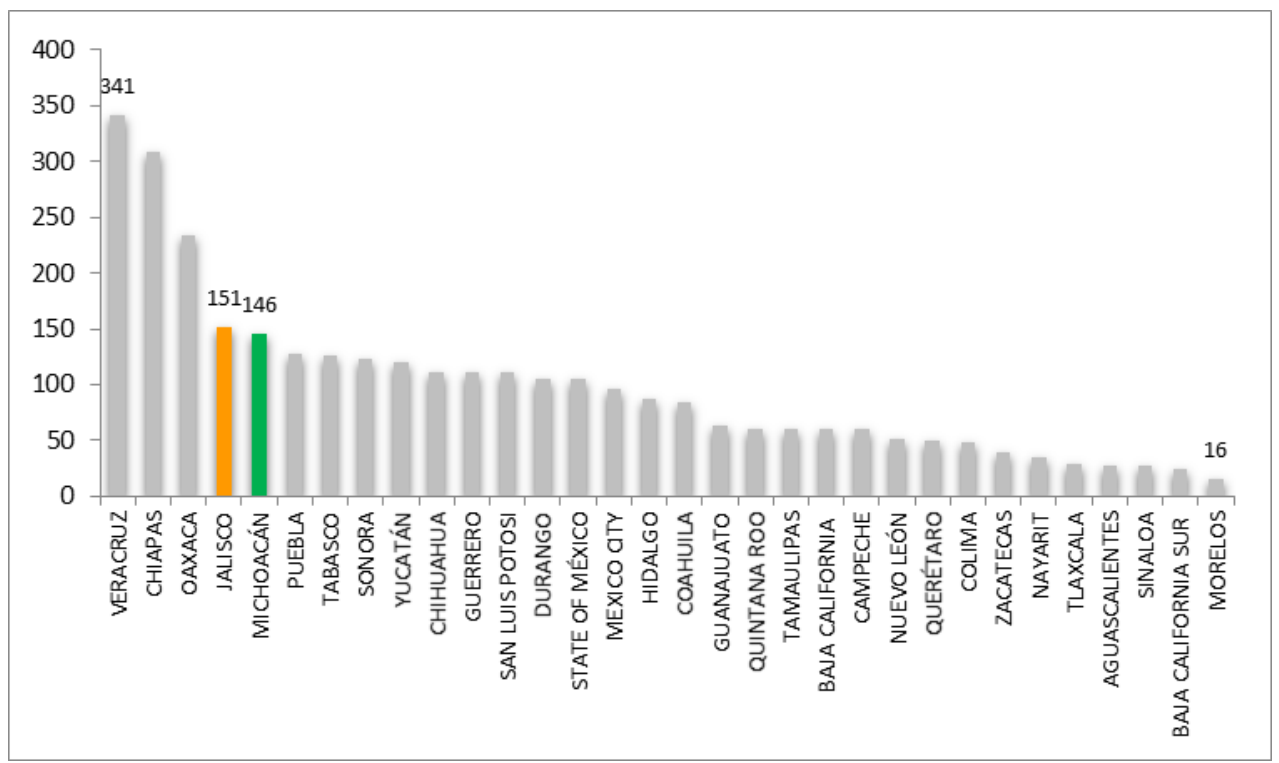

According to the operator of the LAST in CONAFOR, one of the main objectives of the establishment of ProArbol/PRONAFOR was the integration of programmes on a territorial basis, which has not been met, partially because it was expected that TAs would be registered in different technical capabilities in order combine services for several CONAFOR programmes in single territorial units. But on average, there are 1.5 CONAFOR programmes operating per polygon enrolled $(5,2013)$.

The number of TAs in the LAST has increased since 2007, as can be seen in figure 8.2. In the first years of ProArbol (later PRONAFOR) operation the forest technical services were 
mainly provided by individual professionals, but the number of legal entities (i. e. enterprises, consultants' offices, civil associations) has increased over time (CONAFOR, 2013). In the last years, specialised service bureaus and enterprises have been widespread. There are advantages of working in this way: professionals from different disciplines can be hired, and the possibility of participating in more CONAFOR programmes and with more communities increases, which is reflected in incomes.

There is a wide difference in the incomes received by professionals offering services individually and legal entities. According to information from CONAFOR, in 2013, 633 individual TAs received ca. $€ 2,350$, while one legal entity received ca. $€ 190,000$ annually. But on average, TAs get $€ 7,000-23,500$ on an annual basis $(5,2013)$.

Figure 8.2. Number of TAs in the LAST in the period 2007-2012 (Source: CONAFOR, 2013).

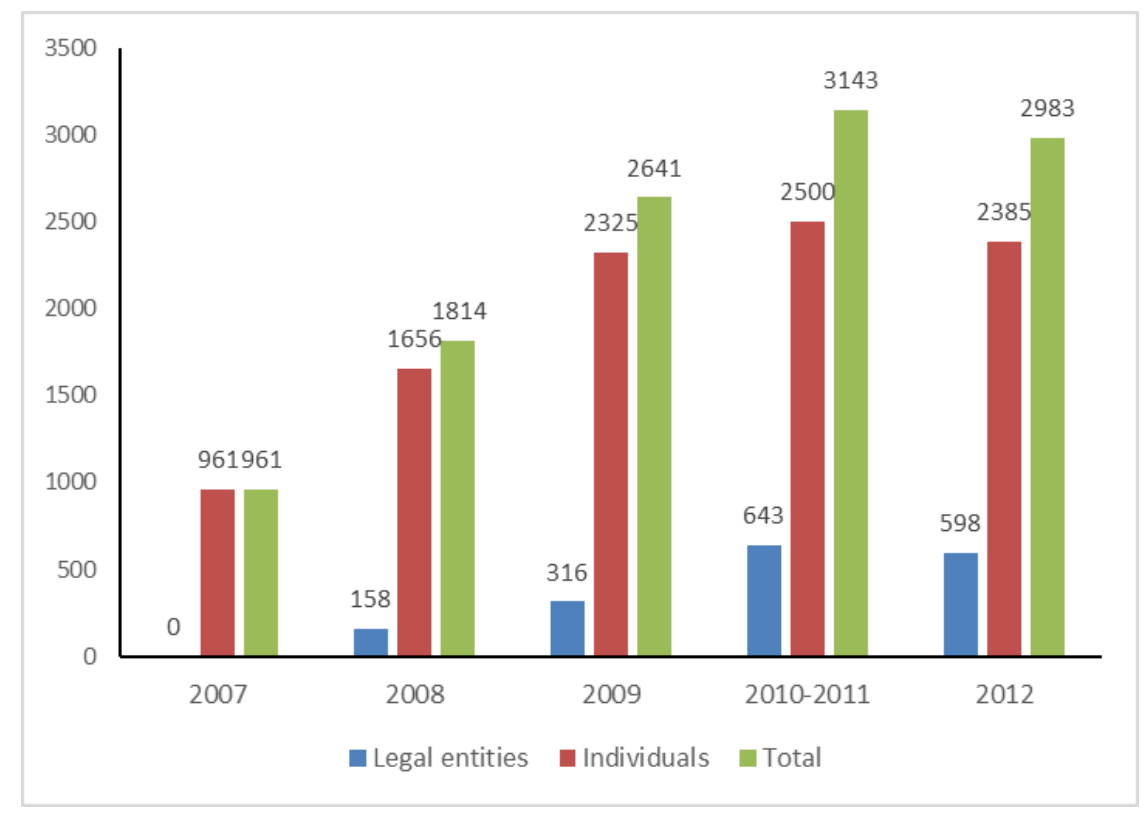

But in the second half of 2012 the number of TAs decreased somewhat (Figure 8.3), mainly due to the beginning of the certification process (CONAFOR, 2013). 
Figure 8.3. Total number of TAs by year. (Source: CONAFOR, 2013)

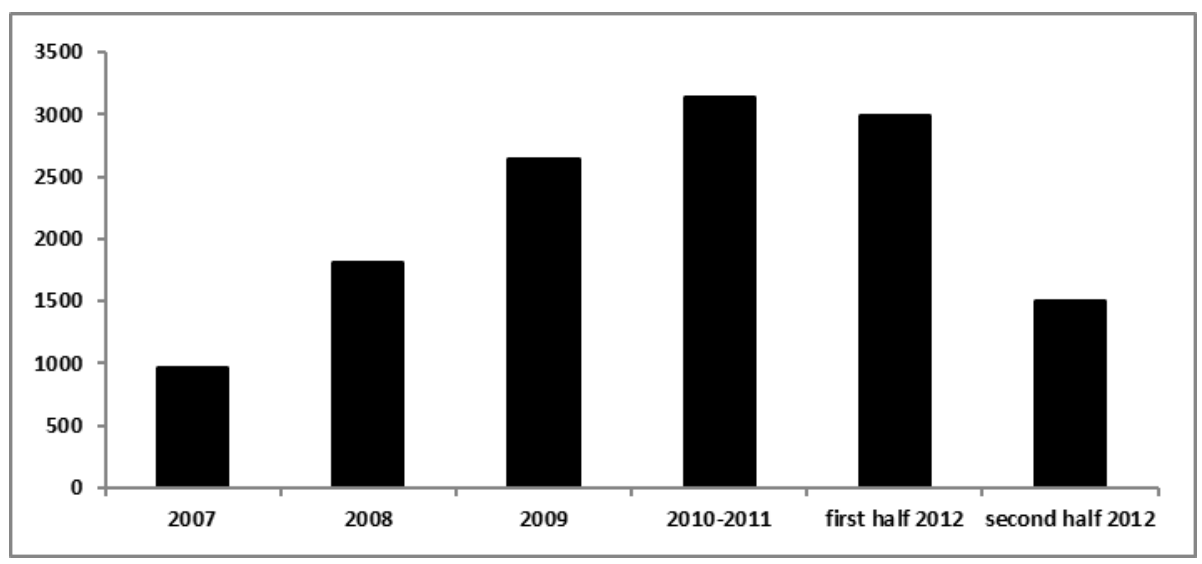

According to the person in charge of the LAST and the certification process, the high number of registered persons in LAST is a consequence of a misunderstanding about the use/role of the LAST. Informant 5 (2013) asserted: "It seems that there is a widespread belief that the LAST list is a job market. Many potential TAs are enrolled with the expectation that they will be called by the forest lands owners to be hired. This is not exactly like that. Communities do not often look for a TA, but rather it is the TA who contacts communities. The real number of active TAs is changing every year, but we estimate that there are around 1500.

About certification, in average, each TA is registered in 5/9 technical capabilities. Up to 2013, when information was gathered, from the 2,800 TAs registered in the LAST, only 200 were certified $(5,2013)$. Of the 9 technical capacities, most of the TAs $(80 \%)$ are certified in reforestation and soil conservation.

\subsubsection{Professional profiles and skills}

According to a survey conducted in 2011, on average TAs are 40 years old, male, mestizo, with undergraduate studies, with between 8-9 years of professional experience, monthly incomes lower than $€ 500.30 \%$ are accredited in the National Forest Registry (RFN) (Rodriguez et al., 2012). In 2012, 814 were from agronomy-related professions, 642 from forestry-related professions, and 424 were biologists (CONAFOR, 2013) (Figure 8.4). 
Figure 8.4. Professional profile of ProArbol TAs in 2010. (Source: CONAFOR, 2013).

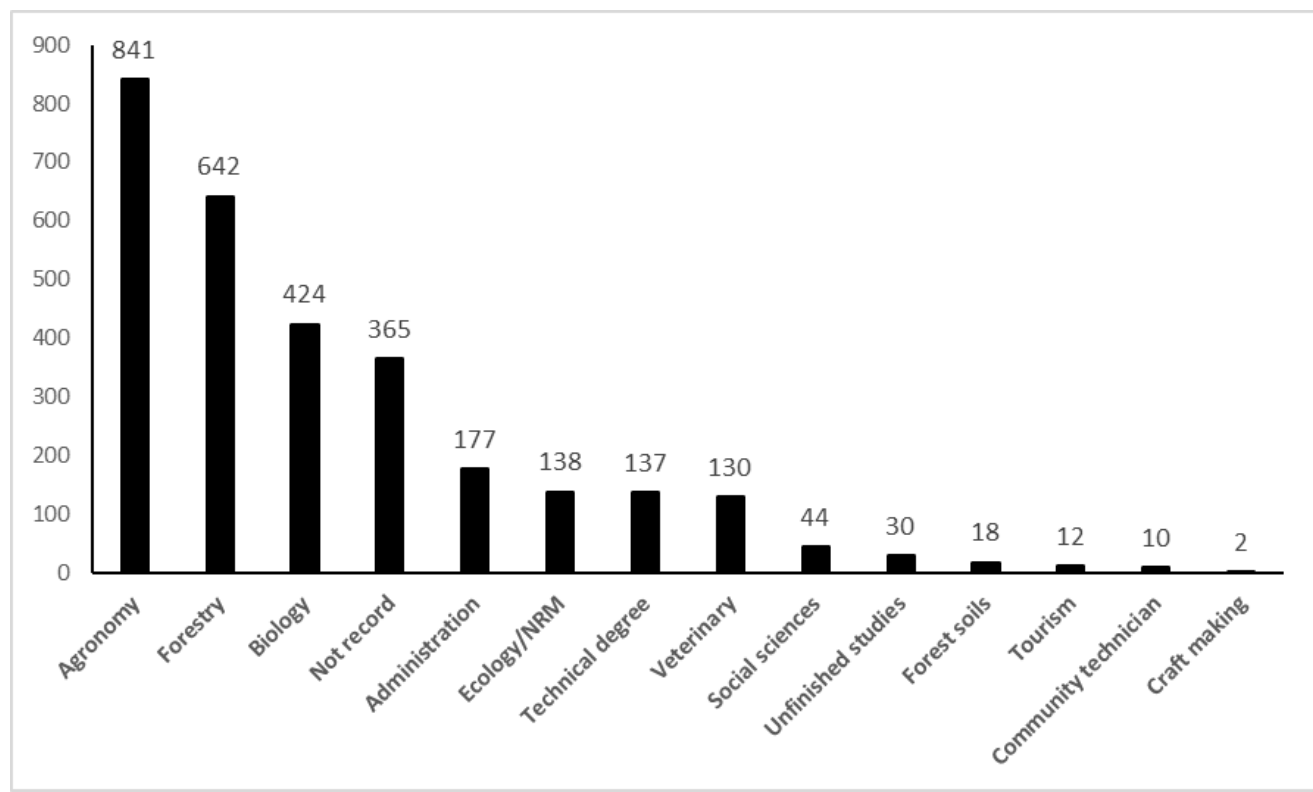

$64.87 \%$ (870) of the LAST TAs reported [knowledge of] English language, and 91 reported knowledge of French, German, Italian, Japanese, Portuguese, Dutch, Hebrew and Russian (CONAFOR, 2012). Only 4.62\% (62 TAs) reported knowledge of indigenous languages (e.g. Mayan, Mixe, Mixtec, Chol, Tzotzil, Tzeltal, Nahuatl, Otomi, Ñhañhu, Totonac and Zapotec), which may be an indicator of the low number of TAs coming from indigenous communities. It also suggests that most of the TAs are external to the rural mestizo and indigenous communities.

In 2009 43.81\% of the TAs reported having their own offices, and 16.07\% rented; 246 TAs reported several offices; 1,842 reported 1-4 work cars, 2,000 TAs reported 1-5 computers (CONAFOR, 2012).

CONAFOR TAs can be categorised in three types by their professional profile. The differences not only reflect professional origin and skills, but also vision about forests, relation with beneficiaries of the programmes, and political power. These differences are very tangible in practice and represent one of the limiting factors for the unity of TAs when it comes to demanding rights and complaining about specific problems in work conditions. The names used in in this text for the categories have emerged from interviews with CONAFOR staff, and two of them are present in an external evaluation (Rodriguez et al., 2012). Although they are no official categories, the divisions among 
them are acknowledged by CONAFOR, by an external evaluator (Rodriguez et al., 2012) and by some TAs:

- 'Old school' TAs (Rodriguez et al., 2012): Also known as 'forestales'. Usually they have extensive experience in the field, having provided technical services in programmes prior to the establishment of CONAFOR, working directly in government forest service units, and providing services to private logging concessions. Most of them are men older than 50, forest engineers, educated in Chapingo University, or with technical level education (Rodriguez et al., 2012). Most of them are enrolled on the National Forestry Registry (RFN, SEMARNAT), and as such are the only TAs allowed to provide technical assistance to community-based forest enterprises to develop forest management plans, forest audits, and forest plantations. Therefore, they have more opportunities to work in CONAFOR programmes on those activities. According to CONAFOR data, the TAs with RFN currently represent $30 \%$ of all of TAs in the $\operatorname{LAST}(5,2013)$, and this percentage has remained steady over time $(5,2013)$. Their vision of forests is more focused on productive activities, and their relation with beneficiaries use to be hierarchical. The places with a long tradition of forest management (such as Jalisco, Michoacán, Chihuahua, Durango, Oaxaca) have the highest numbers of TAs with RFN. Meanwhile the states without this tradition, such as Aguascalientes and Baja California have fewer $(5,2013)$. In general, they are well organised in state, regional and national level unions outside CONAFOR with power to mobilise pressure on key issues. But there are also rivalries between unions.

- 'CONAFOR's children' $(5,2013)$ : They are the TAs as established by CONAFOR and are the most numerous in the LAST. They are mainly men, but there is increasing participation of women. Regarding their professional profile, this group is composed especially of biologists, agronomists, but also lawyers, geographers, economists, and teachers (Rodriguez et al., 2012). In general, they are younger than the "old school" TAs (between 30-40 years old) (5, 2013). Usually they are not enrolled in the RFN. Their vision and approaches concerning forests and communities is diverse. They usually provide technical services in programmes such as PES, and PROCYMAF, and carry out workshops, technical forest diagnostics; and most of them are involved in reforestation and soils restoration projects.

- CECFOR technicians: This is the minority group in the CONAFOR LAST. They are highschool graduates, trained in the Centre of Forestry Education and Training (CECFOR), a forestry-oriented technical high school centre, established between 1988 and 1994, and managed by CONAFOR since 2001. Generally, this school 
receives young people ( $\leq 20$ years old) who come from small surrounding towns, especially rural communities. Most of them see the school as a way to access technical high school studies, and few of them actually participate in CONAFOR programmes. Initially (1990s), the school aimed to train two types of technicians: the forest guards and technicians to be working with the logging companies; and those called "poor" technicians, to assist forest farmers from ejidos and communities (Rodriguez et al., 2012). Some of the graduates are hired by consultant bureaus and more experienced individual TAs, and others work as community promoters of CONAFOR programmes.

\subsection{Discussion}

\subsubsection{Why are technicians so important in Mexican PES?}

In Mexican PES programmes, intermediaries such as TAs are highly relevant (Burstein, et al., 2002; Corbera, et al., 2009; Kosoy et al., 2008; McAfee \& Shapiro, 2010). To understand their significance, it is necessary to see them in relation to the actors between whom they are positioned.

Three factors have made forest TAs key actors in the implementation of policies:

1) The lack of field government employees (and limited financial resources to hire them) to operationalise the programmes;

2) the lack of technical, economic and organisational capacities of forest owners, which (with exceptions) make them perpetually dependent on external agents to manage their own forests;

3) the lack of permanent local capacity building strategies in communities, such as training of community technicians, and support to local initiatives for developing projects.

TAs lie between CONAFOR and the potential beneficiaries (rural ejidos, indigenous communities and smallholders). There are great disparities and pronounced power asymmetries between them. CONAFOR (through documents and staff) speaks in a technical language and use sophisticated platforms to communicate with potential users. The conceptualisation of the programme is not familiar to the potential users, who are accustomed to receiving simple subsidies from government organisations. The PRONAFOR (including PES) ORs are complex because they contain specialised terminology and also change every year. It also has difficult-to-fulfil requirements for the application, such as field surveys and geo-referenced polygons of the lands to be enrolled, which must be presented at the state/regional/national level offices. The PES programme also requires conservation and protection activities, which need technical 
capacities for soil conservation, reforestation, fire prevention, among others. Furthermore, CONAFOR has a very low operational capacity to implement the programme across the country. Unlike other CONAFOR programmes which operate at national, state and sub-state or (inter-municipal) levels, PES operates only at national and state levels. On average, there are only 3 people in charge of PES in each state level office, which makes it difficult for them to be in touch with beneficiaries during all phases of implementation.

On the other hand, with some notable exceptions, forest landowners in México are still disempowered, marginalised and impoverished, with low economic, legal, technical and educational capacities, and little familiarity with bureaucratic and technical procedures. Historically, Mexican forest policies have required the fulfilment of tasks that were beyond the capabilities of communities, since the inception of community forest enterprises in the 1970s and 1980s (Klooster, 1997 in Merino and Segura, 2007). These activities have required the hiring of forestry professionals.

Thus, the work of TAs starts from promoting the participation the programme and extends to implementing, verifying and reporting the conduct of the activities. In order to carry out those activities, TAs have to connect two different institutional settings and systems of knowledge; translating and explaining information and needs, facilitating processes, learning, interactions; adapting the ORs to local contexts and the changing needs of beneficiaries; representing interests, assisting and accompanying decision making (Figure 8.5). New forest management schemes continue to perpetuate the dependence of communities on the forestry professionals, increasing the power of these intermediaries and the disadvantages of communities.

Figure 8.5. Relevance of TAs in connecting the main actors of PES programme (Source: image modified from https://thumbs.dreamstime.com)

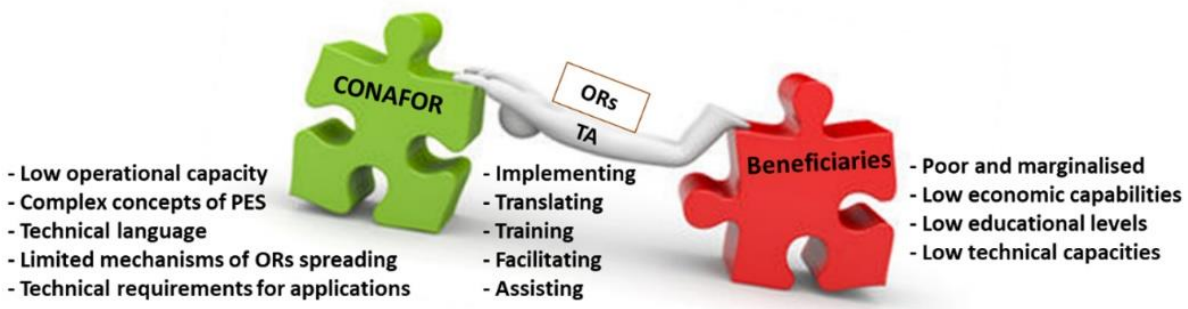




\subsubsection{The double-edged role of the TAs'}

In an idealised image of the intermediaries, such as TAs, it is assumed that they lie in the middle of the interests of the actors they are connecting. But they may have more affinity or shared interests with one or another group, and this will determine the type of influence, dynamics and results (Huber-Stearns., et al 2013).

Although the role of TAs is determined by CONAFOR, they constantly make decisions that affect their own performance. While doing their work in PES, they meet other goals and respond to their own benefit (Huber-Stearns et al., 2013), which may lead to conflicts of interest (Pham et al., 2010, Huber-Stearns et al., 2013).The heterogeneity of those who form the TAs group in the CONAFOR programmes is reflected in their preferences to perform certain tasks over others, or in the level of commitment to contribute to capacity building and empowerment of beneficiaries. When the work of a TA produces positive results for the beneficiaries, it can lead to very close relations between them, but if this happens from an uneven power relation, it can result in the dependence of the beneficiary on the TA, as well as in the establishment of small monopolies, or power spaces, deepening the existing power inequalities.

Additionally, TAs are translators of the ORs, making them accessible to applicants and beneficiaries. But, when interpreting ambiguities in the rules, they also may take advantage of gaps and fissures in them to obtain benefits for themselves, or to make alliances with communities.

\subsubsection{The Historical and current relations among actors}

In forest policy in México, it is possible to see the persistent presence of the provision of technical services in different configurations, accompanying the policy changes over time. TAs have been professionals from urban areas working in the field, close to the forest lands (especially the most productive), and frequently far away from the central government organisations for which they work. The condition of forest communities and ejidos throughout this time is another persistent aspect. With few exceptions, although there have been relevant changes in the position of communities with respect to their forests, most forest landowners have remained marginalised, disempowered and with limited economic, legal and technical capacities for managing their forests. Their possibilities of making decisions about their forests or even monitoring the performance of TAs are limited. The government attempts to improve this situation have been partial and discontinuous (Segura-Warnholtz, 2014, Merino \& Segura 2007; Merino-Perez, 2004). Although since the 1980s, policies have determined that technical services providers are devoted to assist forest communities in sustainable forest management; their contribution to the capacity building of communities is irregular and disputable. 
Another point is the relationship of government organisations, and the provision of technical services. The government, generally centralised, has extended its reach to distant forest lands through the services of these technicians, who have been instruments, with varying degrees of independence from the State for the fulfilment of political objectives. But the State has (deliberately or not) turned a blind eye to the quality of performance of the TAs in charge. The opening of technical services to free competition in the 1990s brought advantages to the communities by allowing them to freely choose their own TAs (Segura-Warnholtz, 2014), but also increased the gap between government and provision of technical service, which in the end affects the beneficiaries.

Throughout this history, researchers have shown explicit evidence to construct a controversial image of TAs performance, including power abuse, corruption, negligence, abandonment, among others (Chapela, 2000; Segura-Warnholtz, 2014; Mathews, 2012). Very explicit is Weaver (2000), who documented accusations and complaints from ejidos about the bad practices of the forest service units' technicians, including corruption, power abuse, collusion with private lumber companies, coercive actions, poor budget allocation, and concealment of information in the north of México, between the 1970s and 1990s. Technicians took advantage of their position to obtain benefits from poorly empowered forest communities. This established dependent relations, and technicians and profited from that. An example, provided by Weaver, of the poor interaction between forest technicians and ejido members, evidencing negligent practices follows:

"In the early 1990s the World Bank [...] heard complaints from ejido members about the foresters [...] were mostly from out of the region, usually from México City, and appeared out of sympathy with local cultures. They were accused of looking down their noses at "rustic" rural mestizos, unsophisticated urbanites, and Indians. They were said to support each other "since they come from the same school [at Chapingo [...]" and seldom went to the field [...]. Forestales were called "diablos" [devils] [...], because "everyone knows they exist, but no one sees them" (Weaver, 2000).

Providers of technical services have served different entities and interests, sometimes working alongside the government to enforce forestry laws, other times assisting private logging companies, and in the last decades assisting the forest communities formerly excluded and exploited by the logging companies, and over-controlled by governments. The next chapter shows in more detail how some of these highly hierarchical and sometimes pernicious relations between communities and TAs remain to the present, especially in areas with high marginalisation and forest management traditions, such as Michoacán, Oaxaca, Jalisco, Chihuahua, among others $(56,2013)$. A reason for this is 
that, although policies have changed over time, they have not broken free from the older culture (Keys, 2005; Schomers et al., 2015); some of the old structures, relations and dynamics have survived, and served as foundations for the new politics and social networks in a kind of path dependency (Keys, 2005).

\subsubsection{How the TAs working situation affects their performance}

The 1990s opening of the market in forest services has had implications for the relationships between government, communities and the service providers. As mentioned earlier, in the first years of this liberalisation, the competition between service providers to obtain more contracts got out of control, as they made reductions in their prices in order to obtain more contracts, and this produced a considerable reduction in the quality of such services (Chapela, 2000). The scheme was adopted by CONAFOR, but the competition was partially reduced after the establishment of PRONAFOR programmes and, within it, the merging into a single National PES scheme, where the government is the only "buyer" of ES, and controls prices and sets standards of TAs services.

However, the implementation of this regime has had consequences in the social and work dynamics of the actors, especially the TAs. They are under considerable pressure in labour terms. Most of them receive low incomes with considerable delays, and they do not have any labour guarantee.

Given that México has experienced a job crisis in recent decades, employment options are scarcer, and the environmental sector has been heavily affected by that. Although the conditions offered by CONAFOR are not especially attractive, environmental and other professionals have found job opportunities in technical assistance.

The pursuit of relatively stable jobs has produced a strong competition between TAs, in establishing zones of influence, and obtaining the largest possible number of contracts. In this scheme there are many TAs receiving low incomes, and only a few, usually legal entities (enterprises and associations) formed by 'old school' TAs get much higher incomes. Under these conditions, the CONAFOR priorities, like the fulfilment of the programme objectives, may become relegated to the background.

Due in part to the competition between TAs, they are not organised in any way, and they don't use to work together. The differences and divisions are more profound between the 'old school' TAs, and the 'CONAFOR children'. The first are fewer in number, but they are still influential in the areas where they work, and they have political power, experience, and higher number of contracts. The second group is highly heterogeneous and competitive, less experienced, and many of them still work individually. But the lack 
of unity also reflects the absence of a feeling of belonging to an organisation or a programme. Each TA has his/her personal/organisational motivations and agendas (Chapter 10).

Maybe as a consequence of the labour regime, the working relation between TAs and CONAFOR is contradictory: they have obligations, but no rights; they receive payments from CONAFOR, but there is no contractual relationship between them. Thus, TAs are under great pressure to find stability and job security, while most of the responsibility for implementation rests with them, even though they are the most undefined programme actor in labour and legal terms.

For its part, CONAFOR has no moral or legal responsibility for the work of the TAs. This outsourcing of services is used to reduce operational costs and administrative responsibilities. But this modality implies a disconnection of the services provided by external suppliers, as well as loss of control over their performance, and legal gaps in the definition of tasks and responsibilities. In part because of the absence of a formal relationship, there are no regulations or accountability for the TAs' performance, so that the quality and ethics of their service provision become a personal choice.

\subsection{Conclusions}

This chapter has explored the historical, labour and operative conditions under which TAs carry out their work. This account provides an overview of the complexity of the relationships and of the scenarios under which TAs function. TAs are key intermediaries in the connection of very disparate actors (government and forest owners), who are related vertically and speak different languages. While implementing the programme, the TAs mediate interactions by translating and adapting the ORs and assisting in processes. At the same time, they can take advantage of their key position and of the older political structures that have empowered them over time to fulfil their own goals.

The information in this chapter will be complemented in the next chapters with empirical information from interviews with key actors in order to present the varied perceptions and responses about the performance of TAs (Chapter 9), including selfperception and the motivations, needs, affinities and factors that enable or hinder their work (Chapter 10). 


\section{Chapter 9. Villains and scapegoats: analysing the narratives of CONAFOR, beneficiaries, and other actors about the TAs}

\subsection{Introduction}

Problems concerning the performance of PES intermediaries are not a new topic. As well as their positive effects some negative consequences have been documented. For instance, Vatn (2010) stated that while PES arrangements control the activities of buyers and sellers, much power and freedom is left to intermediaries, some whom are can be attracted only by the money they can easily earn within the scheme (Vatn, 2010). Kosoy et al., also documented conflicts between ES providers and intermediaries in México (Kosoy, et al., 2008).

This chapter presents empirical data gathered for the thesis on TAs, as regards perceptions, experiences and perspectives of different stakeholders. The approach allows the visualisation of dynamics, problems and needs occurring in practice, especially at the local level, which have not been adequately exposed and analysed before. The main components of the analysis include,

- The perceptions of national and state level CONAFOR employees, as well as some relevant NGOs;

- The response of CONAFOR on the main problems relating to TAs' performance in PES programme,

- The experience of the interaction of TAs with 6 cases of beneficiary communities in Michoacán and Jalisco states.

The chapter is structured as follows: 9.2 covers the problem statement and justification of the analysis. In 9.3 concepts framing this analysis, and methods used to elicit the information are described, as well as the selection and types of informants participating in the fieldwork. 9.4 concerns the results of the interviews and participant observations, and is divided into two sub-sections, 1) the TAs as seen by governmental and other relevant actors, and 2) TAs as seen by beneficiaries. The results obtained are discussed in 9.5 .

\subsection{Problem statement and justification}

Literature has shed light about the significance of the role of intermediaries in PES schemes (Sternlieb et al., 2013). It also has indicated the existence of gaps in empirical information (Huber-Stearns et al., 2013; Medd \& Marvin, 2007; Meulen et al., 2005; 
Moss et al., 2009; Pham et al., 2010). The assertion that Van der Meulen et al. made in 2005 that the research about intermediaries is still theoretically fragmented and impractical, is still valid.

There are still several questions to be answered about the TAs in different PES schemes around the world. Answers to those questions will contribute to understanding of the practical issues in the definition of new schemes and policies but may also provide elements for the construction of theory.

The PES programme has operated in México for more than 15 years, and TAs have been an integral part of it. However, little is known about their real contribution on the ground, though there have been critical questions on their performance, reputation and ethics. There are many loose threads and ambiguities about their legal and institutional position in the programme.

CONAFOR's TA are embedded in an institutional framework, which is not different from that of other social, agricultural and environmental governmental programmes. This model of insertion of TAs is being adopted in new policies, such as REDD+. Because of this, it is necessary to better understand and clearly visualise the chiaroscuro of the construction and performance of this type of intermediaries, and the implications of these policies in the balance of power, in relation to rural communities, and regarding governmental accountability.

A deeper understanding is required around the intermediation of TAs, in order improve the schemes under which they work. But it is important to also analyse the different narratives and views of beneficiaries and of CONAFOR. In addition, field evidence on the scope and limitations of TAs could contribute to a broader reflection on the relevance and emergence of other and new types of intermediaries for PES.

\subsection{Concepts and methods}

\subsubsection{Concepts}

The delegation of responsibilities from CONAFOR to TAs has implications to be analysed in the light of three relational cross-cutting concepts implicitly present during the interviews and discussions with respondents. These concepts are power, accountability, and trust, which are intertwined in this account about TAs.

Although CONAFOR has considered more power-balanced schemes of governance, the administration and management of the programme is still vertical. The power asymmetries among the main stakeholders has remained, and even increased over time. 
Power plays a role in all the processes: in the information flows, the interaction among the actors, in the enforcement of ORs and even in the evolution of ORs.

Delegation of responsibilities implies that there should be a level of trust between the actors within CONAFOR and with the TAs, mediated by institutional frameworks that enable cooperation, (Oskarsson et al., 2009). Elsewhere, it has been acknowledged that trust is determinant in the outcomes of whole PES schemes (Mayer et al., 1995; HuberStearns et al., 2013; Pham et al., 2010; Schomers, et al., 2015; Swallow et al., 2007). In these contexts intermediaries are highly significant in trust building between actors involved (Bosselmann \& Lund, 2013; Huber-Stearns et al., 2013; Schomers et al., 2015; Sternlieb et al., 2013). Better understanding of capacities of TAs as agents of trust building is important, given that their own trustworthiness is widely questioned. Coad and Cullen in their study on inter-organisational relationships, have observed that rather than relationships of trust, certain well established institutional routines develop gradually over time and shape interactions, which mask conflicts of interest and power asymmetries (Coad \& Cullen, 2006). Furthermore, in the development of the relationships, there are many uncertainties about the interests and performance of the other actors, which, together with the power asymmetries, can negatively affect the trust between them.

In the implementation of the programme, responsibility involves trust between the delegators of the responsibilities (or the trustors) and the actors in charge of taking those responsibilities (the trustees) (Hardin, 2002, 2007). Where there is lack of trust between the actors, mechanisms of compensation, such as control measures of the performance and behaviour of actors can be taken (Bijlsma-Frankema \& Costa, 2005; Möllering, 2005). As Giddens (1991) stated, trust and control are necessary constructs for the production of collective action (Giddens, 1991), which are related to structure and agency (Möllering, 2005). In this sense Möllering (2005) notes: "when an actor rests positive expectations on structural influences on the embedded other, we speak of control", and "when an actor rests positive expectations on an assumption of benevolent agency on the part of the other, we speak of trust" (Möllering, 2005, pp. 287).

In this case, through the ORs and specific standards as well as verification and reporting processes, CONAFOR has established control and accountability mechanisms not only for beneficiaries, but also for the state-level employees and the TAs; so they must be accountable to CONAFOR. In turn, CONAFOR must be accountable to other actors, related but external to the PES programme, such as the higher-level governmental organisations, international funding agencies (such as the WB), scholars and NGOs, among others. Here, transparency and strategies of blame avoidance may take place 
(Hood, 2011), by allocating the blame to actors with less power and more responsibilities in implementation when the results are not as expected (Hood, 2011).

\subsubsection{Method}

I conducted participant observations and interviews with relevant actors, including stakeholders who have direct interplay with TAs, such as CONAFOR national and state level employees, beneficiaries of the programme, and actors involved in PES who have indirect relations with TAs, such as non-governmental and civil organisations, some of whom take part of the PES National Advisory Committee (Table 9.1).

Table 9.1. Organisational interviewees, who contributed information on TAs

\begin{tabular}{|l|c|c|}
\hline \multicolumn{1}{|c|}{ Organisation/ level } & $\begin{array}{c}\text { Informant } \\
\text { Initials }\end{array}$ & $\begin{array}{c}\text { Type of relation } \\
\text { with TAs }\end{array}$ \\
\hline \multirow{4}{*}{ CONAFOR National level } & 4 & Indirect \\
\cline { 2 - 3 } & 1 & Indirect \\
\cline { 2 - 3 } & 9 & Indirect \\
\cline { 2 - 3 } & 7 & Indirect \\
\cline { 2 - 3 } & 8 & Direct \\
\cline { 2 - 3 } & 10 & Direct \\
\hline CONAFOR state level & 5 & Direct \\
\cline { 2 - 3 } & 15 & Direct \\
\cline { 2 - 3 } & 12 & Direct \\
\cline { 2 - 3 } & 14 & Direct \\
\hline National level NGOs & 13 & Direct \\
\cline { 2 - 3 } & 50 & Indirect \\
\cline { 2 - 3 } & 51 & Indirect \\
\hline Inter-municipal organisation & 52 & Direct \\
\hline Ayuquila & 54 & Direct \\
\hline Local level NGOs & 55 & Direct \\
\cline { 2 - 3 } &
\end{tabular}

Beneficiaries of the programme (table 9.2) contributed with information through interviews with members of local authority of 6 ejidos, 3 from Jalisco (Ayuquila basin), and 3 from Michoacán ( 1 in Zitácuaro, and 2 in La Huacana (for more information, see chapter 3)). 
Table 9.2. Ejidos consulted for the study on TAs

\begin{tabular}{|l|l|l|}
\hline \multicolumn{1}{|c|}{ State } & \multicolumn{1}{|c|}{ Ejido } & \multicolumn{1}{c|}{$\begin{array}{c}\text { Informants (local } \\
\text { authorities) }\end{array}$} \\
\hline \multirow{3}{*}{ Michoacán } & Cresm & 32,33 \\
\cline { 2 - 3 } & Ich & $34,35,36$ \\
\cline { 2 - 3 } & Cir & 37,38 \\
\hline \multirow{3}{*}{ Jalisco } & Ahu & $39,40,41$ \\
\cline { 2 - 3 } & Ton & 42,43 \\
\cline { 2 - 3 } & Zen & 44,45 \\
\hline
\end{tabular}

Figure 9.1 shows all the actors involved in the study and the type of the relation among them. Some of those relations are potential or indirect.

I also attended 4 workshops, 1 about environmental services, and 2 about rights and obligations, and 1 about "Best Forest Management Practices Guide", all organised by CONAFOR for new beneficiaries of the programme. And I attended field PES verifications in two ejidos. Both the workshops and the verifications are key moments in which it is possible observe the interaction between CONAFOR staff, TAs and beneficiaries.

All the interviews and some of the observations were recorded (with the participants' consent), transcribed and analysed using QSR International NVivo 10. The most illustrative quotes from informants have been translated to English. 
Figure 9.1. The actors involved in the study, and their position relative to the other actors. The arrows represent the type and intensity of the relationships. The dotted lines reflect the potential relations, because the actors involved are not present in all the cases. For instance, the red dotted arrow reflect strong relations of local NGOS, an inter-municipal organisation (JIRA) and a community promoter with TAs and beneficiaries, but these actors are present only in some of the case studies.

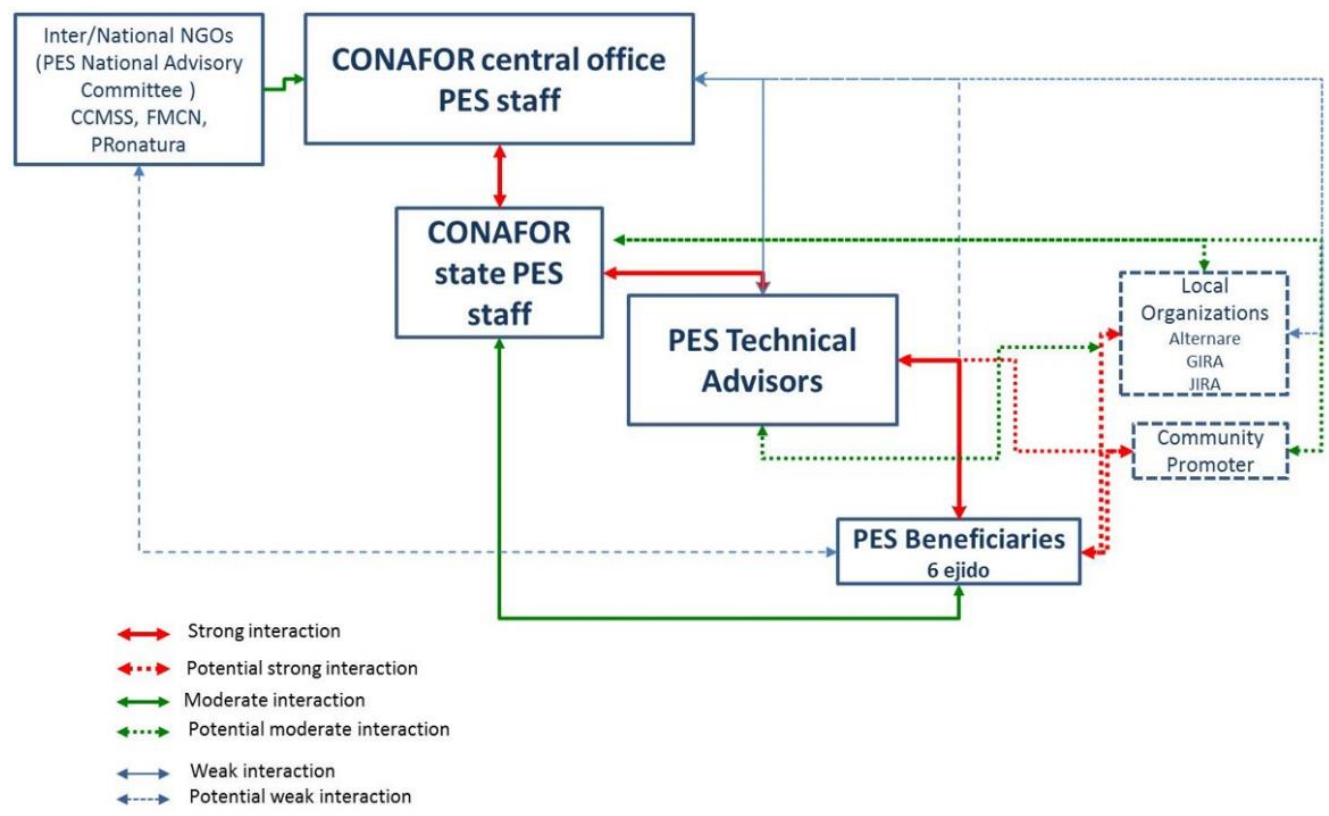

\subsection{Views and perceptions of PES' actors about TAs}

The information gathered is divided in the following sections:

- Section 9.4.1 encompasses the perceptions of national and state level CONAFOR employees and NGOs on the relevance and performance of TAs in PES.

- Section 9.4.2 presents the views of national and state level CONAFOR staff about the response of CONAFOR to deal with the main problems identified in the performance of TAs, and

- Section 9.4.3 reports information from the 6 ejidos and the dynamics of interaction with TAs in PES. 


\subsubsection{CONAFOR and NGOs views about TAs}

\subsubsection{The functioning of TAs in PES and formal expectations about them}

Technical assistance in PES is explained by informants such as the former heads and operators of the programme, firstly in terms of targeting and the need for geoinformation tools for visualisation, since PES was one of the first programmes to use the concept of eligible areas. From the beginning, CONAFOR had difficulties to make public these areas, because potential applicants did not have the information, capacity or tools to know if they were located inside or outside eligible areas. About that informant 7 said:

Forest owners did not know what a shape file was, or how could they visualise it [...]. So, we [...] told them about free visualisation software [...]. But [...] 98\% of landowners remain without access to such tools $(7,2012)$.

This had direct consequences on the results of the programme, especially during the first years of operation, since potential participants were not able to complete the application correctly. 1, former operator of the programme, stated:

[...] During the first and second years of PES, the proportion of rejection [of applications] was 3:1, mainly due to the lack of knowledge in the geo-location of the polygons (as it requires geographic analysis) $(1,2012)$.

On the other hand, it is recognised by interviewees that although CONAFOR is a national level organisation, and it has high level of technical capacity, its operational capacity to aid all the applicants and beneficiaries is limited. Thus, the participation of TAs in the programme was fundamental to fulfil tasks that would be impossible to carrying out by CONAFOR. The work of the TAs was essential by providing assistance on this, and in follow-up beneficiary by beneficiary $(7,2013)$. About that informant 5 said:

Every year CONAFOR [...] launches the call for participation, and publishes the ORs, and state offices [...] convene all the actors [...]. Then, CONAFOR just sits and waits to receive the applications. So the TAs are the ones who actually do the "chamba" [job] of visiting the landowners to say: "Mr., look, there is a programme called PES, your forest is very well conserved and it is within the PES eligible areas, you must fill out this application", etc. $(5,2013)$.

TAs also should play an important role in the strengthening of capacities and decisionmaking processes at the local level, as informant 1 said: 
For me, forest management improves when there is a technical service provider supporting people to make decisions, helping them to create more efficient governance mechanisms, and supporting them in the process. The number of rejected applications has been reduced because [...] state and regional level employees, and the TAs have helped to determine with more clarity the criteria for eligibility. Their presence not only allows people to identify whether they are in eligible areas, [...] TAs are also noticeable in the implementation of the programme [...] and eventually [in] the monitoring and verification $[\ldots](1,2012)$.

For state level CONAFOR employees, TAs are fundamental to their link with beneficiaries, because many of them live in the cities where the CONAFOR state offices are located, and they have access to e-mail and mobile phones. So, CONAFOR employees communicate to beneficiaries through the TAs $(12,2014 ; 14,13$ and 15, 2013), in about $70 \%$ of the cases $(12,2014)$. They also acknowledged that, in cases of change of ejido authorities, TAs bring the new authorities up to date about PES $(14,2013)$.

They are a very important part of the chain between CONAFOR and beneficiaries. They are our connection, they know the regions better, they know the ejidos better, and they know how to treat the people of the communities $[. .].(14,2013)$.

An important task to be fulfilled by TAs is assistance to beneficiaries in the preparation and submission of applications, especially in the delimitation of the forest polygons. Therefore, TAs must have a basic knowledge of tools and procedures of GIS $(7,2012)$, as well as a capacity to communicate efficiently with a diversity of actors $(8,2012)$. CONAFOR also sees TAs as agents of development in communities with capacity to promote a range of other. But according to the person in charge of the TAs and training, this has not happened. Most of TAs instead specialise in one or two programmes (for example reforestation and PES), requesting resources on behalf of one community and leaving it when the programme finishes, and starting again in another community. Very few TAs stay with communities in the long run to look for and facilitate new projects. On average, polygon involved in a CONAFOR programme is enrolled in 1.5 programmes, which means that most TAs are not conceptualising PRONAFOR as an integral programme in the same territorial unit $(5,2013)$. Instead they promote individual projects of the type with which they are most familiar.

\subsubsection{Negative views about TAs and mixed understandings of their role in PES}

Although the importance of the TAs has been recognised in different stages of the programme, they are seen as "double edged agents" $(54,2014)$. As summarised by 9 , a PES employee at the central office of CONAFOR: 
"CONAFOR is very aware that the TA is a key intermediary, and if the technician acts well, if $s /$ he does not grab power and information, if $s /$ he is a good technician, our programmes are much more likely to be successful. But if the TA is not good, they can be a bad influence for communities" $(9,2012)$.

The most general perception of the informants is that there are always ambiguities about TAs' work, creating the impression that TAs performance is beyond the control of CONAFOR. This idea of "uncontrollable actor" is identified as a problem to be solved, acknowledging the need for mechanisms of regulation and control. They are stigmatised as a negative or hindering factor, particularly the high-level central office staff, national and local NGOs and the inter-municipal organisation JIRA. Issues such as corruption, power abuse, incompetence, negligence, among others, are mentioned in the narrative of these informants (Table 9.3). However, most of non-governmental organisations acknowledged that CONAFOR is also part of the problem of the poor performance of TAs. 


\begin{tabular}{|c|c|}
\hline Abusive & $\begin{array}{l}\text { The TAs are very irresponsible, they deceive and abandon the beneficiaries, who can be } \\
\text { registered in a list of unreliable beneficiaries, when in fact it is the TA who is failing (4, } \\
\text { CONAFOR, 2012). } \\
\text { There have already been enough cases of beneficiaries who have been misinformed or } \\
\text { mistreated by TAs (5, CONAFOR, 2013). } \\
\text { They are almighty engineers, who have the upper hand with beneficiaries [...]. Beneficiaries } \\
\text { do exactly what the TA orders them. But the misuse of this power is somehow facilitated } \\
\text { by CONAFOR. [...] (54, JIRA, 2014) }\end{array}$ \\
\hline Corrupt & $\begin{array}{l}\text { There is corruption between ejido/community authorities and [...] TAs; they become } \\
\text { magicians, who "disappear" a percentage of the money for projects (49, NGO, 2014). } \\
\text { [...] TA just take advantage by getting more money from the beneficiaries, or they submit } \\
\text { applications for activities that people do not need, in order to keep almost all the money } \\
\text { and give just a little to the beneficiaries. (1, CONAFOR, 2012). } \\
\text { [...] I am sure that most [of the TAs] act with little ethics. It is something that is learned } \\
\text { fast. [...] And also somehow the same TAs unions put pressure on that (54, JIRA, 2014). }\end{array}$ \\
\hline Deceitful & $\begin{array}{l}\text { In reviewing the best practices guide and reports, we have caught [...] TAs presenting } \\
\text { exactly the same document for all the beneficiaries they are working with, and sometimes } \\
\text { they are so irresponsible that they do not even replace the polygon in each report. We } \\
\text { cannot consider them a support (4, CONAFOR, 2012). } \\
\text { [...] Some technicians copy projects, sometimes get photocopies of other projects they } \\
\text { steal, and present them to CONAFOR }(56, \mathrm{NGO}, 2013) \text {. }\end{array}$ \\
\hline Profit-driven & $\begin{array}{l}\text { They [TAs] have specific interests, they earn money by taking projects with federal } \\
\text { resources [...] and it is in their best interest to get as much of these resources as possible } \\
\text { [...]. They are an interested actor [...]. With exceptions they are not appropriate } \\
\text { intermediaries (51, NGO, 2014). } \\
\text { Pro Arbol and the PES programme have been greatly abducted by the TAs, because it is } \\
\text { necessary to comply with a series of requirements that go beyond [...] the capacities of } \\
\text { most communities [...]. [...] If they need good writing, communities have to appeal to TAs. } \\
\text { And when the call [of the programmes] comes out [...], TAs grab the catalogue of } \\
\text { programmes and choose the most suitable for them, then they say to the community } \\
\text { authorities: -this one is good for you-. This is because some subsidies allocate a part of the } \\
\text { money to TAs (50, NGO, 2014). } \\
\text { An average ES technician only goes to the community, attends the Assembly, gets the } \\
\text { money and the corresponding signatures, delivers the reports, and does the basic activities. } \\
\text { When the money runsout s/he stops doing anything else. They are not going to [...] assume } \\
\text { long-term responsibility (56, NGO, 2013). }\end{array}$ \\
\hline Lazy & $\begin{array}{l}\text { They are not truly committed to their work [...]. They simply see their job as a business, and } \\
\text { PES is a good one because they do not have to do much work. (4, CONAFOR, 2012). } \\
\text { The TAs generally [...] want money for doing nothing [...]. And they do nothing because } \\
\text { maybe they do not know, or because they are lazy (5, CONAFOR, 2013) } \\
\text { TAs are very selective... they do not want to work in remote communities... (54, JIRA, 2014) }\end{array}$ \\
\hline Incompetent & $\begin{array}{l}\text { [...] TAs are not well trained [...]. }(51, N G O, 2014) \\
\text { They have not enough capacities in the social and human areas. In addition, many of them } \\
\text { believe they can do everything well }(56, N G, 2013) \text {. } \\
\text { [...] If the TA has the will, s/he will provide information that s/he has on hand on issues of } \\
\text { ES to the ejido. The TAs have an obligation to carry out two workshops per year on ES, but }\end{array}$ \\
\hline
\end{tabular}




\begin{tabular}{|l|l|}
\hline & $\begin{array}{l}\text { if a technician does not know anything, how can they train the beneficiaries? (50, NGO, } \\
2014)\end{array}$ \\
\hline Negligent & $\begin{array}{l}\text { Unfortunately, most projects are done by TAs because they have the capacity to develop } \\
\text { projects, but often they rely on and get information only from ejido authorities, [although] } \\
\text { they really should go to an Assembly to make a consensus about whether the project is } \\
\text { suitable or not for the whole community [...] (49, NGO, 2014). }\end{array}$ \\
\hline
\end{tabular}

In contrast, state level staff from Michoacán had more moderate and even indulgent views on the performance of TAs, emphasising the good and bad points of the TAs performance, as well as the heterogeneity of TAs. They also recognised their own role of making TAs fulfil their tasks correctly. 13 and 14, CONAFOR state level employees indicated:

[...] In general, TAs work well. There are very responsible technicians who present really good [...] reports. When we ask for information they have it ready in one or two hours. These kinds of technicians have their beneficiaries up to date. But there are TAs who, I think because of high workload, they neglect their beneficiaries [...]. Then we talk to them: [...] "can you really [do it] or not? If not, let another TA handle that, because your delay is affecting the programme" [...]. [...] We are guided by the ORs and we are protected by them. So, when we ask them to correct something it is because we can suspend or cancel the support, and they must rectify [the situation] $(14,2013)$.

[...] I could tell you that $70 \%$ of the TAs do well, [...] but there are still [some] very, very, very bad ones. They are minimal now, but we still have problems about that [...] (13, 2013).

On the other hand, 15, other CONAFOR state level employee talked in less indulgent terms and more similarly to the central office employees.

[...] Approximately one-third of the TAs in Jalisco work properly. [The main problems of TAs are] the lack of ethics and the high workload, because they [...] work with many [beneficiaries] or rather, they neglect many. I say that it is an ethical problem because we realise that they are providing [...] information that is not reliable, because there are a lot of verbal complaints from the beneficiaries, and because of the poor quality of the work they deliver. [...] So technical advice is very important, but it causes us many conflicts and problems, especially in non-compliance $(15,2013)$.

\subsubsection{CONAFOR's response to the problems identified}

Since the main problems about the performance of TAs seem well identified by different actors, the need to understand more clearly the role and response of CONAFOR has also emerged, because CONAFOR determines the roles and interactions of actors in PES. As mentioned above, throughout the interviews the notion that TAs are necessary but 
uncontrollable and unreliable actors was widespread. It seems that TAs are considered to be the only actors responsible for their own performance, and no one else can do anything to prevent or control unethical practices. Another problem to be examined is trust, and whether CONAFOR has developed strategies to address this.

\subsubsection{How CONAFOR monitors and mediates between TAs and beneficiaries}

TAs usually start the contact with potential beneficiaries by visiting communities and smallholders $(8,2012 ; 5,2013)$. But, when applicants become beneficiaries, the relation between them and the TAs changes; it is mediated by a contract, and according to ORs, applicants or beneficiaries have the right to replace their TAs when they need to. In this case, the obligation of CONAFOR employees is to show the LAST (List of Technical Services Advisors) to beneficiaries, so they can freely choose the most convenient TA. CONAFOR is not then allowed to suggest good TAs, nor provide extra-information or warnings about the performance of the selected TA $(8,2012 ; 12,13,14,15,2013)$. That is, even though CONAFOR employees are aware of the bad performance of certain TAs, they cannot do anything to avoid beneficiaries choosing a bad TA.

We had a case [...] of an ejido that was abandoned by their TA before they signed the contract [...]. Then we talked to the ejido: we asked them if they still wanted to be in the programme [...]. They said yes but they did not have a TA anymore. We recommend that they look for a new one in the LAST. And [we] thought hopefully they do not choose the TA that we know is not good. But they [beneficiaries] precisely signed the contract with him. [...] And we could not say or do nothing $(14,2013)$.

There are gaps in the monitoring of the performance of TAs, and in the measures to remove the well-known cases of incompetent or corrupt TAs from the LAST. When I asked if there is staff in charge of checking the interaction between TAs and beneficiaries, one of the operators of the programme said that in the PES area nobody was doing that, and that maybe CONAFOR office of training was focused on that.

“iHijole! (Geez!), I don't know. There is the training office in charge of the TAs process of certification and the rules..." [...] $(4,2013)$.

When I asked the manager of that area, this person told me that every programme has its own evaluation system, because the monitoring of the interaction between TAs and beneficiaries are not part of her office's tasks.

Two other problems became evident through interviews. Firstly, the lack of connection between CONAFOR departments in dealing with issues related to TAs, which crosscut all the PRONAFOR programmes. The other is the lack of operational and institutional 
capacities to take concrete actions in cases of detection of bad practices by TAs. It seems that there are no mechanisms in CONAFOR that facilitate actions to be taken in the face of unethical behaviour.

We have received a lot of complaints ... the truth is that we need to document these, because the data reflect the outcome of the work, and it implies changes in the ORs, but we have none of that $[\ldots](15,162013)$.

On the other hand, there are legal gaps that stop CONAFOR (state level) employees from taking action when there is evidence of unethical practices. Although state level employees directly experience most of these irregularities, they do not have any power to act when necessary:

In case of breach [of the TAs] we cannot do anything, unless a written complaint from the beneficiary [is presented]. We can also report irregularities detected during field verifications. We have only received informal complaints [...] from beneficiaries, but no one has done it in paper [...]. In the very few cases they have, the information is presented [...] to the legal department and the training area [...]. [...] Complaints [...] are the result of [field visits, verifications] [...]. We report cancellations or adjustments, but finally those who evaluate and decide are the headquarters. [...] But we are the ones who go to the field and we know what happens here $[\ldots](15,2013)$.

Thus, they need to wait for central office of CONAFOR to provide possible solutions to those local problems. State level employees can only informally persuade and pressure TAs to do their tasks correctly, which does not always work.

We notify TAs informally [...] to speed up processes, but sometimes this is worse for us and [...] it takes longer, because the TAs do not respect the agreements we make about delivering the reports $[\ldots](15,2013)$.

In terms of possible penalties, interviewees from state level offices said that their own good performance could also prevent TAs from behaving incorrectly; they also mentioned that one of the greatest punishments a TA can receive is the cancelation of the contractual relationship by beneficiary $(12,2014)$. This is a way to justify the lack of mechanisms in CONAFOR at all the levels to regulate TAs work.

[...] I believe that our good performance [...] is a way to warn the TAs that we will not allow failures [...]. [...] This has encouraged TAs [...] to try to go the right way $(13,2013)$

Although the cases of very unethical TAs are well known in the state and sometimes in the central offices of CONAFOR, there are no official mechanisms or protocols for 
tracking and monitoring their work. All information on this is handled in an informal way and it is not reflected in the LAST.

We do not have a TAs follow-up format; we simply know who works and who does not work. If there are problems with certain TA, the beneficiaries can just replace her/him $(12,2014)$.

In the current scheme, the highest punishment to TAs is to remove them from the LAST, but this is considered an extreme measure that is not frequently done $(13,14,2013)$. There is occasional informal communication among different CONAFOR departments to identify the TAs that have good or bad performance in the different programmes, but they have never formally requested the removal of a TA from the LAST $(14,2013 ; 12$, 2014).

Although TAs bad practices seem almost normalised, some informants also considered that CONAFOR needs to pay more attention on those problems, especially concerning the approach and interaction with beneficiaries, as well as specific measures to improve the provision of the technical advice, including the establishment of concrete penalties.

Other recognised weaknesses of CONAFOR are limited staff for verification, as well as the inadequate mechanisms for evaluation of compliance, which is done with a checklist on technical matters. In fact, an integral evaluation is needed, which considers all aspects of interaction with beneficiaries, and performance in the field.

I believe that there is a need for more evaluation, CONAFOR must be closer to the beneficiaries, and I also believe that there is insufficient training for TAs, and they must provide evidence of their capabilities [...], not only in technical issues, but in the social [...] areas. They must prove their abilities to work with people $(15,2013)$.

[...] [We] are often confident that [TAs] do their job well. [...] It has happened several times that when my colleagues go to the verification, it [...] turns out that [...] there are no [...] activities because the TA never worked with beneficiaries, [...] and they just sent reports from their desktops [...]. As the way to evaluate compliance is very technical, some aspects of the implementation are not visible. [...] It is necessary to strengthen or make a new scheme for TAs. [...] Now there is a certification process, but I do not think it's enough, we should see what solutions we find... $(10,2013)$

One of the most remarkable problems about the capacities of CONAFOR regarding TAs performance is the lack of a formal relationship between them and CONAFOR. This fact prevents CONAFOR requiring better services to and from TAs. One of the informants in 
central offices talked about these weaknesses in the definition of actions from CONAFOR:

Since TAs are external service providers for CONAFOR, you cannot demand much of them, because at any time you can be sued. [...] On the other hand, we have not been able to convey to the beneficiaries that the TA is like anyone working in a hairdressing salon: you can decide to go with one or another, depending on who cuts your hair well. People do not have that clear; they think they cannot decide about that. The relationship between beneficiary and TA should be changed (10, 2012).

Thus, from the information obtained it has become evident that 1) CONAFOR has legal limitations in acting, and 2) that the responsibility for reporting, and even 'punishing' TAs in case of unethical practice rests with the beneficiaries. The role of CONAFOR in such situations is to provide advice to beneficiaries and in some cases mediation between parties. As $s$ in the chapters 5 and 6 about ORs, the responsibility of beneficiaries has, regarding TAs, gradually increased over time. On the other hand, in general PES beneficiaries are highly marginalised and disempowered communities and smallholders. Thus, since the work of connecting CONAFOR and beneficiaries is done by TAs, many beneficiaries do not know the channels and the procedures to access CONAFOR, or the mechanisms to file formal complaints. In addition, some beneficiaries are controlled by the TAs, as 54 , an informant from an environmental inter-municipal agency said:

"The beneficiaries are afraid to act. Because the "all-powerful" engineers threatening them to persuade other [TAs] not to work with them. I will make sure no one comes to help you anymore. And indeed, maybe no other [TA] goes with them, and the community will have years of project drought, because the engineer "cursed" them. He tells his friends: "Do not go with that damned ejido, they are very ungrateful" [...]. And then the one that bears the consequences is the ejido [...]. [...] [Some TAs] really exert power, and that is the control they have [...] $(54,2014)$.

At the same time, given the lack of confidence towards the TAs, CONAFOR central office has increased burden of work of state level employees.

TAs are not truly committed to their work [...]. [...] So, I have employees in charge of PES programme in each state-level CONAFOR office. And they are the ones that really do promotion and verification, and also they are advising ejidos and communities about PES issues $(4,2013)$. 


\subsubsection{Training and certification of TAs, or how CONAFOR deals with TAs incompetence issues}

Unlike the cases of unethical practices, the problem of incompetence has been addressed more directly by CONAFOR. The most problematic areas detected by CONAFOR about TAs capacities are GIS and geo-information management, participatory techniques for the involvement of rural people, and environmental services concepts. Significantly these three areas are considered fundamental for the implementation of the PES programme. Furthermore, the external technical assistance in PES programme was designed to address the lack of capacities precisely in GIS and ES concepts of potential applicants and beneficiaries: Social techniques are needed for the adequate transfer of information to beneficiaries.

Many TAs do not know how to use GIS. In a test carried out with 125 technicians [in 2011] $s$, only 4 passed. We know that it is not easy to fulfil the requirement to elaborate the polygons requested by the PES programme. [...] And I believe that the PES office has also identified that as a problem, because it is still the first cause of rejection [of PES' applicants] $(5,2013)$.

In order to address those problems CONAFOR has been providing free training, according to the needs identified by state-level employees, who make suggestions to the central offices, and courses are programmed in an annual basis. However, since the budget for these activities is limited, the number and availability of courses offered for TAs is limited $(12,2014)$.

State-level employees also mentioned that TAs gradually improve as they gain experience in the field. They also considered that since 2010, deficiencies in the georeferential information system have been overcome, so the cases of TAs sending poorly constructed or incorrectly geo-referenced polygons were infrequent in $2013(14,2013)$.

It has also been recognised that the training scheme has left aside issues of communication and transferring of information to the communities, such as methods and techniques of social sciences and participation, as well as sensitisation to gender, vulnerable groups, and indigenous peoples' issues.

TAs need to be strengthened in the social areas, especially on community organisation, indigenous population, gender issues, and attention to vulnerable groups. Because 1 think that part is not within the [CONAFOR] training scheme $(10,2013)$.

According to the person in charge of the development of the courses, the results and statistics derived from the certification scheme could also help to know more precisely the training needs of the TAs $(5,2013)$. 
Although there have been incremental improvements in the capacities and training options for TAs, many informants stressed the need for the development of an integrated evaluation system on TAs work and capacities $(9,5,2012 ; 10,13,14,15$, 2013; 12, 2014).

\section{Appropriateness of the certification process}

In 2011 a certification process for TAs was established. This is so far the most significant, but also controversial measure taken by CONAFOR in addressing TAs performance. As explained in chapter 8 , certification consists of a set of evaluations of capacities and skills by third-party evaluators (Del Angel-Mobarak, 2012), such as research and education organisations; and a certifier council (DOF, 2011), which makes the final decisions.

It is worth mentioning that the certification process was not a CONAFOR initiative, but rather was a requirement imposed by the WB as part of a new loan that would give continuity to PES programme and support activities for the establishment of the REDD+ scheme (CONAFOR, 2011; 5, 2013).

Although all the interviewees recognised the need for a certification process, most of them also acknowledged that certification per se is not enough, since it evaluates only the technical skills of potential TAs to entry to the LAST, and it does not pay attention in the performance of TAs in the field.

I think it is necessary to make an evaluation [...]. Certification is one part, which allows them to entry the CONAFOR register. [...] The CV they present, the interview [...] gives some confidence that the [...] TA has some degree of responsibility. But it would also be good to evaluate their performance $[. .].(11,2013)$

Additionally, the criteria and procedures of the certification have been widely questioned. Both NGOs and other groups have been sceptical about the potential to improve the quality of technical services $(50,2013)$. The division of tasks in CONAFOR is a constraint; the evaluation of TAs performance in the different programmes it should be a shared responsibility between the offices of Training and TAs affairs and each programme management. As 5, said:

[...] Our limit in this department is the work of certification and from that, each programme must establish its own ... [...] evaluation standards of performance $(5,2012)$.

Clearly, TAs themselves have responded negatively about certification, as expected by CONAFOR. 
[...] [the TAs] are furious about that [certification], because we are asking them for training and to be more rigorous [...] $(4,2013)$.

TAs across the country have spoken out against certification. According to CONAFOR employees, TAs consider their long experience should be enough to accredit their work, and that certification is over-regulatory. More detailed information about the opinions of TAs on certification will be addressed in chapter 10 .

According to CONAFOR interviewees, TAs have complained extensively, but few proposals have been presented. The complaints have been done individually and most of these complaints have been verbal $(5,2012)$. It was also acknowledged that CONAFOR received a number of petitions with lists of demands from the TAs, but these immediately became classified documents. In addition, by recommendation of the legal department of CONAFOR, these petitions were not officially answered, in order to prevent these from being used by TAs to file a lawsuit $(5,2012)$. The way in which CONAFOR addressed the problem was through the publication of an online document, which responded to the TAs' frequent asked questions about certification (FAQs) (5, 2013).

[...] We have received manifestos, petitions [...]. But they have become classified documents, which I could not share, because they were not even answered, the unit of legal affairs staff was very fearful that [...] if we answered, they would use it to sue CONAFOR before a court [...]. [...] So, we answered: all your questions are in this document, you can check it on the website [...]. [...] because I am not going to answer you, you leave me alone, because [...] if I answer you, we are going to enter a lawsuit [...]. All your questions are here, so read all the answers [...].

\subsubsection{Measures taken by CONAFOR to improve TAs performance}

Although a comprehensive and long-term mechanism has not been developed to address the TAs issues as a whole, CONAFOR has established several measures to solve specific problems. These measures, which have been mentioned separately throughout section III of this thesis, are categorised in three groups and summarised in Table 9.4, including illustrative quotations. These measures have partially worked, due to the lack of operational capacities of CONAFOR to ensure they are met. TAs also have their own strategies to dodge these measures, many of which are well known by CONAFOR but often overlooked $(56,54,5,2013 ; 12,2014)$. 
Table 9.4. Summary of measures taken by CONAFOR to improve TAs performance

\begin{tabular}{|c|c|}
\hline Category & Measure \\
\hline \multirow{2}{*}{$\begin{array}{l}\text { To improve the } \\
\text { entrance of TAs in } \\
\text { CONAFOR } \\
\text { programmes, and the } \\
\text { quality of services } \\
\text { provided }\end{array}$} & $\begin{array}{l}\text { Establishment of CONAFOR' LAST } \\
{[\ldots] \text { The governing board [...] instructed CONAFOR to establish an evaluation }} \\
\text { system for TAs performance in 2004. It took } 4 \text { years to do so, because at that } \\
\text { time there was not even a list including all the TAs in Excel [...], and each } \\
\text { CONAFOR programme worked independently [...]. [...] If one TA misbehaved in } \\
\text { one programme, then s/he could just move to another programme, and so on. } \\
{[\ldots] \text { In [...] 2008, we began to work in coordination with all CONAFOR areas to }} \\
\text { determine the basic requirements for TAs [...] [and] the [...] LAST was } \\
\text { established }(5,2013) \text {. }\end{array}$ \\
\hline & $\begin{array}{l}\text { Certification process } \\
{[\ldots] \text { I think it is necessary to make an evaluation [...]. Certification is one part, }} \\
\text { which allows them to entry the LAST. [...] The CV they present, the interview } \\
\text { and everything else gives some confidence that the [...] TA has some degree of } \\
\text { responsibility. But it would also be good to evaluate their performance [...] (4, } \\
\text { 2013). }\end{array}$ \\
\hline \multirow{3}{*}{$\begin{array}{l}\text { To inform beneficiaries } \\
\text { about their } \\
\text { relationships with TAs }\end{array}$} & $\begin{array}{l}\text { Contract between beneficiaries and TAs } \\
\text { The contract establishes the amounts of payments the TAs receive, the } \\
\text { responsibilities of each one, and [...] a recession of contract clause [...], } \\
\text { allowing both to stop the relation if it is not convenient of one of them (12, } \\
\text { 2014). }\end{array}$ \\
\hline & $\begin{array}{l}\text { Separate payment for TAs } \\
\text { [...] Recently CONAFOR began to pay directly for the TAs, to ensure that the } \\
\text { beneficiary does not take the TAs' money, although in general [...] it was the } \\
\text { TAs who [...] used to charge the beneficiaries extra money [...]. (14, 2013). }\end{array}$ \\
\hline & $\begin{array}{l}\text { Rights and obligations workshops } \\
\text { "Among other things, we inform beneficiaries about [especially] their right to } \\
\text { dissolve the contract with TAs in case of non-compliance }(12,2014)\end{array}$ \\
\hline \multirow{5}{*}{$\begin{array}{l}\text { To ensure TAs } \\
\text { compliance }\end{array}$} & $\begin{array}{l}\text { Clause of co-responsibility TAs-beneficiaries in PES contract } \\
\text { What we did to solve that was to insert a co-responsibility clause in the } \\
\text { contract, to force the TAs to comply }(4,2013) \text {. }\end{array}$ \\
\hline & $\begin{array}{l}\text { Community Assembly agreement that demonstrate that the community } \\
\text { made collective decisions about participating in the programme, selecting } \\
\text { activities, and using of the PES money. }\end{array}$ \\
\hline & $\begin{array}{l}\text { Best Practices Management Guide/Manual in participatory way } \\
\text { to make sure that TAs include the community in the decision making }\end{array}$ \\
\hline & $\begin{array}{l}\text { Geo-referencing activities in PES polygons } \\
\text { [...] We are now asking for the geo-referencing of works, signs, firebreaks, } \\
\text { reforestation sites, sanitation works, soil conservation and restoration works. } \\
\text { In this way we are going to check in the field [...] in a timely manner. [We } \\
\text { used to ask for] a sketch, but from this year the shape file is being required } \\
{[\ldots](12,2014) \text {. }}\end{array}$ \\
\hline & $\begin{array}{l}\text { Limited number of beneficiaries assisted by TAs in ORs } \\
\text { [...] There are some [TAs] who have more beneficiaries than they can attend } \\
\text { [...]. This is another failure, and for this reason a limit of beneficiaries has been } \\
\text { set, because there were some TAs that had twenty beneficiaries, but they did } \\
\text { not help anyone }[. . .](13,2013) \text {. }\end{array}$ \\
\hline
\end{tabular}




\subsubsection{Communities speaking: Six cases of interaction between PES programme beneficiaries and TAs}

Beyond understanding the conceptual and institutional aspects of TAs and perceptions of their performance, it is also critical to consider the ways in which TAs are actually inserted in local contexts, and the dynamics that occur there. So, the perception of the beneficiaries of the programme is necessary. This section includes a brief account of the experiences of 6 communities involved in PES programme, regarding their interaction with their respective TAs. It includes basic information about the communities, the significance of their participation in the programme, the particularities of the interaction between them and their TAs, and their opinions on the TAs performance and their expectations.

Table 9.5 presents a summary of the roles, as well as good and bad practices carried out by TAs in each ejido. Some of them have replaced their TAs.

\section{i. Ich}

Ich was accepted into the programme for the period of 2008-2013, and two years later an additional area was included into the polygon during my data collection period, being this portion the only one with active PES. They are willing to apply again, because they need the money to continue the conservation activities in the whole area. The ejido has participated in many other projects especially on wildlife, but they have not obtained the financial outcomes they expected. This is other reason why the money received from PES is much appreciated. They see PES as a reward for participating in other forest conservation programmes from more than 10 years. They have designated a portion of the community as a communal conservation area, which was enrolled in PES. The former comisario (local chief) of the ejido is a very influential actor; he is biologist, who, in coordination with the municipal ex-president, also biologist, promoted many environmental programmes and projects during their administrations in the zone. The participation in PES was a natural decision for them, because they were already focused in similar projects. The community has a very good interaction with their TAs (which consist of a group of four women).

Roles of TAs: The ejido is satisfied with the TAs' work, they have fully complied with the activities in PES, and provided guidance, accompaniment and mediation. They have also helped to look for more programmes in which the ejido can be involved, and helped in writing the proposals, but, informants said, they focused on their work within the PES programme, and have not gone further, while the ejido would like them to look for more alternative productive activities. 
The girls [...] are very observant to what the rules [ORs] indicate. And they have done well until now, because they have worked in many other ejidos [laughs]. [...] They already have many years here in the region, but I believe that it is also necessary that they themselves help us generate ideas of [productive] projects, to walk alone as an ejido. [...] [We all] together need to develop projects with more economic and environmental impact [...] to no longer ask for support from the government, but to be able be independent $(34,2014)$.

Importance of TAs in the development of PES: The translation and compliance of the rules, helping in the financial analysis part, estimating costs of projects.

Position regarding TAs: They see the TAs as partners in the development of the ejido. They have good relations and mutual trust.

Vision about CONAFOR: They consider that CONAFOR employees have been far away from the ejido, so the work of TAs has been very important for them.

Perspectives: They identify the need for local technicians, and more training in technical issues at the local level.

Other intermediaries mentioned: the Zicuirán-Infiernillo Biosphere Reserve staff

\section{ii. Cir}

This ejido is in the driest portion of La Huacana, Michoacán, where even the wet-season agriculture is difficult. The main activity is fishing in a reservoir. Recently, fish production has dwindling. Poverty and high marginalisation is common. As in Ich, the arrival of environmental programmes in the early 2000s was a turning point in the life of the community and changed their vision on the forests. The establishment of the ZicuiránInfiernillo Biosphere Reserve also brought new possibilities of projects, but at the same time constrained their productive options. The ejido enrolled in Biodiversity PES programme in 2008, having applied many times before being accepted. They replaced their first TA because he suddenly abandoned them, leaving them with half-finished activities. But they decided to continue working in the PES activities for one year without a TA, but the payments stopped. They did not inform CONAFOR about this problem, and CONAFOR did not realise the situation. One day by chance the comisario (head of the ejido) met CONAFOR employees and was informed that the ejido was being penalised for failure to submit activity reports on time, which is a responsibility of the TA. In the end, CONAFOR and the community agreed to continue the schedule with a year's delay. The ejido hired a new TA, but he also left soon after. Finally, they are concluding the activities with the help of a third TA. Cir's people are really enthusiastic about continuing in the programme, because the money they receive is really necessary for them. The ex- 
comisario sees the programme as a reward (or a prize) for many years participating in environmental projects with no pay.

Our first TA [...] got us into a mess. He did not visit us, I talked to him on the phone and he did not answer [...]. We started having problems because PES money no longer came. [...] All of us were resentful and distrustful... [...] One day after a meeting in La Huacana I met the PES [state-level] manager and I asked him about our payment. [...] And he told me [...] that our payment was suspended because our TA never delivered the reports. And I did not know that. [...] So, he told me that the ejido was penalised and that we had to return the money from the programme. [...] And l asked for an opportunity to look for another TA [...] to help us accomplish the missing activities. And he accepted. [...] I immediately called a meeting in the ejido to warn them of what happened... [...]. [The PES state level manager] came to the ejido [...] and brought [...] a team of two TAs. But then, the team had a conflict [...] and finally [one of them] stayed with us as a TA. CONAFOR has many requirements to fix these problems [...], so we had to go to the central offices, [...] and spent almost a year doing paperwork [...] $(37,2014)$.

Role of the new TA: He has visited the ejido frequently and carried out workshops and fieldwork activities.

We still cannot say if he is good or bad, [...] we do not have any complaints so far, all the work is done, and he has been present in meetings, workshops. But we're just getting started $[. .].(37,2014)$

Importance of TAs in the development of PES: the ejido considers that TAs are especially important to provide them guidance in the search for more projects and support, to connect and communicate with governmental actors, and to improve the capacities of the ejido.

Position on TAs: People from the ejido are disappointed and unconfident about TAs. But they are very enthusiastic about the PES programme, and that is the reason they accepted a new TA.

Vision about CONAFOR: Before the problem with the first TA, the ejido had very little communication with CONAFOR. For this reason, CONAFOR took a year to realise the problem. After the problem with this TA, the relationship between the ejido and CONAFOR is a little closer. The people of the ejido have a lot of respect for the CONAFOR employees who have helped them to solve the problems and visited them. 
Perspectives: Although the informants considered that the presence of TAs is relevant, they identified the need for technicians who can train the ejido to prepare applications to programmes, and in the writing of proposals to participate in new projects.

\section{iii. Cresm}

Cresm is a very complex ejido, it has a large population, and their people are very outspoken and politicised. Cresm is located within the Monarch Butterfly Biosphere Reserve, the most prominent and well financed NPA in México. Before the establishment of the reserve, a big part of the community was devoted to forest use (timber and non-timber production). People saw the reserve as an imposition and resisted to it by clearing and burning the forests. Many governmental and nongovernmental organisations have been working there in order to stop the clearing and to convince people about forest conservation, and the communities have learnt to take advantage of this, because there is a large investment from national and international organisations. PES programme in the region is only one of the numerous programmes with similar objectives, which overlap geographically, so sometimes ejido people are confused by the different rules. In the area there is an indigenous community and an ejido with the same name, but they are ideologically divided and conflicted. In 2013, the comisario had an environmental ideology, an educated man with a strong and structured discourse about the forest's conservation. He recently discovered that the ejido had been enrolled in Hydrological PES from about 2008, but this was concealed from most of the members of the ejido, and the former ejido authorities kept the money obtained for themselves. According to this new comisario, this must have required the complicity the TA operating at that time in the ejido (who consequently was kicked out), and maybe also the CONAFOR employees. The problem was discovered during the last year of the contract. The new comisario let the Assembly know about this situation, and they decided to apply again to the programme. They have had two TAs. The first one is a very influential person in the area, who is working with many communities and ejidos of the region. Their conflict with him started when the hidden PES contract came to light, and it has continued because he has kept important ejido information and did not want to return it to them. Then, the ejido contracted another TAs, a team composed of young unexperienced biologists.

Role of $1^{\text {st }}$ TA: ejido members decided to fire their first TA because they discovered he committed fraud. He also exerted his power over the communities and retained information and documents. He also used the signatures of the authorities of the ejido without their consent, in order to speed up paperwork.

We replaced our TA for a thousand reasons. [...] He does not know anything and at the same time he knows everything [...]. And he hid a lot of things from us. [...] According to CONAFOR, our TA should have informed us that our ejido had already participated in 
CONAFOR programmes, that we had PES, because our authority betrayed us and fled. [The TA] should have informed us [...] He has political [...] power and contacts. We did not want to make a written complaint. [...] We did it verbally [but we told CONAFOR] that we would [...] provide all the evidence at the right time $(32,2014)$.

Role of the $2^{\circ}$ TAs: Accompaniment, guidance in technical issues, understanding and translating of the ORs, looking for more governmental support.

[...] Our new TAs are 3 biologists. We met them as TAs of another ejido, we were surprised that they accompanied their people all the time. [...] They are honest, transparent, but they are still green [newbies] [...]...they are non-political... and people easily eat them $[\ldots](32,2014)$.

Importance of TAs in the development of PES: They are important in the ejido to carry out the technical tasks, and for submitting requests and applications for new support and programmes. In this case, the communication and negotiation between actors is in the hands of the ejido authorities.

Position regarding TAs: In this ejido, TAs are just employees, who help in the implementation of the programme, but they are not involved in the decision making or any internal process.

[The TAs] do their technical part, but as for the political part, we do it [...]. We choose [...] the rivals of the community, not the TAs. We decide when and with whom to fight, not the TAs $(32,2014)$.

Vision about CONAFOR: They have an irregular relation with CONAFOR employees. They are suspicious about CONAFOR, because they believe that CONAFOR has always secret intentions, for instance, that its programmes are used in a political way.

Other intermediaries mentioned: Alternare (NGO), and the Biosphere Reserve staff.

iv. Ahu

This ejido is included in the core and buffer zones of the Sierra de Manantlan Biosphere Reserve; other parts of the ejido have been devoted to forest harvesting. The ejido is composed by three sections. The first and second sections correspond to lands allocated to ejidatarios by the government in the 1930s. But there was a third allocation of land in 1985. This portion is far from the other two, and actually people who received these lands are organised informally as a separate ejido. This area is not valued by the people of the first and second section, because it belongs to the core area of the Biosphere Reserve, so that harvesting and any other kinds of use are forbidden. People of third section asked the ejido authorities for permission to apply to the PES Programme, 
because no other activity is permitted there. The authorities allowed it, and they were accepted in the programme. After three years, people in the first and second sections started to see achievements and realised that people in the third section were receiving money, so they wanted to apply too. But they cannot apply until the third section finishes its contract, because officially they are not separated, and for CONAFOR the whole area counts as a single ejido. They have agreed how to divide into two ejidos, but the procedures to do it are long. They are very happy with their TA, who has helped them a lot in searching for projects, in the management of the PES area, in the paperwork related to the establishment of the new ejido, and in the conflict management with the $1^{\text {st }}$ and $2^{\text {nd }}$ sections.

[...] [Money] we know how to manage [...]. [...] We are even going to distribute it [among the people of the ejido], [...] then our TA will come and make a cashier's cut and bring a list [of expenses]. [...] We then take a copy and give one to each ejidatario [...] to see what we will spend throughout the year [...]. [Our TA] is supporting us well. [...] In fact we are recommending him [...]. And many people have asked us about him [...] He is a very good person, he advises well, [...] I call him for almost everything.[...] In CONAFOR meetings [...] they tell us: your technician has to be with you when you need it [...]. Because there seem to be a lot of complaints [...] that many TAs do not even visit the ejidos and get no support from beneficiaries [...]. [...] And we were the only ones who did not complain [...]. He [...] is efficient, and at the moment we ask, he comes [...] to help us $(39,2014)$.

Role of TA: Accompaniment, help in administration of money, keeps accounts clear, mediation and negotiation in internal problems, translation and guidance in technical issues, mediation and facilitation of interaction with CONAFOR, and facilitation of processes.

Importance of TAs in the development of PES: The 'ejido' is very happy with its TA, and he has a highly relevant role. With him, the ejido started the participation in PES programme; he is a key actor in the internal and external negotiation and conflict management around PES, and he is also helping in the process of separation of this portion of the ejido.

Position regarding the TAs: Although the importance of the TA is recognised, it was not clear if people consider him an authority figure, but dependence on him is evident. Informants stated that they feel privileged having this TA, because they have heard that most of TAs in the region are not good.

Vision about CONAFOR: Apparently most of the interactions with CONAFOR have been mediated by the TA. 
Perspectives: This ejido is in transition, this has been the first programme in which it has participated, and it cannot be involved in other projects until the separation of the parts is complete. In the future they plan to get more support with the help and facilitation of the TA.

Other intermediaries mentioned: JIRA, the Biosphere Reserve staff.

\section{v. Ton}

This ejido is in an agro-industrial town also called Ton, and is devoted to livestock and agriculture, especially blue agave production and manufacturing of tequila and mezcal. Natural vegetation of is TDF, which has historically been undervalued, and is under great pressure as land is needed to expand the growing area of blue agave. This ejido has many ejidatarios (about 300), and many of them live in USA. Most of the lands have been divided into agricultural plots, so that the portion of communal areas with natural forest has been considerably reduced. They started participating in the programme because they realised that they could obtain more profit having PES than by keeping livestock there. During the data collection period, the ejido had two polygons with Biodiversity PES. Although people see advantages, there is also much pressure on the areas with PES. According to the ex-comisario, the current authorities did not have any interest in carrying out this kind of programme. There were people asking permission to use the current PES area to introduce livestock when the contract finished. For Ton's ejidatarios, PES is just other possibility to obtain benefit from those lands. The community was satisfied with their TA, even though there are rumours that he is not very good.

[...] Our TA works well, [...] because some people say that he was not very good [...] but he works well with us [...]. [...] People from JIRA [...] provided us with the TA. We do have confidence in him [...] because he is a reliable [...] person. [...] We never had any problems with him. He is the one [...] who does the paperwork and tells us about the meetings with CONAFOR, [...]. And he also appears at those meetings, [...] and explains to us if we do not understand [...] things. He comes [...] every week, we go to the forests [...] he [...] checks our activities [...]. He is the one [...] who tells us about the meetings with CONAFOR, [...]. With the field activities [...] we already have some experience. [...] But he [...] is important, especially for the paperwork [...] $(42,2014)$.

TA Role: He oversaw handling paperwork, encouraged people to attend meetings with CONAFOR and accompanied them, explaining the doubts, visiting the community to check the activities in the forests

Importance of TAs in the development of PES: The TAs has fulfilled all the activities required by the programme, so the ejido people are satisfied with him. 
Vision about TAs: They trust on him, because consider him an honest person, and have not had any problems. But they have heard this TA has not good reputation with other beneficiaries.

Perspectives: Since the ejido has a very profitable agricultural activity, the informants said that when the PES contract finishes, the ejido will probably devote the area to other activity.

\section{Other intermediaries mentioned: JIRA}

vi. Zen

This ejido is a remote community surrounded by forests, and has three small settlements. Subsistence agriculture (maize) and livestock are the main activities of the people. They have had Biodiversity PES from about 2010 (they did not have a clear idea about the dates). They appreciate very much being part of the programme, because consider it "has helped to stop the destruction of the forests". The interviewees recognise themselves as he forest destruction agents to be controlled. But they say not everyone sees the programme and the reserve as something good. The local history is related to degradation, because prior to the establishment of the ejido, all lands was owned by a rich man, who used to allow campesinos to clear the forest for agriculture, and he appropriated half of the production, and also rented them the needed tools. The farmers were always in debt to him, and they had to clear and cultivate again to return the money, and so on. With the establishment of the Biosphere Reserve, and before they applied to PES programme, some people in the ejido felt distrustful of the government representatives who were trying to convince them about the benefits of the reserve, and they also were afraid of being deprived of their lands or losing rights over them. But finally, the Assembly agreed to be involved in PES programme. Zen has a community promoter, and a TA, who work well together. They have had two TA, the first one is an engineer, who had been working with many communities in Nayarit, Colima and Jalisco states. They had conflicts with him because he used to make many decisions by his own, mismanaged money and projects, and he also treated them badly, speaking rudely to them. With the mediation of the community promoter and CONAFOR employees, they decided to fire him, but he kept important information, and did not want to return it to the ejido. After this experience the ejido people became very attentive and demanding with the new TA, who so far has been correct, but they have no clear view about his work. In this community, the collaboration of other actors who have done intermediation for various purposes has become evident. For example, the JIRA inter-municipal organisation and the Reserve employees have facilitated the ejido's involvement in programmes such as PES. Likewise, the presence of a community promoter working in the area has been fundamental, for example in the process of 
replacement of TA, because the ejido did not know that they had the right to cancel the contract. This promoter also helped to find a new TA and to update him on the progress of the ejido in the programme.

TA comes to [...] train us. We call him when something happens [...] or when we do not understand something. Then he comes or sends the promoter [...]. And he explains the things [...]. For now, we have a lot of confidence in the new TA [...] because he comes and advises us with good words, [...] and we make agreements among all. [...] We are at home with him [...] he speaks very honestly [...]. [...] He is more accessible and [...] he listens more to the people and fits the needs of us [...]. $(45,2014)$

Our first TA [...] sometimes [...] imposed the decisions. [...] We used to do what he said [...], and he began to leave us alone and [...] then we began to fail, because we needed his advice. At the end he talked to us with rudeness and [...] it was too much for us [...]. In the Assembly all the people wanted to fire him [...], [...] because at the end all the time we were scolded [...]. And he said that we would not be able fire him. [...] Then people of JIRA came, with people of the Reserve, and even those of CONAFOR, who explained us what the contract was about [...], the ejido is the boss. [...] He [...] left the things blocked, and the new TA with the [community] promoter had to fix the problem [...], because we did not get the payments [...] $(44,2014)$.

TAs role: The former TA resorted to abusive practices, such as imposition of decisions and ill-treatment of people. He did not interact well with the people of the ejido, nor did he provide enough information to facilitate decision making. In the end, he threatened them to try to avoid the contract cancelation and he tried to retaliate when the ejido dismissed him. He withheld important information of the PES programme and did not send the last reports to CONAFOR.

Second TA: At the time of the interview, the new TA had only been in position for a short time. But he had already facilitated involvement in other programmes. He also mediated communication with CONAFOR in specific cases.

Importance of TA in the development of PES: This new TA is working in coordination with the community promoter, so he visits the ejido every two months, while the promoter does every week. They need the TA to resolve certain doubts about the programme.

Vision about TAs: they have changed their opinion. Confidence was seriously affected because of the problems with the first TA. At first the people of the ejido saw TA as a figure of authority that told them what they had to do. 
Vision about CONAFOR: CONAFOR has also played an important role in the community. They have explained about their rights and mediated the process of replacement of TA.

Perspectives: After the conflict with the first TA, they understood that the decision to maintain or remove a TA depends on them. And with the second TA they are more demanding and do not submit to his decisions. Their posture in the relationship became a little stronger.

Other intermediaries mentioned: the community promoter, JIRA, the reserve staff, CONAFOR. 
Table 9.5. Roles and bad practices carried out by TAs in 6 communities. The ejidos that have had two TAs are included in separate columns: Cir $1^{\text {st }}, 2^{\text {nd }} ;$ Cresm $1^{\text {st }}, 2^{\text {nd }} ;$ Zen $1^{\text {st }}, 2^{\text {nd }}$. In the case of Zen, the community promotor is added as Zen $\mathrm{P}$, since he acquired a relevant role.

\begin{tabular}{|c|c|c|c|c|c|c|c|c|c|c|c|}
\hline & \multirow{2}{*}{ Specific actions } & \multirow[t]{2}{*}{ Ich } & \multicolumn{2}{|c|}{ Cir } & \multicolumn{2}{|c|}{ Cresm } & \multirow{2}{*}{$\begin{array}{c}\text { Ah } \\
\text { u }\end{array}$} & \multirow{2}{*}{$\begin{array}{c}\text { To } \\
\mathbf{n}\end{array}$} & \multicolumn{3}{|c|}{ Zen } \\
\hline & & & $1^{\text {st }}$ & $2^{\text {nd }}$ & $1^{\text {st }}$ & $2^{\text {nd }}$ & & & $1^{\text {st }}$ & $\mathbf{P}$ & $2^{\text {nd }}$ \\
\hline \multirow{17}{*}{ Roles } & $\begin{array}{l}\text { Adapting knowledge to local } \\
\text { conditions }\end{array}$ & & & & & & & & & & \\
\hline & Accompaniment & & & & & & & & & & \\
\hline & Looking after benef. & & & & & & & & & & \\
\hline & Being a spokesman & & & & & & & & & & \\
\hline & Organising activities & & & & & & & & & & \\
\hline & Empowering beneficiaries & & & & & & & & & & \\
\hline & Attesting compliance & & & & & & & & & & \\
\hline & Facilitating processes & & & & & & & & & & \\
\hline & Handling paperwork & & & & & & & & & & \\
\hline & Following up of activities & & & & & & & & & & \\
\hline & $\begin{array}{l}\text { Mediating } \\
\text { interactions/conflicts }\end{array}$ & & & & & & & & & & \\
\hline & Promoting the PES prog. & & & & & & & & & & \\
\hline & Linking different actors & & & & & & & & & & \\
\hline & Training & & & & & & & & & & \\
\hline & Informing benef/CONAFOR & & & & & & & & & & \\
\hline & Translating tech. language & & & & & & & & & & \\
\hline & Explaining terms/procedures & & & & & & & & & & \\
\hline \multirow{14}{*}{$\begin{array}{l}\text { Unethical } \\
\text { practices }\end{array}$} & $\begin{array}{l}\text { Bribing ejido authorities to } \\
\text { be chosen as TA }\end{array}$ & & & & & & & & & & \\
\hline & $\begin{array}{l}\text { Enrolling in the PES prog. } \\
\text { behind the back of the ejido }\end{array}$ & & & & & & & & & & \\
\hline & Requesting extra money & & & & & & & & & & \\
\hline & $\begin{array}{l}\text { Collusion with another } \\
\text { person who acts as frontman }\end{array}$ & & & & & & & & & & \\
\hline & $\begin{array}{l}\text { Coercion and threathening of } \\
\text { beneficiaries }\end{array}$ & & & & & & & & & & \\
\hline & $\begin{array}{l}\text { Rude language and } \\
\text { humiliation }\end{array}$ & & & & & & & & & & \\
\hline & Administration of money & & & & & & & & & & \\
\hline & $\begin{array}{l}\text { Illegal acts on behalf of the } \\
\text { beneficiaries }\end{array}$ & & & & & & & & & & \\
\hline & Monopoly of work areas & & & & & & & & & & \\
\hline & Control of information & & & & & & & & & & \\
\hline & Retaliation against benef. & & & & & & & & & & \\
\hline & Abandonment of benef. & & & & & & & & & & \\
\hline & Poor compliance of activities & & & & & & & & & & \\
\hline & Little presence in PES areas & & & & & & & & & & \\
\hline
\end{tabular}




\subsection{Discussion}

The findings of this chapter are discussed in two sections. 9.5.1 is about the implications of the relationship and interactions of CONAFOR and TAs, and 9.5.2 addresses aspects of the relationship between TAs and beneficiaries. Issues such as responsibility, accountability, blame avoidance, and power are elements encompassed in the analysis.

\subsubsection{Accountability and blame avoidance as the keys to understand the relation between CONAFOR and the TAs}

There are some vicious cycles in the relation between CONAFOR and TAs. The responsibility for the programme is shared by CONAFOR, being the developer and partially executor of the programme, and the TAs as the implementers, who, have consciously and voluntary assumed that responsibility. But they maintain a mutual blame game (Hood, 2011) that gives rise to a series of spaces, which seem to be advantageous for both, since it allows justifying fissures in the development of the programme. The lack of regulatory frameworks, together with the lack of monitoring of TAs performance has blurred problems that occur at the local level, and had opened a space of action that enables impunity and on-going blame-game.

The CONAFOR-TAs interaction clearly follows the model described by the agency theory (Jensen \& Meckling, 1976; Mitnick, 2011), where the principal (CONAFOR) hires the agent's external services (TAs) to carry out the programme at the local level. CONAFOR has delegated authority to the TAs, a heterogeneous group of organisations and individual professionals who participate in the programme motivated by a multiplicity of interests, of which CONAFOR's interest is one. The model assumes an asymmetric distribution of the information, since the TAs carry out their work in local settings, which are partially within the reach of CONAFOR.

In addition, since CONAFOR cannot fully observe the actions of the TAs, it assesses their performance in technical terms, and based on the reports presented periodically. However, CONAFOR does not understand the depth and quality of the services actually provided (moral hazard), so it has to rely on that information, because local monitoring would involve a cost that it is not willing to pay. In that space the TA has the freedom to perform opportunistically. Figure 9.2 shows a scheme of the different factors influencing unethical practices. 
Figure 9.2 Contextual factors of incidence of unethical practices of TAs

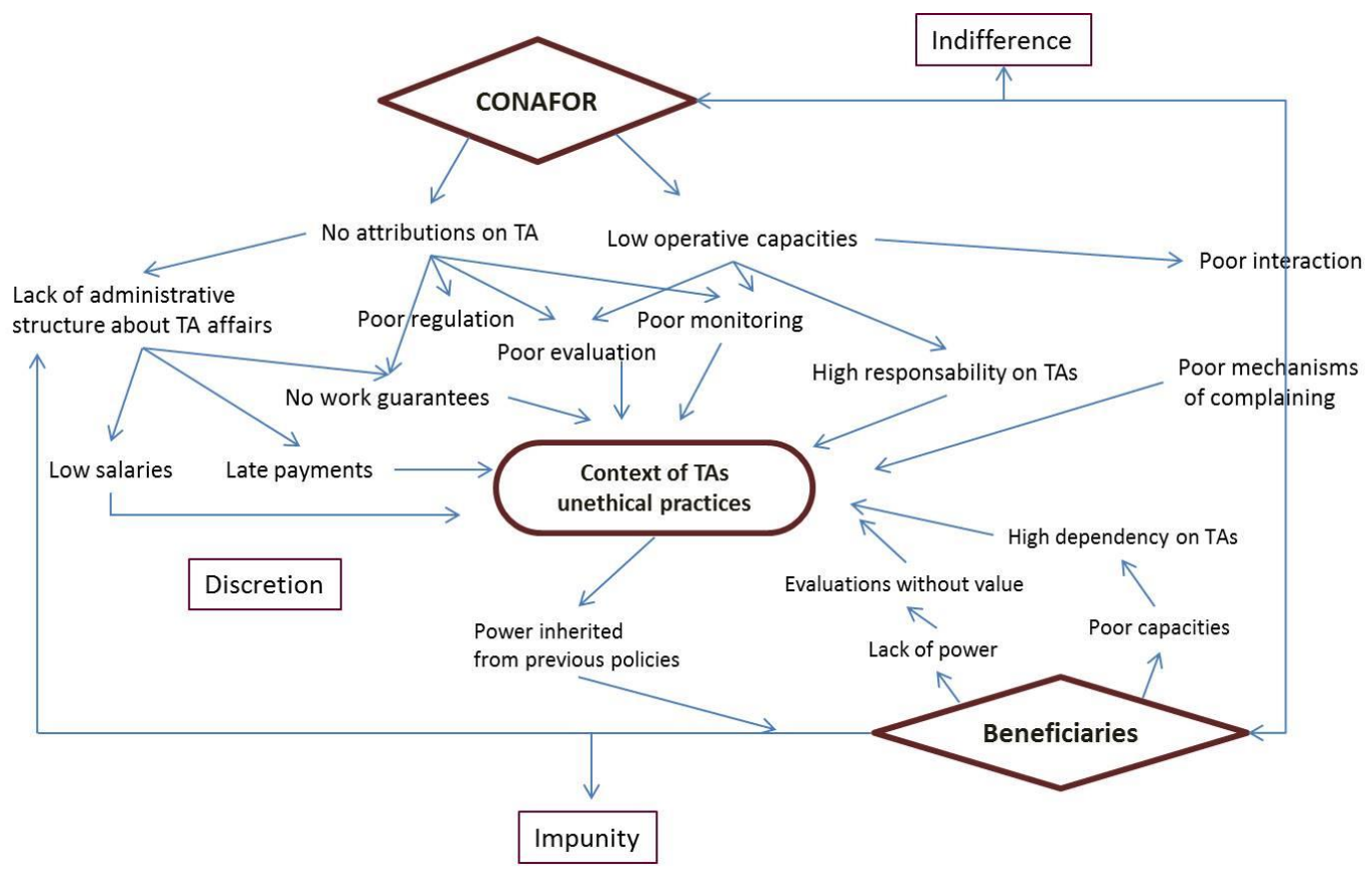

In addition, there are factors that directly affect the performance of TAs in the field, such as insecurity, lack of enough resources, competition, conflicts within the beneficiary communities, among others. These adverse conditions can be used by TAs as a way of justifying poor provision of technical services. Although this model is somewhat deterministic since the interests and actions of the agent and principal are assumed to be rational and predetermined, it does help to illustrate a labour relationship that is typical in governmental organisations and other sectors. In this scheme, the principal must find the appropriate inducements to encourage the agent not to deviate from the objectives. In this case, the incentives have been tended to be negative, as is the case of certification. CONAFOR has not sought more effective ways of positively encouraging the desired behaviour of TAs, such as rewards for good compliance. 
But this model of relationships is intersected by another goal of CONAFOR, which has led to the establishment of strategies for blame avoidance (Hood, 2011; Rajão \& Georgiadou, 2014). As shown in this thesis, the TA scheme has important regulatory and operational gaps. It is certainly arguable that there is an intention to keep things as they are with respect to the TAs, since the existence of a perpetual scapegoat, and one that already has a bad reputation, may be advantageous to CONAFOR, in order to have someone to point to, through whom CONAFOR can save its skin.

On the other hand, middle and low-level CONAFOR staff, especially the state-level employees, are also included in the strategy of blame avoidance by diffusing responsibilities (Rajão \& Georgiadou, 2014). A few employees (on average 3 per state) are in charge of the PES programme and have a gradually increasing number of tasks and no authority to make decisions about TAs. However, monitoring in the field depends on them and are continuously under pressure to losing credibility in CONAFOR central office's eyes, and consequently at risk of losing their jobs. As a TA (22) said, they are "living in a sea of uncertainty" $(22,2014)$.

Additionally, CONAFOR has delegated responsibility for the performance of TAs to beneficiaries, who are the weakest link in the chain, and who can be blamed if they do not complain formally about their TAs, or for not cancelling the TA contract in case of non-compliance.

Finally, the very process of certification can be seen as another strategy for blame avoidance. Certification is a formal measure that apparently addresses the agency problems of TAs to compelling TAs to demonstrate their competence. The idea was developed by an organisation specialised in governmental evaluations. Reputable and "neutral" academic organisations working as the third parties carried out several evaluations for certification, which confers objectivity to the process. Certification seems to be another way of delegating responsibility to other institutions, where the results of the process is of lesser importance. Rather, it is a way to show CONAFOR's commitment to respond formally and objectively to criticisms about TAs performance, while avoiding having to do it themselves.

It is probable that none of these strategies were shrewdly planned at the outset; perhaps CONAFOR has only taken advantage of certain existing situations and used them to cover their backs in what is obviously a difficult operating space.

The lack of regulatory frameworks, together with the gaps in the monitoring of the TAs performance, has blurred problems occurring at the local level, opening a free space of impunity. Unethical practices operate under the carpet of technical procedures and the ORs. 
As is the case of many programmes, PES results are presented in bureaucratic terms, such as of investment per hectare, number of beneficiaries involved, number of hectares enrolled in PES, and of hectares of avoided deforestation. Thus, many aspects of the functioning of the programme are never reported and, are therefore, invisible. CONAFOR constantly needs to improve the results of the current year over the previous year, in order to maintain its own financial flows and standing, so is not in its interest to make visible the operational weaknesses, which, if known, could generate reductions in the budget and threaten the programme itself.

\subsubsection{Communities learn how to balance the relations of power with their TAs}

It is clear that the communities have had different experiences with TAs. The communities of Cir, Cresm and Zen all replaced of their first TAs for different causes. Within the framework of PES, communities have a limited power in decision-making, and they are always supervised by intermediaries. For instance, the activities in their own forests are decided with respect to a set of alternatives or "a menu" previously defined by CONAFOR, which are considered adequate for the maintenance of the provision of ES. They simply choose some activities from this "menu", and that decisionmaking is mediated by the TAs. This also reflects the CONAFOR's lack of trust in beneficiaries. Some communities, such as Zen, have even learned and appropriated a discourse, in which they see themselves as forest destroyers who need outside help to control their own actions. In Cir, the community is more limited due to its poor socioenvironmental, educational and economic conditions. The community has been sensitised to environmental issues and developed interest in PES due to previous programmes that gave them some visibility and hope. On the other hand, the large, politicised, divided but highly empowered community of Cresm has economic support for forestry conservation from national and international organisations, and it has acquired a discourse of forest conservation, since it has proved to be advantageous politically and economically. For this ejido, TAs are employees who work in the community to solve specific problems. In two cases, local external actors have emerged and become mediators through the process of replacement of TAs. In the case of Zen, the community authorities did not know that they had the right to change TA. In Cresm, the internal conflicts and the large size of the community made possible a fraudulent situation where there was evidence of collusion between local authorities, TA and perhaps CONAFOR. In Cir, they simply got paralysed by abandonment of their TA and did not have the information needed to proceed. It took them one year and a chance event (causality) for things to get started again. In all the cases the lack of communication between CONAFOR and the beneficiaries themselves, as well as the lack of simple mechanisms that facilitate the rapprochement is evident. Although several 
replaced their TAs, none of them made a formal complaint to CONAFOR, which left the TAs again in impunity. Even so, these negative events allowed the communities to have a better understanding of their position with regard to their TAs, and also their own rights and responsibilities in their relationship with them.

Another aspect observed was the entrance of new intermediaries in cases of abandonment or serious disagreements between TAs and the beneficiaries. These actors, who are related to the communities through the development of other projects or programmes, have collaborated and facilitated the reconnection of the communities to CONAFOR in the absence of the TA. In the cases studied the emergent intermediaries ranged from NGOs (such as Alternare, who assisted in Cresm), government organisations, (such as the operators of NPAs in Michoacán and Jalisco, and the intermunicipal organisation in Jalisco, JIRA), to a community promoter in Zen. The lack of those alternative intermediaries in the case of Cir hindered the finding of a channel of communication with CONAFOR. When the connection finally occurred, CONAFOR's state employees gave guidance to beneficiaries to make the necessary changes but did not act as regards the TA's non-compliance.

Among the positive cases of interaction between TAs and communities, Ahu's TAs stands out, since he has become a key intermediary actor, not only in the programme, but also in processes that are more relevant to the community. This TA has carried out activities without taking a personal advantage of power in that community. He has apparently taken community interests as his own and provided them with tools and knowledge to meet their needs. In the case of Ich, the community people have been building capacities with the help of their TAs, but their expectations towards them have grown too, so somehow they begin to exert some pressure to shape the relationship on their own terms, and specific objectives. This shows an evolution of the relationship that could lead to a synergy with positive results for both.

Relations between TAs and communities are complex constructions depending on multiple factors, such as community capacities, power of both parties, interests, the verticality of the programme, and on individual choices. These relations can be shaped by the changes that have occurred in the programme too, and vice versa. Thus, some TAs are seen as employees, others as partners or in the worst cases as "owners" of communities. Working on the deep causes of the dependency on TAs at the local level, requires capacity building and strengthening of communities. The cases make evident the need for new forms of understanding of the roles of intermediaries in PES and other programmes, and the need of more and adaptive models of technical advice. The establishment of relationships between them and beneficiaries should be determined in a bilateral way. It would be interesting imagine a scheme that does not oblige the 
beneficiaries to hire a TA, or that allows the development of schemes of technical assistance that are differentiated by the needs of the beneficiaries, for instance, if the beneficiaries demonstrate that they have the capacity to carry out the activities of the programme or they need technical assistance only at certain moments or in certain activities. In those cases, not only CONAFOR, but beneficiaries would have the possibility to determine the conditions under which the contractual relationship is set up.

\subsection{Conclusions}

The chapter addresses the perceptions, experiences and perspectives of different stakeholders on the TAs role and relevance in the implementation of PES in México. The general dynamics and problems of TAs were presented from the point of view of these different stakeholders. The response of CONAFOR to criticisms about TAs has also been analysed.

There has been a discontinuous, ambiguous and irregular response from CONAFOR about TAs performance, since there is not a contractual relationship between them. This produces gaps in the regulation and monitoring of TAs' activities, which in turns enables the TAs impunity. Certification process is the main measure to deal TA issues, but this has been criticised for being partial, subjective and even counterproductive. Several of the measures taken by CONAFOR regarding TAs seem to rather respond to a strategy of blame avoidance, where the TAs play the role of scapegoats. But they are not the only ones that take part of this strategy: beneficiaries and the state-level CONAFOR employees are included too, since they have been given the responsibility for monitoring, reporting and, in the case of beneficiaries, picking up the thread in cases of failures by the TAs.

Trust among actors is also a significant issue emerging from this account. The lack of trust of CONAFOR of the beneficiaries is reflected in the increasing measures of control of their activities in their own forest, and the supervision and guidance of TAs. Rather than enabling conditions to raise trust among actors, TAs fulfil a role in the enforcement of rules, and control of beneficiaries. In the relationship between TAs and CONAFOR trust has become a fundamental problem, which has been only partially addressed. Reduced capacities for decision making of CONAFOR employees at the state level also reflect the trust issue between them and the central office.

For their part, beneficiaries need the presence of an intermediary between them and CONAFOR because there is widespread mistrust in governmental organisations. This is due to the power differences, the generalised historical notion of corruption and systematic disregard for rural communities by governmental organisations. 
The emergence of alternative intermediaries whether from the community or external to it, proved to be decisive reconnecting CONAFOR to beneficiaries, and helped to solve conflicts and make decisions about the relationships between TAs and beneficiaries.

Regarding the TAs, it would be necessary to develop not only a system of evaluation, but also a set of stimuli to promote the fulfilling of activities, ranging from penalisations to incentives for good performance.

About the communities involved in PES, many aspects need to be addressed, some longterm and other short-term. The need to improve the capacities and the decision-making power has been mentioned among other things, in order to reduce the dependence on TAs. In this way they will be able to establish more balanced relations with them. The training of community technicians or promoters can also be helpful to keep a balance between the different interests. Providing more accurate information on acceptable minimum standards of TA's performance, allowing beneficiaries to make informed decisions if the cases they need it, could improve the conditions under which relationships occur, and avoid or reduce cases of power abuse.

The performance and relevance of TAs should be a shared responsibility. As an intermediary, TAs relate to other actors, who also shape the relationships mediated by them. New forms of intermediaries need to be recognised as important components of the programme. Beyond the LAST, deeper implications of the good or bad performance of TAs must be examined. 


\section{Chapter 10. Warhorses and bad apples: analysing the narratives of TAs about themselves}

CONAFOR now is fighting against the monster they created themselves

(24, 2013).

\subsection{Introduction}

The previous chapter addressed the perceptions about TAs and views of CONAFOR employees at the national and state levels and NGOs. It also presented the views and experience of six communities from Michoacán and Jalisco. All these actors provided information which helps understand the present negative image of TAs, as well as the perceived problems in their performance. The way in which CONAFOR is framing and dealing with those problems was also presented. In order to complete the picture, the present chapter addresses:

- the TAs' motivations and interest to participate in PES and other CONAFOR programmes,

- their perceptions about the roles they play in PES programme and their importance in the accomplishment of the programme,

- the dynamics of relations with their colleagues,

- the enabling and hindering factors in their work,

- their views on unethical practices and the certification process, and

- their main needs and perspectives regarding the fulfilment of their tasks in PES.

The chapter is structured as follows: The 10.2 presents the problem statement and the justification of the analysis. In 10.3 the methods used to elicit the information, and the selection and types of informants are described. In 10.4 concerns the results of the interviews and observations. The results obtained are discussed in section 10.5, and concluded in section 10.6

\subsection{Problem statement and justification}

The need for development of theoretical and empirical research on intermediaries has been recognised by different authors (Meulen et al., 2005; Bracer, et al., 2007; Medd and Marvin, 2007; Moss et al., 2009; Moss, 2009; Muradian et al., 2013; Pham, et al., 2013; among others). The lack of literature based on empirical findings about how intermediaries function is especially evident (Meulen et al. 2005). 


\subsubsection{TAs as actors with agency}

As mentioned by Schomers et al., (2015) the potential of intermediaries in PES is affected by several factors, such as their own interests in participating and connecting stakeholders, their technical capacities and social skills (Schomers, et al., 2015), as well as the constraints under which they have to develop their work (Huber-Stearns, et al., 2013). The work of intermediaries cannot be expected to be neutral (Mike \& Simon, 2008); their own interests, values and goals are determined and determinant on the situation in which they are working (Bosselmann \& Lund, 2013; Mike \& Simon, 2008; Moss, 2009) and on the outcomes of those interventions they make (Davis, et al., 2015; Mike \& Simon, 2008).

Hamman and Lane assert that "the formation and implementation of policies implies interpretation and negotiation, sense making, ambiguity management and the exercise of discretion", emphasising the key role of actors working "in the interstices of those processes"(Hamann \& Lane, 2004). In the development of their work, TAs are constantly moving between the boundaries of structure and agency (Keys, 2005), and the interaction shapes their outcomes (Cleaver \& Franks, 2005). By implementing practices and in enforcing rules, they shape them; and at the same time, they influence the other actors' thinking or doing (Sternlieb et al., 2013). The results of such intermediation can help to reduce conflicts and divisions, but they can also produce or maintain divisions between groups, in order to influence and maintain legitimacy (Moss et al., 2009, Bosselman \& Lund, 2013).

\subsubsection{TAs as subordinate intermediaries}

TAs are highly relevant to PES because they work with remote communities where there is limited government presence. Moreover, since the ORs are constantly changing, TAs are necessary to buffer and adapt those changes in different local settings. In this context, TAs can be especially influential in the establishment of institutional dynamics, by directly or indirectly shaping the interactions between actors (Swallow, et al. 2007). Depending on their position in the PES scenario, they can also exert political influence (Khurana, 2002), and act as agents of enforcement of rules and control over resources (Swallow, et al., 2007). As information providers, intermediaries can take advantage of these isolated and dependent stakeholders, and as we have seen already, they may exert excessive influence and control over processes (Huber-Stearns et al., 2013; Pham, et al. 2010; Vatn, 2010). Furthermore, they may contribute to the creation and reinforcement of inequalities in access to resources (Bosselmann \& Lund, 2013; HuberStearns et al., 2013). While they can transfer information between stakeholders, they can also hide it or distribute it discretionally within a social network (Bosselman \& Lund, 
2013), deliberately favouring or negatively affecting actors both inside and outside the network.

Vatn and Angelsen (2009), warn about potential unethical practices in schemes like PES and REDD+, when intermediaries with certain influence hoard resources for other purposes or other actors (Vatn \& Angelsen, 2009). Intermediaries can also be careless and carry out poor practices, (Kosoy, et al., 2008; Pham, et al., 2010).

Gaps in our knowledge include not only the actual importance of TAs in the functioning of the programme (largely covered in previous chapters), but also their perceptions about their own role.

\subsection{Methods}

For the empirical research on TAs, I conducted participant observations in workshops and in the field verification process of the programme, and carried out 15 interviews, including 18 people (Table 10.1), since two of these interviews included more than one person (that is, one with 3 and the other with 2 informants). I attended workshops organised by CONAFOR in order to directly contact and invite them to participate in the research. The names of the TAs are not revealed, for confidentiality reasons.

Table 10.1. Interviewed TAs

\begin{tabular}{|c|c|c|c|c|c|}
\hline Name & State & Professional profile & $\begin{array}{l}\text { Age } \\
\text { range }\end{array}$ & Organisation & $\begin{array}{l}\text { People } \\
\text { interviewed }\end{array}$ \\
\hline $\begin{array}{l}17 \\
+ \\
\text { employees }\end{array}$ & Michoacán & $\begin{array}{l}\text { Forest engineer } \\
\text { Wood technology engineer } \\
\text { Forest engineer }\end{array}$ & $\begin{array}{l}50-60 \\
20-30 \\
20-30\end{array}$ & Consulting firm & $\begin{array}{l}1 \text { woman } \\
2 \text { men }\end{array}$ \\
\hline $\begin{array}{l}18 \text { employee }^{+1} \\
\text { em }^{+1}\end{array}$ & Michoacán & Forest engineers & $\begin{array}{l}40-50 \\
30-40\end{array}$ & Civil society & 2 men \\
\hline 19 & Michoacán & Forest engineer & $50-60$ & Civil society & 1 man \\
\hline 20 & Michoacán & Biologist/MSc Natural resources & $30-40$ & Consulting firm & 1 man \\
\hline 21 & Michoacán & Biologist & $20-30$ & Individual & 1 man \\
\hline 22 & Michoacán & Agroforest engineer & $60-70$ & Individual & 1 man \\
\hline 23 & Michoacán & Geographer & $40-50$ & Consulting firm & 1 man \\
\hline 24 & Michoacán & $\begin{array}{l}\text { Physicist/ Specialist in Conservation, } \\
\text { Restoration and Uses of Forest Resources }\end{array}$ & $50-60$ & NGO & 1 man \\
\hline 25 & Michoacán & Agricultural Engineer & $50-60$ & Consulting firm & 1 man \\
\hline 26 & Jalisco & Agricultural engineer/specialist in forests & $40-50$ & Consulting firm & 1 woman \\
\hline 27 & Jalisco & $\begin{array}{l}\text { Agricultural engineer/specialist in rural } \\
\text { development }\end{array}$ & $30-40$ & Consulting firm & 1 man \\
\hline 28 & Jalisco & $\begin{array}{l}\text { Natural resources and agricultural } \\
\text { engineer/PhD Student }\end{array}$ & $40-50$ & Individual & 1 man \\
\hline 29 & Jalisco & Middle education & $20-30$ & Individual/promotor & 1 man \\
\hline 30 & Jalisco & Forest engineer & $40-50$ & Consulting firm & 1 man \\
\hline 31 & Jalisco & Forest engineer & $40-50$ & Individual & 1 man \\
\hline
\end{tabular}

I also attended 4 workshops, 2 about environmental services, and 1 about rights and obligations, and 1 about a guide to better forest practices, organised by CONAFOR for new beneficiaries of the programme. I also attended meetings and field verifications in 
two ejidos. The interviews, as well as some of the meetings and verifications were recorded (with the participants' consent), transcribed and analysed using QSR International NVivo 10. The most illustrative quotes from informants have been translated into English.

\subsection{Technical advisors seen by themselves}

As it was mentioned by Schomers et al., (2015) the potential an relevance of intermediaries in PES is affected by several factors, such as their own interests in participating and connecting stakeholders, their technical capacities and social skills (Schomers et al., 2015), as well as the constraints they have to develop their work (Huber-Stearns et al., 2013). This section approaches to those questions by exploring the self-perception of TAs based on their own experience.

To know more about the immediate surroundings of the TAs, as well as to know more about their complexities and internal situation, I interviewed TAs who were willing to participate in the study, given that most of TAs I contacted were elusive. This is a reflection of their situation as the most stigmatised and blamed actors in the programme.

The results of the interviews and observations have been grouped as follows:

- What TAs say about their roles, interests and motivations;

- Factors enabling or hindering TAs' work;

- TAs' accounts of unethical practices;

- TAs views on certification as a mechanism of quality control;

- TAs' views on their own needs.

\subsubsection{What TAs say about their roles, interests and motivations}

\subsubsection{Characterisation of interests and motivations}

The motivations of TAs are diverse, from people with a high social commitment who work because they are concerned about the development of the forest communities, to the technicians who joined the programme because other jobs are not available. Table 10.2 presents examples of reasons given by some of the TAs for joining the programme. In table 10.3 a simplified overall categorisation of this is given, showing that social motivations are predominant, followed by environmental, labour and economic. TAs are classified according to the profiles presented in Chapter 8 ('Old school', 'CONAFOR children'. None of the interviewees belonged to the "CECFOR technicians" category). 
Table 10.2. Motivations to work as a TA .

\begin{tabular}{|c|c|}
\hline TA/ profile & Motivation \\
\hline $\begin{array}{l}\text { 28, Environmental } \\
\text { engineer } \\
\text { PhD candidate } \\
\text { Individual TA }\end{array}$ & $\begin{array}{l}\text { [...] I started offering services, since my scholarship concluded ... and this can be a } \\
\text { profitable activity } \\
\text { [...] The scarcity of other labour alternatives in NRM [...]. } \\
\text { [...] I like nature and [...] working with ejidatarios [...]. }\end{array}$ \\
\hline $\begin{array}{l}\text { 24, Physicist } \\
\text { Director of a local NGO }\end{array}$ & $\begin{array}{l}{[\ldots] \text { I have a strong motivation in forestry development and that communities can work }} \\
\text { with us, without us and despite us. }\end{array}$ \\
\hline $\begin{array}{l}\text { 21, Biologist } \\
\text { Individual TA }\end{array}$ & $\begin{array}{l}\text { Working with the rural people [...] in the countryside is a very great motivation for me } \\
{[\ldots] \text {. }} \\
\text { [...] CONAFOR programmes allow people to working and make proposals to improve } \\
\text { their condition [...]. } \\
{[\ldots] \text { It's so easy for me that I do not really consider it a job. [...] I [...] really like what I'm }} \\
\text { doing. }\end{array}$ \\
\hline $\begin{array}{l}\text { 17, Forest engineer } \\
\text { Head of a TAs buffet }\end{array}$ & $\begin{array}{l}\text { It would be hypocrite }[. . .] \text { to say that I like trees }[. . .] \text {. } \\
{[\ldots] \text { My father is an empirical forest technician, }[. . .] \text {. I had to do the same to fit into the }} \\
\text { family. } \\
{[\ldots] \text { I make business. }}\end{array}$ \\
\hline $\begin{array}{l}\text { 22, Forest engineer } \\
\text { Basic schoolteacher } \\
\text { Individual TA }\end{array}$ & $\begin{array}{l}\text { I retired at fifty-two, and since I have forest studies [...], [...] I set the goal [of being] TA. } \\
{[\ldots] \text { It allows me to be physically and intellectually active [...] }} \\
{[\text { It is] an income and [...] it is a job. }}\end{array}$ \\
\hline
\end{tabular}

Table 10.3. Motivations of TAs. At the top of the table the upper initials indicates the ID of the TAs, the lower indicates if they are (OS) Old school TAs, (CC) CONAFOR children. At the bottom of the table, the initials indicate the professional background as follows: (G) Geographer, B (Biologist), (P) Physicist, EE (Environmental engineer), FE (Forest engineer), AE (Agricultural engineer). Not all the informants answered this question, and those who responded gave more than one answer

\begin{tabular}{|c|c|c|c|c|c|c|c|c|c|c|c|c|}
\hline \multicolumn{13}{|c|}{ Why are you a CONAFOR TA? } \\
\hline & & 23 & 20 & 28 & 24 & 21 & 17 & 26 & 27 & 22 & 18 & 19 \\
\hline \multirow[t]{2}{*}{ Type of motivation } & Motivation/Interest & & & & & & & & & & & \\
\hline & & $\mathrm{CC}$ & $\mathrm{CC}$ & $\mathrm{CC}$ & $\mathrm{CC}$ & $\mathrm{CC}$ & OS & OS & CC & OS & OS & OS \\
\hline \multirow[t]{3}{*}{ Environmental } & Forest conservation & & & & & & & & & & & \\
\hline & Forest development & & & & & & & & & & & \\
\hline & Love for nature & & & & & & & & & & & \\
\hline \multirow[t]{2}{*}{ Social } & Communities development & & & & & & & & & & & \\
\hline & Interaction with rural people & & & & & & & & & & & \\
\hline Moral & Moral commitment & & & & & & & & & & & \\
\hline \multirow[t]{2}{*}{ Labour } & Having a job & & & & & & & & & & & \\
\hline & Lack of job options & & & & & & & & & & & \\
\hline \multirow[t]{2}{*}{ Economic } & Earning money & & & & & & & & & & & \\
\hline & Making business & & & & & & & & & & & \\
\hline \multirow[t]{2}{*}{ Vocational } & Interest in the type of job & & & & & & & & & & & \\
\hline & Interest in working in the field & & & & & & & & & & & \\
\hline \multirow[t]{3}{*}{ Other } & The programme is good & & & & & & & & & & & \\
\hline & $\begin{array}{l}\text { Fitting in a family of foresters } \\
\text { It is all I know how to do }\end{array}$ & & & & & & & & & & & \\
\hline & Keeping physically/ intellectually active & & & & & & & & & & & \\
\hline Profession & & G & B & $\mathrm{EE}$ & $P$ & B & $\mathrm{FE}$ & $\mathrm{AE}$ & $\mathrm{AE}$ & $\mathrm{FE}$ & $\mathrm{FE}$ & $\mathrm{FE}$ \\
\hline
\end{tabular}




\subsubsection{Functions of TAs as seen by themselves}

TAs recognised themselves as fundamental actors in the programme functioning, and some of the TAs were very emphatic about this, for example:

- Without us CONAFOR would not be working with the ejidos/communities, because there would be no link with them $(20,2013)$.

- $\quad$ [...] The programme cannot work without TAs $(18,2013)$.

- $\quad$ [...] [Without TAs] CONAFOR programs would fail $(23,2014)$.

- [...] Without us, the programme is useless $(28,2014)$.

TAs considered themselves relevant to the promotion of the programme, helping potential applicants to know if they are eligible (17, 22, 2013; 23, 28, 2014); in helping applicants meet the requirements and do the paperwork to present the application (23, $17,2013)$; in explaining, translating, simplifying and adjusting the changing ORs $(18,24$, $22 ; 2013$ ); in providing guidance and training in specific technical issues $(22,18,2013$; 28, 2014); and in making connections, mediating and facilitating communication between beneficiaries and CONAFOR $(19,18,2013 ; 26,27,21 ; 2014$. Talking about their importance as links between CONAFOR and beneficiaries, informant 21 said:

CONAFOR takes a long time to detect where [...] problems [with beneficiaries] occur. In such cases [...] it becomes evident [that] CONAFOR is not really linked to the beneficiaries, but to the TAs [...]. If a TA leaves an ejido, CONAFOR [...] takes a long time to re-link with it, [...] because it does not have the manpower for implementing and monitoring the programmes [...] $(21,2014)$.

Table 10.4 gives more examples of how TAs envision the dependence of CONAFOR on them.

Table 10.4. CONAFORs dependency on $f$ TAs, according to the TAs programme

\begin{tabular}{|c|c|c|}
\hline $\begin{array}{l}\text { TAs FUNCTIONS } \\
\text { importance in }\end{array}$ & TAs said & $\begin{array}{c}\text { Reasons for } \\
\text { CONAFORs } \\
\text { dependency on TAs }\end{array}$ \\
\hline $\begin{array}{l}\text { Programme } \\
\text { implementation }\end{array}$ & $\begin{array}{l}\text { 28: [...] We are CONAFOR's warhorse, because they do } \\
\text { not ground the project, they do not execute it; they } \\
\text { only propose and finance it. [...]CONAFOR does not } \\
\text { have the operational capacity to follow up } \\
\text { beneficiaries [...]. [...] CONAFOR [also] needs the TAs } \\
{[\ldots] \text { because the rules are changing [...] }}\end{array}$ & $\begin{array}{l}\text { CONAFOR's lack of } \\
\text { operational capacity } \\
\text { Distance between } \\
\text { CONAFOR- } \\
\text { beneficiaries }\end{array}$ \\
\hline $\begin{array}{l}\text { Programme } \\
\text { promotion }\end{array}$ & $\begin{array}{l}\text { 17: [...] thanks to us the programme is made known in } \\
\text { [remote] areas... } \\
\text { 22: [...] The fundamental role played by a TA is to } \\
\text { clarify the owners of forests about the programmes, } \\
\text { because CONAFOR makes promotion but it does not } \\
\text { do it adequately. }\end{array}$ & $\begin{array}{l}\text { CONAFOR's lack of } \\
\text { operational capacity } \\
\text { Distance between } \\
\text { CONAFOR- } \\
\text { beneficiaries }\end{array}$ \\
\hline $\begin{array}{l}\text { Linking CONAFOR- } \\
\text { beneficiaries }\end{array}$ & $\begin{array}{l}\text { 21: CONAFOR takes a long time to detect where [...] } \\
\text { problems occur. In such cases [...] it becomes evident } \\
\text { [that] CONAFOR is not really linked to the }\end{array}$ & $\begin{array}{l}\text { CONAFOR's lack of } \\
\text { operational capacity }\end{array}$ \\
\hline
\end{tabular}




\begin{tabular}{|c|c|c|}
\hline $\begin{array}{l}\text { TAs FUNCTIONS } \\
\text { importance in }\end{array}$ & TAs said & $\begin{array}{c}\text { Reasons for } \\
\text { CONAFORs } \\
\text { dependency on TAs }\end{array}$ \\
\hline & $\begin{array}{l}\text { beneficiaries, but to the TAs [...]. If the TA leaves, } \\
\text { CONAFOR [...] takes a long time to re-link with the } \\
\text { beneficiaries. [...] [CONAFOR] does not have the } \\
\text { manpower for implementing and monitoring the } \\
\text { programmes [...] } \\
\text { 17: CONAFOR must recognise us as the link [with the } \\
\text { beneficiaries] and stop looking down on us [...]; it } \\
\text { should trust us [...] }\end{array}$ & $\begin{array}{l}\text { Distance between } \\
\text { CONAFOR- } \\
\text { beneficiaries }\end{array}$ \\
\hline $\begin{array}{l}\text { Helping } \\
\text { processes/procedures } \\
\text { /paperwork }\end{array}$ & $\begin{array}{l}\text { 23: }[\ldots] \text { From the moment the request is filled [...] the } \\
\text { assistance of a TA [...] is necessary. } \\
\text { 18: [...] If CONAFOR asks the beneficiary for a forest } \\
\text { diagnosis, they will not know [...] how to do it. So, they } \\
\text { need the TAs to tell them what, how, when to do it. } \\
\text { 19: [...] Sometimes the representatives of the agrarian } \\
\text { nuclei have non-conformities, and they do not know } \\
\text { how to translate that into a document to present to } \\
\text { CONAFOR [...], and we help them to write [...]. } \\
\text { 17: [...] For a peasant even the request is difficult to } \\
\text { fill; [...] the TA has to provide support from there }\end{array}$ & $\begin{array}{l}\text { Complex and technical } \\
\text { terms and procedures } \\
\text { PES and ORs } \\
\text { Beneficiaries' poor } \\
\text { capacities }\end{array}$ \\
\hline $\begin{array}{l}\text { Translating, } \\
\text { simplifying, adjusting, } \\
\text { explaining }\end{array}$ & $\begin{array}{l}\text { 19: }[\ldots] \text { Despite the talks [and] courses that CONAFOR } \\
\text { organises, the ORs, }[\ldots] \text { are full of terms that people do } \\
\text { not understand }[\ldots], \text { and we help them to understand } \\
{[\ldots] .}\end{array}$ & $\begin{array}{l}\text { Changing, complex } \\
\text { and technical terms } \\
\text { and procedures PES } \\
\text { and ORs } \\
\text { Beneficiaries' poor } \\
\text { capacities }\end{array}$ \\
\hline $\begin{array}{l}\text { Assisting and training } \\
\text { beneficiaries }\end{array}$ & $\begin{array}{l}\text { 23: [...] Beneficiaries need guidance in specific } \\
\text { technical [...] issues. } \\
\text { 18: [...] If we gave the beneficiaries freedom to do } \\
\text { what they wanted, the forests would be sick and there } \\
\text { would be clandestine felling. } \\
\text { 19: We also provide training on environmental culture } \\
\text { that goes beyond the courses that supports and } \\
\text { promotes CONAFOR [...] }\end{array}$ & $\begin{array}{l}\text { Changing complex and } \\
\text { technical terms and } \\
\text { procedures PES and } \\
\text { ORs } \\
\text { Beneficiaries' poor } \\
\text { capacities }\end{array}$ \\
\hline $\begin{array}{l}\text { Mediating, facilitating } \\
\text { decisions making }\end{array}$ & $\begin{array}{l}28:[\ldots] \text { In order applicants to obtain the money and to } \\
\text { use it in a proper way, they do need [our] guidance } \\
{[\ldots] \text {. }} \\
\text { 18: [...] And also to convince people to participate in } \\
\text { the programme, to [...] hold on until the payment } \\
\text { arrives, to negotiate with opposing groups [...]. }\end{array}$ & $\begin{array}{l}\text { Beneficiaries' poor } \\
\text { capacities }\end{array}$ \\
\hline
\end{tabular}

TAs were also quick to point out that despite the widely recognised dependency on them in PES, CONAFOR undervalues and distrusts them:

\author{
[...] CONAFOR must recognise us as the link [with the beneficiaries] and stop looking \\ down on us $[\ldots](17,2013)$
}

[...] Although CONAFOR says that if there were no TAs the programmes would not go forward, CONAFOR has a wrong concept of us [...]; it distrusts us $(22,2014)$. 
In discussing the factors that make technical assistance necessary, some TAs said that in order to reduce dependency, certain conditions would have to be met, especially related to capacity building in communities, as well as simplification of programme requirements and procedures of the programme.

[...] It would be interesting to think that the beneficiaries do not need [TAs]. In some ejidos and communities there are local technicians who are already sufficiently trained [...]. [...] If they had training in the systematisation of information, [...] to make their own guides of best practices, that would be enough $(24,2013)$.

[...] In the hypothetical case that the TAs did not exist in the CONAFOR programmes, everything should be simplified: the request format, the technical annexes, the best practices guide... [...]. Those people [beneficiaries] are not prepared [...], they have not gone to school $[\ldots](17,2013)$.

[...] Communities and ejidos are not destined to depend on TAs, but certain conditions have to be fulfilled: [...] to improve the fees for technical services; training to enable the formation of community [...] instructors to follow up on the implementation [of the programmes] $(19,2013)$.

\subsubsection{Formal and informal roles}

In their research in PES schemes in Vietnam, Pham et al. (2010) found that intermediaries fulfilled functions of "bridge builders, mediators, arbitrators, equalisers, developers of standards, representatives, and watch-dogs" (Pham, et al, 2010). In Mexican PES, the formal roles of TAs have been predetermined by CONAFOR, according to its own expectations and requirements (as explained earlier However, although may seem that the activities of TAs are fixed, in the local settings there is room for TAs and beneficiaries to improvises. Thus, in reality the finding of Pham is not very different to what we find in the Mexican context. There are additional roles that TAs consider they are playing, which are determined by their own experience, needs, forms of work, and the particularities of the areas where they work, and roles that they take on because of the needs or expectations of beneficiaries. Statements about the roles which TAs say they assume can be found in table 10.5. Some of them also talked about their own expectations of the potential roles a TA should fulfil, as well as about the different levels in which they can be involved in their work, which is beyond the vision of CONAFOR, as 24, a TA working in an NGO, said:

[...] [We must [...] assume a long-term responsibility [...]. They [other, common TAs] do not go any further; they do not invest in supporting communities in their organisational capacity, in their management capacity, in their capacity for power. [...]. [...] The TA should be the community worker, the spokesperson for their needs before any government organisation, [...] should be people of trust. And in this [...] intervention 
before the authorities, TAs should be in charge of defending, protecting the interests of the community, in the space that is conferred on them, not any space $[. .].(24,2013)$.

[...]. No differences have been established to assess levels of depth with what one works in a community $[18,2013]$.

Table 10.5. The roles of TAs in PES as perceived by themselves

\begin{tabular}{|c|c|}
\hline \multicolumn{2}{|r|}{ What are the TAs' main roles in PES programmes? } \\
\hline 20 & $\begin{array}{l}\text { We are a link }[\ldots] \text {. } \\
{[\ldots] \text { I have to pass the information provided by CONAFOR to a simpler language }[\ldots] .[\ldots] \text { If there is any }} \\
\text { information that people do not understand }[\ldots] \text { I transmit them, but in an understandable way }[\ldots] \text {. }\end{array}$ \\
\hline 28 & $\begin{array}{l}{[\ldots] \text { I am a facilitator. [...] You tell me what you want to do, and I see how bring it to you. [...]. }} \\
{[\text { We] are a link between [CONAFOR and beneficiaries] to [...] decode information and make it digestible for }} \\
\text { both. } \\
{[\ldots] \text { [I am] like a figure of moral character... to attest that the activities were fulfilled in the areas of PES. }} \\
{[\ldots] \text { Then, you tell CONAFOR: "Things are already done, can you come to verify?" and it comes the formal }} \\
\text { verification. }\end{array}$ \\
\hline 22 & $\begin{array}{l}\text { Explain clearly to the owners of the forest lands on what the programmes want and imply [...]. } \\
\text { I have a [...] pedagogical profile, because I was a teacher }[\ldots] \text {. So, I explain everything as if they were my } \\
\text { students [...]. }\end{array}$ \\
\hline 18 & $\begin{array}{l}\text { [We] take care of the interests of the }[\text { beneficiaries]. } \\
{[\ldots] \text { The ORs use }[\ldots] \text { terms that people do not understand }[\ldots] .[\ldots] \text { We help them to understand }[\ldots] \text {. }} \\
{[\ldots] \text { There are people from ejidos who [want] to learn about technical issues }[\ldots] .[\ldots] \text { We help them to do }} \\
\text { that }[\ldots] \text {. } \\
{[\ldots] \text { We have hired people from the communities }[\ldots] \text { so that they train their own people in turn }[\ldots] \text {. }} \\
{[\ldots] \text { We encourage people to participate in processes in which they are gradually they get involved, so that, }} \\
\text { in a while they do not have to depend on an external technician }[\ldots] .[\ldots] \text { We promote that they are the } \\
\text { protagonists of their actions. }\end{array}$ \\
\hline 21 & $\begin{array}{l}{[\ldots] \text { Informing: It is important that people know what they are getting into, how they are going to do it. }} \\
{[\ldots] \text { Other important activity is the following-up of the whole project [...]. }} \\
{[\ldots] \text { It is also important [...] the training stage. }} \\
{[\ldots] \text { And the delivery of annual reports. }}\end{array}$ \\
\hline 17 & $\begin{array}{l}{[\ldots] \text { We are not intermediaries [...], we are or should be the most important link [...] to make things }} \\
\text { simpler for both CONAFOR and the beneficiaries [...]. } \\
\text { Who are the real promoters [of the programme]? We are, because [...] doing projects for this programme } \\
\text { implies extra income for us [...]. }\end{array}$ \\
\hline 30 & $\begin{array}{l}\text { Information, training, and presence in the ejido. [...] Clarifying the doubts, [...] provide them the correct } \\
\text { information. Informing people from the beginning of what do they [...] got into, because they sometimes } \\
{[\ldots] \text { do not know it [...]. Training is important because people are not accustomed to working in the forest, }} \\
{[\ldots] \text { very often the common use area is only used as cattle pastures, so they do not know what else to do }} \\
\text { with their forests [...]. [...] And accompaniment, [...] to be with them, helping them to get things right [...]. }\end{array}$ \\
\hline
\end{tabular}

Figure 10.1 contrasts TAs views on their role with CONAFOR's; the data reflects the frequency with which these views were explicitly mentioned in interviews with representatives of both groups I This does not provide a complete picture, but it shows the subtle differences in their views, and between the words they use to describe the tasks. The main roles identified by TAs were related to transferring, explaining, and translating terms, concepts and procedures to beneficiaries, which also relate to training and guidance. Establishing links between CONAFOR and beneficiaries is another 
important role mentioned by them. CONAFOR informants on the other hand identified helping potential and actual beneficiaries in the processing of information, paperwork and requirements, and guiding in the development of plans and activities and (as mentioned by TAs also), linking CONAFOR and beneficiaries.

Figure 10.1. Perceptions of the role of TAs: contrasting the TAs view with that of CONAFOR
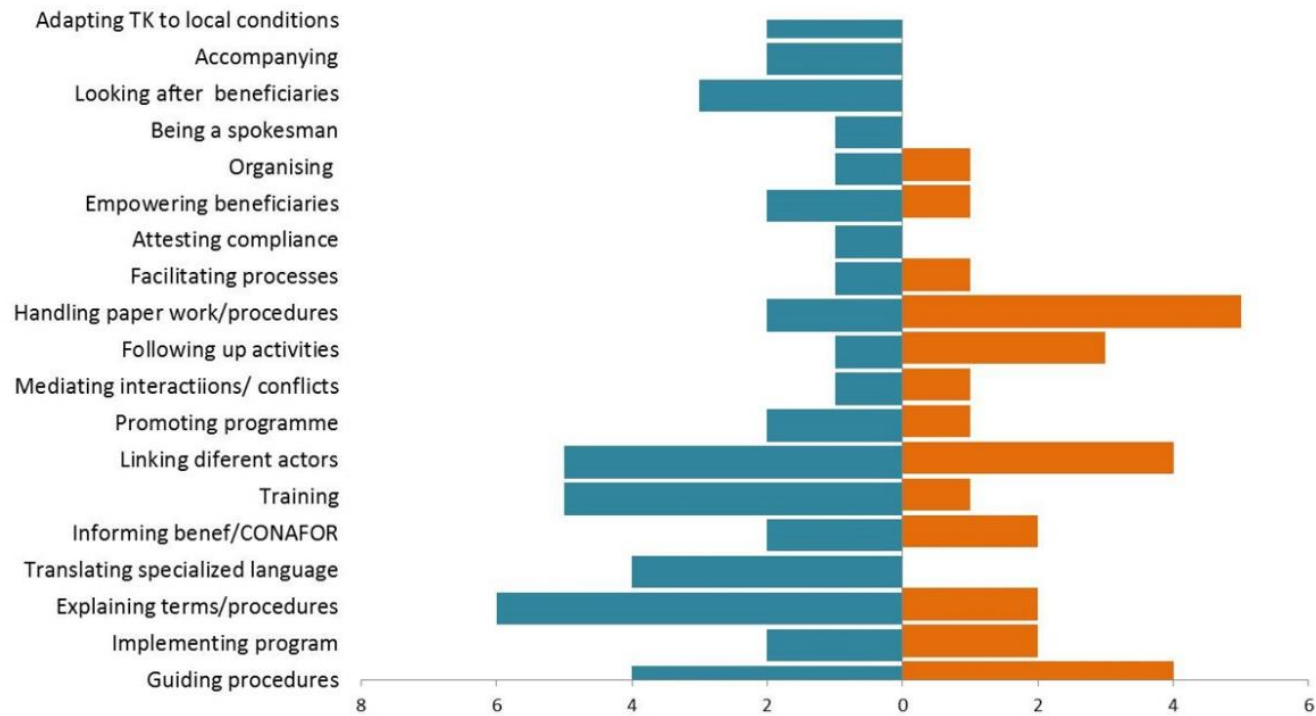

\section{Informal roles of TAs}

Some activities fulfilled by the TAs at the local level, which can be considered informal roles, were not directly mentioned in the semi-structured interviews, but emerged during subsequent conversations. Some of these go beyond the limits of CONAFOR programmes. They may not as visible as the others and, although they are not necessarily improper, they may be deliberately concealed because they might be considered as not acceptable within the CONAFOR schemes. These roles and their implications depend not only on the TAs closeness and influence within the communities, and the interests and ethics of each TA, but also on the needs and demands from the beneficiaries and the arrangements established between them. Informal roles include:

- Moral authority. Some TAs are especially influential in providing advice and suggestions to beneficiaries of the programme, such as the allocation and uses of the money obtained from PES programme and from other sources; but they can also influence the decision making about internal organisation, such as the election of members to the ejido authority $(22,24,20,2013 ; 3,2014)$.

- Internal organisation and conflict management. Similarly, they can influence and actively participate in internal processes of negotiation between opposing 
groups within the communities, independently of whether these processes are related to CONAFOR programmes $(18,19,24,25,2013 ; 28,26,31,2014)$.

- Friendship. Some TAs considered the establishment of closer and personal relationships as part of their role, because it is the result of the active effort of gaining trust from beneficiaries and can generate future benefits. Some of the activities mentioned ranged from attending religious celebrations and family parties, to providing support to members of the communities in their personal problems. The establishment of personal relations can also occur with CONAFOR state level employees $(23,20,19,22,2013)$.

- Administration of money and information. Some TAs mentioned that they themselves or other TAs they know have taken under their own protection historical, technical and geographical information on the community when this was generated during the programme. Similarly, some TAs may take control of the money or resources obtained from programme participation and administer it in the way they deem fit for the community. Cases were mentioned where the bank account data and the legal address of the communities are in the possession of their TAs $(24,18,2013 ; 27,29,2014)$.

- Promoting, facilitating and sometimes making decisions about access to other programmes and projects, as well as resources for the communities they work with $(23,2013 ; 28,2014)$.

- Making decisions about the entrance and participation of new technicians, NGOs or other groups working in the communities for other programmes or projects $(20,24,2013)$.

\subsubsection{TAs' views on colleagues, cohesion and competition}

As was seen in the previous chapter, TAs function as single workers, representing their own interests and competing for the most favourable conditions of work. With few exceptions, CONAFOR's TAs are not organised in any way, each solves their own problems. They look at each other with suspicion, partly because they are in competition. Therefore, they do not meet frequently to discuss their work. The TAs perceptions about colleagues are mixed, but in general their' (bad) reputation as a group is well known to them. They are aware that CONAFOR and other actors have conferred on them the role of villains. As 18 said:

[...] The government blames us, they consider us the villains [...] of the film, there are

ejidos that have won prizes, but you have never seen an awarded TA [...], but if you look for penalised TAs you are going to find a lot $(18,2013)$.

This quote shows that when they referring to themselves as a group, they use metaphorical expressions that, sometimes in a funny way and sometimes reflecting 
disappointment, show their own perceptions and feelings about being branded as bad actors (Figure 10.2).

Figure 10.2. TAs perceptions about themselves, and the way in which they assume they are seen by other actors and by themselves. (Source: image modified from download Reeks Boze Gezichten Royalty-vrije Stock Fotografie- Afbeelding: 17638067)

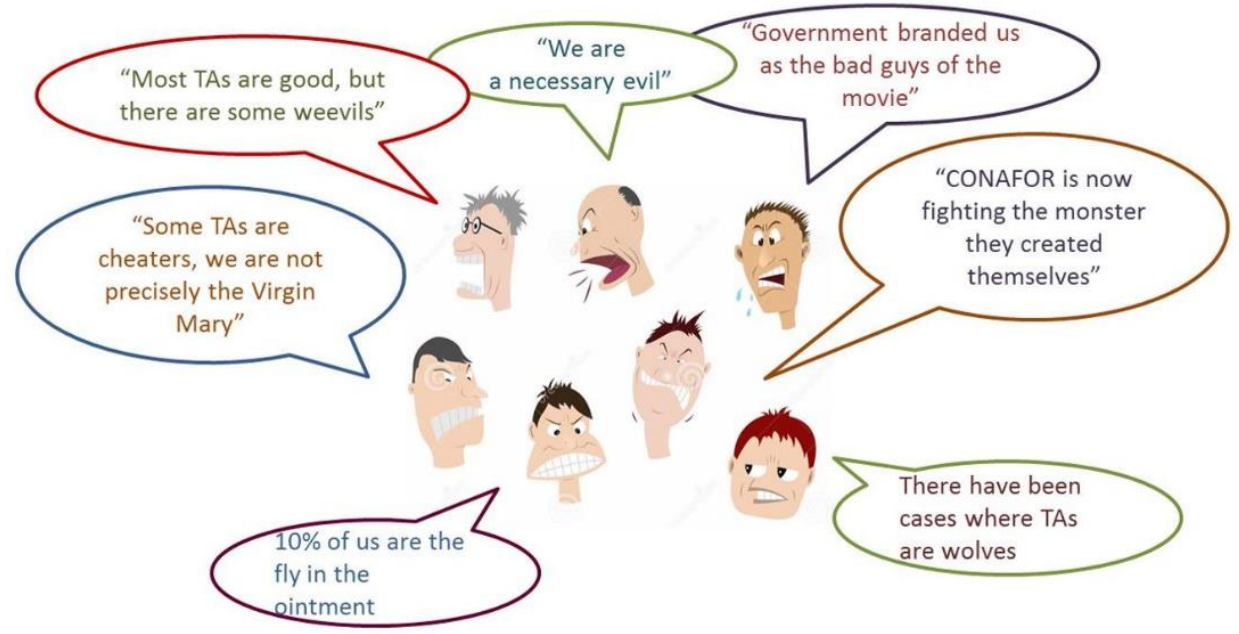

All informants recognised the existence of good and bad TAs, in different proportions. However, the topic of bad practices was always present during conversations, and they recognised the incidence of these, but in all cases the interviewees declared themselves personally outside of those practices. Like the informants of CONAFOR and ONGs, when the TAs referred to bad practices, they especially mentioned corruption, abuse of power, and lack of competencies, and also abandonment and poor quality in the services provided.

There are very good TAs, very committed, very capable, very involved in their work, but there are others who have taken advantage of the circumstances [...], earn money for a while, and leave a lot of problems with the beneficiaries $(18,2013)$.

[...] The quality of the technical service is very limited... there are major deficiencies in services provided by the TAs, there are no good capacities in social areas. Additionally, many TAs believe they do everything well [...] and know everything $(24,2013)$.

They noted that cases of bad practices are treated more as rumours rather than as open, factual information. Somehow the subject is blurred. 
[...] I have known about beneficiaries who have conditioned the payment to the TAs, but I am not sure [why]. [...] TAs are not going to talk about it. They have mentioned that there have been problems, but that is not the common thing. The common thing is that everything goes well, incredibly well (laughs) $(25,2014)$.

This brings us to the subject of collaboration between TAs, which is not common, at least among the "old school" and the "CONAFOR children" groups. Most of the interviewees agreed that in general (which it does not imply that in all cases) there is more rivalry between the TAs than companionship. They do not discuss topics of general interest between them, nor do they facilitate processes with one another [...]. In general TAs only work with other TAs when they are close friends, and just a few of them participate together in specific projects.

In general, the "old school" ones are better organised, as they are often members of well-established and exclusive associations for forestry engineers, with political power and considerable influence in their working areas $(24,2013)$. In contrast, "CONAFOR's children" are not organised, and in general, they are not well received in the forestry engineers' associations. The rivalry between the different types of TAs becomes more evident when there have been attempts to bring together all the TAs. Underestimation and prejudices are increasing the division, which does not allow the establishment of synergies, even to defend certain common issues. On the one hand, "CONAFOR children" believe that "old school TAs" are apathetic, they underestimate the knowledge of TAs with other profiles, and they are not well prepared in the social areas. On the other hand, those of the "old school" consider that entry to the LAST of professionals with different profiles has lowered the quality of the technical services, since they do not have the necessary technical capacity to work in certain programmes of CONAFOR.

[...] Forest engineers are very close each other, [...] but they are apathetic with the rest [...]. [...] They believe they know more. [...] Foresters working in timber production never consider [...] the community organisation in order to lay more solid foundations for community forestry development. They focus on [...] exploitation, but do not [...] see the added value of having long-term results [...]. [...]But our profile is more social [...] and we focus on both production and community organisation $(20,2013)$.

[...] If there is no union between the foresters of the same guild, it is even worse when dealing with an attorney or a biologist, [...] because there are fewer points of coincidence. [...]Perhaps it is a problem of the Mexican people $[. .].(17,2013)$. 


\subsubsection{Cohesion and competition}

According to its informants, although CONAFOR recognises the importance of TAs there are no mechanisms and platforms for among them. The TA are not a guild, rather they are individuals of a multiplicity of backgrounds and motivations that perform the same activity. TAs have not established their own interaction mechanisms, and there are no information or experience exchange mechanisms and platforms. The few moments of interaction among them are related to CONAFOR and the activities with beneficiaries, such as the ES workshops.

Some TAs mentioned that in previous years CONAFOR used to organise meetings with all the TAs, where they could interact and discuss about many topics. Apparently, those meetings were suppressed, coincidentally with the establishment of certification, possibly as a way to avoid them getting together to discuss more seriously and organise formal movements or petitions $(20,18,29,30,2013)$.

TAs do sometimes organise meetings, such as for the definition of payments, and about certification, but even in those moments they recognise their own apathy and lack of interest to mobilise for better conditions. The reasons for this lack of unity are essentially the high level of competition to get working areas and beneficiaries.

The certification process is not helping to solve the situation, but it has empowered the most powerful groups of TAs, who do better in the testing than young TAs with less experience and with more diversified profiles. Views of TAs are shown in table 10.6.

Table 10.6. TAs views on lack of union and competition between colleagues.

\begin{tabular}{|c|c|}
\hline TA & Responses about lack of union and competition \\
\hline 23 & $\begin{array}{l}{[\ldots] \text { There is no communication between TAs. Rather, }[. . .] \text { there is rivalry. }[. . .] \text { There is a lot of competition, }} \\
{[\ldots] \text { due to the national crisis [...]. [...] Everyone tries to take care of [...] their own clients [and] of their }} \\
\text { knowledge as well [...]. }\end{array}$ \\
\hline 20 & $\begin{array}{l}\text { [...] Michoacán is the state that has more TAs at the national level. The competition is very hard and [...] } \\
\text { CONAFOR agrees with this, because they can exert the money given to the programmes, and that is seen } \\
\text { as a success. }\end{array}$ \\
\hline 21 & $\begin{array}{l}{[\ldots][\text { TAs] are never together, because you seek your [...] own benefit, not to benefit others. [...] And it is }} \\
\text { not easy sharing the field [...] }\end{array}$ \\
\hline 22 & $\begin{array}{l}\text { [...] México has no culture of teamwork [...]. That make me feel [...] sad, angry, powerless... because we } \\
\text { cannot get together, we are very individualistic ... we only pray for our saint. [...] Everyone sees in their } \\
\text { own interest. This is due to [...] competition. }\end{array}$ \\
\hline 25 & $\begin{array}{l}\text { We must recognise [...] that in the forestry sector the technicians are a rather disorganised guild, and this } \\
\text { is due to competition.... [...] [There are] terrible disputes for clients, lands, permits, areas of work. That } \\
\text { makes it very difficult for us to organise ourselves [...]. }\end{array}$ \\
\hline
\end{tabular}

In this context, disloyalty to colleagues in getting customers is common, such as offering better contract conditions to beneficiaries who are already working with another TA, or 
even bribing and deceiving local authorities to persuade the rest of the community to choose her/him.

Likewise, some TAs take advantage of good personal relations with the operators of the CONAFOR programmes, who may collaborate with them to favour them, regardless of their technical capacities. Some initiatives to organise groups have emerged in the last few years, but they are weak and there is not much interest from TAs to spend time and energy to organise themselves.

[...] We were trying to develop a code of conduct and professional ethics for all natural resource managers in the area [...]. [...] We were already making good progress; in fact, we were to form a civil association [...]. [...] We also wanted to establish a price tabulator. But the same colleagues are not willing to spend time on such things. [...] At the end, the lack of time and the working pressures were dismantling us ... and did not allow us to establish the idea in practice $(28,2014)$.

\subsubsection{Factors that TAs see as enabling or hindering their work}

Although the TAs' labour situation means that searching for the most favourable conditions of work mainly depends on themselves, there are internal or external factors that may facilitate or hinder their performance. The conditions they mentioned that facilitate their work were varied and personal.

\subsubsection{Enabling factors}

The first condition that allows TAs to develop is freedom of action at the local level. This allows them to make visits, meetings and work in the field in the most convenient way for them. Apart from the reports that must be submitted to CONAFOR on the activities of beneficiaries, they are accountable to CONAFOR, for example use of their time is of no concern to CONAFOR. They also consider that the PES activities are simple and do not require a greater effort, because there are well defined protocols and guidance information available about the ORs, reference terms, and the activities necessary.

[...] For the fieldwork, I used to go one or two days maximum, because the programme is not so demanding, it gives you many facilities to do it, and also [...] way you do the works $[. .$.$] is very flexible (21,2014)$.

[...] Each programme has its $O R$, it gives you all the information on how the request should be filled, [...] there are terms of reference, instructions of how to submit an application or a report [...]. They all (CONAFOR employees) give you facilities [...]; in some cases, you can choose of methods to apply $[\ldots](25,2013)$. 
The type of relationship they establish with both the state-level CONAFOR employees and the beneficiaries is also a personal choice, but the result of establishing good relationships can also facilitate their work greatly.

[...]That is why it is convenient to have a cordial relationship [...]. [...] People treat me very well; they care about me [...].[...] When I started to go, we made the deal that they were going to sell me my meals, but that never happened, because there is always someone who kindly invites me to eat, and someone else who allows me to spend the night in a hammock in a house $[. .].(21,2013)$.

At CONAFOR meetings, I have [...] met people around my age [...]. Some of them are still working at CONAFOR. And I have the confidence to call them [...] to ask questions about procedures, paperwork, etc. [...] $(28,2014)$.

The trust of beneficiaries and CONAFOR employees is an especially important facilitator. In the same way, those TAs who are able to establish alliances and synergies with other TAs can obtain better results.

[...] interact with other NGOs and individuals who know about some issues, [...] and we have done joint projects and activities. [...]. [...] I have worked with biologists, sociologists, architects [...]. Very few technicians work together, but [...] I have sought synergy with others $[\ldots](24,2013)$.

\subsubsection{Hindering factors}

TAs talked more emphatically about the factors that hinder their performance, the reasons why these are considered limiting factors, and the consequences of this in their daily work. The main disabling factors mentioned by interviewees were: the high responsibility, uncertainty and lack of guarantees in work; the lack of unity and the competition among colleagues; the sometimes tense relations with CONAFOR; the safety issues in some local settings; and the reputation for bad practices which though carried out only by some of them, affect them all.

\subsection{Work conditions and uncertainty}

As was mentioned in the previous chapter, the conditions under which TAs do their work have implications for their performance on a daily basis. TAs consider they have a high level of responsibility but that this is not reflected in their wages nor in job certainty and side benefits. They receive a payment of around $20 \%$ of what is paid for the area of each polygon enrolled in PES; they cover all the expenses that they make in their fieldwork themselves. In addition, their payments are usually delayed for months, which directly affect their ability to visit beneficiaries. For this reason, they seek to have as many beneficiaries as possible within the same general areas, to use the money more 
efficiently. These situations have a greater impact on TAs working individually with fewer beneficiaries, than those who have formed enterprises and associations, which may have more beneficiaries and greater financial solvency.

Another problem of their working conditions is the lack of warranties and certainties. Because of the lack of a contractual relation, TAs have no right to benefits (health insurance, pension, etc.) nor any protection in case of accidents during the carrying out of activities in the field. Nor are there any official channels for complaints in case of bad behaviour of CONAFOR or beneficiaries.

We know that [...] at the beginning there were no TAs. CONAFOR employees did all the work we do today, [...] but the world came down on top of them (el mundo se les cayó encima], because it was a lot of work, and little staffing, [...] and then they invented [...] the external forestry TAs [...]. And we do not have a contract [...], they do not want the worker to have rights. Because the more rights [...] the more [CONAFOR's] obligations: medical service, benefits, holidays... [...] $(22,2014)$

For CONAFOR it is convenient to have TAs because [...] CONAFOR says: I pay you and you do the work, I do not care about the expenses, that is your problem [...]. [...] But there is no work commitment, because the TAs sign a contract only with the beneficiaries, not with CONAFOR [...] and if a TA is injured or something happens in the field [...] it is the TA's problem, the TA assume the responsibility for everything and [...] is the one that has to give results $(20,2013)$.

[...] But also [...] the guild is unprotected; we are on our own. We do not have the guarantee or certainty of anything [...]. [...] And we do not have anyone to complain to in case you need it. And sometimes we also do not complain to CONAFOR because you fear [...] possible negative consequences [...]. [...] So, [...] who cares for me? Because the whole weight of the programme $[\ldots]$ is on $u s . . .(27,2014)$.

\subsection{Relation with CONAFOR and trust}

The relationship of TAs with CONAFOR employees can be very good but can also be very tense. CONAFOR state employees can exert a lot of pressure on TAs, because the results of state-level employees depend directly on the results of the TAs. Between them, they carry the weight of the programme, and even though CONAFOR employees have labour rights, their contracts are signed every six months, so they also live in constant uncertainty and pressure to keep their jobs. Thus, they blame and pressure TAs, so they can show their good performance to the heads of central office. As 22 said: 
CONAFOR's employees [...], poor people, I see them living in a sea of uncertainty: -If I do not do my job well, they're going to fire me-. So, in order to keep their jobs, they think they have to press us $[\ldots](22,2014)$.

Trust is a topic that came up constantly during TAs interviews. The TAs feel that their work and results are constantly in question, and that they are not valued as they deserve to be, because CONAFOR has no confidence in them. They mention that there is always a defensive attitude from CONAFOR with them, as if it were normal that TAs make mistakes or try to cheat $(25,17,18,2013$; $30,28,26,27,2014)$. But this problem of trust concerns not only the employees of CONAFOR, because according to the informant 25 , the employees of the central office also have no confidence in the state- level employees:

[...] Sometimes people from state office come to do the verification [...] but they do not trust anyone. They do not trust us; but then central office staff comes to check [...] whether state offices are actually verifying our work. And now, external staff has been hired to check the work of general offices $[\ldots](25,2013)$.

\subsection{Security issues}

In the last decade, levels of violence and insecurity in México have increased significantly. Michoacán and Jalisco are among the states with greater risk, especially in the most marginalised rural areas. This makes it difficult for persons working in the field, especially in sparsely populated areas or the midst of forests lands. TAs are affected by this reality, they have had to learn to work in situations of potential risk. Given that this is a very sensitive subject, during the interviews I did not try to get more information than was openly offered to me. The sections of the interviews concerning this topic were off the record at the request of the informants, and I am only disclosing general information on this topic. Many TAs have stopped working in the most dangerous areas, and others have developed their own adaptation strategies, such as traveling only in the mornings, not camping in isolated areas, and only working in areas where they have reliable contacts, among others. It is known that some TAs have left their working areas because they were extorted by criminal groups; in other cases TAs have been kicked out of areas, so they have not been able to finish their work, but none have reported this to the police for fear of reprisals. Since there are no mechanisms in CONAFOR for dealing with those problems, its response has been poor, and both CONAFOR state-level staff and TAs have had to continue operating as if there was no risk. This implies that noncompliance by beneficiaries and TAs in areas under the control of criminal gangs is penalised in the same way as it is in safe areas.

\subsubsection{TAs' accounts of unethical practices}

Bad practices, corruption and power abuse are topics that emerged spontaneously and constantly in the interviews with TAs. The existence of unethical practices of TAs is 
widely recognised (Figure 10.3). Corruption is an especially sensitive issue in México. It is part of the popular narrative, and it is socially assumed that corruption is endemic in México. This is how some informants emphasised it:

Although it is sad, there is a lot of corruption in our country; that is not new nor will it disappear soon. It is surprising how people perform illegal activities knowingly, with such ease $[\ldots](6,2012)$.

Corruption is part of the Mexican culture $(22,2013)$

[...] You know there's rarely a corrupt Mexican, right? (laughs) [...] $(4,2013)$.

Interviewees provided several examples of the unethical practices carried out by (other) TAs, and some of them proposed causes and explanations for the incidence of this. Unethical practices are carried out at all stages of the programme, but some of them go beyond the CONAFOR operation (Table 10.7). Although these practices are present from initial contacts with potential beneficiaries, they are intensified in the implementation activities, since at that time there is a direct interaction between TAs and beneficiaries, with little or no monitoring by CONAFOR. However, some of these practices are carried out within sight of CONAFOR, and in some cases complaisance and active participation of CONAFOR's state-level and/or the beneficiaries is required. In other cases, these activities are obscured and carried out without the consent of these actors. Interviewees provided examples of corruption, power abuse, negligence, and other unethical practices, which can be seen in table 10.7

Table 10.7. Unethical practices carried out by TAS as mentioned in their interviews.

\begin{tabular}{|c|c|c|}
\hline Practice & $\begin{array}{l}\text { Stage of PES } \\
\text { programme }\end{array}$ & Specific actions \\
\hline \multirow{4}{*}{$\begin{array}{l}\text { Corruption } \\
\text { Different causes, } \\
\text { meanings, forms }\end{array}$} & Application & $\begin{array}{l}\text { Bribing community/ejido authorities to be chosen as TA (20, } \\
25 \text { ) }\end{array}$ \\
\hline & & $\begin{array}{l}\text { Enrol in the programme with the complicity of community } \\
\text { authorities to access the money behind the back of the rest } \\
\text { of the community }(24,21) \text {. }\end{array}$ \\
\hline & Implementation & $\begin{array}{l}\text { Requesting extra money to the beneficiaries, sometimes } \\
\text { without a concrete reason, or as support for transportation, } \\
\text { food, accommodation and materials used in the field, or as } \\
\text { compensation of delayed payments }(24,28,18,20,22,19) \text {. }\end{array}$ \\
\hline & $\begin{array}{l}\text { Report and } \\
\text { verification }\end{array}$ & $\begin{array}{l}\text { Bribing and collusion with CONAFOR employees to report } \\
\text { compliance in areas where the activities were not performed } \\
(20,24,54) \text {. }\end{array}$ \\
\hline
\end{tabular}




\begin{tabular}{|c|c|c|}
\hline Practice & $\begin{array}{l}\text { Stage of PES } \\
\text { programme }\end{array}$ & Specific actions \\
\hline & All stages & $\begin{array}{l}\text { Collusion with another person who acts as frontman }{ }^{9} \text { in } \\
\text { order to continue working as TA in cases when a) the TA has } \\
\text { been penalised, b) The TA wants to have more beneficiaries } \\
\text { than is allowed, or c) The TA is a CONAFOR employee who } \\
\text { cannot practice as a TA but wants to continue doing so ( } 20 \text {, } \\
24,22) \text {. }\end{array}$ \\
\hline \multirow{7}{*}{ Power abuse } & All stages & $\begin{array}{l}\text { Coercion and threatening beneficiaries to impose decisions, } \\
\text { activities, uses of money }(28,27,26)\end{array}$ \\
\hline & Implementation & III-treatment and humiliation of beneficiaries $(28,17,29)$ \\
\hline & Implementation & $\begin{array}{l}\text { Control and administration of beneficiaries' PES money, and } \\
\text { control to the access to other programmes (24) }\end{array}$ \\
\hline & All stages & $\begin{array}{l}\text { Illegal acts on behalf of the beneficiaries they represent (24, } \\
\text { 28) }\end{array}$ \\
\hline & All stages & $\begin{array}{l}\text { Monopoly of work zones, and hampering of the work of new } \\
\text { TAs in those zones }(24,17,21)\end{array}$ \\
\hline & All stages & Control of community information $(24,28,29)$ \\
\hline & All stages & $\begin{array}{l}\text { Collusion with other TAs to retaliate against beneficiaries } \\
\text { who complained or cancelled the contract }(30,24)\end{array}$ \\
\hline \multirow{5}{*}{$\begin{array}{l}\text { Negligence and } \\
\text { lack of capacities }\end{array}$} & Application & $\begin{array}{l}\text { Submission of incomplete applications, false information, } \\
\text { poorly constructed polygons }(23,30,24,18,19,22)\end{array}$ \\
\hline & Implementation & Abandonment of beneficiaries $(21,23,28)$ \\
\hline & Implementation & Poor compliance of activities, inadequate guidance $(24,19)$ \\
\hline & Implementation & $\begin{array}{l}\text { Poor attention to beneficiaries, little presence in the areas, } \\
\text { provision of incomplete and erroneous information }(24,26 \text {, } \\
27)\end{array}$ \\
\hline & Report & $\begin{array}{l}\text { Submission of incomplete, repeated or false reports, } \\
\text { plagiarism (24) }\end{array}$ \\
\hline \multirow{4}{*}{ Other practices } & Beyond PES & $\begin{array}{l}\text { Double registration in the LAST, as enterprise and as } \\
\text { individual technician }(21,24)\end{array}$ \\
\hline & Beyond PES & Contracts with more beneficiaries than allowed $(20,21,22)$ \\
\hline & Beyond PES & Disloyal practices among colleagues $(23,20,28,26)$, \\
\hline & Beyond PES & Use of the programme for political purposes $(31,27,25)$ \\
\hline
\end{tabular}

${ }^{9}$ Frontman in this thesis (Table 10.7, in Chapter 10, and Table 12.3, in Chapter 12) is used as a translation of the Spanish word "prestanombres", which refers to a person who pretends to perform financial transactions and assumes the obligations as if they were his/hers, nevertheless the money or benefits obtained by these transactions is in fact for another person. (https://www.gob.mx/condusef/articulos/prestar-tu-nombre?idiom=es) 
As mentioned in the Chapter 8 , some practices, especially of power abuse by TAs, have a direct historical background (Chapela, 2000; Weaver, 2001), and have been maintained and normalised over time. Old structures of forest policies have been used in the construction of new policies and schemes. Not only actors from CONAFOR and TAs, but also forest communities have assumed those practices to be inherent. This may be another reason why there are not as many complaints as one might expect. Some of the "old school" TAs who have provided technical services for years, and before the creation of CONAFOR, exert excessive power not only on the forest communities, but also on CONAFOR employees who cannot do much, as many of these TAs are very influential, and who are connected and allied to political parties and others in power. It seems that this dynamic is reproduced and can be inherited to new generations through the unions of forest engineers $(24,2013)$, although not all "old school" TAs operate this way. Figure 10.3 shows different types of unethical practices carried out during different key moments of implementation of PES programme. Solid coloured areas represent the presence of the actors at each moment of programme execution. The shaded areas show the moments when each actor is not present in the process. It is notorious that TAs act in almost the entire process, often out of sight of CONAFOR. 
Figure 10.3. Unethical practices committed by TAs (purple lines), in relation with key moments of the PES programme to illustrating the monitoring gaps in PES, and the presence of the other main actors.
ORs Call Application
Acceptance
Implementation
Reporting
Verification

\section{CONAFOR Central office}

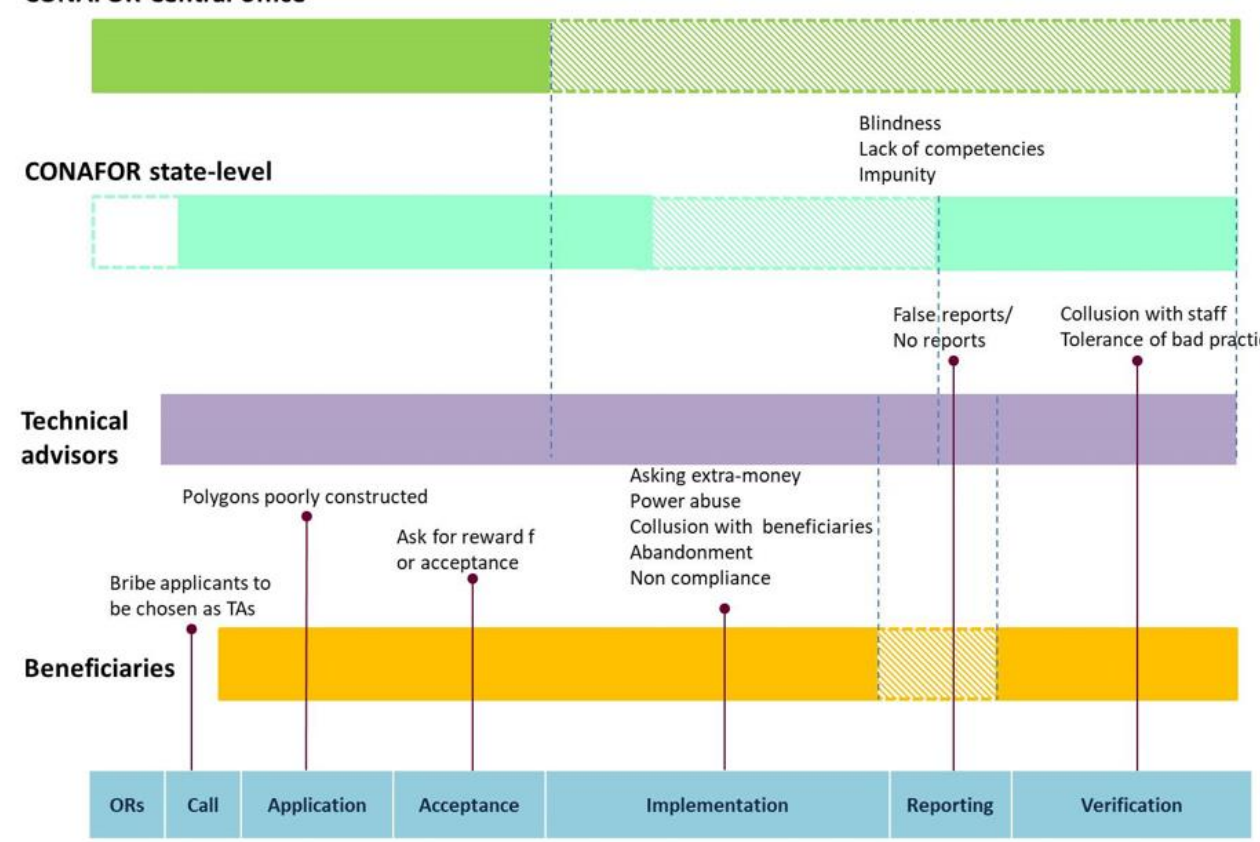

Unethical practices are complex issues with many edges. In order to understand the scope and limits of these practices in PES programme, a much deeper study would be required. But some TAs shared their reflections on this problem and its complexities. 24, for example, speaks of levels of corruption, such as the "word" level, where there is no concrete evidence to take specific actions.

[...] In this country there is a level of corruption that cannot be verified, because it is word against word [...]. [...] And before that, how does CONAFOR react if it does not have evaluation schemes or does not want to apply them? [...] $(24,2013)$

TAs mentioned more specific causes of unethical practices, such as the low and delayed payments to TAs, the lack of surveillance and concrete actions from CONAFOR (Figure 10.3), and lack of capacities of (potential) beneficiaries. A detailed explanation of this 
was provided by informant 54 from an inter-municipal organisation which advises to communities in sustainability themes:

[...] TAs depend on having CONAFOR money on time. [...] And CONAFOR requires the TAs to carry out the activities on the scheduled dates, although the money is slow to arrive and is low. And how are we going to do the activities if we do not have the money? [...] CONAFOR itself causes the situation in which the TAs will do anything to prove that they did the project. And if that implies corrupting the CONAFOR official who does verification and says: -the activity is not complete-, and the TA says:-Yes, but we did not have the resources on time, and my services have not been still paid! [...] How do you want me to do it right?-, [...] and the CONAFOR official says: - I will report it as a breach -.-[...] and the TA says -We can reach an agreement...- so that the TA is not affected, but now he owes the supervisor something [...]. And in that way, he learned that the supervisor is "flexible"... and every time he does more serious things. And nothing happens, because impunity [...] is a very important element in this game. Then, the TA tells the beneficiary that the problem is solved, but now the beneficiary owes money to the TA. And the beneficiary is now obliged to give money ... And that becomes a habit. [...] And that perverse game of lack of ethics and professionalism begins.... [...] There is a disconnection [...] between the fiscal year of CONAFOR and the times of nature and people, when it rains and when people are available [...]. It is incredible that someone at a desk cannot visualise this ... [...] This could change [if] the resources of CONAFOR for the provision of technical services are timely and if the capacities of communities are strengthened to [...] have a better position against the TAs [...] $(54,2014)$.

At least at the state level, interviewees easily identify the unethical TAs because, they say, it is obvious and sometimes there is concrete evidence. As it was mentioned, impunity is an important element in the commission of abusive practices. In that sense, all the TAs agreed that although CONAFOR is fully aware of these practices, its main reaction has been to look the other way, and this inaction is a facilitator for impunity. According to the TAs, lack of action from CONAFOR is due to: 1 ) the lack of a regulatory body and framework to deal with these activities, 2) the lack of operative capacity and, in some cases, 3 ) the collusion of certain employees (especially from the state-level) with unethical TAs.

CONAFOR [people] do know, but they do as if they do not know $(25,2013)$.

CONAFOR does know who [...] is doing the best and worst job. [But] they cannot act directly on that [...] because the ORs do not indicate it $(30,2014)$.

[...] We know perfectly well who the corrupt TAs are. It is an open secret. And of course, CONAFOR knows, there is too much evidence to prove it [...], [but] there is no a regulatory 
body that can limit and punish unethical activities... [...] Nor is there the operational capacity to control and limit the reach of these people. [...] The only thing CONAFOR can say is: "There was a change of TA". And that's it [...] $(28,2014)$.

[CONAFOR] should know these bad practices [...] because they are so obvious. All the people say it [...]. [...] And people say it because it's happening. I have personally seen it and have seen my colleagues. [...] Some TAs really exert a power, [that is] somehow facilitated by CONAFOR $(31,2014)$.

[...] CONAFOR also participates, the TAs become friends of those who work there [...]. [...] It is a comfortable position, people who are in CONAFOR work with people they already know, and the TA knows that his [...] "mate" will help him (21, 2014).

Although the interviewees recognised the existence of a deep problem in their own profession regarding bad practices, they also consider that CONAFOR has been coresponsible and a facilitator of those practices and impunity. Some TAs have gone further, arguing that CONAFOR itself has set the ideal conditions for corrupt TAs, such that they feel free to exercise their power to make profits at the expense of others. Thus, they say, CONAFOR has fallen into the contradiction of fighting against its own creation, avoiding its responsibility, and placing TAs in an untouchable place, making TAs actors against which nothing can be done.

If this vision of CONAFOR is not modified, we will continue [...] perpetuating the existence of ever more corrupt, increasingly enriched, increasingly powerful TAs [...]. And the people of CONAFOR will continue to fight against the same monster they created, because they created it: they gave them privileges and permission to handle very large areas, and although there are a lot of other TAs working in the same areas, these TAs continue to have influence and invulnerability [...] $(24,2013)$.

\subsubsection{TAs views on certification as a mechanism of quality control}

Certification was an emerging topic in the interviews in general, but it acquired more relevance as I advanced in the interviews with the TAs. This was because this research coincided with the time that certification was established as a mandatory process for TAs, becoming a hot issue. But additionally, because certification has been a turning point in the relationship between CONAFOR and TAs. It is also a very controversial measure taken by CONAFOR to deal with TAs. With one exception, the responses of TAs about the topic were negative (Figure 10.4). And, according to the TAs interviewed, this negative vision about certification is the general feeling of TAs throughout the country. 
Figure 10.4. Expressions used by the TAs when referring to the certification. Of the all interviewees, only one considered that it is a positive strategy (Source: Images taken and modified from https://es.123rf.com)
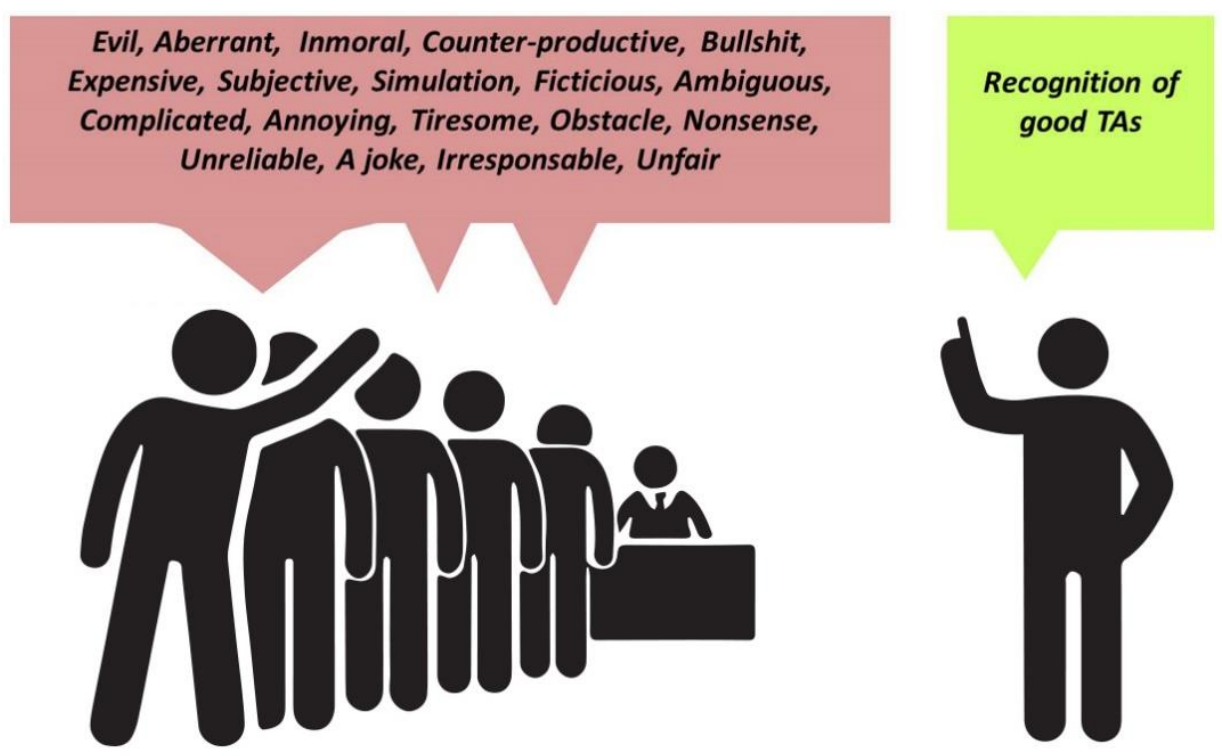

Most of the TAs acknowledged the need for the establishment of an evaluation system of their performance, as well as formal mechanisms for rewarding and penalising TAs. But they argue that the current process has plenty or gaps and misperceptions, and that the methodological approach is inadequate. Moreover, the process does not address the problems in an integrated way, and it can even produce counterproductive results. More reasons provided by interviewees to justify their discontent with certification are shown in the following table 10.8 .

Table 10.8. Main criticisms of TAs about the misconceptions, gaps and suitability of the certification process

Main problems of the certification process according to TAs 


\begin{tabular}{|c|c|}
\hline \multicolumn{2}{|r|}{ Main problems of the certification process according to TAs } \\
\hline & $\begin{array}{l}\text { - Evaluate attitudes in hypothetical situations that are sometimes far from } \\
\text { reality, and requires simulation }(17,24, \mathrm{RV}) \\
\text { - Does not evaluate moral commitment or work ethics }(20,24,18,25) \\
\text { - The evaluation of social capacities among others is subjective }(24)\end{array}$ \\
\hline It is not serious & $\begin{array}{l}\text { - The exam is very general }(18,19,24,21,28) \\
\text { - If a TA has no evidence to prove experience, s/he can invent it }(17,31,27) \\
\text { - As you have to simulate and perform like in a theatre play, they actually } \\
\text { evaluate your drama abilities (24) }\end{array}$ \\
\hline Ambiguous & $\begin{array}{l}\text { - The final intention of the process is unclear }(24,26) \\
\text { - Evaluates rigorously the evidence from experienced TAs, but encourages } \\
\text { invention of information from inexperienced TAs }(31,29)\end{array}$ \\
\hline Arbitrary & $\begin{array}{l}\text { - It does not recognise the degrees and professional knowledge of TAs } \\
\text { (MRN) } \\
\text { - It does not recognise the RFN (National Forestry Registry), a permission } \\
\text { which is granted by the ministry to which CONAFOR belongs }(30,24,17 \text {, } \\
\text { MRN, 18) } \\
\text { - The certification would have to be done not only to TAs, but also the } \\
\text { employees of CONAFOR }(18,19) \\
\text { - There is no way to verify that the evaluators act honestly, or that they can } \\
\text { incorrectly score the tests to make the TAs pay for a re-examination (22). }\end{array}$ \\
\hline Incomplete & $\begin{array}{l}\text { - The certifying mechanism has no powers to deal with specific cases of } \\
\text { corruption }(28,30) \\
\text { - Do not take into account results in the field, such as reports, number of } \\
\text { successful projects, nor evaluations from beneficiaries }(23,20,28,25,24 \text {, } \\
31,18,30)\end{array}$ \\
\hline $\begin{array}{l}\text { It favours groups with } \\
\text { greater power }\end{array}$ & $\begin{array}{l}\text { - TAs with financial solvency are more likely to be certified regardless of } \\
\text { their experience and ethics, than experienced TAs with less resources }(28, \\
18,19,25,24) \\
\text { - Individual TAs have more limitations on the number of beneficiaries and } \\
\text { therefore less resources to pay }(20,18,21,17, M R N) \\
\text { - New graduates do not have the experience or money to get certified and } \\
\text { start working }(20, M V, 27)\end{array}$ \\
\hline Counter-productive & $\begin{array}{l}\text { - Contributes to quality reduction by allowing NGO people to individually } \\
\text { certify, which enables them to engage more projects individually }(23,24,20 \text {, } \\
25) \\
\text { - Simplifies capacities, allowing TAs with very different abilities to be } \\
\text { homogenised and with the permission to do the same things (24) } \\
\text { - Verification in the field is done by CONAFOR employees, who are not } \\
\text { certified }(28,31)\end{array}$ \\
\hline
\end{tabular}

\subsubsection{TAs' needs and perspectives}

All the TAs with whom I spoke had already participated in CONAFOR programmes for some years, and most of them had decided not to carry out this activity in the long term. Only two intend to continue doing this work, but they would also be willing to look for other job options.

Most TAs are eager to see progress not only in their working conditions, but also in the development of the programme, and of the beneficiaries they work with. They presented several ideas on the topics they consider could be improvements. Some 
general points emerged in all interviews, and others were very specific suggestions. These have been classified as follows.

\section{Evaluation and monitoring of performance}

- Regarding evaluation, TAs consider that monitoring of TAs performance evaluation must be an integral part of the scheme, and must be based on evidence that already exists in CONAFOR, such as the TA activity reports, verification documents, and the performance evaluations made by the beneficiaries, which have not been used up to now.

- The rethinking of the certification process, so that it actually contributes to improve the quality of the services offered by the TAs

- Certification should be adjusted for the case of community technicians, who have no documents for validating their knowledge

\section{Interaction between actors}

- Formal spaces for interaction between TAs, such as forums for exchange experiences and regional networks, as well as specific spaces for interacting with CONAFOR to solve doubts or expose problems of general interest

- Presence and support from CONAFOR to networking initiatives among beneficiaries mediated by TAs

- Better platforms for interaction between TAs outside and independent of CONAFOR. Creation of diversified TA unions.

\section{Training}

- More, better and specialised training in theoretical and technical topics

\section{Administrative processing}

- Speed-up paperwork procedures in CONAFOR such as submission of applications and reports. Digitisation of information and creation of databases that avoid repeated delivery of the same information to CONAFOR for new applications with the same beneficiaries, in order to save time and money on travel and document printing and improve the follow-up of projects.

\section{Situation of TAs in the CONAFOR programmes}

- More confidence in the work of TAs

- Recognition of TAs as valuable and fundamental agents in the development of programmes

- More flexibility of CONAFOR and freedom of action for TAs to make technical decisions according to local conditions, even if these are outside the rules

- More TA participation, and consideration of suggestions and proposals for modification of ORs

- Differentiation of TAs by type of technical capacity, but also by level of commitment 
- Establishment of a unit within CONAFOR that allows to complaints, disagreements and problems of TAs to be processed, as well as some protection measures (e.g. to cover accidents in the field)

- Increase in the payments for technical assistance, and extra support to cover expenses in the field or transfers to the state-level CONAFOR offices for necessary paperwork and procedures on behalf of beneficiaries.

\subsection{Discussion: The non-visible influence of TAs on the ORs}

With all the evidence shown in the results, now it is possible to understand the flexibility and adaptability of the TAs' roles. Several factors determine the range of tasks TAs can fulfil in the field; many of them go beyond the expectations of CONAFOR.

The influence of the TAs in the evolution of the PES programme has little visible in the CONAFOR narrative. Although some of the changes proposed by TAs come to the attention of CONAFOR through reports, and the verification acts, many of these suggestions are diluted, owing to the lack organisation of the TAs, and the lack of trust in this group. However, in this study it can be seen that TAs can shape the programme in informal ways 1) through the use of discretion in the interpretation and fulfilment of ORs; b) through the relationships established with the beneficiaries of PES, and their influence on community decision-making, and c) through their individual decisions to select suitable areas of work. On this last case it is still necessary to understand the position and role of TAs in the targeting of PES in the ground.

Since they are who approach and convince potential beneficiaries to be involved in PES, their motivations may be significant in the selection of areas and beneficiaries. For example, if most of TAs are driven by practical or economic criteria, they might choose the most accessible or largest areas to obtain more benefits for themselves; or if they prefer smallholders over communities, to gain more control over the decision-making. But if they are driven by social or environmental criteria, they could actually contribute to the inclusion of marginalised communities (Bosselmann \& Lund, 2013), or improve the possibilities of fulfil the PES' environmental goals.

TAs in PES in México are a diversity of organisations and individuals with different objectives, strategies, levels of social-environmental commitment, and professional backgrounds. For most of them, the fulfilling of CONAFOR goals may be a secondary task. They themselves determine their position in relation to the other actors, whether they work is closer to the interests of CONAFOR, of those of the communities, or simply they work for themselves. Coupled with this are the differences between the "old- 
school" and "CONAFOR's children" TAs, which further complicates the understanding of the role of TAs, as well as the dynamics of TAs as a group.

TAs have not been passive actors in this construction of their own situation. Despite many adverse conditions, as a group, they have frequently placed the blame on CONAFOR for their own circumstances; and although there are specific problems that afflict them, TAs have remained neglectful in the search for collective solutions. It was recognised by all the TAs involved in the study that incidence of unethical practices is a problem seriously affecting the image and work of all the TAs. They have also recognised deeper problems, such as the insertion of TAs in the programmes, and the fuzzy delimitation of the roles of different actors.

There is a lack of information to understand the internal processes that may enable the functioning of TAs as a guild, - for the establishment of common spaces, behaviour standards and processes of self-regulation, and for mobilising pressure to collectively improve their work conditions. There are also many gaps of information about the real proportion of TAs engaging in bad practices or providing poor services. All the information about that is blurred and the little formal evidence is reserved in CONAFOR. Furthermore, it seems that the results of the PES programme are not influenced in any way by the problems happening during the implementation. There is no concrete evidence of the extent in which the performance of TAs is positively or negatively affecting the programme, so it seems that CONAFOR meet its goals successfully every year. As an informant sarcastically said, "everything always seems to work well...incredibly well in PES programme".

\subsection{Conclusions: Possible future roles of TAs}

In this chapter we have explored the visions of the TAs regarding their participation in the Mexican PES scheme. They fulfil a set of roles in a flexible and adaptive way, depending of their own interests, the local conditions, the needs and characteristics of the beneficiaries. They move between the official (formal) and the informality in implementation of PES.

Through this chapter we have seen the great heterogeneity of the TAs that participate in the PES program. However, it is also important to make visible the common points regarding the problems they face in carrying out their work, and their vision regarding their relationship with CONAFOR and with the communities. The official narrative of CONAFOR has focused more on representing this heterogeneity as well as the questionable aspects of the performance of, ignoring aspects that can be improved in the relationship with TAs. 
About the bad reputation of TAs, TAs own perceptions about their relationship with CONAFOR, beneficiaries and the other TAs are complex. The identity of TAs has plenty of contradictions and ambiguities; their relationship with CONAFOR is, as Stone says, "simultaneously adversarial and symbiotic" (2002), which have contributed to consolidate the TAs' negative image.

The informal roles they perform are highly relevant to understand the ways in which they can influence local decision making and the ORs. Their motivation to participate in the programme is the main factor determining the type of work they carry out, and whether they contribute in the sense of empowering the local communities training them in specific issues and stimulating participation.

The importance of TAs as agents for the development of forest policy should be a shared responsibility. New forms of intermediaries could be identified as relevant components of the programme. Beyond the LAST, deeper implications of the performance of TAs need to be examined. It is also necessary to think about new configurations to discourage harmful practices, which have been partly the result of incorporation of older elements of forest policy, but which are also partly rooted in the new labour schemes that have been adopted by CONAFOR to reduce costs and their own responsibilities. Several informants from CONAFOR, NGOs and also the TAs acknowledged the need for major changes in the PES programme, as one of the TAs stated:

Michoacán [...] is a state with forest potential of more than $75 \%$ and [...] a large number of technicians. Michoacán has academic institutions for forest education, a diversity of forest companies [...] and also has a great infrastructure, but unfortunately there is a huge backwardness. [...] It means [...] that we have all failed, from the government itself, the technicians, the entrepreneurs, the academic institutions [...]. The problems remain the same [...] because we have been trying to solve them in the same ways [...] then, well; we have claimed that these problems require major surgery, a fundamental transformation. We can no longer do things the same way $(18,2013)$.

\section{References of Section III}

Aguilar, J., Reyes, J., \& Rendon, R. (2010). Del extensionismo agrícola a las redes de innovación rural (Vol. 53). http://doi.org/10.1017/СВO9781107415324.004

Aguirre, F. (2012). El Nuevo Impulso de la Extension Rural en America Latina. Situacion actual y perspectivas. Santiago de Chile: Red Latinoamericana para los Servicios de Extensión Rural.

Alix-Garcia, J., Janvry, A. De, Sadoulet, E., Manuel, J., \& Torres, J. M. (2009). 10 Lessons Learned from México's Payment for Environmental Services Program. In Payment for Environmental Services in Agricultural Landscapes (Vol. 1951, pp. 1-27). http://doi.org/10.1007/978-0387-72971-8

Angelsen, A. (2009). Policy options to reduce deforestation. In Realising REDD+: National Strategy and Policy Options (pp. 125-138). Center for International Forestry Research: Bogor, Indonesia. http://doi.org/10.1007/978-81-322-0539-5 
Berghöfer, A., Mumbunan, S. \& Muñoz, M. (2011). Institutional Analysis of Intermediaries in Payments for Ecosystem Services.

Bijlsma-Frankema, K., \& Costa, A. C. (2005). Understanding the Trust-Control Nexus. International Sociology, 20(3), 259-82. http://doi.org/10.1177/0268580905055477

Bijlsma, R. M., Bots, P. W. G., Wolters, H. A., \& Hoekstra, A. Y. (2011). An Empirical Analysis of Stakeholders' Influence on Policy Development: The Role of Uncertainty Handling. Ecology \& Society, 16(1), 1-16.

Boon, W. P. C., Moors, E. H. M., Kuhlmann, S., \& Smits, R. E. H. M. (2011). Demand articulation in emerging technologies: Intermediary user organisations as co-producers? Research Policy, 40(2), 242-252. http://doi.org/10.1016/j.respol.2010.09.006

Bosselmann, A. S., \& Lund, J. F. (2013). Do intermediary institutions promote inclusiveness in PES programs? The case of Costa Rica. Geoforum, 49, 50-60. http://doi.org/10.1016/j.geoforum.2013.05.009

Bracer, C., Scherr, S., Molnar, A., Sekher, M., Ochieng, B. O. \& Sriskanthan, G. 2007. Organization and Governance for Fostering Pro-Poor Compensation for Environmental Services. Working paper. CES Scoping Study Issue Paper no. 4. ICRAF Working Paper no. 39. Nairobi, Kenya: World Agroforestry Centre.

Bray, D. B. \& Merino, L. (2005). La experiencia de las comunidades forestales en México. Veinticinco años de silvicultura y construccion de empresas forestales comunitarias. México: INE-CCMSS.

Bray, D. B., Duran, E., Merino, L., Torres, J., \& Velazquez, A. (2007). Nueva evidencia: los bosques comunitarios de México. Agrupacion Sierra Madre S.C.-CONAFOR, 1, 1-24.

Burstein, J., Chapela, G., Aguilar, J. \& de Leon, E. 2002. Informe sobre la propuesta de pago por servicios ambientales en México. Informe del proyecto "Pago por servicios ambientales en Las Américas". México: Fundacion FORD- Fundacion PRIMSA.

Campbell, J. L. (2004). Problems of Institutional Analysis. In Campbell, J. L. Institutional Change and Globalization (pp. 1-30.). N J Princeton: Princeton University Press.

Campbell, J. L. (2010). Institutional reproduction and change. In Morgan, G., Campbell, J.L., Crouch, C., Pedersen, O.K., \& Whitley, R. (Eds.). Oxford Handbook of Comparative Institutional Analysis (pp.87-115), New York: Oxford University Press.

Chapela, G. (2000). Gobernabilidad y Manejo Forestal Sustentable. Problemas y Propuestas para el Mejoramiento de los Servicios Tecnicos Forestales. In Escalante, S. R. \& Aroche, R. F. (Eds.) El sector forestal Mexicano: paradojas de la explotacion de un recurso natural (pp. 115-152). México: Facultad de Economia, UNAM.

Cleaver, F. D. (2001). Institutional bricolage, conflict and cooperation in Usangu, Tanzania. IDS Bulletin, 32(4), 26-35. http://doi.org/10.1111/j.1759-5436.2001.mp32004004.x

Cleaver, F. D., \& Franks, T. R. (2005). How institutions elude design: river basin management and sustainable livelihoods. Development, (12), 1-21.

Coad, A. F., \& Cullen, J. (2006). Inter-organisational cost management: Towards an evolutionary perspective 17, 342-369. http://doi.org/10.1016/j.mar.2006.02.003

Coggan, A., Buitelaar, E., Whitten, S. M., \& Bennett, J. (2013). Intermediaries in environmental offset markets: Actions and incentives. Land Use Policy, 32, 145-154. http://doi.org/10.1016/j.landusepol.2012.10.002

CONAFOR. 2012. Informe del Listado de Asesores Tecnicos. Internal Report. Gerencia de Educacion y Capacitacion, CONAFOR. México.

CONAFOR. 2013. Informe del Listado de Asesores Tecnicos. Internal Report. Gerencia de Educacion y Capacitacion, CONAFOR. México.

Corbera, E., \& Brown, K. (2008). Building Institutions to Trade Ecosystem Services: Marketing Forest Carbon in México. World Development, 36(10), 1956-1979. http://doi.org/10.1016/j.worlddev.2007.09.010 
Corbera, E., Soberanis, C., \& Brown, K. (2009). Institutional dimensions of Payments for Ecosystem Services: An analysis of México's carbon forestry programme. Ecological Economics, 68(3), 743-761. http://doi.org/10.1016/j.ecolecon.2008.06.008

Costedoat, S., Corbera, E., Ezzine-de-Blas, D., Honey-Rosés, J., Baylis, K., \& Castillo-Santiago, M. A. (2015). How Effective Are Biodiversity Conservation Payments in México? PLoS One, 10(3), e0119881. http://doi.org/10.1371/journal.pone.0119881

Costedoat, S., Koetse, M., Corbera, E., \& Ezzine-de-Blas, D. (2016). Cash only? Unveiling preferences for a PES contract through a choice experiment in Chiapas, México. Land Use Policy, 58, 302-317. http://doi.org/10.1016/j.landusepol.2016.07.023

Cuevas, Venancio Baca, J., Cervantes, F., \& Aguilar, J. (2012). Asistencia tecnica en el sector agropecuario en Mexico: analisis del VIII censo agropecuario y forestal, Revista mexicana de ciencias agricolas, 3(5), 943-957.

Daniels, A. E., Bagstad, K., Esposito, V., Moulaert, A., \& Rodriguez, C. M. (2010). Understanding the impacts of Costa Rica's PES: Are we asking the right questions? Ecological Economics, 69(11), 2116-2126. http://doi.org/10.1016/j.ecolecon.2010.06.011

Davis, E. J., Gwin, L., Moseley, C., Gosnell, H., \& Burright, H. (2015). Beer, beef, and boards: the role of intermediaries in payment for ecosystem services arrangements in north western Montana. Journal of Environmental Planning and Management, 58(9),1562-1576. http://doi.org/10.1080/09640568.2014.938803

DOF. (2008). Ley General De Desarrollo Forestal Sustentable, México. Diario Oficial de la Federación. Last reform: April, 23, 2012. Mexico: Secretaria de Gobernacion.

DOF. (2008). MECANISMO de ingreso al Listado de Asesores Tecnicos de Pro-Arbol de la Comision Nacional Forestal. Diario Oficial de la Federacion. April, 22. Mexico: Secretaria de Gobernacion.

DOF. (2009). MECANISMO de ingreso al Listado de Asesores Tecnicos de Pro-Arbol de la Comision Nacional Forestal. Diario Oficial de la Federacion. March, 19. Mexico: Secretaria de Gobernacion.

DOF. (2010). MECANISMO de ingreso al Listado de Asesores Tecnicos de Pro-Arbol de la Comision Nacional Forestal. Diario Oficial de la Federacion. March, 18. Mexico: Secretaria de Gobernacion.

DOF. (2011). NORMA que regula el Mecanismo de Certificacion de los Asesores Tecnicos del Programa ProArbol. Diario Oficial de la Federacion. July, 26. Mexico: Secretaria de Gobernacion.

Giddens, A. (1991). The Consequences of Modernity. The British Journal of Sociology, 188. http://doi.org/10.2307/591454

Hamann, E. T., \& Lane, B. (2004). The roles of state departments of education as policy intermediaries: Two cases. Educational Policy, 18(3), 426-455. http://doi.org/10.1177/0895904804265021

Hardin, R. (2002). Trust and Trustworthiness. New York: Russell Sage Foundation.

Hardin, R. (2013). Government without trust. Journal of Trust Research, 3(1),32-52, http://doi.org/10.1080/21515581.2013.771502

Hood, C. (2011). The Blame Game: Spin, Bureaucracy, and Self-Preservation in Government. Princeton: Princeton University Press.

Howells, J. (2006). Intermediation and the role of intermediaries in innovation. Research Policy, 35(5), 715-728. http://doi.org/10.1016/j.respol.2006.03.005

Huber-Stearns, H. R., Goldstein, J. H., \& Duke, E. A. (2013). Intermediary roles and payments for ecosystem services: A typology and program feasibility application in Panama. Ecosystem Services, 6, 104-116. http://doi.org/10.1016/j.ecoser.2013.09.006 
Jensen, M., \& Meckling, W. H. (1976). Theory of the firm: Managerial behaviour, agency costs and ownership structure. Journal of Financial Economics, 3(4), 305-360. http://doi.org/10.1016/0304405X(76)90026-X

Jindal, R., \& Kerr, J. (2007). Buyers, Sellers, Intermediaries. USAID PES Brief 3.1.

Keys, E. (2005). Exploring market-based development: Market intermediaries and farmers in Calakmul, México. The Geographical Review, 95(1), 24-46. http://doi.org/10.1017/CBO9781107415324.004

Khurana, R. (2002). Market triads: A theoretical and empirical analysis of market intermediation. Journal for the Theory of Social Behaviour, 32(2), 239-262

Klerkx, L., \& Leeuwis, C. (2008). Delegation of authority in research funding to networks: experiences with a multiple goal boundary organization. Science and Public Policy. 35(3), 183-196. http://doi.org/10.3152/030234208X299053

Kosoy, N., Corbera, E., \& Brown, K. (2008). Participation in payments for ecosystem services: Case studies from the Lacandon rainforest, México. Geoforum, 39(6), 2073-2083. http://doi.org/10.1016/j.geoforum.2008.08.007

Kritsanaphan, A., \& Sajor, E. (2011). Intermediaries and informal interactions in decentralised environmental management in peri-urban Bangkok. International Development Planning Review. 33(3), 247-272. http://doi.org/10.3828/idpr.2011.11

Leimona, B., \& Lee, E. (2008). Pro-Poor Payment for Environmental Services Some Considerations. Bogor: RUPES- ICRAF-SEA.

Locatelli, B., Rojas, V., \& Salinas, Z. (2008). Impacts of payments for environmental services on local development in northern Costa Rica: A fuzzy multi-criteria analysis. Forest Policy \& Economics, 10(5), 275.

Lopez-Arzola. (2007). El empoderamiento del manejo forestal comunitario en Oaxaca. La Union de Comunidades Forestales y Ejidos de Oaxaca 1985-1996. In Bray, D., Merino, L. \& Barry, D. (Eds.) Los bosques comunitarios de México. Manejo sustentable de paisajes forestales (pp. 147-162). México: INE- SEMARNAT.

Mayer, R. C., Davis, J. H. \& Schoorman, F. D. (1995). An Integrative Model of Organisational Trust. The Academy of Management Review 20(3), 709-734.

McAfee, K., \& Shapiro, E. N. (2010). Payments for Ecosystem Services in México: Nature, Neoliberalism, Social Movements, and the State. Annals of the Association of American Geographers, 100(3), 579-599. http://doi.org/10.1080/00045601003794833

Medd, W., \& Marvin, S. (2007). Strategic intermediation: Between regional strategy and local practice. Sustainable Development, 15(5), 318-327. http://doi.org/10.1002/sd.345

Merino-Perez, L. (2004). Conservacion o deterioro. El impacto de las politicas publicas en las instituciones comunitarias y en los usos de los bosques en México. México City: SEMARNATINE-CCMSS.

Merino-Perez, L., \& Hernandez-Apolinar, M. (2004). Destruccion de instituciones comunitarias y deterioro de los bosques en la Reserva de la Biosfera Mariposa Monarca, Michoacán, México. Revista Mexicana de Sociologia, 66(2), 261-309. http://doi.org/10.2307/3541458

Merino-Perez, L. \& Segura, G., (2002). Las politicas forestales y de conservacion y sus impactos en las comunidades forestales en México. In Bray, D.B., Merino-Perez, L., Barry, D. (Eds.) Los Bosques Comunitarios de México (pp. 77-98). México City: INE-CCMSS.

Merino-Perez, L. \& Gonzalez, A. (2004). El programa de pago por servicios ambientales hidrologicos: Revision critica y propuestas de modificacion. México City: CCMSS.

Mike, H., \& Simon, M. (2008). Glossary of Intermediaries. Research Note 1. , UK: University of Salford, SURF Centre.

Mitnick, B. M. (2011). Origin of the Theory of Agency: An Account By One of the Theory's Originators. SSRN Electronic Journal, (March), 15. http://doi.org/10.2139/ssrn.1020378 
Möllering, G. (2005). The Trust/Control Duality: An Integrative Perspective on Positive Expectations of Others. International Sociology, 20(3), 283-306.

http://doi.org/10.1177/0268580905055478

Möllering, G. (2006). Trust: Reason, routine, reflexivity. Oxford: Elsevier.

Moss, T. (2009). Intermediaries and the governance of sociotechnical networks in transition. Environment and Planning A, 41(6), 1480-1495. http://doi.org/10.1068/a4116

Moss, T., Medd, W., Guy, S., \& Marvin, S. (2009). Organising water: The hidden role of intermediary work. Water Alternatives, 2(1), 16-33.

Muñoz, R. M. \& Santoyo, C. V. H. (2010). Del extensionismo a las redes de Innovacion. In Aguilar, A. J.; Altamirano, C. J. R.; Rendon, M. R. \& Santoyo, C. V. H. (Coord.). Del extensionismo agricola a las redes de innovacion rural (pp. 31-70).). Chapingo, México: UACH.

Noordwijk, M. Van, Leimona, B., Emerton, L., Tomich, T. P., Velarde, S. J., Kallesoe, M., ... Swallow, B. (2007). Criteria and indicators for environmental service compensation and reward mechanisms: realistic, voluntary, conditional and pro-poor. Development, $63 \mathrm{p}$. http://doi.org/10.5716/WP14964.PDF

Oskarsson, S., Svensson, T., \& Oberg, P. (2009). Power, Trust, and Institutional Constraints: Individual Level Evidence. Rationality and Society, 21(2), 171-195. http://doi.org/10.1177/1043463109103898

Pagiola, S. (2008). Payments for environmental services in Costa Rica. Ecological Economics, 65(4), 712-724. http://doi.org/10.1016/j.ecolecon.2007.07.033

Pham, T. T., Campbell, B. M., Garnett, S., Aslin, H., \& Hoang, M. H. (2010). Importance and impacts of intermediary boundary organizations in facilitating payment for environmental services in Vietnam. Environmental Conservation, 37(1), 64-72. http://doi.org/10.1017/S037689291000024X

Rajão, R., \& Georgiadou, Y. (2014). Blame Games in the Amazon: Environmental Crises and the Emergence of a Transparency Regime in Brazil. Global Environmental Politics, 14(2), 82101. http://doi.org/10.1162/GLEP

Rivero Cob, E. (2012). Problemas de Agencia y Busqueda de Rentas en el Programa de Pago por Servicios Ambientales Hidrologicos de México. Revista de Economia, XXIX (79), 33-70.

Rodriguez, G. G., Robles, B. H., Matus, M., Perez, C. E. \& Molina, M. C. 2012. Evaluacion Complementaria del Programa Pro-Arbol -Capacitacion Ambiental y Desarrollo Sustentable- Ejercicio Fiscal 2011. México: CIESAS- CONACYT.

Schomers, S., Matzdorf, B., Meyer, C., \& Sattler, C. (2015). How Local Intermediaries Improve the Effectiveness of Public Payment for Ecosystem Services Programs: The Role of Networks and AgriEnvironmental Assistance. Sustainability, 7 (10) 13856-13886 http://doi.org/10.3390/su71013856

Segura-Warnholtz, G. (2014). Quince años de politicas publicas para la accion colectiva en comunidades forestales. Revista Mexicana de Sociologia, 76, 105-135.

Shapiro-Garza, E. (2013). Contesting the market-based nature of México's national payments for ecosystem services programs: Four sites of articulation and hybridization. Geoforum, 46, 515. http://doi.org/10.1016/j.geoforum.2012.11.018

Sims, K. R. E., Alix-Garcia, J. M., Shapiro-Garza, E., Fine, L. R., Radeloff, V. C., Aaronson, G., ... YañezPagans, P. (2014). Improving Environmental and Social Targeting Through Adaptive Management in México's Payments for Hydrological Services Program. Conservation Biology, 28(5), 1151-1159. http://doi.org/10.1111/cobi.12318

Sternlieb, F., Bixler, R. P., Huber-Stearns, H., \& Huayhuaca, C. (2013). A question of fit: Reflections on boundaries, organizations and social-ecological systems. Journal of Environmental Management, 130, 117-125. http://doi.org/10.1016/j.jenvman.2013.08.053

Stone, D. (2002). Policy Paradox: The Art of Political Decision Making. New York: W.W. Norton \& Company. 
Swallow, B., Kallesoe, M., Iftikhar, U., Van Noordwijk, M., Bracer, C., Scherr, S., Raju, K.V., Poats, S., Duraiappah, A., Ochieng, B., Mallee, R. R. (2007). Compensation and Rewards for Environmental Services in the Developing World. Ecology and Society. 14: 26.

Van der Meulen, B., Nedeva, M., \& Braun, D. (2005). Intermediaries Organisation and Processes: theory and research issues. PRIME Workshop.

Van Lente, H., Hekkert, M., Smits, R., \& Van Waveren, B. (2003). Roles of Systemic Intermediaries in Transition Processes. International Journal of Innovation Management, 7 (3), 247-279. http://doi.org/10.1142/S1363919603000817

Vatn, A., \& Angelsen, A. (2009). Options for a national REDD + architecture. Options.

Vatn, A. (2010). An institutional analysis of payments for environmental services. Ecological Economics, 69 (6), 1245-1252. http://doi.org/10.1016/j.ecolecon.2009.11.018

Weaver, T. (2000). Changes in Forestry Policy, Production, and the Environment in Northern México: 1960--2000. Ecology, 7, 1-18.

Wunder, S., Engel, S., \& Pagiola, S. (2008). Taking stock: A comparative analysis of payments for environmental services programs in developed and developing countries. Ecological Economics, 65(4), 834-852. http://doi.org/10.1016/j.ecolecon.2008.03.010 


\section{What we have learned about the monster: Synthesis of the research}

Chapter 11. Recapitulation of the main findings

Chapter 12. Central conclusions: how formal and informal dynamics have together determined the persistence of PES

Chapter 13. Future research to further explore the monster

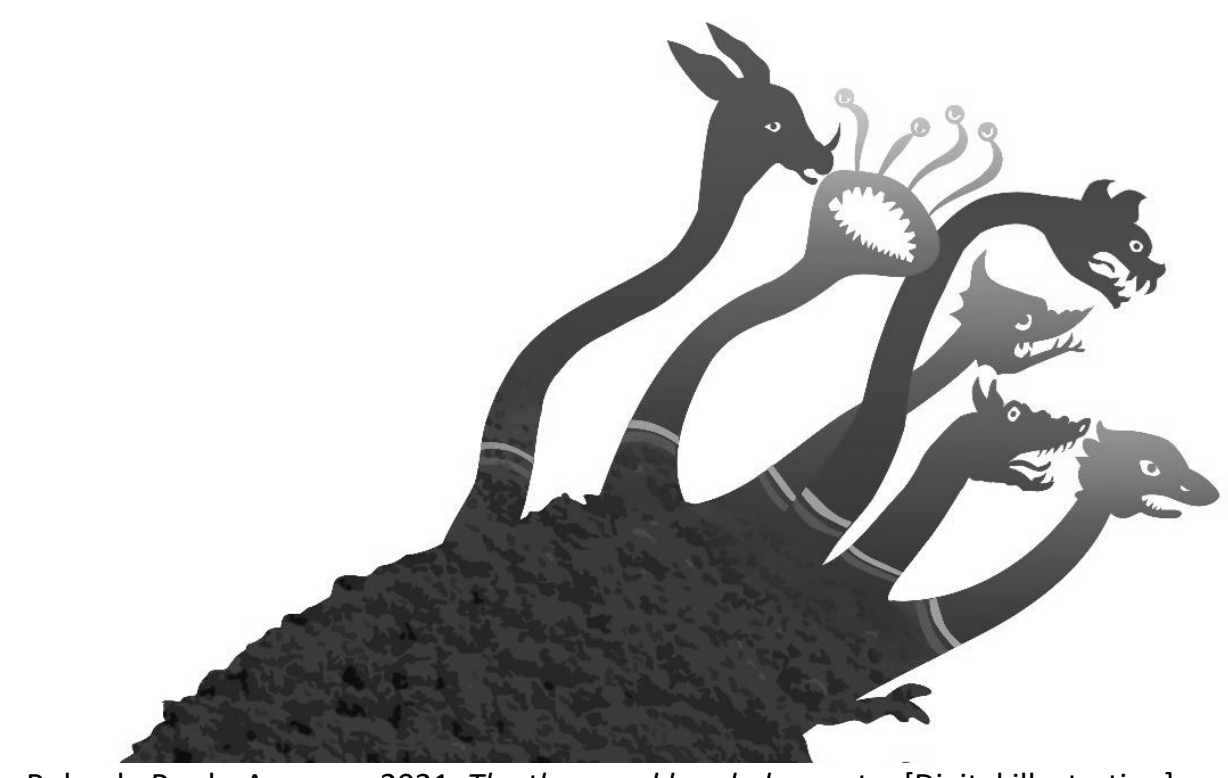

Rolando Prado-Arangua. 2021. The thousand headed monster [Digital illustration]. Michoacán, México. 


\section{Chapter 11. Recapitulation of the main findings}

\subsection{Introduction}

This research has focused on the processes occurring at a number of interfaces within México's PES programme: the interfaces between concepts and practices; between the national and the local levels; between public and individual interests, and between sets of values and understandings about forests and "best forest management practices". Implementation reflects the frictions that occur at these interfaces. In particular, this research has addressed the roles and dynamics produced by two fundamental elements in the Mexican PES programme: the ORs, that is, the operational rules of the programme, and the TAs (technical advisors) as the key intermediaries in the programme.

By studying the evolution of the ORs, it was possible to examine the concepts that explain the dynamics of change and stability from the institutional perspective, the external and internal factors affecting how and why these rules changed, and the dynamics of the interaction of the actors involved which have influenced on the microcosm of the PES through the ORs. Three factors are seen to be fundamental in the evolution of ORs: power, ambiguity and agency. Through them, actors (try to) influence and control the processes of change, by manipulating the information in order to create and transmit persuasive storylines and gain legitimacy. Observation of the phenomena through the lens of institutional and organisational theories has enabled the visualisation of the ways in which ORs are narratively represented, especially by CONAFOR, to build a façade, that is, the exhibition aspect of organisations (Kühl, 2013).

TAs are actors with great plasticity. They adapt to and shape the conditions under which they work. The findings of this research were sustained by a diversity of concepts about intermediaries in forestry and PES schemes, and the ways in which they are defined in different contexts and disciplines. The relationships established by TAs as intermediaries with all the other actors are, like the ORs, determined by power, agency and ambiguity, but also by trust, accountability and blame avoidance.

The result of the two apparently distinct parts of the research (the two chapters about ORs and three about TAs) are embedded in a framework of structures, actors, interactions and practices that constitute the implementation of the PES programme. They are closely related, both discursively and practically, and they shape each other through certain dynamics. At this point, perspectives from organisational and institutional theorists (Kühl, 2013; Helmke and Levitsky, 2004) about the interaction 
between formality and informality have helped to integrate the disparate findings of the research (see section 11.2). Thus, it is important to discuss how the combination of formal and informal structures in relation to ORs and TAs have shaped a multiplicity of interpretations, practices and benefits that coexist in the PES universe and contribute, if not to the success, at least to the fluid interactions between actors and therefore to the adaptation, evolution and continuity of the PES programme over time.

Following this brief introduction, chapter 11 continues by providing a recapitulation regarding the research questions related to objectives 1, 2 and 3 (for reference see table 11.1. Chapter 12 answers the questions related to objective 4 by articulating the main findings of the research in light of the interaction between formality and informality and its role in the persistence of PES programme. Chapter 13 includes some future research directions, and a brief outline of policy recommendations based on the empirical observations and research findings.

\section{Table 11.1. Recapitulation of the objectives and research questions of this thesis}

\begin{tabular}{|c|c|c|}
\hline \multicolumn{3}{|c|}{ Objectives and research questions } \\
\hline $\begin{array}{l}\text { General } \\
\text { objective }\end{array}$ & \multicolumn{2}{|c|}{$\begin{array}{l}\text { To investigate the main processes and the dynamics involved in the implementation of } \\
\text { PES programme, identifying and analysing the role and relevance of key components } \\
\text { and actors involved in the transference of the information. This includes considering the } \\
\text { mediating interactions between the main actors, and the contributions of formal and } \\
\text { informal practices in the continuing of the programme and their implications in the } \\
\text { construction of local (appropriated, contextualised, adapted) PES. }\end{array}$} \\
\hline \multirow[t]{2}{*}{ Objective 1} & \multirow[t]{2}{*}{$\begin{array}{l}\text { To identify the key components involved } \\
\text { in the transfer of the PES message for the } \\
\text { implementation of the programme and } \\
\text { the dynamics that occur in this process. }\end{array}$} & $\begin{array}{l}\text { 1.1 Who are the main actors involved in } \\
\text { different stages of implementation of PES } \\
\text { programme? (Section I: chapters 1, 3) }\end{array}$ \\
\hline & & $\begin{array}{l}\text { 1.2 What are the key elements enabling } \\
\text { the establishment of relationships } \\
\text { between actors in PES implementation? } \\
\text { (Section I, chapters } 1 \text { and 3; Section II, } \\
\text { chapter 4; and Section III, chapter 7) }\end{array}$ \\
\hline \multirow[t]{2}{*}{ Objective 2} & \multirow{2}{*}{$\begin{array}{l}\text { To analyse the evolution of the PES } \\
\text { programme through the examination of } \\
\text { its ORs, as the key device for } \\
\text { implementation, in terms of objectives, } \\
\text { priorities, and the intended role of the } \\
\text { actors involved, as well as the influence } \\
\text { of actors and events in shaping this } \\
\text { evolution }\end{array}$} & $\begin{array}{l}2.1 \text { How has the PES programme evolved? } \\
\text { What changes have been most relevant? In } \\
\text { what way are such changes represented } \\
\text { over time? (Chapter } 5 \text { ) }\end{array}$ \\
\hline & & $\begin{array}{l}\text { 2.2 What are the main influences (actors } \\
\text { and factors) shaping the evolution of the } \\
\text { ORs and the programme? (Chapter } 6 \text { ) }\end{array}$ \\
\hline \multirow[t]{2}{*}{ Objective 3} & \multirow{2}{*}{$\begin{array}{l}\text { To analyse the significance of the } \\
\text { establishment of the relationships } \\
\text { between actors and rules in the PES } \\
\text { programme, emphasising the role and } \\
\text { relevance of the TAs, as messengers and } \\
\text { mediators between local knowledge and } \\
\text { official agencies. }\end{array}$} & $\begin{array}{l}\text { 3.1 What are the main characteristics of } \\
\text { CONAFOR's TAs and their expected roles in } \\
\text { the programme? (Chapters } 7 \text { and } 8 \text { ) }\end{array}$ \\
\hline & & $\begin{array}{l}\text { 3.2 What are the perceptions of the main } \\
\text { actors (CONAFOR staff and the local } \\
\text { beneficiaries involved in the programme) } \\
\text { about the role and performance of TAs, as }\end{array}$ \\
\hline
\end{tabular}




\begin{tabular}{|c|c|c|}
\hline \multicolumn{3}{|c|}{ Objectives and research questions } \\
\hline & & $\begin{array}{l}\text { well as their power and influence on the } \\
\text { beneficiaries? (Chapter 9) }\end{array}$ \\
\hline & & $\begin{array}{l}\text { 3.3 What are the actual roles, problems, } \\
\text { needs and relevance of the TAs in the } \\
\text { different processes involved in the } \\
\text { implementation of PES? (Chapter 10) }\end{array}$ \\
\hline \multirow[t]{3}{*}{ Objective 4} & \multirow{3}{*}{$\begin{array}{l}\text { To analyse how the dynamics occurring } \\
\text { between formality and informality in the } \\
\text { roles and representations of ORs and TAs } \\
\text { have contributed to the persistence of } \\
\text { the PES programme over time. }\end{array}$} & $\begin{array}{l}\text { 4.1 How are ORs and TAs articulated } \\
\text { through the interaction of formality and } \\
\text { informality? (Chapter 12) }\end{array}$ \\
\hline & & $\begin{array}{l}\text { 4.2 What is the significance of the official } \\
\text { representations of ORs and TAs in the } \\
\text { continuity of the programme, and how do } \\
\text { informal accounts contribute to it? } \\
\text { (Chapter 12) }\end{array}$ \\
\hline & & $\begin{array}{l}\text { 4.3 What dynamics and alternative } \\
\text { understandings, practices and benefits } \\
\text { have contributed to the persistence of the } \\
\text { Mexican PES over time? (Chapter 12). }\end{array}$ \\
\hline
\end{tabular}

\subsection{Recapitulation of research results}

\subsubsection{On the importance of ORs and TAs in the PES programme implementation}

In this research, the ORs represent a formal structure, and the TAs are key intermediaries involved in the co/re-production of informality while enforcing the formal structures. As such, TAs move in the space between formality and informality, this enables their interaction in the development of the programme.

ORs and TAs are trans-boundary, multi-faceted and multipurpose elements aimed at enabling the implementation of the PES programme. They mediate relations between actors and processes, as well as the translation of the PES concepts into local forest management practices. Analysis of them allowed an understanding of the dynamics that result from the interaction of actors with different values and interests, and the negotiations that took place between them which gave rise to the enforcement of the programme and which influenced its evolution. It is precisely in the arena of implementation that formal and informal structures shape and give meaning to the programme at the local level.

They are symbiotic elements: ORs establish the limits of the programme's universe, prescribe the actions to be taken within it (programme), and determine which actors are to be included (members), as well as their roles and modes of interaction (communication channels). TAs not only convey the PES message; they align the diversity of interests of actors, and mediate between the ORs and local institutions, but also between types of knowledge (e.g. local, technical). In other words, ORs provide the 
precision, and TAs the flexibility in implementation. They shape each other: the ORs directly define the TAs' role, and TAs indirectly affect the ORs through the processes and negotiations involved in implementation. However, this mutual shaping is asymmetrical, because there are other powerful actors influencing the ORs.

Operational Rules (ORs) are formal (legal) structures for the implementation; they are published annually. ORs are communicative devices which specify how the programme will function, the target populations and requirements that apply. They determine which information has to be transferred, learned and adapted by the main actors involved, mediating the interactions between them, determining the scenarios and roles to be performed and providing a common language for mutual understanding.

On the other hand, the TAs, who are CONAFOR's technical advisors, are a link between the rules and the people; they are the technicians contracted externally by communities, and they are in charge of making the programme work in local contexts. The ways in which they interact with beneficiaries and CONAFOR (both the staff and the ORs) are key to understand the functioning, problems and continuity of the PES programme over time.

\subsubsection{On ORs evolution}

In this thesis (specifically in chapters 5 and 6), the ORs are shown to be a significant element not only as the formal representation of the PES programme, that is, as an explicit compendium of the goals, actions, targets, and criteria for implementation. They are also shown to be the implicit expression of the values, aspirations and expectations about actors, and ethical guidelines to achieve the goals. They have been often referred to as "transparent", "objective", "fair", considering the "public interest" and promoting "efficiency" and "fairness". In the view of CONAFOR's employees, the ORs protect their work and relieve pressures on CONAFOR staff, providing a buffer against the need for constant questioning of the decisions made.

CONAFOR's PES is widely considered to be 'flexible' and 'adaptive' as a result of the multiplicity of changes that have occurred since 2003; indeed, change has become a hallmark of the programme. Its evolution, reflected in the ORs, is seen by informants as an intentional, thorough and positive process, showing the willingness of CONAFOR to improve implementation, as well as its ability to learn from the experience and to take into account the feedback coming from both employees and external actors.

The evolution of the PES scheme as reflected in changing ORs has consequences for the operation and results of the programme. They also have consequences for the behaviour and response of actors involved, their interactions and the power balance among them. These impacts are especially relevant for the beneficiaries of the 
programme and their relation with government, but also affect the beneficiaries' relation with their own forests.

The ORs tend to change constantly, parts fluctuating between precision and vagueness, and other parts from flexibility and rigidity. This may reflect the existence of different visions coexisting, but also the intent of CONAFOR to publicly show an official position on such aspects. Of the many changes identified in the ORs in a period of 11 years, some of the most relevant to this research have been those which relate to the representation, definition of roles, obligations and responsibilities delegated to the main actors (chapter 5). For instance, while the role of CONAFOR has become increasingly ambiguous, the obligations and responsibilities of the beneficiaries have increased and become more specific. Although the options for local participation and decision-making have increased, these are constrained interventions mostly defined by CONAFOR, and always monitored by the TAs. Although TAs are fundamental actors in the implementation of the PES programme, their role is poorly represented in ORs, which show only specific obligations and increasing restrictions to their work. On the other hand, the way in which CONAFOR has determined the criteria for selection of polygons has become more specified/rigid. In this respect, while the priority criteria have remained rather stable over time, the terms underpinning the criteria have increasingly been based on technical and scientific specifications, while those based on local demands and demands of social groups, that shaped the programme significantly during its first years of operation, have been diluted over time (Chapter 5). Stone (2002) also remarks on the constant interplay between flexibility and precision of the rules in organizational settings. In the case of the PES ORs, precision and vagueness occur unevenly across different areas of the ORs. According to Stone, precision brings predictability, justice and eliminates arbitrariness in the behaviour of enforcers, but the ability to manoeuvre and react to changes is reduced. In contrast, flexibility ensures greater sensitivity to contexts and differences, allows creative solutions to new situations, and allows the use of intuition and discretion, which is closely related to informality (Stone, 2002).

\subsubsection{The main drivers of change in ORs}

It is necessary to make clear the existence of an official narrative about the significance of ORs and the drivers in their evolution. CONAFOR has largely been able to create and control a story where ORs are the main enabler of the PES programme and strict compliance to them ensures the success of the implementation. Likewise, most of the processes influencing the evolution of the ORs are presented as being formal and visible. Finally, the story is aimed to make it appear that ORs are instruments which are not open to question or discretion. 
But when ORs cross over to the operational level and reach the local actors, especially the TAs, new narratives emerge, converge and compete with the dominating narratives of CONAFOR. For instance, actors from NGOs and TAs have talked about the multiple areas of ambiguity, vagueness, gaps, and subjectivity in ORs. This makes evident that changes in ORs reflect the power struggles, negotiations and tensions between the highlevel actors for the prevalence of their interests, values and approaches. The main tensions/struggles taking place in the programme are between 1) environmental vs social criteria, 2) technical/scientific vs political choices, 3) centralised vs decentralised decision making, 4) traditional vs innovative conceptual approaches about programmes (e.g. subsidy vs incentive), and 5) traditional vs innovative administrative procedures. Although a variety of actors participate in the conceptualisation of ORs for the implementation of PES, they are not equally influential in the programme. Following the traditional vertical model of government, the most influential actors are those at the highest levels of national policymakers (the government in power), and forest policysetters, funding agencies (especially the World Bank), and officials from other national level government ministries. Additionally, other external actors provide advice, feedback, assessment and validation; these include recognised NGOs and universities, through their participation in the PES Advisory Committee or through external evaluations. The actual influence of actors in ORs decreases as one moves down to the local level. CONAFOR's state-level employees have a closer relation with local actors, so they oversee providing feedback based on their observations in the field. Since their official position gives them credibility or legitimacy with CONAFOR at national level, they also tend to act as spokespersons for the claims and suggestions the beneficiaries and TAs, whose direct influence in ORs is limited (chapter 6).

However, although there is a tendency at national level to undervalue or not to recognise the role of TAs as ORs change agents, they are actually more influential in the programme evolution than it seems. This occurs indirectly through 1) their "influence over" /"guidance of" beneficiaries' decision-making, 2) their personal choices about their own roles at the local level, 3) their influence in shaping relations among actors, 4) their ability to interpret, negotiate and adapt the changing OR rules to local conditions, and 5 ) their individual preferences and expertise on the criteria for the selection of eligible forest lands (types of forests, large vs small areas, distance, etc.) and of the beneficiaries (big, small communities or private smallholders) to work with (chapter 9 and 10).

\subsubsection{On the TAs and their roles, performance and relevance}

TAs are agents who are expected enforce the programme rules (ORs) in local contexts by preparing applicants to enrol in the scheme, as well as accompanying, facilitating, 
monitoring and reporting the activities involved in PES implementation. In practice, they also become involved in interpreting and negotiating the ORs, and aligning them with local interests, knowledge and perceptions. They often fulfil these tasks by combining formal and informal practices. In general, TAs establish complex relationships with all the actors involved in PES programme, especially the beneficiaries.

In the official narrative TAs are often seen as "double edged agents" in the functioning of the PES programme. On the one hand, their importance in the enforcement and translation of ORs at the local level is widely recognised. On the other hand, they are considered a hindering factor of the fluidity of the processes, since they are seen as selfinterested, inefficient agents, driven by opaque and subjective purposes, and with a tendency to engage in unethical practices locally (chapter 9). TAs performance is also questioned because they are not simple messengers and mediators in the implementation. They have agency and particular interests may shape their interventions; their function and influence go beyond the scope of the official PES programme. This means that they work not only in the formally expected way. TAs make alliances with other actors, especially with the beneficiaries, and also with state level employees of CONAFOR, with a view to influencing the process and outcomes both inside and outside the PES implementation. This has led to their generalised stigmatisation and undervaluation of their role and positive influence (Chapters 8 and 9).

At the local level TAs play multiple formal and informal roles and although these roles are not necessarily improper, sometimes they are deliberately concealed from CONAFOR. These roles and their implications depend on their closeness and influence within the communities as well as their individual interests and ethics but are also a response to the needs and demands of the beneficiaries and the arrangements established between them (Chapter 8).

TAs have heterogeneous backgrounds and interests, and their working conditions mean that they function as single workers, representing their own interests and competing for the most favourable individual conditions of work. Unethical practices for getting customers are common, and perhaps as a result of the high levels of competition, in general they do not trust each other. These realities mean that they do not function well as a group, and this limits the extent to which they can bargain for better working conditions. TAs work under high pressure: they must deal with labour uncertainty, a generally bad reputation and high competition, while most of the burden of PES implementation rests with them (chapters 8 and 10).

According to their own narrative (chapter 10), TAs consider themselves more relevant to the operation of programmes than CONAFOR recognises. For instance, they are the real link between CONAFOR and beneficiaries; they contribute to the promotion of the 
programme and help potential applicants to know in advance whether they are eligible. They learn and adapt to the changing ORs and enable the smooth interaction between beneficiaries and the rules (ORs).

As regards their bad reputation, TAs partially agree with CONAFOR that unethical practices are carried out by some of them. But they disagree with the broad and generalised blame/stigmatisation to which they are subject. They also consider that CONAFOR has actively and widely contributed to the problem through its own indifference, neglect, and sometimes, through collusion. In addition, unethical practices are not exclusive to TAs. They are also carried out by some beneficiaries and employees of CONAFOR, and some TAs claim that they have also been subject to bribes, robbery and mistreatment. On the other hand, there is a normalisation of unethical practices in the field, that is, not only actors from CONAFOR and TAs, but also some communities have just assumed that unethical practices are an inherent part of involvement in governmental programmes. This may be a reason why there are not as many complaints from beneficiaries about the behaviour of TAs as might be expected.

Intermediaries like CONAFOR's TAs were present long before the existence of PES, and their performance and reputation have always been disputed (Chapter 7$)$. Three factors which determine the dependence of CONAFOR on TAs have persisted throughout the history of Mexican forest policy: 1) The lack of operational capacity of governmental organisations, 2) the sustained lack of technical and economic capacities of forest owners, 3 ) the changing ORs expressed in technical language and requirements. Due to financial and operative restrictions, TAs are not officially linked to CONAFOR and most of their activities are performed outside of the control of CONAFOR. In labour terms, TAs are temporarily contracted by the beneficiaries, not by CONAFOR, although they have to be selected from CONAFOR's list of registered TAs. This means that CONAFOR has no moral or legal responsibility for the work of the TAs. In part because of this absence of a formal institutional relationship, there are no regulations or formal evaluations of the TAs performance.

The role of CONAFOR in the provision of TA technical services is limited to a) allocating a fixed portion of the total PES money paid to the beneficiaries for technical services; $b$ ) providing the format for the contract/agreement between beneficiaries and TAs; $c$ ) mediating the possible conflicts between TAs and beneficiaries (in case of formal complaints), and d) keeping a list of approved/ certified TAs who are eligible to provide technical services (the so called LAST) (Chapter 9).

The lack of formal mechanisms or protocols for monitoring TAs performance, and lack of sanctioning in cases of unethical and incompetent practices has meant that the problems occurring at the local level remain "under the carpet", which in turn has enabled impunity. The responsibility for reporting and even "punishing" TAs for bad 
practice by termination of the contract rests with the beneficiaries, who often do not know the channels and the procedures needed to access CONAFOR, nor the mechanisms necessary to file formal complaints. In addition, some beneficiaries are persuaded, controlled or threatened by TAs if they try to complain or cancel the contract between them.

The measures taken by CONAFOR regarding TA unethical practices are not sufficient to improve technical services provision; rather, they seem to suggest a strategy of blame avoidance, in which the TAs play the role of scapegoats. TAs portrayed as "villains" can function as a relief valve for tensions between the actors, and impunity can work as an incentive for TAs, so that they deliver the results that CONAFOR requires to keep the programme working fluidly, regardless the ways in which they enforce the ORs at the local level.

As regards the capacities of TAs, the areas detected by CONAFOR as most problematic are those of GIS and geo-information management, participatory techniques, and environmental services concepts, which essentially correspond to the three main areas in which external technical assistance is needed. To address these problems CONAFOR has been providing free training according to individual TA needs as detected by the state-level employees. However, this training scheme is insufficient to correct all these weaknesses. In this matter, the certification process is CONAFOR's formal attempt to improve the quality of service provision of TAs, and it is the most significant and controversial measure taken by CONAFOR to addressing TA performance so far. However, it is widely acknowledged that this scheme of certification is not enough, and it has been criticised for being partial, subjective and even counterproductive. Although certification is a formal measure to address the competence problems of TAs, it can also be seen as a blame-avoidance strategy by CONAFOR since the outcomes of the evaluation process do not really offer clear solutions. Rather, it seems to be a way of dealing CONAFOR's need to respond formally to TA performance reports, reviews of which are carried out by external academic organisations, conferring objectivity to the process (Chapters 8 and 9).

\subsubsection{Interaction between PES beneficiaries and TAs}

As far as the experience of the communities goes, the performance of TAs and their interplay with local actors have been variable. Three of the communities studied replaced their first TAs, for different reasons: abandonment, mistreatment, and fraud respectively. In two of the three cases, external local actors emerged and assisted in the process of replacement of TAs. In all these cases, lack of communication between CONAFOR and the beneficiaries about the conflict was evident, and there appears to be no simple mechanism to facilitate the re-establishment of the communication, work and 
flow of funds. The two communities who got help were fortunate: they had prior contacts with local NGOs, external technicians and employees from other ministries and programmes (see chapter 9) who were related to the communities through the development of other projects, Lack of such alternative intermediaries is a hindering factor for PES beneficiaries in re-establishing a channel of communication with CONAFOR. However, all three communities did successfully replace their TAs, none of them made a formal complaint to CONAFOR, so the ousted TAs remain in the list of TAs, the LAST, without consequences as regards contraction with other beneficiaries. However, the negative experiences of the three beneficiaries allowed these communities to have a better understanding of their position regarding their TAs, and also regarding their own rights and responsibilities in their relationship with them.

On the other hand, three other communities have had positive interactions with their TAs, who provided the necessary basic guidance for implementation, and in one case took the community interests as his own and provided them with tools and knowledge to meet other needs, not only in PES.

Relations between TAs and communities are complex constructions which depend on multiple factors, such as community capacities, the power of each party, interests, the verticality of the programme, and on individual choices. These relations can also be shaped by changes that have occurred in ORs, and vice versa. Working on the deep causes of the beneficiary dependency on TAs at the local level, including capacity building and strengthening of communities, is required to improve their possibilities of establishing constructive relationships. The cases reviewed make clear the need for visibility in new forms of understanding of intermediation in PES, as well as the need for more adaptive models of local technical support.

Not only the TAs, but also the PES beneficiaries are highly heterogeneous. With the help of the TAs, communities can transform the PES programme through exercise of their everyday agency. Despite the relative rigidity and homogeneity of ORs, it can be said that in each community a different/unique PES was developed. PES in turn produces changes in communities' visions. Beneficiaries have learned (at least partially) the PES language and carried out the "good practices", but in addition they have begun to conceive the forests in different ways. However, it is not clear if this vision will persist in every community involved in PES, and if the effects will be visible at the local and regional level and in the long term. 


\section{Chapter 12. Central conclusions: how formal and informal dynamics have together determined the persistence of PES}

\subsection{Introduction}

When analysing the ORs and the TAs, the great complexity of the relationships between the actors involved is clear, as is the complexity of their relations with the ORs, and the variety of shortcomings and problems that can occur in these interactions. However, what is remarkable about PES programme is precisely its persistence over time, despite all these kinds of shortcomings. So, the question is, given the shortcomings, how has the programme managed to survive over time? In this chapter, the results of the research are analysed in a holistic manner by looking at the interaction between formality and the informality in the PES programme as a fundamental way of explaining its evolution and persistence.

This analysis is an attempt to see what could be learned more generally about how public environmental policies pull through even if they are not entirely effective in objective terms. The case is specific - PES in a particular area in México - but the lessons may be more general. This approach was not originally considered when the research was planned; it has been adopted close to the end, since it was during the process of field information analysis, and throughout the writing of the chapters, that this underlying theme began to emerge and take shape. The need to address the complementary roles of informality in implementation of the PES programme and the formal structures, represented by the ORs, has only gradually become apparent. In this, the role of the TAs as the key intermediary between CONAFOR and the beneficiaries of PES, is controversial, because, according to Olivier de Sardan "the intermediaries comprise the primary vectors of the moral economy of corruption [...] by virtue of their functions, which are centred around mediation"(Olivier de Sardan, 2005, p. 168). However, as found in the current study, these agents are not only (or always) involved in corruption, but importantly, in the co/re-production of informality while enforcing the formal practices of the programme. In their study on access to rural water in two districts of Tanzania, Katomero \& Georgiadou (2018) observed that formality and informality interact in a positive way in the provision of water to rural populations. Thus, unlike the classic dichotomous conceptualisation "either-or", which visualises formality and informality as mutually exclusive, they suggest that the recognition of the formal and informal aspects or "both-and" is empirically more sensitive to reality in the analysis of human activities (Katomero \& Georgiadou, 2018). Following this logic, it is assumed 
that informality in the form of "open secrets, unwritten rules and hidden practices" (Ledeneva, 2018, p. 1) and their interaction with formality are critical to understanding the complexity of social interactions in implementation of policies and their outcomes.

The analysis allowed an understanding of the dynamics resulting from the interaction of actors with different values, understandings and interests, and the negotiations that took place between. It is precisely in the arena of implementation where a diversity of informal practices shape and give meaning to the programme at the local level.

In addition to exploring the role of the interaction between formality and informality in the PES programme, the discussion in this chapter takes into consideration other related aspects that may contribute to the overall picture. These include firstly (section 12.2), some of the critical considerations about the adoption of globally-based models of development policy, designed by international agencies for developing countries under over-simplified, rationalist (and in this case market-based) views of reality, and the role of informality in the development of those schemes. Secondly, section 12.3 considers the significance and plasticity of the roles that ORs and TAs play in the programme, their interaction and mutual influence, and the ways in which these elements are incorporated into the official discourse for the construction of a public image or a façade. Over time, CONAFOR has constructed an official narrative about the PES programme, which is actively transferred to the primary actors and to the public. At the same time, alternative, contrasting visions from other actors coexist, sometimes compete, but always shape and are shaped by the official narrative. The ways in which ORs and TAs have been portrayed in this narrative have determined to some extent the evolution of the programme, and the struggles for coexistence with the competing narratives. Thirdly (in section 12.4), we assume, given the popularity of PES programme, that it fulfils multiple needs at various levels. Therefore, it is important to explore the ways in which this policy produces alternative, diversified and even surprising meanings and results as soon as these schemes encounter local realities and are mediated by actors. The alternative interests, incentives, and benefits that have been created and coexist with the official expectations, motivate the actors (particularly the TAs) to get involved and comply with the ORs, through the establishment of specific dynamics of cooperation, negotiation and agreement, which have become fundamental for the continuity of the programme.

\subsection{PES as a global model, with adaptation and co- construction at the local level}

PES as a global idea has been adopted in many countries and in a diversity of regimes. All of them are based in the same principle of commodification of forests to avoid deforestation and to incentivise the continuous provision of environmental services. In 
the development of the global green enterprise of ES (and REDD+) many values, guidelines, dynamics and cultures are shared around the world. The PES programme in México follows one of the models proposed and implemented by international funding agencies in many developing countries (Andrews et al., 2013; Pritchett et al., 2011). These models include a set of objectives, best practices, rules, standards, and performance indicators, which allow their adoption and evaluation in a diversity of local environments. Olivier de Sardan, when referring to the development programmes implemented in Africa, addresses a point that resonates in the reality of the PES and many others programmes in Latin America: "the functioning of the administrative apparatus, entirely copied from a European pattern, is schizophrenic in type. In law, official functioning and budget, it is totally occidental. In practice, it is otherwise, traversed by logics in drastic contradiction with the original model" (Olivier de Sardan, 1999, p. 263, in Anders, 2002).

In the case of the PES programme in México, the WB has been the main funding agency and provider of technical assistance, and a major influence on its evolution. According to Pritchett et al., 2011, Andrews et al. 2013, these development schemes are in a capacity trap, because proposals for solutions that come from abroad require simple compliance and little participation and feedback from local actors, both to define their problems and to find adaptive solutions to them. In addition, the model has limited the possibility of experimentation, learning and innovation. With the implementation of these models, organisations adopt "isomorphic mimicry" strategies, that is, "the tendency to introduce reforms that enhance an entity's external legitimacy and support, even when they do not demonstrably improve performance" in order to look like successful organisations (Andrews et al., 2013). The policies and programmes under these schemes tend to function in appearance, contributing to the construction of what Kühl calls the façade of an organisation, since the countries participating in such frameworks acquire legitimacy and the possibility of obtaining and keeping more financial support. However, they are also under pressure to make international commitments (Andrews et al., 2013; Pritchett et al., 2011) that can be difficult to achieve in the terms in which they are conceived. At the subnational and local levels, these programmes may fall into gaps or present problems and conflicts in implementation, because they lack elements that allow them to connect and adjust to local contexts, such as the local social structures, values and perceptions about resources and problems and strategies to deal with such problems and the consequent absence of motivation of local people.

In these contexts where formal structures are aligned with global schemes, in rigid bureaucratic environments which have little in the way of local roots, it is possible to visualise the role of informality as something that allows the connection of the imposed 
schemes with national and local cultural realities. These can modify the results and effects of the formal structures without necessarily subverting them. Informality results from the convergence of different value systems and rules (institutions) as a natural response to the over simplified top-down approaches to local problems (Ledeneva, 2018). There are different levels of resistance to the imposition of a universal and scientifically-based "reading" of reality, or what Scott's calls techne, which often neglects the diversity of practical, local knowledge, the metis (Scott, 1998). It is the metis which provides alternative and local embedded understandings, embracing complexity. This research has been centred in the space between policy design and its operationalisation, a space with fuzzy boundaries. In this space, iterative interpretation and negotiation processes between many images of the reality are found, and it is these that determine (facilitate or obstruct) the adaptation for implementation of PES programme. But the often over-simplified version of realities also shapes the definition of actors involved, and the expectations about their roles in the implementation of policies. In this context, the assistance of technically skilled professionals usually from outside the communities (development agents, forest intermediaries, TAs in CONAFOR programmes) is necessary to bring the technical knowledge to the local level in order to ensure good results of policies. But as found in this study, these actors do the job not in an aseptic way; they also respond to the simplification of their roles in the programme by grafting (interweaving) their ideas and interests in the PES prescriptions, they make alliances with other actors, especially beneficiaries, to influence the process and outcomes of implementation.

\subsection{CONAFOR's narratives about ORs and TAs and their value in the construction of a façade}

During the development of this research, I often recalled Deborah Stone's assertion: "In politics, as in life, relationships are simultaneously adversarial and symbiotic" (Stone, 2002), since I was often faced with the ambivalence of the relationships between actors, and between the ORs and TAs. In this section I examine those relationships mediated by both ORs and TAs, and how they are framed to create and control images which fit with what CONAFOR wants to show about the operation and success of its programmes.

Stone examines the way in which political actors employ certain story lines and symbolic devices in order to control or manipulate understandings about certain problems and their solutions, making it appear that decisions are "objectively" based on facts. The narrative of CONAFOR is very clear in determining who the heroes are, but especially who are the villains of the story line of PES. The control of narrative about the roles of actors and devices in PES programme is also useful for the construction of CONAFOR's façade, which according to Kühl is needed to present a "coherent and convincing 
picture" of the organisation, hiding unresolved conflicts and protecting mistakes or administrative/legal gaps from being exposed (Kühl, 2014).

Over time, CONAFOR has constructed -with the help of other influential actors/organisations- an officially-accepted narrative about the PES programme, which is actively exhibited and transferred to the primary actors and to the public. The ways in which ORs and TAs have been portrayed in this narrative have determined to some extent the evolution of the programme, the public image of it, and the struggles for coexistence with competing narratives. As Stone suggests, control of the narrative plays a political role in the positioning of the actors, and in shaping alliances (Stone, 2002). But when ORs cross over to the operational levels and reach the local actors, especially the TAs, new narratives emerge, converge and compete with the dominating narrative of CONAFOR.

\subsubsection{The ambivalent relationships in implementation}

CONAFOR recognises the relevance of both ORs and TAs in implementation of PES, but while CONAFOR's narrative about ORs is straightforward, its narrative about TAs is ambivalent. CONAFOR often places these different elements at the extremes of the operation of the programme. Thus, the function of ORs is indisputable (i.e. clear, correct, rational), while TAs performance is always questionable. Hence, although both ORs and TAs are recognised as fundamental for the PES functioning, their nature, drivers and image are different and, according to the dominant CONAFOR narratives, they are opposites. The CONAFOR narrative paints roles and images of TAs and beneficiaries without including their own ideas in that conversation. According to Czarniawska, "this is what power is about", adding: "but even as puppets in a power game, people are still co-authors of history" (Czarniawska, 2004, p. 5).

However, as it has been explained, ORs and TAs also have similarities in their key roles in connecting the actors and levels of operation, mediating processes and aligning interests; it is rather that the ways in which they fulfil their roles is different: ORs are on the side of the formal structures; TAs move between the formality and informality, which enable them to interact with the ORs and to (at least partially) enforce the rules.

By examining the perceptions of the different actors involved, and through an exhaustive revision of the ORs, this thesis has allowed the less visible narratives to be identified: those that compete with the dominant narrative of CONAFOR. For instance, according to these alternative narratives the ORs have inconsistencies, omissions, contradictions and gaps on quite fundamental issues, and as shown in chapter 6, these reflect struggles and tensions between the actors involved. They are certainly not as 
objective and transparent as they are portrayed by CONAFOR. They are objects of representation, with a load of expectations and persuasive intentions, which reflect the struggles of the actors involved to gain influence on the programme. On the other hand, there is no homogeneous guild of TAs, with similar profiles, interests, motivations and performances. There are also unequal power relations between different types of TAs, which also determines their relationship with CONAFOR. Not all the informal practices that TAs carry out subvert the formal ones or have negative effects on the implementation. Many of these practices actually contribute to the fluidity of the operation (Ledeneva, 2018b), since they connect and adapt the rules with local contexts, perceptions, and practices, and fill operational gaps.

\subsubsection{The image of ORs as indisputable device}

The ORs are the one of the most important formal structures (in terms of Kühl) in all CONAFOR's programmes, not only PES. The image created about ORs fulfils the roles described by Kühl on formal structures. According to this, formal structures make it possible to absorb uncertainty and reduce the complexity of decisions. On the other hand, the ORs allow organisations to "allocate the burden of proof", since, although the "decision premises", as Kühl calls them, do not determine every detail of the application of such rules, members of the organisations do not need to prove the legitimacy and rationality for each action they take, because legitimacy and rationality are already present and built in, in the rules (ORs).

In this sense, rather than really discussing the values associated with ORs, there is a tendency for maintenance of these values, preserving the "myth of the perfectly precise, neutral and applied rules" (Stone, 2002), thereby strengthening their legitimacy. On that, Stone says that "rules derive their power from legitimacy [...] [and] work best when they are perceived as legitimate" (Stone, 2002). Partly for this reason, CONAFOR has made an effort to show that changes tend towards precision, based scientific and technical knowledge, and not on "whims, prejudices, moods, or predilections of officials" $(9,2012)$. In this sense, the role of the PES advisory committee has played an important role as a legitimation device (Jasanoff, 2003) for CONAFOR's decisions (see chapter 6).

\subsubsection{The functions of the image of TAs as "villains"}

The information presented in chapters 8,9 and 10 was based on the visions of informants, who made evident the negativity bias regarding TAs. The negative image of TAs as reflected in the opinion of many informants does not mean that all, or even most, TAs carry out unethical practices. As we have seen they are a very heterogeneous group with a variety of interests and approaches, and insufficient information is available to say with any confidence how many in fact engage in such unethical practices. The information obtained in this research shows that there are also TAs whose interests are 
closer to the communities they work with, who may enable empowerment of beneficiaries, as well as capacity building and the strengthening of internal processes of organisation and social cohesion (see chapters 9 and 10). However, what is clear is that CONAFOR has been building and transferring a narrative about the TAs in which they are framed as the "villain" of the programme. And, ultimately the portrayal of TAs as "villains" can be seen as an organisational strategy of blame avoidance (Hood, 2011), since under the simplified schematisation of the reality, and where there are unintended (negative) results, the creation of blame agents seems a necessary element for policy. In the case of CONAFOR's programmes, the evidence of (some) unethical practices has made TAs, in the discourse, the main recipients of blame (the scape-goats)(Hood, 2011).

So, seemingly the TAs portrayed in this negative way play the role of smokescreen that CONAFOR can hide behind to account for failings, actual and potential, and divert attention away from responsibility for other questionable aspects of the PES operation. The idea of using this narrative about TAs is that they are located in the frontier between the inside and the outside of the programme; they are not quite recognised as part of it, and they also do not have the sense of belonging to it. So, ORs can be perceived by TAs as "external rules" (Anders, 2002), given their dubious allegiance to CONAFOR, and hence, they adopt and fulfil their own sets of rules. They also work in a space physically far away of the eye of CONAFOR, with the potential to create, promote and carry out a diversity of informal practices.

\subsubsection{The invisible effects of the representation of ORs and TAs in CONAFOR's façade}

In a way, the dominant discursive representation about TAs and ORs does not affect the outcomes of the PES scheme, at least those shown to the public. What is often blurred and invisible is that in practice, the main carriers of responsibility are the beneficiaries, that is, the communities who face sanctions in the case of breaches of rules by themselves or by their TAs. It is the beneficiaries who in fact pay the costs of the CONAFOR's silent tolerance of unethical behaviour of TAs. In this context, the main effects on the beneficiaries are: a) the on-going abuse of power and unethical practices at the local level, b) the preservation of the power imbalances behind the ORs which shield or justify omissions of CONAFOR, c) the failure to improve local capabilities, power and autonomy of beneficiaries for managing their own forests, d) potential penalties and loss of access to CONAFOR programmes, and e) the continuation of the conditions permitting impunity.

CONAFOR's tolerance and turning of a blind eye to unethical practices can be explained through three factors based on conceptualisations of informality (Helmke \& Levitsky, 2004; Kühl, 2014; Ledeneva, 2018b). First, since informality works outside of formal 
structures, it is difficult for the organisations to address it. Second, TAs position in relation to membership within the CONAFOR is puzzling, so there are no structures or means to deal with the problems related to them. Third, the free space for impunity works well as an incentive to provide actors (not only TAs) with opportunities to obtain alternative benefits, as motivations to ensure their participation and the continuation of the programme.

\subsubsection{Implications of the official narrative for governance in the PES programme}

The governance of the Mexican PES programme is predominantly vertical (top-down). Three (intertwined) aspects of the PES programme as regards the relationship of CONAFOR with non-state stakeholders are salient, namely, the allocation of responsibility, the balance of power, and the influence of the actors involved on the evolution of the programme. In this context, CONAFOR has delegated some responsibilities, especially to the programme beneficiaries and has yielded the capacity to make some decisions, as shown in table 12.1:

Table 12.1. Three aspects of governance and the relation of state and non-state actors in the PES programme. The arrows show CONAFOR's control over the other governance aspects and the interaction of the actors in PES.

\begin{tabular}{|c|c|c|}
\hline $\begin{array}{l}\text { Aspects of } \\
\text { governance }\end{array}$ & Actors involved & The relationship between the actors \\
\hline Power & CONAFOR & $\begin{array}{l}\text { It keeps the control over most decisions: administration of financial } \\
\text { resources, the definition of the roles of actors involved, selection } \\
\text { and evaluations of beneficiaries, evolution of ORs and other } \\
\text { regulations. }\end{array}$ \\
\hline \multirow{4}{*}{ Responsibility } & \multirow{3}{*}{ Beneficiaries } & $\begin{array}{l}\text { They are responsible for complying with predefined and verifiable } \\
\text { activities in exchange for payments }\end{array}$ \\
\hline & & $\begin{array}{l}\text { They oversee selecting, in a participatory manner, the practices to } \\
\text { be carried out in the polygons with PES }\end{array}$ \\
\hline & & $\begin{array}{l}\text { They are responsible for the hiring and cancellation of technical } \\
\text { services by TAs. }\end{array}$ \\
\hline & TAs & $\begin{array}{l}\text { They oversee the promotion of the programme, recruitment of } \\
\text { applicants, and of implementation, reporting, and monitoring of } \\
\text { beneficiaries. }\end{array}$ \\
\hline \multirow{3}{*}{ Influence } & $\begin{array}{l}\text { Advisory } \\
\text { Committee }\end{array}$ & \multirow{3}{*}{$\begin{array}{l}\text { Including widely recognised academic actors, NGOs, and } \\
\text { international bodies (such as the World Bank) to provide advice and } \\
\text { technical support and carry out evaluations. Some of the feedback, } \\
\text { not only from these actors, contributes to the annual modification } \\
\text { of ORs. }\end{array}$} \\
\hline & $\begin{array}{l}\text { Academic } \\
\text { organisations }\end{array}$ & \\
\hline & $\begin{array}{l}\text { International } \\
\text { bodies }\end{array}$ & \\
\hline
\end{tabular}

Likewise, to date, the PES programme is the only one of CONAFOR's programmes that has maintained power at the federal level, preventing state offices from making relevant 
decisions about the programme. In addition, unlike the other programmes conducted by CONAFOR, this is the only one that does not have offices at the municipal level.

As Arts (2014) describes, a) the delegation of responsibilities by CONAFOR is not in order to "transfer of authority from the government to local authorities, but control 'at a distance' by the state to solve wicked policy problems locally, which tends to reaffirm power relations and structures instead of changing them" and, b) "community participation is not about "increasing decision-making power [...], but the shaping of environmentally responsible subjects and the creation of mutual consent around local forestry problems and objectives": (Arts, 2014, p. 21). Thus, the state, represented by CONAFOR, has strategically used governance elements to keep control and maintain legitimacy, while avoiding complex problems in the implementation of the governance elements (responsibility, balance of power, and influence) which can be considered bricks of the organisational façade.

\subsection{The interplay between formality and informality in theory and in practice.}

In the previous sections I have addressed the construction of narratives, and the dynamics between the ORs and TAs, under the assumption that the interplay between formality and informality plays a fundamental role the implementation and adaptation of PES, and shapes a diversity of understandings, motivations and benefits of the programme in local contexts that enable and constrain its functioning. This is because informality creates or strengthens the incentives to comply with formal rules (Helmke \& Levitsky, 2004). This section includes a description of three specific examples of observations in the field (section 12.4.2), in order to frame, contrast and discuss them in terms of formality and informality as posed by organisational and institutional theorists. Although these visions have been very useful to incorporate the analysis of informality as a fundamental aspect for the continuity of the PES programme, it has also been interesting to find discrepancies between the research findings and such concepts. Discrepancies allow discussion, and the identification and questioning of some of the theoretical assumptions, as well as offering the opportunity to look back on this research in a self-critical way.

Informality is ambivalent in terms of its effects on formal structures, and in the visions about them. They can be functional or dysfunctional for processes, it can enhance or hinder social interactions, it can be problem solving or problem creating (Helmke \& Levitsky, 2004; Ledeneva, 2018). In the interviews, the most visible practices recognised as informal were those with a particularly negative connotation, such as unethical practices, which are frequently associated with TAs, and considered a problem that must be solved in the implementation of PES. Examples of the unethical practices provided by 
informants were discussed in chapter 10. On the other hand, both the "positive" informal practices and the potential positive effects of informality were less visible, and some of them were identified in participant observations and during the analysis of field information. These relate to cooperation and negotiation between the actors and their values and interests, which contributes to the fluidity of the processes of implementation of the PES programme (two examples will be addressed in section 12.4.2).

In this research, informality has been approached through the analysis of the interactions between the main actors of the PES programme, for the understanding of the roles of TAs, and the influence of actors in the evolution of the ORs. Rather than an in-depth study of the dynamics, origins, and mechanisms of informality, I identified processes, interactions, interpretations and changes in formal structures that could be catalysed by informal practices. So the contribution of this research with respect to informality in the PES programme may be seen as a starting point for further research on the extent to which it operates and is reproduced, the forms it acquires, and the specific ways in which it interacts with and shapes the formal structures. Likewise, it is not clear if some of the practices described can be considered informal structures, that is to say, routine and generalised behaviours which adhere to the formal structures, noncompliance with which would result in sanctions. It can also be debated whether the practices that do not strictly comply with the conditions established by the formal approaches should be considered informal structures or not (Chapter 2 ). The available information allows us to suggest the general influence of these practices in the programme, but more information would be needed to categorise them in a more specific way.

Regarding the non-compliance of the informal structures, in conceptual terms, Kühl defines informality as "all of the expectations in an organisation that are not (or cannot be) formulated with reference to the terms of membership" (Kühl, 2014), that means those which are generally unwritten expectations, "open secrets" that are communicated and enforced outside of formally sanctioned channels. Mechanisms of informal enforcement are usually subtle, hidden, and even illegal (Helmke \& Levitsky, 2004). However, according to Kühl, sometimes the imposition of informal expectations can be also linked to formal structures: "when imposing informal expectations, we must not overlook that it is also possible to draw on the resources available through an organisation's formal structure" (Kühl, 2014, p. 128). In the case of PES, the noncompliance of informal expectations is linked to formal sanctioning in an indirect relationship. For instance, since the beneficiaries of one of the communities under study resisted giving control of the PES money to their TA, after several threats, he abandoned them (informal sanction) and stopped delivering reports of activities to CONAFOR, which 
resulted in a formal sanction for the community; CONAFOR asked them to return the PES programme money. In the end, through a process of negotiation (CONAFOR's employees suggested a new TA that they trusted, although such an appointment represents a violation of formal procedures) and after almost one year of delay, the community was able to avoid the sanction and continue in the programme.

\subsubsection{Informality in PES: how they can be identified and how they interact with formality}

In determining if an informal way of acting should be considered structural or not, Kühl mentions that the attitude of people with respect to such behaviours can indicate whether they are recognised as informal structures in an organisation, or as isolated behaviours that occasionally disrupt the formal ones: "A single deviation from the rule, a single occurrence of an unaccustomed procedure would not cause us to speak of informality [...], we speak in those terms only when we recognise that the deviation occurs with a certain regularity"[...] Thus, informality is not defined as a one-time improvisation used to clear a swath through the jungle of requirements and regulations, but rather a network of reliable organisational pathways that are travelled time and time again" (Kühl, 2014). In the PES programme certain practices that can be considered informal are opportunistically carried out by some actors in parallel with formal practices. These practices are usually "an open secret" but socially recognised as a crosscutting phenomena, rooted in the functioning of the programme. One TA mentioned that "[CONAFOR] should know these bad practices [...] because they are so obvious. All the people say it [...]. [...] And people say it because it's happening. I have personally seen it and have seen my colleagues. [...] Some TAs really exert a power, [that is] somehow facilitated by CONAFOR" $(31,2014)$. Corruption and abuse of power, extra-official negotiation processes, manipulation of relationships and information, alternative social networks, as well as arrangements and adaptations to pressures from organised crime in certain areas are behaviours that can take a variety of forms, since they are configured according to specific circumstances, and yet they are easily recognisable by all the actors as the "underground" aspect of the programme.

The practices identified in this work are mostly somewhere at a midpoint between the "one-time improvisation" and "an informally proven mode of thinking and acting" (Kühl, 2014). These behaviours are well known to people in PES, but they often generate two reactions, or an exercise of double standards (Blundo \& Olivier de Sardan, 2006; Ledeneva, 2018). On the one hand, one could say, "within the system", they are observed and tolerated as a daily reality. And on the other hand, "outside the system" they are rejected and condemned as if they were exceptional (Blundo \& Olivier de Sardan, 2006). According to Luhmann, informality is essential for organisations to 
survive by quickly adapting to changes and balancing the rigidity of rules. This often means it is necessary to "tolerate or even promote illegality" (Luhmann, 1964, in Kühl, 2014). He also distinguishes three forms of informality according to the relationship to the organisation's formal order: informality compatible with formality, informality that breaks the rules, and informality that breaks the law. Table 12.2 shows examples of informal practices in PES programmes mentioned by informants, which have been organised according this classification.

Table 12.2. Informal practices carried out by actors in PES programme, according to the Luhmann's forms of informality

\begin{tabular}{|c|c|c|}
\hline $\begin{array}{l}\text { Informality compatible with } \\
\text { formality }\end{array}$ & Informality that breaks the rules & Informality that breaks the law \\
\hline 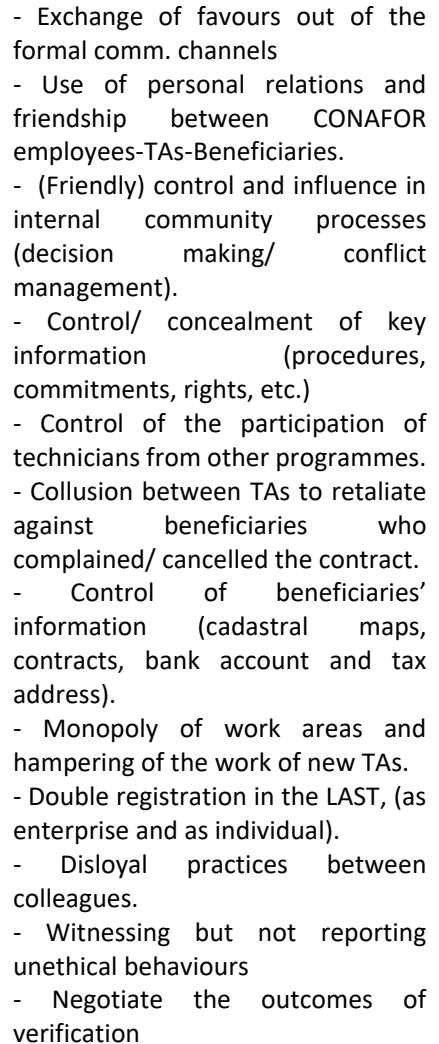 & $\begin{array}{l}\text { - Bribing community authority to be } \\
\text { chosen as TA } \\
\text { - Bribing a TA by communities to } \\
\text { work with her/him } \\
\text { - Requesting extra money to the } \\
\text { beneficiaries } \\
\text { - Control and administration of PES' } \\
\text { money } \\
\text { - Collusion with CONAFOR } \\
\text { employees to report compliance in } \\
\text { areas where the activities were not } \\
\text { performed } \\
\text { - Collusion with another person who } \\
\text { acts as frontman in order to continue } \\
\text { working as TA despite s/he has been } \\
\text { penalised, s/he wants having more } \\
\text { beneficiaries than allowed). } \\
\text { - Persuasion/coercion } \\
\text { beneficiaries to impose decisions, } \\
\text { activities, uses of money } \\
\text { - Mistreatment to beneficiaries } \\
\text { - Contracts with more beneficiaries } \\
\text { than allowed }\end{array}$ & $\begin{array}{l}\text { - Enrol in the programme with the } \\
\text { complicity of community authority } \\
\text { to obtain the CONAFOR's support } \\
\text { behind the back of the rest of the } \\
\text { community. } \\
\text { - Beneficiaries extort and rob TAs } \\
\text { - Collusion with another person who } \\
\text { acts as frontman in order to continue } \\
\text { working as TA despite s/he is a } \\
\text { CONAFOR employee. } \\
\text { - Illegal acts on behalf of the } \\
\text { beneficiaries they represent } \\
\text { - Use/conditioning the programme } \\
\text { for political purposes (elections) } \\
\text { - Community authorities keep the } \\
\text { money the programme for } \\
\text { themselves. } \\
\text { - Bribing beneficiaries/TAs for not to } \\
\text { report breaches and avoid sanctions. }\end{array}$ \\
\hline
\end{tabular}

\subsubsection{The combination of formality and informality in PES}

On the other hand, certain practices occurring at key moments of the programme's implementation have been recognised as being a combination of formality and 
informality. They allow the fluidity of processes and decisions, by avoiding conflicts and sanctions, facilitating cooperation between the actors and producing "substantively similar results from that expected from a strict and exclusive adherence to formal rules"(Helmke \& Levitsky, 2004). Table 12.3 gives a summary of some of the formalinformal interactions identified in this study, that is, the different arrangements around formal structures which help the programme to continue over time. They are organised by reference to the three types of (in)formal structures suggested by Luhmann, namely programmes, communication channels and personnel (in Kühl, 2014). (For more information about the three types of structures see chapter 2 ). 
Table 12.3. Interaction between formality and informality in PES programme, organised according to the organisational structures.

\begin{tabular}{|c|c|c|c|}
\hline $\begin{array}{c}\text { Organisational } \\
\text { structures of PES }\end{array}$ & Formal structures & Informal structures & $\begin{array}{c}\text { Combination of formality/informality conducive } \\
\text { to "PES" continuation }\end{array}$ \\
\hline $\begin{array}{l}\text { 1.Programme: } \\
\text { - ORs }\end{array}$ & $\begin{array}{l}\text { Which actions do the ORs permit and which do } \\
\text { they not permit? } \\
\text { ORs determine the general guidelines, } \\
\text { foundations and objectives of the programme, as } \\
\text { well as the main roles and tasks of the actors. } \\
\text { However, much of the operative part of the } \\
\text { programme happens through informal } \\
\text { agreements between the actors involved. }\end{array}$ & $\begin{array}{l}\text { Which actions are taken? } \\
\text { Selection of areas can be determined by the } \\
\text { needs of TAs (distance, size of forests, property } \\
\text { regimes, etc.) } \\
\text { Selection of TAs can be done by coercion, bribing, } \\
\text { monopolisation of areas. } \\
\text { The compliance of rules can be done by coercion, } \\
\text { by negotiation with CONAFOR, Beneficiaries' } \\
\text { negotiation of rights and obligations. } \\
\text { The selection of activities/money/uses of money } \\
\text { can be controlled by TAs } \\
\text { Reporting negotiated } \\
\text { Verification negotiated } \\
\text { Tolerance of breaches and unethical practices }\end{array}$ & $\begin{array}{l}\text { ORs are complied with, reinforcing their } \\
\text { "indisputability" and legitimacy. } \\
\text { No official sanctions applied } \\
\text { Fluid functioning of the programme. } \\
\text { Impunity } \\
\text { Persistence of the initial condition of beneficiaries } \\
\text { (dependency, poor capacities, low collective- } \\
\text { confidence). }\end{array}$ \\
\hline $\begin{array}{l}\text { 2.Communication } \\
\text { channels: } \\
\text { - ORs and flows of } \\
\text { Information, } \\
\text { workshops }\end{array}$ & $\begin{array}{l}\text { Who should be responsible, which are the } \\
\text { proper channels? } \\
\text { - Central CONAFOR in charge of targeting and } \\
\text { selection of beneficiaries } \\
\text { - CONAFOR' s state level in charge of } \\
\text { implementation and communication with } \\
\text { beneficiaries, verification and review of reports, } \\
\text { accountable to central CONAFOR } \\
\text { - TAs in charge of implementation of best } \\
\text { practices, training of communities through } \\
\text { assembly decisions and reporting of activities } \\
\text { - Beneficiaries comply the obligations and } \\
\text { commitments, make decisions in assembly about } \\
\text { the best practices, uses of money, and } \\
\text { hiring/supervising TAs. }\end{array}$ & $\begin{array}{l}\text { Who is really responsible, which are the real } \\
\text { channels of communication? } \\
\text {-Communities by- passing TAs } \\
\text {-TAs bypassing Assembly } \\
\text { - CONAFOR state employees link with TAs rather } \\
\text { than beneficiaries } \\
\text { - CONAFOR state employees do the job of TAs } \\
\text {-TAs do the job of CONAFOR state level } \\
\text { employees } \\
\text {-Workshops as a platform of negotiation of } \\
\text { favours; training is relegated to the background } \\
\text {-Verification and special meals for CONAFOR } \\
\text { employees } \\
\text {-Cooperation mediated by functional trust } \\
\text { between actors }\end{array}$ & $\begin{array}{l}\text { More fluid communication based on practicality } \\
\text { that predominates over what is established in the } \\
\text { ORs, avoidance of possible conflicts. } \\
\text { Tolerance and persistence of unethical practices }\end{array}$ \\
\hline 3. Personnel: & Who can be a TA, who can be a beneficiary? & Who is a TA, who is a beneficiary community? & \\
\hline
\end{tabular}




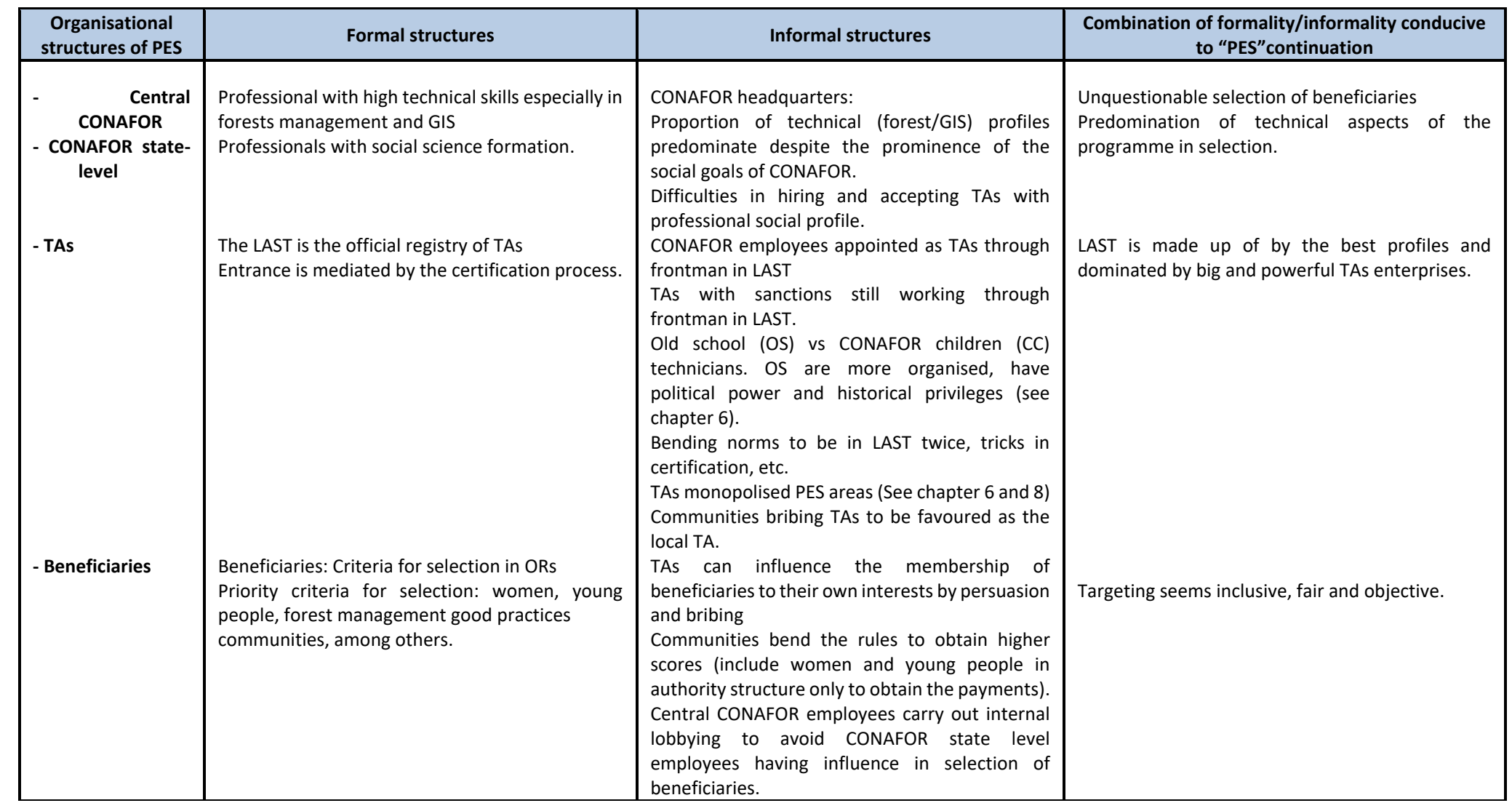


In order to illustrate the way in which informality operates in PES, the following section includes the description of two concrete cases observed in the field, which are taken from several examples showed in Table 12.4. They are key moments that can be comparable to the Swidler and Watkins's ritual binding actors (Swidler \& Cotts-Watkins, 2017; Watkins \& Swidler, 2013) in PES development, which involve the interactions between CONAFOR employees, TAs and beneficiaries of PES programme, as well as these actors' relation with the prescriptions of ORs. The two cases are: a) Workshops for beneficiaries about rights and obligations, best forest management practices, and environmental services, and b) the field verification of compliance of PES activities. Beyond the formal purposes for which these two activities are carried out, in practice the interaction among all the actors enables processes of negotiation, cooperation mediated by a degree of functional trust, mutual understanding and/or selective tolerance, and alignment of a diversity of objectives and priorities of all those participants.

\section{a) CONAFOR and PES workshops for beneficiaries}

Workshops are key moments of interplay between CONAFOR, beneficiaries and technical advisors. Until 2013, CONAFOR used to organise three types of workshops: for strengthening beneficiaries' capacity, on the rights and obligations, and the best practices guide. The workshops have become an important tool of communication of CONAFOR with ejidos/communities and landholders $(10,2012)$. In the workshops, CONAFOR staff provides information and instruction to new beneficiaries about different aspects of the programme, and also receives feedback from beneficiaries and TAs. The so called 'strengthening of beneficiaries' workshop, carried out since 2009, is the only one which is still not official $(10,2012)$. However, in words of informants, "this type of workshop has been successful, because it allows information to flow more effectively among participants" (10, 2012; 13, 15, 2013; 12, 2014). Although these workshops are specifically targeted to new beneficiaries, and TAs are not necessarily welcome, they also attend. In these workshops beneficiaries and TAs can express doubts, complaints and opinions regarding the different steps of the programme and on concepts related to environmental services, ES markets, etc. The workshops generally take place in regional venues, where attendees have to arrive by their own means, although snacks or meals are provided by CONAFOR during the meeting (sometimes meals are exclusively for one or two members of communities or forest owners). In general, these events tend to be very friendly, CONAFOR'S state level employees give presentations and facilitate activities such as participatory mapping and rapid inventories in beneficiaries' forests, but this information is not systematised or analysed later. Most of the topics officially addressed in workshops are not especially relevant to attendees, so there are other motivations to be there. For example, beneficiaries are interested on making contacts, solving problems and raising questions related to 
paperwork on PES and other programmes with CONAFOR employees, solving conflicts with other beneficiaries or TAs, meeting and hiring new TAs, among others. For their part, the TAs also attend the workshops to be aware of what the CONAFOR employees are communicating to the beneficiaries and even to demonstrate their performance during the workshops, as well as to find out which TAs were selected by which communities. Likewise, some TAs use these moments to complain about the reduction of polygons for PES, or the rejection of requests of applicants they have assisted, negotiate to get reconsiderations, extensions, and favours from CONAFOR, as well as to negotiate about situations with other beneficiaries. Finally, the workshops are used to reinforce the roles of actors, even the bad ones. Given the frequent problems between beneficiaries and TAs, CONAFOR employees use the workshops to warn beneficiaries about potential problems with TAs, by making more explicit the conditions for interaction between them $(13,2013)$. CONAFOR employees sometimes substitute the TAs role, by directly helping beneficiaries to carry out paperwork. The results of informality in the workshops may or may not influence direct or specific results in the programme so it is a kind of, shall we say, "soft" process of negotiation, that is, it promotes the smooth functioning of the programme and reinforces the rules (programme), roles and positions in the organisation (membership expectations), and communication channels, re-configuring some of the future relationships, but not visibly affecting official outcomes of the programme.

\section{b) Verification in the field}

Field verification ${ }^{10}$ is a process in which the beneficiaries, the TAs and CONAFOR staff converge in the PES polygons. They walk together to the sites where the PES works have been carried out; beneficiaries and TAs describe the activities while CONAFOR staff fill the checklist, take pictures and ask about the procedures and results of those activities. All of them follow well defined protocols and sign an act formalising the process. Independently of the results of the verification, it usually ends in a special meal prepared by the beneficiaries, who are often grateful for the visit of CONAFOR staff, which represents a valuable moment for negotiation and agreements and the opening of new forms of interaction and expectations about new opportunities for involvement in other CONAFOR programmes.

Reports are prepared relating to this verification process. They are carried out by TAs, and CONAFOR staff. There are standardised formats that allow the transfer of information from beneficiaries to CONAFOR; these are focused on the areas that can be located on maps and measured in different ways. In these documents there is no place

\footnotetext{
${ }^{10}$ Verification of compliance is also done by land-cover monitoring of satellite images, but this is a technical procedure carried out in CONAFOR's central office.
} 
to explain differences in the processes that occur in each community, or to visualise operative gaps or problems in the interaction of TAs with beneficiaries. CONAFOR's employees have learned to fill an almost automated checklist to verify that the basic requirements in each report are sufficiently met, so that the case can pass smoothly to the next level of supervision $(10,2013)$. Both in verification and in the reports, the actors have specific roles to play when interacting. Each one of these actors has their own different set of rules and ORs are the meeting point. During the interviews several informants made it clear that everybody is aware of the problems in the performance of all the actors, especially the TAs, and they also recognise that bad practices are deliberately ignored, especially by CONAFOR $(50,51,2013 ; 54,20,28,21,24,22,30$, 2014). Despite prejudices or obvious malpractice examples, during the verification and in the report on it, the actors deliberately disregard (overlook, ignore) the discrepancies between the ORs and the actual practices of the participants. There are informal processes of negotiation that help to ignore problems that do not have short-term solutions due to lack of regulatory frameworks, or because the problems are so complex that they could prevent the progress of all those involved. Thus, beneficiaries do not report problems with TAs or vice versa if these do not threaten the continuity of the programme. For its part, CONAFOR does not report problems detected in the verification, and just encourages beneficiaries and TAs to make the adjustments needed to comply, rather than taking formal measures to ensure these occur, and they approve reports with deficiencies if these are not too obvious. In these ways, actors contribute to create the illusion that, as one of the informants said sarcastically, in PES "everything seems to work excessively well" $(25,2014)$. It could be said then that, in the PES universe, the actors give preference to the effects or outcomes of the programme that are visible in the short term, and allow the fluid cooperation between actors over those outcomes that have deeper consequences and that may only be visible in the long term.

Through these interactions, actors exchange favours or give concessions, expecting to receive something in return later. This creates bonds of functional trust between actors. Trust plays a very important role in informality because through it, long-term committed social networks and alliances are created, which increase the possibility of survival of the PES programme (Kühl, 2014). Actually, delegation of responsibilities implies that there should be a level of trust between the actors, mediated by (formal and informal) routines that enable cooperation, despite the existing power asymmetries (Oskarsson, Svensson, \& Oberg, 2009). Coad and Cullen (2006) in their study on inter-organisational relationships have observed certain institutional routines developing gradually over time that shape interactions, and which mask conflicts of interest and power asymmetries between organisations (Coad \& Cullen, 2006). Some authors have suggested that trust is determinant in the outcomes of PES schemes all around the world (Mayer, et al., 1995; Huber-Stearns et al., 2013; Pham et al., 2010; Schomers, et al., 
2015), and intermediaries, such as TAs, should play a significant role in trust building among actors involved (Bosselmann \& Lund, 2013; Huber-Stearns et al., 2013; Schomers et al., 2015; Sternlieb et al., 2013).

Negotiation does not occur equally in all the processes of PES. For instance, in the selection of beneficiaries and polygons, CONAFOR headquarters maintains an almost absolute power in decision making (which does not mean they are not creating and performing informal behaviours). Special attention is given to the proposed PES polygons, which are selected by high level trained technical staff, using rigorous protocols and recent high-resolution satellite images $(7,16,2013)$. At this stage it is very important to justify to funders and public that the money invested in the programme is allocated in the most suitable forest areas, as this will be directly evaluated by other governmental organisations, scholars, NGOs and the PES national advisory committee.

In contrast, in the verification process the three main actors are involved in proving that ORs have been fulfilled within the enrolled polygons of PES. At this stage, negotiation between the actors about the ORs procedures and results occurs, which is more flexible and adaptive to the particular conditions of the polygons to be visited. The results of the PES activities depend especially on the work of beneficiaries with the TAs, with CONAFOR only in second place. CONAFOR does not have full control over these activities, but the problems that occur at the local level may not be significant at the national level. In contrast with the strict control of the selection process by CONAFOR, implementation and the subsequent verification are carried out in less rigorous ways, even though the aim is to prove that the money invested in the polygons has directly contributed to avoided deforestation, reduction of poverty or to encourage the establishment of actual ES markets. In verification, the process of negotiation is mobilised by beneficiaries and TAs in order to influence specific and tangible results, that is, the reports that the CONAFOR employees present to headquarters. Therefore, it is, shall we say, "hard" negotiation through informal practices, which affects official results and enables the survival of formal structures, especially the 'programmes' mentioned by Kühl.

\subsection{PES: successful outcomes or continuity?}

Although many countries supposedly follow the "script" or "recipe" for the implementation of the programmes, at the same time, each PES scheme has been adapted to the conditions, creating specific rules and social networks. In the case of the implementation of the Mexican PES, CONAFOR has put emphasis on continuous feedback from experts (generally NGOs, and universities) through their participation in the PES advisory committee. But to a lesser extent, local actors are also influencing the 
evolution of the programme through informality, and through their interaction with CONAFOR's state level employees.

CONAFOR's state employees and TAs perform their tasks exercising their agency and discretion and developing or maintaining informal practices that facilitate their work (Tummers \& Bekkers, 2014). For their part, the beneficiaries of the programme have adapted the programme's conditions, requirements and supports and built new understandings of it, often turning it into an intervention more in line with local needs (Van Hecken et al., 2017). In and around the ORs, spaces have been actively created (through resistance, discretion, learning, adaptation, and bricolage) for the appropriation of the principles of the programme at the local level, and at the same time meeting some expectations of the actors. The perception of local actors about the programme can even be considerably different from what was originally proposed by its creators and funders. This diversity of visions and perspectives transcends the objectives of the PES scheme, which are nevertheless at least partially fulfilled because they ensure the continuity of the programme for the benefit of all the actors involved.

Particularly regarding the PES programme and its measures of "success", Corbera, et al. (2009) mention that these measures are not conditional on results, and we may recall Wunder, et al. (2008), who suggest that this lack of conditionality is common in government-led programmes, which implicitly acknowledge the political difficulties involved in prosecuting poor landowners for non-compliance (Corbera, et al. 2009).

Authors such as Swidler \& Watkins have gone further by analysing the dynamics resulting from the interaction between donors, brokers and beneficiaries in HIV prevention in Malawi (another internationally funded development project). They found that the projects failed to have any effect on the HIV pandemic, but, at the same time they have "changed the landscape in fundamental ways, including new understandings of possible careers; new cultural themes to be mastered; and the adaptation and multiplication of imported social structures" (Swidler \& Cotts-Watkins, 2017; Swidler \& Watkins, 2009; Watkins \& Swidler, 2013).

As in that example, this research found that multiple opportunities developed around PES with direct and indirect benefits to everyone involved, regardless of the officially expected outcomes, which has enabled the persistence of the programme. The most obvious and tangible benefit is the money that all actors receive for participating, in the form of financing, salaries, and as subsidies. The programme also provides employment in different schemes: formal for CONAFOR employees, temporary for beneficiaries, and freelance for TAs. The training activities are also a highly appreciated benefit for all the stakeholders. But participating in the programme also provides indirect or potential benefits too, such as the creation of a history of participation in PES schemes, and the 
establishment or reinforcement of relationships and networks that may lead to the development of future projects. In some cases, the programme has produced certain degrees of expectation, promoted by CONAFOR itself, about the creation of ES markets that would enable self-sufficiency of forest communities, which also implies the provision of technical services by the TAs in the longer term.

In this context, cooperation mediated through a degree of functional trust between the actors takes place, which allows the continuity of relations in the medium and long term. The role of TAs is relevant in this process, since they are fundamental in the implementation of the programme, and also in the spreading of the PES concepts and expectations about the development of ES markets. Interactions between TAs and beneficiaries can be very advantageous for both, since the former are the gateway for communities to forest development programmes, especially those that require GIS skills for the application, which are still unfamiliar to many communities. So, the programme also helps to counteract uncertainty about the lack of employment and economic opportunities. The establishment of permanent relations with beneficiaries can provide greater job security to the TAs, since it is possible to manage more resources when accessing new projects for them. This is also a benefit for CONAFOR, since increasing the numbers of beneficiaries and hectares enrolled are important indicators measuring the success of the programme, resulting in rewards for compliance, such as new loans, debt forgiveness, and higher "good governance" indicator scores (Andrews et al., 2013).

In terms of career aspirations in PES, training at the local level is especially relevant, since the increasing of capabilities can help to obtain better job opportunities, but also more influence. At the community level, some community members aspire to be trained in forest management issues in order to become community technicians. In this research, the key informants in 5 of the 6 communities talked about the need for having community members trained to fulfil the roles of intermediaries, mediators, trainers, and facilitators in the development of community forest management, and for securing access to governmental programmes and other supports. This is also relevant in so far as they could keep more money and control of the decision making within the community, as well as providing more opportunities for training.

The existence of a community technician nurtures the aspirations of progress and selfsufficiency of the communities $(34,35,32,39,40,44,2014)$. Besides the community ones, some informants from CONAFOR and TAs agreed that community level technicians can be an important element in the implementation of policies in local contexts, linking community interests with the governmental priorities. But there have been administrative and legal constraints in CONAFOR regarding recognising non-professional people as formal technicians $(9,5,2013)$. In the last years (2011), the position of local 
forest technical promoter has been developed by CONAFOR in a parallel programme, supporting the training of local people in sustainable forest development. Only one community in this study has been working with a promoter, who is a young man from a nearby community. However, the idealised image of highly committed community technicians who are motivated only by the collective interest is just that; an idealisation that is unlikely to be found in reality.

For their part, TAs aspire to obtain permanent jobs within CONAFOR or at least to have a steady/ increasing number of contracts with CONAFOR beneficiaries; CONAFOR state level officers aspire to obtain positions of greater responsibility at the state level or to jump to headquarters, and in times of greater uncertainty, just to keep their jobs. Finally, leaders of federal programme at CONAFOR headquarters aspire to keep their jobs and further their own careers by adopting and accepting the conditions imposed by international development agencies. CONAFOR's front line workers also aspire to increase the statistics of PES and other programmes to keep /increase the international funding.

Additionally, the present analysis has shown that there are complex dynamics in terms of job opportunities and mechanisms for earning money and getting power through informality. For instance, several TAs have previously been members of CONAFOR's staff, so they know the ins-and-outs of the rules and take advantage of them. Conversely, some CONAFOR employees who have been TAs in the past use tricks (such as associating with a front man (see footnote on page 216) and take advantage of the gaps and soft spots in the rules in order to maintain their monopolies over beneficiaries and to continue providing private and public services at the same time.

Beyond the level of achievement of the programme objectives, a small PES culture has indeed been building. There is a specific language or at least a specialised code that has been created, which requires a time of immersion for participants to understand and use it. It is possible that this shared language contributes to creating a sense of belonging among the people involved in PES. ORs contain that language, but also the scenarios, the rituals, and the actors to perform a role in the programme. And the TAs are the necessary connection between the ORs and beneficiaries, since they provide and interpret and translate them, to make them accessible for their execution in the field by the beneficiaries.

There is a considerable amount of geo-information, as well as manuals, reference terms, norms, propaganda and suggestions in form of videos, and digital and printed publications (brochures, posters, maps) which aim to spread the discourse and practices of PES, providing evidence of the successful work developed by CONAFOR. At other levels, CONAFOR organises periodic (annual, bi-annual) discussion forums with scholars 
and influential NGOs to analyse and evaluate different aspects of the development of the programme, which also helps to nurture the image of an open, flexible and participatory programme.

In terms of the cultures created around the PES programme, some elements of the Mexican scheme have transcended to other forest policies. For instance, the PES programme itself has been a reference for the structuring of ORs in other national level forest management programmes in CONAFOR, and the determination of eligible areas, the verification process and the conditioning of payment to the performance of predetermined activities (1, 2013, Del Angel-Mobarak, 2012). The programme itself is a symbol of an ideological and discursive shift around the economic vision of forests in México, for example, the idea of the forest as a provider of intangible services that can be commoditised, the identification (pre-definition) of sets of "suitable" and "unsuitable" practices for forest conservation and management, and the corresponding expectations about reduction of poverty and deforestation.

Another impact of the PES programme on forestry policy has been the establishment of a permanent relation with different types of specialists from universities and NGOs (some of whom have been highly critical about the programme's conceptualisation and scope), who provide advice and develop evaluations on the rules and targeting of the programme. Some of the suggestions are integrated in the following year's ORs. So, the PES programme has also helped to transform the relationship with new actors and sources of knowledge, and the programme has gained social approval from some sectors, contributing to the configuration of new communication channels and membership of CONAFOR.

At the local level, the PES programme has not only produced effects in some aspects of the forest policy landscape figuratively speaking: it has also geographically changed the very forests where the programme has been executed. The activities aimed at enhancing forest condition for the provision of ES (such as forest firebreaks, watering holes, reforestation patches, measures to protect soil from erosion), and even the signs and fences showing the areas enrolled, leave tangible traces of PES implementation in the forest landscapes. Regardless of whether they produce actual reductions in deforestation rates or in poverty, the PES polygons are clearly delimited, also evidencing the difference between the forest owners that are in and out of the programme (providing a geographically explicit indication of membership). The effects and the duration of these marks in the landscape over the longer terms are of course still not known and may be questions to be answered in future research.

In addition to these direct marks on the forest landscapes, communities have the right to decide on the use of the surplus money, if any, from PES activities. In the past, the 
money could be distributed freely among members of the community, but in recent years CONAFOR started encouraging, and more recently obligating, beneficiaries to use it in "collective benefit" works. Thus, PES money has also contributed to the modification of the local landscape by the construction of streets or roads, remodelling of communal houses (ejido houses for assemblies and meetings), churches, health clinics, rural schools, or for the purchase of equipment for monitoring forests and for the combat of fires, among many other possible uses.

\subsection{Local PES constructions beyond the official expectations of outcomes}

During the research, it became evident that one of the components that contributes to the complexity of the implementation of the PES programme is the heterogeneity of the professionals and individuals who are responsible for taking the ORs to beneficiaries. The TAs interpret, adjust and bend the ORs by taking advantage of their soft spots and ambiguities. Since beneficiaries do not have direct contact with ORs, the PES message they receive is always mediated by the TAs, and just partially regulated by CONAFOR, which leaves a margin of freedom in the implementation of the programme. Once the TAs bring the ORs to the beneficiaries, they in turn re-interpret them according to their own schemes and endow it with their own meanings. The sense making and adaptation of the PES programme is also an exercise of agency of all actors involved.

Although the beneficiary communities are key players in the operation of the programme, the research addressed their participation and the relevance of their role in PES especially from the point of view of their interaction with TAs. Despite this limitation in the approach, the direct interaction with them in the fieldwork allowed hints to be gathered about the multiple ways in which the programme operates locally and the positioning of the beneficiaries regarding the TAs and CONAFOR. It also allowed visualising the terms by which communities give meaning to the programme, in order to understand its relevance in each case, as well as the motivations for getting involved in it.

The communities included in this study have similarities, but also particularities. Regarding the similarities, all the communities are located in protected areas (two in the core zone, three in buffer zones and one in influence area of the Manantlan, the Monarca Butterfly and the Zicuirán-Infiernillo Biosphere reserves), which in principle restricts the possible uses of the forests. In such conditions, PES is one of the few subsidies that are compatible with the rules for the protected areas that these communities can access. All the communities are located in areas with a long tradition of forestry, so the dynamics between TAs and communities are also determined to some 
extent by the historical context of forest management in México and the power relations between the actors.

On the other hand, the environmental and social conditions of the communities are divergent and determine the attractiveness of the programme in each of them. For example, in the ejidos found in zones of tropical dry forest, which is subject to frequent drought, there are few productive options for agriculture, there is high marginalisation and poverty, and low access to services and jobs; PES is highly relevant in economic terms for these communities. The programme also nurtures community expectations of being involved in other programmes in the future. PES is also an incentive to continue participating in conservation activities, in which they had previously been engaged without economic remuneration, which makes them consider that the PES as a reward for those years of effort.

In Zen, a remote and marginalised ejido, there have always been divided opinions about participating in the programme. Some people see it as an intrusion, an invasion of local uses and customs, and a way to restrict activities and to lose property rights. For others it means having economic resources to control the logging and fires, which are common problems in the area, and to protect springs. Their participation in the programme has allowed them to have a good relationship with the employees of the reserve and through it they have obtained more support. They consider that the money they receive is not enough, but it has helped them to mobilise and motivate people to carry out activities that they previously did without payment.

In the community with lands located in the core zone of a temperate forest protected area (Ahu), the PES has acquired a more symbolic meaning. This group of ejidatarios recently received this portion of land in response to their demands to the other owners of the ejido through an informal agreement. The PES is the first government support they have received, through the intermediation of their TA, and with the approval of the ejido to which they still belong. Since all land uses are restricted, ejido people had lost interest on it. However, access to the programme has contributed to re-valuing of these lands, and it has been an incentive to exercise their rights and make decisions about the regularisation of the property.

For two communities PES is one of the most productive options that exist for them. Cresm is a very large and empowered ejido with many projects supported by national and international governmental and non-governmental agencies. Internally there are groups with diverse interests, which results in severe internal conflicts. Their participation in PES has been affected by a major conflict over corruption of the previous ejido authority in collaboration with the TAs and presumably also employees of CONAFOR, which had resulted in participation in the programme without the 
authorisation of the community assembly. Despite the distrust generated by this situation, the community assembly decided to be involved in the programme again. For them, PES is a right that they can exercise as a forest community. For its part, Ton, located in a prosperous agro-industrial area of blue agave, uses the PES programme as an alternative to livestock in areas that do not have much value in terms of agriculture. For Ton's people, PES is just another possibility to obtain benefits from those lands. In this community, forest areas are in latent danger due to competition with other uses and the division of common use areas, but there is no explicit commitment to continue with this programme in the future.

The examples provided above allow visualisation of the heterogeneity of the communities that are involved in the programme. Each of them responds in a different way to the concepts and formal structures, and often these are in second place when facing the local ways of understanding, valuing and interacting with forests. This encounter of disparate institutional frameworks produces diverse effects in the configuration of the programme in each community, in terms of how it gets implemented. With the help of the TAs, communities transform the PES programme through exercise of their everyday agency through decisions, practices and interactions (Mahoney and Thelen, 2010). Despite the relative rigidity and homogeneity of ORs, it can be said that in each community a different/unique PES is developed.

PES in turn produces changes in communities' vision. Beneficiaries have learned (at least partially) the PES language and carried out the "good practices", but in addition they have begun to conceive of the forests in different ways. It is not clear if this vision will persist in each community, and whether the effects will be visible at the local and regional level and in the long term. In interviews informants from four communities (2013) mentioned that the existence of the programme has helped them to visit more often and re-value their forests, because the works for conservation require time and money that is not available otherwise.

In this sense, the perspective of institutional bricolage can be useful to examine the interaction of local institutions (beliefs, rules and norms) with the formal structures of CONAFOR. Institutional bricolage, described by Cleaver as "a process by which people consciously and unconsciously draw on existing social and cultural arrangements to shape institutions in response to changing situations", can help to explain the role of creativity of actors in the development of institutions (Cleaver, 2001). It helps to make evident the ways in which actors use the resources they have at hand, making different types of arrangements to transform or produce institutions (Cleaver, 2001; Douglas, 1986; Koning \& Cleaver, 2012). Actors employ their cultural background, social arrangements from other institutions, ideas and emotions, rather than acting only under 
rational strategies (Koning \& Cleaver, 2012). This approach focuses on the observation of the processes through which new official institutions, such as the ORs, are introduced in local contexts, and interact with the already existing sets of norms and beliefs, producing different possible effects on the local ones. The ways in which this encounter is produced can also shape the formal institutional framework.

Thus, a programme whose conceptualisation is considered to be relatively linear, which has been frequently criticised for the simplification of the interaction between forests and society, and whose implementation homogenises local contexts and expected results, produces complex effects locally. This combined with the heterogeneity of the TAs that catalyse the appropriation of PES in the communities, and the fact that the ORs change each year, result in the symbolic diversification of the PES on the ground. That is, although the rules and procedures are the same in appearance, in the ground PES is inhabited with multiple meanings, and alternative conceptualisations. The continuity of the PES programme at its most local level is related to this diversity of appropriations, since it becomes a means to achieve different objectives and obtain multiple benefits.

\subsection{Conclusion}

From all this evidence it is possible to visualise the multiple roles of (in)formality in the PES programme. For example, independently of the officially expected outcomes, PES is shaped by the behaviours and practices surrounding the ORs' prescriptions, producing parallel, alternative PES benefits for all the actors involved. It also helps to fill administrative and operative gaps and soft spots, and enable multiple interpretations and actions which provide flexibility to vague and ambiguous areas. About that, Stone says: "informal rules applied to vague formal rules, gives greater flexibility in reaching an acceptable decision in society and keeping the myth of perfectly precise, neutral, and enforced rules alive"(Stone, 2002). This means that informality also contributes to the maintenance of the PES façade. However, the "under the carpet" practices have transformed the official PES programme. The actors with greater influence at the local level are actually co-producing and implementing alternative forms of PES. At this point, it is possible to suggest that what is really being implemented on the ground is not the formal PES, but something different, let us call it "PES" - a (evolving) combination of formal and informal structures and perceptions.

Informality in PES not only enhances the fluidity of processes for implementation and keeps the formal structures alive. It can also be seen as a product of resistance from the less powerful actors (Ledeneva, 2018), in Scott's term: the "weapons of the weak" (1985), which allow the creation of alternative meanings, practices, alliances and benefits as incentives to fulfil the ORs expectations, which are themselves devices symbolising the power relations in CONAFOR's programmes. Through informality, actors 
with no power to change formal structures at least temporarily modify these power relations and hence also the expected outcomes of the enforcement of formal structures. At the same time, just as informal structures play an important role in the continuation of the PES, it has also been documented that some of them have negative effects at the local level, obstructing communication channels, affecting the ties of cooperation between actors, limiting the beneficiaries' options and deepening their disadvantaged condition. Thus, fluidity of processes in PES through informality can also have social costs for the less powerful. Regarding understanding of the ambivalence of informality Ledeneva (2018) says: "The ambivalence of informal practices, multiple moralities, inconsistent legitimacies and blurred boundaries makes it possible to solve private problems on a daily basis. At the same time, however, this ambivalence also creates obstacles, or filters, that in the longer term impede the efficient implementation of public policy and may accordingly be harmful to society in general" (Ledeneva, 2018, p. 15).

Although the (inter-) national models of PES have designed a set of objectives, good practices, rules, standards, expected outcomes and performance indicators, the effects produced in implementation of the PES programme on the ground have not been linear. The Mexican PES programme has been filled with alternative values, practices, expectations and understandings at the local level that transcend the official objectives. And this has, in some way, given meaning to its existence, and has produced motivations or incentives for the actors to keep it alive and fulfil the ORs. About that, Van Hecken et al. (2017) suggest the adoption of research perspectives that consider "the multi-scalar, plural and mutually constituted discourses and practices", in order to illustrate the ways in which conceptualisations of PES "can be discursively (re)imagined, in turn impacting grounded practice and socio-environmental outcomes" (Van Hecken et al., 2017).

Regardless of whether PES is as successful as the CONAFOR's storyline asserts, and beyond the formal expected PES outcomes in forests and people, this research has explored alternative readings, benefits and motivations of the main actors that ensure their participation in the scheme. The incorporation of the vision of these actors has enriched the explanations about the persistence of PES over time. The dynamics between ORs and TAs are complex and not always friendly, but in the end, the ways in which they are portrayed (the ORs as "indisputable", and the TAs as "villains") have a positive effect on PES programme since they contribute to the construction of the organisation's façade. Additionally, the ORs and TAs interaction produces a suitable combination of formal and informal structures, which contributes to the fluidity of the relations between the actors through the flexible interpretation/implementation of the PES concepts and rules. However, the positive effect in PES is not in the success of the programme. The positive effect is its continuation. 
At this point I recall again the metaphor once used by the manager of the programme, who told me that sometimes PES was like a thousand-headed monster, to explain to me its complexity and the difficulty of transmitting the message of the policy to forest owners and to the public. According to her, this is the reason why many people cannot understand what PES is, and who and what is being paid for. After my interplay with ORs, and the main actors of the programme, especially the TAs, as well as the further analysis of findings, the thousand-headed monster has acquired new implications for me. It is not only that the PES' message is difficult to explain, and it is not only that people do not understand the message. It is that the message has been transformed over time, and it has been co-produced, and reproduced in different contexts, and it has been implemented through a variety of elements and (in)formal practices that are locally available. The diversity of PES perceptions and meanings is somehow aligned by ORs and TAs, which, together could be the most important head of the monster. The diversification has made the programme complex, but attractive to the actors involved, as they receive multiple benefits from it. And because of that, all of them cooperate to keep the monster alive. I also remember the second allusion to the monster, this time by a TA, when he referred to the performance of the TAs, and to how CONAFOR has contributed to the problem by giving the TAs indiscriminate power, and by ignoring their malpractices, meanwhile imposing control measures that give no results: "CONAFOR created this monster against whom it fights". Now I can see that this monster, the "villain" has to be alive, because it is a building stone of the PES façade. Finally, on a personal level, the result of my confrontation with the monster is that, it is still there, alive, but that now it seems much friendlier. 


\section{Chapter 13. Future research to further explore the monster, and reflections on policy}

\subsection{Introduction}

This chapter includes final considerations on the potential use of the results of this research in two areas: research and policy. Firstly, some general questions that emerged during the research, as well as some specific topics that can be potentially addressed in future research on PES in México are identified and presented. Secondly, the practical implications of the research in terms of its possible application in forestry policy are explored. By considering not only my learning in this research, but also my experience as an ex-governmental employee, I reflect on the way in which the findings of this research could nourish PES and other forest policy. Final remarks are included on the co-production of policy-relevant knowledge, and the exploration of alternative approaches for dealing with complex socio-environmental problems such as those that surround PES.

\subsection{Future research directions}

Throughout the chapters of this thesis I have mentioned some specific topics addressed in the research which remain unanswered. For example, in chapter 9, I mentioned that it would be important to carry out a deeper investigation to analyse some issues that could not be addressed in this research. These include the number and incidence of unethical practices carried out by the TAs and the real repercussions that this has on LAST, or what kind of follow-up occurs in cases of formal complaints, among others. In this final chapter, however, I will address some directions for future research in more general terms, with respect to information gaps and areas that have not been addressed in depth by this research. Some questions have also emerged from what I have learned from the findings of the research and may be threads to be followed in the future.

\subsubsection{Gaps and limitations in the research which generate ideas for future research}

\section{- Community- based in depth research}

Initially, an in-depth participatory study in communities was considered, with a view to understanding their relationship with ORs and other actors, as well as their perceptions on forests, ES, and their participation in the PES scheme. A trajectory study following the process of decision-making in PES implementation in such communities was also contemplated. However, when I decided to focus on the role of the TAs as key actors, 
the approach to the beneficiaries of the programme was limited to documenting their interactions with TAs. However, undoubtedly it would be interesting to carry out studies that deepen understanding of the diversity of ways in which the PES programme is adopted in different local contexts. It is also important to recognise the local strategies of resistance, accommodation, adaptation, re-creation, combination and shaping that occur at the interface between the ORs (as sets of rules) and local institutions. On the other hand, it would be important to understand the mechanisms that contribute to the resolution of possible internal or inter-community conflicts when they enter the programme, and the interaction of beneficiaries in this context with CONAFOR staff and TAs. For this, the concepts relating to institutional bricolage (Cleaver, 2001; Koning \& Cleaver, 2012) could be useful. This approach would help to understand the mechanisms by which two (or more) sets of rules/ institutions interact to produce shifts in both and solve (or not) the tensions generated by these encounters. This approach could be used, for example, to test the conclusions of this thesis concerning the perpetuation of the weakened position of communities over time. Additionally, more research is needed to understand the ways in which communities appropriate and obtain benefits that go beyond of those that I described in this work.

It would also be relevant to complete the account of informal community structures and the relationship of communities with the other actors. It is also important to see to what extent unethical practices permeate the communities, and with what effects, since it is in the communities that the effects of these practices are tangible; they become more intangible as they pass to higher administrative levels.

\section{- An in-depth analysis of the interactions between formality and informality in PES programme}

Given that the organisational and institutional perspectives of (in)formality were adopted in the last part of this thesis, it was possible to identify some informal practices, behaviours and agreements that are connected to the formal structures and that enable fluidity of certain processes in the programme. But this has been a starting point in the understanding of the interaction between formality and informality in PES, and the role of all the actors in the co-production and reproduction of informal practices working together with CONAFOR's formal structures. It is also relevant to understand the different (positive, negative, ambiguous and for whom) effects that informality is producing not only in the programme, but also in the actors' roles, influence/power relations and capacities, especially at the local level. 


\subsubsection{Questions for future research that came directly out of the findings}

\section{- Connecting the findings in PES with other related policies}

The institutional and organisational settings in which PES policy is carried out are not unique but hold also for other related forest policies, especially those established in the framework Forest and Climate Change 2012-2018 (a project carried out by CONAFOR with funding and guidance of the World Bank), such as the Local Mechanisms of PES, and the REDD+. However, there are also significant differences in the approaches of these programmes, and they involve different actors. Therefore, it would be interesting to carry out a comprehensive/cross-cutting analysis of the dynamics, interactions and processes occurring in the implementation of those programmes. Likewise, it would be interesting to analyse the ways in which they coexist spatially and administratively, and the effects and practices (planned and unintended) produced by them in the communities involved. The interactions between actors in concurrent funds for local mechanisms of PES and REDD+ involve new actors, such as investors, real ES buyers, partners and other forms of intermediaries, information about whom may be interesting in terms of the ((in) formal) blend of arrangements that take place in the implementation of such schemes.

\subsubsection{Other actors to be analysed}

\section{- CONAFOR's field level employees in PES}

In this research, I centred on the role of the TAs as key actors in PES, since they are located at many interfaces of the programme, but also because of their connection with the informal side of the programme. I would suggest a similar analysis should be extended to other actors who perform an intermediary role, especially the CONAFOR state-level employees. In this research my interaction with them was intense, especially in Michoacán, because they often helped me to connect with TAs, I joined them on fieldwork visits, and of course, I interviewed them. In those moments I realised the relevance of their role as well as the problematic conditions under which they work, which also influences the implementation process and its outcomes. Field-level bureaucrats of this kind represent the State in policy implementation, and occupy an ambiguous position in which they are expected to implement rules and policies with limited tools and resources in a diversity of local contexts (Funder \& Marani, 2015). They fulfil their tasks through a combination of exercise of discretion and power expressed in a combination of formal and informal practices, as well as selective display and concealment of information both to their superiors, and to the local actors. 
Although a study on their role and performance in the local implementation of PES could certainly be relevant, the topic was outside of my research objectives. Therefore, I recommend an in depth study focused on the CONAFOR state-level field employees, maybe with a larger sample, which could be focused either only in PES or done from a more transversal perspective, considering "street-level bureaucrats" in different forest or environmental programmes. State-level employees are relevant because they also perform an intermediary role in PES but represent the interests of CONAFOR in relation to TAs and beneficiaries. They share some conditions with TAs, for instance, they have a high responsibility and are under considerable pressure, because the burden of the implementation also lies with them, but they have little or no power to make decisions (e.g. as regards selection of beneficiaries, sanctioning for incompliance, and taking measures against unethical practices). On the other hand, unlike TAs, they are under much control from CONAFOR's central office, so they have to manoeuvre with the few formal elements they have in hand to solve problems and deliver good results, in order to keep their jobs. In a context where TAs are not considered reliable by CONAFOR headquarters, CONAFOR state-level employees often adopt the interests of TAs, and feel obliged to report only good results to central office, and hide the bad news about what is happening locally. Studies from a variety of authors have been carried out on this topic, such as Lipsky (2010), Blundo and Glasman (2013), Olivier de Sardan (2014), Funder \& Marani (2015), and Mathews (2012) in México, among many others.

\section{- The role and dynamics of the PES National Advisory Committee and other influential actors in PES/REDD+}

As it was mentioned above, the PES national advisory committee is composed primarily of NGOs, academic institutions and members of other ministries, but also other actors, forester unions and forest enterprises. Usually they discuss and evaluate the annual outcomes of the PES programme, and provide advice and suggestions to modify the ORs, especially the targeting criteria. The committee is recognised as highly influential in the evolution of the ORs. But tensions between the visions of the members in recommending changes in certain areas of the programme have been evident in this evolution. Therefore, it would be interesting to investigate how the composition, dynamics, motivations of the members, power asymmetries between the participants play out, and what their specific influence is, not only in the targeting criteria and sources of information but also in other aspects of PES programme. In this respect, the extent to which the contributions of committee members focus on the improvement of the capacities of the PES beneficiaries, or on developing mechanisms to obtain direct feedback from these actors might be interesting. Other points to be addressed would be what sources, types of organisations (members) and knowledge are considered valuable, legitimate, objective, or valid by CONAFOR in support of decisions about the programme. Moreover, it would be advisable to analyse to what extent CONAFOR 
actually takes into account the contributions of the Committee in improving the policy design, implementation and outcomes, since, as Jasanoff argues, "these bodies are often used as 'end-of-pipe' legitimation devices, reassuring the public that normative issues have not been omitted from governmental deliberation"(Jasanoff, 2003, pp. 241). Additionally, Jasanoff mentions that advisory committees not only address purely technical or scientific issues, but also social, normative, and even metaphysical points (Jasanoff, 1990, 2003). Likewise, rather than the quality of the information (which is usually assessed by scientific peers), it is their power and credibility that underlies "their probity, representativeness, transparency, and accountability to higher authority" and to the public (Jasanoff, 2003, p. 233).

\section{- TAs certification process}

Finally, as we have seen, the TAs form a complex group of people working in complex settings. Among the several topics that can be addressed in future research about TAs, is the certification process. Certification was established as a mechanism to improve the quality of the services of TAs, but the efficacy of this is contested. Different aspects of certification could be studied, for instance what the impacts and scope of certification of TAs are on the beneficiaries (e.g. if there is a relation between the complaints presented by beneficiaries before and after certification) and the outcomes of the programme; which criteria are (or are not) considered in the process, and who (e.g. which professional profiles, men or women, ages, enterprises, NGOs, individuals, "CONAFOR children or Old school", etc.) benefit or are negatively affected by the certification; and finally what kinds of mechanisms exist to assess certification results.

\subsection{Reflections on policy}

[...] [In forest development] [w] have all failed, from the government itself, the technicians, the entrepreneurs, the academic institutions [...]. The problems remain the same [...] because we have tried to solve them in the same ways [...]. Then, well, we have claimed that these problems require major surgery, a fundamental transformation. We cannot longer do things in the same way $(18,2013)$.

Throughout this thesis I have made observations on specific areas of PES that could be improved. In this section I offer a reflection about the possible contributions to policy of a research project such as this. To do this I use ideas from my own learning process not only in this research, but also as an ex-governmental employee. Additionally, this reflection is nourished by the visions of two authors who have contributed to the discussion on the approaches of science and technology to the resolution of policy problems.

Given the nature of this thesis, it is relevant at least to discuss the relevance of the potential improvements in the elements analysed in the PES programme. According to its former director, PES is the most evaluated government programme in México, however, some actors consider that there are still many problems in its formulation, implementation and outcomes. As a starting 
point, I recall a claim made by a TA (see top of this section) about the role of different actors in forest policy like PES, which is very relevant to understanding the need for changes not only in the programme but more generally in forest policy in México .

This observation makes evident the lack of connection between relevant actors in solving tangible problems about forest development. In terms of the relationship between the researchers on forest policy and the policy makers, I find some factors that limit the chances that policy suggestions deriving from this research will be considered in the actual implementation of PES in the future.

In first place, one of the problems that I have seen throughout my career is the difference in the approaches and frames used in public policy compared to those used in research for academic purposes. The changes that a researcher may suggest are not necessarily within the reach of those who make and implement the policies. Researchers frequently ignore the fact that policies are restricted by administrative, institutional, operational and financial factors, which limit the opportunities to take these 'helpful' suggestions into account. This is partially due to the different nature of approaches. Certainly, these are not immovable restrictions, but public policy evolves at a much slower pace than the ideas proposed by scientists about it.

As we have seen, public policy is complex because it requires the participation of diverse actors with a variety of backgrounds, interests and ways of framing problems; actors who cooperate in a functional way to achieve certain objectives. In these cooperative efforts it is also acknowledged that, regardless of the quantity and quality of information available, power struggles and politic motivations often influence policies more than the information produced from policy-relevant research.

Second, another problem that not only concerns forestry policy, but also public policy in the wider sense in México, is the lack of continuity. Historically, the six-year changes of presidential administration in México follow a "clean slate" dynamic. That is to say, the policies, the personnel of the organisations, and even the organisations themselves tend to be replaced with each new administration. This has been nuanced over time, with programmes that are considered successful being allowed to continue in some cases, even if their names and senior members/personnel get changed (which is almost always the case). Additionally, the direction in which changes in policies occur is directly related to the regimes and political parties that are in power, as is only to be expected. CONAFOR and the PES programme were established during the first administration of the National Action Party (PAN), a conservative party which it was in power from 2001 to 2012. In 2012, this was replaced by a party (the Institutional Revolutionary Party, PRI) that had governed for the last 70 years of the previous century and it was voted in again from 2012 to 2018. Currently, a new centre-left party, the National Regeneration Movement (MORENA), has taken power for the first time in México, in 2019. In this scenario it is still not clear if the forest policy in general and PES programme in particular will change in a subtle or an abrupt way.

Third, PES is recognised for having received extensive feedback from academic organisations since its establishment. CONAFOR's informants in this matter have clearly been aware of the limitations and shortcomings of the programme, as described in their evaluations, articles and theses; and as 
expressed in the advisory committee's sessions and public forums, and through the daily experience of the employees. Criticisms and suggestions cover aspects such as the targeting, the selection and role of the beneficiaries, the performance of the TAs, the certification process, the definition of the amounts to pay, and the measurement of outcomes, among many others. In this context, it is quite possible that my observations on the programme are already known by CONAFOR's circle of policy makers and implementers, even if, as I hope, I have provided a slightly different angle in my critique and more substance to the criticisms, based on extensive observation in the field and discussion with people directly involved at the local level.

In this context, I would like to end the thesis by expounding certain reflections and points of discussion on the role of researchers like me in the co-production of policy-relevant knowledge, emphasising how some shifts in traditional visions can concretely improve PES implementation.

\subsubsection{Policy- relevant research approaches and contributions}

As has been seen in the theoretical framework of this thesis, two main approaches to the analysis of policy are widely recognised: the analysis of policy and analysis for policy. These are distinguished by the nature of the questions posed, the degree of application, and the type of interaction with government organisations, among others (Parsons, 1995). Related to this, some authors focusing on the interface science-policy have made explicit the need for approaches that are more in line with the complexity of the problems to be addressed in policy. In 2003, the year that PES was launched, Sheila Jasanoff suggested that scientific and technological progress has increasingly been disconnected from the governance schemes, and proposed exploring a new approach through what she calls the "technologies of humility, that is methods, or institutionalised habits of thought, that try to come to grips with the unknown, the uncertain, the ambiguous, and the uncontrollable"(Jasanoff, 2003, p. 227) [...] "to make explicit the normative that lurks within the technical; and to acknowledge from the start the need for plural viewpoints and collective learning" (Jasanoff, 2003, p. 240). Her statement is still valid for evaluation of the PES programme, which must deal not only with the interface between science and policy, but also between science and society. These technologies of humility are presented as a complementary response to the predominant predictive scientific and technical approaches, which she calls "technologies of hubris". Jasanoff's perspective can also be connected to other critical responses of 'rational' models of approach to science (and knowledge in general) and policy, such as the Stone's frameworks "market and polis", and especially to Funtowicz

and Ravetz's definition of "post-normal" science, and Scott's "metis" and "techne" among others.

Since its establishment in 2003, the PES programme has relied on science/technology for its learning and construction of knowledge. More recent and accurate information 
and efficient methods for targeting of forest lands and beneficiaries, verification of PES activities and outcomes, and models on land-use change have progressively evolved. But although the programme has employed increasingly sophisticated information sources in some aspects of the programme, the inclusion of alternative views from nonscientific/non-technical sources, such local/indigenous knowledge, is still very necessary. The understandings from the technologies of humility can contribute to enriching the vision and improving the reach of the programme, by bringing together "different expert capabilities and forms of engagement between experts, decisionmakers, (Jasanoff, 2003, p. 227), and in this case the TAs and local people, engagements which require a permanent mechanism of participation and an "intellectual environment where participants are encouraged to bring their knowledge and skills to bear on the resolution of common problems" (Jasanoff, 2003, p. 227)

On a similar line, but more focused on approaches to science quality, Funtowicz and Ravetz visualise policy-relevant science as corresponding to three nested areas, namely: 1) the "normal" science, meaning the most traditional and accepted approach to scientific research; 2) the "consultancy science", corresponding to what we know as applied science, which is focused on solving well-characterised problems; and 3) the "post-normal science" to attend to contemporary complex problems with highly uncertain conditions as well as multiple and often contested knowledge sources. The quality standards of those approaches are also different, for instance as regards the conventional peer review carried out in "normal" and "consultancy" science. However, the quality of 'post-normal' science should involve not only scientific peers, but also the different stakeholders who are in some way affected by the decisions made from the use of science, as a kind of "extended peer community" (Funtowicz \& Ravetz, 1994, 2003; Ravetz, 1999).

Funtowicz and Ravetz (2003), assert that approaches from 'normal' science tend to "foster(s) expectations of regularity, simplicity and certainty in the phenomena and in policy interventions". And in this way, our understandings of the problems and the appropriate methods for solutions remain limited (Funtowicz \& Ravetz, 2003). Through presenting examples of possible improvements to policy on PES, I will now illustrate the ways in which the visions of these authors can enrich/complement traditional approaches in the interaction between scientists and policy-makers in the development of PES, for example, by involving the vision of the actors located at the margins of the operation. This could contribute to asking and answering the fundamental questions proposed by Jasanoff about the policy interventions in the local people's life, such as "what is the purpose; who will be hurt; who benefits; and how can we know?" (Jasanoff, 2003). 
Although CONAFOR has relied on a set of research organisations to obtain feedback and legitimacy, not all types of researchers are included, and this is gives rise to another point of analysis regarding the elitism and power operating in the science-policy interface. For instance, in terms of numbers, experts on social issues and participatory research are not as represented as strongly as forest specialists in the scheme. As regards feedback from local communities and TAs, although external evaluations have included analysis of the local level perspectives on the PES programme, results of such evaluations may or may not be taken into account, since they are not binding instruments. Therefore, permanent channels for capturing the knowledge and perceptions of beneficiaries are still needed. Technologies of humility are necessary in revisiting policy priorities for PES. On that, Jasanoff states: "Humility directs us to alleviate known causes of people's vulnerability to harm, to pay attention to the distribution of risks and benefits, and to reflect on the social factors that promote or discourage learning". One could add that considering and recognising the local informal practices through which the PES programme is producing (or not producing) the expected and positive alternative outcomes, is an additional means for increasing understanding about the programme.

According to Jasanoff, there are some misconceptions about scientific progress, for instance, that this allows reduction of uncertainty. Scientific progress does not necessarily lead to finding a unique truth that reduces discrepancies. The complexity of socio-environmental problems can have a diversity of readings and interpretations. So, more than trying to arrive at a unique knowledge, mutual understanding could come from the acceptance of the diversity of visions about a problem and its solutions. Thus, Jasanof suggests: "new avenues need to be designed through which societies can collectively reflect on the ambiguity of their experiences and assess the strengths and weaknesses of alternative explanations".

Rethinking the interface between science and society in PES also can help us to understand who the main beneficiaries are of the inclusion of scientific information in the programme design and implementation. Also, which aspects of the programme are considered by scientists and which are not under observation? Do the interventions of different evaluators and analysts contribute to good governance? Are we addressing sufficiently the complexity and ambiguity of practices and knowledge?

Although the elements analysed in this research are the ORs and the TAs, these policy recommendations are oriented to beneficiaries, because many of the problems I found regarding the roles and representations of these elements are directly related to the effects they have on the condition of the beneficiaries. The specific recommendations are the following: 


\subsubsection{Forms for effective inclusion of local feedback and decision making}

Although in discourse CONAFOR considers participation of beneficiaries a highly relevant issue, in practice the formal expectations about participation in PES programme are reduced to complying with the rules and fulfilling the expected activities in order to keep their membership in the programme. Some of these tasks involve making decisions about the specific activities to be carried out in the PES polygons in a participatory way.

Feedback from beneficiaries is still limited and mediated by state-level employees and TAs. A big effort has been made to find the best indicators for targeting in PES, but as Jasanoff claims, technologies of humility may enable much more feedback from the multiple local experiences and interpretations about the programme. She reminds us that the causes and possible solutions of a given problem "may appear one way to those in power, and in quite another way to the marginal or the excluded" (Jasanoff, 2003, p. 242), which not only includes the beneficiaries, but also the TAs. However, as Funtowicz and Ravetz (2003) assert, "when persons with no formal qualifications attempt to participate in the processes of innovation, evaluation or decision-making, their efforts have tended to be viewed with suspicion or scorn".

Here I am not proposing a completely new form of involvement and or a participatory approach which is unrealistic. I am proposing that there are sources of information, as well as mechanisms that already exist in the programme that can be used in more creative ways for the inclusion of local visions. This would not necessarily imply much extra cost for CONAFOR. For instance, the workshops for beneficiaries are moments of interaction between actors, and these have provided a considerable amount of information every year about the local perceptions of the forests and the ES. However, this information is not systematised or analysed for further uses by CONAFOR. Then again, CONAFOR carries out annual surveys/polls to capture the opinion of beneficiaries. However, this information (probably mandated by higher level governmental organisations, the internal evaluation office or the funder agency) is often employed for evaluation of 'client satisfaction'. But this effort, which is already systematically carried out, could also be useful to obtain more feedback from beneficiaries about aspects of the programme to be examined, discussed and improved at the local levels. This feedback could also help to enhance the relation between CONAFOR and communities and TAs and by widening the official perception about them as real actors, that is, "active, imaginative agents, as well as a source of knowledge, insight, and memory" (Jasanoff, 2003, p. 243). This includes the recognition of alternative interpretations, different understandings of "good forest management practices", as well as positive informal norms, practices, and networks that could all improve the operation of the programme. 
Further, McAfee \& Shapiro (2010) have shown the relevance of the social movements that resisted national anti-rural policies in the re-shaping of PES at the beginning of the programme. This intervention resulted in the establishment of CABSA in 2004 (see chapter 6) as a more inclusive modality of the PES scheme. Although versions of PES based on biodiversity conservation and agroforestry are still operating (both derived from (ABSA), the homogenisation and simplification of the ORs in 2006 reduced the impact that had resulted from these actors' demands in the evolution of the programme. In these moments of change of political regime in México, the reinforcement of the connection between CONAFOR, the PES national advisory committee and these groups is to be recommended.

Strategies that give visibility to the formal and informal processes that occur especially at the local level are needed. Beneficiaries should have simpler mechanisms to present suggestions, observations and complaints directly to CONAFOR, so that they may be properly channelled and resolved. Recognising PES schemes as a multi-scalar and plural co-production, where global, national and local discourses and practices converge and are mutually constituted (Van Hecken et al., 2017) would allow the integration of local experience as a fundamental element of PES programme functioning.

\subsubsection{Alternative and diverse perceptions of "good forest management practices"}

As was mentioned in the section 11.2, good practices are often determined by external agents, such as international funding agencies and other bodies specialised in development, sustainability, forest management, climate change, and related issues. In the PES programme they are presented in the form of a planning tool for beneficiaries, the "guide/manual of forest management best practices". In order to choose activities to be carried out, beneficiaries have a menu-like format with a set of pre-determined options of such activities. Generally, TAs and communities chose from the menu and sometimes they also propose another activity. In this sense, the programme could also receive local feedback about perceptions of what constitutes good practice. In this matter, the advisory committees and the external evaluators can contribute by exploring local perceptions of good forest management practices. Given that the communities involved in PES are heterogeneous and with different backgrounds with respect to forest practices, it would be advisable to categorise the communities by capabilities and by their capacity to propose activities that are compatible with PES.

The diverse understandings and contexts of what constitutes good practices in forests for PES or other schemes would also be a point of collective reflexion between the actors influencing the programme, and the actors affected by the programme. Jasanoff argues that the traditional approaches to policy-relevant science may limit the vision of what 
problems are to be addressed, and because of this the inclusion of other visions could be complementary and closer to reality. "Institutions see only what their discourses and practices permit them to see. Experience, moreover, is polysemic or subject to many interpretations" (Jasanoff, 2003).

\subsubsection{TAs and their role in PES}

As has been showed in chapters 8,9 and 10, TAs are controversial, since they are recognised as very important actors in implementation of PES, but at the same time they are criticised and stigmatised because of their poor performance and unethical practices. In this matter, changes are need in various aspects of their work. However, in the same way as with communities, I will make recommendations only on aspects that I consider feasible.

In first place, TAs should be fully recognised as a fundamental part of the programme, not only in its implementation, but also in its promotion and continuity. Recognition of their role as agent of institutional change in ORs is also required, since their decisions in the field, their criteria for choosing beneficiaries (e.g. whether to work more with communities or private landholders, indigenous communities or ejidos, in which ecosystem types, and of what sizes and distance to the lands, etc.) effect on the evolution of the programme. At the same time, TAs need space to present their opinions, to provide feedback and to discuss aspects of implementation and their interaction with CONAFOR and beneficiaries.

Evaluation of TAs should be integral to the programme, including a system of sanctions in cases of poor performance or unethical practices, and this should have direct consequences in the LAST. But there should also be space for rewards for good performance, such as training opportunities, certificates, and discounts in the payment of the certification process, among others. In this sense, certification should consider a range of criteria, such as the real performance of TAs in the field, as well as the quality of the activity reports they present to CONAFOR. This requires the active participation of communities, state-level employees and central office staff. All this information is already available, but it is not systematised in a way that could make it useful in evaluation.

The involvement of new types of intermediaries, especially the community level technicians, is also necessary. Opportunities for certification of non-technical intermediaries would allow community-level assistants who provide services to their own communities and others to be recognised as an important element in the PES programme. In the same line, it is necessary to gain information about these new types of intermediaries, some of whom are already working in the communities, in order to 
know how and why are they collaborating with the community, and the ways in which may be possible to foster good interaction for the benefit of all involved in the PES universe.

Additionally, rather than obligatorily connecting the beneficiaries with TAs, a more flexible system of hiring of TAs is required if the community needs it. Certain conditions must be improved to reduce the great dependence of the beneficiaries on the TAs. For instance, ORs should be expressed in more accessible ways, and more and better training for communities is required. This would allow the TAs to be agents of accompaniment and guidance at the local level, allowing the processes of learning and development of communities without their monopolising the tasks and becoming indispensable in the implementation of programmes.

Finally, since many of the problems found in the programme occur or have repercussions at the local level, it is important to emphasise that people in the communities must provide more feedback to the programme, and this information should have an impact on the ORs. About local people's contributions to policy Funtowicz and Ravetz say: "Particularly at the local level, the discovery is being made, again and again, that people not only care about their own environment, but can also become quite ingenious and creative in finding practical means for its improvement, integrating the social and technological aspects. For local people can imagine solutions and reformulate problems in ways that the accredited experts, with the best will in the world, do not find 'normal'. This provides the communities with both the means and the confidence, in their struggle to build a better life" (Funtowicz \& Ravetz, 2003, p. 7).

\subsubsection{Informality as a source of knowledge}

Jasanoff suggests framing, vulnerability, distribution and learning as central points around which to develop technologies of humility, which can be expressed in the questions: "what is the purpose? who will be hurt? who benefits? and how can we know?" (Jasanoff, 2003, p. 240).

The acknowledgment of the co-existence, interaction and mutual constitution of formality and informality allows us to answer Jasanoff questions. Thus, the first step is the recognition of informality not only in its negative expression (e.g. corruption), but as a fundamental cross-cutting aspect of the implementation of PES. Informality is inherent to human activities, always accompanying and shaping formal structures, in this case of PES. Once we have recognised that, we can see informality as a source of knowledge about PES and start answering the "how can we know?" question. It is of relevance to policy analysis and policy making to understand the ways in which the informality (the 
non-visible, unwritten) is created, adapted and connected to formal structures (the visible, written) and the ways in which each actor plays a role in its co/reproduction.

So, what is the purpose? Informality provides flexibility and facilities the adaptation of the ORs to local settings. Through informality actors fill the gaps and interpret the ambiguities of ORs to link/align them with the local institutions and individual interests/motivations. So, in some cases the presence of informal structures may be an indicator of formal institutional gaps, soft spots and ambiguities of the ORs to be addressed, although not all the informal structures need be or can be formalised (Kühl, 2014). It can also be useful to identify contested/controversial aspects of the programme, in order to raise awareness of the critical and resistant responses of different actors, especially those with little or no power to directly transform the formal structures (Helmke \& Levitsky, 2002).

This is also related to the "who benefits?" and "who will be hurt?" questions. Regarding the first, and as mentioned in chapter 12, the combination of formal and informal structures/institutions may provide benefits for all the actors involved. In the examples of PES workshops, but especially in the field verification process, it has been shown that both tolerance to some breaches and extra official negotiation contribute to the smooth functioning of the programme. In other cases, informal practices provide more benefits to one actor than others and may even have negative consequences for some actors and processes.

Thus, to answer the question, "who will be hurt?" it is especially important to make visible and to learn from the ways in which certain informal practices and sanctions can negatively affect actors, especially the PES programme beneficiaries. Given that the current strategies of "turning a blind eye" and blaming the TAs are contributing to inaction, impunity, and the worsening of the vulnerable condition of the beneficiaries, it is necessary to examine the factors that enable the emergence and persistence of harmful practices. Rather than hiding informality under the carpet, it would be more productive to welcome it, and open discussion with different actors in order to address and find creative and diverse solutions to its adverse effects, while not losing its positive ones. In order to do that, it is necessary to capture the ways in which informality (and the multiple forms it takes) is mutually constituted with formality. And, rather than ignoring the "elephant in the room" as described by Katomero \& Georgiadou (2018), it is necessary to internalise the contribution of informality and the applicability of the knowledge that this interaction can deliver for the improvement of the PES programme in a diversity of local settings.

Having come now to the end of this thesis, I remember that at its beginning, I mentioned that an informant used the metaphor of the "thousand-headed monster" to describe 
the PES programme. Throughout the interviews other ways of representing the programme arose, but none had as much resonance as the 'monster', since both in the research of the PES, and in my personal evolution as a researcher, I felt that many times I faced different types of monsters, or rather, a monster with many heads. For this reason I decided that the title of this thesis should include the allusion to such a monster, because its heads reflect well the different sources of complexity of the PES programme, and at the same time the complexity of my own personal transformation during the development of this research. This final section has been a recapitulation of everything I have learned in this long expedition, in order to tell the readers where my adventure confronting the thousand-headed monster took me.

\section{References of Section IV}

Anders, G. (2002). Like chameleons: Civil servants and corruption in Malawi. Le Bulletin De L'APAD, 23-24.

Alix-Garcia, J., Janvry, A. De, Sadoulet, E., Manuel, J., \& Torres, J. M. (2009). 10 Lessons Learned from México's Payment for Environmental Services Program. In Payment for Environmental Services in Agricultural Landscapes, 1951, 1-27. http://doi.org/10.1007/978-0-387-729718

Andrews, M., Pritchett, L., \& Woolcock, M. (2013). Escaping Capability Traps Through Problem Driven Iterative Adaptation (PDIA). World Development, 51, 234-244. http://doi.org/10.1016/j.worlddev.2013.05.011

Arts, B. (2014). Assessing forest governance from a "Triple G" perspective: Government, governance, governmentality. Forest Policy and Economics, 49, 17-22. http://doi.org/10.1016/j.forpol.2014.05.008

Blundo, G., \& Glasman, J. (2013). Introduction: Bureaucrats in uniform. Sociologus, 63(1-2), 1-9. http://doi.org/10.3790/soc.63.1-2.1

Blundo, G. \& Olivier de Sardan, J. P. (2006). Why Should We Study Everyday Corruption and How Should We Go About It? In Blundo, G. \& Olivier de Sardan, J.P. Everyday Corruption and the State: Citizens and Public Officials in Africa. London: Zed Books.

Bosselmann, A. S., \& Lund, J. F. (2013). Do intermediary institutions promote inclusiveness in PES programs? The case of Costa Rica. Geoforum, 49, 50-60. http://doi.org/10.1016/j.geoforum.2013.05.009

Cleaver, F. (2001). Institutional bricolage, conflict and cooperation in Usangu, Tanzania. IDS Bulletin, 32(4), 26-35. http://doi.org/10.1111/j.1759-5436.2001.mp32004004.x

Coad, A. F., \& Cullen, J. (2006). Inter-organisational cost management : Towards an evolutionary perspective. Management Accounting Research, 17, 342-369. http://doi.org/10.1016/j.mar.2006.02.003

Corbera, E., Soberanis, C., \& Brown, K. (2009). Institutional dimensions of Payments for Ecosystem Services: An analysis of México's carbon forestry programme. Ecological Economics, 68(3), 743-761. http://doi.org/10.1016/j.ecolecon.2008.06.008

Costedoat, S., Corbera, E., Ezzine-de-Blas, D., Honey-Rosés, J., Baylis, K., \& Castillo-Santiago, M. A. (2015). How Effective Are Biodiversity Conservation Payments in México? Plos One, 10(3), e0119881. http://doi.org/10.1371/journal.pone.0119881

Costedoat, S., Koetse, M., Corbera, E., \& Ezzine-de-Blas, D. (2016). Cash only? Unveiling preferences for a PES contract through a choice experiment in Chiapas, México. Land Use Policy, 58, 302-317. http://doi.org/10.1016/j.landusepol.2016.07.023 
Czarniawska, B. (2004). Narratives in Social Science Research. Knowledge Creation Diffusion Utilization, 2, 157. http://doi.org/10.4135/9781849209502

Del Angel-Mobarak, G. (2012). La Comision Nacional Forestal en la historia y el futuro de la politica forestal de México. Coyuntura y Ensayo. México City: CIDE-CONAFOR.

Douglas, M. (1986). How Institutions Think (Vol. 17, p. 383). Syracuse: Syracuse University Press. http://doi.org/10.2307/2069673

Funder, M., \& Marani, M. (2015). Local bureaucrats as bricoleurs. The everyday implementation practices of county environment officers in rural Kenya. International Journal of the Commons, 9(1), 87-106. http://doi.org/10.18352/ijc.526

Funtowicz, S. O., \& Ravetz, J. R. (1994). Uncertainty, complexity and post-normal science. Environmental Toxicology and Chemistry, 13(12), 1881-1885.

Funtowicz, S. O. \& Ravetz, J. R. (2003). Post-normal science. In International Society for Ecological Economics (Ed.) Online Encyclopedia of Ecological Economics.

Helmke, G., \& Levitsky, S. (2004). Informal Institutions and Comparative Politics: A Research Agenda. Perspectives on Politics, 2(4), 725-740.

Hood, C. (2007). What Happens When Transparency Meets Blame-Avoidance?. Public Management Review, 9. 191-210. http://doi.org/10.1080/14719030701340275.

Hood, C. (2011). The Blame Game: Spin, Bureaucracy, and Self-Preservation in Government. http://doi.org/10.1109/52.730852

Huber-Stearns, H. R., Goldstein, J. H., \& Duke, E. A. (2013). Intermediary roles and payments for ecosystem services : A typology and program feasibility application in Panama. Ecosystem Services, 6, 104-116. http://doi.org/10.1016/j.ecoser.2013.09.006

Jasanoff, S. (1990). Rationalizing Politics. In Jasanoff, S. The fifth branch Science Advisers as Policy makers (pp. 1-19). Harvard University Press.

Jasanoff, S. (2003). Technologies of Humility: Citizen Participation in Governing Science. Minerva, 41, 223-244. http://doi.org/10.1023/A:1025557512320.

Katomero, J. G., \& Georgiadou, P. Y. (2018). The Elephant in the Room: Informality in Tanzania's Rural Waterscape. ISPRS international journal of geo-information, 7(11), 1-21. https://doi.org/10.3390/ijgi711043713.

Koning, J., \& Cleaver, F. (2012). Institutional bricolage in community forestry: an agenda for future research. In: Arts B., van Bommel S., Ros-Tonen M., Verschoor G. (Eds.). Forest-people interfaces. Wageningen, N.L.: Wageningen Academic Publishers.

Kosoy, N., Corbera, E., \& Brown, K. (2008). Participation in payments for ecosystem services: Case studies from the Lacandon rainforest, México. Geoforum, 39(6), 2073-2083. http://doi.org/10.1016/j.geoforum.2008.08.007

Kühl, S. (2014). Machines, Games, and Façades: the Three Aspects of an Organization. In Organizations. A system approach. New York: Routledge

Ledeneva, A. (2018). The Global Encyclopaedia of Informality vol. 1 \& 2 . http://doi.org/https://doi.org/10.14324/111.9781787351899

Lipsky, M. (2010). Street Level Bureaucracy: Dilemmas of the Individual in Public Services. The Russel Sage Foundation. http://doi.org/10.1073/pnas.0703993104

Mahoney, J., \& Thelen, K. (2010). Explaining Institutional Change: Ambiguity, Agency, and Power. Cambridge: Cambridge University Press.

Mathews, A. S. (2011). Instituting Nature. Authority, Expertise, and Power in Mexican Forests. The MIT Press.

Mayer, R. C., Davis, J. H., \& Schoorman, F. D. (1995). An integrative Model of Organizational Trust. Academy of Management Review, 20(3), 709-734. http://doi.org/10.5465/AMR.1995.9508080335 
McAfee, K., \& Shapiro, E. N. (2010). Payments for Ecosystem Services in México: Nature, Neoliberalism, Social Movements, and the State. Annals of the Association of American Geographers, 100(3), 579-599. http://doi.org/10.1080/00045601003794833

Merino-Perez, L. (2004). Conservacion o deterioro. El impacto de las politicas publicas en las instituciones comunitarias y en los usos de los bosques en México. México City: SEMARNATINE-CCMSS.

Merino-Perez, L., \& Hernandez-Apolinar, M. (2004). Destruccion de instituciones comunitarias y deterioro de los bosques en la Reserva de la Biosfera Mariposa Monarca, Michoacán, México. Revista Mexicana de Sociologia, 66(2), 261-309. http://doi.org/10.2307/3541458

Merino-Perez, L. \& Segura, G., (2002). Las politicas forestales y de conservacion y sus impactos en las comunidades forestales en México. In Bray, D.B., Merino-Perez, L., Barry, D. (Eds.) Los Bosques Comunitarios de México (pp. 77-98). México City: INE-CCMSS.

Olivier de Sardan, J. P. (1999). A Moral Economy of Corruption in Africa. The Journal of Modern African Studies, 37 (1): 25-52.

Olivier de Sardan, J. P. (2005). Anthropology and Development: Understanding Contemporary Social Change. London: Zed Books.

Olivier de Sardan, J. P. (2014). The Delivery State in Africa. Interface Bureaucrats, Professional. Cultures and the Bureaucratic Mode of Governance. In Bierschenk, T. \& Olivier de Sardan, J. P. (Eds). States at Work. The Dynamics of African Bureaucracies. Leyden: Brill.

Oskarsson, S., Svensson, T., \& Oberg, P. (2009). Power, Trust, and Institutional Constraints: Individual Level Evidence. Rationality and Society, 21(2), 171-195. http://doi.org/10.1177/1043463109103898

Parsons, W. (1995). Public Policy: An Introduction to the Theory and Practice of Policy Analysis. UK: Edgard Elgar.

Pham, T. T., Campbell, B. M., Garnett, S., Aslin, H., \& Hoang, M. H. (2010). Importance and impacts of intermediary boundary organizations in facilitating payment for environmental services in Vietnam. Environmental Conservation, 37(01), 64-72. http://doi.org/10.1017/S037689291000024X

Pritchett, L. \& Woolcock, M. \& Andrews, M. (2010). Capability Traps? The Mechanisms of Persistent Implementation Failure. Working Paper. SSRN Electronic Journal, 234. http://doi.org/10.2139/ssrn.1824519.

Ravetz, J. R. (1999). What is post-normal science. Futures, 31(7), 647-653. http://doi.org/10.1016/S0016-3287(99)00024-5

Schomers, S., Matzdorf, B., Meyer, C., \& Sattler, C. (2015). How Local Intermediaries Improve the Effectiveness of Public Payment for Ecosystem Services Programs: The Role of Networks and Agri-Environmental Assistance. Sustainability, 7 (10) 13856-13886

Scott, J. C. (1985). The Weapons of the Weak. Everyday Forms of Peasant Resistance. New Haven: Yale University Press.

Scott, J. C. (1998). Seeing Like a State. Yale University Press (1st ed.). New Haven: Yale University Press.

Segura-Warnholtz, G. (2014). Quince años de politicas publicas para la accion colectiva en comunidades forestales. Revista Mexicana de Sociologia, 76, 105-135.

Shapiro-Garza, E. (2013). Contesting the market-based nature of México's national payments for ecosystem services programs: Four sites of articulation and hybridization. Geoforum, 46, 515. http://doi.org/10.1016/j.geoforum.2012.11.018

Sternlieb, F., Bixler, R. P., Huber-Stearns, H., \& Huayhuaca, C. (2013). A question of fit: Reflections on boundaries, organizations and social-ecological systems. Journal of Environmental Management, 130, 117-125. http://doi.org/10.1016/j.jenvman.2013.08.053

Stone, D. A. (2002). Policy paradox: The art of political decision making. New York: Norton. 
Swidler, A., \& Cotts-Watkins, S. (2017). Altruism from Afar. In A Fraught Embrace: The Romance and Reality of AIDS Altruism in Africa (pp. 1-18).

Swidler, A., \& Watkins, S. C. (2009). "Teach a Man to Fish": The Sustainability Doctrine and Its Social Consequences. World Development, 37(7), 1182-1196. http://doi.org/10.1016/j.worlddev.2008.11.002

Tummers, L., \& Bekkers, V. (2014). Policy Implementation, Street-level Bureaucracy, and the Importance of Discretion. Public Management Review, 16(4), 527-547. http://doi.org/10.1080/14719037.2013.841978

Van Hecken, G., Kolinjivadi, V., Windey, C., McElwee, P., Shapiro-Garza, E., Huybrechs, F., \& Bastiaensen, J. (2017). Silencing Agency in Payments for Ecosystem Services (PES) by Essentializing a Neoliberal "Monster" Into Being: A Response to Fletcher \& Bu"scher's "PES Conceit." Ecological Economics, (October), 0-1. http://doi.org/10.1016/j.ecolecon.2017.10.023

Vatn, A. (2010). An institutional analysis of payments for environmental services. Ecological Economics, 69(6), 1245-1252. http://doi.org/10.1016/j.ecolecon.2009.11.018

Watkins, S. C., \& Swidler, A. (2013). Working Misunderstandings: Donors, Brokers, and Villagers in Africa's AIDS Industry. Population and Development Review, 38 (1), 197-218. http://doi.org/10.1111/j.1728-4457.2013.00560.x 


\section{Epilogue. An update of the forest policy in Mexico}

\section{Introduction}

Forest policy evolves according to changes in ideologies, budget cuts, improvisation, and political and economic interests (Madrid, 2020). In recent years, some important changes have occurred in the formulation of environmental/forest policy and implementation in Mexico. Although this goes beyond the theme of this thesis, I consider it important to provide a non-exhaustive review of what has happened with forest policy after the end of the period covered by this research, emphasising the PES programme.

In the thesis the analysis of ORs covers the first 10 years of Mexico's PES programme, 2003-2013, and the interviews and interactions with informants occurred between 2011 and 2014. The study covered the period of operations of the PES programme through three presidential administrations, namely:

- the final three years of the administration of Vicente Fox Quezada, PAN (20002006)

- $\quad$ the whole period governed by Felipe Calderón Hinojosa, PAN (2006-2012)

- the first year governed by Enrique Peña Nieto, PRI (2012-2018)

In Mexico, the position and principles for the development of public policy depend more on the vision of the presidents than on the ideology of the party to which they belong. Thus, presidents have had the quasi-absolute power to continue or dismiss the policies of previous administrations. In the last 18 years, although PRI (which has fluctuated between left, centre and right over time) and PAN (which is a centre-right party with religious and conservative values) have started from different ideological foundations, in practice the public policies implemented by their respective presidents have been relatively similar and can be catalogued as neoliberal. On its part, the National Regeneration Movement (Morena) accurately represents AMLO's ideological position (Section 2), since it was created by him after he broke from previous opposition parties to promote his second presidential campaign for the 2012 elections.

This text provides a general description of the most evident changes occurring in forestry policy, in 1) the last years of Enrique Peña Nieto's administration (about 2016-2018); and 2) the first two years in office of the current president, Andrés Manuel López Obrador (2018-2024). 


\section{Enrique Peña Nieto (EPN) Administration}

With the arrival of Enrique Peña Nieto to the presidency in 2012, the hegemonic party that ruled for 70 years (the Institutional Revolutionary Party, PRI) returned to power after a period of 12 years during which the National Action Party (PAN) governed (20002012). What distinguished EPN's government (2012-2018) were the so-called structural reforms that modified the institutional and regulatory governance framework, under which private companies operate in 11 areas, the most controversial being energy, finance, labour and education. Although this had also occurred in the previous six years under PAN's government, the high level of corruption, waste of public money and opacity in government actions became more evident during EPN's six-year term. Moreover, according to a report published by the organisation Global Witness and UK Newspaper The Guardian, Mexico became the fourth most dangerous country for the safety of environmental defenders during Peña Nieto's administration (Benet, 2018).

\section{a) Investment in the environmental/ forestry sector}

Specifically, around MXN \$37 000 million (EUR 1424 million) were invested from 2013 to 2018 in the forestry sector through CONAFOR (Navarro, 2018). We can divide EPN's administration into two stages. The first stage (2012-2016) was basically the continuation and growth of the previous policy, so that 2016 is the year in which the most money was allocated to PES: about EUR 55 million (Hernandez \& Gomez, 2020). However, after 2016, the federal government's income collapsed, which caused a $47.52 \%$ cut to the following year's forestry budget. This reduction placed the forestry budget at the same level of spending as reported for 2000, which is the year in which CONAFOR was created (Cravioto, 2019).

Although $45 \%$ of CONAFOR's budget was allocated to reforestation and restoration programmes (Benet, 2018), 262,000 hectares of natural forest were lost in Mexico in 2018 , mainly associated with an increase in soybean, African oil palm and avocado crops, according to data from Global Forest Watch (Gomez, 2020a). Thus, the hectare loss has doubled from that in 2000 (Benet, 2019). NGOs have claimed that in this six-year period, the illegal cutting and sale of timber products was a constant (Lira, 2018). In Jalisco and Michoacán states in particular, deforestation is caused by the expansion of avocado cultivation which includes activity by organised crime groups (Gomez, 2020a; Gomez, 2020b).

During this six-year period, forestry investment for timber production was reactivated and greater support was given to forest plantations and private investment options, and the promotion of community forest management was reduced. However, only $50 \%$ of the goals of all the programmes were met (Benet, 2018). 


\section{b) Institutional and organisational aspects}

In 2018 the General Law on Sustainable Forest Development was approved, which has several positive points, such as an ecosystem approach, an emphasis on communitybased forest management, and a set of conditions for compliance with environmental and social safeguards (Benet, 2018; Gomez, 2020 a). It also gives more powers to CONAFOR. However, the General Law has gaps as well, which allow private companies to intervene without appropriate regulation (Lira, 2018).

The ORs of the PES programme suffered modifications in terms of targeting and the eligibility conditions, in terms of zoning, in order to align with a national campaign called "The Crusade Against Hunger". The Crusade maintained the lines of the socioenvironmental programme but gave even greater priority to the most marginalised municipalities in Mexico, which produced a blurring of the technical guidelines. This led to conflicts and in some cases the dismissal of employees of the PES programme ${ }^{11}$. Although more money was allocated to the PES programme in 2016 (Hernandez \& Gomez, 2020), the budget for this programme after 2017 was also affected by the budget adjustment and began to decline.

According to Reyes (2019), CONAFOR became an employment agency for friends and political negotiations. The regional managers disappeared and only the state-level managers were left, whose incumbents were appointed according to political interests. In my own experience, I was able to observe that after 2013 most of the informants from the National CONAFOR headquarters in charge of the PES programme whom I interviewed had been dismissed. As for the TAs, working conditions did not change substantially, although the ups and downs of the programme have had a direct impact on the number and type of TAs involved in CONAFOR programmes.

\section{Andrés Manuel López Obrador (AMLO) Administration}

Andrés Manuel López Obrador, who had been presidential candidate in two federal elections (2006 and 2012) before achieving the presidency in 2018, holds a centre-left ideology and a narrative of rupture with the previous neoliberal governments. AMLO has spoken out against corruption and wasteful government spending. For this second reason, he has implemented austerity measures at all government levels, which has brought certain operational complications. In his discourse he has emphatically claimed his support for the poor, but from a different perspective than that of previous governments. This is important because both CONAFOR and the PES programme were created during Vicente Fox's (PAN) administration under a market vision that is not

\footnotetext{
${ }^{11}$ This information come from various interviews carried out during PhD fieldwork.
} 
acceptable to the current government. AMLO's arrival has produced unprecedented political battles with the opposition, cases of media manipulation, and a certain degree of social polarisation. It is precisely the tackling of environmental problems that has been one of the strongest arguments from left and environmentalist critics against AMLO's administration. Although this government has been in operation for two years, some environmentalists claim that environmental and, partially, forestry policy, are not a priority of this government. The main trends so far are the following:

\section{a) Reductions in the budget}

In AMLO's administration, budget allocation for the environmental sector has been reduced to $67 \%$, which is even less than in the last two years of the previous (PRI) administration (Reyes, 2018; Cravioto, 2019). The current budget is around MXN \$29 billion (EUR 1116 million) (Gomez, 2020b).

CONAFOR's budget has gradually decreased in the past two years. In 2019 it was just under MXN \$2 800 million (around EUR 108 million), and in 2020 about MXN \$2 600 million (around EUR 100 million) were approved. These amounts are even less than what CONAFOR received in the final year of the previous Peña-Nieto administration, that is, almost MXN \$4 billion (around EUR 154 million) (Gomez, 2020b). Apparently, part of the budget previously allocated to CONAFOR programmes has been redirected to a new programme called Sembrando Vida (see section d).

The PES programme has continued to decline. In 2019, MXN \$1 020 million (EUR 39 million) were granted to the programme and in 2020 this amount was reduced considerably to MXN \$188 518361 (just over EUR 7 million) (Hernandez \& Gomez, 2020). In 2019, 489 applications were approved to join the programme and in the first half of 2020, only 29 projects out of 1520 applications covering 26437 hectares were authorised, for which MXN 54875856 (around EUR 2 million) will be allocated (Hernandez \& Gomez, 2020). However, the projects approved in the 2020's second allocation for MXN \$300 million (close to EUR 12 million), are still pending (Hernandez \& Gomez, 2020). However, the fact that the PES programme is being cut back is not necessarily a bad sign. Already in 2010, the PES management itself planned to reduce funding to the national PES in order to strengthen local PES mechanisms, or "concurrent funds" (SC, 2012), which started in 2008. In 2020, 44 local PES projects have been supported, with an allocation of MXN \$134 million (just over EUR 5 million).

Given that the communities studied in this research were located near or within natural protected areas, it is relevant to mention that the National Commission on Protected Areas (CONANP) also suffered a budget reduction, receiving only MXN \$867 million (EUR 33.5 million) in 2020, compared to MXN \$1 300 million (EUR 50 million) in 2016 (Gomez, 
2020 c). This has especially affected the employment status of staff in Mexico's 182 protected areas, which cover an area of 1 million hectares, and whose employees used to have direct interaction with communities. Significantly, CONANP programmes used to liaise with PES in communities that do not have access to other types of support because of restrictions on the use of forests in protected areas.

\section{b) Institutional and organisational readjustment}

Regardless of its results, over the last 30 years an environmental institutional framework has been built and reflected in the creation and modification of environmental laws, regulations and operating rules for environmental/forestry policy (Madrid, 2020). Likewise, ministries such as SEMARNAT (2000) and commissions such as CONANP (2000) and CONAFOR (2001) have been created to address different aspects of environmental policy. This gradually increased the political priority of the environmental sector, which implied an increase in financing (Cravioto, 2019).

However, in this period, partly due to the recent austerity policy and partly to ideological differences, undersecretaries and middle management have disappeared, programmes have been eliminated and merged, and staff have been laid off and relocated. In CONAFOR, nearly $70 \%$ of operational staff, especially trusted staff, and $67 \%$ of temporary staff have been dismissed, especially at the state level (Miranda, 2019; Reyes, 2019), even though the new Forestry Law assigned more powers to CONAFOR. These reductions directly affect the employment options of CONAFOR's TAs. According to Madrid (2020), the main problem is that, beyond the adjustments, no alternative ways for the implementation of forest policy in the country are being proposed. This has led to delays in the implementation of concrete, practical government actions such as firewatching, firefighting and surveillance against illegal logging, as well as all the paperwork involved. This is especially significant at the local level (Madrid, 2020).

CONANP has also dismissed approximately 200 employees. The loss of staff means a threat to natural areas. In Michoacán, for example, natural forest continues to be deforested for avocado plantations in the buffer zones of protected areas (Gomez, $2020 b$ ). In addition, the temporary employment programme (PET) run by SEMARNAT, which allowed people from the communities to be employed in reforestation work, fire prevention and erosion control actions, among others, was eliminated removing a source of income from regions were employment opportunities are limited.

\section{c) Vague and delayed definition of plans, regulations and targets}

The problems mentioned above are reflected in delays and lack of definition in planning, regulatory and implementation instruments. For example, the Third Special Programme 
on Climate Change, which includes an action plan for mitigation and adaptation in the short term, was expected since 2019 but has not yet been presented (UNEP, 2019; Gomez, 2020b). There is a delay in the publication of the rules which allow for the implementation of the new General Law on Sustainable Forest Development (Gomez, 2019b). Likewise, the Sectorial Programme for the Environment and Natural Resources 2020-2024 (PROMARNAT), which is the instrument for environmental policy planning, was published a year and a half later than planned, and it has omissions and vagueness in its goals. In this document, the PES programme remains identical in terms of objectives, components, and the requirements for potential beneficiaries from previous years. So, at least in these two years, the only change in the PES programme is in terms of budget. In contrast, the programmes for the development of commercial forestry plantations have changed substantially, possibly to facilitate synergy with the Sembrando Vida programme (Cravioto, 2019; CCMSS, 2020).

\section{d) The Sembrando Vida (SV) programme and its great impulse}

A flagship programme of the current AMLO administration is called Sembrando Vida (which means sowing life), implemented by the new Ministry of Welfare, which promotes productive agro-forestry projects in marginalised and vulnerable rural communities. Its aim is to strengthen peasant economies, reduce migration and achieve food self-sufficiency. Thus, in addition to producing maize, vegetables, fruit trees and timber, "forests are rehabilitated and native flora and fauna are protected" (https://www.gob.mx/bienestar/acciones-y-programas/programa-sembrando-vida ${ }^{12}$ ). Under this scheme "learning communities" are formed, composed of 25 farmers, one agroforestry technician and one social technician, in addition to three young grant holders from a programme called "Youth Building the Future" (Ortega, 2020; Expansión Política, 2019). The programme implements the MIAF (Milpa Intercalada en Árboles Frutales) technique, which consists of a hybrid crop that alternates maize and beans with local fruit or timber trees (Dominguez, 2018). In 2019, 2388 technicians were set to participate in training and organising producers in ejidos and communities and each technician would support 100 farmers (Expansión Política, 2019).

Because the programme includes tree planting, it is often compared to CONAFOR community forestry or agroforestry programmes. However, the objectives of the programmes are different. Sembrando Vida is primarily aimed at rural development (Cravioto, 2019; Ortega, 2020) and does not contemplate the conservation of forest ecosystems, sustainable forest production, provision of environmental services, or attention to forest environmental contingencies. The target population and the

\footnotetext{
${ }^{12}$ Access date: August 13th, 2020
} 
characteristics of the eligible areas also differ (Cravioto, 2019). However, it is important to remember that much of the money cut from the environmental sector in general has been allocated to financing SV which has been allocated around MXN \$28 billion for 2020 (just over EUR 1 billion) (Cravioto, 2019; Gomez, 2020; Hernandez \& Gomez, 2020).

CONAFOR has no influence on the SV programme and only participates by providing technical advice (El Universal, 2019). It has been suggested that the potential beneficiaries might prefer to join SV rather than the PES programme, since, while PES pays the communities or ejidos up to MXN \$1 000 (EUR 38.5) per hectare per year for five years, SV gives MXN \$5000 to each producer every month, for 2.5 hectares over six years. However, the SV programme currently does not prevent beneficiaries from being enrolled in other forestry or agricultural programmes (Benet, 2019). Generally, at least in ejidos and communities, the suitable areas for PES are conserved forests usually located in areas of common use, while the SV programme is established in agricultural plots and lands adjacent to settlements. However, this will depend on the configuration of each ejido or community. Critical voices claim that this programme is full of inconsistencies, and it can even be a perverse incentive by opening up the possibility for peasants to burn portions of forest in order to apply for SV (Benet, 2019; Cravioto, 2019; El Universal, 2019; Hernandez \& Gomez, 2020). Although this may happen, in my opinion such a critique overgeneralises and underestimates the capacity of communities to make decisions about their own territories. Furthermore, the PES and SV programmes can coexist with the help of adequate territorial planning instruments.

\section{Final considerations}

It is not surprising that in Mexico's forestry history governments have radically changed public policy. At this moment we are in the middle of a process of change where there are more questions than answers. The current administration still has four more years to go in which there will surely be modifications, adjustments, and even changes in direction. It is clear that the environmental sector must once again become a priority, although not necessarily following the pathway of previous governments. Nowadays, it is probably more important to contribute to strengthening the capacity for selfmanagement and sovereignty of the communities, many of which have always conserved their forests.

\section{References}

Benet, R. (November 14th, 2018). El fracaso de la política forestal de Peña Nieto. Aristegui noticias. https://aristeguinoticias.com/1411/opinion/el-fracaso-de-la-politica-forestal-de-pena-nieto-articulo/

Benet, R. (Jun3 3rd, 2019). Sembrando Vida: virtudes y riesgos de un programa visionario. Aristegui noticias. https://aristeguinoticias.com/0306/opinion/sembrando-vida-virtudes-y-riesgos-de-un-programavisionario-articulo/ 
Benet, R. (January 13th, 2020). Estamos sorprendidos y decepcionados por megaproyectos de corte neoliberal. Aristegui noticias. https://aristeguinoticias.com/1301/mexico/estamos-sorprendidos-ydecepcionados-por-megaproyectos-de-corte-neoliberal-benet-articulo/

CCMSS. (July 20th, 2020) ¿Nueva SEMARNAT? Un programa sectorial con metas recortadas e insuficientes. Verdebandera. https://verdebandera.mx/nueva-semarnat-un-programa-sectorial-con-metasrecortadas-e-insuficientes/

Cravioto, F. (2019). Análisis de las Reglas de Operación del programa Apoyos para el Desarrollo Forestal Sustentable 2019. Nota informativa. CCMSS. 12 pages.

Dominguez, L. (November, 19th, 2018). "Sembrando Vida", sin técnicos capacitados. El Universal. https://www.eluniversal.com.mx/ciencia-y-salud/sembrando-vida-sin-tecnicos-capacitados

Gobierno de AMLO requiere programa integral para aprovechar potencial forestal de México. (August 20th, 2018) Imagen Agropecuaria. https://imagenagropecuaria.com/2018/gobierno-de-amlorequiere-programa-integral-para-aprovechar-potencial-forestal-de-mexico/

Gomez, D. T (January 9th, 2020 a). México: desdén presupuestal, deforestación y defensores asesinados. Mongabay Latam. https://es.mongabay.com/2020/01/mexico-balance-deudas-ambientales-2019/

Gomez, D. T. (January 14th, 2020 b). Los desafios ambientales de México para el 2020. Mongabay Latam. https://es.mongabay.com/2020/01/los-desafios-ambientales-de-mexico-para-el-2020/

Gomez, D. T (June 8th, 2020 c). México: protección de Areas Naturales Protegidas esta en vilo por ajuste al presupuesto. Mongabay Latam. https://es.mongabay.com/2020/06/mexico-proteccion-de-areasnaturales-protegidas-esta-en-vilo-por-ajuste-al-presupuesto/

Greenpeace México. (September 1st, 2014). ¿Cómo le ha ido al medio ambiente con Peña Nieto? Verdebandera. https://verdebandera.mx/como-le-ha-ido-al-medio-ambiente-con-pena-nieto/

Hernandez, M. P. \& Gomez, D. T. (June 18th, 2020). ¿Cuánto se debe pagar a las comunidades que conservan los bosques? Mongabay Latam. https://es.mongabay.com/2020/06/mexico-pago-por-conservarbosques-manejo-forestal-comunitario/

Hogewoning, J. (July 4th, 2020). Sembrando Vida Now Part of COVID-19 Strategy. Agribusiness and Food. https://mexicobusiness.news/agribusiness/news/sembrando-vida-now-part-covid-19-strategy

Lira, I. (August 15th, 2018) Este sexenio fue terrible con los bosques, dicen ONGs: tala, venta ilegal, ataques a los defensores. Sin embargo. https://www.sinembargo.mx/15-08-2018/3457292

Madrid, R. L. (2020). El desmantelamiento institucional del sector ambiental: un balazo en el pie. Nota informativa. CCMSS. 12 pages.

Miranda, F. (July 6th, 2019) Vencido, contrato de $67 \%$ del personal de Conafor. Milenio https://www.milenio.com/politica/vencido-contrato-de-67-del-personal-de-conafor

Navarro, M. F. (October 8th, 2018). Así es el plan de AMLO para apoyar a pequeños productores del campo. Forbes Mexico. https://www.forbes.com.mx/asi-es-el-plan-de-amlo-para-apoyar-a-pequenosproductores-del-campo/

Plan de AMLO de reforestación puede dañar bosques. (September 5th, 2019). El Universal. https://www.eluniversal.com.mx/ciencia-y-salud/senalan-que-plan-de-amlo-de-reforestacion-puededanar-bosques

Ortega, A. (February 16th, 2020). Sembrando Vida vs. ProÁrbol: dos programas de AMLO y Calderón, cara a cara. Expansión Política. https://politica.expansion.mx/mexico/2020/02/16/sembrando-vida-vsproarbol-dos-programas-de-amlo-y-calderon-cara-a-cara

Reyes, R. J. (July 6th, 2019). ¿CONAFOR, en peligro de extinción? Su futuro depende de AMLO. Sin Compromisos. https://periodismosincompromisos.wordpress.com/2019/07/06/conafor-en-peligrode-extincion-su-futuro-depende-de-amlo/

Sembrando Vida, el programa de AMLO para reforestar y combatir la violencia (February, 3rd. 2019). Expansión Política. $\quad$ https://politica.expansion.mx/presidencia/2019/02/03/sembrando-vidaprograma-para-reforestar-y-combatir-violencia

United Nations Environment Programme (2019). Emissions Gap Report 2019. UNEP, Nairobi. http://www.unenvironment.org/emissionsgap 


\section{Summary}

The Payment for Environmental Services (PES) programme is a federal financial transfer initiative established in México in 2003, aimed at protecting and improving the capacities of legal forest owners to provide environmental services. Implementation is carried out following guidelines or directives called Operational rules (ORs). A great deal of the ORs are operationalised and applied by external intermediary professionals, Technical Advisors (TAs), who interact directly with the beneficiaries of the programme - individual forest owners/rights holders, mostly communities and ejidos. The research is focused on the analysis of the role and relevance of both the ORs and TAs, and the dynamics between them and mediated by them. The research is concerned with the grounded implementation and operationalisation of the PES programme, and the reaction to it by the primary implementary actors, and not with the ultimate impacts of PES on the provision of environmental services, water resources, forest conservation, etc. Over time, CONAFOR has constructed an officially accepted narrative about the PES programme, which is actively transferred to the primary actors and to the public. The ways in which ORs and TAs have been portrayed in this CONAFOR narrative have determined to some extent the evolution of the programme, the public image of it, and the struggles from the coexistence with competing narratives. The salient findings from the research are:

First, the ORs, as the message and a messenger over time

ORs are the formal representation of the "PES message". But more than this, the ORs are not only the explicit compendium of the actions, targets, criteria, etc. - the "rules" - of the PES implementation; they are also the implicit expression of the values, goals, and expected roles of the actors, and implicit ethical guidelines to achieve the goals. ORs change annually, through a variety of mechanisms. The changes in ORs reflect the conceptual and procedural evolution of the programme. Over eleven years, the PES programme has simplified, and the initial two PES programmes have merged into a single one (including hydrological ES, and ES provided by biodiversity conservation and agroforestry). The initial goal of establishing ES markets has been nuanced, and the priority objectives have shifted from environmental (avoiding deforestation, hydrological conservation), to social-environmental (including alleviating poverty). While the role of CONAFOR has become ambiguous, the obligations and responsibilities of the beneficiaries have been increased. Although the options for local participation and decision-making have increased, those are constrained interventions mostly defined by CONAFOR, and always monitored by the TAs. The role of TAs is poorly represented in ORs, only showing specific obligations and increasing restrictions to their work. The terms underpinning the priority criteria for selection of beneficiaries and lands have increasingly based on technical and scientific sources.

Second. The Key Players and Narratives

Although a variety of actors participate in the conceptualisation of ORs for the implementation of $\mathrm{PES}$, they are not equally influential in the programme. The most influential actors are those at the highest levels of national policymakers (the government in power), and forest policy-setters, funding agencies (especially the World Bank), and officials from other national level government ministries. Additionally, other external actors provide advice, feedback, assessment and 
validation, such as recognised NGOs and universities, through their participation in the PES advisory committee or in evaluations. The actual influence of actors in ORs decreases as they approach the local levels. CONAFOR's state-level operators provide feedback from their observations in the field, and they are also the main spokespersons of the beneficiaries' and TAs' claims and suggestions, whose influence in ORs is limited. Without being local actors properly, CONAFOR state level employees are those that have greater interaction with the local actors, and their official position gives them credibility or legitimacy before the CONAFOR's national level operators. Changes in ORs reflect the power struggles, negotiations and tensions between the high-level actors for the prevalence of their interests, values and approaches. The main tensions/struggles taking place in the programme are between 1 ) environmental vs social criteria, 2) technical/scientific vs political choices, 3) centralised vs decentralised decision making, 4) older vs innovative approaches about programmes (e.g. subsidy vs incentive), and 5) older vs innovative administrative procedures.

The official nature of the ORs, their processes of change, and the influence of the powerful and recognised actors have the intention of inscribing into the ORs a set of values, that include flexibility, transparency, efficiency, objectivity, public interest, and credibility. Those values have been taken advantage of by CONAFOR to build a narrative about ORs aimed to make them appear as legitimate and even unquestionable instruments to the public. Thus, CONAFOR has been able to create and control the story to tell about the programme. But when ORs cross over the operational levels and reach the local actors, especially the TAs, new narratives emerge, converge and compete with the dominating narratives of CONAFOR. In this research special attention has been given to the TAs' own version of the programme and their role in it.

Third, TAs' historical and actual roles

TAs are a diverse group of independent professionals (organisations and individuals) who provide technical support and guidance to the beneficiaries of PES. TAs are agents who are expected to understand and apply the rules (ORs), but in practice, they also become involved in interpreting and negotiating the ORs within varying local contexts. The expected roles of TAs as intermediaries in PES are: a) to prepare applicants to enrol in the scheme, b) to accompany and facilitate the implementation, and c) to monitor and report beneficiaries' activities. Three factors which determine this dependence of CONAFOR on TAs have persisted throughout the history of Mexican forest policy: 1) The lack of operational capacity of governmental organisations, 2) the lack of technical and economic capacities of forest owners, 3) the changing ORs expressed in technical language and requirements.

Due to financial and operative restrictions, most of the TAs' activities are performed outside of the control/scope of CONAFOR. Historically, the role and reputation of forest intermediaries (presently called TAs) have been disputed. Currently, their complex relationships with CONAFOR and working conditions are factors affecting their identity and performance. Their performance is questioned because of the incidence of unethical and poor practices carried out by some of them at the local level. This has led to the stigmatisation of TAs in the CONAFOR programmes, and their undervaluation as agents of institutional change. They have obligations, but no rights. CONAFOR 
pays their salary, but there is no contractual relationship between them, while the burden of implementation rests with them.

Fourth, CONAFOR's Vision of the TAs - CONAFOR's Narrative

In CONAFOR's narrative, the key roles of TAs are recognised, but they are also portrayed as selfinterested actors driven by opaque purposes, and with a tendency to engage in unethical practices locally. All of which leads to defining them as an 'unreliable actor' outside the control of CONAFOR. Because of the lack of a contractual relation between CONAFOR and TAs, there are legal limitations to act formally against any cases of TAs' bad practices. The responsibility of reporting and "punishing" (by termination of the contract with TAs) rests with the beneficiaries, (the forest rights holders, the communities), who often do not have access to the channels and procedures to formally complain. In such cases, CONAFOR's role is limited to mediating the conflict, and, in extreme cases, to eliminate him/her from the list of TAs, which does not happen often. In some cases, TAs pressurise the communities and / or negotiate to persuade them not to complain or to cancel the contract between them. In the study cases of conflicts between TAs and beneficiaries, the emergence of alternative intermediaries from different sectors (e.g. local NGOs, community promoters, government employees, other TAs) has made a big difference to re-connect beneficiaries with CONAFOR to solve such problems.

Bad practices operate under the OR's carpet: the regulatory and monitoring deficiencies have blurred the negative aspects of the relationship with beneficiaries. CONAFOR has partially increased the control measures. Certification is the most significant measure taken so far by CONAFOR to address TAs' performance. This consists of a set of tests carried out by a qualified third party to assess the TAs technical skills, in order to start or keep providing services. The process has been criticised since it does not evaluate the work of TAs in the field, nor address underlying problems. CONAFOR and researchers have not analysed the actual evidence of unethical practices by TAs, and their supposed impacts on the PES scheme.

\section{Fifth, TA'S Self Vision}

According to their own narratives, TAs play multiple roles at the local level, some of which go beyond the scope of CONAFOR. The TAs' heterogeneity of backgrounds and interests, as well as the competition and distrust amongst them make it difficult for them to organise as a group. This lack of unity has limited them in achieving better working conditions. The TAs self-narrative agrees partially with CONAFOR's about the unethical practices carried out by some TAs. But they disagree with the broad generalisation of blame/stigmatisation of TAs in PES. They consider that CONAFOR has actively and widely contributed to the problem through their indifference, neglect, and sometimes, collusion. At the local level, TAs spread their own narrative and make alliances with local beneficiaries. The main needs as expressed by the TAs are for: trust and more recognition from CONAFOR, the establishment of a suitable evaluation system, opening of dialogue spaces for TAs-CONAFOR interplay, and for better training, salaries, and working conditions. TAs stress the need to balance the power and co-responsibility of all the actors involved in the functioning of the PES programme. Although the tendency is to undervalue the TAs as OR change agents, they are more influential than it seems. However, this happens indirectly through 1) their "influence"/ 
"guidance" of beneficiaries' decision-making, 2) their personal choice about their own roles at the local level, 3) their influence in shaping relations among actors, 4) their ability to interpret, negotiate and adapt the changing OR rules to local conditions, and 5) their individual experience and expertise in the criteria for the selection of eligible forest lands and beneficiaries to work with.

\section{Final, ORs and TAs as multipurpose, transboundary elements}

Both ORs and TAs are multipurpose and transboundary elements of the PES programme aimed at enabling its implementation. Even though they are apparently different in nature and functions, they have similarities in their key roles of connecting the actors and the levels of operation. They mediate relations between actors and processes and the transition of the PES concepts into forest management practices. They are in constant interaction and they shape each other: the ORs directly define the TAs' role, and TAs indirectly affect the ORs through the processes involved in implementation. However, this mutual shaping is asymmetrical, because other powerful actors are influencing the ORs. ORs and TAs are both necessary elements, but their nature, drivers and image are different and, according to the CONAFOR dominant narratives, they are contested.

\section{The non-visible effects of ORs' and TAs' representation and role in PES}

In a way the TAs' practices and their representation do not affect the outcomes of the PES scheme, at least those shown to the public. So, seemingly TAs also play the role of a smokescreen that CONAFOR can hide behind to account for potential failings in the PES operation. However, at the local level, TAs being frequently portrayed as "evil", as well as the re-defining, omissions and changes in ORs have direct (negative) effects on beneficiaries, often blurred and even not visible, because they are not included in the narrative of success being built by CONAFOR. These effects on the beneficiaries are: a) the ongoing abuse of power and unethical practices at the local level, b) the preservation of the power imbalances behind the ORs shield or justify omissions of CONAFOR, c) the failure to improve the local capabilities, power and autonomy of beneficiaries to managing their own forests, d) potential penalties and loss of access to CONAFOR programmes for the beneficiaries, and, e) the continuation of the conditions permitting impunity.

\section{The good effects of cooperation - "Mutual positives"}

Despite the problems outlined above, the PES programme also provides tangible benefits to the actors involved, including income, training, jobs, relationships, recognition, and infrastructure. Therefore, regardless of its general results, there is an active effort from all parties involved to keep the programme alive through cooperation and negotiation, - which necessitates the concomitant blurring and disregard of certain breaches and conflicts occurring at all levels. Similarly, the dynamics between ORs and TAs are complex and not always friendly, but in the end, the ways in which they are portrayed (the ORs as "undisputable", and the TAs as "evil") have a positive effect on PES programme, since it allows for the fluidity of the relations between the actors through the flexible interpretation/implementation of the PES concepts and rules. The positive effect is not in the success of the programme. The positive effect is its continuation. 


\section{Sammenvatting}

Het PES-programma, dat in 2003 in Mexico van start is gegaan, is een federaal initiatief dat financiële middelen ter beschikking stelt om legale boseigenaren te helpen hun capaciteiten op het gebied van milieudiensten in stand te houden en te verbeteren. Bij de implementatie van het PES-programma wordt een reeks richtlijnen gevolgd, de zogenaamde Operationele Regels (OR's), waarin naast de formele doelstellingen en procedures ook is vastgelegd wie de voornaamste actoren zijn en wat hun rollen, verplichtingen, rechten en beperkingen binnen het programma zijn. Binnen het kader van dit onderzoek worden OR's daarnaast ook beschouwd als een formele representatie van de boodschap van PES met een bepaald narratief dat kan worden doorgegeven van CONAFOR aan de begunstigden en het publiek. Tevens zijn ze een multifunctioneel en veelzijdig hulpmiddel waarmee de interacties tussen actoren kunnen worden doorgegeven en waarmee zowel formele als informele praktijken in het PES-universum kunnen worden vormgegeven.

De voornaamste actoren die betrokken zijn bij de implementatie zijn de nationale commissie voor bosbeheer (Comisión Nacional Forestal (CONAFOR)) en de boseigenaren (particulieren en gemeenschappen) die de potentiële begunstigden van het programma zijn. De uitvoering van OR's ligt veelal in handen van externe intermediairs, zogenaamde Technisch Adviseurs (TA's). Dit zijn professionals uit diverse disciplines die de boodschap van PES doorgeven, de OR's handhaven en rechtstreeks contact onderhouden met de begunstigden van het programma. TA's zijn echter niet enkel boodschappers en bemiddelaars bij de implementatie, zij zijn zelf actoren vanuit een organisatie met belangen en waarden die hun interventie in het programma vormgeven. Hun functie en invloed reiken daarmee verder dan formeel verwacht zou worden. Vanwege de complexiteit van de relaties die zij opbouwen en de informele praktijken die zij op lokaal niveau co- en reproduceren, worden er in CONAFOR regelmatig vraagtekens gezet bij de rol van TA's.

In dit onderzoek ligt de focus op het analyseren van de rol en de relevantie van de OR's en de TA's als de twee grenscomponenten bij de implementatie van het landelijke PES-programma. De doelstellingen van het onderzoek zijn: het analyseren van het PES-programma door de OR's tegen het licht te houden op het punt van doelstellingen, prioriteiten en de beoogde rol van de betrokken actoren alsmede de invloed van actoren en gebeurtenissen bij het vormgeven van deze evolutie; het analyseren van het belang van het opbouwen van relaties tussen actoren en regels, met de nadruk op de rol van de TA's; en het analyseren van de dynamiek tussen het formele en het informele en hoe deze in de rol en representatie van de OR's en TA's heeft bijgedragen tot het voortbestaan van het PES-programma in de loop der tijd.

De informatie werd voornamelijk verkregen door documentbeoordeling en semigestructureerde interviews met sleutelactoren op verschillende uitvoeringsniveaus van het programma. Voor de documentbeoordeling werd een vergelijkende analyse van de OR's uitgevoerd om veranderingen in de loop van het eerste decennium te identificeren op basis van de jaarlijks gepubliceerde OR's van 2003 tot 2013. Ik heb actoren op drie uitvoeringsniveaus van het programma geïnterviewd. Op nationaal niveau was dat voornamelijk CONAFOR, een decentrale overheidsorganisatie die is opgericht in 2001. Op subnationaal niveau heb ik me gericht op de deelstaatkantoren van 
CONAFOR in Jalisco en Michoacán. Op lokaal niveau heb ik TA's geïnterviewd die in deze regio's werkzaam zijn en lokale autoriteiten van zes ejidos, drie ervan gelegen in het Ayuquila Basin, Jalisco, en drie in de gemeentes La Huacana en Zitacuaro, in Michoacán. De informatie uit de interviews is daarna gecodeerd en geanalyseerd met QSR Nvivo 10.

De meest in het oog springende resultaten van het onderzoek voor wat betreft OR's zijn: 1) OR's veranderen jaarlijks als gevolg van diverse mechanismes. De definitie van PES is in de loop van elf jaar regelmatig veranderd en wordt geleidelijk aan vereenvoudigd. De rol van CONAFOR is onduidelijker geworden, terwijl de verplichtingen en verantwoordelijkheden van de begunstigden zijn toegenomen. Maar hoewel de opties voor lokale participatie en besluitvorming op lokaal niveau zijn toegenomen, blijven deze beperkt tot interventies, voornamelijk gedefinieerd door CONAFOR en altijd onder toezicht van de TA's. De rol van de TA's is ondervertegenwoordigd in de OR's. De voorwaarden die worden gehanteerd bij de prioriteitscriteria voor de selectie van begunstigden en land zijn steeds vaker gebaseerd op technische en wetenschappelijke bronnen.

2) Er zijn weliswaar verschillende actoren betrokken bij de conceptualisatie van de implementatie van het PES-programma, maar zij hebben niet in gelijke mate invloed op het programma. De meest invloedrijke actoren zijn te vinden onder beleidsmakers en uitvoerders op het hoogste niveau en bij de financieringsorganen (met name de Wereldbank). Daarnaast zijn er nog andere externe actoren, bijvoorbeeld erkende ngo's en universiteiten, die feedback geven door hun deelname in de PES-adviescommissie en door evaluaties. De mate van invloed van actoren in OR's neemt af naarmate ze meer op lokaal niveau actief zijn. Veranderingen in OR's zijn een weerslag van machtsstrijd, onderhandelingen en spanningen tussen de actoren op hoog niveau die allemaal hun eigen belangen, waarden en benaderingen willen doorzetten. De belangrijkste spanningen in het kader van het programma vinden plaats tussen a) milieu- versus sociale criteria, b) technische/wetenschappelijke versus politieke keuzes, c) ouderwetse versus meer innovatieve benaderingen in beleid en administratieve procedures.

Voor wat betreft de analyses van de TA's: 3) De verwachte rollen van TA's als intermediairs in PES zijn: a) het voorbereiden van aanvragers die deel willen nemen aan het programma, b) het ondersteunen en begeleiden van de implementatie en c) toezicht houden op en rapportage van de activiteiten van begunstigden. In de praktijk zijn TA's betrokken bij de uitleg en uitvoering van de gewijzigde OR's binnen diverse lokale contexten. CONAFORs afhankelijkheid van TA's is terug te voeren op drie factoren die door de hele geschiedenis van het Mexicaanse bosbouwbeleid te zien zijn: a) het gebrek aan operationele capaciteit van overheidsorganisaties, b) het gebrek aan technische en economische capaciteiten van boseigenaren, c) de frequente wijzigingen in OR's, die bovendien worden vervat in technische taal en voorschriften. Als gevolg van financiële en operatieve restricties vinden de meeste activiteiten van de TA's buiten de controle/het kader van CONAFOR plaats. De complexe relatie tussen TA's en CONAFOR en de werkomstandigheden zijn van invloed zijn op hun identiteit en hun prestaties. Dat er vraagtekens worden gezet bij hun rol is echter ook te wijten aan het feit dat sommigen van hen op lokaal niveau soms onethisch te werk gaan en slecht presteren. Dit heeft ertoe geleid dat TA's in de CONAFOR-programma's een slechte naam hebben gekregen. 
4) CONAFOR erkent weliswaar de sleutelfunctie van de TA's, maar schildert hen tegelijkertijd af als een 'onbetrouwbare actor' waar CONAFOR geen controle over heeft. Vanwege het ontbreken van een contractuele relatie tussen CONAFOR en de TA's kan CONAFOR maar beperkt optreden tegen onethische praktijken van de TA's. De verantwoordelijkheid om TA's aan te klagen en te 'bestraffen' ligt bij de begunstigden, die echter vaak geen toegang hebben tot de kanalen en procedures om formele klachten in te dienen. CONAFORs rol blijft in dergelijke gevallen beperkt tot het bemiddelen in het conflict en, in extreme gevallen, het verwijderen van dienstverleners van de lijst met TA's, wat echter maar zelden gebeurt. In de bestudeerde gevallen van conflicten tussen TA's en begunstigden blijkt dat sommige gemeenschappen hebben geleerd hier effectief mee om te gaan, terwijl in andere gevallen andere bemiddelaars hebben geholpen de begunstigden weer in contact te brengen met CONAFOR om de problemen op te lossen. Onethische praktijken vinden plaats onder het tapijt van de OR's: zwakke plekken in regelgeving en toezicht zorgen ervoor dat negatieve aspecten van de relaties met PES-begunstigden niet opvallen. Van alle maatregelen die CONAFOR tot nu toe heeft genomen om het functioneren van TA's aan te pakken is certificering de belangrijkste. In het kader hiervan voert een gekwalificeerde derde partij een reeks testen uit om de technische vaardigheden van TA's te beoordelen, op grond waarvan wordt besloten of zij hun diensten mogen (blijven) aanbieden. Ook op dit proces is kritiek omdat hierbij niet het werk van TA's in het veld wordt beoordeeld en de onderliggende kwesties niet worden aangepakt.

5) Het narratief van de TA's zelf is dat zij op lokaal niveau diverse rollen spelen die soms het kader van CONAFOR te buiten gaan. Omdat de TA's zo'n heterogene groep zijn is er sprake van veel onderlinge competitie en wantrouwen, wat het lastig maakt zich te organiseren en betere arbeidsvoorwaarden af te dwingen. De TA's kunnen zich deels wel vinden in het narratief van CONAFOR over hen, maar ze verzetten zich ertegen dat TA's de schuld krijgen voor alle ontwikkelingen in de PES en zijn van mening dat CONAFOR zelf in hoge mate aan het probleem heeft bijgedragen door nalatigheid en soms ook collusie. Hoewel TA's meestal niet worden gezien als aanjagers van veranderingen in OR's hebben ze wel degelijk indirect invloed door a) hun interventie bij besluitvorming van begunstigden, b) hun persoonlijke keuze omtrent hun eigen rol op lokaal niveau, c) hun invloed bij het opbouwen van relaties tussen actoren, d) hun vermogen om de wijzigingen in OR's uit te leggen, uit te voeren en aan lokale omstandigheden aan te passen en e) hun individuele voorkeuren en kennis bij de selectie van bosgronden en begunstigden.

In het narratief van CONAFOR is het functioneren van de OR's altijd onaanvechtbaar, terwijl bij de prestaties van de TA's altijd vraagtekens worden gezet. Door de TA's af te schilderen als 'slechteriken' kan CONAFOR echter ook een rookgordijn optrekken waar het zich achter kan verschuilen om feitelijke en potentiële fouten te verantwoorden en de aandacht af te leiden van de verantwoordelijkheid voor andere dubieuze aspecten van het functioneren van PES. CONAFOR heeft de controle over het narratief omtrent de rollen van actoren en voorzieningen in het PESprogramma en kan zo ook gemakkelijk een façade oprichten. Maar als OR's via de operationele niveaus uiteindelijk de lokale actoren bereiken, met name de TA's, dan ontstaan er nieuwe narratieven die kunnen afwijken van het dominante narratief en er de strijd mee aan kunnen gaan. In zekere zin hebben de praktijken van de TA's en de manier waarop zij worden afgeschilderd geen invloed op de resultaten van het PES-programma, in elk geval niet op de resultaten die het publiek 
te zien krijgt. Op lokaal niveau heeft het feit dat de TA's vaak als de 'slechteriken' worden afgeschilderd, naast de tekortkomingen en wijzigingen van de OR's, echter wel degelijk (negatieve) gevolgen voor begunstigden, al zijn die vaak onduidelijk of zelfs onzichtbaar. Deze effecten op begunstigden zijn: a) het voortduren van machtsmisbruik en onethische praktijken op lokaal niveau, b) het voortbestaan van onevenwichtige machtsverhoudingen, c) het uitblijven van verbeteringen van lokale capaciteiten, d) potentiële boetes of verlies van aanspraak op CONAFORprogramma's en e) het voortbestaan van straffeloosheid. De dynamiek tussen OR's en TA's, die kan worden gezien als de interactie tussen formele structuren en krachten die het informele coproduceren en reproduceren, speelt een fundamentele rol bij de implementatie en adaptatie van het PES-programma. Zo wordt voor de betrokken actoren een heel scala aan onderlinge verstandhoudingen, motivaties en tastbare voordelen gecreëerd, inclusief inkomen, training, banen, relaties, erkenning en infrastructuur. Dit is de reden waarom alle actoren proberen het programma door samenwerking in leven te houden, waarbij het onvermijdelijk is dat bepaalde gebreken en conflicten, die op alle niveaus voorkomen, worden uitgewist en genegeerd. De dynamiek tussen OR's en TA's en de manier waarop zij worden afgeschilderd (OR's als 'onaanvechtbaar' en TA's als 'slechteriken') hebben een positief effect op het PES-programma, omdat ze een voorwaarde zijn voor de plooibaarheid van de relaties tussen actoren dankzij de flexibele interpretatie/implementatie van de boodschap van PES. Het positieve effect is niet het succes van het programma, maar de continuïteit ervan. 


\section{Resumen}

El programa PSA es una iniciativa federal de transferencia financiera establecida en México en 2003, cuyo objetivo es proteger y mejorar las capacidades de los propietarios legales de bosques para proporcionar servicios ambientales. La aplicación del PSA sigue un conjunto de directrices denominadas "Reglas de Operación" (OR), que establecen los objetivos formales, los procedimientos, los principales actores y sus funciones, obligaciones, derechos y restricciones en el programa. En esta investigación, las OR también son vistas como una representación formal del mensaje del PSA con una narrativa particular que puede ser transmitida desde la CONAFOR a los beneficiarios y al público, y como un dispositivo multipropósito/multifacético que media las interacciones entre los actores, y da forma a las prácticas formales e informales en el programa. Los principales actores involucrados en la implementación son la Comisión Nacional Forestal (CONAFOR), y los propietarios de los bosques (individuales y comunitarios), que son los potenciales beneficiarios del programa. Gran parte de las OR son operadas por intermediarios externos, llamados Asesores Técnicos (TA), que son profesionales de diversas disciplinas que transmiten el mensaje del PSA, hacen cumplir las OR y mantienen una interacción directa con los beneficiarios del programa. Sin embargo, los TA no son meros mensajeros y mediadores en la implementación; son actores con agencia, intereses y valores que moldean su intervención en el programa, y sus funciones e influencia van más allá de sus expectativas formales. El papel de los TA ha sido ampliamente cuestionado por la complejidad de las relaciones que establecen, así como por las prácticas informales que co-producen y re-producen a nivel local.

Esta investigación se centra en el análisis del papel y la relevancia de las OR y los TA, como dos componentes de frontera en la implementación del programa nacional de PSA. Los objetivos son: 1) identificar los componentes clave involucrados en la implementación del programa y las dinámicas que ocurren en este proceso; 2) analizar la evolución del programa de PSA a través del examen de sus OR en términos de sus objetivos, prioridades, y el rol previsto de los actores involucrados, así como la influencia de los actores y eventos en la conformación de esta evolución; 3) analizar la importancia del establecimiento de las relaciones entre actores y reglas en el programa PSA, haciendo hincapié en el papel de los TA; y 4) analizar cómo la dinámica que se produce entre la formalidad y la informalidad en los roles y representaciones de las OR y los TA ha contribuido a la persistencia del programa PSA en el tiempo. La información se recopiló principalmente a partir de la revisión de documentos y de entrevistas semiestructuradas con actores clave en los diferentes niveles de operación del programa. Para la revisión documental, se realizó un análisis comparativo de las OR para identificar los cambios a lo largo de la primera década de funcionamiento del programa PSA, que incluyen las OR, publicadas anualmente, desde 2003 hasta 2013. Se entrevistó 
a actores de tres niveles de operación del programa. El nivel nacional fue principalmente la CONAFOR, un organismo gubernamental descentralizado creado en 2001. A nivel subnacional, se entrevistó a personal de las oficinas estatales de la CONAFOR en Jalisco y Michoacán. A nivel local, se entrevistaron TA que trabajan en estas regiones y a las autoridades locales de seis ejidos, tres de Jalisco ubicados en la Cuenca de Ayuquila, y tres de Michoacán, ubicados en los municipios de La Huacana y Zitácuaro. La información obtenida en las entrevistas fue codificada y analizada con el software QSR NVivo 10.

Los hallazgos más destacados de la investigación en cuanto a las OR son: 1) Las OR cambian anualmente, a través de diversos mecanismos. A lo largo de once años, la definición de PSA ha cambiado con frecuencia y se está simplificando gradualmente. Mientras que el papel de la CONAFOR se ha vuelto ambiguo, las obligaciones y responsabilidades de los beneficiarios se han incrementado. Aunque las opciones de participación y toma de decisiones a nivel local han aumentado, se trata de intervenciones limitadas, definidas en su mayoría por la CONAFOR, y siempre supervisadas por los TA. El papel de los TA está poco representado en las OR. Los términos en los que se basan los criterios de prioridad para la selección de beneficiarios y tierras se han basado cada vez más en fuentes técnicas y científicas.

2) Aunque en la conceptualización de las OR para la aplicación del PSA participan diversos actores, éstos no tienen la misma influencia en el programa. Los actores más influyentes son los que se encuentran en los responsables de alto nivel de la formulación e implementación de políticas forestales, así como los organismos de financiación (especialmente el Banco Mundial). Además, otros actores externos aportan información, como ONG reconocidas y universidades, a través de su participación en el comité consultivo del PSA o a través de evaluaciones. La influencia real de los actores en las OR disminuye a medida que se acercan a los niveles locales de acción. Los cambios en las OR reflejan las luchas de poder, las negociaciones y las tensiones entre los actores de alto nivel por la prevalencia de sus intereses, valores y enfoques. Las principales tensiones/luchas que tienen lugar en el programa son entre a) los criterios medioambientales frente a los sociales, b) las opciones técnicas/científicas frente a las políticas, c) la toma de decisiones centralizada frente a la descentralizada, d) los enfoques más antiguos frente a los innovadores de los procedimientos políticos y administrativos.

A partir del análisis de los TA, 3) Las funciones que se espera que desempeñen los TA como intermediarias en el PSA son: a) preparar a los solicitantes para que se inscriban en el programa, b) acompañar y guiar a los solicitantes, y c) supervisar las actividades de los beneficiarios e informar sobre ellas. En la práctica, los TA se involucran en la 
interpretación y negociación de OR, que son cambiantes, dentro de una variedad de contextos locales. Tres factores determinan la dependencia de la CONAFOR de los TA, que han persistido a lo largo de la historia de la política forestal mexicana: a) la falta de capacidad operativa de las organizaciones gubernamentales, b) la falta de capacidades técnicas y económicas de los propietarios de bosques, c) los cambios frecuentes en las OR, que además están expresadas en lenguaje técnico. Debido a las restricciones financieras y operativas, la mayoría de las actividades de los TA se realizan fuera del control/alcance de la CONAFOR. La compleja relación de los TA con la CONAFOR y las condiciones de trabajo son factores que afectan su identidad y desempeño. Su papel también es cuestionado por la incidencia de prácticas poco éticas y deficientes realizadas por algunos de ellos a nivel local. Esto ha llevado a la estigmatización de los TA en los programas de la CONAFOR.

4) En la narrativa de la CONAFOR se reconocen las funciones clave de los TA, pero al mismo tiempo se les presenta como un "actor no confiable", que está fuera del control de la CONAFOR. Debido a la falta de una relación contractual entre la CONAFOR y los TA, existen limitaciones para actuar formalmente contra prácticas poco éticas de los TA. La responsabilidad de denunciar y "castigar" a las TA recae en los beneficiarios, quienes frecuentemente no tienen acceso a los canales y procedimientos para quejarse formalmente. En estos casos, el papel de la CONAFOR se limita a mediar en el conflicto $y$, en casos extremos, a eliminar prestadores de servicios de la lista de TA, pero esto no ocurre con frecuencia. En los casos estudiados de conflictos entre TA y beneficiarios, algunas comunidades han aprendido a lidiar con ellos de manera efectiva, y en otros casos han surgido intermediarios alternativos que han ayudado a reconectar a los beneficiarios con la CONAFOR para resolver dichos problemas. Las prácticas poco éticas operan bajo la alfombra de las OR: las deficiencias normativas y de control han desdibujado los aspectos negativos de las relaciones con los beneficiarios del programa. La certificación es la medida más importante adoptada hasta ahora por la CONAFOR para hacer frente al desempeño de los TA. Consiste en un conjunto de pruebas realizadas por un tercero calificado para evaluar las capacidades técnicas de los TA, a fin de iniciar o mantener la prestación de servicios. El proceso ha sido criticado, ya que no evalúa el trabajo de los TA en el campo, ni aborda problemáticas subyacentes.

5) Según sus propias narrativas, los TA desempeñan múltiples funciones a nivel local, algunas de las cuales van más allá del ámbito de la CONAFOR. La heterogeneidad de los TA, la competencia y la desconfianza entre ellos dificultan que se organicen como grupo y logren mejores condiciones de trabajo. Los TA están parcialmente de acuerdo con la narrativa de la CONAFOR sobre ellos mismos, pero no están de acuerdo con la amplia generalización de la culpa de los TA en el desarrollo del PSA, ya que consideran que la CONAFOR ha contribuido ampliamente al problema por su negligencia $y$, a veces, ha 
habido colusión. Aunque se tiende a infravalorar a los TA como agentes de cambio de las $\mathrm{OR}$, en realidad tienen una influencia indirecta a través de a) su intervención en la toma de decisiones de los beneficiarios, b) su elección personal sobre sus propios roles a nivel local, c) su influencia en la configuración de las relaciones entre los actores, d) su capacidad para interpretar, negociar y adaptar las cambiantes reglas de las OR a las condiciones locales, y e) sus preferencias y conocimientos individuales para la selección de tierras forestales y beneficiarios con los que trabajar.

En la narrativa de la CONAFOR la función de las OR es siempre incuestionable, mientras que la actuación de las TA es siempre cuestionable. Sin embargo, los TA retratados como "villanos" pueden jugar el papel de cortina de humo detrás de la cual la CONAFOR puede esconderse para dar cuenta de las fallas, reales y potenciales, y desviar la atención de la responsabilidad por otros aspectos cuestionables de la operación del PSA. Así, el control de la narrativa sobre los roles de los actores y dispositivos en el programa de PSA también es útil para la construcción de la fachada de la CONAFOR. Pero cuando las OR traspasan los niveles operativos y llegan a los actores locales, especialmente a las TA, surgen nuevas narrativas que convergen y compiten con las dominantes. En cierto modo, las prácticas de los TA y su representación no afectan los resultados del programa PSA, al menos los que se muestran al público. Sin embargo, a nivel local, el hecho de que los TA sean frecuentemente representadas como "villanos", en conjunto con las omisiones y cambios en las OR, tienen efectos directos (negativos) sobre los beneficiarios, a menudo difuminados e incluso no visibles. Estos efectos sobre los beneficiarios son: a) el continuo abuso de poder y las prácticas poco éticas a nivel local, b) la preservación de los desequilibrios de poder, c) la no mejora de las capacidades locales, d) las posibles sanciones y la pérdida de acceso a los programas de la CONAFOR, y, e) la continuación de la impunidad. La dinámica entre las OR y los TA, vista como la interacción entre las estructuras formales con los agentes que coadyuvan y reproducen la informalidad, juega un papel fundamental en la implementación y adaptación del programa PSA. Conforma una diversidad de entendimientos, motivaciones y beneficios tangibles para los actores involucrados, incluyendo ingresos, capacitación, empleos, relaciones, reconocimiento e infraestructura. Por lo tanto, existe un esfuerzo por parte de todos los actores para mantener vivo el programa a través de la cooperación, lo que hace necesario desdibujar y desconocer ciertos incumplimientos y conflictos que se producen a todos los niveles. La dinámica entre las OR y los TA, y las formas en que se presentan (las OR como "incuestionables", y los TA como "villanos") tienen un efecto positivo en el programa de PSA, ya que permiten la fluidez de las relaciones entre los actores, a través de la interpretación/implementación flexible del mensaje del PSA. EI efecto positivo no está en el éxito del programa, sino en su continuidad. 


\section{Annex 1. Questions for semi structured interviews}

\section{I.Guía de preguntas generales CONAFOR}

1. Información general

- Fecha

- Nombre y Cargo

- Jerarquía del área

- Profesión

- Cuánto personal labora en el área y funciones o colaboradores

- Tiempo de trabajar en CONAFOR/área específica

- Descripción breve del cargo

- ¿ ¿El área tiene técnicos de campo o prestadores externos?

- ¿ ¿Con qué otro personal está directamente relacionado de otras áreas?

- ¿ ¿Hay trato directo con comunidades?

- ¿Con qué otras instancias se coordinan directamente? INEGI, secretarías estatales, regionales, municipales,

2. Antecedentes PSA (para fundadores)

- ¿Quién lo creó?

- Conceptualización y desarrollo

- ¿ ¿Por qué se creó?

- Objetivos anteriores vs. Obj. Actuales

- Criterios iniciales vs actuales.

- Indicadores iniciales vs actuales.

- Cambios conceptuales, estructurales, operativos

3. Fuentes de información:

- ¿Principales fuentes de información que generen cambios en el programa?

- ¿ ¿De qué sectores provienen?

- Formas de incorporación de conocimiento o conceptos,

- Consultas, etc.

- ¿Conocimiento local?

4. Información generada

- Documentos importantes: guías, manuales, etc. en los que se basa para realizar su actividad

- ¿ ¿linformación generada periódicamente? Tipo de información (mapas, informes, información estadística, etc.) A quién va dirigida (es interna o a usuarios específicos)

- ¿QQué información generada por esta área está disponible a todo público?

5. Información, difusión y acceso (Convocatorias/Reglas de operación):

- ¿ ¿ ¿a quién se dirigen? Tipo de información

- ¿ ¿Cómo se accede a ella? ¿por qué se eligieron los medios que se usan para publicarla?

- ¿La información genera dudas?

- ¿Cuáles son las más frecuentes?

6. Resultados: ¿a quién se rinde cuentas?

- ¿ ¿Existen documentos específicos o mapas para comunidades

- ¿Qué papel tienen en los resultados las comunidades?

- - Participación:

- ¿ ¿Quién se encarga de captar opiniones, necesidades, quejas, etc., provenientes de otros sectores sobre PSA, y especialmente beneficiarios y TAs?

- ¿ ¿Existen foros y espacios de interacción y participación entre todos los actores?

- Frecuencia de realización

- ¿Cómo se usa la información de estos espacios? 


\section{7. Áreas de influencia /elegibilidad: (Específicas para especialistas)}

- ¿ ¿Cómo se determinaron bosques y no bosques? (INEGI, CONAFOR o alguna otra fuente)

- ¿ ¿Qué áreas incluir y cómo seleccionarlas? (tipos de vegetación, degradación, bosque y no bosque.

- Diferencia en las áreas elegibles por modalidad (bosques templados para PSAH, bosques tropicales para biodiversidad)

- ¿ ¿Cómo se incorporaron más áreas? Criterios, etc. ¿cómo han cambiado estos criterios?

- ¿ ¿Qué áreas y beneficiarios (privados, ejidos, etc.) condiciones y por qué? Análisis de elegibilidad

8. Conceptos sobre el bosque

- Definición oficial de bosque, en términos técnicos. Documentos que contengan definición de bosque y conceptos relacionados

- $\quad$-Importancia de la definición de bosque en su área de trabajo,

- Importancia de la definición de bosques para los beneficiarios del programa

- $\quad$ Problemas por interpretación distinta de este concepto en la realización de las actividades:

- $\quad$ con usuarios específicos, prestadores de servicios, otras áreas de CONAFOR, otras instancias (como SAGARPA), etc.?

- - ¿La definición es o puede ser la misma para todos los involucrados?

- $\quad$ - Cómo su labor específica ha influido o puede influir en la forma en la que las comunidades y gente local ve/valora/ transforma su actitud o ideas sobre sus bosques?

- - ¿Qué cambios haría en las formas de definir bosque para que funcionen mejor a nive operativo?

9. Evaluación y cambios:

- Evaluaciones, ¿se hacen? ¿Se publican? ¿Se pueden adquirir para análisis?

- ¿Quién las hace, qué criterios se toma en cuenta para evaluaciones? ¿quién define esos criterios?

- ¿ ¿Contribuyen a generar cambios conceptuales o sólo operativos? resultados, medición de resultados y criterios.

10. Funcionamiento programa:

- (Preguntas específicas por informante)

- Aspectos operativos: pagos, informes técnicos, cumplimiento comunidades, etc.

- Problemas institucionales: límites para realizar la función. Fondos.

11. Actores:

- ¿ ¿Cómo se visualiza a los participantes o actores involucrados: ¿quiénes son? ¿Cuál es el público principal? ¿Qué actores inesperados se integraron? ¿Qué actores están aún por ser considerados?

- Consejos consultivos: ¿cómo funcionan y quiénes están involucrados?

- Beneficiarios: ¿Cómo se definieron las condiciones y requerimiento de los beneficiarios? Condiciones y requerimiento de los beneficiarios. ¡Qué tienen que hacer y demostrar?

- ATécnicos:

- ¿ ¿Cómo y por qué se determinó el papel de los prestadores? ¿Por qué externos?

¿qué requerimientos deben cumplir?

¿cómo se evalúa su trabajo?

¿Cómo se da la interacción de estos con CONAFOR?

¿Qué relevancia tienen en la comunicación con las comunidades? ¿Esto se evalúa?

- ¿ ¿Reciben comunicación de las comunidades sobre desempeño de los técnicos?

- Técnicos comunitarios

- Interrelación con CONAFOR estatal y regional y con otras dependencias de jurisdicción estatal 
- Dependencias de SEMARNAT, otras oficinas de CONAFOR, otras secretarías:

- Otros actores: (los informantes los determinan)

\section{Información general}

\section{I.1 CONAFOR estatal}

- Fecha

- Nombre y Cargo

- Jerarquía del área

- Profesión

- Cuánto personal labora en el área y funciones o colaboradores

- Tiempo de trabajar en CONAFOR/área específica

- Descripción breve del cargo/

- Relación con CONAFOR Nacional

- ¿ ¿El área tiene técnicos de campo o prestadores externos?

- ¿Con qué otro personal está directamente relacionado de otras áreas?

- ¿Hay trato directo con comunidades?

\section{Descripción actividades}

- ¿Cómo funciona la oficina estatal?

- ¿Cuánta gente trabaja para el departamento?

- Relación con oficinas regionales o nacionales

- ¿lindependencia en toma de decisiones?

- $\quad$ Principales modalidades del programa funcionando en Michoacán/Jalisco y por qué

- Verificaciones o monitoreo

- Talleres de beneficiarios

- Guía/Manual de mejores prácticas

- Otros programas relacionados dentro o fuera de CONAFOR

3. Actores:

- Interacción con CONAFOR nacional

- Frecuencia de comunicación con oficina central

- ¿Problemas, conflictos o quejas, como se resuelven?

- Interacción con ATs

- ¿ ¿cuántos en Michoacán/Jalisco?

¿cómo se da la interacción con ellos?

Certificación

relevancia de asesores técnicos en el programa

¿Qué relevancia tienen en la comunicación con las comunidades?

¿Qué necesitan saber los asesores técnicos para realizar su trabajo?

¿Qué información importante proveen los asesores?

¿Se evalúa su trabajo? qué se evalúa?

Quejas sobre AT ¿cómo se gestionan?

Sanciones a AT?

Cuántos AT hacen bien su trabajo

- Interacción con beneficiarios

- ¿Qué tan frecuente es la interacción con los beneficiarios?

\section{Información general}

\section{Guía para entrevistas con Asesores Técnicos}

- Nombre

- ¿ ¿Trabaja de forma independiente o forma parte de grupo, A.C., ONG, empresa, etc.?

- Perfil: Profesión, especialización, etc.

- $\quad$ Ejidos o comunidades en los que ha trabajado o trabaja con PSA

- Tiempo trabajando como asesor técnico de CONAFOR.

- $\quad$ Tipo de actividades certificadas por CONAFOR (dentro de CONAFOR o de otra dependencia).

\section{Relación con y percepción sobre los núcleos agrarios}

- Actividades específicas de AT en el presente, descripción de sus casos: 
- Antes del Programa:

a) Búsqueda y contacto de nuevos grupos agrarios para trabajar

b) ¿Con quién es el principal contacto?

c) ¿Cómo se convence a la comunidad para seleccionarlo(a) como AT?

- Procedimientos para la realización de la solicitud para ingresar al programa:

a) Delimitación de polígono

b) Preparación de la documentación y de la solicitud

c) Etc.

- Personas del núcleo agrario con quien toma decisiones a ese nivel.

- Definición de representante legal (hombre, mujer/ parte de la autoridad/parte de la comunidad, etc.)

- Después de aceptación dentro del programa: ,

a) ¿qué actividades realizan con la comunidad?

b) ¿cómo se definen las actividades a realizar en el núcleo agrario?,

c) Número aproximado de visitas en un año,

d) ¿Cómo se realiza el manual de mejores prácticas? ¿quién participa?

e) ¿Qué aporta la comunidad durante la operación del programa?

f) conocimiento local (de qué tipo), insumos, acompañamiento, etc.

- Durante todo el proceso de formar parte del PSA, quién es el principal(es) contactos(s) dentro de los núcleos agrarios

- Respuestas y actitudes de los distintos tipos de comunidades en las que trabaja.

- ¿Considera que la gente dentro de los núcleos agrarios conoce y entiende enteramente el objetivo del programa de PSA?

- ¿ ¿Cuáles son los principales aspectos que causan confusión dentro de los núcleos agrarios?

- ¿ ¿Qué aspectos de la operación del programa se facilitan o dificultan más dentro de las comunidades?

- ¿ ¿Qué obstáculos/problemas existen dentro de los núcleos para la realización del trabajo de los AT?

- $\quad$ ¿Ha tenido problemas específicos con comunidades, de qué tipo, cómo se resolvió? ¿Conafor intervino? ¿existen algún otro tipo de intermediarios entre la comunidad y los AT, en caso de desacuerdos?

- ¿ ¿Se considera usted una persona influyente en la toma de decisiones del núcleo agrario? ¿en qué tipo de decisiones?

- ¿Con quién reporta el cumplimiento de actividades dentro del núcleo agrario? ¿Le piden cuentas, lo evalúa la comunidad de alguna manera?

- Manual de mejores prácticas:

a) ¿Cómo se definen las actividades del manual,

b) ¿Quién decide en qué áreas del polígono con PSA y cuándo se realizan estas actividades?

c) ¿Qué opinión tiene más valor dentro de la comunidad para tomar estas decisiones?

d) Participación femenina en la toma de decisiones en general.

- ¿ ¿En qué momentos coinciden CONAFOR, AT y los beneficiarios del programa?

- ¿ ¿Consideran que el trabajo de un AT está correctamente valoradolos núcleos agrarios con los que trabaja? Explicar.

\section{Relación con CONAFOR}

- Principal contacto con CONAFOR (con oficinas centrales de conafor, con oficinas estatales o regionales) y formas de contacto.

- ¿ ¿Qué reciben de CONAFOR como AT?:

- Información: ¿Específica para AT, o la misma información que los beneficiarios? (como las reglas de operación, convocatorias, términos de referencia, etc.)

- Apoyo técnico: ¿qué tipo de asesoría técnica reciben, capacitación, etc.?; 
- Insumos: por ejemplo, imágenes de satélite, software, etc.?;

- Pagos: ¿por qué concepto? ¿̇es suficiente? ¿Existen costos no cubiertos en el pago?

- ¿ ¿Existen reuniones u otro tipo de interacción con CONAFOR, en donde están juntos los diferentes AT del estado?

- (Si ha colaborado desde el principio del programa (2003) o más de tres años): Cambios en las convocatorias y requisitos para aplicar como asesor técnico hasta llegar al proceso de certificación actual.

- ¿ ¿Qué se necesitaba para ser parte del padrón de AT antes de que existiera la certificación?

- ¿Con esos procedimientos era posible asegurar un buen servicio de las AT?

- Certificación: (percepción general)

- ¿ ¿Considera que el proceso actual de certificación contribuye a mejorar la prestación de servicios técnicos? ¿Por qué?

- ¿Qué cambiaría del proceso de certificación para hacerlo más efectivo?

- Cuando un AT tienen dudas, observaciones, inquietudes, inconformidad, requieren asesoría sobre algún aspecto del programa, ¿̇a quién recurren, por qué medios?

- ¿ ¿Podría explicar de qué manera percibe CONAFOR a los AT en general?

- ¿Considera que su labor es valorada y reconocida adecuadamente por CONAFOR? ¿Por qué?

- ¿ ¿Qué condiciones de su interrelación con CONAFOR podrían mejorar los resultados de su trabajo como AT?

- ¿ ¿Mantiene colaboración con otros actores (presidentes municipales, académicos, ONG, etc.) u otros AT?

- $\quad$ Rendición de cuentas a CONAFOR de actividades y desempeño.

\section{Autopercepción como AT}

- Motivaciones de ser AT: ¿Por qué trabaja como AT de PSA?

- ¿Qué perfil profesional, conocimientos y habilidades debe tener un AT de PSA?

- Dentro del desarrollo de PSA, ¿̇en qué procesos considera fundamental la actividad de los AT?

- ¿Cómo se auto describen profesionalmente? como servidores, intermediarios, enlaces, representantes de CONAFOR, de las comunidades, extensionista, etc. Explorar más ese tema: ¿en qué aspectos?

- ¿ ¿Existe información proveniente de CONAFOR (o relacionada) que frecuentemente es necesario "traducir" constantemente a los núcleos agrarios y viceversa?

- ¿ ¿Es fundamental la presencia de AT en la operación del programa? ¿Qué pasaría con el programa si no existiera la figura de AT?

- $\quad$ ¿Existen uniones de AT o al menos reuniones en las que hablen de sus problemáticas comunes, compartan experiencias, etc.?

- $\quad$ Sí: ¿Qué tipo de organización tienen, temporal o permanente, ¿qué tan útil es? ¿Cuántos participan?

- No: ¿Por qué razones no existe unión entre AT? ¿Qué obstáculos hay? ¿Serviría de algo?

- ¿ ¿Cómo es su percepción en general sobre el desempeño de otros AT? Porcentaje de AT que conoce que a usted la parecen confiables.

- ¿ ¿ ¿En qué puntos puede mejorar el desarrollo del trabajo de AT? (las mejores condiciones bajo las cuales el trabajo podría desarrollarse, considerando aspectos externos e internos).

- ¿ ¿Con quién tienen más entendimiento, cercanía, afinidad, interés, etc: Conafor o las comunidades con las que trabaja?

\section{Datos generales:}

\section{Guía de entrevistas para autoridades ejidales}

- Fecha

- Nombre del entrevistado

- Ocupación

- Edad 


\section{Sobre el ejido}

- Cargos que tiene y ha tenido en ejido

- Nombre del ejido, año de fundación

- ¿Cuántos habitantes son?

- ¿Cuántas familias?

- ¿Cuántos ejiditarios/posesionarios/avencindados hay? ¿Se han aumentado el número de ejiditarios en los últimos 15 años?

- ¿ ¿Hay pequeños propietarios?

- $\quad$ ¿Hay gente de afuera rentando tierras? ¿De dónde son?¿Para que lo usa?

- ¿ ¿Hay gente que vive afuera? ¿Dónde?

- ¿ ¿Qué actividades productivas principales se llevan a cabo en el ejido?

3. Programas y subsidios y vinculaciones institucionales:

- ¿Qué programas/subsidios del gobierno tiene el ejido?

- ¿ ¿ Desde hace cuándo?

- ¿Cómo se distribuye los recursos?

- ¿Desde hace cuándo ha tenido programas de CONAFOR?

- ¿Cómo sabe de las convocatorias?

4. Sobre PSA:

- ¿Cuántos hectáreas están apoyados?

- ¿ ¿Para qué sirve el PSA?

- ¿Cuánto tiempo tiene participando en el programa?

- ¿ ¿Cuál fue la motivación para participar?

- ¿ ¿Qué actividades hay que realizar?

- ¿Cuántos ejidatarios están involucrados?

- ¿ ¿Principales formas de participación de los ejidatarios en el programa?

- ¿Cómo se distribuye los recursos?

- ¿Qué tipo de información les ha sido proporcionada desde el inicio del programa hasta la fecha? (contando un poco los procedimientos que han tenido que seguir a lo largo de su participación en el programa)

- ¿ ¿Quién tiene acceso al polígono final? ¿al contrato con el AT ¿al convenio con CONAFOR ¿al manual de Mejores Prácticas?

- ¿ ¿Para qué usa el manual de Mejores Prácticas? ¿Es útil?

- ¿ ¿ ¿cómo se definió el área a participar en el programa? ¿Quién(es) lo decidió (ieron)? ¿Quién hizo el polígono? ¿Quién(es) conoce el número de hectáreas apoyado y en dónde se encuentran?

- ¿ ¿Alguien(es) acompañó(aron) el Técnico en eso?

- Para los que tienen muchos años de participación, ¿̇ué resultados han tenido? Por ejemplo, si hay actividades que han 1) disminuido y 2) dejado de realizar desde que está el programa, o 3) incrementada (ej. Incendios)

- $\quad$ ¿Ha habido conflictos entre distintas formas de entendimiento en temas relevantes al programa?

- $\quad$ ¿Existen conceptos que usan los empleados de CONAFOR, o los asesores técnicos (AT) que resultan confusos, difíciles de entender o diferentes del que tienen las comunidades (por ejemplo servicios ambientales, bosques, los conceptos de pago, mejores prácticas, etc.).

- ¿ ¿ ¿ Cuál es su opinión sobre reuniones y talleres en donde empleados de CONAFOR les dan a conocer la convocatoria, explican las reglas del programa, explican conceptos importantes, derechos y obligaciones, etc.?

- ¿ ¿Qué tipo de conocimiento les hace falta como comunidad que puede ser importante para que funcione mejor el programa?

- ¿ ¿ ¿En qué consideran que necesitan entrenamiento o explicaciones más claras?

- ¿ ¿ ¿lnformación que les ha sido solicitada para llevar a cabo los proyectos?

- $\quad$ ¿Información que pueden proveer como ejido, necesitan por parte de los a) AT, ¿̇b) CONAFOR estatal o federal? 
- ¿Hay Influencia de otros actores en la toma de decisiones: estudiantes y académicos, asociaciones civiles, asesores técnicos, oficiales de gobierno de otras instancias, partidos políticos, otros ejidos o comunidades, etc.?

- ¿Cuál es la importancia del programa en su comunidad?

- ¿ ¿Ha influido en programa en la manera en la que ven sus bosques? ¿De qué forma?

- ¿ ¿Le cambiaría algo al programa para hacerlo mejor?

\section{Asesores técnicos}

- ¿Cuentan con un Asesor Técnico?

- ¿ ¿Quién es? (sería mejor nombre y datos de contacto para hacer seguimiento)

- ¿ ¿Cómo supieron de él?

- ¿Desde hace cuándo lo conocieron?

- ¿ ¿Por qué lo contrataron?

- ¿Han contratado otros?

- Si han cambiado ¿Por qué decidieron cambiar su Asesor Técnico?

- ¿Quién lo decidió o quienes lo decidieron?

- ¿Qué opinión tienen sobre su trabajo?

- ¿Podrían hacer todas las actividades de PSA sin AT?

- ¿ ¿Qué tanto recurren a ustedes los AT para obtener información sobre el manejo de áreas o sobre las actividades a realizar en las áreas de PSA?

- ¿Cuánta confianza hay entre ustedes?

- Si hay un problema con el TA, ¿̇a quién recurren? A CONAFOR o a otra organización, etc. 